Pacific Northwest National Laboratory

Operated by Battelle for the

U.S. Department of Energy

\section{Hanford Tanks 241-C-203 and 241-C-204: Residual Waste Contaminant Release Model and Supporting Data}
W. J. Deutsch
K. J. Cantrell
K. M. Krupka
C. F. Brown
M. J. Lindberg
H. T. Schaef

May 2007

Prepared for CH2M HILL Hanford Group, Inc. and the U.S. Department of Energy under Contract DE-AC05-76RL01830 


\title{
DISCLAIMER
}

This report was prepared as an account of work sponsored by an agency of the United States Government. Neither the United States Government nor any agency thereof, nor Battelle Memorial Institute, nor any of their employees, makes any warranty, express or implied, or assumes any legal liability or responsibility for the accuracy, completeness, or usefulness of any information, apparatus, product, or process disclosed, or represents that its use would not infringe privately owned rights. Reference herein to any specific commercial product, process, or service by trade name, trademark, manufacturer, or otherwise does not necessarily constitute or imply its endorsement, recommendation, or favoring by the United States Government or any agency thereof, or Battelle Memorial Institute. The views and opinions of authors expressed herein do not necessarily state or reflect those of the United States Government or any agency thereof.

\author{
PACIFIC NORTHWEST NATIONAL LABORATORY \\ operated by \\ BATTELLE \\ for the
UNITED STATES DEPARTMENT OF ENERGY under Contract DE-AC05-76RL01830

Printed in the United States of America

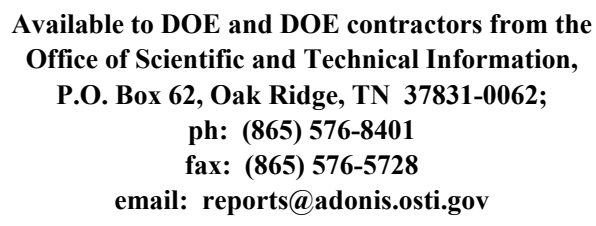

Available to the public from the National Technical Information Service, U.S. Department of Commerce, 5285 Port Royal Rd., Springfield, VA 22161

ph: (800) 553-6847

fax: (703) 605-6900

email: orders@ntis.fedworld.gov

online ordering: http://www.ntis.gov/ordering.htm 


\section{Hanford Tanks 241-C-203 and 241-C-204: Residual Waste Contaminant Release Model and Supporting Data}
W. J. Deutsch
K. J. Cantrell
K. M. Krupka
C. F. Brown
M. J. Lindberg
H. T. Schaef

May 2007

Prepared for

CH2M HILL Hanford Group, Inc., and the U.S. Department of Energy under Contract DE-AC06-76RL01830

Pacific Northwest National Laboratory

Richland, Washington 99352 


\section{Summary}

This report was revised in May 2007 to correct ${ }^{90} \mathrm{Sr}$ values in Chapter 3. The changes were made on page 3.9, paragraph two and Table 3.10; page 3.16, last paragraph on the page; and Tables 3.21 and 3.31. The rest of the text remains unchanged from the original report issued in October 2004.

This report describes the development of release models for key contaminants that are present in residual sludge remaining after closure of Hanford Tanks 241-C-203 (C-203) and 241-C-204 (C-204). The release models were developed from data generated by laboratory characterization and testing of samples from these two tanks. Key results from this work are that future releases from the tanks of the primary contaminants of concern $\left({ }^{99} \mathrm{Tc}\right.$ and $\left.{ }^{238} \mathrm{U}\right)$ can be represented by relatively simple solubility relationships between infiltrating water and solid phases containing the contaminants. In addition, it was found that high percentages of ${ }^{99} \mathrm{Tc}$ in the sludges (20 wt\% in C-203 and $75 \mathrm{wt} \%$ in C-204) are not readily water leachable, and, in fact, are very recalcitrant. This is similar to ${ }^{99} \mathrm{Tc}$ results found in related studies of sludges from Tank AY-102 (Lindberg and Deutsch 2003; Krupka et al. 2004). These release models are being developed to support the tank closure risk assessments performed by CH2M HILL Hanford Group, Inc., for the U.S. Department of Energy.

The material used for testing consisted of sludge samples collected from the tanks in September 2003. Initial (Tier 1) testing of the sludges consisted of 1) fusion analysis and acid digestion to determine the total composition of the sludges and 2) water leaching to estimate the soluble portion of the solids. Based on the results of these tests, subsequent analyses were conducted (Tier 2). These included X-ray diffraction (XRD) measurements to identify crystalline solids and scanning electron microscopy/energy dispersive spectroscopy (SEM/EDS) analysis to provide a close-up view of the morphologies of the sludge material and identify the major constituents of individual minerals and amorphous solids. Periodic replenishment and selective extraction tests were also conducted during the Tier 2 tests to further evaluate water leachability and identify solid phases limiting the release of contaminants to solution. The test data were used to develop conceptual contaminant release models based on a series of solubility controls.

The ${ }^{99} \mathrm{Tc}$ release model developed from the laboratory testing of C-203 and C-204 sludges is based on the concentrations and solubilities of technetium-bearing solids in contact with pore water migrating through the sludges. There are two stages of technetium release to solution:

1. Initially, part of the ${ }^{99} \mathrm{Tc}$ is present in the sludge as a highly soluble solid phase. The composition of this solid is not known; however, $\mathrm{NaTcO}_{4}$ has been used as a surrogate. The calculated concentrations of $\mathrm{NaTcO}_{4}$ in the sludges are $0.074 \mu \mathrm{g}{ }^{99} \mathrm{Tc} / \mathrm{g}$-sludge in C-203 and $0.128 \mu \mathrm{g}{ }^{99} \mathrm{Tc} / \mathrm{g}$-sludge in $\mathrm{C}-204$. The calculated solubility of $\mathrm{NaTcO}_{4}$ for both tanks is $706 \mathrm{~g}{ }^{99} \mathrm{Tc} / \mathrm{L}$. The high solubility effectively allows all the ${ }^{99} \mathrm{Tc}$ from this source to dissolve in a very small quantity of water, and this portion of the ${ }^{99} \mathrm{Tc}$ is very mobile.

2. After the soluble $\mathrm{NaTcO}_{4}$ solid is removed from the waste by dissolution, the remaining ${ }^{99} \mathrm{Tc}$ is relatively immobile because it is likely incorporated in a very insoluble iron mineral, which is assumed to be ferrihydrite $\left[\mathrm{Fe}(\mathrm{OH})_{3}\right]$ for modeling purposes. The residual concentration of ${ }^{99} \mathrm{Tc}$ in $\mathrm{C}-203$ is $0.030 \mu \mathrm{g}{ }^{99} \mathrm{Tc} / \mathrm{g}$-sludge, and in C-204 it is $0.259 \mu \mathrm{g}{ }^{99} \mathrm{Tc} / \mathrm{g}$-sludge. In this stage of release, 
the ferrihydrite must dissolve to release the trace amounts of ${ }^{99} \mathrm{Tc}$ found in its structure. Based on the concentrations of ${ }^{99} \mathrm{Tc}$ in the ferrihydrite and a calculated solubility of ferrihydrite for tank conditions, the release of ${ }^{99} \mathrm{Tc}$ during this stage is $0.28 \mathrm{pg}{ }^{99} \mathrm{Tc} / \mathrm{L}$ from Tank C-203 and $0.74 \mathrm{pg}{ }^{99} \mathrm{Tc} / \mathrm{L}$ for Tank C-204. These low dissolved concentrations effectively eliminate movement of ${ }^{99} \mathrm{Tc}$ from these tanks at this stage. The immobile ${ }^{99} \mathrm{Tc}$ represents $29 \mathrm{wt} \%$ of the total ${ }^{99} \mathrm{Tc}$ in $\mathrm{C}-203$ sludges and $67 \mathrm{wt} \%$ of the total in C-204 sludge.

The ${ }^{238} \mathrm{U}$ release model for C-203 and C-204 sludges is based on the concentrations and solubilities of uranium- and sodium-bearing minerals in contact with pore water migrating through the sludges. There are three stages of uranium release to solution:

1. Initially, soluble čejkaite $\left[\mathrm{Na}_{4}\left(\mathrm{UO}_{2}\right)\left(\mathrm{CO}_{3}\right)_{3}\right]$ and a sodium nitrate solid are present in the sludges at concentrations of $0.16 \mathrm{~g} \mathrm{U} / \mathrm{g}$-sludge and $0.22 \mathrm{~g} \mathrm{NaNO}_{3} / \mathrm{g}$-sludge for C-203 and $0.068 \mathrm{~g} \mathrm{U} / \mathrm{g}$-sludge and $0.04 \mathrm{~g} \mathrm{NaNO}_{3} / \mathrm{g}$-sludge for $\mathrm{C}-204$. The common ion effect due to $\mathrm{Na}^{+}$limits the solubility of čejkaite to $0.19 \mathrm{~g} \mathrm{U} / \mathrm{L}$ until all the $\mathrm{NaNO}_{3}$ is dissolved. The solubility of $\mathrm{NaNO}_{3}$ is constant at $629 \mathrm{~g} / \mathrm{L}$.

2. After all the $\mathrm{NaNO}_{3}$ has dissolved, the solubility of čejkaite increases to $69 \mathrm{~g} \mathrm{U} / \mathrm{L}$ and all the remaining čejkaite dissolves.

3. A residual non-čejkaite uranium mineral present at a concentration of $0.058 \mathrm{~g} \mathrm{U} / \mathrm{g}$-sludge in C-203 and $0.013 \mathrm{~g} \mathrm{U} / \mathrm{g}$-sludge in C-204 controls the final release of uranium to pore water. The solubility of this solid is estimated at $0.42 \mathrm{~g} \mathrm{U} / \mathrm{L}$. The non-čejkaite uranium mineral represents $27 \mathrm{wt} \%$ of the total ${ }^{238} \mathrm{U}$ in $\mathrm{C}-203$ sludges and $16 \mathrm{wt} \%$ of the total in C-204 sludge.

The uranium stages of release do not coincide with the technetium stages of release.

${ }^{129} \mathrm{I}$ is a potential contaminant of concern in the tank sludges because of its mobility and long half-life; however, it was not measured above the estimated quantitation limit of $71.1 \mathrm{pCi} / \mathrm{g}$ in C-203 sludge using the fusion extraction method. This number should be considered a qualitative upper limit for ${ }^{129} \mathrm{I}$ concentration in the sludge because the extraction method was not successful at dissolving the entire sludge sample. The sludge extraction method is being improved to produce complete sludge dissolution and iodine capture. ${ }^{129}$ I was also analyzed in the water leachates from the single-contact tests. In almost all cases, ${ }^{129}$ I was not measured above the estimated quantitation limits for these tests, which were in the range of 18.7 to $30.6 \mathrm{pCi} / \mathrm{g}$-sludge. In two cases, ${ }^{129} \mathrm{I}$ was reported at estimated concentrations of less than $1 \mathrm{pCi} / \mathrm{g}$-sludge in the water leachates.

The total concentrations of ${ }^{99} \mathrm{Tc}$ by the fusion extraction method were $0.104 \mu \mathrm{g} / \mathrm{g}$ in C-203 sludge and $0.387 \mu \mathrm{g} / \mathrm{g}$ in C-204. Uranium was a major component in the sludge samples from both tanks. The fusion extraction method gave concentrations of ${ }^{238} \mathrm{U}$ of $218,000 \mu \mathrm{g} / \mathrm{g}$ (C-203) and 80,200 $\mu \mathrm{g} / \mathrm{g}(\mathrm{C}-204)$. This corresponds to čejkaite mineral concentrations of about $50 \mathrm{wt} \%$ of the sludge in C-203 and $18 \mathrm{wt} \%$ in C-204. The other predominant metals in C-203 sludge were $\mathrm{Na}(17 \mathrm{wt} \%), \mathrm{Fe}(3.9 \mathrm{wt} \%)$, and $\mathrm{Cr}$ $(2.4 \mathrm{wt} \%)$. The predominant anions in this sludge were carbonate $(17.1 \mathrm{wt} \%)$, nitrate $(16.3 \mathrm{wt} \%)$, oxalate ( $2.54 \mathrm{wt} \%)$, and nitrite $(0.8 \mathrm{wt} \%)$. The predominant metals in $\mathrm{C}-204$ sludge, in addition to ${ }^{238} \mathrm{U}$, were $\mathrm{Fe}$ (12.7 wt \%), Na (9.1 wt\%), Si (3.6 wt\%), and $\mathrm{Al}(2.8 \mathrm{wt} \%)$. The predominant anions in this sludge were 
carbonate $(8.32 \mathrm{wt} \%)$, nitrate $(2.93 \mathrm{wt} \%)$, and nitrite $(1.94 \mathrm{wt} \%)$. Another major component of the C-204 sludge was the organic compound tributyl phosphate $(28.3 \mathrm{wt} \%)$.

The sum of the ${ }^{239} \mathrm{Pu}$ and ${ }^{241} \mathrm{Am}$ isotopes in C-203 sludge measured by the fusion method was $4,039 \mathrm{nCi} / \mathrm{g}$; by the EPA acid digestion method it was 2,470 nCi/g. Based on the DOE definition of transuranic (TRU) waste ( $>100 \mathrm{nCi} / \mathrm{g})$, this would classify the sludge in Tank C-203 as TRU waste; however, the final waste form in the tank will be a mixture of residual sludge and a tank-filling grout, which will lower the concentrations of contaminants an amount dependent on the mixing ratio of the sludge and the grout. The sum of the ${ }^{239} \mathrm{Pu}$ and ${ }^{241} \mathrm{Am}$ isotopes in C-204 sludge measured by the fusion method was $13.8 \mathrm{nCi} / \mathrm{g}$ and by the EPA acid digestion method was $5.73 \mathrm{nCi} / \mathrm{g}$. These measurements suggest that the sludge in tank C-204 is not TRU waste; however, this sludge contained $28.3 \mathrm{wt} \% \mathrm{TBP}$ that was not totally extracted by the test methods and may have retained TRU constituents. These test results should not be used to classify the waste in C-204.

The water-leachable amount of ${ }^{99} \mathrm{Tc}$ in C-203 sludge ranged from 56.3 to $71.3 \mathrm{wt} \%$ of the total ${ }^{99} \mathrm{Tc}$ in the sludge for the single-contact batch tests. The leachable percentage of ${ }^{99} \mathrm{Tc}$ increases with contact time. For Tank C-204, the water-leachable ${ }^{99} \mathrm{Tc}$ ranged from 28.0 to $33.9 \mathrm{wt} \%$ of the total ${ }^{99} \mathrm{Tc}$. The lowest percentage of ${ }^{99} \mathrm{Tc}$ is released in the one-day contact test $(28.0 \mathrm{wt} \%)$, and similar amounts are released at total contact times of two weeks $(33.9 \mathrm{wt} \%)$ and one month $(32.9 \mathrm{wt} \%)$. For the water leach tests in which the water was periodically replaced with fresh water, most of the leachable ${ }^{99} \mathrm{Tc}$ occurs in the first contact stage. During subsequent stages, low percentages (below detection to $2.9 \mathrm{wt} \%$ ) of ${ }^{99} \mathrm{Tc}$ are water leachable from the sludge. The recalcitrant nature of some of the ${ }^{99} \mathrm{Tc}(20$ to $75 \mathrm{wt} \%)$ in Hanford tank sludges has been documented in previous similar water leach studies of sludge from the AY-102 tank (Lindberg and Deutsch 2003; Krupka et al. 2004).

The water-leachable amount of ${ }^{238} \mathrm{U}$ in $\mathrm{C}-203$ sludge from the single-contact batch tests ranges from 70.4 to $75.8 \mathrm{wt} \%$ of the total ${ }^{238} \mathrm{U}$ in the sludge. There is no apparent time dependence on ${ }^{238} \mathrm{U}$ water leachability. In the periodic water replenishment tests, there does appear to be a time dependence on ${ }^{238} \mathrm{U}$ leachability. For the first five stages, in which contact time was two to three days per stage, the leachable amount decreased in the order $74.2 \mathrm{wt} \%, 2.4 \mathrm{wt} \%, 0.8 \mathrm{wt} \%, 0.2 \mathrm{wt} \%, 0.1 \mathrm{wt} \%$; however, in stage $6 \mathrm{a}$, where the contact time was 65 days, the amount leachable increased to $0.8 \mathrm{wt} \%$, and in stage $6 \mathrm{~b}$ ( 86 day contact) the value is $3.2 \mathrm{wt} \%$. This suggests the presence of at least two uranium minerals (čejkaite plus possibly clarkeite) with different solubilities and reaction rates in the C-203 sludge.

The water-leachable amount of ${ }^{238} \mathrm{U}$ in C-204 sludge for the single-contact batch tests ranged from 76.0 to $92.1 \mathrm{wt} \%$ of the available ${ }^{238} \mathrm{U}$ in the single-contact tests. This is within the range of analytical precision for these measurements, thus the differences between the values are not statistically significant. For the periodic water replenishment tests of C-204 sludge, almost all of the ${ }^{238} \mathrm{U}$ was leached in the first stage and there is a smaller increase in stages $6 \mathrm{a}$ and $6 \mathrm{~b}$, similar to that observed in testing C-203 sludge.

If a wet retrieval method is used for the sludge in these tanks, it is likely that a large fraction of the contaminants in the soluble portion of the sludge will be removed by the retrieval process. A wet sludge retrieval method could remove as much as $73 \%$ of the uranium in Tank C-203 and $84 \%$ of the uranium in $\mathrm{C}-204$. This method would also remove as much as $52 \%$ of the ${ }^{99} \mathrm{Tc}$ in Tank C-203 and $25 \%$ of the ${ }^{99} \mathrm{Tc}$ in C-204. 
Čejkaite was identified by XRD and SEM/EDS analyses as an important uranium-containing phase in the C-203 and C-204 sludges. The solubility of čejkaite $\left[\mathrm{Na}_{4}\left(\mathrm{UO}_{2}\right)\left(\mathrm{CO}_{3}\right)_{3}\right]$ in water in contact with the tank sludges was found to be strongly influenced by the dissolution of other sludge solids (primarily sodium nitrate and possibly sodium carbonate) that provide common ions $\left(\mathrm{Na}\right.$ and $\left.\mathrm{CO}_{3}{ }^{2-}\right)$ to the solution. Čjkaite solubility increased by a factor of 6 (from 0.03 to $0.18 \mathrm{~mol} / \mathrm{L}$ ) as the other sodium and carbonate minerals were dissolved and removed from the system. The common ion effect is important from a contaminant release standpoint because it can suppress the solubility of minerals containing contaminants, thereby limiting their release to solution.

Čejkaite was the dominant crystalline phase identified by XRD analysis of the sludges from C-203. A yellow nugget material separated from the C-203 sludge was also found to be predominantly čejkaite; however, the XRD pattern for this material also showed the possible presence of nitratine (soda niter, $\mathrm{NaNO}_{3}$ ) in the nuggets. The lack of a čejkaite pattern in the XRD analysis of the solids after two weeks of leaching with water is a clear indication of the high solubility of čejkaite in water. The XRD pattern for the water-leached sludge suggests the presence of a small amount of poorly crystalline clarkeite $\left[\mathrm{Na}\left[\left(\mathrm{UO}_{2}\right) \mathrm{O}(\mathrm{OH})\right]\left(\mathrm{H}_{2} \mathrm{O}\right)_{0-1}\right]$ in the residual solid. Čejkaite is also the dominant crystalline phase identified by XRD analysis of the sludges from tank C-204. This mineral in the C-204 sludge was also very leachable with water.

SEM/EDS analysis of C-203 sludge showed the presence of predominantly čejkaite, which has distinctive acicular and rod-shaped crystals in this sludge. Some of the čejkaite crystals were bound in a matrix with a sodium nitrate solid, possibly nitratine $\left(\mathrm{NaNO}_{3}\right)$. The yellow nugget material appeared to be a combination of čejkaite and this sodium nitrate phase. A second uranium mineral with a smooth surface was identified at lower concentration in this sludge. This other mineral may be represented by the composition $\mathrm{Na}_{2} \mathrm{U}_{2} \mathrm{O}_{7}$ or clarkeite $\mathrm{Na}\left[\left(\mathrm{UO}_{2}\right) \mathrm{O}(\mathrm{OH})\right]\left(\mathrm{H}_{2} \mathrm{O}\right)_{0-1}$. Micrographs of the water-leached sludge did not show the readily soluble čejkaite but did show the presence of the apparently less-soluble/reactive clarkeite.

SEM/EDS analysis of C-204 sludge showed that it is composed of čejkaite and an amorphous solid composed of $\mathrm{Na}, \mathrm{Al}, \mathrm{P}, \mathrm{O}$, and possibly $\mathrm{C}$. Within this mixture, there were particles, sometimes as aggregates, of an iron oxide that often also contained $\mathrm{Cr}$ and $\mathrm{Ni}$. Water leaching completely eliminated the čejkaite crystals from this sludge. The remaining solid consisted of a variety of non-descript particles, many of which had pitted altered surfaces. These particles included phases composed of Si oxide (probably quartz), Fe oxide (often as globular or botryoidal aggregates), Na-Al silicate, and a porouslooking material (or an aggregate of sub-micrometer particles) that typically contained $\mathrm{Al}, \mathrm{Cr}, \mathrm{Fe}, \mathrm{Na}, \mathrm{Ni}$, $\mathrm{Si}, \mathrm{U}, \mathrm{P}, \mathrm{O}$, and C. Cavities were found on the surfaces of some of the iron oxide particles. These likely represent the locations of solids that preferentially dissolved in the water. These water-soluble solids had been trapped in the iron mineral during its precipitation. If these solids contained contaminants, then the release of these contaminants to water would be limited by dissolution of the low solubility iron oxides in future infiltrating water. This process may account for at least some of the release of recalcitrant ${ }^{99} \mathrm{Tc}$ found in these sludges.

Testing of sludges from Tanks C-203 and C-204 has shown the need for future development of analytical techniques and release models. These future developments include: 
- Improved ${ }^{129}$ I extraction and measurement techniques

- Evaluation of actinide partitioning in TBP and extraction methods for analysis of total actinides in sludge

- Testing of contaminant release from sludge under environmental conditions other than fresh water infiltration (e.g., cement grout/sludge system)

- Release model for chromium from residual sludge. 


\section{Acknowledgments}

The authors wish to acknowledge M. Connelly, F. J. Anderson, and T. E. Jones at CH2M HILL Hanford Group, Inc. (Richland, WA) for providing project funding and technical guidance. We greatly appreciate the technical reviews provided by F. M. Mann (CH2M HILL), M. I. Wood (Fluor Hanford, Inc., Richland, WA), and R. J. Serne (PNNL). The authors would also like to thank B. W. Arey, S. R. Baum, K. M. Geiszler, I. V. Kutnyakov, and R. D. Orr (all of PNNL) for completing the SEM/EDS and chemical and radiochemical analyses of the solution samples from our studies. We are particularly grateful to Sheila Bennett (PNNL) for completing the editorial review and Rose Urbina (PNNL) for final word processing of this technical report. 


\section{Acronyms and Abbreviations}

$\mathrm{AE}$

AEA

ASTM

am

avg

bse

$\mathrm{CCV}$

DDI

DOE

DUP

EDS

EMSP

EPA

EQL

ESL

EXAFS

FUS

GEA

HLW

IC

ICP-AES

ICP-MS

ICP-OES

ICDD

JCPDS

LOQ

N/A

ND

NR

PDFTM

PNC-CAT

PNNL

QA

QC

RPL

se

SEM

TBP

TEM

TIC

TOC sample that has undergone the EPA acid digestion (or extraction) procedure

alpha energy analysis

American Society for Testing and Materials

amorphous

average

backscattered electron

continuing calibration verification

distilled deionized (water)

U.S. Department of Energy

duplicate sample

energy-dispersive X-ray spectrometry

DOE's Environmental Management Science Program

U.S. Environmental Protection Agency

estimated quantitation limit

Environmental Science Laboratory

extended X-ray absorption fine structure

sample that has undergone the $\mathrm{KOH}-\mathrm{KNO}_{3}$ fusion treatment

gamma energy analysis

high-level radioactive waste

ion chromatography (chromatograph)

inductively coupled plasma-atomic emission spectroscopy (same as ICP-OES)

inductively coupled plasma-mass spectroscopy (spectrometer)

inductively coupled plasma-optical emission spectroscopy (same as ICP-AES)

International Center for Diffraction Data, Newtown Square, Pennsylvania

Joint Committee on Powder Diffraction Standards

limit of quantification

not applicable

not detected

not reported

powder diffraction file

Pacific Northwest Consortium - collaborative access team

Pacific Northwest National Laboratory

quality assurance

quality control

Radiochemical Processing Laboratory

secondary electron

scanning electron microscopy (or microscope)

tributyl phosphate

transmission electron microscopy (or microscope)

total inorganic carbon

total organic carbon 
TRU transuranic (waste)

WE sample that has undergone a water extraction procedure

XAS X-ray absorption spectroscopy

XANES X-ray absorption near edge structure

$\mathrm{XRD} \quad \mathrm{X}$-ray powder diffractometry analysis (commonly called X-ray diffraction) 


\section{Units of Measure}

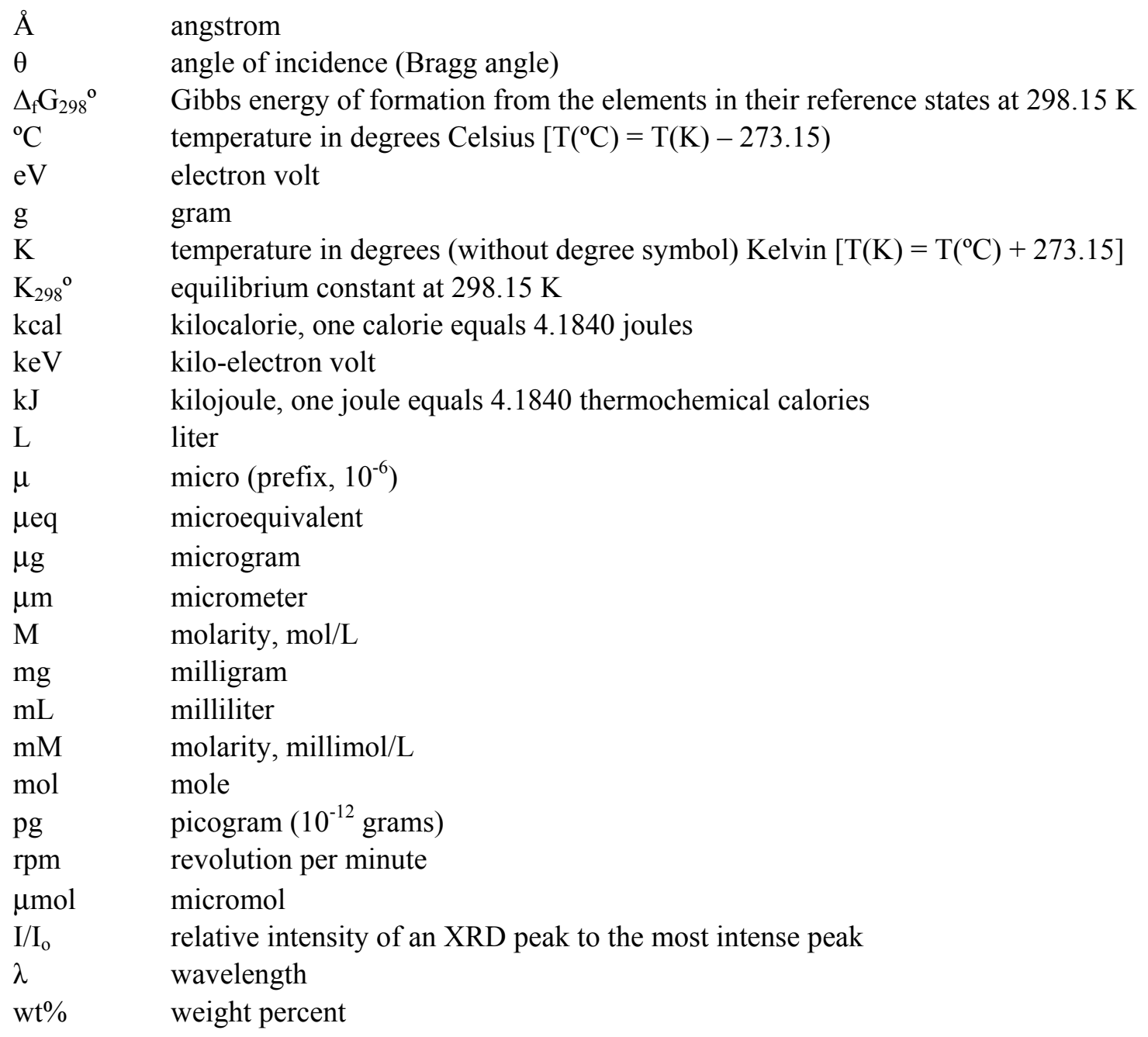




\section{Contents}

Summary

Acknowledgments................................................................................................................... ix

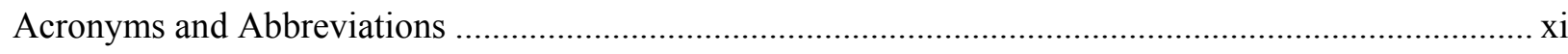

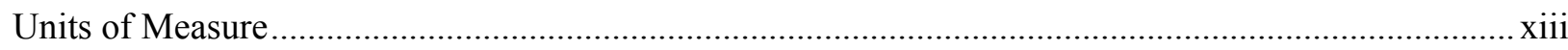

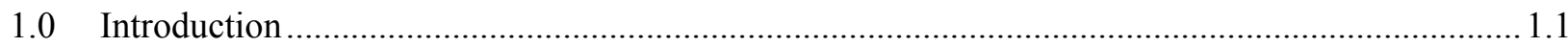

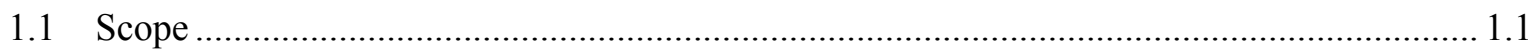

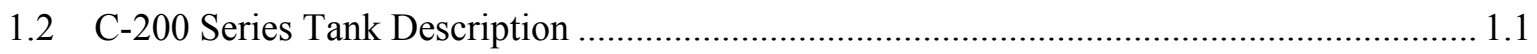

2.0 Materials and Laboratory Test Methods ………………......................................................... 2.1

$2.1 \quad$ C-203 and C-204 Sludge Samples................................................................................... 2.1

2.2 Sludge Composition by Fusion Analysis and Acid Digestion ............................................ 2.3

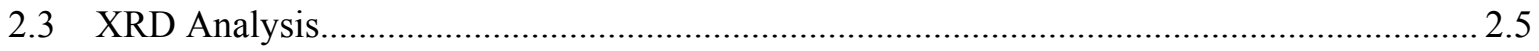

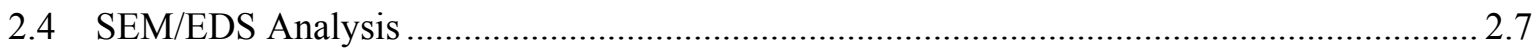

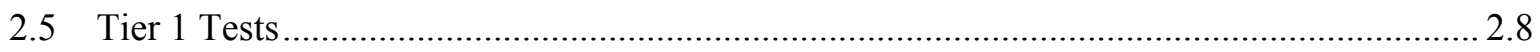

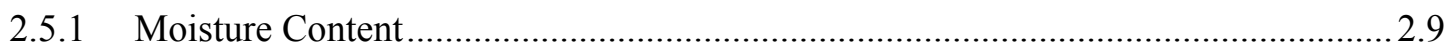

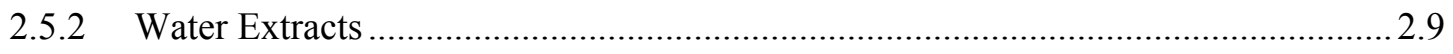

2.5.3 Periodic Replenishment Tests ......................................................................... 2.9

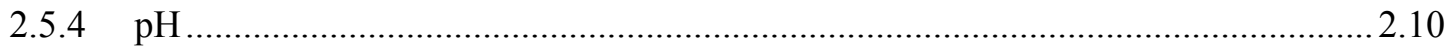

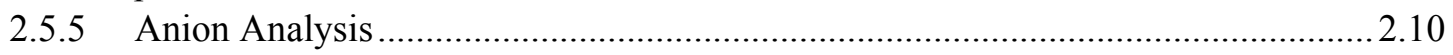

2.5.6 Cations and Trace Metals …………………………....................................... 2.10

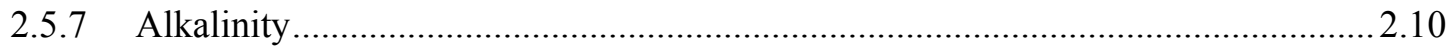

2.5.8 ${ }^{129}$ I Extraction and Analysis ................................................................................... 2.10

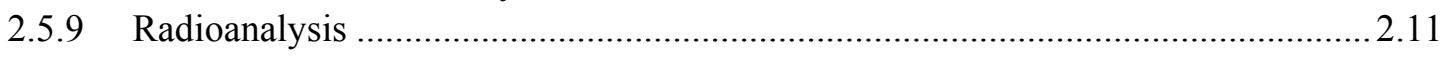

2.6 Selective Extraction Tests ................................................................................................ 2.13

2.7 Uranium Mineral Solubility Measurements ................................................................... 2.15

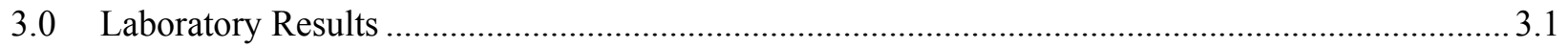

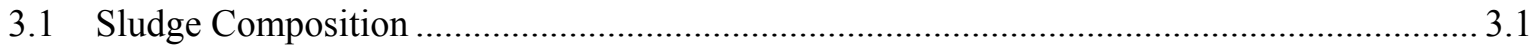

$3.2 \quad{ }^{129} \mathrm{I}$ Extraction and Measurement.................................................................................... 3.10 


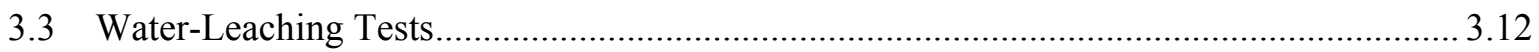

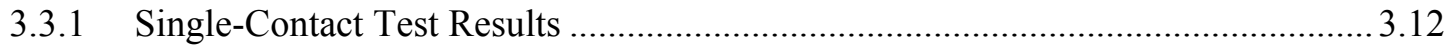

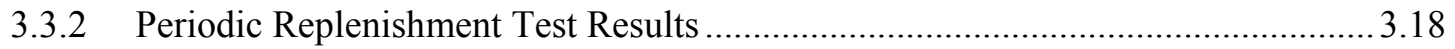

3.3.3 Uranium Mineral Solubility Measurements ...................................................... 3.27

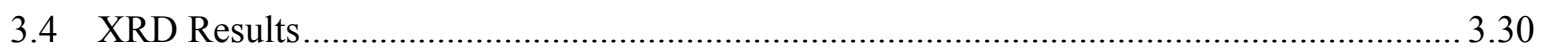

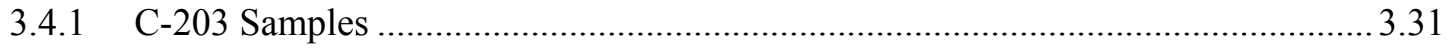

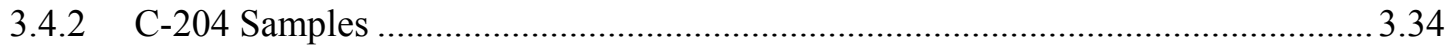

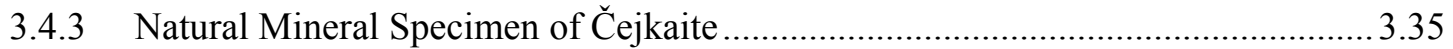

3.4.4 Comparison of Leached and Unleached C-203 and C-204 Sludge Samples ...........3.35

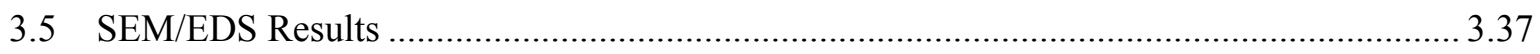

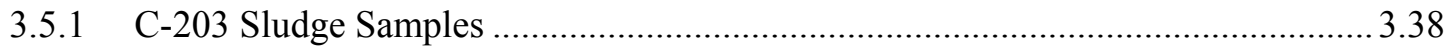

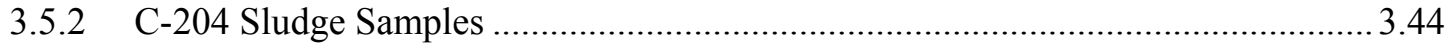

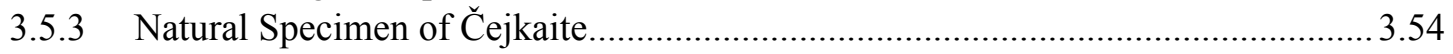

3.6 Selective Extraction Results .................................................................................... 3.54

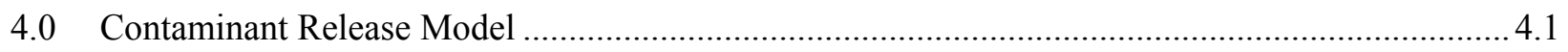

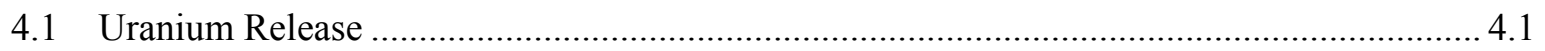

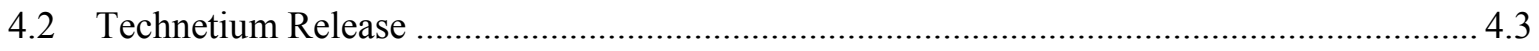

4.3 Integration of C-203 and C-204 Release Data with Fate and Transport Modeling Codes..... 4.5

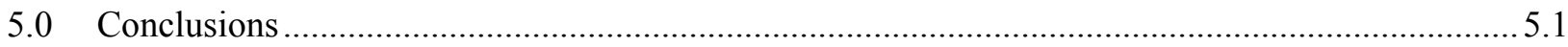

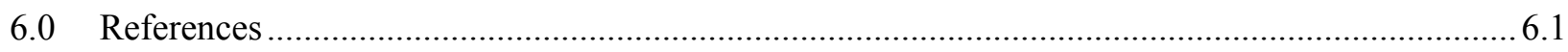

Appendix A - X-Ray Diffraction Patterns for Sludge Samples and Natural Specimen of Čejkaite ......... A.1

Appendix B - SEM Micrographs and EDS Spectra for C-203 Sludge Samples.....................................1

Appendix C - SEM Micrographs and EDS Spectra for C-204 Sludge Samples.....................................1

Appendix D - SEM Micrographs and EDS Spectra for Natural Specimen of Čejkaite........................... D.1 


\section{Figures}

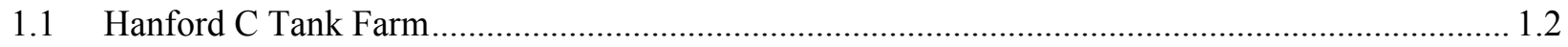

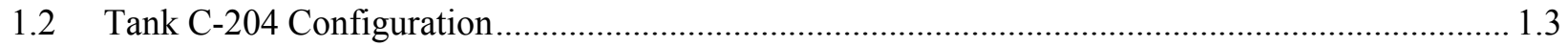

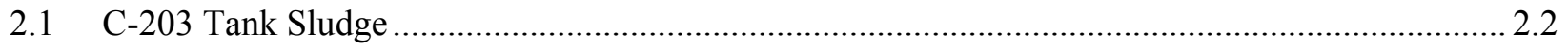

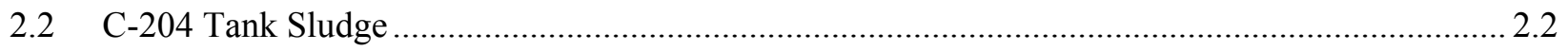

2.3 Yellow Nuggets Discovered in the Matrix of C-203 Tank Sludge............................................... 2.2

2.4 Exploded Schematic View of the XRD Sample Holder ........................................................ 2.6

2.5 XRD Pattern for Collodion Film Measured in the Absence of Sludge Material .......................... 2.6

2.6 Extraction Sequence to Determine Phase Associations of ${ }^{99} \mathrm{Tc}$ and $\mathrm{U}$.................................... 2.14

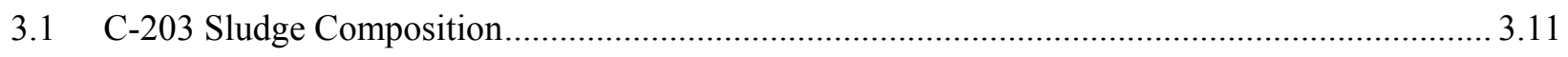

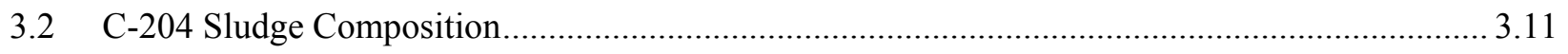

3.3 Background-Subtracted XRD Pattern for the Unleached C-203 Bulk Sludge Shown with XRD Patterns for Čejkaite and Clarkeite............................................................................. 3.32

3.4 As-Measured XRD Pattern for Yellow Nugget Material in Unleached C-203 Bulk Sludge Shown with XRD Patterns for Čejkaite and Natratine ............................................................. 3.32

3.5 As-Measured and Background-Subtracted XRD Patterns for Two-Week Water-Leached C-203 Sludge

3.6 Background-Subtracted XRD Pattern for the Unleached C-204 Bulk Sludge Shown with the XRD Pattern for Čejkaite

3.7 As-Measured XRD Pattern for Two-Week Water-Leached C-204 Bulk Sludge ......................... 3.35

3.8 Background-Subtracted XRD Pattern for the Natural Specimen of Unleached Čejkaite Shown with Database XRD Pattern .................................................................................. 3.36

3.9 Background-Subtracted XRD Patterns for the Unleached C-203 and C-204 Sludge Samples ..... 3.36

3.10 SEM Micrographs Showing Typical Particles Present in the Unleached C-203 Bulk Sludge ...... 3.38

3.11 Secondary-Electron SEM Micrographs of Yellow Nugget Material from Unleached C-203 Bulk Sludge Sample

3.12 SEM Micrographs Showing Typical Particles Present in Two-Week Water-Leached C-203 Bulk Sludge 
3.13 Micrographs of Unusual Particle in the Sample of Two-Week Water-Leached C-203

Sludge Coated with Oriented Crystals of Čejkaite

3.14 SEM Micrographs Showing Typical Particles Present in the Two-Month Water-Leached

C-203 Bulk Sludge

3.15 SEM Micrographs Showing Typical Particles Present in the Three-Month Water Leach

of C-203 Bulk Sludge

3.16 SEM Micrographs of Solid Products Remaining at the Termination of the 1:1 Solubility

Experiments with C-203 Bulk Sludge

3.17 SEM Micrographs Showing Typical Particles Present in Unleached C-204 Sludge.

3.18 SEM Micrographs Showing Typical Particles Present in Two-Week Water-Leached C-204 Sludge

3.19 SEM Micrographs Showing Typical Particles Present in Two-Month Water-Leached C-204 Sludge

3.20 SEM Micrographs of Botryoidal Aggregates of Fe Oxide with Preferential Dissolution

Pits from the Two-Month Water Leach of C-204 Sludge.

3.21 SEM Micrographs Showing Dissolution of an Fe Oxide Coating on a Large Particle of Possibly Na-Al-P-O from the Two-Month Water Leach of C-204 Sludge ....

3.22 SEM Micrographs of Typical Particles in Water-Contact Selective Extraction of C 204 Sludge

3.23 SEM Micrographs of Typical Particles in Acetate-Contact Selective Extraction of C 204 Sludge

3.24 SEM Micrographs of Typical Particles in Ethanol-Contact Selective Extraction of C 204 Sludge

3.25 SEM Micrographs Showing the Morphology of Typical Particles in Material Remaining from the Three-Day HF/Na Sequential Extraction of C-204 Sludge.

3.26 SEM Micrographs Showing the Morphology of U-Containing Platy Particles Observed on the Surfaces of a Few Grains Present in Residue from the Three-Day HF/Na Sequential Extraction of C-204 Sludge

3.27 SEM Micrographs of Typical Crystals Present in the Natural Mineral Specimen of Čejkaite...... 3.54

4.1 Source Release Model Development for Long-Term Performance Assessments 4.1

xviii 


\section{Tables}

1.1 Tank C-204 Estimated Contents Based on Historical Transfer Data.............................................. 1.5

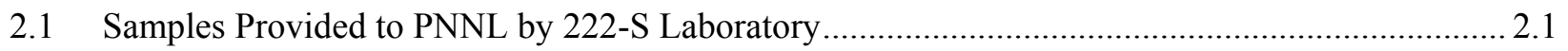

2.2 Digestion Factors for Samples of C-203 and C-204 Sludge Solids Used for the EPA Acid

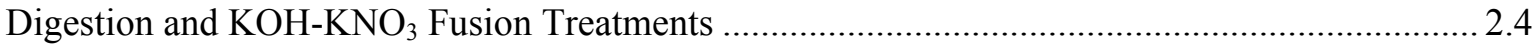

2.3 Summary of the Sludge Samples Analyzed by XRD or SEM/EDS …........................................2.5

2.4 Digestion Factors for Samples of C-203 Sludge Solids Used for the Modified KOH-KNO Water Fusion Treatment to Measure ${ }^{129} \mathrm{I}$............................................................................. 2.11

3.1 Moisture Contents of C-203 and C-204 Sludge Samples ........................................................... 3.2

3.2 Concentrations of Elements Measured by ICP-OES per Gram of Dry Sludge ............................. 3.3

3.3 Concentrations of Elements Measured by ICP-OES per Gram of Dry Sludge ............................. 3.3

3.4 Concentrations of Elements Measured by ICP-OES per Gram of Dry Sludge ............................ 3.4

3.5 Concentrations of Elements Determined from ICP-MS Analysis per Gram of Dry Sludge ........... 3.6

3.6 Concentrations of Elements Determined from ICP-MS Analysis per Gram of Dry Sludge ........... 3.6

3.7 Concentrations of ${ }^{99} \mathrm{Tc}$ and ${ }^{238} \mathrm{U}$, Measured by ICP-MS per Gram of Dry Sludge ....................... 3.7

$3.8 \quad{ }^{137}$ Cs Concentrations in Dry Sludge as Measured by GEA...................................................... 3.8

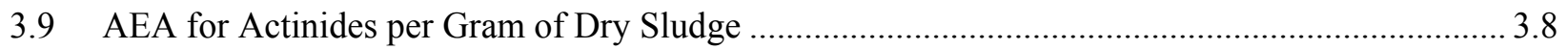

3.10 Total Beta and Total Alpha Activities and ${ }^{90}$ Sr Concentrations per Gram of Dry Sludge .............. 3.9

3.11 Summary of Average Concentrations from the $\mathrm{KOH}-\mathrm{KNO}_{3}$ Fusion and EPA Acid Digestion Analyses for C-203 and C-204 Sludge Samples.................................................................... 3.10

3.12 Summary of ${ }^{129} \mathrm{I}$ Concentrations for Modified $\mathrm{KOH}-\mathrm{KNO}_{3}$ Water Fusion Extracts for

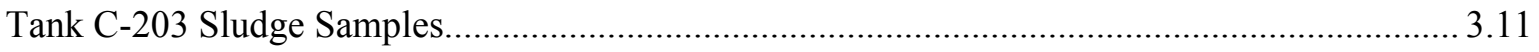

3.13 Water Extract pH and Alkalinity Values Corrected to Grams of Dry Sludge ............................ 3.13

$3.14{ }^{99} \mathrm{Tc}$ and ${ }^{238} \mathrm{U}$ Concentrations in C-203 and C-204 Sludge from Single-Contact Water-Leach Tests

3.15 Water-Leachable Percentages of ${ }^{99} \mathrm{Tc}$ and ${ }^{238} \mathrm{U}$ in C-203 and C-204 Sludge Samples Compared with Fusion Results 
3.16 Summary of ${ }^{129}$ I Concentrations from the Single-Contact Water-Leach Tests for C-203 and C-204.

3.17 Water-Leachable Average Metal Concentrations in C-203 and C-204 Single-Contact Water Extract.

3.18 Water-Leachable Metals in C-203 and C-204 Single-Contact Water Extract Compared with Fusion Results.

3.19 Average Anion Concentrations in C-203 and C-204 Single-Contact Water Extract.

3.20 GWA for C-203and C-204 Single-Contact Water Extractions and Direct Solids

3.21 Total Beta, Total Alpha, and ${ }^{90} \mathrm{Sr}$ Single-Contact Water Extracts

3.22 Actinide Analysis for C-203 and C-204 Single-Contact Water Extracts.

3.23 Water-Leachable Percentage for Actinides in C-203 and C-204 Single-Contact Water Extracts Compared with Fusion Analysis.

3.24 Contact Times and Average pH Values for Periodic Replenishment Test on

Tanks C-203 and C-204 Sludge.

3.25 ${ }^{99} \mathrm{Tc}$ and ${ }^{238} \mathrm{U}$ Concentrations in C-203 and C-204 Sludge for Periodic Replenishment Water Extracts

3.26 Water-Leachable Percentages of ${ }^{99} \mathrm{Tc}$ and ${ }^{238} \mathrm{U}$ in C-203 and C-204 Sludge Samples for Periodic Replenishment Relative to Fusion Results

3.27 Water-Leachable Average Metals in C-203 and C-204 Periodic Replenishment Water Extract

3.28 Water-Leachable Average Metal Concentrations in C-203 and C-204 Periodic Replenishment Water Extract

3.29 Average Anion Concentrations in C-203 and C-204 Periodic Replenishment Water Extract ...... 3.25

3.30 GEA for C-203 and C-204 Periodic Replenishment Water Extraction ...................................... 3.26

3.31 Total Beta, Total Alpha, and ${ }^{90} \mathrm{Sr}$ Analysis for C-203 and C-204 Periodic Replenishment Water Extracts

3.32 Actinide Analysis for C-203 and C-204 Periodic Replenishment Water Extracts

3.33 Water-Leachable Percentage for Actinides in C-203 and C-204 Periodic Replenishment Water Extracts Compared with Fusion Analysis. 
3.34 Empirical Čejkaite Solubility Results for C-203 and C-204 Sludge Samples.....

3.35 Selective Extraction Experiment Results for C-203 and C-204 Sludge Samples.....

3.36 Average and Total Selective Extraction Results as a Percentage of the Fusion Results for C-203 and C-204 Sludge Samples

3.37 Extracted Concentrations of Selected Elements from C-204 Sludge by 0.02 M Hydrofluoric Acid/0.01 Sodium Fluoride Buffer Solution.

3.38 Percent Extracted for Selected Elements from C-204 Sludge by 0.02 M Hydrofluoric Acid/0.01 Sodium Fluoride Buffer Solution. 3.57

4.1 Summary of Uranium Release Model Data. 4.3

4.2 ${ }^{99}$ Tc Concentrations Measured in Čejkaite Solubility Extracts......

4.3 Summary of ${ }^{99}$ Tc Release Model Data for C-203 and C-204 Sludge 4.4

4.4 Conceptual Contaminant Release Model for Tanks C-203 and C-204. 


\subsection{Introduction}

This report describes the development of release models for contaminants of concern that may be present in residual waste in Hanford Tanks 241-C-203 (C-203) and 241-C-204 (C-204) after closure. These release models are necessary components of the performance assessments being conducted as part of the closure process. From the perspective of long-term risk to the environment, the primary contaminants of concern are ${ }^{99} \mathrm{Tc},{ }^{238} \mathrm{U}$, and ${ }^{129} \mathrm{I}$ because of their mobility in the environment and long halflives. Sludges from Tanks C-203 and C-204 were collected during preretrieval activities to characterize the geochemistry of the solids and to quantify the release of the primary contaminants into water that may contact residual sludge after tank closure.

The remainder of this section describes the scope of work for laboratory testing and release model development as well as background information on the C-200 series tanks. The sludge samples and laboratory testing procedures for this project are described in Section 2 of this report, and the results are provided in Section 3. Release models are discussed in Section 4 and general conclusions in Section 5. Cited references are listed in Section 6, and supporting material is included in the appendixes.

\subsection{Scope}

Initial (Tier 1) laboratory tests were conducted to characterize the sludge and identify water-leachable constituents. The Tier 1 tests consisted primarily of fusion analysis and acid digestion, which measured elemental concentrations in the solid and water leaching of contaminants from the sludge to evaluate their mobility in infiltrating water. Based on the results of the Tier 1 tests, additional analyses were performed to augment the characterization of the material and elucidate the controlling mechanism(s) for the release of contaminants. Tier 2 tests consisted of X-ray diffraction (XRD) and scanning electron microscopy/ energy dispersive spectrometry (SEM/EDS) analyses of the solids to identify reactive phases and selective extraction and uranium mineral solubility measurements and to quantify the release of contaminants from particular solid phases.

The laboratory results of sludge testing were used to develop source term models that describe the release of contaminants as infiltrating water contacts the solids in the future. These models simulate the geochemical system in the tank sludge and take into account interactions between the solution phase and the contaminant-containing solids. The release models are simplifications of the complex geochemical interactions occurring between the phases; however, they adequately represent the release of the key contaminants technetium and uranium from the sludge as measured in laboratory tests. ${ }^{129}$ Iodine was not present at measurable concentrations in the sludge or most water extracts; therefore, a release model could not be developed for this radionuclide in the two sludges that were studied.

\subsection{C-200 Series Tank Description}

The C-200 series consists of four single-shell underground waste tanks (C-201 through C-204) in the C Tank Farm in the 200 East Area of the Hanford Site (Figure 1.1). These tanks are 20 feet in diameter and have a capacity of 55,000 gal when filled to a depth of 24 feet. Figure 1.2 is a schematic of the configuration of Tank C-204. 


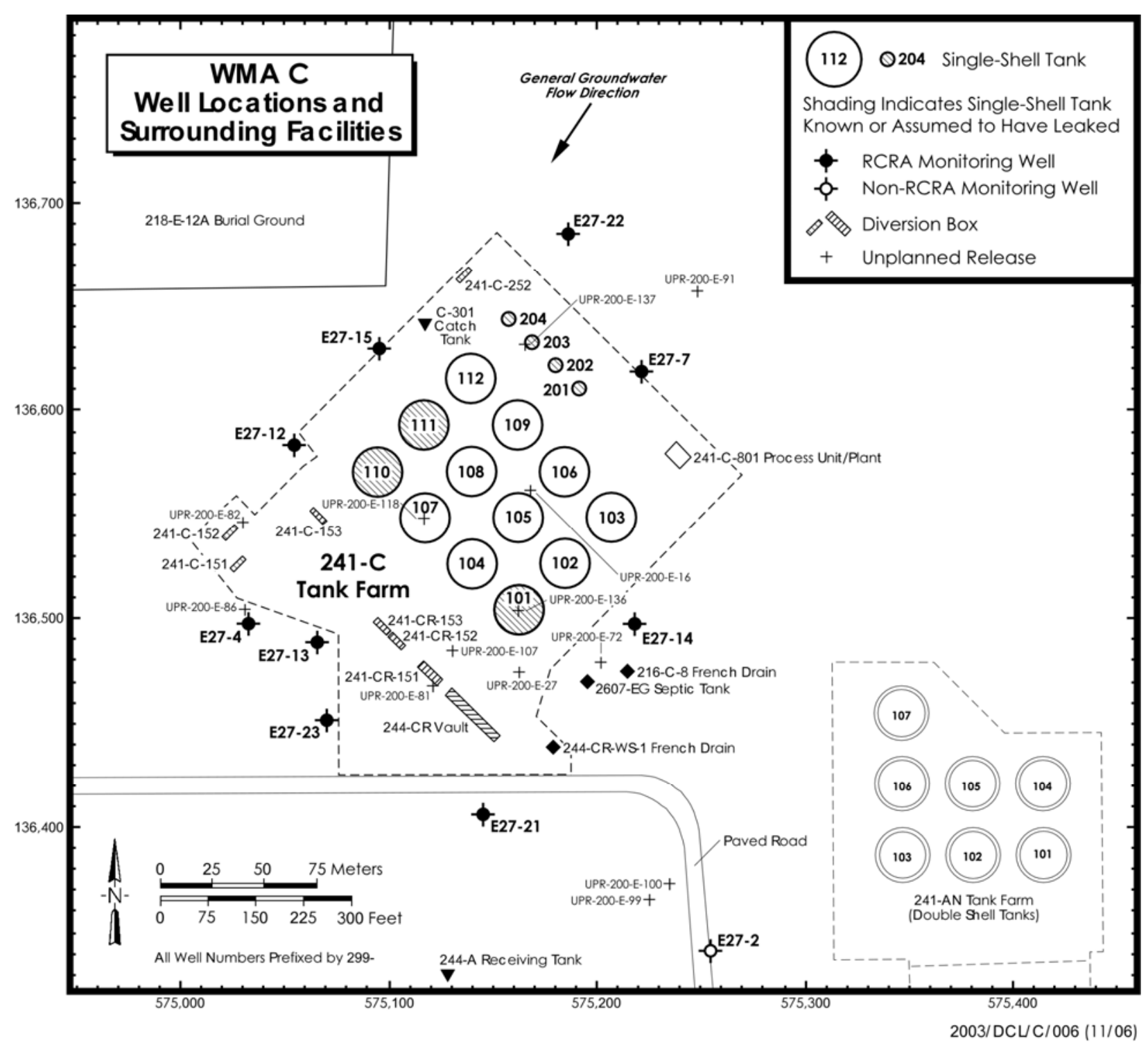

Figure 1.1. Hanford C Tank Farm

The history of waste transfers into and removals from these tanks provides an indication of the types of residual materials that may be present in the tanks. The following information on tank transfers is summarized from Johnson (2003).

- Metal waste transfers

- November 1947 to January 31, 1948 - four tanks filled with metal waste

- Measurements on May 27, 1948 showed each tank had about 4 feet of sludge and 18 feet of liquid above the sludge

- February 1952 - metal waste began to be removed from these tanks by pumping and sluicing

○ February 1955 - removal complete; all sludge reportedly removed, as shown by visual inspections through a periscope (undoubtedly some residual waste remained) 


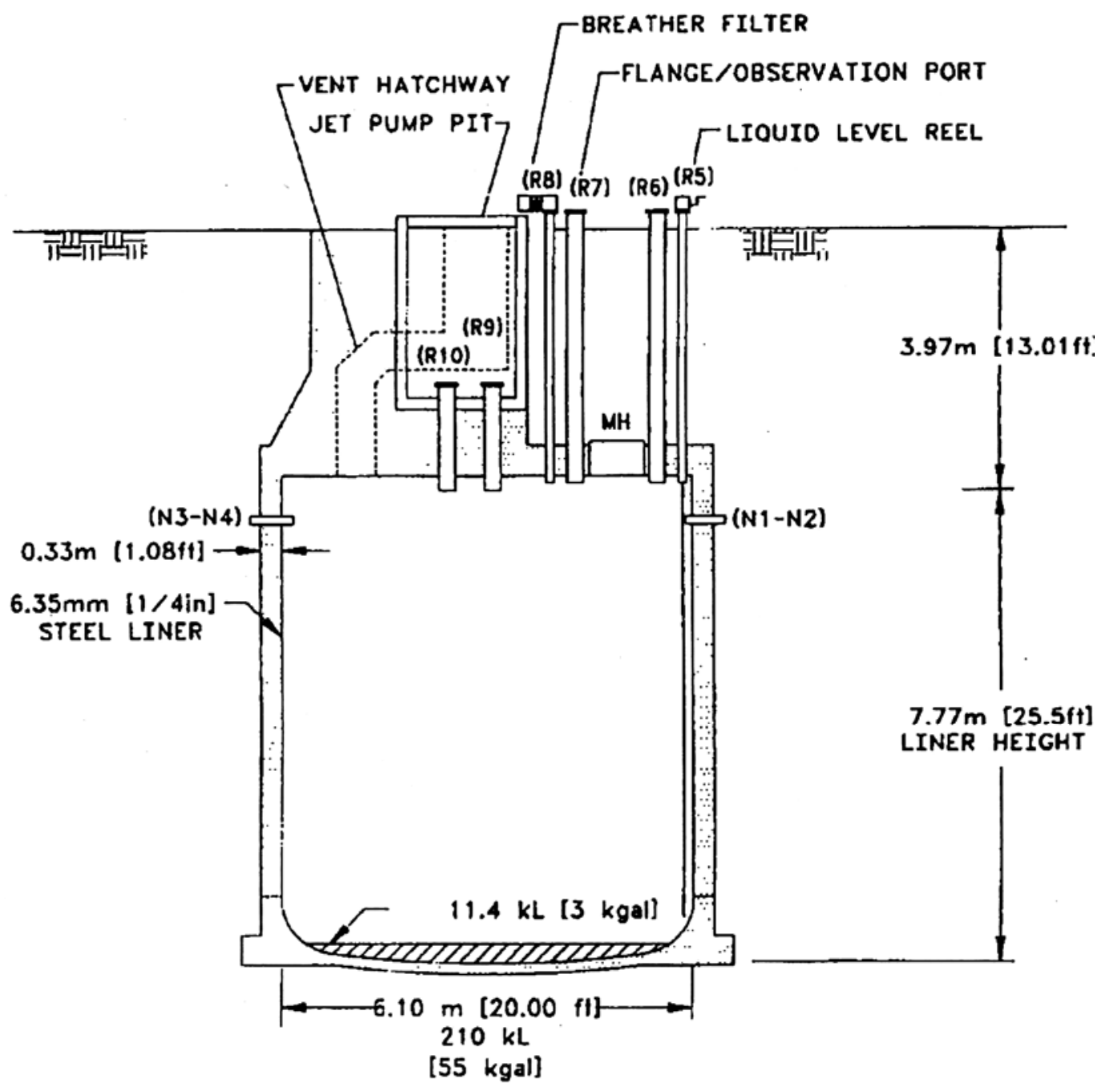

Figure 1.2. Tank C-204 Configuration (Conner 1996)

- Hot Semiworks transfers

- May 1955-November 1956 - highly radioactive waste from research and development (R\&D) of PUREX process in the Hot Semiworks facility was concentrated to recover nitric acid, neutralized with sodium hydroxide solution, and transferred to the four tanks.

- May 1956 - C-201 and C-202 were reported filled with this waste.

$\circ$ November 1956 - C-203 and C-204 were reported to contain 34,500 gal of this waste

- PUREX plant cold uranium run wastes

- November 1955 - C-203 and C-204 received waste from cold uranium runs as part of startup operations at the PUREX plant

- No additional waste after November 1956 
- Supernatant Removal

o January-March 1970 - C-203: 19,000 gal pumped to C-109

$\circ$ April-June 1970 - C-201 through C-204: supernatant pumped to C-104; with the exception of C-204, these tanks contained only a heel of sludge following the transfer of these amounts:

- C-201: 54,000 gal

- C-202: 55,000 gal

- C-203: 12,000 gal

- C-204: 14,000 gal (contained 41,000 gal of supernatant in June 1970)

○ July 10, 1977 - C-204: supernatant pumped out, leaving only 3,000 gal in this tank

- October 1980 - C-201 through C-204 supernatant pumped into C-106 using a submersible pump

- Because of the limitations of sludge removal by sluicing and supernatant removal by pumping, some residual material remained in the tanks after the removal campaigns.

Two auger samples of the sludges in Tank C-204 were collected in May 1995 (Conner 1996). At that time, it was estimated that the tank contained $11 \mathrm{~kL}(3 \mathrm{kgal}, 1.3 \mathrm{ft})$ of waste in the form of sludge. The solid samples were analyzed for energetics, moisture, total alpha content, total organic carbon content, and organic compounds. The analytical results (on a wet weight basis) were:

- Percent water

- Energetics

- Total alpha

- Total inorganic carbon

- Total organic carbon

- Tributyl phosphate

- Dibutyl phosphate
$56.95 \%$

$813->1,234$ Joules/g (dry basis)

$0.0322 \mu \mathrm{Ci} / \mathrm{g}$

$10,500 \mu \mathrm{g} \mathrm{C} / \mathrm{g}$

$126,000 \mu \mathrm{g} \mathrm{C} / \mathrm{g}$

$330,000 \mu \mathrm{g} / \mathrm{g}$

$2,000 \mu \mathrm{g} / \mathrm{g}$

Tributyl phosphate was used as an organic solvent in several separations processes at the Hanford Site.

Other previous sampling and analysis events for the C-200 series tanks are not known; however, Conner (1996) estimated the contents of C-204 based on historical transfer data. These data were from the Waste Status and Transaction Record Summary for the Northeast Quadrant (Agnew et al. 1995b), the Hanford Tank Chemical and Radionuclide Compositions: HDW Model Rev. 3 (Agnew et al. 1996), the Tank Layer Model (TLM) (Agnew et al. 1995a), and the Historical Tank Content Estimate for the Northeast Quadrant of the Hanford 200 East Area (Brevick et al. 1994). Conner (1996) cautions that several errors are introduced as the models create the estimate, and model predictions require further evaluation using analytical measurements. Table 1.1 shows the estimate of the expected waste constituents and their concentrations.

The histories of the C-200 series tanks suggest that the wastes in the tanks should be of similar composition; however, as seen in the following sections, the materials in Tanks C-203 and C-204 have very different chemical compositions. 
Table 1.1. Tank C-204 Estimated Contents Based on Historical Transfer Data ${ }^{(\mathrm{a}, \mathrm{b})}$ (from Conner 1996)

\begin{tabular}{|c|c|}
\hline Physical Properties & "Concentration/Amounts \\
\hline Total Solid Waste & $18,700 \mathrm{~kg}(3.0 \mathrm{kgal})$ \\
\hline Bulk Density & $1.65 \mathrm{~g} / \mathrm{cm}^{3}$ \\
\hline Water Content & $44.1 \mathrm{wt} \%$ \\
\hline Chemical Constituents & ppm \\
\hline $\mathrm{Na}^{+}$ & 55,400 \\
\hline $\mathrm{Fe}^{3+}($ total $\mathrm{Fe})$ & 66,700 \\
\hline$\overline{\mathrm{Cr}^{3+}}$ & 95.5 \\
\hline $\mathrm{Pb}^{2+}$ & 6,350 \\
\hline $\mathrm{Ni}^{2+}$ & 2,210 \\
\hline $\mathrm{Ca}^{2+}$ & 1,400 \\
\hline $\mathrm{K}^{+}$ & 583 \\
\hline $\mathrm{OH}^{-}$ & 146,000 \\
\hline $\mathrm{NO}_{3}^{-}$ & 1,570 \\
\hline $\mathrm{NO}_{2}^{-}$ & 8,520 \\
\hline $\mathrm{CO}_{3}{ }^{2-}$ & 45,900 \\
\hline $\mathrm{PO}_{4}^{3-}$ & 15,400 \\
\hline $\mathrm{SO}_{4}{ }^{2-}$ & 4,270 \\
\hline $\mathrm{Si}\left(\right.$ as $\left.\mathrm{SiO}_{3}{ }^{2-}\right)$ & 17.6 \\
\hline $\mathrm{Cl}-$ & 309 \\
\hline $\mathrm{C}_{6} \mathrm{H}_{5} \mathrm{O}_{7}{ }^{3-}$ & 1,260 \\
\hline EDTA $^{4-}$ & 3,840 \\
\hline acetate & 5,020 \\
\hline $\mathrm{NH}_{3}$ & 1,530 \\
\hline \multicolumn{2}{|l|}{ Radiological Constituents } \\
\hline $\mathrm{U}(\mathrm{ppm})$ & 192,000 \\
\hline $\mathrm{Pu}(\mu \mathrm{Ci} / \mathrm{g})$ & 0.00263 \\
\hline $\mathrm{Cs}(\mu \mathrm{Ci} / \mathrm{g})$ & 0.34 \\
\hline $\mathrm{Sr}(\mu \mathrm{Ci} / \mathrm{g})$ & 3,650 \\
\hline \multicolumn{2}{|l|}{ (a) Agnew et al. 1996.} \\
\hline \multicolumn{2}{|c|}{$\begin{array}{l}\text { (b) The HTCE predictions have not been validated and should be used } \\
\text { with caution. }\end{array}$} \\
\hline
\end{tabular}




\subsection{Materials and Laboratory Test Methods}

Sludge samples from Tanks C-203 and C-204 were collected by CH2M HILL during preretrieval activities in September 2003. Samples were collected for testing prior to final sludge retrieval because of the greater likelihood of successful sampling before than after final retrieval, when less sludge would be available to sample. Also, because a dry retrieval method would be used on these tanks, it was not expected that retrieval would change the composition of the waste appreciably. Because of the availability of sludge from Tanks C-203 and C-204, wastes from these tanks were used for laboratory testing to develop representative contaminant release models for the C-200 series tanks. Sludge samples from these two tanks were supplied to Pacific Northwest National Laboratory (PNNL) by CH2M HILL on December 11, 2003. Preretrieval sludge samples were subsequently collected from Tanks C-201 and C-202; however, at this time, testing and release model development is not scheduled for these tanks.

This section provides a description of the sludge samples and the various tests used to characterize the material, measure contaminant release, and identify controlling solids.

\subsection{C-203 and C-204 Sludge Samples}

Four grab samples of sludge were collected by CH2M HILL from Riser 6 (Figure 1.2) of Tank C-203 on September 16, 2003; five grab samples of sludge were collected from Riser 7 of this tank on September 29, 2003. Four grab samples were collected by CH2M HILL from Riser 6 of Tank C-204 on September 9, 2003, and an additional five grab samples were collected from Riser 7 on September 10, 2003. All samples were sent to the Hanford 222-S laboratory, where they were composited for each riser. Before the samples were shipped to PNNL, the composited samples from each riser were combined to produce a single sludge sample to represent each tank. The tank samples listed in Table 2.1 were received by PNNL on December 11, 2003.

During preparation of residual tank waste samples for Tier 2 testing, large yellow particles (or nuggets) (Figure 2.3) were discovered embedded in the bulk unleached C-203 sludge sample from jar 19649. These particles are referred to as "yellow nuggets" throughout this report. The discovery occurred when sludge was being removed from jar \#19649 for Tier 2 testing, and some clumps of brown bulk sludge were found to be resistant to fragmentation when poked with a spatula. Further inspection showed that the interiors of these clumps of sludge contained nuggets of yellow mineralization. These nuggets range in size from several millimeters to over a centimeter in diameter (Figure 2.3). Material from one of these yellow nuggets was submitted for characterization by XRD and SEM/EDS analysis.

Table 2.1. Samples Provided to PNNL by 222-S Laboratory

\begin{tabular}{||c|c|c|c|c||}
\hline \hline Tank & Jar \# & Jar Size (mL) & Labcore Number & Net Weight of Material (g) \\
\hline \hline $241-C-203$ & 19649 & 250 & S03T001858 & 139.7 \\
\hline $241-C-204$ & 19650 & 250 & S03T001815 & 141.1 \\
\hline
\end{tabular}




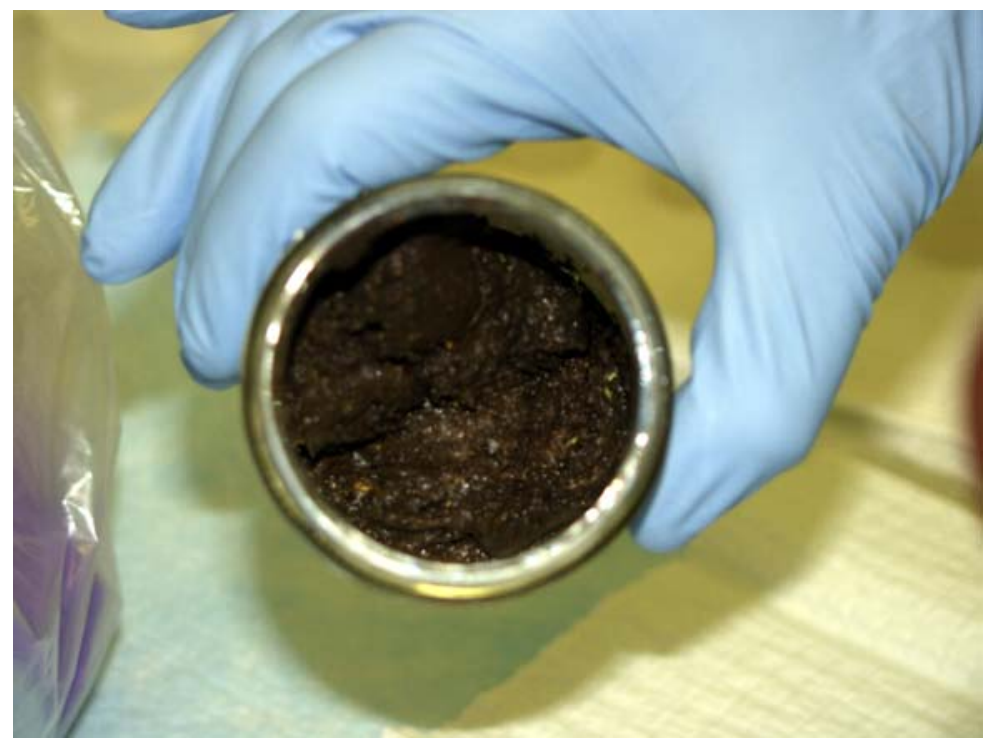

Figure 2.1. C-203 Tank Sludge (Jar 19649)

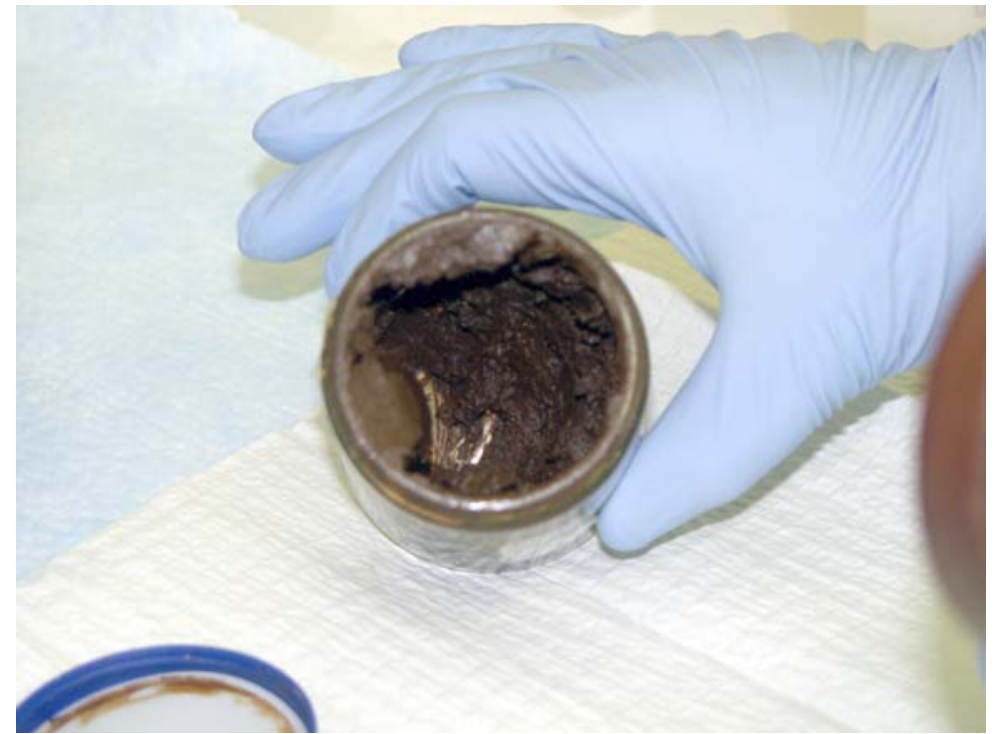

Figure 2.2. C-204 Tank Sludge (Jar 19650)

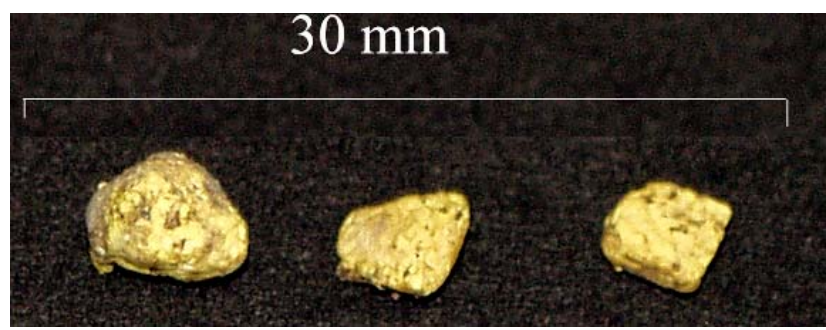

Figure 2.3. Yellow Nuggets Discovered in the Matrix of C-203 Tank Sludge 


\subsection{Sludge Composition by Fusion Analysis and Acid Digestion}

The bulk compositions of the sludge solids were determined using accepted PNNL internal procedure AGG-ESL-001, Solubilization of Metals from Solids Using a $\mathrm{KOH}-\mathrm{KNO}_{3} \mathrm{Fusion}^{(a)}$ and a modified version of U.S. Environmental Protection Agency (EPA) SW-846 Method 3050B (EPA 2000). These methods were used to measure the elemental composition of the sludge, but are not appropriate for the anion concentrations due to the acids used in the analyses. The anion compositions were measured separately in solutions obtained by water leaching of the solids (see Section 2.5.5).

The potassium hydroxide $(\mathrm{KOH})$-potassium nitrate $\left(\mathrm{KNO}_{3}\right)$ fusion-dissolution procedure is the most commonly used method for solubilization of Hanford tank sludge samples for chemical analysis by inductively coupled plasma-mass spectroscopy (ICP-MS) and other methods (De Lorenzo et al. 1994; Simpson 1994; Fiskum et al. 2000; Smith et al. 2001). Benefits of this procedure include: effective metathesizing of insoluble salts such as $\mathrm{SrSO}_{4}, \mathrm{PuPO}_{4}, \mathrm{PuF}_{3}$, and $\mathrm{ThF}_{3}$ into acid soluble hydroxides; completed fusion at relatively low temperature $\left(550^{\circ} \mathrm{C}\right)$ compared to other fluxing agents, such as $1100^{\circ} \mathrm{C}$ for the $\mathrm{LiBO}_{2}$ (lithium metaborate) fluxing agent; and use of nickel or zirconium crucibles, as opposed to the more costly platinum crucibles, for the fusion. ${ }^{(b)}$

The $\mathrm{KOH}-\mathrm{KNO}_{3}$ fusion-dissolution procedure consists of chemical analyses of a solution resulting from water and acid dissolutions of a solid that has been fused at a high temperature with a caustic fluxing agent. In this procedure, $300 \mathrm{mg}$ of the tank waste sludge material was mixed with $10 \mathrm{~mL}$ of a $20 \% \mathrm{KOH}$ and $2 \% \mathrm{KNO}_{3}$ solution as a fluxing agent in a zirconium crucible. The crucible was then placed on a hot plate and allowed to evaporate to dryness, after which it was covered and transferred to a muffle furnace preheated to $550^{\circ} \mathrm{C}$. Fusion was accomplished by heating the sample-flux mixture for 60 minutes at $550^{\circ} \mathrm{C}$. After 60 minutes, the crucible was removed from the furnace and allowed to cool to ambient room temperature. The fused solid was then dissolved in distilled deionized (DDI) water. The resulting solution was transferred to a $100-\mathrm{mL}$ volumetric flask to which $1 \mathrm{~mL}$ of $1.0 \mathrm{M}$ hydroxylamine $\mathrm{HCl}$ was added. Ten $\mathrm{mL}$ of an $8 \mathrm{M}$ nitric acid $\left(\mathrm{HNO}_{3}\right)$ solution was added to the crucible to try to dissolve any remaining residual solid. The acid wash solution was also added to the volumetric flask. The crucible was then triple-rinsed with DDI water, and these solutions were also added to the volumetric flask. The resulting solution was diluted up to a total volume of $100 \mathrm{~mL}$ with DDI water. Prior to chemical analysis, the final $100-\mathrm{mL}$ solution was passed through a Whatman 41 filter with final filtration through a $0.45-\mu \mathrm{m}$ pore-size syringe filter to remove any insoluble particles that did not dissolve in the nitric acid solution. The insoluble fractions are difficult to characterize because of the difficulty in removing them from the filter media.

Chemical analyses of an acid digestion of the sludge solids were also completed for comparison with the $\mathrm{KOH}-\mathrm{KNO}_{3}$ fusion procedure. For the acid digestion, $300 \mathrm{mg}$ of the tank waste sludge was digested following the basic procedure described in U.S. Environmental Protection Agency (EPA) SW-846 Method 3050B (EPA 2000) with the following exceptions: 1) all reagent volumes were reduced by 50\% because safety considerations necessitated smaller sample masses due to the high radioactivity levels

(a) Lindberg MJ. 2003. "Solubilization of Metals from Solids Using a KOH-KNO${ }_{3}$ Fusion." AGG-ESL-001 (Rev. 0), unpublished PNNL Technical Procedure, Pacific Northwest National Laboratory, Richland, WA.

(b) Personal communication with WI Winters (CH2M HILL), December 22, 2003. 
associated with these sludge solids, and 2) $\mathrm{HCl}$ was not added during the digestion to allow analysis of the resulting solutions by ICP-MS. If $\mathrm{HCl}$ is used, an $\mathrm{ArCl}^{+}$species is formed during ICP-MS analysis, which creates a spectral interference that impedes analysis of certain analytes. Throughout the remainder of this report, this treatment of sludge solids will be referred to as "EPA acid digestion."

For the EPA acid digestion procedure, $300 \mathrm{mg}$ of the sample is placed in a $50 \mathrm{~mL}$ Griffin beaker; $8 \mathrm{M}$ $\mathrm{HNO}_{3}$ is added to the sample, the beaker is covered with a watch glass, and the unit is heated to $95^{\circ} \mathrm{C}$. Successive additions of concentrated $\mathrm{HNO}_{3}$ and heating are performed until no reaction with the sample is noted. The sample is then allowed to digest for two hours at $95^{\circ} \mathrm{C}$. The sample is removed and allowed to cool; $30 \% \mathrm{H}_{2} \mathrm{O}_{2}$ is added to the sample, and the temperature is increased to $95^{\circ} \mathrm{C}$. Successive addition of $\mathrm{H}_{2} \mathrm{O}_{2}$ and heating are performed until no reaction is noticed. The sample is allowed to digest for 2 hours at $95^{\circ} \mathrm{C}$. After cooling, the solution is filtered through a Whatman 41 filter to remove any insoluble particles and brought to a final volume of $50 \mathrm{~mL}$ with DDI water. Samples are filtered through a $0.45-\mu \mathrm{m}$ pore-size syringe filter prior to analysis. The limited quantity of the insoluble fractions and the inability to remove this material from the filter media precluded their characterization.

Table 2.2 lists the digestion factors (wet solid-to-solution ratios) for the samples of C-203 (jar 19649) and C-204 (jar 19650) sludge solids used for the $\mathrm{KOH}-\mathrm{KNO}_{3}$ fusion treatments and EPA acid digestion. These factors were calculated from the wet weight of sludge material divided by the volume of extracting solution. The digestion factors were then multiplied by the percent solids, as determined from moisture content analysis, to convert to a dry weight basis. All EPA acid-digestion and fused-sample solutions were filtered using $0.45-\mu \mathrm{m}$ pore-size syringe filters prior to analysis. The dissolved metal concentrations and the total beta and total alpha activities for the filtered solutions were then analyzed by a combination of methods, including ICP-MS, inductively coupled plasma-optical emission spectroscopy (ICP-OES), and several radiochemical analytical techniques. These analytical methods are described in Lindberg and Deutsch (2003).

Table 2.2. Digestion Factors for Samples of C-203 (Jar 19649) and C-204 (Jar 19650) Sludge Solids Used for the EPA Acid Digestion and $\mathrm{KOH}-\mathrm{KNO}_{3}$ Fusion Treatments

\begin{tabular}{|c|c|c|}
\hline Treatment & Sample Number & $\begin{array}{l}\text { Dry Weight Corrected } \\
\text { Digestion Factor }(g / L)\end{array}$ \\
\hline \multirow{3}{*}{$\mathrm{KOH}-\mathrm{KNO}_{3}$ fusion } & Jar 19649 (203) & 5.7882 \\
\hline & Jar $19650(204)$ & 5.2551 \\
\hline & Jar 19650 (204) Dup & 6.4648 \\
\hline \multirow{4}{*}{ EPA acid digestion } & Jar $19649(203)$ & 11.0940 \\
\hline & Jar 19649 (203) Dup ${ }^{(a)}$ & 10.2869 \\
\hline & Jar 19650 (204) & 12.2803 \\
\hline & Jar 19650 (204) Dup & 12.5732 \\
\hline
\end{tabular}




\subsection{XRD Analysis}

Crystalline phases present in the as-received and the water-leached sludge samples were characterized by standard powder XRD techniques. Samples of solid materials remaining at the end of certain selective extraction tests and solubility experiments were also characterized by XRD and SEM/EDS methods. Table 2.3 contains a summary of the sludge samples analyzed by XRD and SEM/EDS. To help validate the uranium mineralization identified in the unleached C-203 and C-204 sludge samples, a natural specimen of čejkaite $\left[\mathrm{Na}_{4}\left(\mathrm{UO}_{2}\right)\left(\mathrm{CO}_{3}\right)_{3}\right]$ from the Svornost Mine at Jachymov in the Czech Republic was purchased from a commercial mineral-specimen company, and characterized by XRD and SEM/EDS. ${ }^{\text {(a) }}$

Because the sludge materials were highly radioactive, dispersible powders, it was necessary to prepare the XRD and SEM/EDS mounts of these samples inside a fume hood regulated for handling radioactive materials. Sludge samples were prepared for XRD analysis by placing milligram quantities of each sample into a mixture of water and collodion solution. The collodion solution consists of $2 \%$ nitrocellulose dissolved in amyl acetate. It was an X-ray amorphous, viscous binder commonly used to make random powder mounts for XRD when only a limited amount of sample is available. The slurry was pipetted onto a circular-shaped platform (1-cm diameter) and placed on top of the post located on the base inside a disposable XRD specimen holder (Figure 2.4). This specimen holder was designed specifically for safe handling of dispersible powders containing highly radioactive or hazardous materials (Strachan et al. 2003). After allowing samples to air dry overnight, the holder was assembled and a piece of Kapton ${ }^{\circledR}$ film placed between the cap and the retainer. The holder was sealed with wicking glue and removed from the fume hood.

Table 2.3. Summary of the Sludge Samples Analyzed by XRD or SEM/EDS

\begin{tabular}{|c|c|c|c|}
\hline \multicolumn{2}{|c|}{ Type of Solid Sample } & $\begin{array}{c}\text { Analysis by } \\
\text { XRD }\end{array}$ & $\begin{array}{l}\text { Analysis by } \\
\text { SEM/EDS }\end{array}$ \\
\hline \multirow{6}{*}{ C-203 (Jar 19649) sludge } & Unleached bulk solid & $\mathrm{x}$ & $\mathrm{x}$ \\
\hline & Unleached yellow nuggets & $\mathrm{x}$ & $\mathrm{x}$ \\
\hline & Water leached for 2 week & $\mathrm{x}$ & $\mathrm{x}$ \\
\hline & Water leached for 2 months & & $\mathrm{x}$ \\
\hline & Water leached for 3 months & $\mathrm{x}$ & $\mathrm{x}$ \\
\hline & $1: 1$ solubility experiment & & $\mathrm{x}$ \\
\hline \multirow{7}{*}{ C-204 (Jar 19650) sludge } & Unleached bulk solid & $\bar{x}$ & $\bar{x}$ \\
\hline & Water leached for 2 week & $\mathrm{x}$ & $\mathrm{x}$ \\
\hline & Water leached for 2 months & & $\mathrm{x}$ \\
\hline & Selective extraction - water contact & & $\mathrm{X}$ \\
\hline & Selective extraction - acetate contact & & $\mathrm{x}$ \\
\hline & Selective extraction - ethanol contact & & $\mathrm{x}$ \\
\hline & Selective extraction - HF acid/NaF buffer & & $\mathrm{x}$ \\
\hline $\begin{array}{l}\text { Natural specimen of } \\
\text { čejkaite mineralization }\end{array}$ & Unleached & $\overline{\mathrm{x}}$ & $\overline{\mathrm{x}}$ \\
\hline
\end{tabular}

(a) Excalibur Mineral Corp., Peekskill, NY. 


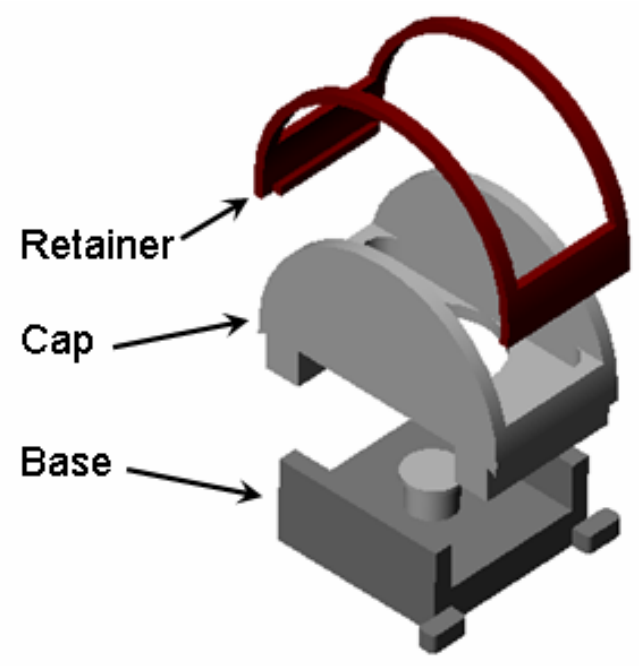

Figure 2.4. Exploded Schematic View of the XRD Sample Holder [Kapton ${ }^{\circledR}$ film not shown]

Each sample was analyzed using a Scintag XRD unit equipped with a Pelter thermoelectrically cooled detector and a copper X-ray tube. The diffractometer was operated at $45 \mathrm{kV}$ and $40 \mathrm{~mA}$. Individual scans were obtained from 2 to $65^{\circ} 2 \theta$ with a dwell time of 4 and 14 seconds. Scans were collected electronically and processed using the $\mathrm{JADE}^{\circledR}$ XRD pattern-processing software.

A sample consisting of only a dry film of the collodion solution was also prepared and analyzed by XRD so that its contribution relative to the background signals of the XRD patterns for the sludge samples could be quantified. The resulting XRD pattern for the collodion solution film is shown in Figure 2.5. The most obvious feature of this diffraction pattern is the broad peak positioned between $10^{\circ}$

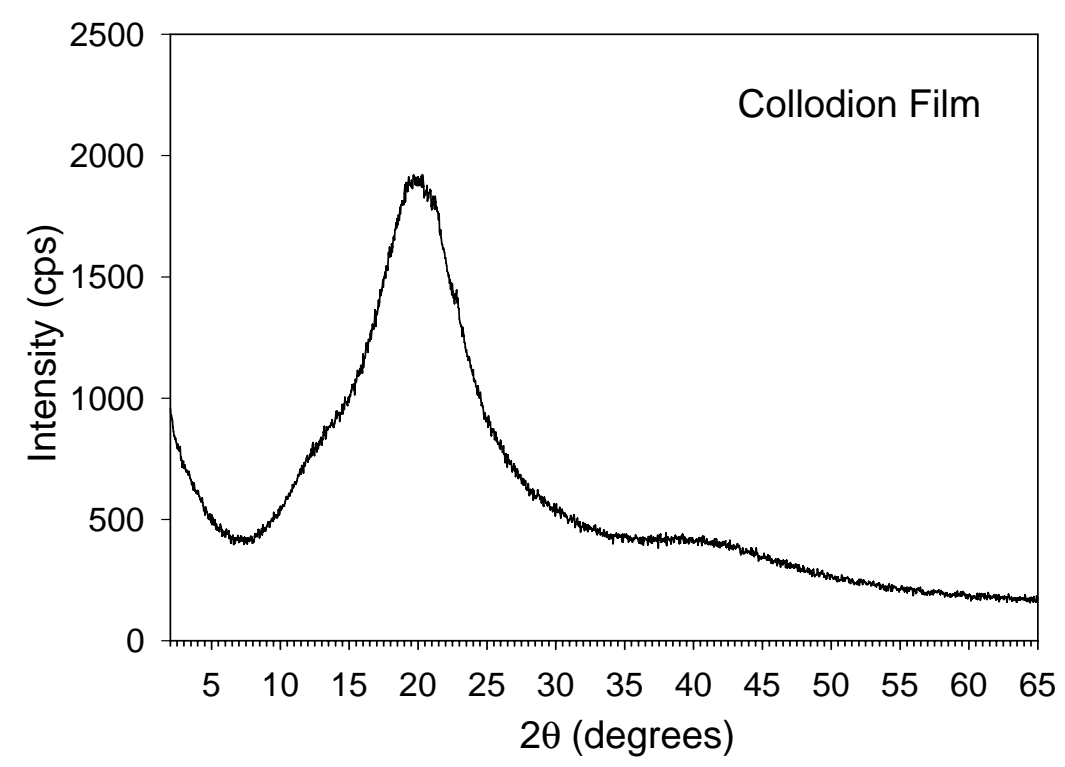

Figure 2.5. XRD Pattern for Collodion Film Measured in the Absence of Sludge Material 
and $30^{\circ} 2 \theta$. The symmetry of this peak is characteristic of those resulting from the XRD of amorphous (noncrystalline) material. Although subtracting the collodion background from sludge XRD patterns allows for better phase matching, this process may eliminate minor reflections and inconspicuous features of a pattern. Therefore, each as-measured XRD pattern was examined before and after background subtraction to ensure that the integrity of the pattern was maintained. For background subtraction, the $\mathrm{JADE}^{\circledR}$ software provides the user with control over the selection of background-subtraction points. This process allows a better fit to $2 \theta$ regions under broad reflections, such as those resulting from amorphous materials. On average, 30 to 40 background points were selected from each XRD pattern, and a cubicspline curve was then fit through each set of points. Adjustments to this curve were made by selecting additional background points in regions of a pattern that were difficult to fit. Once a well-matched curve was fitted to a pattern, the background was subtracted from each as-measured XRD pattern, resulting in a smooth tracing.

Identification of the mineral phases in the background-subtracted patterns was based on a comparison of the XRD patterns measured for the sludge samples with the mineral powder diffraction files (PDFTM) published by the Joint Committee on Powder Diffraction Standards (JCPDS) International Center for Diffraction Data (ICDD). As a rule of thumb, a crystalline phase must be present at greater than $5 \mathrm{wt} \%$ of the total sample mass (greater than $1 \mathrm{wt} \%$ under optimum conditions) to be readily detected by XRD. In general, the measured peak intensities depend on several factors, including the combined mass of each crystalline phase in the sample. Due to the physical characteristics of these tank sludge samples such as high radioactivity, high dispersibility, and variable moisture content, the mass of tank sludge combined with the collodion solution for each XRD mount could not be controlled or easily determined. Dissimilarities in mineral segregation (settling) resulting from the different densities of minerals mixed with the collodion solution and associated effects on relative peak intensities also influence the overall pattern intensity. The combined effect of these factors could have some effect on the characteristic mineral peak intensities, which precluded quantitative comparisons of peak intensities for equivalent reflections in background-subtracted XRD patterns for different sludge samples.

\subsection{SEM/EDS Analysis}

Samples of unleached and water-leached sludges and of solid materials remaining at the end of certain extraction tests and solubility experiments were characterized by SEM/EDS (Table 2.3). A natural specimen of čjkaite $\left[\mathrm{Na}_{4}\left(\mathrm{UO}_{2}\right)\left(\mathrm{CO}_{3}\right)_{3}\right]$ from the Svornost Mine at Jachymov in the Czech Republic was also analyzed by SEM/EDS for comparison with the uranium mineralization identified in the C-203 and C-204 sludge samples. Two or three mounts were prepared of each sample to compensate for the possibility that one or more less-than-optimum mounts of a sample might occur, thus improving the likelihood of obtaining representative SEM images of each sample. The mounts used for SEM/EDS consisted of double-sided carbon tape attached to standard aluminum mounting stubs. For each mount, small aliquots of each sludge sample were placed on the exposed upper surface of the carbon tape using a micro spatula. Each mount was then coated with carbon using a vacuum sputter-coater to improve the conductivity of the samples and thus the quality of the SEM images and EDS signals.

A JEOL JSM-840 SEM was used for high-resolution imaging of micrometer/submicrometer-sized particles from the sludge samples. The SEM system is equipped with an Oxford Links ISIS 300 EDS that 
was used for qualitative elemental analysis. Operating conditions consisted of 10 to $20 \mathrm{keV}$ for SEM imaging and $20 \mathrm{keV}, 100$ live seconds ${ }^{(\mathrm{a})}$ for the EDS analyses. The EDS analyses of particles are limited to elements with atomic weights heavier than boron. Photomicrographs of high-resolution secondary electron (se) images and backscattered electron (bse) images were obtained as digital images and stored in electronic format. To help identify particles that contain elements with large atomic number, such as uranium, the SEM was typically operated in the bse mode. Secondary electrons are low-energy electrons ejected from the probed specimen as a result of inelastic collisions with beam electrons, whereas backscattered electrons are primary electrons emitted as a result of elastic collisions. Backscattered electron emission intensity is a function of the specimen's atomic number, the larger the atomic number, the brighter the signal. Backscattered electron images are obtained in exactly the same way as secondary electron images.

The SEM micrographs included in this report were selected because they show typical morphologies, sizes, and surface textures of particles in the sludge subsample mounts. The name of each digital image file, sample identification number, and a size scale bar are given, respectively, at the bottom left, center, and right of each SEM micrograph in this report. Micrographs labeled bse to the immediate right of the digital image file name indicate that the micrograph was collected with bse. Areas outlined by a white or black dotted-line square in a micrograph designate sample material that is imaged at higher magnification, which is typically shown in the next figure of the series for that subsample.

Areas labeled "eds" in SEM micrographs in this report indicate areas of particles for which EDS spectra were recorded and qualitative compositions were calculated and tabulated. Compositions determined by EDS are qualitative and have large uncertainties resulting from alignment artifacts caused by the variable sample and detector configurations that exist when different particles are imaged by SEM.

\subsection{Tier 1 Tests}

Tank waste samples were analyzed in a tiered approach similar to the one developed for investigating contaminant fate and transport issues associated with past single-shell tank leaks in the vadose zone. Such an approach allows for initial (Tier 1) screening of samples using relatively inexpensive analytical techniques. This is followed by an analysis of the data to determine the need for further testing (Tier 2). The Tier 1 tests are described in this section and the Tier 2 tests are described Sections 2.6-2.8.

All laboratory activities were conducted in accordance with the requirements of Title 10, Code of Federal Regulations, Part 830.120 "Quality Assurance" and the Hanford Analytical Services Quality Assurance Requirements Document (HASQARD). These requirements were implemented using PNNL's on-line QA Plan, "Conducting Analytical Work in Support of Regulatory Programs." PNNL's QA Plan is based on the requirements of U.S. DOE Order 414.1A as described in PNNL's Standards-Based Management System (SBMS), the HASQARD, relevant elements of NQA-1, as well as recognized industry standards (e.g., EPA, ASTM, American National Standards Institute).

(a) Live time is when (real time less dead time) the EDS system is available to detect incoming X-ray photons. Dead time is the portion of the total analyzing time that is actually spent processing or measuring X-rays. While each X-ray pulse is being measured, the system cannot measure another X-ray that may enter the detector and is therefore said to be "dead." 


\subsubsection{Moisture Content}

The moisture contents of the tank waste samples were measured to calculate dry weight concentrations for constituents in the waste. Dry weight concentrations provide a consistent measurement unit for comparison purposes that eliminates the effect of variable water content on sample concentrations.

Gravimetric water content of the waste material was determined using the ASTM procedure D2216-98, Standard Test Method for Laboratory Determination of Water (Moisture) Content of Soil and Rock by Mass (ASTM 1998) with the following minor exceptions: 1) the volume of sample recommended was decreased due to radiological concerns and 2) the sample was dried at a lower oven temperature, $105^{\circ} \mathrm{C}$, for a longer period of time to prevent dehydration of the solids.

Sludge samples were placed in tared containers, weighed, and dried in an oven until a constant weight was achieved, usually 24 to 48 hours. The container was then removed from the oven, sealed, cooled, and weighed. All weighings were performed using a calibrated balance. The gravimetric water content is computed as the percentage change in soil weight before and after oven drying (i.e., [ $\{$ wet weight - dry weight $\}$ /dry weight]).

\subsubsection{Water Extracts}

Water-soluble inorganic constituents were determined using a DDI water extraction method. The extract was prepared by adding $30 \mathrm{~mL}$ of DDI water to 0.200 to $0.600 \mathrm{~g}$ of the sample contained in a $50 \mathrm{~mL}$ polypropylene centrifuge tube. The centrifuge tube was sealed and briefly shaken by hand, and then placed on a mechanical orbital shaker from one day up to one month. After shaking for the predetermined time, the tube was placed in a centrifuge and spun at $4000 \mathrm{rpm}$ for 20 minutes. The supernatant was carefully decanted and filtered through $0.45-\mu \mathrm{m}$ pore size membrane. More details can be found in ASTM Procedure D3987-85, Standard Test Method for Shake Extraction of Solid Waste with Water (ASTM 1999).

\subsubsection{Periodic Replenishment Tests}

Periodic replenishment tests were conducted on samples of sludge from Tanks C-203 and C-204. In this test, the water-leachate solution was periodically removed and replaced with an equal volume of fresh solution. This test was conducted to evaluate whether solution concentration might be limited by the solubility of one or more solid phases. For these tests, the samples were contacted with DDI water for a total of five times. The contact periods ranged from two to three days, the length of time between replenishment of water-leachate solutions. The sludge samples were prepared and handled in the same manner as the single-contact water extracts for each repetitive step. After the fifth stage, samples were replenished with fresh solutions and placed back on the shaker for evaluation of long-term solubilities. The contact time for one of these long-term samples was 65 days. This has been designated as Stage 6a of the periodic replenishment test. For the other long-term test the contact time was 86 days (Stage 6b).

After these long-term tests, the samples were centrifuged and the supernatant carefully decanted and filtered through $0.45-\mu \mathrm{m}$ pore size membranes prior to analysis for the same constituents as the shorterterm tests. 


\subsection{4 $\mathrm{pH}$}

The $\mathrm{pH}$ of the solutions was measured using a solid-state $\mathrm{pH}$ electrode and a $\mathrm{pH}$ meter calibrated with buffers bracketing the expected range. This measurement is similar to Test Methods for Evaluating Solid Wastes: Physical/Chemical Methods SW-846 9040B (EPA 2000).

\subsubsection{Anion Analysis}

Anion analysis was performed using an ion chromatograph. Fluoride, acetate, formate, chloride, nitrite, bromide, nitrate, carbonate, sulfate, oxalate, and phosphate were separated on a Dionex AS17 column with a gradient elution technique from $1 \mathrm{mM}$ to $35 \mathrm{mM} \mathrm{NaOH}$ and measured using a conductivity detector. This methodology is similar to Test Methods for Evaluating Solid Wastes: Physical/Chemical Methods EPA SW-846 Method 9056 A (EPA 2000) with the exception of using gradient elution with $\mathrm{NaOH}$.

\subsubsection{Cations and Trace Metals}

Major cation analysis (including aluminum, silicon, calcium, magnesium, sodium, potassium, iron, and manganese) was performed by ICP-OES EPA Method 6010B (EPA 2000). Trace metals analysis (including chromium, molybdenum, arsenic, selenium, cadmium, silver, lead, ${ }^{99} \mathrm{Tc}$, and uranium isotopes) was performed by inductively coupled plasma mass spectrophotometry (ICP-MS). This method is similar to EPA Method 6020 (EPA 2000).

For both ICP-OES and ICP-MS, high-purity calibration standards were used to generate calibration curves and to verify continuing calibration during the analysis. Dilutions of $10 \mathrm{x}$ and $5 \mathrm{x}$ were made for each sample and analyzed to investigate and correct for matrix interferences.

\subsubsection{Alkalinity}

The sample alkalinity was measured by standard titration. A volume of standardized sulfuric acid $\left(\mathrm{H}_{2} \mathrm{SO}_{4}\right)$ was added to the sample to an endpoint of $\mathrm{pH} 8.3$ and then an endpoint of $\mathrm{pH} 4.5$. The volume of $\mathrm{H}_{2} \mathrm{SO}_{4}$ needed to achieve each endpoint is used to calculate the phenolphthalein $\left(\mathrm{OH}^{-}+\mathrm{CO}_{3}{ }^{2-}\right)$ and total $\left(\mathrm{OH}^{-}+\mathrm{HCO}_{3}{ }^{-}+\mathrm{CO}_{3}{ }^{2-}\right)$ alkalinity as calcium carbonate $\left(\mathrm{CaCO}_{3}\right)$ The alkalinity procedure is similar to Standard Method 2320 B (Clesceri et al. 1998).

\subsection{8 $\quad{ }^{129} I$ Extraction and Analysis}

From a long-term risk standpoint, ${ }^{129} \mathrm{I}$ is a key potential contaminant in residual Hanford tank waste. For this reason, its presence in the waste material and mobility in infiltrating water is of interest. Although iodine is generally considered mobile as a dissolved constituent in water, small partition coefficients $(0.2$ to $1 \mathrm{~mL} / \mathrm{g})$ are typically calculated when its uptake is measured on Hanford sediments (Cantrell et al. 2003; Um et al. 2004). Therefore, it is imperative to identify an extraction method that will enable quantitative measurement of total iodine in solid samples such as tank waste. Previous research (Brown et al. 2004) has shown the potential applicability of water leaches and $\mathrm{KOH}: \mathrm{KNO}_{3}$ water fusions for the removal of iodide from solid samples spiked with ${ }^{129} \mathrm{I}$. The results from Brown et al. 
(2004) have led to the modification of the accepted PNNL internal procedure AGG-ESL-001, ${ }^{\text {(a) }}$ to determine the ${ }^{129} \mathrm{I}$ concentration in sludge solids. In the case of ${ }^{129} \mathrm{I}$, the $\mathrm{KOH}-\mathrm{KNO}_{3}$ fusion-dissolution procedure (Section 2.2) was modified (steps 10 through 14 were omitted) to prevent volatilization of I. In this procedure, $300 \mathrm{mg}$ of the tank waste sludge material was mixed with $10 \mathrm{~mL}$ of a $20 \% \mathrm{KOH}$ and $2 \%$ $\mathrm{KNO}_{3}$ solution as a fluxing agent in a zirconium crucible. The crucible was then placed on a hot plate and allowed to evaporate to dryness, after which it was covered and transferred to a muffle furnace preheated to $550^{\circ} \mathrm{C}$. Fusion was accomplished by heating the sample-flux mixture for 60 minutes at $550^{\circ} \mathrm{C}$. After 60 minutes, the crucible was removed from the furnace and allowed to cool to ambient room temperature. The fused solid was then dissolved in DDI water. The resulting solution was transferred to a 50-mL volumetric flask. The crucible was then triple-rinsed with DDI water, and these solutions were also added to the volumetric flask. The resulting solution was diluted up to a total volume of $50 \mathrm{~mL}$ with DDI water. Prior to chemical analysis, the final 50-mL solution was passed through a Whatman 41 filter with final filtration through a $0.45-\mu \mathrm{m}$ pore-size syringe filter to remove insoluble particles, if any, that did not dissolve in the DDI water.

Table 2.4 lists the digestion factors (wet solid-to-solution ratios) for the samples of C-203 sludge solids used for the modified $\mathrm{KOH}-\mathrm{KNO}_{3}$ water fusion treatments to measure ${ }^{129} \mathrm{I}$. These factors were calculated from the wet weight of sludge material divided by the volume of extracting solution. The digestion factors were then multiplied by the percent solids, as determined from moisture content analysis, to convert to a dry weight basis. The fused samples, as well as all of the samples from the periodic replacement tests (Section 2.5.3), were analyzed for dissolved ${ }^{129}$ I concentrations using a VG Elemental PQS ICP-MS. Spectrasol CFA-C from Spectrasol, Inc. (Warwick, NY) was diluted in DDI water $(18 \mathrm{M} \Omega-\mathrm{cm})$ to create a $5 \%$ working solution. Calibration standards were prepared by diluting a $1 \mathrm{mg} / \mathrm{L}{ }^{129}$ I certified stock standard (NIST, Gaithersburg, MD) into appropriate volumes of the 5\% Spectrasol CFA-C solution containing $5 \mathrm{ng} / \mathrm{mL}^{121} \mathrm{Sb}$ as the internal standard to calibrate the ICP-MS for masses neighboring iodine. An independent calibration check standard was prepared from a $1 \mathrm{mg} / \mathrm{L}^{129} \mathrm{I}$ certified stock standard (Amersham, Piscataway, NJ) in 5\% Spectrasol CFA-C. Five percent Spectrasol $\mathrm{CFA}-\mathrm{C}$ was used to prepare instrument blanks and was used as the rinse solution throughout the run.

Table 2.4. Digestion Factors for Samples of C-203 (Jar 19649) Sludge Solids Used for the Modified $\mathrm{KOH}-\mathrm{KNO}_{3}$ Water Fusion Treatment to Measure ${ }^{129} \mathrm{I}$

\begin{tabular}{||c|c|c||}
\hline \hline & Sample Number & $\begin{array}{c}\text { Dry Weight Corrected } \\
\text { Digestion Factor (g/L) }\end{array}$ \\
\hline \hline \multirow{2}{*}{$\mathrm{KOH}-\mathrm{KNO}_{3}$ water fusion } & Jar 19649 (203) & 6.2149 \\
\cline { 2 - 3 } & Jar 19649 Spike & 6.1304 \\
\hline
\end{tabular}

\subsubsection{Radioanalysis}

In addition to the radionuclides listed above that were analyzed in solution by ICP-MS, short-lived radionuclides were analyzed by conventional counting methods as described below.

(a) Lindberg MJ. 2003. "Solubilization of Metals from Solids Using a KOH-KNO3 Fusion". AGG-ESL-001 Rev. 0, unpublished PNNL Technical Procedure, Pacific Northwest National Laboratory, Richland, WA. 


\subsubsection{Gamma Energy Analysis}

All samples for GEA were analyzed using $60 \%$ efficient intrinsic-germanium gamma detectors. All germanium counters were efficiency calibrated for distinct geometries using mixed gamma standards traceable to the NIST. Direct solids, acid extracts, and water extracts were analyzed for gamma energy. Spectral analysis was conducted using libraries containing most mixed-fission products, activation products, and natural decay products. Control samples were run throughout the analysis to ensure correct operation of the detectors. The controls contained isotopes with photo peaks spanning the full detector range and were monitored for peak position, counting rate, and full-width half-maximum. Details are found in procedure RRL-001. ${ }^{\text {(a) }}$

\subsubsection{Strontium-90 and Actinides Analyses}

Aliquots of filtered acid extracts, fusions, and water extracts were diluted in $8 \mathrm{M} \mathrm{HNO}_{3}$ and submitted for strontium separation and analysis by PNNL procedure PNL-RRL-003.2. ${ }^{\text {(b) }}$ A 0.1-5 mL aliquot of sample was spiked with ${ }^{85} \mathrm{Sr}$ tracer and passed through a SrSpec ${ }^{\circledR}$ column (Eichrom Technologies, Chicago) to capture strontium. The columns were washed with 10 column volumes $(20 \mathrm{~mL})$ of $8 \mathrm{M}$ nitric acid. The strontium was eluted from the SrSpec column into glass liquid scintillation vials using $15 \mathrm{~mL}$ of deionized water. The vials were placed under a heat lamp overnight to evaporate the water to dryness. A $15 \mathrm{~mL}$ Optifluor ${ }^{\circledR}$ scintillation cocktail was added to each vial. Gamma spectroscopy was used to determine the chemical yield from the added ${ }^{85} \mathrm{Sr}$ tracer. The samples were then analyzed by liquid scintillation counting (LSC) to determine the amount of ${ }^{90} \mathrm{Sr}$ originally present in the sludge sample. A matrix spike, a blank spike, a duplicate, and blanks were run with each sample set to determine the efficiency of the separation procedure as well as the purity of reagents.

Aliquots of filtered acid extracts, fusions, and water extracts were diluted in $8 \mathrm{M} \mathrm{HNO}_{3}$ and submitted for actinide analysis by procedure PNL-ALO-496. ${ }^{(\mathrm{c})}$ Sample aliquots of $0.1-1 \mathrm{~mL}$ were spiked with ${ }^{252} \mathrm{Cf}$ tracer and $50 \mu \mathrm{g}$ of $\mathrm{Nd}$ carrier. The samples were taken through an iron hydroxide precipitation by adding concentrated ammonium hydroxide until the solution $\mathrm{pH}$ was $>10$ and a red-brown precipitate formed. The samples were centrifuged, the supernatant discarded, and the precipitate resuspended in $5 \mathrm{~mL}$ of $4 \mathrm{M}$ hydrochloric acid. Approximately $1 \mathrm{~mL}$ of concentrated hydrofluoric acid was added to the samples (this step precipitates the actinides as fluorides). The samples were allowed to equilibrate for approximately 30 minutes and were then filtered through $0.45 \mu \mathrm{m}$ Supor ${ }^{\circledR}$ filters. The filters were dried under a heat lamp, affixed to metal planchettes using double-stick tape, and counted using alpha energy analysis (AEA). A matrix spike, a blank spike, a duplicate, and blanks were run with each sample set to determine the efficiency of the separation procedure as well as the purity of reagents.

(a) RRK-001, "Gamma Energy Analysis, Operation, and Instrument Verification using Genie2000 Support Software," unpublished PNNL Technical Procedure, Pacific Northwest National Laboratory, Richland, WA.

(b) PNL-RRL-003.2. 2000. "Tc99 and Sr90 analysis using Eichrom TEVA-spec and Sr-spec resin." Technical Procedure, Pacific Northwest National Laboratory, Richland, WA.

(c) PNL-ALO-496. 1995. "Precipitation plating of actinides for high-resolution alpha spectrometry." Technical Procedure, Pacific Northwest National Laboratory, Richland, WA. 


\subsubsection{Gross Alpha and Beta Analysis}

Gross alpha and beta measurement were made on both the water and acid extracts. For each extract, $0.100 \mathrm{~mL}$ sample volume was placed in a $20-\mathrm{mL}$ liquid scintillation vial containing $15 \mathrm{~mL}$ of scintillation cocktail. ${ }^{\text {(a) }}$ The samples were then mixed and counted on a Wallace model 1415 liquid scintillation counter as prescribed in procedure AGG-RRL-002. ${ }^{\text {(b) }}$

\subsection{Selective Extraction Tests}

Selective extractions were conducted to facilitate the identification of phases containing ${ }^{99} \mathrm{Tc}$ and uranium and to evaluate how these contaminants would be released from C-203 and C-204 sludge. For each extraction step, $0.3 \mathrm{~g}$ sludge and $30 \mathrm{~mL}$ of extractant were combined and placed on a shaker table for a contact time of typically 24 hours. For the unleached C-203 and C-204 samples, the following sequential extraction process was used.

- Step 1: DDI water for soluble salt removal

- Step 2: DDI water for soluble salt removal

- Step 3: $0.1 \mathrm{M}$ acetic acid/0.1 M acetate buffer $(\mathrm{pH} \sim 4.6)$ for residual carbonate removal

- Step 4: Ethanol extraction for tributyl phosphate (TBP) removal

- Step 5: Ethanol extraction for TBP removal

- Step 6: $8 \mathrm{M} \mathrm{HNO}_{3}$ extraction for dissolution of residuals [Fe and $\mathrm{Al}$ oxyhydroxides]

- Step 7: Hot concentrated $\mathrm{HNO}_{3}$ extraction for dissolution of recalcitrant residuals

Figure 2.6 shows this sequence of extractions schematically. Steps 1 and 2 are deionized water extracts. Deionized water is expected to remove readily soluble salts along with readily soluble ${ }^{99} \mathrm{Tc}$ and uranium. In step 3, a buffer solution of $0.1 \mathrm{M}$ acetic acid/0.1 M potassium acetate $(\mathrm{pH} \sim 4.6)$ was used for removal of any carbonate phases that were not removed in the DDI extractions. Steps 4 and 5 consisted of two ethanol extractions conducted to remove tributyl phosphate. The extracts were saved for future analysis if all the uranium was not accounted for in the other extracts. Because all the uranium was found in the other extracts, it was concluded that little or no uranium is associated with the TBP, and the ethanol extractions were not analyzed. Step 6 of the sequential extraction process consisted of an $8 \mathrm{M}$ $\mathrm{HNO}_{3}$ extraction that was expected to remove a majority of the residual material contained within the Fe and $\mathrm{Al}$ oxyhydroxides. The last step of the sequence was a hot concentrated $\mathrm{HNO}_{3}$ extraction intended to dissolve recalcitrant residuals not dissolved in step 6.

(a) The scintillation cocktail used is Packard Optifluor, which is based on the high flash-point solvent LAB (Linear Alkylbenzene) (http://las.perkinelmer.com/catalog/Product.aspx?ProductId=6013199).

(b) AGG-RRL-002, "Liquid Scintillation Counting and Instrument Verification using the $1400 \mathrm{DSA}^{\mathrm{TM}}$ Support Software," unpublished PNNL Technical Procedure, Pacific Northwest National Laboratory, Richland, WA. 


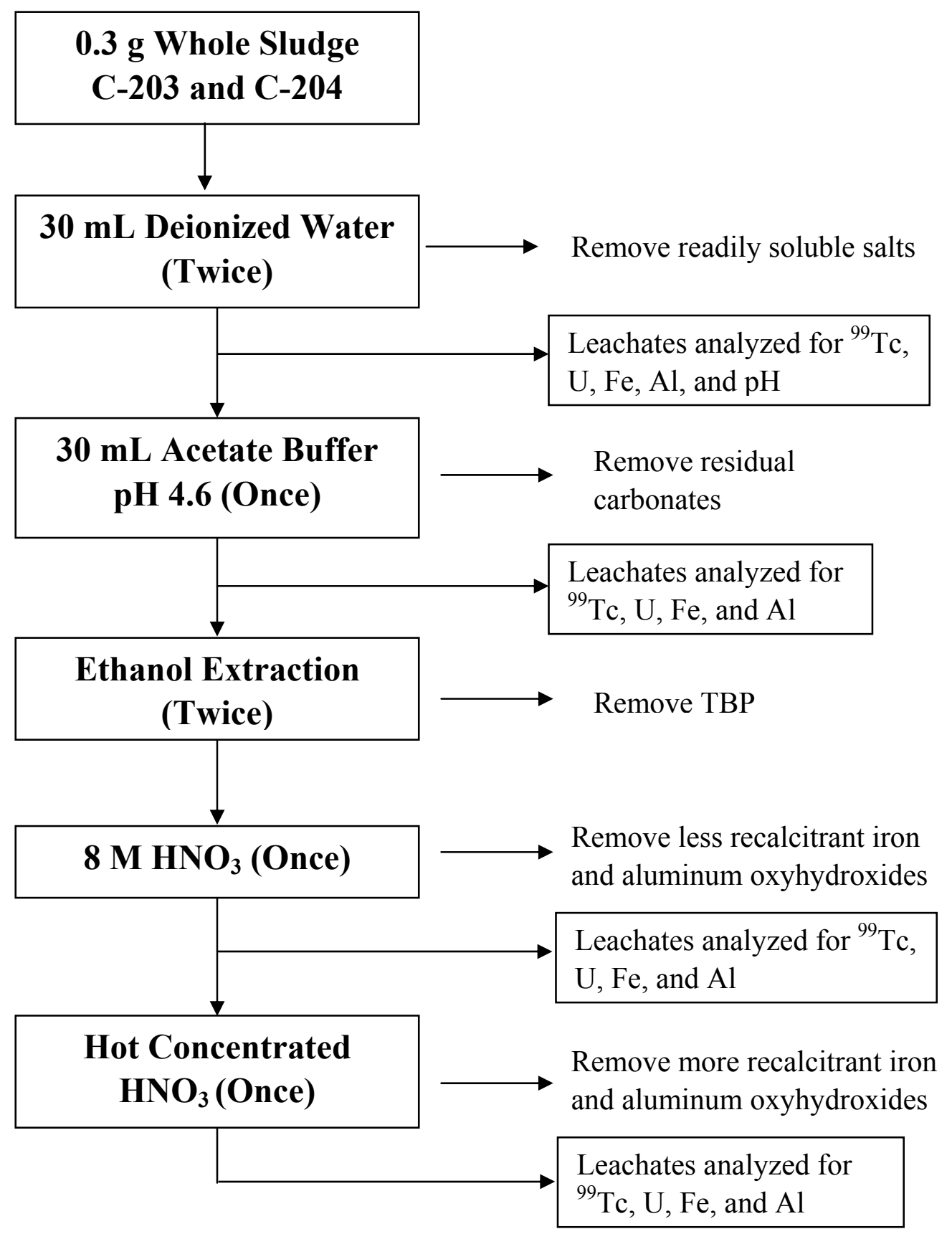

Figure 2.6. Extraction Sequence to Determine Phase Associations of ${ }^{99} \mathrm{Tc}$ and $\mathrm{U}$

A second set of sequential extractions was conducted to differentiate the amount of ${ }^{99} \mathrm{Tc}$ contained within recalcitrant aluminum oxyhydroxides from that associated with iron oxyhydroxides. Hydrofluoric acid was used in these extractions to preferentially dissolve the aluminum solids. The following sequence of extractions was used for this test:

- Step 1: DDI water for soluble salt removal 
- Step 2: DDI water for soluble salt removal

- Step 3: $0.02 \mathrm{M}$ hydrofluoric acid/0.01 M sodium fluoride buffer ( $\mathrm{pH}$ approximately 2.9) for $\mathrm{Al}$ oxide(hydroxide) removal. Extract for two hours.

- Step 4: $0.02 \mathrm{M}$ hydrofluoric acid/0.01 M sodium fluoride buffer ( $\mathrm{pH}$ approximately 2.9) for $\mathrm{Al}$ oxide(hydroxide) removal. Extract for two hours.

Each extract was analyzed for ${ }^{99} \mathrm{Tc}, \mathrm{Al}$, and Fe.

\subsection{Uranium Mineral Solubility Measurements}

Results of work conducted as part of the Tier 1 testing of C-203 and C-204 tank sludges indicated that the majority of the uranium in these sludges was in the form of the mineral čejkaite $\left[\mathrm{Na}_{4} \mathrm{UO}_{2}\left(\mathrm{CO}_{3}\right)_{3}\right]$ (Sections 3.4.1 and 3.4.2). The results of Tier 1 water-leaching experiments (subsection 3.3.1.3) indicated that nearly all the uranium in the C-203 and C-204 sludges was soluble at a solid-to-solution ratio of 1:100 and dissolved in less than 24 hours at room temperature (final solution $\mathrm{pH}$ values near 9.5). As a result of these findings, an empirical determination of the solubility of čejkaite in C-203 and C-204 sludges was conducted. The solubility of čejkaite is needed to develop a release model for tank closure performance assessments. A more detailed study to determine the thermodynamic solubility constant for čejkaite was beyond the scope of this study.

To estimate the solubility limit of čejkaite in C-203 and C-204 sludge in contact with infiltrating water, a series of water extraction experiments was conducted at lower solution-to-solid ratios than used in the initial water-leach experiments. In addition to the sludge samples, solubility determinations were also conducted on some of the large yellow nuggets removed from C-203 sludge (Figure 2.3), which are composed primarily of a random intergrowth of needles and rods of crystalline čejkaite (Section 3.4.1). Lower solution-to-solid ratios were used to prevent the complete dissolution of the čejkaite during the extractions and assure that equilibrium with the solid is achieved. For the sludge samples, two solid-tosolution ratios (1:1 and 2:1) were used. Two solubility experiments were conducted with the nuggets, one with a whole nugget and other with crushed nugget material. In the case of the nugget solubility experiments, a solid-to-solution ratio of approximately 1:2 was used. All solubility experiments used DDI water as the solvent for comparison purposes with the other batch experiments.

To remove potential common ion effects that could result from dissolution of salts in the sludge, other than čejkaite, the solubility determinations were conducted using a series of multiple contacts. After the equilibration period, most of the supernatant was removed for analysis and replaced with fresh deionized water. All solubility experiments were contacted for 24 hours at ambient temperature, except the first C-203 sample, which was contacted for four days. As indicated earlier, 24 hours was determined to be adequate to achieve equilibrium. For the C-203 sludge samples, the water was removed and replaced with fresh DDI water and re-equilibrated for a total of four times. For the nugget samples, two sequential contacts were performed. All experiments were conducted in $50 \mathrm{~mL}$ centrifuge tubes and equilibrated on a shaker table for the indicated time period. After the prescribed equilibration period, the tubes were centrifuged at $4000 \mathrm{rpm}$ for 30 minutes. Upon removal, the supernatants were analyzed for uranium, ${ }^{99} \mathrm{Tc}$, major cations and anions, and $\mathrm{pH}$. 


\subsection{Laboratory Results}

This section provides the results of the tests conducted on sludge samples from Tanks C-203 and C-204. The discussion begins with sludge composition by fusion analysis and acid digestion in Section 3.1. Section 3.2 presents ${ }^{129} \mathrm{I}$ extraction and measurement results, and Section 3.3 contains the results of batch water-leaching tests, including single-contact, periodic replenishment, and uranium mineral solubility measurements. X-ray diffraction (XRD) and SEM/EDS analyses are described in Section 3.4, while Section 3.5 discusses selective extractions.

\subsection{Sludge Composition (from Fusion and Acid Digestion Results)}

An important component of contaminant release rate calculations is an accurate measurement of the total concentrations of the contaminants in the source material. As described in Section 2.2, the total metals and radionuclide concentrations of the sludges were measured using two methods (fusion analysis and acid digestion). The results of these analyses are described in this section. The anionic (nonmetal) composition of the sludge was estimated by water extraction as part of the Tier 1 analyses (Section 2.5.2). Tier 1 results are discussed in Section 3.3.1 and included in the summary table of sludge composition at the end of Section 3.1 (Table 3.11).

An insoluble amount of solids representing a very small fraction of the original mass of the sludges was observed in the fusion preparations for samples of both C-203 and C-204. The residuals for both samples consisted of very fine rust-colored particles. A very small insoluble fraction was also observed in the C-203 and the C-204 samples at completion of the acid digestion. The C-203 solids consisted of very fine brown particles and small black specks. The C-204 solid consisted of a wax-like emulsion with black specks. The wax-like emulsion is believed to be the incomplete digestion of TBP, which was a major constituent of the C-204 sludge. Because the insoluble fractions are not a significant mass of the sludges, their presence is not expected to have a large impact on the measured total elemental composition of the solids.

Concentrations listed in parentheses in the tables in Section 3 are defined as less than the estimated quantitation limit (EQL) but greater than a zero instrument signal. These values are reported for informational purposes only. They may reflect actual concentrations that are real but have larger associated uncertainties than values above the EQL or may reflect values that were calculated from the instrument's background signal and are not representative of actual sludge composition. The EQL of an element is determined by analyzing a suite of continuing calibration verification (CCV) standards at the beginning and end of each analytical run. The lowest CCV standard that is within $\pm 10 \%$ of its certified value is multiplied by the dilution factor for the sample to determine the EQL for the element for the particular analytical run. The EQL may vary with each analysis depending on sample matrix, dilution factors, and instrument performance.

Concentrations listed as less-than $(<)$ values in the tables refer to instrument measurements that are less than zero. In these instances, the reported analyte concentration is assigned a value of " $<$ EQL" using the EQL value appropriate for that particular analyte and set of analytical conditions. 
The following discussion of elemental concentrations of the sludges is organized in terms of the analytical method used to measure concentrations in the solution extract: ICP-OES, ICP-MS, gamma energy analysis (GEA), wet chemical separations and AEA (actinides), wet chemical separations and liquid scintillation $\left({ }^{90} \mathrm{Sr}\right)$, and gross alpha/beta analysis. For the tables, the solution concentrations have been converted from a per-liter basis to a dry sludge mass basis. Each table provides results from the fusion analysis and EPA acid digestion methods. Table 3.11 summarizes the composition of the sludges.

Table 3.1 lists the moisture content (relative to total sludge mass) of the C-203 and C-204 sludge samples used for the fusion extractions and EPA acid digestions. These values are used with the digestion factors (Table 2.2) to convert the solution analyses of the extracts from the treatments to dry weight solid concentrations. The moisture contents of the sludge samples ranged from 37.1 to $40.2 \%$, suggesting that the samples were completely water saturated.

Tables 3.2 through 3.4 contain the results of ICP-OES analyses. Because K compounds are used as the fluxing agent for the fusion technique, $\mathrm{K}$ values are not reported in Table 3.3 for the fusion analysis. The metals detected above their respective EQLs in C-203 and C-204 sludges were $\mathrm{Al}, \mathrm{Ca}, \mathrm{Cr}, \mathrm{Fe}, \mathrm{Mn}$, $\mathrm{Ni}, \mathrm{Pb}, \mathrm{Zn}, \mathrm{Na}$, and $\mathrm{Ti}$. For these elements, there is some variability in concentration between the fusion method and the EPA acid digestion technique. For C-203 sludge, the fusion method gave higher concentrations of $\mathrm{Al}(28 \mathrm{wt} \%), \mathrm{Ca}(10 \mathrm{wt} \%), \mathrm{Cr}(18 \mathrm{wt} \%), \mathrm{Mn}(9 \mathrm{wt} \%), \mathrm{Na}(6 \mathrm{wt} \%)$, and $\mathrm{Ti}(2 \mathrm{wt} \%)$. The percent difference is shown in parentheses when values above the EQL were measured for both methods; elements with no value were below EQL. The acid digestion of C-203 sludge resulted in higher concentrations for $\mathrm{Fe}(29 \mathrm{wt} \%), \mathrm{Ni}, \mathrm{P}$, and $\mathrm{Pb}(9 \mathrm{wt} \%)$. The elements present in highest concentrations in $\mathrm{C}-203$ sludge and their maximum values in units of $\mu \mathrm{g} / \mathrm{g}$ are $\mathrm{Na}\left(1.7 \times 10^{5}\right), \mathrm{Fe}\left(5.3 \times 10^{4}\right), \mathrm{Cr}\left(2.4 \times 10^{4}\right), \mathrm{Pb}$ $\left(8.4 \times 10^{3}\right), \mathrm{Ca}\left(7.9 \times 10^{3}\right)$, and $\mathrm{P}\left(6.6 \times 10^{3}\right)$. For C-204 sludge, the fusion method gave higher concentrations for $\mathrm{Al}(50 \mathrm{wt} \%), \mathrm{Ca}(98 \mathrm{wt} \%), \mathrm{P}(14 \mathrm{wt} \%), \mathrm{Na}(35 \mathrm{wt} \%)$, and $\mathrm{Ti}$. Acid digestion of $\mathrm{C}-204$ sludge resulted in higher concentrations for $\mathrm{Cr}(12 \mathrm{wt} \%)$, $\mathrm{Fe}(42 \mathrm{wt} \%), \mathrm{Mn}(33 \mathrm{wt} \%)$, Ni (37 wt\%), and $\mathrm{Pb}$. The greater variability in results for the two methods for C-204 sludge compared to C-203 sludge is likely due to the high concentration of TBP in C-204 that affected the extractions and analyses. A separate organic analysis of the C-204 sludge showed a TBP concentration of $28 \mathrm{wt} \%\left(2.8 \times 10^{5} \mu \mathrm{g}\right.$ TBP $/ \mathrm{g}$ or $3.3 \times 10^{4} \mu \mathrm{g}$ $\mathrm{P} / \mathrm{g})$. The elements present in highest concentration in C-204 sludge, with their maximum values in units of $\mu \mathrm{g} / \mathrm{g}$, are $\mathrm{Fe}\left(2.4 \times 10^{5}\right), \mathrm{Na}\left(9.3 \times 10^{4}\right), \mathrm{P}\left(5.6 \times 10^{4}\right), \mathrm{Al}\left(2.7 \times 10^{4}\right)$, and $\mathrm{Cr}\left(1.1 \times 10^{4}\right)$.

Table 3.1. Moisture Contents of C-203 (Jar 19649) and C-204 (Jar 19650) Sludge Samples [(wet wt - dry wt)/dry wt]

\begin{tabular}{||l|c||}
\hline \multicolumn{1}{|c|}{ Sample Number } & Moisture Content \\
\hline \hline Jar 19649 (203) & $37.8 \%$ \\
\hline Jar 19649 (203) Dup ${ }^{(a)}$ & $39.2 \%$ \\
\hline \hline Jar 19650 (204) & $40.2 \%$ \\
\hline Jar 19650 (204) Dup & $37.1 \%$ \\
\hline (a) Dup = Duplicate sample. \\
\hline
\end{tabular}


Table 3.2. Concentrations of Elements Measured by ICP-OES per Gram of Dry Sludge

\begin{tabular}{|c|c|c|c|c|c|c|c|c|c|c|}
\hline \multirow{2}{*}{ Sample Number } & $\mathbf{A l}$ & As & B & $\mathbf{B a}$ & $\mathrm{Be}$ & $\mathbf{B i}$ & $\mathbf{C a}$ & Cd & Co & $\mathbf{C r}$ \\
\hline & \multicolumn{10}{|c|}{$\mu \mathrm{g} / \mathrm{g}$} \\
\hline \multicolumn{11}{|c|}{$\mathrm{KOH} \mathrm{KNO}_{3}$ Fusions } \\
\hline Jar $19649(203)$ & $1.3 \mathrm{E}+03$ & $<4.3 \mathrm{E}+03$ & $(4.8 \mathrm{E}+02)$ & $(2.1 \mathrm{E}+02)$ & $<4.3 \mathrm{E}+02$ & $<4.3 \mathrm{E}+03$ & $7.9 \mathrm{E}+03$ & $<4.3 \mathrm{E}+02$ & $<8.6 \mathrm{E}+02$ & $2.4 \mathrm{E}+04$ \\
\hline Jar $19650(204)$ & $2.5 \mathrm{E}+04$ & $(2.8 \mathrm{E}+01)$ & $(4.4 \mathrm{E}+02)$ & $(2.1 \mathrm{E}+02)$ & $<4.8 \mathrm{E}+02$ & $(6.6 \mathrm{E}+01)$ & $4.3 \mathrm{E}+03$ & $<4.8 \mathrm{E}+02$ & $<9.5 \mathrm{E}+02$ & $8.7 \mathrm{E}+03$ \\
\hline Jar 19650 (204) Dup & $2.7 \mathrm{E}+04$ & $<4.0 \mathrm{E}+03$ & $(3.6 \mathrm{E}+02)$ & $(1.3 \mathrm{E}+02)$ & $<4.0 \mathrm{E}+02$ & $<4.0 \mathrm{E}+03$ & $4.4 \mathrm{E}+03$ & $<4.0 \mathrm{E}+02$ & $<8.0 \mathrm{E}+02$ & $9.1 \mathrm{E}+03$ \\
\hline 19650 (204) Avg & $2.59 \mathrm{E}+04$ & $(2.0 \mathrm{E}+03)$ & $(4.0 \mathrm{E}+02)$ & $(1.7 \mathrm{E}+02)$ & $<4.4 \mathrm{E}+02$ & $(2.0 \mathrm{E}+03)$ & $4.4 \mathrm{E}+03$ & $<4.4 \mathrm{E}+02$ & $<8.8 \mathrm{E}+02$ & $8.9 \mathrm{E}+03$ \\
\hline \multicolumn{11}{|c|}{ EPA Acid Digestion } \\
\hline Jar $19649(203)$ & $1.1 \mathrm{E}+03$ & $(8.2 \mathrm{E}+01)$ & $(8.7 \mathrm{E}+02)$ & $(1.4 \mathrm{E}+02)$ & $(4.4 \mathrm{E}+01)$ & $<2.3 \mathrm{E}+03$ & $7.4 \mathrm{E}+03$ & $(2.3 \mathrm{E}+01)$ & $(6.3 \mathrm{E}+01)$ & $2.0 \mathrm{E}+04$ \\
\hline Jar 19649 (203) Dup & $9.1 \mathrm{E}+02$ & $<2.4 \mathrm{E}+03$ & $(6.1 \mathrm{E}+02)$ & $(6.0 \mathrm{E}+01)$ & $(1.1 \mathrm{E}+01)$ & $<2.4 \mathrm{E}+03$ & $7.1 \mathrm{E}+03$ & $(5.1 \mathrm{E}+00)$ & $<4.9 \mathrm{E}+02$ & $2.0 \mathrm{E}+04$ \\
\hline Jar $19650(204)$ & $1.7 \mathrm{E}+04$ & $<2.0 \mathrm{E}+03$ & $(3.7 \mathrm{E}+02)$ & $(7.5 \mathrm{E}+01)$ & $<2.0 \mathrm{E}+02$ & $(2.2 \mathrm{E}+01)$ & $1.7 \mathrm{E}+03$ & $(1.7 \mathrm{E}+01)$ & $<4.1 \mathrm{E}+02$ & $1.1 \mathrm{E}+04$ \\
\hline Jar 19650 (204) Dup & $1.4 \mathrm{E}+04$ & $<2.0 \mathrm{E}+03$ & $(2.7 \mathrm{E}+02)$ & $(9.0 \mathrm{E}+01)$ & $<2.0 \mathrm{E}+02$ & $<2.0 \mathrm{E}+03$ & $1.4 \mathrm{E}+03$ & $(1.7 \mathrm{E}+01)$ & $<4.0 \mathrm{E}+02$ & $8.8 \mathrm{E}+03$ \\
\hline Jar 19649 (203) Avg & $9.81 \mathrm{E}+02$ & $(1.3 \mathrm{E}+03)$ & $(7.4 \mathrm{E}+02)$ & $(9.8 \mathrm{E}+01)$ & $(2.7 \mathrm{E}+01)$ & $<2.3 \mathrm{E}+03$ & $7.3 \mathrm{E}+03$ & $(1.4 \mathrm{E}+01)$ & $(2.7 \mathrm{E}+02)$ & $2.0 \mathrm{E}+04$ \\
\hline Jar 19650 (204) Avg & $1.56 \mathrm{E}+04$ & $<2.0 \mathrm{E}+03$ & $(3.2 \mathrm{E}+02)$ & $(8.2 \mathrm{E}+01)$ & $<2.0 \mathrm{E}+02$ & $(1.0 \mathrm{E}+03)$ & $1.5 \mathrm{E}+03$ & $(1.7 \mathrm{E}+01)$ & $<4.0 \mathrm{E}+02$ & $1.0 \mathrm{E}+04$ \\
\hline
\end{tabular}

Table 3.3. Concentrations of Elements Measured by ICP-OES per Gram of Dry Sludge

\begin{tabular}{|c|c|c|c|c|c|c|c|c|c|c|}
\hline \multirow{2}{*}{ Sample Number } & $\mathbf{C u}$ & $\mathbf{F e}$ & $\mathbf{K}$ & $\mathbf{L i}$ & Mg & Mn & Mo & $\mathbf{N i}$ & $\mathbf{P}$ & $\mathbf{P b}$ \\
\hline & \multicolumn{10}{|c|}{$\mu \mathrm{g} / \mathrm{g}$} \\
\hline \multicolumn{11}{|c|}{${\mathrm{KOH}-\mathrm{KNO}_{3} \text { Fusions }}$} \\
\hline Jar $19649(203)$ & $<4.3 \mathrm{E}+03$ & $3.9 \mathrm{E}+04$ & NR & $<1.7 \mathrm{E}+04$ & $(6.3 \mathrm{E}+02)$ & $2.3 \mathrm{E}+03$ & $(1.7 \mathrm{E}+02)$ & $(5.4 \mathrm{E}+02)$ & $(1.2 \mathrm{E}+03)$ & $7.3 \mathrm{E}+03$ \\
\hline Jar $19650(204)$ & $<4.8 \mathrm{E}+03$ & $1.2 \mathrm{E}+05$ & NR & $<1.9 \mathrm{E}+04$ & $(1.9 \mathrm{E}+03)$ & $8.7 \mathrm{E}+02$ & $(4.6 \mathrm{E}+02)$ & $2.6 \mathrm{E}+03$ & $5.2 \mathrm{E}+04$ & $(1.6 \mathrm{E}+03)$ \\
\hline Jar 19650 (204) Dup & $<4.0 \mathrm{E}+03$ & $1.4 \mathrm{E}+05$ & NR & $<1.6 \mathrm{E}+04$ & $(2.0 \mathrm{E}+03)$ & $1.2 \mathrm{E}+03$ & $(1.9 \mathrm{E}+02)$ & $3.1 \mathrm{E}+03$ & $5.6 \mathrm{E}+04$ & $(1.7 \mathrm{E}+03)$ \\
\hline 19650 (204) Avg & $<4.4 \mathrm{E}+03$ & $1.3 \mathrm{E}+05$ & NR & $<1.8 \mathrm{E}+04$ & $(2.0 \mathrm{E}+03)$ & $1.0 \mathrm{E}+03$ & $(3.3 \mathrm{E}+02)$ & $2.9 \mathrm{E}+03$ & $5.4 \mathrm{E}+04$ & $(1.7 \mathrm{E}+03)$ \\
\hline \multicolumn{11}{|c|}{ EPA Acid Digestion } \\
\hline Jar $19649(203)$ & $(1.5 \mathrm{E}+02)$ & $5.1 \mathrm{E}+04$ & $(2.6 \mathrm{E}+03)$ & $<9.0 \mathrm{E}+03$ & $(5.1 \mathrm{E}+02)$ & $2.2 \mathrm{E}+03$ & $(3.6 \mathrm{E}+02)$ & $8.9 \mathrm{E}+02$ & $6.6 \mathrm{E}+03$ & $8.4 \mathrm{E}+03$ \\
\hline Jar 19649 (203) Dup & $(3.1 \mathrm{E}+01)$ & $5.3 \mathrm{E}+04$ & $(5.9 \mathrm{E}+02)$ & $<9.7 \mathrm{E}+03$ & $(5.3 \mathrm{E}+02)$ & $2.1 \mathrm{E}+03$ & $(3.4 \mathrm{E}+02)$ & $7.6 \mathrm{E}+02$ & $6.6 \mathrm{E}+03$ & $7.6 \mathrm{E}+03$ \\
\hline Jar $19650(204)$ & $(8.6 \mathrm{E}+01)$ & $1.5 \mathrm{E}+05$ & $(5.3 \mathrm{E}+02)$ & $<8.1 \mathrm{E}+03$ & $(1.2 \mathrm{E}+03)$ & $1.1 \mathrm{E}+03$ & $(1.4 \mathrm{E}+02)$ & $4.7 \mathrm{E}+03$ & $2.4 \mathrm{E}+04$ & $1.4 \mathrm{E}+03$ \\
\hline Jar 19650 (204) Dup & $(4.6 \mathrm{E}+01)$ & $2.4 \mathrm{E}+05$ & $<9.9 \mathrm{E}+03$ & $<8.0 \mathrm{E}+03$ & $(9.8 \mathrm{E}+02)$ & $1.6 \mathrm{E}+03$ & $(1.0 \mathrm{E}+02)$ & $3.6 \mathrm{E}+03$ & $1.9 \mathrm{E}+04$ & $1.6 \mathrm{E}+03$ \\
\hline Jar 19649 (203) Avg & $(9.3 \mathrm{E}+01)$ & $5.2 \mathrm{E}+04$ & $(1.6 \mathrm{E}+03)$ & $<9.4 \mathrm{E}+03$ & $(5.2 \mathrm{E}+02)$ & $2.1 \mathrm{E}+03$ & $(3.5 \mathrm{E}+02)$ & $8.3 \mathrm{E}+02$ & $6.6 \mathrm{E}+03$ & $8.0 \mathrm{E}+03$ \\
\hline Jar 19650 (204) Avg & $(6.6 \mathrm{E}+01)$ & $1.9 \mathrm{E}+05$ & $(5.2 \mathrm{E}+03)$ & $<8.0 \mathrm{E}+03$ & $(1.1 \mathrm{E}+03)$ & $1.4 \mathrm{E}+03$ & $(1.2 \mathrm{E}+02)$ & $4.1 \mathrm{E}+03$ & $2.1 \mathrm{E}+04$ & $1.5 \mathrm{E}+03$ \\
\hline
\end{tabular}


Table 3.4. Concentrations of Elements Measured by ICP-OES per Gram of Dry Sludge

\begin{tabular}{|c|c|c|c|c|c|c|c|c|c|c|}
\hline \multirow[b]{2}{*}{ Sample Number } & Se & $\mathbf{S r}$ & $\overline{\mathrm{TI}}$ & $\mathbf{V}$ & $\mathbf{Z n}$ & $\mathbf{N a}$ & $\mathbf{S i}$ & $\mathbf{S}$ & $\overline{T i}$ & $\overline{Z \mathbf{r}}$ \\
\hline & \multicolumn{10}{|c|}{$\mu \mathrm{g} / \mathrm{g}$} \\
\hline \multicolumn{11}{|c|}{ " KOH-KNO ${ }_{3}$ Fusions } \\
\hline Jar $19649(203)$ & $(1.7 \mathrm{E}+03)$ & $(1.8 \mathrm{E}+02)$ & $<8.6 \mathrm{E}+03$ & $<4.3 \mathrm{E}+03$ & $(5.8 \mathrm{E}+02)$ & $1.7 \mathrm{E}+05$ & $(1.5 \mathrm{E}+04)$ & $(1.2 \mathrm{E}+03)$ & $5.4 \mathrm{E}+02$ & $(7.8 \mathrm{E}+03)$ \\
\hline Jar $19650(204)$ & $(2.0 \mathrm{E}+03)$ & $(4.0 \mathrm{E}+02)$ & $<9.5 \mathrm{E}+03$ & $<4.8 \mathrm{E}+03$ & $(7.5 E+02)$ & $(8.8 \mathrm{E}+04)$ & $(3.7 \mathrm{E}+04)$ & $(1.9 \mathrm{E}+03)$ & $7.1 \mathrm{E}+02$ & $(2.5 \mathrm{E}+02)$ \\
\hline Jar 19650 (204) Dup & $(9.6 \mathrm{E}+02)$ & $(4.4 \mathrm{E}+02)$ & $<8.0 \mathrm{E}+03$ & $<4.0 \mathrm{E}+03$ & $(7.4 \mathrm{E}+02)$ & $9.3 \mathrm{E}+04$ & $(3.4 \mathrm{E}+04)$ & $(3.6 \mathrm{E}+03)$ & $6.7 \mathrm{E}+02$ & $(7.8 \mathrm{E}+01)$ \\
\hline 19650 (204) Avg & $(1.5 \mathrm{E}+03)$ & $(4.2 \mathrm{E}+02)$ & $<8.8 \mathrm{E}+03$ & $<4.4 \mathrm{E}+03$ & $(7.5 \mathrm{E}+02)$ & $(9.1 \mathrm{E}+04)$ & $(3.6 \mathrm{E}+04)$ & $(2.8 \mathrm{E}+03)$ & $6.9 \mathrm{E}+02$ & $(1.6 \mathrm{E}+02)$ \\
\hline \multicolumn{11}{|c|}{ EPA Acid Digestion } \\
\hline Jar $19649(203)$ & $(7.7 \mathrm{E}+02)$ & $(2.3 \mathrm{E}+02)$ & $<4.5 \mathrm{E}+03$ & $<2.3 \mathrm{E}+03$ & $5.8 \mathrm{E}+02$ & $1.6 \mathrm{E}+05$ & $(7.1 \mathrm{E}+03)$ & $(2.4 \mathrm{E}+03)$ & $(2.0 \mathrm{E}+02)$ & $<4.5 \mathrm{E}+03$ \\
\hline Jar 19649 (203) Dup & $(5.0 \mathrm{E}+02)$ & $(1.8 \mathrm{E}+02)$ & $<4.9 \mathrm{E}+03$ & $<2.4 \mathrm{E}+03$ & $(4.5 \mathrm{E}+02)$ & $1.6 \mathrm{E}+05$ & $(6.3 \mathrm{E}+03)$ & $(2.2 \mathrm{E}+03)$ & $(1.5 \mathrm{E}+02)$ & $<4.9 \mathrm{E}+03$ \\
\hline Jar $19650(204)$ & $(5.9 \mathrm{E}+01)$ & $4.5 \mathrm{E}+02$ & $<4.1 \mathrm{E}+03$ & $(1.4 \mathrm{E}+01)$ & $5.2 \mathrm{E}+02$ & $7.1 \mathrm{E}+04$ & $(5.5 \mathrm{E}+03)$ & $(2.2 \mathrm{E}+03)$ & $(9.7 \mathrm{E}+01)$ & $<4.1 \mathrm{E}+03$ \\
\hline Jar 19650 (204) Dup & $<4.0 \mathrm{E}+03$ & $(3.6 \mathrm{E}+02)$ & $<4.0 \mathrm{E}+03$ & $<2.0 \mathrm{E}+03$ & $6.2 \mathrm{E}+02$ & $5.9 \mathrm{E}+04$ & $(4.7 \mathrm{E}+03)$ & $(2.1 \mathrm{E}+03)$ & $(1.0 \mathrm{E}+02)$ & $<4.0 \mathrm{E}+03$ \\
\hline Jar 19649 (203) Avg & $(6.3 \mathrm{E}+02)$ & $(2.1 \mathrm{E}+02)$ & $<4.7 \mathrm{E}+03$ & $<2.3 \mathrm{E}+03$ & $5.2 \mathrm{E}+02$ & $1.6 \mathrm{E}+05$ & $(6.7 \mathrm{E}+03)$ & $(2.3 \mathrm{E}+03)$ & $(1.8 \mathrm{E}+02)$ & $<4.7 \mathrm{E}+03$ \\
\hline Jar 19650 (204) Avg & $(2.0 \mathrm{E}+03)$ & $4.0 \mathrm{E}+02$ & $<4.0 \mathrm{E}+03$ & $(1.0 \mathrm{E}+03)$ & $5.7 \mathrm{E}+02$ & $6.5 \mathrm{E}+04$ & $(5.1 \mathrm{E}+03)$ & $(2.1 \mathrm{E}+03)$ & $(9.9 \mathrm{E}+01)$ & $<4.0 \mathrm{E}+03$ \\
\hline
\end{tabular}


The element concentrations in Tables 3.5 and 3.6 were derived from the ICP-MS analyses, which require user calibration with multi-element standards in concentrations ranging from $5 \mathrm{pg} / \mathrm{mL}$ to $20 \mathrm{ng} / \mathrm{mL}$. Standard ICP-MS operating software does not allow the input of the various elemental isotope concentrations as percent relative abundance. Under most circumstances, the lack of correction for percent abundances creates no analytical quantification issues when only naturally occurring isotopes are present. However, care must be taken to interpret data under circumstances where the products of nuclear fission could be present.

In this case, the greatest impact to the quantification of elemental data using standard calibration methods would be an overestimation of the concentration of an element in the presence of a fission product. For instance, Mo has seven natural isotopes with relative abundances ranging from $9.25 \%$ to $24.13 \%$. When the ICP-MS is calibrated, the counts per second measured at a specific mass are assigned a concentration by the operator. Unfortunately, the current manufacturer-supplied software does not account for the relative percent abundance of the seven Mo isotopes, nor will it allow the operator to assign different standard concentrations for the isotopes. In other words, for a $1 \mathrm{ng} / \mathrm{mL}$ calibration standard, $1 \mathrm{ng} / \mathrm{mL}$ must be assigned as the concentration for all seven Mo isotopes rather than $1 \mathrm{ng} / \mathrm{mL}$ multiplied by the percent abundance of the natural isotope. As mentioned above, this is not an issue when dealing only with natural systems, which will always have the relative abundance breakdown of $9.25 \%$ to $24.13 \%$ for the seven Mo isotopes. However, if ${ }^{95} \mathrm{Mo},{ }^{97} \mathrm{Mo},{ }^{98} \mathrm{Mo}$, or ${ }^{100} \mathrm{Mo}$ fission products are present in the samples being analyzed, the actual fission product contribution to the total isotope concentration will be overestimated by a factor of 100 divided by the percent relative abundance of the natural isotope.

For future studies of tank sludge, the new Perkin Elmer Elan DRC II ICP-MS software will be available. It appears to allow the operator to assign different concentration values for each isotope of a respective element. This feature will enable user calibration based on the percent relative abundance of the natural isotopes. Measurement in this manner will permit the determination of individual masses without corrections for natural abundance. As the new ICP-MS is brought online, this technique will be tested with the objective that all subsequent calibration will be the direct quantification of total isotope concentrations. This will aid in the interpretation and possible quantification of fission products present in tank sludges.

The only elements listed in Tables 3.5 and 3.6 with concentrations greater than their EQLs are Cr and $\mathrm{Pb}$. The concentrations for the other listed elements (As, Se, Mo, $\mathrm{Ru}, \mathrm{Ag}$ and $\mathrm{Cd}$ ) are less than the EQL; however, qualitative data (listed in parentheses) are available for some elements in one or more of the samples. The average $\mathrm{Cr}$ concentrations (based on ${ }^{52} \mathrm{Cr}$ and ${ }^{53} \mathrm{Cr}$ ) in the $\mathrm{C}-203$ sludge measured by the fusion method is $2.30 \times 10^{4} \mu \mathrm{g} / \mathrm{g}$ and by EPA acid digestion $1.77 \times 10^{4} \mu \mathrm{g} / \mathrm{g}$, which are similar to the ICP-OES respective values of $2.4 \times 10^{4}$ and $2.0 \times 10^{4} \mu \mathrm{g} / \mathrm{g}$. The average $\mathrm{Pb}$ concentrations (based on ${ }^{208} \mathrm{~Pb}$ ) in the $\mathrm{C}-203$ sludge measured by the fusion method is $6.97 \times 10^{3} \mu \mathrm{g} / \mathrm{g}$ and by EPA acid digestion $7.63 \times 10^{3} \mu \mathrm{g} / \mathrm{g}$, which are similar to the ICP-OES respective values of $7.3 \times 10^{3}$ and $8.0 \times 10^{3} \mu \mathrm{g} / \mathrm{g}$.

The average $\mathrm{Cr}$ concentrations (based on ${ }^{52} \mathrm{Cr}$ and ${ }^{53} \mathrm{Cr}$ ) in the $\mathrm{C}-204$ sludge measured by the fusion method is $8.29 \times 10^{3} \mu \mathrm{g} / \mathrm{g}$ and by EPA acid digestion $8.77 \times 10^{3} \mu \mathrm{g} / \mathrm{g}$, which are similar to the ICP-OES respective values of $8.9 \times 10^{3}$ and $1.0 \times 10^{4} \mu \mathrm{g} / \mathrm{g}$. The average $\mathrm{Pb}$ concentration (based on ${ }^{208} \mathrm{~Pb}$ ) in the 
Table 3.5. Concentrations of Elements Determined from ICP-MS Analysis per Gram of Dry Sludge

\begin{tabular}{|c|c|c|c|c|c|c|c|}
\hline \multirow[b]{3}{*}{ Sample Number } & \multicolumn{2}{|c|}{$\mathrm{Cr}$ - total based on } & \multirow{2}{*}{\begin{tabular}{|c|} 
As - total based on \\
${ }^{75} \mathrm{As}$ \\
\end{tabular}} & \multirow{2}{*}{$\begin{array}{c}\text { Se - total based on } \\
{ }^{82} \mathrm{Se} \\
\end{array}$} & \multicolumn{3}{|c|}{ Mo - total based on } \\
\hline & ${ }^{52} \mathrm{Cr}$ & ${ }^{53} \mathrm{Cr}$ & & & ${ }^{95} \mathrm{Mo}$ & ${ }^{98} \mathrm{Mo}^{(\mathrm{a})}$ & ${ }^{100} \mathrm{Mo}$ \\
\hline & \multicolumn{7}{|c|}{$\mu \mathrm{g} / \mathrm{g}$} \\
\hline \multicolumn{8}{|c|}{ 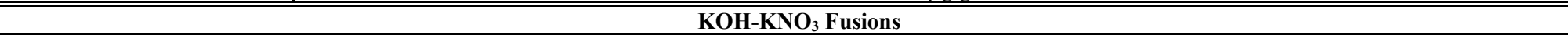 } \\
\hline Jar 19649 (203) & $2.28 \mathrm{E}+04$ & $2.31 \mathrm{E}+04$ & $(6.43 \mathrm{E}+01)$ & $(4.91 \mathrm{E}+01)$ & $(3.35 \mathrm{E}+01)$ & $<4.32 \mathrm{E}+01$ & $<4.32 \mathrm{E}+01$ \\
\hline Jar $19650(204)$ & $(8.09 \mathrm{E}+03)$ & $8.41 \mathrm{E}+03$ & $(1.34 \mathrm{E}+02)$ & $(2.16 \mathrm{E}+02)$ & $(3.79 \mathrm{E}+01)$ & $(9.32 \mathrm{E}+00)$ & $(7.61 \mathrm{E}-01)$ \\
\hline Jar 19650 (204) Dup & $8.17 \mathrm{E}+03$ & $8.50 \mathrm{E}+03$ & $(2.03 \mathrm{E}+01)$ & $(1.80 \mathrm{E}+02)$ & $(2.75 \mathrm{E}+01)$ & $(4.18 \mathrm{E}+00)$ & $<4.02 \mathrm{E}+01$ \\
\hline 19650 (204) Avg & $(8.13 \mathrm{E}+03)$ & $8.45 \mathrm{E}+03$ & $(7.73 \mathrm{E}+01)$ & $(1.98 \mathrm{E}+02)$ & $(3.27 \mathrm{E}+01)$ & $(6.75 \mathrm{E}+00)$ & $(2.05 \mathrm{E}+01)$ \\
\hline \multicolumn{8}{|c|}{ EPA Acid Digestion } \\
\hline Jar 19649 (203) & $1.74 \mathrm{E}+04$ & $1.81 \mathrm{E}+04$ & $(1.83 \mathrm{E}+01)$ & $(5.01 \mathrm{E}+01)$ & $<2.25 \mathrm{E}+02$ & $<2.25 \mathrm{E}+01$ & $(8.11 \mathrm{E}-01)$ \\
\hline Jar 19649 (203) Dup & $1.73 \mathrm{E}+04$ & $1.77 \mathrm{E}+04$ & $<9.72 \mathrm{E}+02$ & $(1.18 \mathrm{E}+02)$ & $<2.43 \mathrm{E}+02$ & $<2.43 \mathrm{E}+01$ & $<2.43 \mathrm{E}+01$ \\
\hline Jar $19650(204)$ & $9.75 \mathrm{E}+03$ & $9.83 \mathrm{E}+03$ & $(2.50 \mathrm{E}+01)$ & $(9.71 \mathrm{E}+01)$ & $(2.36 \mathrm{E}+00)$ & $(3.09 \mathrm{E}+00)$ & $(2.69 \mathrm{E}+00)$ \\
\hline Jar 19650 (204) Dup & $7.69 \mathrm{E}+03$ & $7.81 \mathrm{E}+03$ & $(3.49 \mathrm{E}+01)$ & $(1.02 \mathrm{E}+02)$ & $<1.99 \mathrm{E}+02$ & $(5.57 \mathrm{E}-01)$ & $(3.18 \mathrm{E}-01)$ \\
\hline Jar 19649 (203) Avg & $1.74 \mathrm{E}+04$ & $1.79 \mathrm{E}+04$ & $(4.95 \mathrm{E}+02)$ & $(8.42 \mathrm{E}+01)$ & $<2.34 \mathrm{E}+02$ & $<2.34 \mathrm{E}+01$ & $(1.26 \mathrm{E}+01)$ \\
\hline Jar 19650 (204) Avg & $8.72 \mathrm{E}+03$ & $8.82 \mathrm{E}+03$ & $(3.00 \mathrm{E}+01)$ & $(9.97 \mathrm{E}+01)$ & $(1.01 \mathrm{E}+02)$ & $(1.83 \mathrm{E}+00)$ & $(1.50 \mathrm{E}+00)$ \\
\hline
\end{tabular}

Table 3.6. Concentrations of Elements Determined from ICP-MS Analysis per Gram of Dry Sludge

\begin{tabular}{|c|c|c|c|c|c|c|c|c|c|}
\hline \multirow[b]{3}{*}{ Sample Number } & \multicolumn{3}{|c|}{ Ru -total based on } & \multicolumn{2}{|c|}{ Ag - total based on } & \multicolumn{2}{|c|}{ Cd - total based on } & \multicolumn{2}{|c|}{$P b$ - total based on } \\
\hline & ${ }^{101} \mathbf{R u}$ & ${ }^{102} \mathbf{R u} *$ & ${ }^{104} \mathrm{Ru}$ & ${ }^{107} \mathrm{Ag}$ & ${ }^{109} \mathrm{Ag}^{*}$ & ${ }^{111} \mathrm{Cd}$ & ${ }^{114} \mathrm{Cd}^{*}$ & ${ }^{206} \mathrm{~Pb}$ & ${ }^{208} \mathbf{P b}^{(\mathbf{a})}$ \\
\hline & \multicolumn{9}{|c|}{$\mu \mathrm{g} / \mathrm{g}$} \\
\hline \multicolumn{10}{|c|}{ KOH-KNO ${ }_{3}$ Fusions } \\
\hline Jar 19649 (203) & $<4.32 \mathrm{E}+01$ & $<1.73 \mathrm{E}+01$ & $(8.64 \mathrm{E}-01)$ & $(1.74 \mathrm{E}+01)$ & $<8.64 \mathrm{E}+01$ & $(7.08 \mathrm{E}+00)$ & $<1.73 \mathrm{E}+02$ & $6.35 \mathrm{E}+03$ & $6.97 \mathrm{E}+03$ \\
\hline Jar $19650(204)$ & $<4.76 \mathrm{E}+01$ & $<1.90 \mathrm{E}+01$ & $<1.90 \mathrm{E}+01$ & $(1.90 \mathrm{E}+00)$ & $<9.51 \mathrm{E}+01$ & $(1.10 \mathrm{E}+01)$ & $(2.85 \mathrm{E}+00)$ & $1.46 \mathrm{E}+03$ & $1.57 \mathrm{E}+03$ \\
\hline Jar 19650 (204) Dup & $(2.90 \mathrm{E}+00)$ & $<1.61 \mathrm{E}+01$ & $<1.61 \mathrm{E}+01$ & $<8.05 \mathrm{E}+01$ & $<8.05 \mathrm{E}+01$ & $(1.45 \mathrm{E}+00)$ & $(3.22 \mathrm{E}-01)$ & $1.50 \mathrm{E}+03$ & $1.63 \mathrm{E}+03$ \\
\hline 19650 (204) Avg & $<2.52 \mathrm{E}+01$ & $<1.76 \mathrm{E}+01$ & $<1.76 \mathrm{E}+01$ & $(4.12 \mathrm{E}+01)$ & $<8.78 \mathrm{E}+01$ & $(6.24 \mathrm{E}+00)$ & $(1.59 \mathrm{E}+00)$ & $1.48 \mathrm{E}+03$ & $1.60 \mathrm{E}+03$ \\
\hline \multicolumn{10}{|c|}{$\begin{array}{l}\text { EPA Acid Digestion } \\
\end{array}$} \\
\hline Jar $19649(203)$ & $(3.24 \mathrm{E}+00)$ & $(8.11 \mathrm{E}-01)$ & $(3.70 \mathrm{E}+00)$ & $(9.92 \mathrm{E}-01)$ & $(1.17 \mathrm{E}+00)$ & $(3.34 \mathrm{E}+00)$ & $(3.15 \mathrm{E}+00)$ & $7.36 \mathrm{E}+03$ & $8.06 \mathrm{E}+03$ \\
\hline Jar 19649 (203) Dup & $(3.99 \mathrm{E}+00)$ & $(3.11 \mathrm{E}+00)$ & $(5.15 \mathrm{E}+00)$ & $<4.86 \mathrm{E}+01$ & $(9.72 \mathrm{E}-02)$ & $(2.62 \mathrm{E}+00)$ & $(1.07 \mathrm{E}+00)$ & $6.60 \mathrm{E}+03$ & $7.20 \mathrm{E}+03$ \\
\hline Jar $19650(204)$ & $(5.37 \mathrm{E}+00)$ & $(6.51 \mathrm{E}-01)$ & $(4.89 \mathrm{E}+00)$ & $<4.07 \mathrm{E}+01$ & $(3.26 \mathrm{E}-01)$ & $<4.07 \mathrm{E}+01$ & $<8.14 \mathrm{E}+01$ & $1.29 \mathrm{E}+03$ & $1.39 \mathrm{E}+03$ \\
\hline Jar 19650 (204) Dup & $(4.77 \mathrm{E}+00)$ & $(1.83 \mathrm{E}+00)$ & $(2.78 \mathrm{E}+00)$ & $<3.98 \mathrm{E}+01$ & $<3.98 \mathrm{E}+01$ & $(5.57 \mathrm{E}-01)$ & $(2.39 \mathrm{E}-01)$ & $1.37 \mathrm{E}+03$ & $1.51 \mathrm{E}+03$ \\
\hline \begin{tabular}{|l|} 
Jar $19649(203)$ Avg \\
\end{tabular} & $(3.62 \mathrm{E}+00)$ & $(1.96 \mathrm{E}+00)$ & $(4.42 \mathrm{E}+00)$ & $(2.48 \mathrm{E}+01)$ & $(6.35 \mathrm{E}-01)$ & $(2.98 \mathrm{E}+00)$ & $(2.11 \mathrm{E}+00)$ & $6.98 \mathrm{E}+03$ & $7.63 \mathrm{E}+03$ \\
\hline \begin{tabular}{|l|} 
Jar $19650(204)$ Avg \\
\end{tabular} & $(5.07 \mathrm{E}+00)$ & $(1.24 \mathrm{E}+00)$ & $(3.83 \mathrm{E}+00)$ & $<4.02 \mathrm{E}+01$ & $(2.00 \mathrm{E}+01)$ & $<2.06 \mathrm{E}+01$ & $<4.08 \mathrm{E}+01$ & $1.33 \mathrm{E}+03$ & $1.45 \mathrm{E}+03$ \\
\hline
\end{tabular}


C-204 sludge measured by the fusion method is $1.60 \times 10^{3} \mu \mathrm{g} / \mathrm{g}$ and by EPA acid digestion $1.45 \mathrm{x}$ $10^{3} \mu \mathrm{g} / \mathrm{g}$, which are similar to the ICP-OES respective values of $\left(1.7 \times 10^{3}\right) \mu \mathrm{g} / \mathrm{g}$ and $1.5 \times 10^{3} \mu \mathrm{g} / \mathrm{g}$.

The sludge concentrations of ${ }^{99} \mathrm{Tc}$ and ${ }^{238} \mathrm{U}$ measured by ICP-MS are listed in Table 3.7. The ${ }^{99} \mathrm{Tc}$ concentration in C-203 sludge measured by the fusion method is $0.100 \mu \mathrm{g} / \mathrm{g}$, and the average value by the EPA acid digestion method is $0.088 \mu \mathrm{g} / \mathrm{g}$. The ${ }^{99} \mathrm{Tc}$ average concentration in C-204 sludge measured by the fusion method is $0.387 \mu \mathrm{g} / \mathrm{g}$, and the average value by the EPA acid digestion method is $0.206 \mu \mathrm{g} / \mathrm{g}$. The ${ }^{238} \mathrm{U}$ concentration in C-203 sludge measured by the fusion method is $2.18 \times 10^{5} \mu \mathrm{g} / \mathrm{g}$, and the average value by the EPA acid digestion method is $1.95 \times 10^{5} \mu \mathrm{g} / \mathrm{g}$. The ${ }^{238} \mathrm{U}$ average concentration in C-204 sludge measured by the fusion method is $8.02 \times 10^{4} \mu \mathrm{g} / \mathrm{g}$, and the average value by the EPA acid digestion method is $3.31 \times 10^{4} \mu \mathrm{g} / \mathrm{g}$. The large difference in ${ }^{238} \mathrm{U}$ concentration between fusion and acid digestion may be due to the TBP present in the C-204 sludge.

The ${ }^{137}$ Cs concentrations in the C-203 and C-204 sludges measured by GEA are listed in Table 3.8. Data are presented for the untreated sludge and for the fusion and EPA acid digestion extracts. For Tank C-203, the values range from 0.0396 to $0444 \mu \mathrm{g} / \mathrm{g}(3.45$ to $3.86 \mu \mathrm{Ci} / \mathrm{g})$, and for Tank C-204 the range is 0.0522 to $0.0966 \mu \mathrm{g} / \mathrm{g}(4.37$ to $8.41 \mu \mathrm{Ci} / \mathrm{g})$.

Table 3.9 lists the concentrations of the transuranics (TRU) ${ }^{239} \mathrm{Pu},{ }^{241} \mathrm{Am}$, and ${ }^{244} \mathrm{Cm}$ in the sludges. The ${ }^{239} \mathrm{Pu}$ concentration in C-203 sludge measured by the fusion method is $63 \mu \mathrm{g} / \mathrm{g}(3.9 \mu \mathrm{Ci} / \mathrm{g})$, and the average value by the EPA acid digestion method is $38 \mu \mathrm{g} / \mathrm{g}(2.36 \mu \mathrm{Ci} / \mathrm{g})$. The ${ }^{241} \mathrm{Am}$ concentration in C-203 sludge measured by the fusion method is $0.041 \mu \mathrm{g} / \mathrm{g}(0.139 \mu \mathrm{Ci} / \mathrm{g})$, and the average value by the EPA acid digestion method is $0.031 \mu \mathrm{g} / \mathrm{g}(0.105 \mu \mathrm{Ci} / \mathrm{g})$. The ${ }^{244} \mathrm{Cm}$ concentration in $\mathrm{C}-203$ sludge measured by the fusion method is $7.16 \times 10^{-5} \mu \mathrm{g} / \mathrm{g}\left(5.8 \times 10^{-3} \mu \mathrm{Ci} / \mathrm{g}\right)$, and the average value by the EPA acid digestion method is $7.00 \times 10^{-5} \mu \mathrm{g} / \mathrm{g}\left(5.67 \times 10^{-3} \mu \mathrm{Ci} / \mathrm{g}\right)$.

Table 3.7. Concentrations of ${ }^{99} \mathrm{Tc}$ and ${ }^{238} \mathrm{U}$ Measured by ICP-MS per Gram of Dry Sludge

\begin{tabular}{||l|c|c||}
\hline \multirow{2}{*}{ Sample Number } & ${ }^{\mathbf{9 9}} \mathbf{T c}$ & ${ }^{{ }^{238} \mathbf{U}}$ \\
\cline { 2 - 4 } KOH-KNO ${ }_{3}$ Fusions \\
\hline \hline \multicolumn{3}{|c|}{ KOg } \\
\hline Jar 19649 (203) & $1.04 \mathrm{E}-01$ & $2.18 \mathrm{E}+05$ \\
\hline Jar 19650 (204) & $3.23 \mathrm{E}-01$ & $7.71 \mathrm{E}+04$ \\
\hline Jar 19650 (204) Dup & $4.51 \mathrm{E}-01$ & $8.32 \mathrm{E}+04$ \\
\hline 19650 (204) Avg & $3.87 \mathrm{E}-01$ & $8.02 \mathrm{E}+04$ \\
\hline \hline \multicolumn{3}{|c||}{ EPA Acid Digestion } \\
\hline Jar 19649 (203) & $1.08 \mathrm{E}-01$ & $1.99 \mathrm{E}+05$ \\
\hline Jar 19649 (203) Dup & $6.80 \mathrm{E}-02$ & $1.90 \mathrm{E}+05$ \\
\hline Jar 19650 (204) & $2.73 \mathrm{E}-01$ & $2.93 \mathrm{E}+04$ \\
\hline Jar 19650 (204) Dup & $1.39 \mathrm{E}-01$ & $3.70 \mathrm{E}+04$ \\
\hline Jar 19649 (203) Avg & $8.81 \mathrm{E}-02$ & $1.95 \mathrm{E}+05$ \\
\hline Jar 19650 (204) Avg & $2.06 \mathrm{E}-01$ & $3.31 \mathrm{E}+04$ \\
\hline \hline
\end{tabular}


Table 3.8. $\quad{ }^{137}$ Cs Concentrations in Dry Sludge as Measured by GEA

\begin{tabular}{|c|c|c|}
\hline \multirow[b]{2}{*}{ Sample Number } & ${ }^{137} \mathrm{Cs}$ & $\overline{{ }^{137} \mathrm{Cs}}$ \\
\hline & $\mu \mathrm{Ci} / \mathrm{g}$ & $\mu \mathrm{g} / \mathrm{g}$ \\
\hline \multicolumn{3}{|c|}{ "Untreated (Raw) Solid } \\
\hline Jar 19649 (203) & $3.45 \mathrm{E}+00$ & $3.963 \mathrm{E}-02$ \\
\hline Jar 19649 (203) Dup & $3.77 \mathrm{E}+00$ & $4.333 \mathrm{E}-02$ \\
\hline Jar $19650(204)$ & $6.66 \mathrm{E}+00$ & $7.655 \mathrm{E}-02$ \\
\hline Jar 19650 (204) Dup & $8.41 \mathrm{E}+00$ & $9.661 \mathrm{E}-02$ \\
\hline \multicolumn{3}{|c|}{ "KOH-KNO ${ }_{3}$ Fusions } \\
\hline Jar 19649 (203) & $3.61 \mathrm{E}+00$ & $4.152 \mathrm{E}-02$ \\
\hline Jar $19650(204)$ & $6.27 \mathrm{E}+00$ & $7.203 \mathrm{E}-02$ \\
\hline Jar 19650 (204) Dup & $6.63 \mathrm{E}+00$ & $7.625 \mathrm{E}-02$ \\
\hline 19650 (204) Avg & $6.45 \mathrm{E}+00$ & $7.414 \mathrm{E}-02$ \\
\hline \multicolumn{3}{|c|}{ EPA Acid Digestion } \\
\hline Jar $19649(203)$ & $3.47 \mathrm{E}+00$ & $3.992 \mathrm{E}-02$ \\
\hline Jar 19649 (203) Dup & $4.25 \mathrm{E}+00$ & $4.891 \mathrm{E}-02$ \\
\hline Jar $19650(204)$ & $4.02 \mathrm{E}+00$ & $4.617 \mathrm{E}-02$ \\
\hline Jar 19650 (204) Dup & $4.72 \mathrm{E}+00$ & $5.426 \mathrm{E}-02$ \\
\hline Jar 19649 (203) Avg & $3.86 \mathrm{E}+00$ & $4.441 \mathrm{E}-02$ \\
\hline Jar 19650 (204) Avg & $4.37 \mathrm{E}+00$ & $5.021 \mathrm{E}-02$ \\
\hline
\end{tabular}

Table 3.9. $\quad$ AEA for Actinides per Gram of Dry Sludge

\begin{tabular}{|c|c|c|c|c|c|c|}
\hline Sample Number & $\begin{array}{r}{ }^{239} \mathrm{Pu} \\
\mu \mathrm{Ci} / \mathrm{g}\end{array}$ & $\begin{array}{r}{ }^{239} \mathrm{Pu} \\
\mu \mathrm{g} / \mathrm{g}\end{array}$ & $\begin{array}{r}{ }^{241} \mathrm{Am} \\
\mu \mathrm{Ci} / \mathrm{g}\end{array}$ & $\begin{array}{r}{ }_{\mu \mathrm{g} / \mathrm{g}}^{241} \mathrm{Am} \\
\end{array}$ & $\begin{array}{l}{ }^{244} \mathrm{Cm} \\
\mu \mathrm{Ci} / \mathrm{g}\end{array}$ & $\begin{array}{c}{ }^{244} \mathrm{Cm} \\
\mu \mathrm{g} / \mathrm{g}\end{array}$ \\
\hline \multicolumn{7}{|c|}{$\mathrm{KOH} \mathrm{KNO}_{3}$ Fusions } \\
\hline Jar 19649 (203) & $3.90 \mathrm{E}+00$ & $6.30 \mathrm{E}+01$ & $1.39 \mathrm{E}-01$ & $4.08 \mathrm{E}-02$ & $5.80 \mathrm{E}-03$ & $7.16 \mathrm{E}-05$ \\
\hline Jar $19650(204)$ & $9.23 \mathrm{E}-03$ & $1.49 \mathrm{E}-01$ & $<6.43 \mathrm{E}-03$ & $<1.89 \mathrm{E}-03$ & $6.23 \mathrm{E}-03$ & $7.69 \mathrm{E}-05$ \\
\hline Jar 19650 (204) Dup & $9.60 \mathrm{E}-03$ & $1.55 \mathrm{E}-01$ & $<5.44 \mathrm{E}-03$ & $<1.60 \mathrm{E}-03$ & $5.65 \mathrm{E}-03$ & $6.97 \mathrm{E}-05$ \\
\hline 19650 (204) Avg & $9.42 \mathrm{E}-03$ & $1.52 \mathrm{E}-01$ & $<5.94 \mathrm{E}-03$ & $<1.75 \mathrm{E}-03$ & $5.94 \mathrm{E}-03$ & $7.33 \mathrm{E}-05$ \\
\hline \multicolumn{7}{|c|}{ EPA Acid Digestion } \\
\hline Jar 19649 (203) & $2.37 \mathrm{E}+00$ & $3.82 \mathrm{E}+01$ & $1.07 \mathrm{E}-01$ & $3.13 \mathrm{E}-02$ & $5.35 \mathrm{E}-03$ & $6.61 \mathrm{E}-05$ \\
\hline \begin{tabular}{|l}
$J a r$ \\
19649 (203) Dup
\end{tabular} & $2.34 \mathrm{E}+00$ & $3.78 \mathrm{E}+01$ & $1.04 \mathrm{E}-01$ & $3.06 \mathrm{E}-02$ & $5.99 \mathrm{E}-03$ & $7.40 \mathrm{E}-05$ \\
\hline Jar 19650 (204) & $2.55 \mathrm{E}-03$ & $4.11 \mathrm{E}-02$ & $2.76 \mathrm{E}-03$ & $8.11 \mathrm{E}-04$ & $2.68 \mathrm{E}-03$ & $3.31 \mathrm{E}-05$ \\
\hline Jar 19650 (204) Dup & $3.42 \mathrm{E}-03$ & $5.51 \mathrm{E}-02$ & $2.75 \mathrm{E}-03$ & $8.08 \mathrm{E}-04$ & $3.16 \mathrm{E}-03$ & $3.90 \mathrm{E}-05$ \\
\hline \begin{tabular}{|l|} 
Jar 19649 (203) Avg \\
\end{tabular} & $2.36 \mathrm{E}+00$ & $3.80 \mathrm{E}+01$ & $1.05 \mathrm{E}-01$ & $3.10 \mathrm{E}-02$ & $5.67 \mathrm{E}-03$ & $7.00 \mathrm{E}-05$ \\
\hline Jar 19650 (204) Avg & $2.98 \mathrm{E}-03$ & $4.81 \mathrm{E}-02$ & $2.75 \mathrm{E}-03$ & 8.09E-04 & $2.92 \mathrm{E}-03$ & $3.61 \mathrm{E}-05$ \\
\hline
\end{tabular}

The ${ }^{239} \mathrm{Pu}$ concentration in C-204 sludge measured by the fusion method is $0.152 \mu \mathrm{g} / \mathrm{g}(9.42 \mathrm{x}$ $\left.10^{-3} \mu \mathrm{Ci} / \mathrm{g}\right)$, and the average value by the EPA acid digestion method is $0.048 \mu \mathrm{g} / \mathrm{g}\left(2.98 \times 10^{-3} \mu \mathrm{Ci} / \mathrm{g}\right)$. The ${ }^{241} \mathrm{Am}$ concentration in C-204 sludge measured by the fusion method is $1.3 \times 10^{-3} \mu \mathrm{g} / \mathrm{g}(4.4 \mathrm{x}$ $\left.10^{-3} \mu \mathrm{Ci} / \mathrm{g}\right)$, and the average value by the EPA acid digestion method is $8.09 \times 10^{-4} \mu \mathrm{g} / \mathrm{g}(2.75 \mathrm{x}$ $\left.10^{-3} \mu \mathrm{Ci} / \mathrm{g}\right)$. The ${ }^{244} \mathrm{Cm}$ concentration in C-204 sludge measured by the fusion method is $7.33 \times 10^{-5} \mu \mathrm{g} / \mathrm{g}$ $\left(5.94 \times 10^{-3} \mu \mathrm{Ci} / \mathrm{g}\right)$, and the average value by the EPA acid digestion method is $3.61 \times 10^{-5} \mu \mathrm{g} / \mathrm{g}(2.92 \mathrm{x}$ $\left.10^{-3} \mu \mathrm{Ci} / \mathrm{g}\right)$. 
DOE defines TRU waste as radioactive waste that at the time of assay contains more than $100 \mathrm{nCi} / \mathrm{g}$ of alpha-emitting isotopes with atomic numbers greater than 92 and half-lives greater than 20 years (DOE Order $5820.2 \mathrm{~A}$ ). ${ }^{239} \mathrm{Pu}$ and ${ }^{241} \mathrm{Am}$ are TRU isotopes with half-lives greater than 20 years, while ${ }^{244} \mathrm{Cm}$ is a TRU isotope with a half-life of less than 20 years. The sum of the ${ }^{239} \mathrm{Pu}$ and ${ }^{241} \mathrm{Am}$ isotopes in C-203 sludge measured by the fusion method is $4,039 \mathrm{nCi} / \mathrm{g}$ and by the EPA acid digestion method 2,470 nCi/g. Based on the definition, this would classify the sludge in C-203 as TRU waste. The sum of the ${ }^{239} \mathrm{Pu}$ and

${ }^{241} \mathrm{Am}$ isotopes in $\mathrm{C}-204$ sludge measured by the fusion method is $13.8 \mathrm{nCi} / \mathrm{g}$ and by the $\mathrm{EPA}$ acid digestion method $5.73 \mathrm{nCi} / \mathrm{g}$. These values should not be used to classify the waste in $\mathrm{C}-204$ because this waste included $28.3 \%$ TBP. It is known that TBP is an effective adsorbent for actinides (Schulz et al. 1984). The fusion and acid extraction methods used for measuring total actinide concentrations in the C-204 sludge left a residue after digestion that likely contained TBP. Consequently, the actinides in this residue were not accounted for in the measurement, and the reported concentrations are considered minimum values.

Table 3.10 lists the gross beta, gross alpha, and ${ }^{90} \mathrm{Sr}$ concentrations in sludge samples from Tanks C-203 and C-204. The gross beta value for C-203 sludge measured by fusion extraction was $67.54 \mu \mathrm{Ci} / \mathrm{g}$; by EPA acid digestion the average value was $75.8 \mu \mathrm{Ci} / \mathrm{g}$. The gross alpha value for this sludge measured by fusion extraction was $29.25 \mu \mathrm{Ci} / \mathrm{g}$ and by EPA acid digestion $27.7 \mu \mathrm{Ci} / \mathrm{g}$. The ${ }^{90} \mathrm{Sr}$ value for $\mathrm{C}-203$ measured by fusion extraction was $70.9 \mu \mathrm{Ci} / \mathrm{g}$, and the average by EPA acid digestion was $76.4 \mu \mathrm{Ci} / \mathrm{g}$. The gross beta value for C-204 sludge measured by the fusion extraction was $26.45 \mu \mathrm{Ci} / \mathrm{g}$, and by EPA acid digestion the average was $23.1 \mu \mathrm{Ci} / \mathrm{g}$. The gross alpha value for this sludge measured by fusion extraction was $4.162 \mu \mathrm{Ci} / \mathrm{g}$; by EPA acid digestion it was $5.95 \mu \mathrm{Ci} / \mathrm{g}$. The ${ }^{90} \mathrm{Sr}$ value for $\mathrm{C}-204$ measured by fusion extraction was $24.2 \mu \mathrm{Ci} / \mathrm{g}$, and the average by EPA acid digestion was $22.5 \mu \mathrm{Ci} / \mathrm{g}$.

Table 3.11 provides a summary of the major components of the sludges as measured for the metals by fusion and EPA acid digestion analysis. For completeness, the anion analyses, as measured by the

Table 3.10. Total Beta and Total Alpha Activities and ${ }^{90} \mathrm{Sr}$ Concentrations per Gram of Dry Sludge

\begin{tabular}{|c|c|c|c|c|}
\hline \multirow[b]{2}{*}{ Sample Number } & Gross Beta & Gross Alpha & \multicolumn{2}{|c|}{${ }^{90} \mathrm{Sr}$} \\
\hline & \multicolumn{2}{|c|}{$\mu \mathrm{Ci} / \mathrm{g}$} & $\mu \mathrm{Ci} / \mathrm{g}$ & $\mu \mathrm{g} / \mathrm{g}$ \\
\hline \multicolumn{5}{|c|}{ "KOH-KNO${ }_{3}$ Fusions } \\
\hline Jar 19649 (203) & $6.754 \mathrm{E}+01$ & $2.925 \mathrm{E}+01$ & $7.09 \mathrm{E}+01$ & $5.06 \mathrm{E}-01$ \\
\hline Jar 19650 (204) & $2.521 \mathrm{E}+01$ & $2.879 \mathrm{E}+00$ & $2.20 \mathrm{E}+01$ & $1.57 \mathrm{E}-01$ \\
\hline Jar 19650 (204) Dup & $2.769 \mathrm{E}+01$ & $5.446 \mathrm{E}+00$ & $2.64 \mathrm{E}+01$ & $1.88 \mathrm{E}-01$ \\
\hline 19650 (204) Avg & $2.645 \mathrm{E}+01$ & $4.162 \mathrm{E}+00$ & $2.42 \mathrm{E}+01$ & $1.73 \mathrm{E}-01$ \\
\hline \multicolumn{5}{|c|}{ EPA Acid Digestion } \\
\hline Jar $19649(203)$ & $7.565 \mathrm{E}+01$ & $2.864 \mathrm{E}+01$ & $7.50 \mathrm{E}+01$ & $5.35 \mathrm{E}-01$ \\
\hline Jar 19649 (203) Dup & $7.597 \mathrm{E}+01$ & $2.680 \mathrm{E}+01$ & $7.78 \mathrm{E}+01$ & $5.55 \mathrm{E}-01$ \\
\hline Jar $19650(204)$ & $2.133 \mathrm{E}+01$ & $4.885 \mathrm{E}+00$ & $2.30 \mathrm{E}+01$ & $1.64 \mathrm{E}-01$ \\
\hline Jar 19650 (204) Dup & $2.496 \mathrm{E}+01$ & $7.015 \mathrm{E}+00$ & $2.20 \mathrm{E}+01$ & $1.57 \mathrm{E}-01$ \\
\hline Jar 19649 (203) Avg & $7.58 \mathrm{E}+01$ & $2.77 \mathrm{E}+01$ & $7.64 \mathrm{E}+01$ & $5.45 \mathrm{E}-01$ \\
\hline Jar 19650 (204) Avg & $2.31 \mathrm{E}+01$ & $5.95 \mathrm{E}+00$ & $2.25 \mathrm{E}+01$ & $1.61 \mathrm{E}-01$ \\
\hline
\end{tabular}


Table 3.11. Summary of Average Concentrations from the $\mathrm{KOH}-\mathrm{KNO}_{3}$ Fusion and $\mathrm{EPA}$ Acid Digestion Analyses for C-203 and C-204 Sludge Samples

\begin{tabular}{|c|c|c|c|c|c|}
\hline \multirow[b]{2}{*}{ Analyte } & \multicolumn{2}{|c|}{ C-203 ( $(\mu \mathrm{g} / \mathrm{g})$} & \multirow[b]{2}{*}{ Analyte } & \multicolumn{2}{|c|}{ C-204 ( $(\mu \mathrm{g} / \mathrm{g})$} \\
\hline & Fusion & $\begin{array}{l}\text { EPA Acid } \\
\text { Digestion }\end{array}$ & & Fusion & $\begin{array}{l}\text { EPA Acid } \\
\text { Digestion }\end{array}$ \\
\hline$\overline{\mathrm{Al}}$ & 3,900 & 3,270 & $\mathrm{Al}$ & 28,000 & 16,500 \\
\hline $\mathrm{Ca}$ & 7,900 & 7,270 & $\mathrm{Ca}$ & 4,370 & 1,520 \\
\hline $\mathrm{Cr}$ & 24,000 & 19,700 & $\mathrm{Cr}$ & 8,900 & 10,100 \\
\hline $\mathrm{Fe}$ & 39,000 & 51,800 & $\mathrm{Fe}$ & 127,000 & 195,000 \\
\hline $\mathrm{K}$ & NA & $(1,600)$ & $\mathrm{K}$ & $\mathrm{NA}$ & $(530)$ \\
\hline $\mathrm{Mn}$ & 2,300 & 2,140 & $\mathrm{Mn}$ & 1,020 & 1,380 \\
\hline $\mathrm{Na}$ & 170,000 & 158,000 & $\mathrm{Na}$ & 90,700 & 65,200 \\
\hline $\mathrm{Ni}$ & $(540)$ & 827 & $\mathrm{Ni}$ & 2,850 & 4,140 \\
\hline $\mathrm{P}$ & $(1,200)$ & 6,600 & $\mathrm{P}$ & 54,100 & 21,400 \\
\hline $\mathrm{Pb}$ & 7,300 & 8,000 & $\mathrm{~Pb}$ & $(1,700)$ & 1,480 \\
\hline $\mathrm{Si}$ & $(15,000)$ & $(6,700)$ & $\mathrm{Si}$ & $(36,000)$ & $(5,100)$ \\
\hline $\mathrm{Sr}$ & $(180)$ & 206 & $\mathrm{Sr}$ & $(420)$ & 403 \\
\hline $\mathrm{Zn}$ & $(580)$ & 517 & $\mathrm{Zn}$ & $(750)$ & 571 \\
\hline${ }^{99} \mathrm{Tc}$ & 0.104 & 0.0881 & ${ }^{99} \mathrm{Tc}$ & 0.387 & 0.206 \\
\hline \multirow[t]{2}{*}{${ }^{238} \mathrm{U}$} & 218,000 & 195,000 & ${ }^{238} \mathrm{U}$ & 80,200 & 33,100 \\
\hline & \multicolumn{2}{|c|}{ Water Leach } & & \multicolumn{2}{|c|}{ Water Leach } \\
\hline $\mathrm{F}^{-}$ & \multicolumn{2}{|c|}{5,890} & $\mathrm{~F}^{-}$ & \multicolumn{2}{|c|}{184} \\
\hline Formate & \multicolumn{2}{|c|}{2,050} & Formate & \multicolumn{2}{|c|}{1,900} \\
\hline $\mathrm{Cl}^{-}$ & \multicolumn{2}{|c|}{1,580} & $\mathrm{Cl}^{-}$ & \multicolumn{2}{|c|}{800} \\
\hline $\mathrm{NO}_{2}^{-}$ & \multicolumn{2}{|c|}{8,240} & $\mathrm{NO}_{2}^{-}$ & \multicolumn{2}{|c|}{19,400} \\
\hline $\mathrm{NO}_{3}{ }^{-}$ & \multicolumn{2}{|c|}{163,000} & $\mathrm{NO}_{3}{ }^{-}$ & \multicolumn{2}{|c|}{29,300} \\
\hline $\mathrm{CO}_{3}{ }^{2-}$ & \multicolumn{2}{|c|}{171,000} & $\mathrm{CO}_{3}{ }^{2-}$ & \multicolumn{2}{|c|}{83,200} \\
\hline $\mathrm{SO}_{4}{ }^{2-}$ & \multicolumn{2}{|c|}{4,463} & $\mathrm{SO}_{4}^{2-}$ & \multicolumn{2}{|c|}{3,760} \\
\hline Oxalate & \multicolumn{2}{|c|}{25,370} & Oxalate & \multicolumn{2}{|c|}{645} \\
\hline $\mathrm{PO}_{4}{ }^{3-}$ & \multicolumn{2}{|c|}{776} & $\mathrm{PO}_{4}{ }^{3-}$ & \multicolumn{2}{|c|}{5,440} \\
\hline
\end{tabular}

water-leaching tests, and the TBP result for the analysis of C-204 have been included. Figure 3.1 shows the components of the $\mathrm{C}-203$ sludge that were measured at concentrations greater than $1,000 \mu \mathrm{g} / \mathrm{g}$ by the fusion method for the metals and represents the average of the batch water-leaching experiments for the anions (Table 3.19). The predominant metals are ${ }^{238} \mathrm{U}(21.8 \mathrm{wt} \%), \mathrm{Na}(17 \mathrm{wt} \%), \mathrm{Fe}(3.9 \mathrm{wt} \%)$, and $\mathrm{Cr}$ (2.4 $\mathrm{wt} \%)$. The predominant anions in C-203 sludge are carbonate $(17.1 \mathrm{wt} \%)$, nitrate $(16.3 \mathrm{wt} \%)$, oxalate $(2.54 \mathrm{wt} \%)$, and nitrite $(0.8 \mathrm{wt} \%)$. Figure 3.2 shows the components of the $\mathrm{C}-204$ sludge. The predominant metals are $\mathrm{Fe}(12.7 \mathrm{wt} \%), \mathrm{Na}(9.1 \mathrm{wt} \%),{ }^{238} \mathrm{U}(8 \mathrm{wt} \%), \mathrm{Si}(3.6 \mathrm{wt} \%)$, and $\mathrm{Al}(2.8 \mathrm{wt} \%)$. The predominant anions in C-204 sludge are carbonate $(8.32 \mathrm{wt} \%)$, nitrate $(2.93 \mathrm{wt} \%)$, and nitrite $(1.94 \mathrm{wt} \%)$. A major component of the $\mathrm{C}-204$ sludge is the organic compound TBP $(28.3 \mathrm{wt} \%)$.

\section{2 $\quad{ }^{129}$ I Extraction and Measurement}

Table 3.12 contains results of the ${ }^{129} \mathrm{I}$ analysis of the modified $\mathrm{KOH}: \mathrm{KNO}_{3}$ water fusion of C-203 sludge material. The data are reported as $\mathrm{pCi}^{129} \mathrm{I}$ per gram of sludge (calculated on a dry weight basis). ICP-MS analysis of ${ }^{129}$ I was better than $\pm 10 \%$ of certified reference standards, with the linear operating 


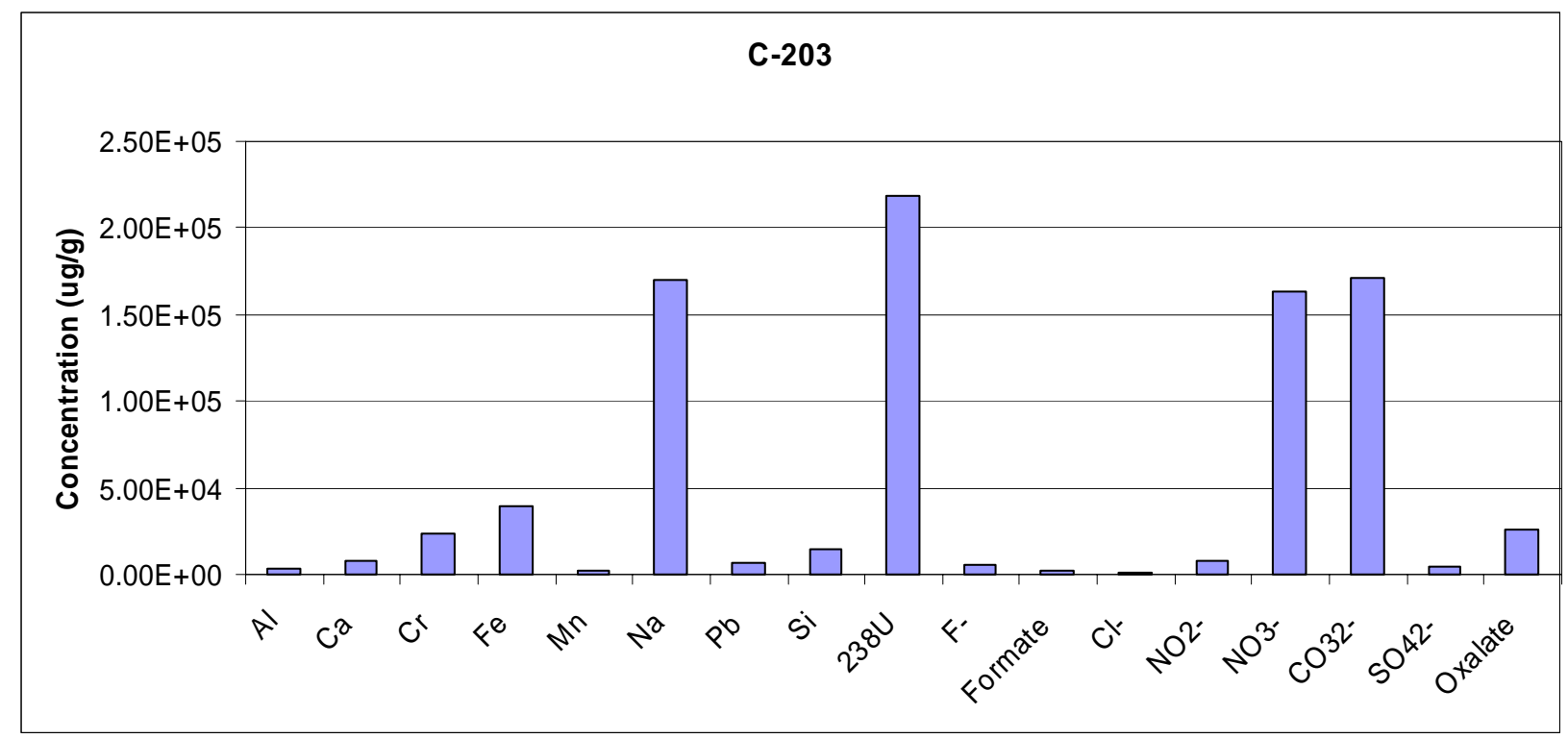

Figure 3.1. C-203 Sludge Composition

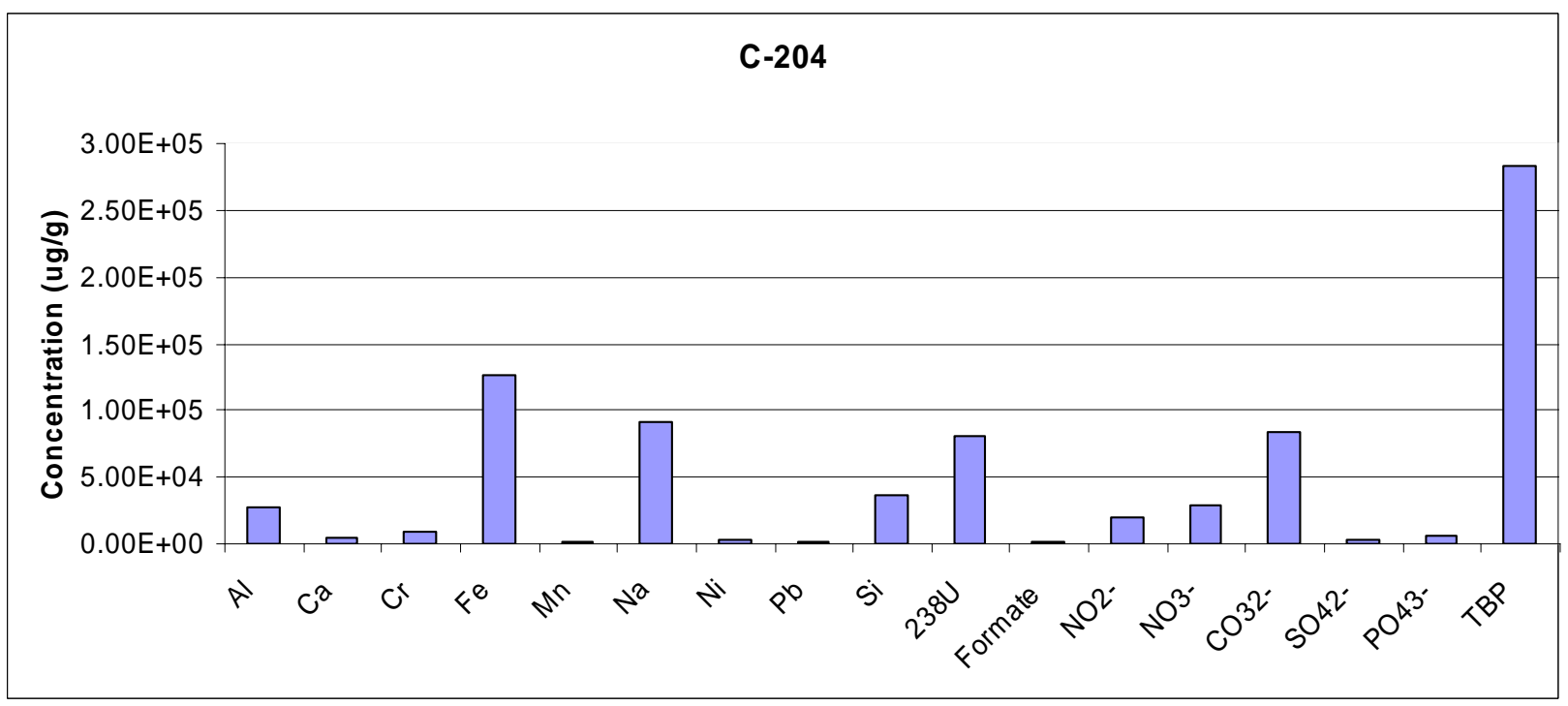

Figure 3.2. C-204 Sludge Composition

Table 3.12. Summary of ${ }^{129} \mathrm{I}$ Concentrations for Modified $\mathrm{KOH}-\mathrm{KNO}_{3}$ Water Fusion Extracts for Tank C-203 Sludge Samples

\begin{tabular}{||c|c||}
\hline Sample Number & $\begin{array}{c}{ }^{\mathbf{1 2 9}} \mathbf{I} \\
\text { pCi/g }\end{array}$ \\
\hline 19649 (203) Water fusion & $<71.1$ \\
\hline 19649 (203) WF spike & $(19.3)$ \\
\hline
\end{tabular}


range extending beyond two orders of magnitude $(0.05$ to $25 \mathrm{ng} / \mathrm{mL})$. The water-leachable ${ }^{129} \mathrm{I}$ in extracts from the water fusion sample was less than the EQL (see Section 3.1 for a discussion of EQL calculation) for the analysis. The instrument EQL for this analysis was $8.8 \mathrm{pCi} / \mathrm{L}$, which resulted in dilution corrected sample EQLs ranging from 18.7 to $71.1 \mathrm{pCi} / \mathrm{g}$. Unfortunately, the modified $\mathrm{KOH}: \mathrm{KNO}_{3}$ water fusion method was unsuccessful at dissolving the entire sludge sample tested. Additionally, the dilution corrected concentration of the ${ }^{129}$ I spike used as a tracer during the fusion process was less than the EQL of the analysis; therefore, the water fusion data reported in Table 3.12 should be considered qualitative. At this time, internal procedure AGG-ESL- $001^{(a)}$ is being modified further to improve on the extent of dissolution of solid samples.

\subsection{Water-Leaching Tests}

The results of the water-leaching tests of sludge samples are discussed in this section. These include results from the single-contact and periodic replenishment tests.

\subsubsection{Single-Contact Test Results}

The single-contact water-leach tests were run in duplicate with contact times of one day, two weeks and one month. DDI water was used as the leaching solution. The results of the solution analyses of the water extracts are described in this section.

\subsubsection{Digestion Factors and Moisture Contents - Single-Contact Water Extracts}

The digestion factors for C-203 and C-204 sludge samples used for the water extracts varied from 16 to $19 \mathrm{~g} / \mathrm{L}$. These digestion factors are the ratios of wet weight of sludge to $30 \mathrm{~mL}$ DDI water used to dissolve the soluble portion of the solid. The digestion factors were then multiplied by the percent solids, as determined from moisture content analysis, to convert to a dry weight basis. The variability is a function of the mass of sludge used, which ranged from approximately 0.6 to $1.0 \mathrm{~g}$. The moisture contents averaged about $38.6 \%$ for the $\mathrm{C}-203$ and C-204 samples (Table 3.1). This is similar to the porosity of a saturated soil.

\subsubsection{Water Extract pH and Alkalinity - Single-Contact Water Extracts}

The average $\mathrm{pH}$ values of the duplicate water extracts of the sludge samples are listed in Table 3.13. The values for Tank C-203 range from 9.41 to 9.55, and the values for C-204 range from 9.47 to 9.67. The high $\mathrm{pH}$ values are likely associated with neutralization of tank wastes with $\mathrm{NaOH}$ to minimize corrosion of the carbon steel tank liner.

The total alkalinities of the water extracts reported in units of $\mathrm{mg} \mathrm{CaCO}_{3} / \mathrm{g}$-sludge are also shown in Table 3.13. The values for Tank C-203 range from 189 to $215 \mathrm{mg} / \mathrm{g}$, and the range for Tank C-204 is 91.7 to $104 \mathrm{mg} / \mathrm{g}$. The ranges of values for $\mathrm{pH}$ and alkalinity are small, and there does not appear to be a trend based on contact time.

(a) Lindberg MJ. 2003. "Solubilization of Metals from Solids Using a $\mathrm{KOH} \mathrm{KNO} 3$ Fusion." AGG ESL 001 Rev. 0, unpublished PNNL Technical Procedure, Pacific Northwest National Laboratory, Richland, WA. 
Table 3.13. Water Extract $\mathrm{pH}$ and Alkalinity Values Corrected to Grams of Dry Sludge

\begin{tabular}{||l|c|c||}
\hline \multicolumn{1}{|c|}{ Sample Number } & pH & $\begin{array}{c}\text { Total Alkalinity as } \\
\mathbf{C a C O}_{\mathbf{3}} \mathbf{~ m g / g}\end{array}$ \\
\hline Jar 19649 (203) 1 Day Avg & 9.55 & 215 \\
\hline Jar 19649 (203) 2 Week Avg & 9.53 & 189 \\
\hline Jar 19649 (203) 1 Month Avg & 9.41 & 194 \\
\hline \hline Jar 19650 (204) 1 Day Avg & 9.52 & 104 \\
\hline Jar 19650 (204) 2 Week Avg & 9.67 & 102 \\
\hline Jar 19650 (204) 1 Month Avg & 9.47 & 91.7 \\
\hline
\end{tabular}

\subsubsection{3 $\quad{ }^{99} \mathrm{Tc}$ and ${ }^{238} \mathrm{U}-$ Single-Contact Water Extracts}

${ }^{99} \mathrm{Tc}$ and ${ }^{238} \mathrm{U}$ are two of the more important potential long-term risk constituents in tank sludge because of their long half-lives and high mobility once dissolved in water. Table 3.14 lists the concentrations of these two radionuclides in units of $\mu \mathrm{g} / \mathrm{g}$-solid and $\mu \mathrm{Ci} / \mathrm{g}$-solid for the single-contact water extracts. Table 3.15 lists the percentage of the total ${ }^{99} \mathrm{Tc}$ and ${ }^{238} \mathrm{U}$ leached from the sludge by each waterleach test with the total available concentration given by the fusion analysis. The water-leachable amount of ${ }^{99} \mathrm{Tc}$ in Tank C-203 ranges from 0.0584 to $0.0739 \mu \mathrm{g} / \mathrm{g}$, which is 56.3 to $71.3 \%$ of the total ${ }^{99} \mathrm{Tc}$ in the sludge. The leachable percentage of ${ }^{99} \mathrm{Tc}$ increases with contact time. For Tank C-204, the waterleachable ${ }^{99} \mathrm{Tc}$ ranges from 0.108 to $0.131 \mu \mathrm{g} / \mathrm{g}$, which is 28.0 to $33.9 \%$ of the available ${ }^{99} \mathrm{Tc}$. The lowest

Table 3.14. ${ }^{99} \mathrm{Tc}$ and ${ }^{238} \mathrm{U}$ Concentrations in C-203 and C-204 Sludge from Single-Contact WaterLeach Tests

\begin{tabular}{||l|c|c|c|c||}
\hline \multirow{2}{*}{\multicolumn{1}{|c|}{ Sample Number }} & ${ }^{99} \mathbf{T c}$ & ${ }^{238} \mathbf{U}$ & ${ }^{99} \mathbf{T c}$ & ${ }^{238} \mathbf{U}$ \\
\cline { 2 - 6 } & \multicolumn{2}{|c|}{$\mu \mathbf{g} / \mathbf{g}$} & \multicolumn{2}{c||}{$\boldsymbol{\mu C} \mathbf{C} / \mathbf{g}$} \\
\hline Jar 19649 (203) 1 Day Avg & $5.84 \mathrm{E}-02$ & $1.59 \mathrm{E}+05$ & $9.92 \mathrm{E}-04$ & $1.13 \mathrm{E}-01$ \\
\hline Jar 19649 (203) 2 Week Avg & $6.38 \mathrm{E}-02$ & $1.65 \mathrm{E}+05$ & $1.08 \mathrm{E}-03$ & $1.17 \mathrm{E}-01$ \\
\hline Jar 19649 (203) 1 Month Avg & $7.39 \mathrm{E}-02$ & $1.53 \mathrm{E}+05$ & $1.26 \mathrm{E}-03$ & $1.09 \mathrm{E}-01$ \\
\hline Jar 19650 (204) 1 Day Avg & $1.08 \mathrm{E}-01$ & $7.39 \mathrm{E}+04$ & $1.84 \mathrm{E}-03$ & $5.24 \mathrm{E}-02$ \\
\hline Jar 19650 (204) 2 Week Avg & $1.31 \mathrm{E}-01$ & $7.05 \mathrm{E}+04$ & $2.23 \mathrm{E}-03$ & $5.01 \mathrm{E}-02$ \\
\hline Jar 19650 (204) 1 Month Avg & $1.27 \mathrm{E}-01$ & $6.09 \mathrm{E}+04$ & $2.17 \mathrm{E}-03$ & $4.33 \mathrm{E}-02$ \\
\hline
\end{tabular}

Table 3.15. Water-Leachable Percentages of ${ }^{99} \mathrm{Tc}$ and ${ }^{238} \mathrm{U}$ in C-203 and C-204 Sludge Samples Compared with Fusion Results

\begin{tabular}{||l|c|c||}
\hline \multirow{2}{*}{\multicolumn{1}{|c|}{ Sample Number }} & ${ }^{\mathbf{9 9}} \mathbf{T c}$ & ${ }^{{ }^{238} \mathbf{U}}$ \\
\cline { 2 - 3 } & \multicolumn{2}{|c||}{ Percent Water Leachable } \\
\hline \hline Jar 19649 (203) 1 Day Avg & 56.3 & 72.7 \\
\hline Jar 19649 (203) 2 Week Avg & 61.5 & 75.8 \\
\hline Jar 19649 (203) 1 Month Avg & 71.3 & 70.4 \\
\hline \hline Jar 19650 (204) 1 Day Avg & 28.0 & 92.1 \\
\hline Jar 19650 (204) 2 Week Avg & 33.9 & 88.0 \\
\hline Jar 19650 (204) 1 Month Avg & 32.9 & 76.0 \\
\hline
\end{tabular}


amount of ${ }^{99} \mathrm{Tc}$ leaches in the one-day contact test, and similar amounts leach at contact times of two weeks and one month. The recalcitrant nature of some of the ${ }^{99} \mathrm{Tc}$ in Hanford tank sludges has been documented in other water-leach studies (Lindberg and Deutsch 2003; Krupka et al. 2004).

The water-leachable amount of ${ }^{238} \mathrm{U}$ in Tank C-203 ranges from 153,000 to $165,000 \mu \mathrm{g} / \mathrm{g}$, which is 70.4 to $75.8 \%$ of the total ${ }^{238} \mathrm{U}$ in the sludge. There is no apparent time dependence on ${ }^{238} \mathrm{U}$ water leachability. For Tank C-204, the water-leachable ${ }^{238} \mathrm{U}$ ranges from 60,900 to $73,900 \mu \mathrm{g} / \mathrm{g}$, which is 76.0 to $92.1 \%$ of the available ${ }^{238} \mathrm{U}$. The water leachability of ${ }^{238} \mathrm{U}$ appears to decrease with contact time; however, this range is within the analytical variability of these measurements and is not considered to be a statistically meaningful trend.

\subsubsection{4 $\quad{ }^{129}$ I Concentrations - Single-Contact Water Extracts}

Table 3.16 contains results of the ${ }^{129}$ I analysis of water extracts (single-contact tests) of the C-203 and $\mathrm{C}-204$ sludge samples. The data are reported as $\mathrm{pCi}{ }^{129} \mathrm{I}$ per gram of sludge (calculated on a dry weight basis). ICP-MS analysis of ${ }^{129}$ I was better than $\pm 10 \%$ of certified reference standards, with the linear operating range extending beyond two orders of magnitude $(0.05$ to $25 \mathrm{ng} / \mathrm{mL})$. The water-leachable ${ }^{129} \mathrm{I}$ in extracts from the single-contact water-leach tests was less than the EQL (see Section 3.1 for a discussion of EQL calculation) for the analysis. The instrument EQL for this analysis was $8.8 \mathrm{pCi} / \mathrm{L}$, which resulted in dilution-corrected sample EQLs ranging from 18.7 to $30.7 \mathrm{pCi} / \mathrm{g}$ for the water extracts. The variability reported for duplicate analyses of the single-contact samples is a result of the water:solid ratio used for the experiment and is not an artifact of analytical reproducibility.

\subsubsection{Selected Metal Concentrations - Single-Contact Water Extracts}

Metals detected at measurable concentrations in one or more samples in the water extracts or the fusion analyses are listed in Table 3.17. A discussion of the meaning of the less-than values $(<)$ and the

Table 3.16. Summary of ${ }^{129}$ I Concentrations from Single-Contact Water-Leach Tests for C-203/C-204

\begin{tabular}{||l|c||}
\hline \multicolumn{1}{|c|}{ Sample Number } & ${ }^{\mathbf{1 2 9}} \mathbf{I ~ p C i / g}$ \\
\hline \hline Jar 19649 (203) 1 Day & $<26.7$ \\
\hline Jar 19649 (203) 1 Day Dup & $(0.68)$ \\
\hline Jar 19649 (203) 2 Week & $<20.2$ \\
\hline Jar 19649 (203) 2 Week Dup & $<30.7$ \\
\hline Jar 19649 (203) 1 Month & $<22.3$ \\
\hline Jar 19649 (203) 1 Month Dup & $<20.0$ \\
\hline \hline Jar 19650 (204) 1 Day & $<18.7$ \\
\hline Jar 19650 (204) 1 Day Dup & $<20.3$ \\
\hline Jar 19650 (204) 2 Week & $<26.9$ \\
\hline Jar 19650 (204) 2 Week Dup & $(0.44)$ \\
\hline Jar 19650 (204) 1 Month & $<24.9$ \\
\hline Jar 19650 (204) 1 Month Dup & $<23.2$ \\
\hline \hline
\end{tabular}


Table 3.17. Water-Leachable Average Metal Concentrations in C-203 and C-204 Single-Contact Water Extract

\begin{tabular}{|c|c|c|c|c|c|c|c|c|c|c|c|c|c|}
\hline \multirow{2}{*}{\begin{tabular}{|c|} 
Sample \\
Number
\end{tabular}} & Al & $\overline{C \mathbf{C a}}$ & $\overline{\mathrm{Cr}}$ & $\mathbf{F e}$ & $\mathbf{K}$ & Mn & $\mathrm{Na}$ & $\mathbf{N i}$ & $\overline{\mathbf{P}}$ & $\mathbf{P b}$ & $\overline{\mathbf{S i}}$ & Sr & $\overline{Z Z n}$ \\
\hline & \multicolumn{13}{|c|}{$\mu \mathrm{g} / \mathrm{g}$} \\
\hline $\begin{array}{l}\begin{array}{l}\text { Jar } 19649(203) \\
1 \text { day }\end{array} \\
\text { 1 }\end{array}$ & $3.11 \mathrm{E}+02$ & $1.82 \mathrm{E}+02$ & $2.66 \mathrm{E}+03$ & $(7.98 \mathrm{E}+01)$ & $7.17 \mathrm{E}+03$ & $(2.15 \mathrm{E}+01)$ & $1.67 \mathrm{E}+05$ & $(3.20 \mathrm{E}+01)$ & $(1.63 E+03)$ & $(1.56 \mathrm{E}+02)$ & $(2.53 \mathrm{E}+03)$ & $(7.29 \mathrm{E}+00)$ & $<1.56 \mathrm{E}+02$ \\
\hline \begin{tabular}{|l} 
Jar $19649(203)$ \\
2 week
\end{tabular} & $<2.88 \mathrm{E}+02$ & $7.81 \mathrm{E}+03$ & $2.65 \mathrm{E}+03$ & $2.58 \mathrm{E}+02$ & $(1.14 \mathrm{E}+03)$ & $(4.30 \mathrm{E}+01)$ & $1.63 \mathrm{E}+05$ & $(2.07 \mathrm{E}+01)$ & $(1.70 \mathrm{E}+03)$ & $(3.82 \mathrm{E}+02)$ & $(3.73 \mathrm{E}+02)$ & $(2.87 \mathrm{E}+01)$ & $2.07 \mathrm{E}+02$ \\
\hline \begin{tabular}{|l} 
Jar $19649(203)$ \\
1 month
\end{tabular} & $<2.0 \mathrm{E}+02$ & $1.08 \mathrm{E}+03$ & $2.54 \mathrm{E}+03$ & $7.00 \mathrm{E}+02$ & $(1.27 \mathrm{E}+03)$ & $(3.76 \mathrm{E}+01)$ & $1.66 \mathrm{E}+05$ & $(3.25 \mathrm{E}+01)$ & $8.04 \mathrm{E}+02$ & $(1.10 \mathrm{E}+02)$ & $(1.74 \mathrm{E}+03)$ & $(7.88 \mathrm{E}+00)$ & $<1.20 \mathrm{E}+02$ \\
\hline $\begin{array}{l}\begin{array}{l}\text { Jar } 19650(204) \\
1 \text { day }\end{array} \\
\end{array}$ & $6.17 \mathrm{E}+02$ & $(<2.21 \mathrm{E}+02)$ & $(1.47 \mathrm{E}+02)$ & $(1.76 \mathrm{E}+02)$ & $(1.65 \mathrm{E}+03)$ & $(7.84 \mathrm{E}+00)$ & $6.97 \mathrm{E}+04$ & $(7.54 \mathrm{E}+01)$ & $1.12 \mathrm{E}+04$ & $(8.65 \mathrm{E}+01)$ & $(1.48 \mathrm{E}+03)$ & $(5.97 \mathrm{E}+01)$ & $1.06 \mathrm{E}+02$ \\
\hline \begin{tabular}{|l} 
Jar $19650(204)$ \\
2 week
\end{tabular} & $1.17 \mathrm{E}+03$ & $<3.09 \mathrm{E}+02$ & $3.21 \mathrm{E}+02$ & $1.54 \mathrm{E}+03$ & $(4.40 \mathrm{E}+02)$ & $(3.21 E+01)$ & $6.99 \mathrm{E}+04$ & $1.95 \mathrm{E}+02$ & $1.41 \mathrm{E}+04$ & $(1.48 \mathrm{E}+02)$ & $(3.24 \mathrm{E}+02)$ & $(3.19 \mathrm{E}+01)$ & $1.76 \mathrm{E}+02$ \\
\hline $\begin{array}{l}\text { Jar } 19650(204) \\
1 \text { month }\end{array}$ & $1.03 \mathrm{E}+03$ & $(<2.73 \mathrm{E}+02)$ & $(1.09 \mathrm{E}+02)$ & $1.60 \mathrm{E}+03$ & $(8.59 \mathrm{E}+02)$ & $(2.88 \mathrm{E}+01)$ & $7.66 \mathrm{E}+04$ & $1.25 \mathrm{E}+02$ & $1.25 \mathrm{E}+04$ & $(9.86 \mathrm{E}+01)$ & $(1.94 \mathrm{E}+03)$ & $(6.75 E+00)$ & $1.36 \mathrm{E}+02$ \\
\hline
\end{tabular}


values in parentheses is provided in Section 3.1. The fusion analyses showed that ${ }^{238} \mathrm{U}, \mathrm{Na}, \mathrm{Fe}, \mathrm{Si}, \mathrm{Cr}$, and $\mathrm{Al}$ are the dominant metals present in the C-203 and C-204 sludges (Figures 3.1 and 3.2). The water extracts show that $\mathrm{Na}, \mathrm{K}, \mathrm{Cr}$ and (perhaps) $\mathrm{Si}$ and $\mathrm{P}$ are the primary water-soluble constituents in C-203 sludge. For Tank C-204, the metals present at highest concentrations in the water leachate are $\mathrm{Na}, \mathrm{P}$, and (perhaps) $\mathrm{K}$ and $\mathrm{Si}$. (Note that the concentrations measured in the water leachates are the sums of the water-leachable amounts and the initial dissolved pore water concentrations.)

Table 3.18 lists the leachable percentages of metals present in the single-contact water extracts. Assuming that the initial dissolved concentrations in the pore water are relatively small compared with the amount of metal leached from the solid by the water extract, it appears that $\mathrm{Na}$ is completely water leachable for both sludge samples, and P is highly leachable from C-204 (52.5 to 66\%). Other elements that have leachabilities greater than $10 \%$ in one or more of the tests are $\mathrm{Al}, \mathrm{Ca}, \mathrm{Cr}$, and $\mathrm{Zn}$. Elements with lower water leachabilities are $\mathrm{Fe}, \mathrm{Mn}, \mathrm{Ni}$, and $\mathrm{Pb}$.

\subsubsection{Anion Concentrations - Single-Contact Water Extracts}

The anion concentrations in the C-203 and C-204 sludge samples, estimated from the concentrations in the water extracts, are listed in Table 3.19. The primary anions in C-203 sludge are carbonate, nitrate, oxalate, nitrite, fluoride, and sulfate. The primary anions in C-204 sludge are carbonate, nitrate, nitrite, phosphate, and sulfate. (Note that the water-soluble phosphate concentration for C-204 sludge in Table 3.19 does not include the phosphate in TBP in this sludge, which was measured separately at a concentration of $3.3 \times 10^{4} \mu \mathrm{g} \mathrm{P} / \mathrm{g}$.) The carbonate concentrations closely track the water extract alkalinity values (Table 3.13 values converted to $\mu \mathrm{g} \mathrm{CO}_{3}{ }^{2-} / \mathrm{g}$-sludge); however, anion carbonate concentrations are generally higher than the alkalinity calculated carbonate concentrations. The presence of high concentrations of nitrite $\left(6.17 \times 10^{3}\right.$ to $\left.2.07 \times 10^{4} \mu \mathrm{g} / \mathrm{g}\right)$ and oxalate $\left(6.30 \times 10^{-2}\right.$ to $\left.3.21 \times 10^{4} \mu \mathrm{g} / \mathrm{g}\right)$ in the water extracts shows that the sludges have the capacity to act as a reductant for more oxidized species. However, their presence in the sludge in contact with air suggests they are not very reactive in this environment.

\subsubsection{Radioanalytical Results - Single-Contact Water Extracts}

The results of the GEA analysis for ${ }^{137} \mathrm{Cs}$ in the water extractions and the direct (untreated) solid sludges are listed in Table 3.20. For the C-203 sludge samples, the water extracts are similar to, although slightly lower than, the direct solid values, showing that most of the ${ }^{137} \mathrm{Cs}$ in the solid is water-leachable. On the other hand, the water-extraction values for the C-204 sludges are about 10 times less than the direct solid values. ${ }^{137} \mathrm{Cs}$ is much less water leachable from the C-204 sludge than it is from the C-203 sludge.

Total beta and total alpha levels for the water-leach experiments are listed in Table 3.21. Comparing these results with the fusion analysis levels (Table 3.10) shows that about $8 \%$ of the total beta is water leachable from C-203 sludge, and 4.4\% is water leachable from C-204 sludge. Approximately 3.6\% of the total alpha is water leachable from C-203, and 3.2\% is water leachable from C-204. Table 3.21 also lists the water-leachable concentrations of ${ }^{90} \mathrm{Sr}$. Comparing these levels to the fusion analysis values (Table 3.10) shows that 5.3\% is water leachable from C-203 sludge and $2.4 \%$ is water leachable from C204 sludge. 
Table 3.18. Water-Leachable Metals in C-203 and C-204 Single-Contact Water Extract Compared with Fusion Results (\%)

\begin{tabular}{|c|c|c|c|c|c|c|c|c|c|c|c|c|c|}
\hline \multirow{2}{*}{\begin{tabular}{c|} 
Sample \\
Number
\end{tabular}} & Al & $\overline{\mathbf{C a}}$ & $\mathrm{Cr}$ & $\mathbf{F e}$ & $\bar{K}$ & Mn & $\mathbf{N a}$ & $\mathbf{N i}$ & $\mathbf{P}$ & $\mathbf{P b}$ & $\mathbf{S i}$ & $\mathrm{Sr}$ & $\mathbf{Z n}$ \\
\hline & \multicolumn{13}{|c|}{ \% Water Leachable } \\
\hline $\begin{array}{l}\text { Jar } 19649(203) \\
1 \text { day }\end{array}$ & 31.7 & 2.3 & 13.5 & $(0.15)$ & N/A & $(1.00)$ & 106.1 & $(3.87)$ & $(24.73)$ & $(1.95)$ & $(37.75)$ & $(3.53)$ & $(24.3)$ \\
\hline $\begin{array}{l}\text { Jar } 19649(203) \\
2 \text { week }\end{array}$ & $<29.3$ & 9.9 & 13.5 & 0.5 & N/A & $(2.01)$ & 103.5 & $(2.50)$ & $(25.73)$ & $(4.77)$ & $(5.57)$ & $(13.89)$ & $(35.5)$ \\
\hline $\begin{array}{l}\text { Jar } 19649(203) \\
1 \text { month }\end{array}$ & $<20.4$ & 13.6 & 12.9 & 1.4 & N/A & $(1.75)$ & 105.1 & $(3.94)$ & 12.2 & $(1.38)$ & $(26.02)$ & $(3.82)$ & $(6.1)$ \\
\hline $\begin{array}{l}\text { Jar } 19650(204) \\
1 \text { day }\end{array}$ & 4.0 & $(<14.5)$ & $(1.5)$ & $(0.09)$ & N/A & $(0.57)$ & 106.8 & $(1.82)$ & 52.5 & $(5.84)$ & $(28.78)$ & $(14.81)$ & $(9.1)$ \\
\hline $\begin{array}{l}\text { Jar } 19650(204) \\
2 \text { week }\end{array}$ & 7.5 & $<20.3$ & 3.2 & 0.8 & N/A & $(2.32)$ & 107.1 & 4.7 & 66.0 & $(9.97)$ & $(6.33)$ & $(7.92)$ & $(23.5)$ \\
\hline $\begin{array}{l}\text { Jar } 19650(204) \\
1 \text { month }\end{array}$ & 6.6 & $(<6.2)$ & $(1.1)$ & 0.8 & N/A & $(2.08)$ & 117.4 & 3.0 & 58.2 & $(6.66)$ & $(37.76)$ & $(1.68)$ & $(9.5)$ \\
\hline
\end{tabular}

Table 3.19. Average Anion Concentrations in C-203 and C-204 Single-Contact Water Extract

\begin{tabular}{|c|c|c|c|c|c|c|c|c|c|c|}
\hline & Fluoride & Acetate & Formate & Chloride & Nitrite & Nitrate & Carbonate & Sulfate & Oxalate & Phosphate \\
\hline Sample Number & \multicolumn{10}{|c|}{$\mu \mathrm{g} / \mathrm{g}$} \\
\hline $\operatorname{Jar} 19649$ (203) 1 day & $6.16 \mathrm{E}+03$ & $<8.53 \mathrm{E}+02$ & $2.27 \mathrm{E}+03$ & $1.95 \mathrm{E}+03$ & $9.38 \mathrm{E}+03$ & $1.78 \mathrm{E}+05$ & $1.87 \mathrm{E}+05$ & $5.09 \mathrm{E}+03$ & $2.58 \mathrm{E}+04$ & $1.26 \mathrm{E}+03$ \\
\hline Jar 19649 (203) 2 week & $6.68 \mathrm{E}+03$ & $<7.88 \mathrm{E}+02$ & $2.19 \mathrm{E}+03$ & $1.62 \mathrm{E}+03$ & $9.17 \mathrm{E}+03$ & $1.74 \mathrm{E}+05$ & $1.89 \mathrm{E}+05$ & $4.70 \mathrm{E}+03$ & $3.21 \mathrm{E}+04$ & $7.04 \mathrm{E}+02$ \\
\hline Jar 19649 (203) 1 month & $4.84 \mathrm{E}+03$ & $<6.56 \mathrm{E}+02$ & $1.69 \mathrm{E}+03$ & $1.16 \mathrm{E}+03$ & $6.17 \mathrm{E}+03$ & $1.38 \mathrm{E}+05$ & $1.38 \mathrm{E}+05$ & $3.60 \mathrm{E}+03$ & $1.82 \mathrm{E}+04$ & $3.64 \mathrm{E}+02$ \\
\hline Jar 19650 (204) 1 day & $1.70 \mathrm{E}+02$ & $<6.05 \mathrm{E}+02$ & $1.93 \mathrm{E}+03$ & $8.23 \mathrm{E}+02$ & $2.07 \mathrm{E}+04$ & $2.81 \mathrm{E}+04$ & $9.03 \mathrm{E}+04$ & $3.78 \mathrm{E}+03$ & $6.54 \mathrm{E}+02$ & $4.43 \mathrm{E}+03$ \\
\hline Jar 19650 (204) 2 week & $2.07 \mathrm{E}+02$ & $<8.46 \mathrm{E}+02$ & $1.87 \mathrm{E}+03$ & $9.44 \mathrm{E}+02$ & $2.06 \mathrm{E}+04$ & $3.36 \mathrm{E}+04$ & $8.39 \mathrm{E}+04$ & $3.87 \mathrm{E}+03$ & $6.50 \mathrm{E}+02$ & $5.71 \mathrm{E}+03$ \\
\hline Jar 19650 (204) 1 month & $1.74 \mathrm{E}+02$ & $<7.47 \mathrm{E}+02$ & $1.89 \mathrm{E}+03$ & $6.34 \mathrm{E}+02$ & $1.69 \mathrm{E}+04$ & $2.62 \mathrm{E}+04$ & $7.53 \mathrm{E}+04$ & $3.63 \mathrm{E}+03$ & $6.30 \mathrm{E}+02$ & $6.18 \mathrm{E}+03$ \\
\hline
\end{tabular}


Table 3.20. GWA for C-203and C-204 Single-Contact Water Extractions and Direct Solids

\begin{tabular}{||l|c|c||}
\hline \multirow{2}{*}{ Sample Number } & \multicolumn{2}{|c||}{${ }^{\mathbf{1 3 7}} \mathbf{C s}$} \\
\cline { 2 - 3 } & $\boldsymbol{\mu C i} / \mathbf{g}$ & $\boldsymbol{\mu g} / \mathbf{g}$ \\
\hline \hline War 19649 (203) 1 day & 2.59 & 0.0298 \\
\hline Jar 19649 (203) 2 week & 2.24 & 0.0258 \\
\hline \hline Jar 19650 (204) 1 day & 0.602 & 0.00069 \\
\hline Jar 19650 (204) 2 week & 0.720 & 0.00083 \\
\hline & \multicolumn{2}{|c||}{ Direct Solid } \\
\hline Jar 19649 (203) & 3.61 & 0.0415 \\
\hline \hline Jar 19649 (204) & 7.54 & 0.0866 \\
\hline
\end{tabular}

Table 3.21. Total Beta, Total Alpha, and ${ }^{90} \mathrm{Sr}$ Single-Contact Water Extracts

\begin{tabular}{||c|c|c|c|c||}
\hline \multirow{2}{*}{ Sample Number } & Total Beta & Total Alpha & \multicolumn{2}{c||}{${ }^{\mathbf{9 0}} \mathbf{S r}$} \\
\cline { 2 - 5 } & \multicolumn{2}{|c|}{$\boldsymbol{\mu C i} / \mathbf{g}$} & $\boldsymbol{\mu C i} / \mathbf{g}$ & $\boldsymbol{\mu g} / \mathbf{g}$ \\
\hline \hline Jar 19649 (203) 1 day & $4.09 \mathrm{E}+00$ & $1.63 \mathrm{E}+00$ & $3.17 \mathrm{E}+00$ & $2.26 \mathrm{E}-02$ \\
\hline Jar 19649 (203) 2 week & $6.64 \mathrm{E}+00$ & $4.76 \mathrm{E}-01$ & $4.37 \mathrm{E}+00$ & $3.12 \mathrm{E}-02$ \\
\hline \hline Jar 19650 (204) 1 day & $8.07 \mathrm{E}-01$ & $1.60 \mathrm{E}-01$ & $1.92 \mathrm{E}-01$ & $1.37 \mathrm{E}-03$ \\
\hline Jar 19650 (204) 2 week & $1.54 \mathrm{E}+00$ & $1.05 \mathrm{E}-01$ & $9.65 \mathrm{E}-01$ & $6.90 \mathrm{E}-03$ \\
\hline
\end{tabular}

Table 3.22 lists the water-leachable concentrations of ${ }^{239} \mathrm{Pu},{ }^{241} \mathrm{Am}$, and ${ }^{244} \mathrm{Cm}$ in terms of the original sludge compositions. The percent water leachabilities for these actinides are listed in Table 3.23. The water leachability of ${ }^{239} \mathrm{Pu}$ and ${ }^{241} \mathrm{Am}$ from C-203 sludge is about $1 \%$. The leachabilities of ${ }^{244} \mathrm{Cm}$ from C-203 sludge and all three actinides from C-204 sludge were not measurable at the listed EQLs.

Table 3.22. Actinide Analysis for C-203 and C-204 Single-Contact Water Extracts

\begin{tabular}{||c|c|c|c|c|c|c||}
\hline \multirow{2}{*}{ Sample Number } & \multicolumn{2}{|c|}{${ }^{239} \mathbf{P u}$} & \multicolumn{2}{c||}{${ }^{241} \mathbf{A m}$} & \multicolumn{2}{c||}{${ }^{244} \mathbf{C m}$} \\
\cline { 2 - 7 } & $\boldsymbol{\mu C i} / \mathbf{g}$ & $\boldsymbol{\mu g} / \mathbf{g}$ & $\boldsymbol{\mu C i} / \mathbf{g}$ & $\boldsymbol{\mu g} / \mathbf{g}$ & $\boldsymbol{\mu C i} / \mathbf{g}$ & $\boldsymbol{\mu g} / \mathbf{g}$ \\
\hline Jar 19649 (203) 1 day & $2.68 \mathrm{E}-02$ & $4.32 \mathrm{E}-01$ & $2.27 \mathrm{E}-03$ & $6.68 \mathrm{E}-04$ & $<4.66 \mathrm{E}-03$ & $<5.75 \mathrm{E}-05$ \\
\hline Jar 19649 (203) 2 week & $2.65 \mathrm{E}-02$ & $4.28 \mathrm{E}-01$ & $2.25 \mathrm{E}-03$ & $6.62 \mathrm{E}-04$ & $<4.31 \mathrm{E}-03$ & $<5.31 \mathrm{E}-05$ \\
\hline \hline Jar 19650 (204) 1 day & $<1.38 \mathrm{E}-03$ & $<2.23 \mathrm{E}-02$ & $<1.49 \mathrm{E}-03$ & $<4.39 \mathrm{E}-04$ & $<3.30 \mathrm{E}-03$ & $<4.08 \mathrm{E}-05$ \\
\hline Jar 19650 (204) 2 week & $<1.93 \mathrm{E}-03$ & $<3.12 \mathrm{E}-02$ & $<2.09 \mathrm{E}-03$ & $<6.14 \mathrm{E}-04$ & $<4.62 \mathrm{E}-03$ & $<5.70 \mathrm{E}-05$ \\
\hline
\end{tabular}

\subsubsection{Periodic Replenishment Test Results}

The periodic replenishment tests were conducted by contacting a sludge sample with sequential $30 \mathrm{~mL}$ quantities of fresh DDI water. As shown in Table 3.24, the sludges were contacted seven times with fresh water. The first five contacts were of short duration (two or three days each), which was assumed sufficient for leaching contaminants of concern from the sludges. To test this assumption, the sixth leaching period was extended to about two months, and the final stage lasted almost three months. 
Table 3.23. Water-Leachable Percentage for Actinides in C-203 and C-204 Single-Contact Water Extracts Compared with Fusion Analysis

\begin{tabular}{||l|c|c|c||}
\hline \multicolumn{1}{|c|}{ Sample Number } & ${ }^{239} \mathbf{P u}$ & ${ }^{\mathbf{2 4 1}} \mathbf{A m}$ & ${ }^{{ }^{244}} \mathbf{C m}$ \\
\hline \hline & \multicolumn{3}{|c||}{ \%ater Leachable } \\
\hline Jar 19649 (203) 1 day & 0.7 & 1.6 & N/A \\
\hline Jar 19649 (203) 2 week & 0.7 & 1.6 & N/A \\
\hline \hline Jar 19650 (204) 1 day & N/A & N/A & N/A \\
\hline Jar 19650 (204) 2 week & N/A & N/A & N/A \\
\hline \multicolumn{4}{||l}{ N/A = Results below detection limit. } \\
\hline
\end{tabular}

Table 3.24. Contact Times and Average $\mathrm{pH}$ Values for Periodic Replenishment Test on Tanks C-203 (Jar 19649) and C-204 Sludge (Jar 19650)

\begin{tabular}{|c|c|c|c|}
\hline Sequential Contacts & $\begin{array}{c}\text { Contact Duration } \\
\text { (days) }\end{array}$ & pH & $\begin{array}{c}\text { Alkalinity as mg/g } \\
\mathrm{CaCO}_{3}\end{array}$ \\
\hline \multicolumn{4}{|c|}{ C-203 (Jar 19649) } \\
\hline 1 & 2 & 9.50 & 184.27 \\
\hline 2 & 2 & 9.70 & 5.74 \\
\hline 3 & 3 & 9.28 & 3.05 \\
\hline 4 & 2 & 9.17 & 1.09 \\
\hline 5 & 2 & 8.84 & 1.02 \\
\hline $6 a$ & 65 & 8.76 & NA \\
\hline $6 \mathrm{~b}$ & 86 & 8.44 & $\mathrm{NA}$ \\
\hline \multicolumn{4}{|c|}{ C-204 (Jar 19650) } \\
\hline 1 & 2 & 9.54 & 110.84 \\
\hline 2 & 2 & 9.41 & 13.69 \\
\hline 3 & 3 & 9.27 & 5.01 \\
\hline 4 & 2 & 9.00 & 2.61 \\
\hline 5 & 2 & 8.93 & 1.43 \\
\hline $6 a$ & 65 & 8.44 & NA \\
\hline $6 b$ & 86 & 7.86 & NA \\
\hline
\end{tabular}

The objective was to evaluate the long-term leaching characteristics of contaminants from the sludge. Most, if not all, of the water-leachable content of the key contaminants ${ }^{99} \mathrm{Tc}$ and ${ }^{238} \mathrm{U}$ occurred in the first two water leaches. All of the water-leachable ${ }^{99} \mathrm{Tc}$ and over $90 \%$ of the leachable ${ }^{238} \mathrm{U}$ was found in these two stages of the tests. Very little ${ }^{99} \mathrm{Tc}$ or ${ }^{238} \mathrm{U}$ was leachable in the subsequent five leaching stages.

This section also provides the analytical results for other components of the sludges that were measured during the periodic replenishment tests. 


\subsubsection{Digestion Factors and Moisture Contents - Periodic Replenishment Water Extracts}

The digestion factors for the C-203 and C-204 sludge samples used for replenishment tests varied from $18 \mathrm{~g} / \mathrm{L}$ to $36 \mathrm{~g} / \mathrm{L}$. These digestion factors are the ratios of wet weight of sludge to the amount of DDI water $(30 \mathrm{~mL})$ used to dissolve the soluble portion of the solid. The digestion factors were then multiplied by the percent solids, as determined from moisture content analysis, to convert concentrations to a dry weight basis. The variability in digestion factors is a function of the mass of sludge used, which ranged from approximately 0.5 to $1.0 \mathrm{~g}$.

The moisture content [(wet wt - dry wt)/dry wt] averaged about $38.6 \%$ for both the C-203 and C-204 samples. This is similar to the porosity of a saturated soil.

\subsubsection{Water Extract pH and Alkalinity - Periodic Replenishment Water Extracts}

Table 3.24 lists the $\mathrm{pH}$ values and alkalinities from the replenishment tests. The $\mathrm{pH}$ consistently decreases with addition of fresh water, which flushes out the alkaline pore water initially in the sludges and reduces the carbonate content (as measured by the alkalinity) of the solids. By the last stage (6b, 86 days) of the process, the $\mathrm{pH}$ values were 8.44 in both sludges, and there was no measurable alkalinity in the solutions in contact with the sludges.

\subsubsection{3 $\quad{ }^{99}$ Tc and ${ }^{238} \mathrm{U}-$ Periodic Replenishment Water Extracts}

Table 3.25 lists the amount of ${ }^{99} \mathrm{Tc}$ and ${ }^{238} \mathrm{U}$ leached from the two sludges during the replenishment tests, and Table 3.26 lists the percentages of the available radionuclides that were leached. Most of the

Table 3.25. ${ }^{99} \mathrm{Tc}$ and ${ }^{238} \mathrm{U}$ Concentrations in C-203 and C-204 Sludge for Periodic Replenishment Water Extracts

\begin{tabular}{|c|c|c|c|c|c|}
\hline \multirow{2}{*}{$\begin{array}{c}\text { Sequential } \\
\text { Contact }\end{array}$} & \multirow{2}{*}{$\begin{array}{c}\text { Contact Duration } \\
\text { (days) }\end{array}$} & 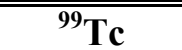 & 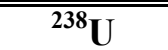 & 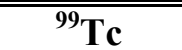 & 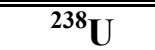 \\
\hline & & \multicolumn{2}{|c|}{$\mu \mathrm{g} / \mathrm{g}$} & \multicolumn{2}{|c|}{$\mu \mathrm{Ci} / \mathrm{g}$} \\
\hline \multicolumn{6}{|c|}{ C-203 (Jar 19649) } \\
\hline 1 & 2 & $6.47 \mathrm{E}-02$ & $1.62 \mathrm{E}+05$ & $1.10 \mathrm{E}-03$ & $5.51 \mathrm{E}-02$ \\
\hline 2 & 2 & (3.00E-03) & $5.28 \mathrm{E}+03$ & $(5.10 \mathrm{E}-05)$ & $1.79 \mathrm{E}-03$ \\
\hline 3 & 3 & $(2.23 \mathrm{E}-03)$ & $1.82 \mathrm{E}+03$ & $(3.79 \mathrm{E}-05)$ & $6.20 \mathrm{E}-04$ \\
\hline 4 & 2 & $<7.64 \mathrm{E}-03$ & $3.66 \mathrm{E}+02$ & $<1.30 \mathrm{E}-04$ & $1.24 \mathrm{E}-04$ \\
\hline 5 & 2 & $<7.64 \mathrm{E}-03$ & $2.22 \mathrm{E}+02$ & $<1.30 \mathrm{E}-04$ & $7.54 \mathrm{E}-05$ \\
\hline $6 a$ & 65 & $(1.54 \mathrm{E}-03)$ & $1.79 \mathrm{E}+03$ & $(1.54 \mathrm{E}-03)$ & $1.79 \mathrm{E}+03$ \\
\hline $6 \mathrm{~b}$ & 86 & $<1.37 \mathrm{E}-02$ & $6.93 \mathrm{E}+03$ & $<1.37 \mathrm{E}-02$ & $6.93 \mathrm{E}+03$ \\
\hline \multicolumn{6}{|c|}{ C-204 (Jar 19650) } \\
\hline 1 & 2 & $1.21 \mathrm{E}-01$ & $8.26 \mathrm{E}+04$ & $2.06 \mathrm{E}-03$ & $2.81 \mathrm{E}-02$ \\
\hline 2 & 2 & $(5.52 \mathrm{E}-03)$ & $2.73 \mathrm{E}+03$ & $(9.39 \mathrm{E}-05)$ & $9.30 \mathrm{E}-04$ \\
\hline 3 & 3 & $<1.51 \mathrm{E}-02$ & $8.01 \mathrm{E}+02$ & $<2.58 \mathrm{E}-04$ & $2.72 \mathrm{E}-04$ \\
\hline 4 & 2 & $(1.66 \mathrm{E}-02)$ & $8.08 \mathrm{E}+01$ & $\begin{array}{l}(2.82 \mathrm{E}-04) \\
\end{array}$ & $2.75 \mathrm{E}-05$ \\
\hline 5 & 2 & (4.13E-03) & $5.24 \mathrm{E}+01$ & $(7.03 \mathrm{E}-05)$ & $1.78 \mathrm{E}-05$ \\
\hline $6 a$ & 65 & $<<2.76 \mathrm{E}-02$ & $2.73 \mathrm{E}+02$ & $<2.76 \mathrm{E}-02$ & $2.73 \mathrm{E}+02$ \\
\hline $6 \mathrm{~b}$ & 86 & (5.51E-03) & $1.42 \mathrm{E}+03$ & $(5.51 \mathrm{E}-03)$ & $1.42 \mathrm{E}+03$ \\
\hline
\end{tabular}


Table 3.26. Water-Leachable Percentages of ${ }^{99} \mathrm{Tc}$ and ${ }^{238} \mathrm{U}$ in C-203 and C-204 Sludge Samples for Periodic Replenishment Relative to Fusion Results

\begin{tabular}{|c|c|c|c|}
\hline \multirow{2}{*}{$\begin{array}{c}\text { Contact Stage } \\
\text { (duration, days) }\end{array}$} & \multirow{2}{*}{$\begin{array}{c}\text { Contact Duration } \\
\text { (days) }\end{array}$} & 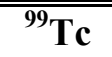 & 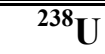 \\
\hline & & \multicolumn{2}{|c|}{ \% Water Leachable } \\
\hline \multicolumn{4}{|c|}{ C-203 (Jar 19649) } \\
\hline 1 & 2 & 62.4 & 74.2 \\
\hline 2 & 2 & 2.9 & 2.4 \\
\hline 3 & 3 & $<\mathrm{EQL}$ & 0.8 \\
\hline 4 & 2 & $<\mathrm{EQL}$ & 0.2 \\
\hline 5 & 2 & $<\mathrm{EQL}$ & 0.1 \\
\hline $6 a$ & 65 & $<\mathrm{EQL}$ & 0.8 \\
\hline $6 b$ & 86 & $<\mathrm{EQL}$ & 3.2 \\
\hline \multicolumn{4}{|c|}{ C-204 (Jar 19650) } \\
\hline 1 & 2 & 31.4 & 103.1 \\
\hline 2 & 2 & 1.4 & 3.4 \\
\hline 3 & 3 & $<\mathrm{EQL}$ & 1.0 \\
\hline 4 & 2 & $<\mathrm{EQL}$ & 0.1 \\
\hline 5 & 2 & $<$ EQL & 0.1 \\
\hline $6 a$ & 65 & $<\mathrm{EQL}$ & 0.3 \\
\hline $6 \mathrm{~b}$ & 86 & $<\mathrm{EQL}$ & 1.8 \\
\hline
\end{tabular}

leachable ${ }^{99} \mathrm{Tc}$ and ${ }^{238} \mathrm{U}$ occurs in the first contact with DDI water. Some portion of these constituents may be dissolved in the sludge pore water and not be representative of leached constituents in the fresh water added during the test. Therefore, this percentage may over-estimate the amount of contaminant leachable from the solid phase. Only 1.4 to $3.4 \%$ of the leachable ${ }^{99} \mathrm{Tc}$ and ${ }^{238} \mathrm{U}$ appears in the second stage of the leaching process, and less than $1 \%$ additional appears in any one of the subsequent leaches except for the final leaching stage, in which the ${ }^{238} \mathrm{U}$ leachable percentage is $3.2 \%$ for Tank $\mathrm{C}-203$ and $1.8 \%$ for C-204. In the final leaching stage (6b), water was in contact with the sludge for the longest period of time ( 86 days for this individual stage). The relatively high percentage of ${ }^{238} \mathrm{U}$ leached at this stage may be due to the relatively slow dissolution of a uranium mineral. There is also an increase in uranium leachability for stage $6 \mathrm{a}$, which had an individual contact time of 65 days.

\subsubsection{Selected Metal Concentrations - Periodic Replenishment Water Extracts}

Table 3.27 lists the concentrations of metals leached during the periodic replenishment tests, and Table 3.28 lists the percentage of the total available metals that were leached during each stage of the test. $\mathrm{Ca}, \mathrm{Cr}$, and $\mathrm{Na}$ are the only metals that appear to be water leachable in both sludges. $\mathrm{Al}$ and $\mathrm{P}$ also appear to be water leachable in $\mathrm{C}-203$ sludge, but not in $\mathrm{C}-204$ sludge. The remaining metals ( $\mathrm{Fe}, \mathrm{Mn}, \mathrm{Ni}, \mathrm{Pb}$, $\mathrm{Si}$, and $\mathrm{Sr}$ ) are not water leachable from either of the sludge samples. 
Table 3.27. Water-Leachable Average Metals in C-203 and C-204 Periodic Replenishment Water Extract ( $\mu \mathrm{g} / \mathrm{g})$

\begin{tabular}{|c|c|c|c|c|c|c|c|c|c|c|c|c|c|}
\hline $\begin{array}{c}\text { Sequential } \\
\text { Contact }\end{array}$ & Al & Ca & $\mathrm{Cr}$ & $\mathbf{F e}$ & $\mathbf{K}$ & Mn & $\mathrm{Na}$ & $\mathrm{Ni}$ & $\mathbf{P}$ & $\mathbf{P b}$ & $\underline{\mathrm{Si}}$ & $\mathrm{Sr}$ & Zn \\
\hline \multicolumn{14}{|c|}{ C-203 (Jar 19649) } \\
\hline 1 & $<1.46 \mathrm{E}+02$ & $<1.4 \mathrm{E}+02$ & $2.4 \mathrm{E}+03$ & $(6.8 \mathrm{E}+02)$ & $(6.9 \mathrm{E}+02)$ & $(3.4 \mathrm{E}+01)$ & $1.5 \mathrm{E}+05$ & $(7.1 \mathrm{E}+01)$ & $(1.3 \mathrm{E}+03)$ & $(1.5 \mathrm{E}+02)$ & $(2.1 \mathrm{E}+02)$ & $(1.2 \mathrm{E}+01)$ & $(<6.9 \mathrm{E}+01)$ \\
\hline 3 & $(5.6 \mathrm{E}+01)$ & $3.3 \mathrm{E}+02$ & $5.3 \mathrm{E}+02$ & $3.2 \mathrm{E}+02$ & $(9.9 \mathrm{E}+03)$ & $(5.2 \mathrm{E}+01)$ & $2.6 \mathrm{E}+03$ & $(4.3 \mathrm{E}+01)$ & $(6.4 \mathrm{E}+02)$ & $(2.8 \mathrm{E}+02)$ & $(4.3 \mathrm{E}+02)$ & $(1.3 \mathrm{E}+01)$ & $8.9 \mathrm{E}+01$ \\
\hline 4 & $(5.3 \mathrm{E}+01)$ & $<1.4 \mathrm{E}+02$ & $7.1 \mathrm{E}+01$ & $9.4 \mathrm{E}+01$ & $(2.9 \mathrm{E}+02)$ & $(8.8 \mathrm{E}+00)$ & $1.2 \mathrm{E}+03$ & $(5.0 \mathrm{E}+00)$ & $(3.8 \mathrm{E}+02)$ & $(7.2 \mathrm{E}+01)$ & $(3.6 \mathrm{E}+02)$ & $(6.1 \mathrm{E}+00)$ & $1.0 \mathrm{E}+02$ \\
\hline 5 & $(2.1 \mathrm{E}+01)$ & $<1.4 \mathrm{E}+02$ & $(4.3 \mathrm{E}+01)$ & $(6.1 \mathrm{E}+01)$ & $(4.2 \mathrm{E}+02)$ & $(5.1 \mathrm{E}+00)$ & $7.2 \mathrm{E}+02$ & $<7.29 \mathrm{E}+01$ & $(3.3 \mathrm{E}+02)$ & $(6.7 \mathrm{E}+01)$ & $(2.3 \mathrm{E}+02)$ & $(4.4 \mathrm{E}+00)$ & $8.0 \mathrm{E}+01$ \\
\hline $6 a$ & $3.1 \mathrm{E}+02$ & $7.4 \mathrm{E}+02$ & $3.8 \mathrm{E}+02$ & $2.7 \mathrm{E}+02$ & $(6.5 \mathrm{E}+01)$ & NA & $(2.7 \mathrm{E}+03)$ & NA & NA & NA & NA & NA & $1.6 \mathrm{E}+02$ \\
\hline \multicolumn{14}{|c|}{ C-204 (Jar 19650) } \\
\hline 1 & $7.4 \mathrm{E}+02$ & $<2.75 \mathrm{E}+02$ & $(8.9 \mathrm{E}+01)$ & $2.4 \mathrm{E}+02$ & $(2.6 \mathrm{E}+02)$ & $(1.8 \mathrm{E}+01)$ & $7.4 \mathrm{E}+04$ & $1.4 \mathrm{E}+02$ & $1.2 \mathrm{E}+04$ & $(1.2 \mathrm{E}+02)$ & $(4.1 \mathrm{E}+02)$ & $(1.6 \mathrm{E}+01)$ & $<1.4 \mathrm{E}+02$ \\
\hline 2 & $(6.8 \mathrm{E}+02)$ & $<2.75 \mathrm{E}+02$ & $(9.9 \mathrm{E}+01)$ & $(3.4 \mathrm{E}+02)$ & $(3.7 \mathrm{E}+02)$ & $(6.7 \mathrm{E}+00)$ & $(4.4 \mathrm{E}+03)$ & $(7.6 \mathrm{E}+01)$ & $(1.6 \mathrm{E}+03)$ & $(5.2 \mathrm{E}+01)$ & $(5.0 \mathrm{E}+02)$ & $(1.2 \mathrm{E}+01)$ & $1.5 \mathrm{E}+02$ \\
\hline 3 & $9.8 \mathrm{E}+02$ & $<2.75 \mathrm{E}+02$ & $6.3 \mathrm{E}+02$ & $2.2 \mathrm{E}+03$ & $<1.74 \mathrm{E}+04$ & $(3.9 \mathrm{E}+01)$ & $2.8 \mathrm{E}+03$ & $3.1 \mathrm{E}+02$ & $(2.0 \mathrm{E}+03)$ & $(2.1 \mathrm{E}+02)$ & $(6.3 \mathrm{E}+02)$ & $(3.7 \mathrm{E}+01)$ & $<1.4 \mathrm{E}+02$ \\
\hline 4 & $4.2 \mathrm{E}+02$ & $<2.75 \mathrm{E}+02$ & $(4.3 \mathrm{E}+01)$ & $2.4 \mathrm{E}+02$ & $(9.2 \mathrm{E}+02)$ & $(5.0 \mathrm{E}+00)$ & $1.6 \mathrm{E}+03$ & $(1.9 \mathrm{E}+01)$ & $(1.3 \mathrm{E}+03)$ & $(7.2 \mathrm{E}+01)$ & $(4.4 \mathrm{E}+02)$ & $(1.0 \mathrm{E}+01)$ & $<1.4 \mathrm{E}+02$ \\
\hline 5 & $2.9 \mathrm{E}+02$ & $1.1 \mathrm{E}+03$ & $(3.0 \mathrm{E}+01)$ & $1.7 \mathrm{E}+02$ & $<1.78 \mathrm{E}+04$ & $(6.8 \mathrm{E}+00)$ & $(9.5 \mathrm{E}+02)$ & $(1.3 \mathrm{E}+01)$ & $(1.2 \mathrm{E}+03)$ & $(7.0 \mathrm{E}+01)$ & $(4.1 \mathrm{E}+02)$ & $(1.8 \mathrm{E}+01)$ & $<1.4 \mathrm{E}+02$ \\
\hline $6 a$ & $6.9 \mathrm{E}+02$ & $(9.8 \mathrm{E}+02)$ & $3.2 \mathrm{E}+02$ & $1.1 \mathrm{E}+03$ & $(7.2 \mathrm{E}+01)$ & NA & $(4.1 \mathrm{E}+03)$ & NA & NA & NA & NA & NA & $2.5 \mathrm{E}+02$ \\
\hline $6 \mathrm{~b}$ & $1.5 \mathrm{E}+03$ & $(1.0 \mathrm{E}+03)$ & $1.1 \mathrm{E}+03$ & $4.2 \mathrm{E}+03$ & $(4.1 \mathrm{E}+03)$ & NA & $(4.2 \mathrm{E}+03)$ & NA & NA & NA & NA & NA & $2.2 \mathrm{E}+02$ \\
\hline
\end{tabular}


Table 3.28. Water-Leachable Average Metal Concentrations in C-203 and C-204 Periodic Replenishment Water Extract (\%)

\begin{tabular}{|c|c|c|c|c|c|c|c|c|c|c|c|c|c|}
\hline \multirow{2}{*}{$\begin{array}{c}\text { Sequential } \\
\text { Contact }\end{array}$} & $\overline{\mathrm{Al}}$ & $\overline{\mathbf{C a}}$ & $\mathbf{C r}$ & $\mathbf{F e}$ & $\overline{\mathrm{K}}$ & Mn & $\mathbf{N a}$ & $\mathbf{N i}$ & $\mathbf{P}$ & $\mathbf{P b}$ & $\overline{\mathrm{Si}}$ & $\overline{\mathrm{Sr}}$ & $\overline{\overline{Z n}}$ \\
\hline & \multicolumn{13}{|c|}{ \% Water Leachable } \\
\hline \multicolumn{14}{|c|}{ C-203 (Jar 19649) } \\
\hline 1 & $<10.9$ & $<1.73$ & 9.8 & $(1.8)$ & N/A & $(1.5)$ & 89.4 & $(13.1)$ & $(102.6)$ & $(2.1)$ & $(1.5)$ & $(6.9$ & $(1.67)$ \\
\hline 2 & 27.9 & 1.81 & 1.4 & 0.8 & N/A & $(1.1)$ & 5.9 & 11.6 & 128.5 & (2.6) & (2.6) & (5.9) & $(10.1)$ \\
\hline 3 & $(4.2)$ & 2.86 & 2.2 & 0.8 & $\mathrm{~N} / \mathrm{A}$ & $(2.2)$ & 1.5 & $(8.0)$ & $(51.8)$ & (3.8) & (2.9) & (7.4) & $(15.3)$ \\
\hline 4 & $(4.0)$ & $<1.73$ & 0.3 & 0.2 & $\mathrm{~N} / \mathrm{A}$ & $(0.4)$ & 0.7 & $(0.9)$ & $(31.0)$ & $(1.0)$ & $(2.5)$ & (3.4) & $(17.4)$ \\
\hline 5 & $(1.6)$ & $(<1.73)$ & $(0.2)$ & $(0.2)$ & N/A & $(0.2)$ & 0.4 & $<13.4$ & $(26.3)$ & $(0.9)$ & $(1.6)$ & $(2.4)$ & (13.7) \\
\hline $6 \mathrm{a}$ & 22.9 & 9.4 & 1.5 & 0.7 & N/A & NA & $(1.6)$ & NA & NA & NA & NA & NA & $(27.6)$ \\
\hline $6 \mathrm{~b}$ & 16.6 & 12.7 & 6.3 & 2.1 & N/A & NA & $(1.4)$ & NA & NA & NA & NA & NA & $(25.4)$ \\
\hline \multicolumn{14}{|c|}{ C-204 (Jar 19650) } \\
\hline 1 & 2.8 & $(6.30)$ & $(1.0)$ & 0.2 & $\mathrm{~N} / \mathrm{A}$ & $(1.8)$ & 81.1 & 4.8 & 21.7 & $(7.3)$ & $(1.2)$ & (3.8) & $(0.10)$ \\
\hline 2 & $(2.6)$ & $(6.30)$ & $(1.1)$ & $(0.3)$ & N/A & $(0.7)$ & $(4.8)$ & $(2.7)$ & $(3.0)$ & (3.1) & $(1.4)$ & (2.8) & $(20.6)$ \\
\hline 3 & 3.8 & 6.30 & 7.1 & 1.7 & N/A & (3.8) & 3.1 & 10.8 & (3.6) & $\begin{array}{l}(12.6) \\
\end{array}$ & $\begin{array}{l}(1.8) \\
\end{array}$ & (8.8) & (16.9) \\
\hline 4 & 1.6 & 6.30 & $(0.5)$ & 0.2 & N/A & $(0.5)$ & 1.8 & $(0.7)$ & (2.4) & $(4.3)$ & $(1.2)$ & (2.5) & $(9.33)$ \\
\hline 5 & 1.1 & 17.48 & $(0.3)$ & 0.1 & N/A & $(0.7)$ & $(1.0)$ & $(0.5)$ & $(2.2)$ & $(4.2)$ & $(1.1)$ & $(4.3)$ & $(11.8)$ \\
\hline $6 a$ & 2.7 & $\begin{array}{l}(15.7) \\
\end{array}$ & 3.6 & 0.9 & N/A & NA & $\begin{array}{l}(4.5) \\
\end{array}$ & NA & NA & NA & NA & NA & $\begin{array}{l}(03.5) \\
\end{array}$ \\
\hline $6 \mathrm{~b}$ & 5.6 & $(17.0)$ & 12.3 & 3.3 & N/A & NA & (4.6) & NA & NA & NA & NA & NA & $\begin{array}{l}(29.0) \\
\end{array}$ \\
\hline
\end{tabular}


Cr water leachability from the sludges is potentially important because it can be a major contributor to noncarcinogenic risk and the hazard index calculation. Cr was found to be about $13 \%$ water leachable from C-203 sludge in the single contact tests (Table 3.18) and about 10\% leachable in the first stage of the periodic replenishment test (Table 3.28). Its water leachability decreased in the next four stages of the periodic replenishment test, which had short contact times of two to three days. However, for stages $6 \mathrm{a}$ and $6 \mathrm{~b}$ of this test, which had contact times of 65 and 86 days, respectively, the Cr percentages leached were 1.5 and $6.3 \%$. This increase in leachability was also found in stages $6 \mathrm{a}$ and $6 \mathrm{~b}$ of the C-204 periodic replenishment test, where the percentages were 3.6 and 12.3\%. Almost all other stages of the C-204 water leach tests had much lower values. Sufficient data are not available to determine the release mechanism for $\mathrm{Cr}$; however, it is possible that a low solubility, slow-reacting mineral (such as ferrihydrite) contains $\mathrm{Cr}$ that is released to solution as the mineral dissolves.

\subsubsection{Anion Concentrations - Replenishment Water Extracts}

The leachable anion concentrations at the seven stages of the periodic replenishment tests are listed in Table 3.29. The major leachable anions in C-203 sludge are carbonate, nitrate, sulfate, nitrite, and fluoride. The major leachable anions in C-204 sludge are carbonate, nitrate, nitrite, phosphate, and sulfate. In most cases, the leachable anion concentrations decrease by a factor of 10 or more between the first and second leach stages. The factors are not as large for fluoride, chloride, and phosphate.

\subsubsection{Radioanalytical Results - Replenishment Water Extracts}

The results of the GEA analysis of the replenishment water extracts for ${ }^{137} \mathrm{Cs}$ are listed in Table 3.30. The leachable concentrations for the first contacts for C-203 $(2.75 \mu \mathrm{Ci} / \mathrm{g})$ and C-204 $(0.706 \mu \mathrm{Ci} / \mathrm{g})$ are similar to the values for the single-contact batch leach tests (Table 3.20). Leachable concentrations in subsequent stages of the replenishment water tests are much lower (factors of 6 to over 100), showing that the remaining portion of ${ }^{137} \mathrm{Cs}$ is relatively recalcitrant. We speculate that the initial release of ${ }^{137} \mathrm{Cs}$ is enhanced by high dissolved concentrations of $\mathrm{Na}$ and $\mathrm{K}$ loading to ${ }^{137} \mathrm{Cs}$ description. After removal of $\mathrm{Na}$ and $\mathrm{K}$ from the system, the remaining ${ }^{137} \mathrm{Cs}$ is not as leachable.

Total beta, total alpha and ${ }^{90} \mathrm{Sr}$ levels for the periodic replenishment tests are listed in Table 3.31 . These results show that similar amounts of each of these constituents were leachable during the first three stages of the test, whereas the amounts decrease by a large amount (about a factor of 5 to 10) for the subsequent two stages.

The ${ }^{239} \mathrm{Pu},{ }^{241} \mathrm{Am}$, and ${ }^{244} \mathrm{Cm}$ leachable concentrations for the replenishment tests are listed in Table 3.32, and the leachable percentages are shown in Table 3.33. For Tank C-203, ${ }^{239} \mathrm{Pu}$ and ${ }^{241} \mathrm{Am}$ were not very leachable $(0.2$ to $4.4 \%)$ at any stage of the test. The leachability of ${ }^{244} \mathrm{Cm}$ was too low to measure for C-203. For Tank C-204, the leachabilities of all three radionuclides were too low to measure. 
Table 3.29. Average Anion Concentrations in C-203 and C-204 Periodic Replenishment Water Extract

\begin{tabular}{|c|c|c|c|c|c|c|c|c|c|c|}
\hline $\begin{array}{c}\text { Sequential } \\
\text { Contact }\end{array}$ & Fluoride & Acetate & Formate & Chloride & Nitrite & Nitrate & Carbonate & Sulfate & Oxalate & Phosphate \\
\hline \multicolumn{11}{|c|}{$\mu \mathrm{g} / \mathrm{g}$} \\
\hline \multicolumn{11}{|c|}{ C-203 (Jar 19649) } \\
\hline 1 & $5.15 \mathrm{E}+03$ & $5.59 \mathrm{E}+02$ & $2.15 \mathrm{E}+03$ & $1.53 \mathrm{E}+03$ & $9.49 \mathrm{E}+03$ & $1.72 \mathrm{E}+05$ & $1.57 \mathrm{E}+05$ & $2.24 \mathrm{E}+04$ & $<1.01 \mathrm{E}+02$ & $1.02 \mathrm{E}+03$ \\
\hline 2 & $2.02 \mathrm{E}+03$ & $<3.99 \mathrm{E}+01$ & $9.94 \mathrm{E}+01$ & $9.97 \mathrm{E}+01$ & $2.36 \mathrm{E}+02$ & $4.51 \mathrm{E}+03$ & $7.82 \mathrm{E}+03$ & $1.30 \mathrm{E}+02$ & $9.52 \mathrm{E}+02$ & $1.13 \mathrm{E}+03$ \\
\hline 3 & $1.10 \mathrm{E}+03$ & $<4.89 \mathrm{E}+01$ & $1.56 \mathrm{E}+01$ & $9.09 \mathrm{E}+01$ & $<1.31 \mathrm{E}+01$ & $1.40 \mathrm{E}+02$ & $<1.46 \mathrm{E}+03$ & $1.24 \mathrm{E}+01$ & $9.68 \mathrm{E}+01$ & $9.46 \mathrm{E}+02$ \\
\hline 4 & $5.36 \mathrm{E}+02$ & $<3.99 \mathrm{E}+01$ & $<1.18 \mathrm{E}+01$ & $4.81 \mathrm{E}+01$ & $<1.31 \mathrm{E}+01$ & $1.57 \mathrm{E}+01$ & $<1.46 \mathrm{E}+03$ & $<1.20 \mathrm{E}+01$ & $2.41 \mathrm{E}+01$ & $5.50 \mathrm{E}+02$ \\
\hline 5 & $3.11 \mathrm{E}+02$ & $<3.99 \mathrm{E}+01$ & $<1.18 \mathrm{E}+01$ & $4.07 \mathrm{E}+01$ & $<1.31 \mathrm{E}+01$ & $<1.26 \mathrm{E}+01$ & $<1.46 \mathrm{E}+03$ & $<1.20 \mathrm{E}+01$ & $1.47 \mathrm{E}+01$ & $3.42 \mathrm{E}+02$ \\
\hline $6 \mathrm{a}$ & $3.33 \mathrm{E}+02$ & $5.78 \mathrm{E}+01$ & $6.42 \mathrm{E}+01$ & $1.76 \mathrm{E}+01$ & $<1.39 \mathrm{E}+01$ & $2.94 \mathrm{E}+02$ & $<1.54 \mathrm{E}+03$ & $3.70 \mathrm{E}+01$ & $6.01 \mathrm{E}+01$ & $2.87 \mathrm{E}+02$ \\
\hline $6 \mathrm{~b}$ & $4.18 \mathrm{E}+02$ & $5.69 \mathrm{E}+01$ & $7.76 \mathrm{E}+01$ & $1.65 \mathrm{E}+01$ & $<1.24 \mathrm{E}+01$ & $2.76 \mathrm{E}+02$ & $<1.37 \mathrm{E}+03$ & $1.13 \mathrm{E}+01$ & $8.19 \mathrm{E}+01$ & $4.76 \mathrm{E}+02$ \\
\hline \multicolumn{11}{|c|}{ C-204 (Jar 19650) } \\
\hline 1 & $1.77 \mathrm{E}+02$ & $<7.56 \mathrm{E}+02$ & $1.93 \mathrm{E}+03$ & $8.44 \mathrm{E}+02$ & $2.07 \mathrm{E}+04$ & $3.01 \mathrm{E}+04$ & $8.52 \mathrm{E}+04$ & $3.91 \mathrm{E}+03$ & $6.48 \mathrm{E}+02$ & $4.35 \mathrm{E}+03$ \\
\hline 2 & $5.94 \mathrm{E}+01$ & $8.35 \mathrm{E}+01$ & $6.66 \mathrm{E}+01$ & $2.24 \mathrm{E}+02$ & $4.78 \mathrm{E}+02$ & $6.70 \mathrm{E}+02$ & $1.20 \mathrm{E}+04$ & $9.98 \mathrm{E}+01$ & $3.97 \mathrm{E}+01$ & $4.54 \mathrm{E}+03$ \\
\hline 3 & $1.88 \mathrm{E}+01$ & \begin{tabular}{|c|}
$<7.56 \mathrm{E}+01$ \\
\end{tabular} & $<2.23 \mathrm{E}+01$ & $1.43 \mathrm{E}+02$ & $<2.49 \mathrm{E}+01$ & $2.07 \mathrm{E}+01$ & $<2.80 \mathrm{E}+03$ & $<2.26 \mathrm{E}+01$ & $<1.90 \mathrm{E}+01$ & $2.91 \mathrm{E}+03$ \\
\hline 4 & $5.52 \mathrm{E}+00$ & $<7.56 \mathrm{E}+01$ & $<2.23 \mathrm{E}+01$ & $1.39 \mathrm{E}+02$ & $<2.49 \mathrm{E}+01$ & $<2.39 \mathrm{E}+01$ & $<2.76 \mathrm{E}+03$ & $<2.26 \mathrm{E}+01$ & $<1.90 \mathrm{E}+01$ & $1.62 \mathrm{E}+03$ \\
\hline 5 & $3.83 \mathrm{E}+00$ & $<7.56 \mathrm{E}+01$ & $<2.23 \mathrm{E}+01$ & $1.38 \mathrm{E}+02$ & $<2.49 \mathrm{E}+01$ & $3.08 \mathrm{E}+01$ & $<2.76 \mathrm{E}+03$ & $<2.26 \mathrm{E}+01$ & $<1.90 \mathrm{E}+01$ & $1.13 \mathrm{E}+03$ \\
\hline $6 a$ & $1.02 \mathrm{E}+01$ & $<7.57 \mathrm{E}+01$ & $3.37 \mathrm{E}+01$ & $2.50 \mathrm{E}+01$ & $<2.49 \mathrm{E}+01$ & $5.43 \mathrm{E}+01$ & $<2.76 \mathrm{E}+03$ & $2.79 \mathrm{E}+01$ & $<1.91 \mathrm{E}+01$ & $2.67 \mathrm{E}+03$ \\
\hline $6 \mathrm{~b}$ & $1.30 \mathrm{E}+01$ & $8.74 \mathrm{E}+01$ & $8.15 \mathrm{E}+01$ & $3.90 \mathrm{E}+01$ & $<2.48 \mathrm{E}+01$ & $4.84 \mathrm{E}+01$ & $<2.75 \mathrm{E}+03$ & $3.45 \mathrm{E}+01$ & $2.14 \mathrm{E}+01$ & $3.92 \mathrm{E}+03$ \\
\hline
\end{tabular}


Table 3.30. GEA for C-203 and C-204 Periodic Replenishment Water Extraction

\begin{tabular}{|c|c|c|c|}
\hline \multirow[b]{2}{*}{ Sequential Contact } & \multirow{2}{*}{$\begin{array}{c}\text { Contact Duration } \\
\text { (days) }\end{array}$} & \multicolumn{2}{|c|}{${ }^{137} \mathrm{Cs}$} \\
\hline & & $\mu \mathrm{Ci} / \mathrm{g}$ & $\mu \mathrm{g} / \mathrm{g}$ \\
\hline \multicolumn{4}{|c|}{ C-203 (Jar 19649) } \\
\hline 1 & 2 & 2.75 & $3.16 \mathrm{E}-02$ \\
\hline 2 & 2 & 0.157 & $1.80 \mathrm{E}-03$ \\
\hline 3 & 3 & 0.055 & $6.35 \mathrm{E}-04$ \\
\hline 4 & 2 & 0.036 & $4.15 \mathrm{E}-04$ \\
\hline 5 & 2 & 0.022 & $2.47 \mathrm{E}-04$ \\
\hline $6 a$ & 65 & NA & NA \\
\hline $6 \mathrm{~b}$ & 86 & NA & NA \\
\hline \multicolumn{4}{|c|}{ C-204 (Jar 19650) } \\
\hline 1 & 2 & 0.706 & $8.12 \mathrm{E}-03$ \\
\hline 2 & 2 & 0.123 & $1.42 \mathrm{E}-03$ \\
\hline 3 & 3 & 0.073 & 8.36E-04 \\
\hline 4 & 2 & 0.030 & $3.49 \mathrm{E}-04$ \\
\hline 5 & 62 & 0.018 & $2.07 \mathrm{E}-04$ \\
\hline $6 a$ & 65 & NA & NA \\
\hline $6 \mathrm{~b}$ & 86 & NA & NA \\
\hline NA $=$ Not analyzed. & & & \\
\hline
\end{tabular}

Table 3.31. Total Beta, Total Alpha, and ${ }^{90} \mathrm{Sr}$ Analysis for C-203 and C-204 Periodic Replenishment Water Extracts

\begin{tabular}{|c|c|c|c|c|}
\hline \multirow[b]{2}{*}{ Sequential Contact } & Total Beta & Total Alpha & & \\
\hline & \multicolumn{2}{|c|}{$\mu \mathrm{Ci} / \mathrm{g}$} & $\mu \mathrm{Ci} / \mathrm{g}$ & $\mu g / g$ \\
\hline \multicolumn{5}{|c|}{ C-203 (Jar 19649) } \\
\hline 1 & $4.72 \mathrm{E}+00$ & $3.73 \mathrm{E}-01$ & $2.45 \mathrm{E}+00$ & $1.75 \mathrm{E}-02$ \\
\hline 2 & $2.62 \mathrm{E}+00$ & $2.01 \mathrm{E}-01$ & $2.49 \mathrm{E}+00$ & $1.78 \mathrm{E}-02$ \\
\hline 3 & $2.85 \mathrm{E}+00$ & $2.29 \mathrm{E}-01$ & $3.10 \mathrm{E}+00$ & $2.21 \mathrm{E}-02$ \\
\hline 4 & $5.08 \mathrm{E}-01$ & $3.71 \mathrm{E}-02$ & $6.26 \mathrm{E}-01$ & 4.47E-03 \\
\hline 5 & $3.43 \mathrm{E}-01$ & $3.09 \mathrm{E}-02$ & $3.21 \mathrm{E}-01$ & $2.29 \mathrm{E}-03$ \\
\hline $6 a$ & NA & NA & NA & NA \\
\hline $6 b$ & NA & NA & NA & NA \\
\hline \multicolumn{5}{|c|}{ C-204 (Jar 19650) } \\
\hline 1 & $8.72 \mathrm{E}-01$ & $8.14 \mathrm{E}-02$ & $2.54 \mathrm{E}-01$ & $1.81 \mathrm{E}-03$ \\
\hline 2 & $5.95 \mathrm{E}-01$ & $2.86 \mathrm{E}-02$ & 5.99E-01 & $4.28 \mathrm{E}-03$ \\
\hline 3 & $1.27 \mathrm{E}+00$ & $5.01 \mathrm{E}-02$ & $1.53 \mathrm{E}+00$ & $1.09 \mathrm{E}-02$ \\
\hline 4 & $1.25 \mathrm{E}-01$ & $6.91 \mathrm{E}-03$ & $1.10 \mathrm{E}-01$ & 7.83E-04 \\
\hline 5 & 8.89E-02 & $5.30 \mathrm{E}-03$ & $6.94 \mathrm{E}-02$ & $4.96 \mathrm{E}-04$ \\
\hline $6 a$ & NA & NA & NA & NA \\
\hline $6 b$ & NA & $\mathrm{NA}$ & $\mathrm{NA}$ & NA \\
\hline
\end{tabular}


Table 3.32. Actinide Analysis for C-203 and C-204 Periodic Replenishment Water Extracts

\begin{tabular}{|c|c|c|c|c|c|c|}
\hline \multirow[t]{2}{*}{$\begin{array}{c}\text { Sequential } \\
\text { Contact }\end{array}$} & \multicolumn{2}{|c|}{${ }^{239} \mathrm{Pu}$} & \multicolumn{2}{|c|}{${ }^{241} \mathrm{Am}$} & \multicolumn{2}{|c|}{${ }^{244} \mathrm{Cm}$} \\
\hline & $\mu \mathrm{Ci} / \mathrm{g}$ & $\mu \mathrm{g} / \mathrm{g}$ & $\mu \mathrm{Ci} / \mathrm{g}$ & $\mu \mathrm{g} / \mathrm{g}$ & $\mu \mathrm{Ci} / \mathrm{g}$ & $\mu \mathrm{g} / \mathrm{g}$ \\
\hline \multicolumn{7}{|c|}{ C-203 (Jar 19649) } \\
\hline 1 & 7.09E-03 & $1.14 \mathrm{E}-01$ & $<9.85 \mathrm{E}-04$ & $<2.90 \mathrm{E}-04$ & $<2.18 \mathrm{E}-03$ & $<2.69 \mathrm{E}-05$ \\
\hline 2 & $1.06 \mathrm{E}-01$ & $1.71 \mathrm{E}+00$ & 4.29E-03 & $1.26 \mathrm{E}-03$ & $<2.18 \mathrm{E}-03$ & $<2.69 \mathrm{E}-05$ \\
\hline 3 & $1.55 \mathrm{E}-01$ & $2.51 \mathrm{E}+00$ & $6.14 \mathrm{E}-03$ & $1.81 \mathrm{E}-03$ & $<2.18 \mathrm{E}-03$ & $<2.69 \mathrm{E}-05$ \\
\hline 4 & $1.93 \mathrm{E}-02$ & $3.11 \mathrm{E}-01$ & $1.32 \mathrm{E}-03$ & $3.87 \mathrm{E}-04$ & $<2.18 \mathrm{E}-03$ & $<2.69 \mathrm{E}-05$ \\
\hline 5 & $1.29 \mathrm{E}-02$ & $2.09 \mathrm{E}-01$ & $<1.18 \mathrm{E}-03$ & $<3.49 \mathrm{E}-04$ & $<2.18 \mathrm{E}-03$ & $<2.69 \mathrm{E}-05$ \\
\hline $6 a$ & NA & NA & NA & NA & NA & NA \\
\hline $6 b$ & NA & NA & NA & NA & NA & NA \\
\hline \multicolumn{7}{|c|}{ C-204 (Jar 19650) } \\
\hline 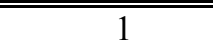 & 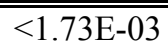 & $=2<2.78 \mathrm{E}-02$ & $\begin{array}{c}<1.86 \mathrm{E}-03 \\
\end{array}$ & 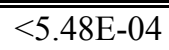 & 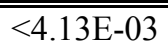 & $=<5.09 \mathrm{E}-05$ \\
\hline 2 & $<1.73 \mathrm{E}-03$ & $<2.78 \mathrm{E}-02$ & $<1.86 \mathrm{E}-03$ & $<5.48 \mathrm{E}-04$ & $<4.13 \mathrm{E}-03$ & $<5.09 \mathrm{E}-05$ \\
\hline 3 & $<2.02 \mathrm{E}-03$ & $<3.26 \mathrm{E}-02$ & $<1.86 \mathrm{E}-03$ & $<5.48 \mathrm{E}-04$ & $<4.13 \mathrm{E}-03$ & $<5.09 \mathrm{E}-05$ \\
\hline 4 & $<1.73 \mathrm{E}-03$ & $<2.78 \mathrm{E}-02$ & $<1.86 \mathrm{E}-03$ & $<5.48 \mathrm{E}-04$ & $<4.13 \mathrm{E}-03$ & $<5.09 \mathrm{E}-05$ \\
\hline 5 & $<1.73 \mathrm{E}-03$ & $<2.78 \mathrm{E}-02$ & $<1.86 \mathrm{E}-03$ & $<5.48 \mathrm{E}-04$ & $<4.13 \mathrm{E}-03$ & $<5.09 \mathrm{E}-05$ \\
\hline $6 a$ & NA & NA & NA & NA & NA & NA \\
\hline $6 \mathrm{~b}$ & NA & NA & NA & NA & NA & NA \\
\hline
\end{tabular}

Table 3.33. Water-Leachable Percentage for Actinides in C-203 and C-204 Periodic Replenishment Water Extracts Compared with Fusion Analysis

\begin{tabular}{||c|c|c|c||}
\hline Sequential Contact & ${ }^{\mathbf{2 3 9}} \mathbf{P u}$ & ${ }^{241} \mathbf{A m}$ & ${ }^{244} \mathbf{C m}$ \\
\hline \multicolumn{4}{|c||}{ Water Leachable } \\
\hline \hline \multicolumn{4}{|c|}{ C-203 (Jar 19649) } \\
\hline 1 & 0.2 & 0.5 & N/A \\
\hline 2 & 2.7 & 3.1 & N/A \\
\hline 3 & 4.0 & 4.4 & N/A \\
\hline 4 & 0.5 & 0.9 & N/A \\
\hline 5 & 0.3 & 0.7 & N/A \\
\hline \multicolumn{4}{|c|}{ C-204 (Jar 19650) } \\
\hline \hline N/A & N/A & N/A \\
\hline 2 & N/A & N/A & N/A \\
\hline 3 & N/A & N/A & N/A \\
\hline 4 & N/A & N/A & N/A \\
\hline 5 & N/A & N/A & N/A \\
\hline
\end{tabular}

\subsubsection{Uranium Mineral Solubility Measurements}

Results of the solubility experiments are provided in Table 3.34. The concentrations of uranium, sodium, total carbonate, and nitrate are shown along with $\mathrm{pH}$ and the molar ratios of sodium/uranium and 
total carbonate/uranium. In the sample ID column, the solid-to-solution ratio is indicated in parentheses. The number after the parentheses indicates the contact sequence number. In the sequential solubility determinations conducted with the C-203 samples, the uranium concentration increased with each sequential solubility determination. The dissolution of čejkaite can be written as follows:

$$
\mathrm{Na}_{4} \mathrm{UO}_{2}\left(\mathrm{CO}_{3}\right)_{3}(\mathrm{~s}) \leftrightarrow \mathrm{UO}_{2}{ }^{2+}+3 \mathrm{CO}_{3}{ }^{2-}+4 \mathrm{Na}^{+}
$$

Because of the strong affinity of uranyl ion to form carbonate complexes, the net reaction for the conditions of our experiments is more appropriately written as (Blake et al. 1956):

$$
\mathrm{Na}_{4} \mathrm{UO}_{2}\left(\mathrm{CO}_{3}\right)_{3}(\mathrm{~s}) \leftrightarrow \mathrm{UO}_{2}\left(\mathrm{CO}_{3}\right)_{3}{ }^{4-}+4 \mathrm{Na}^{+}
$$

From this equation, it is apparent that if additional sodium or carbonate is added to the solution from other soluble minerals, a reduction in the equilibrium uranium concentration will occur by forcing the equilibrium to the left (common ion effect). In the case of C-203 sludge, the additional sodium comes primarily from the dissolution of sodium nitrate in the sludge. Lesser amounts of sodium and carbonate are contributed from sodium carbonate and sodium nitrite in the sludge. The nitrite concentrations in the

Table 3.34. Empirical Čejkaite Solubility Results for C-203 and C-204 Sludge Samples

\begin{tabular}{||l|c|c|c|c|c|c|c||}
\hline \multicolumn{1}{|c|}{ Sample ID } & $\begin{array}{c}\mathbf{U} \\
\mathbf{m o l} / \mathbf{L})\end{array}$ & $\begin{array}{c}\mathbf{N a} \\
(\mathbf{m o l} / \mathbf{L})\end{array}$ & $\begin{array}{c}\text { Nitrate } \\
(\mathbf{m o l} / \mathbf{L})\end{array}$ & $\begin{array}{c}\text { Total } \\
\text { Carbonate } \\
(\mathbf{m o l} / \mathbf{L})\end{array}$ & $\mathbf{p H}$ & $\begin{array}{c}\text { Total } \\
\mathbf{N a} / \mathbf{U} \text { in } \\
\text { Solution }\end{array}$ & $\begin{array}{c}\text { Carbonate/U } \\
\text { in Solution }\end{array}$ \\
\hline \hline C-203 (1:1)-1 & 0.03 & 2.98 & 2.54 & 0.23 & 9.53 & 94.9 & 7.39 \\
\hline C-203 (1:1)-2 & 0.09 & 1.66 & 1.10 & 0.41 & 9.55 & 18.6 & 4.58 \\
\hline C-203 (1:1)-3 & 0.13 & 1.06 & 0.47 & 0.58 & 9.52 & 8.10 & 4.43 \\
\hline C-203 (1:1)-4 & 0.18 & 1.08 & 0.26 & 0.75 & 9.48 & 6.03 & 4.22 \\
\hline \hline C-203 (2:1)-1 & 0.03 & 3.14 & 2.38 & 0.23 & 9.57 & 95.1 & 6.96 \\
\hline C-203 (2:1)-2 & 0.08 & 1.64 & 1.10 & 0.32 & 9.57 & 21.3 & 4.17 \\
\hline C-203 (2:1)-3 & 0.14 & 1.29 & 0.49 & 0.62 & 9.55 & 9.08 & 4.34 \\
\hline C-203 (2:1)-4 & 0.18 & 1.11 & 0.23 & 0.63 & 9.51 & 6.35 & 3.58 \\
\hline \hline Whole Nugget (1:2)-1 & 0.16 & 1.33 & 0.61 & 0.50 & 9.48 & 8.31 & 3.16 \\
\hline Whole Nugget (1:2)-2 & 0.23 & 1.02 & 0.11 & 0.80 & 9.20 & 4.42 & 3.45 \\
\hline \hline Crushed Nugget (1:2)-1 & 0.16 & 1.35 & 0.63 & 0.56 & 9.46 & 8.64 & 3.55 \\
\hline Crushed Nugget (1:2)-2 & 0.25 & 1.14 & 0.13 & 0.94 & 9.18 & 4.50 & 3.71 \\
\hline \hline C-204 (1:1)-1 & 0.03 & -- & 0.28 & 0.29 & 8.98 & -- & 9.09 \\
\hline C-204 (2:1)-1 & 0.03 & -- & 0.44 & 0.15 & 8.68 & -- & 5.82 \\
\hline
\end{tabular}

extract solutions (not shown) are typically about an order of magnitude lower than the nitrate concentrations. From Table 3.34, it can be seen that both the sodium and carbonate concentrations generally decrease with each water replacement, indicating that decreasing amounts of sodium nitrate and sodium carbonate remain in the sludge after each water replacement. If the concentrations of uranium, sodium, and carbonate in solutions were the result of dissolution of $\mathrm{Na}_{4} \mathrm{UO}_{2}\left(\mathrm{CO}_{3}\right)_{3}(\mathrm{~s})$ alone, the molar ratio of $\mathrm{Na} / \mathrm{U}$ in solution would be 4 and the molar ratio of total carbonate/ $\mathrm{U}$ would be 3 . The actual values 
measured approach these values by the fourth equilibration step, but additional excess sodium and carbonate still remain in the sludge even after the fourth equilibration step.

Two single-contact experiments were conducted with the C-204 sludge. The sodium concentrations in these experiments were not measured, but the uranium concentrations were and were very similar to those measured in the $\mathrm{C}-203$ experiments. The carbonate concentrations were also similar; however, the $\mathrm{pH}$ values measured were significantly lower (by 0.6 to $0.9 \mathrm{pH}$ units).

The results of the nugget solubility experiments are very similar to those of the fourth sequential contact conducted with the C-203 sludge (Table 3.34). No significant differences were observed between the whole nugget and the crushed nugget results; thus, crushing does not appear to change the rates of dissolution. The second contacts for the whole and crushed nuggets [Whole Nugget Solid (1:2)-2 and Crushed Nugget (1:2)-2] have the highest uranium concentrations measured in this study. The second contact for the nugget experiments also had Na/U and total carbonate/ $\mathrm{U}$ ratios in solution that were close to the theoretical values for čejkaite; however, it is clear that other sodium- and carbonate-containing salts in the nuggets have not completely dissolved during the first contact. The dissolution of these other sodium- and carbonate-containing salts is responsible for the reduced uranium concentration observed in the first contact relative to the second (common ion effect). The uranium concentrations measured in the second contact experiments $(0.23$ and $0.25 \mathrm{M})$ compare well with solubility measurements conducted on "hard sludge-crystalline carbonate material [(believed to be mainly $\mathrm{Na}_{4} \mathrm{UO}_{2}\left(\mathrm{CO}_{3}\right)_{3}$ ]" commonly present in some tanks, according to the Uranium Recovery Technical Manual (GE 1951). The equilibrium solubility of this material was found to maintain a uranium concentration in pure water of about $0.26 \mathrm{M}$ at $30^{\circ} \mathrm{C}$. In addition, Blake et al. (1956) measured the solubility of $\mathrm{Na}_{4} \mathrm{UO}_{2}\left(\mathrm{CO}_{3}\right)_{3}(\mathrm{~s})$ in various solutions. In pure water, they determined the equilibrium uranium concentration to be $0.286 \mathrm{M}$ at $26^{\circ} \mathrm{C}$. The slightly reduced equilibrium uranium concentrations observed in our experiments are likely to be the result of the continued influence of the common ion effect. It is clear from our results that the readily soluble sodiumand carbonate-containing salts will have a significant effect on the equilibrium uranium concentrations leaching from the C-203 and C-204 sludges until the other sodium- and carbonate-bearing salts have been completely dissolved.

To confirm equilibrium with čejkaite, it is important to verify that the čejkaite did not completely dissolve during the experiments. The solid product remaining at the termination of the solubility experiment with the 1:1 solid:solution ratio was inspected by SEM/EDS. These analyses of the residual solid showed it containing large quantities of hexagonal, acicular (i.e., needle-like) crystals (Figure 3.15) that are composed of sodium, uranium, oxygen, and carbon. As discussed in Sections 3.4.1 and 3.5.1.1, these acicular crystals have been identified as čejkaite based on XRD and SEM/EDS analyses.

From a tank-closure performance assessment perspective, it is clear that the solubility and rate of dissolution of čejkaite in C-203 and C-204 sludges are relatively high. Because of the common ion effect (Equation 3.1) and the relatively high concentrations of sodium nitrate in the sludges, the initial solubility of čejkaite in C-203 and C-204 sludges will be suppressed until the readily soluble sodium salts have dissolved. After this, the čejkaite solubility will peak and remain high until all the remaining mineral has dissolved away. 
It is noteworthy that the highest nitrate concentrations observed in the C-203 solubility experiments was $2.54 \mathrm{~mol} / \mathrm{L}$. Using data from Oosterhof et al. (1999), the solubility of $\mathrm{NaNO}_{3}$ at $20^{\circ} \mathrm{C}$ was calculated to be $7.39 \mathrm{~mol} / \mathrm{L}$. It is clear from the results of later extractions (Table 3.34), that all the sodium nitrate did not completely dissolve during the first extraction contact. The reason for the lack of equilibrium between the solution and the sodium nitrate in the sludge in the first extraction is not readily apparent. However, based on mass balance considerations and observations made using SEM images of unleached C-203 tank sludge (subsection 3.5.1.1), a plausible explanation has been developed. From these images, it can be observed that a large fraction of the sludge is composed of čejkaite crystals and that a major portion of these crystals form larger aggregate particles and appear to be "glued" together by an amorphouslooking phase (see Figure 3.11). This phase is presumed to be $\mathrm{NaNO}_{3}$. If all the $\mathrm{U}$ measured in the C-203 sludge is assumed to occur as čejkaite, it can be calculated that $50 \mathrm{wt} \%$ of the C-203 sludge is composed of čejkaite. If all of the nitrate measured in C-203 sludge is assumed to occur as $\mathrm{NaNO}_{3}$, then $22 \%$ of the C-203 sludge is $\mathrm{NaNO}_{3}$. During the solubility extractions, C-203 sludge is added to water, and both čejkaite and $\mathrm{NaNO}_{3}$ quickly begin to dissolve. The solubility of čejkaite is reduced because of the common ion effect (Na present in both dissolving solids). In this case, the common ion effect causes the solubility of the less-soluble mineral (čejkaite) to be depressed because of the high concentration of $\mathrm{Na}^{+}$in solution provided by the more soluble $\mathrm{NaNO}_{3}$ mineral. As the minerals dissolve, the solubility of čejkaite is reached at a lower level than would be attained if $\mathrm{NaNO}_{3}$ were not also dissolving. $\mathrm{NaNO}_{3}$ that is exposed to water will continue to dissolve until its solubility limit is reached. Any $\mathrm{NaNO}_{3}$ trapped within the consolidated particles cannot dissolve further until it is exposed to water. This can occur in later extractions when additional čejkaite is dissolved, allowing more of the $\mathrm{NaNO}_{3}$ "glue" to be exposed to water.

Although this process provides a reasonable explanation of why equilibrium with $\mathrm{NaNO}_{3}$ was not attained during the laboratory čejkaite solubility experiments, it suggests that release of uranium from sludge in the C-203 and C-204 tanks would be a very dynamic process and require a relatively complex model for simulation purposes. However, it is believed that these dynamic complexities will not be important during actual residual sludge release. This is because the contact times between the water and sludge during tank release will be very long compared with the laboratory experiments ( 24 hours). As a result of these long contact times, diffusion of $\mathrm{NaNO}_{3}$ from within the consolidated particles to the outside solution is likely to occur, allowing the $\mathrm{NaNO}_{3}$ to reach its solubility limit (or dissolve completely). This will result in a constant čejkaite solubility until all the $\mathrm{NaNO}_{3}$ has dissolved.

\subsection{XRD Results}

This section discusses the crystalline solids identified in the XRD patterns for the unleached and water-leached C-203 (jar 19649) and C-204 (jar 19650) sludge samples, solids remaining at the end of certain extraction tests and solubility experiments (see Table 2.3), and čejkaite $\left[\mathrm{Na}_{4}\left(\mathrm{UO}_{2}\right)\left(\mathrm{CO}_{3}\right)_{3}\right]$ particles removed from a natural mineral specimen. The as-measured and background-subtracted XRD patterns for these samples are found in Appendix A. Phase identification was based on a comparison of the peak reflections and intensities observed in each pattern to the mineral powder diffraction files (PDFTM) published by the Joint Committee on Powder Diffraction Standards (JCPDS) International Center for Diffraction Data (ICDD). The XRD patterns in Appendix A show greater detail than those plotted in this 
section because they do not include the schematic PDF-XRD database patterns used for phase identification (as plotted in this section).

Each pattern in this section and Appendix $A$ is shown as a function of degrees $2 \theta$ based on $\mathrm{Cu}_{\mathrm{K} \alpha}$ radiation $(\lambda=1.5406 \AA$ ). The vertical axis in each pattern represents the intensity or relative intensity of the XRD peaks. The XRD patterns included in this section show for comparison purposes one or more schematic database (PDF) patterns considered for phase identification. The height of each line in the schematic PDF patterns represents the relative intensity of an XRD peak [i.e., the most intense (the highest) peak has a relative intensity $\left(\mathrm{I} / \mathrm{I}_{\mathrm{o}}\right)$ of $100 \%$ ]. Quantitative analyses of the relative masses of individual phases present in each solid sample were not estimated using these XRD patterns due to the factors discussed at the end of Section 2.3. Also, as noted previously, a crystalline phase typically must be present at greater than $5 \mathrm{wt} \%$ of the total sample mass (greater than $1 \mathrm{wt} \%$ under optimum conditions) to be readily detected by XRD.

\subsubsection{C-203 Samples}

The background-subtracted XRD pattern measured for the sample of unleached C-203 (jar 19649) bulk sludge and the as-measured (without background subtraction) XRD pattern measured for the yellow nugget material separated from the unleached C-203 bulk sludge are shown in Figures 3.3 and 3.4, respectively. For comparison, the XRD pattern for the unleached C-203 sludge is shown in Figure 3.3 along with the XRD patterns for čejkaite from Ondruš et al. (2003) and clarkeite (PDF \#50 1586). The XRD pattern for the yellow nugget material is shown in Figure 3.4 along with the XRD patterns for čejkaite from Ondruš et al. (2003) and natratine (soda niter, $\mathrm{NaNO}_{3}$ ). The $\mathrm{XRD}$ results indicate that unleached C-203 bulk sludge and yellow nugget material consist primarily of čejkaite $\left[\mathrm{Na}_{4}\left(\mathrm{UO}_{2}\right)\left(\mathrm{CO}_{3}\right)_{3}\right]$. The XRD patterns for the unleached bulk sludge and yellow nugget material were exact matches to the XRD for čejkaite presented in Ondruš et al. (2003) and database pattern PDF \#51-1474. ${ }^{\text {(a) }}$ There were no unassigned reflections in the XRD patterns for the unleached C-203 bulk sludge and yellow nugget material. This implies that these materials likely did not contain any other major crystalline solid, which, if present, would exist at less that $5-10 \mathrm{wt} \%$ of the total sample mass.

The XRD patterns measured for the various C-203 and C-204 samples were also checked for the possible presence of other sodium uranium phases previously identified in other Hanford tank sludges, such as $\mathrm{Na}_{2} \mathrm{U}_{2} \mathrm{O}_{7}$ and clarkeite $\mathrm{Na}\left[\left(\mathrm{UO}_{2}\right) \mathrm{O}(\mathrm{OH})\right]\left(\mathrm{H}_{2} \mathrm{O}\right)_{0-1}$. Based on the absence of the major reflection at

(a) Database pattern PDF \#51-1474 is assigned to an "unnamed mineral" with the formula $\mathrm{Na}_{4}\left(\mathrm{UO}_{2}\right)\left(\mathrm{CO}_{3}\right)_{3}$. The PDF \#51-1474 file and Ondruš et al. (2003) both cite Ondruš et al. (1997) as the source of the mineralogical information for the $\mathrm{Na}_{4}\left(\mathrm{UO}_{2}\right)\left(\mathrm{CO}_{3}\right)_{3}$ phase. It was therefore assumed that both sources were referring to the same mineral with the now accepted name čejkaite as described in Ondruš et al. (2003). This has been confirmed by Petr Ondruš (personal communication) at the Czech Geological Survey, Prague, Czech Republic. 


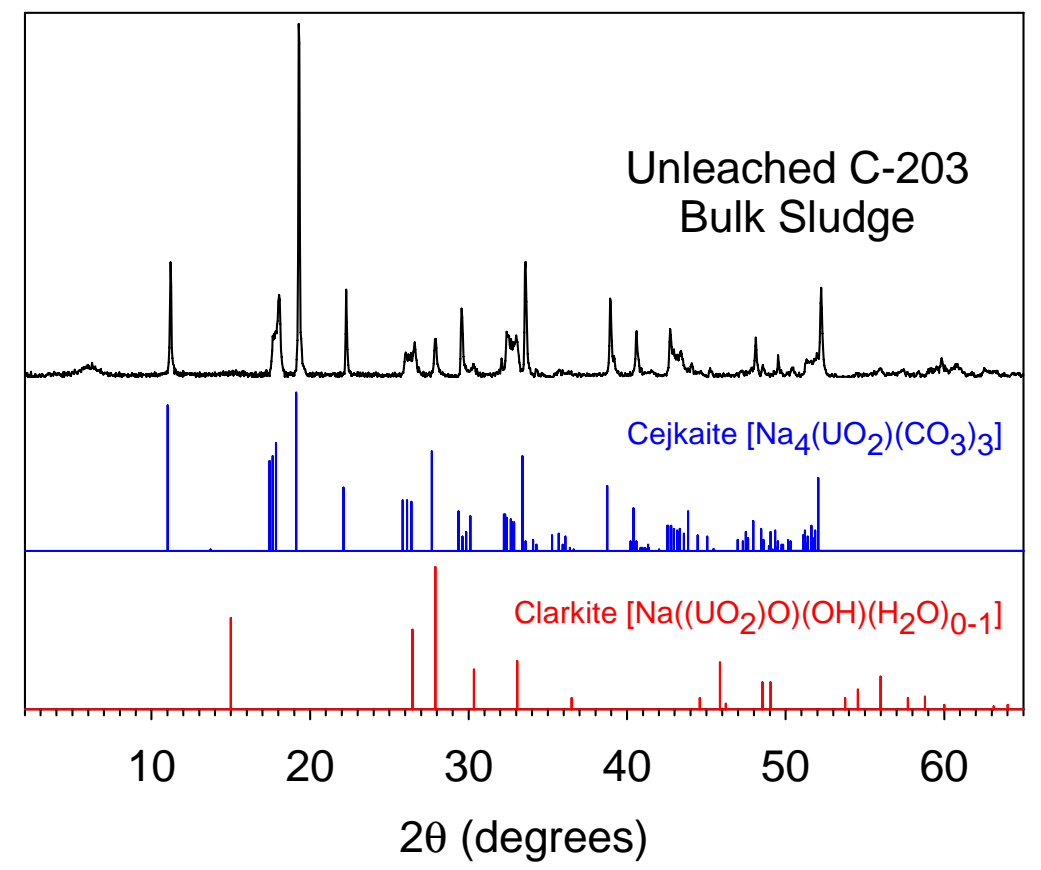

Figure 3.3. Background-Subtracted XRD Pattern for the Unleached C-203 Bulk Sludge Shown with XRD Patterns for Čejkaite (Ondruš et al. 2003) and Clarkeite (PDF \#50-1586)

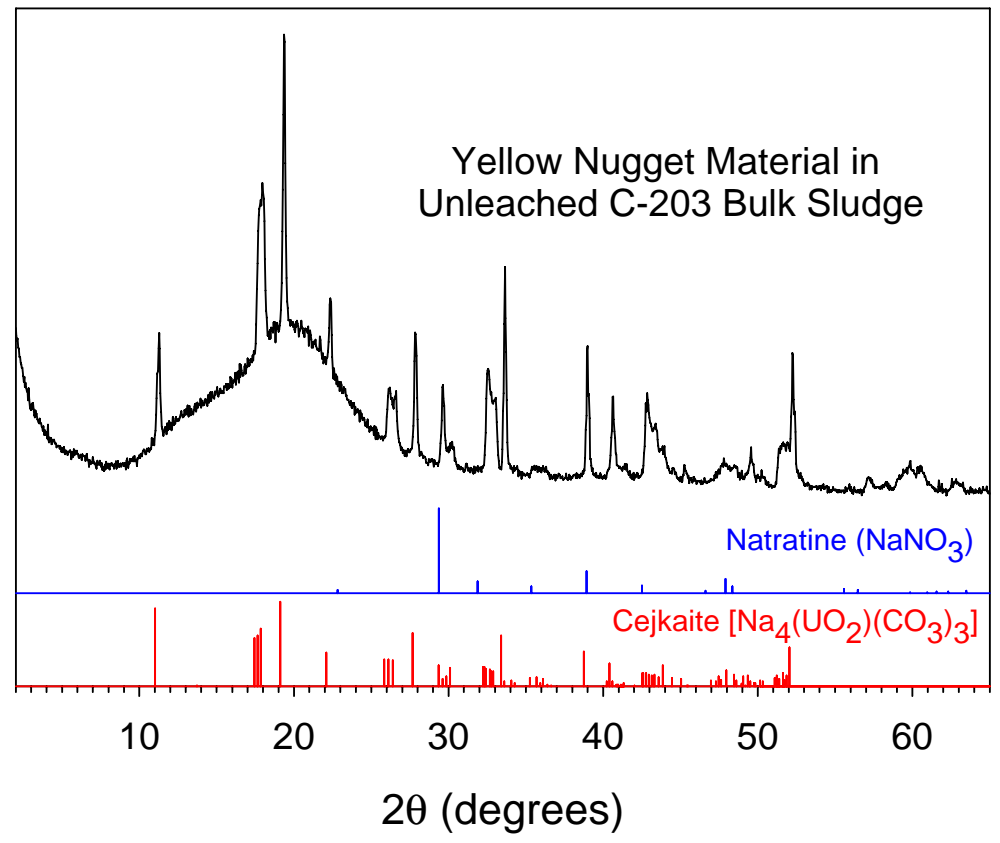

Figure 3.4. As-Measured XRD Pattern for Yellow Nugget Material in Unleached C-203 Bulk Sludge Shown with XRD Patterns for Čejkaite (Ondruš et al. 2003) and Natratine (PDF \#36-1474) 
approximately $15^{\circ} 2 \theta$ for clarkeite (PDF \#50 1586) in the measured XRD patterns for unleached C-203 bulk sludge (Figure 3.3) and yellow nugget material (Figure 3.4), crystalline clarkeite was not detected in these solids. If present, the concentration of clarkeite would be less than 5-10 wt $\%$ of the total mass of the unleached materials. Sodium uranate solids have been identified by others in tank sludge materials from the Hanford Site (Rapko and Lumetta 2000). For example, Temer and Villareal $(1995,1996,1997)$ used XRD to identify sodium diuranate $\left(\mathrm{Na}_{2} \mathrm{U}_{2} \mathrm{O}_{7}\right)$ in sludge samples from Hanford Tanks BX-103, BX-105, and BX-109. Herting et al. (2002) observed using SEM(bse)/EDS a "sodium/ uranium-particulate" in saltcake from Hanford Tank BY-109 and in residues from water and $\mathrm{NaOH}$ washing of saltcake from Hanford Tank S-112. Their XRD analysis of these samples indicated that the uranium phase was $\mathrm{Na}_{2} \mathrm{U}_{2} \mathrm{O}_{7}$. Experiments reported by Traina et al. (2001) showed that mixing $10^{-3} \mathrm{M} \mathrm{UO}_{2}{ }^{2+}$ in a NaOH solution resulted in precipitation of a yellow solid that they identified as " $\mathrm{Na}_{2} \mathrm{U}_{2} \mathrm{O}_{7}$ (clarkeite)" by XRD. Clarkeite \{ideal end-member formula $\mathrm{Na}\left[\left(\mathrm{UO}_{2}\right) \mathrm{O}(\mathrm{OH})\right]\left(\mathrm{H}_{2} \mathrm{O}\right)_{0-1}$ \} is isostructural with $\mathrm{Na}_{2} \mathrm{U}_{2} \mathrm{O}_{7}$ and $\mathrm{Na}_{6} \mathrm{U}_{7} \mathrm{O}_{24}$, and is therefore difficult to distinguish using XRD (Finch and Ewing 1997).

The results of the XRD analysis of the yellow nugget material mounted without the use of collodion solution suggests that the nugget material also contains a significant, but undeterminable, mass of noncrystalline component(s) based on the broad peak positioned between 10 and $30^{\circ} 2 \theta$ (Figure 3.4). The symmetry of this peak is characteristic of those resulting from the XRD of amorphous (non-crystalline) material. The XRD pattern for the yellow nugget material is also consistent with the possible presence of natratine (soda niter, $\mathrm{NaNO}_{3}$ ) ( $\left.\mathrm{PDF} \# 36-1474\right)$ at a concentration that is estimated from relative peak heights to be less than $25 \%$ of čejkaite.

Figure 3.5 shows the as-measured and background-subtracted XRD patterns for the two-week waterleached C-203 sludge sample. Based on the as-measured XRD pattern, no crystalline solids were detected in this sample. Unlike the XRD patterns for unleached C-203 bulk sludge (Figure 3.3) and

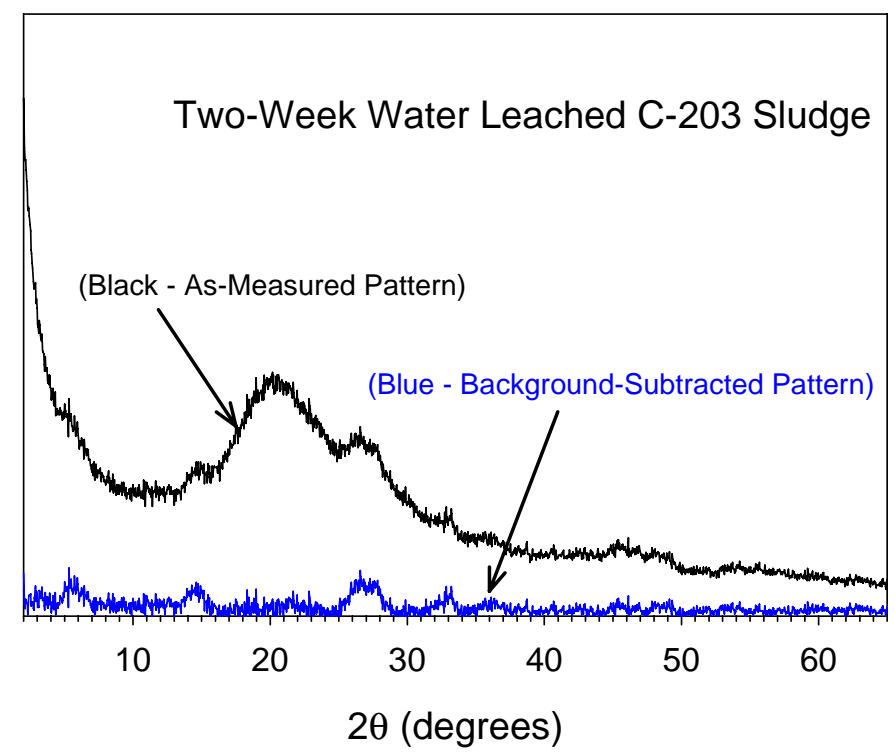

Figure 3.5. As-Measured and Background-Subtracted XRD Patterns for Two-Week Water-Leached C-203 Sludge 
yellow nugget material (Figure 3.4), the as-measured and background-subtracted XRD patterns for the two-week water-leached sample did not contain any reflections for čejkaite. This result indicates that the majority of the čejkaite originally present in the bulk sludge had dissolved during the course of the twoweek water-leach test. Analysis of the XRD pattern for the sample (Figure 3.5) suggests that this material may contain a small amount of clarkeite that is likely poorly crystalline. This conclusion is based on the small broad reflections observed at approximately $15,27,33,46$, and $49^{\circ} 2 \theta$ in the background-subtracted pattern in Figure 3.5. These five reflections correspond to the major reflections listed for clarkeite (PDF \#50-1586) (see clarkeite pattern in Figure 3.3).

The XRD patterns for the two-week water-leached C-203 sample (Figure 3.5) are identical to those obtained for the three-month water leached C-203 sludge sample. The only crystalline phase possibly present in the three-month water-leached C-203 sludge sample was a small amount of poorly crystalline clarkeite. This result is uncertain because identification of clarkeite in this sample, like that for the twoweek water-leached C-203 sample, is based on a few small broad reflections at approximately 15, 27, and $33^{\circ} 2 \theta$ in the background-subtracted pattern.

\subsubsection{C-204 Samples}

The background-subtracted XRD pattern measured for the sample of unleached C-204 (jar 19650) bulk sludge is shown in Figure 3.6 along with the XRD pattern for čejkaite from Ondruš et al. (2003). The XRD results indicate that unleached C-204 bulk sludge consists primarily of čejkaite. There were no unassigned major reflections in the XRD pattern, which suggests that this material did not contain any

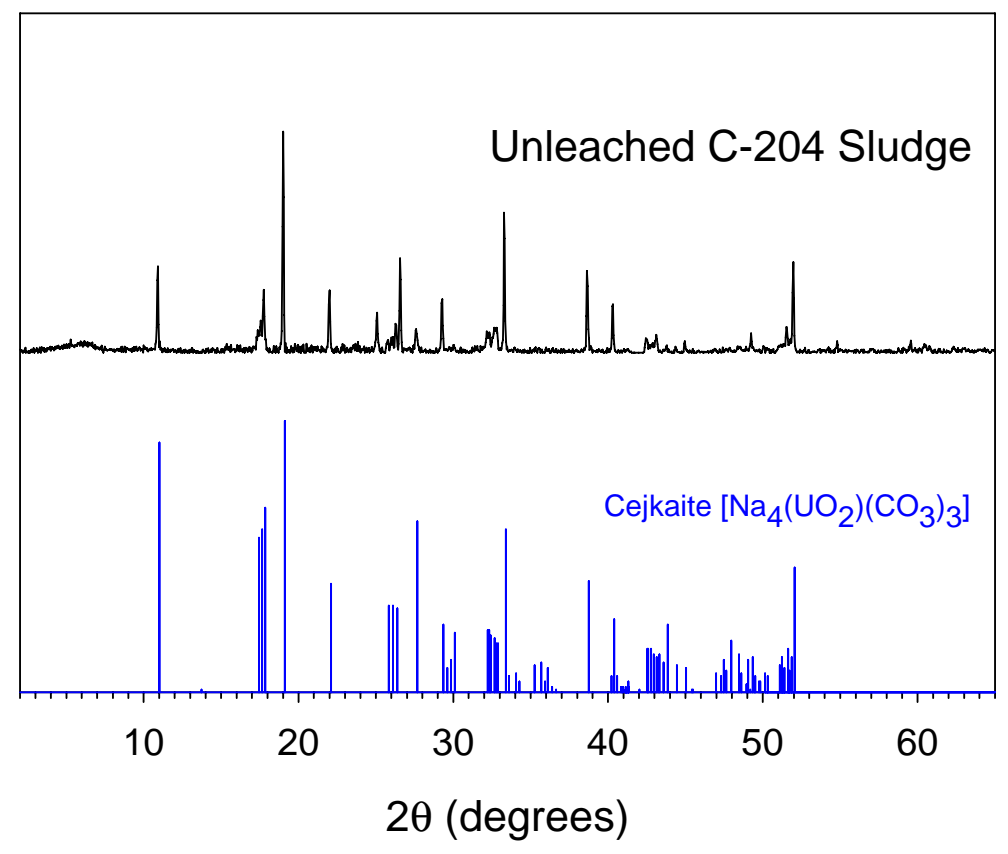

Figure 3.6. Background-Subtracted XRD Pattern for the Unleached C-204 Bulk Sludge Shown with the XRD Pattern for Čejkaite (Ondruš et al. 2003) 
other crystalline solids, which, if present, would exist at less that $5-10 \mathrm{wt} \%$ of the total sample mass. The XRD pattern was also analyzed for the possible presence of sodium uranate solids such as $\mathrm{Na}_{2} \mathrm{U}_{2} \mathrm{O}_{7}$ and clarkeite, but none were detected.

The as-measured XRD pattern for two-week water-leached C-204 bulk sludge is shown Figure 3.7. As with the XRD pattern for the 2-week water leached C-203 sludge, the XRD pattern for two-week water-leached C-204 sludge does not contain any reflections for čejkaite. The two large sharp reflections present in this XRD pattern were matched to major reflections for quartz $\left(\mathrm{SiO}_{2}\right)(\mathrm{PDF} \# 85-1053)$. The phase associated with the small, but discernible, broad peak at approximately $5^{\circ} 2 \theta$ in Figure 3.7 could not be identified. No reflections for $\mathrm{Na}_{2} \mathrm{U}_{2} \mathrm{O}_{7}$ or clarkeite were observed in the as-measured (Figure 3.8) or background-subtracted XRD patterns for two-week water-leached C-204 sludge.

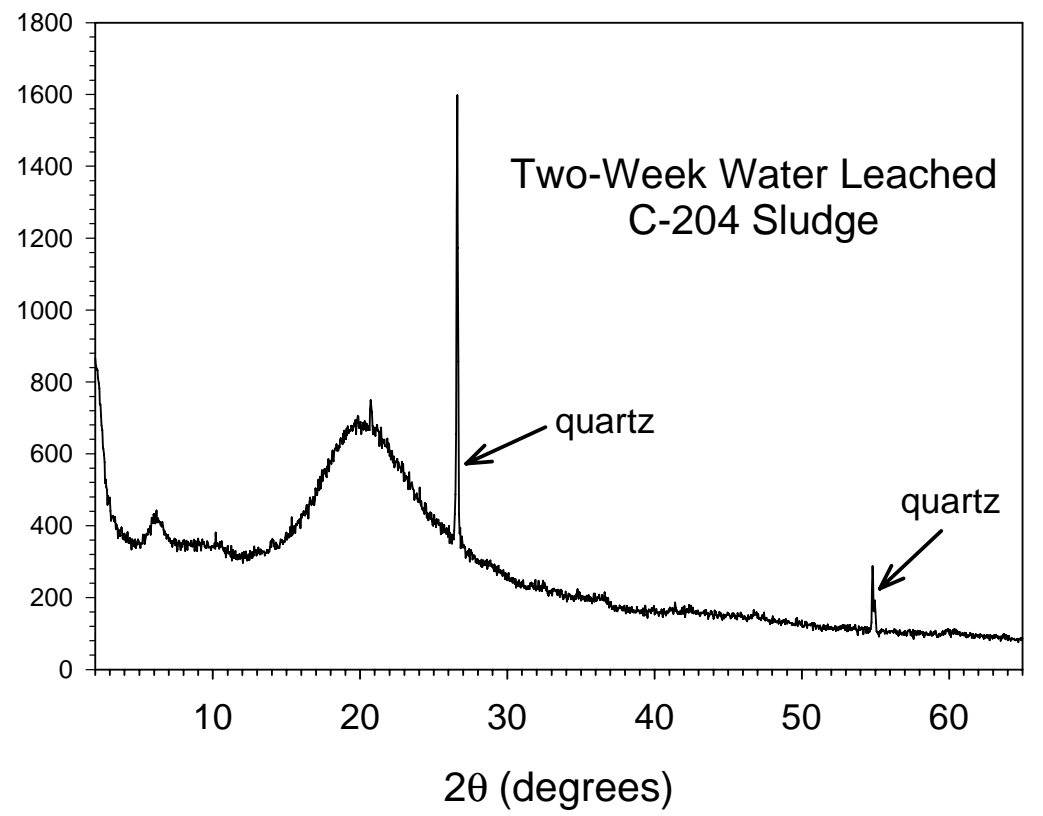

Figure 3.7. As-Measured XRD Pattern for Two-Week Water-Leached C-204 Bulk Sludge

\subsubsection{Natural Mineral Specimen of Čejkaite}

The measured XRD pattern for the natural specimen of unleached čejkaite is shown in Figure 3.8. The pattern is in excellent agreement with the database pattern PDF \#51-1474. This agreement was expected because, as noted in a footnote in Section 3.4.1, pattern PDF \#51-1474 is based on a sample of čejkaite obtained from the sample locality as the natural mineral sample used in our study.

\subsubsection{Comparison of Leached and Unleached C-203 and C-204 Sludge Samples}

The XRD results for equivalent samples of C-203 and C-204 material analyzed by XRD were similar. Figure 3.9 shows the background-subtracted XRD patterns for unleached C-203 and C-204 bulk sludge. The XRD patterns for the two samples are essentially identical and indicate that čejkaite is the dominant crystalline phase (Figures 3.3 and 3.6) in the unleached C-203 and C-204 sludge. Our study may be the 


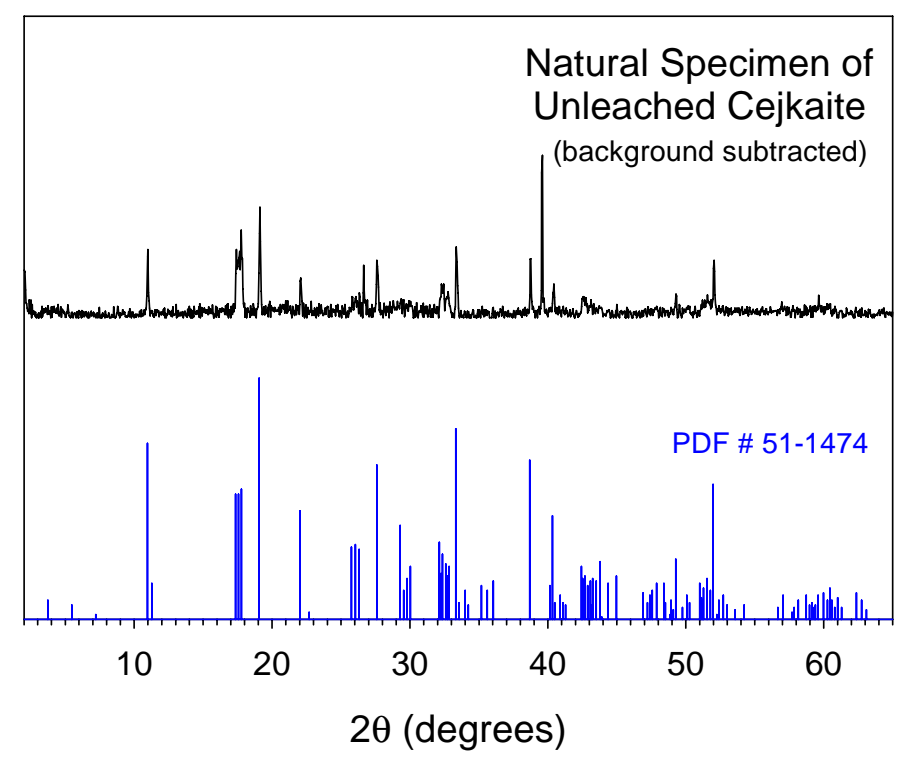

Figure 3.8. Background-Subtracted XRD Pattern for the Natural Specimen of Unleached Čejkaite Shown with Database XRD Pattern (PDF \#51-1474)

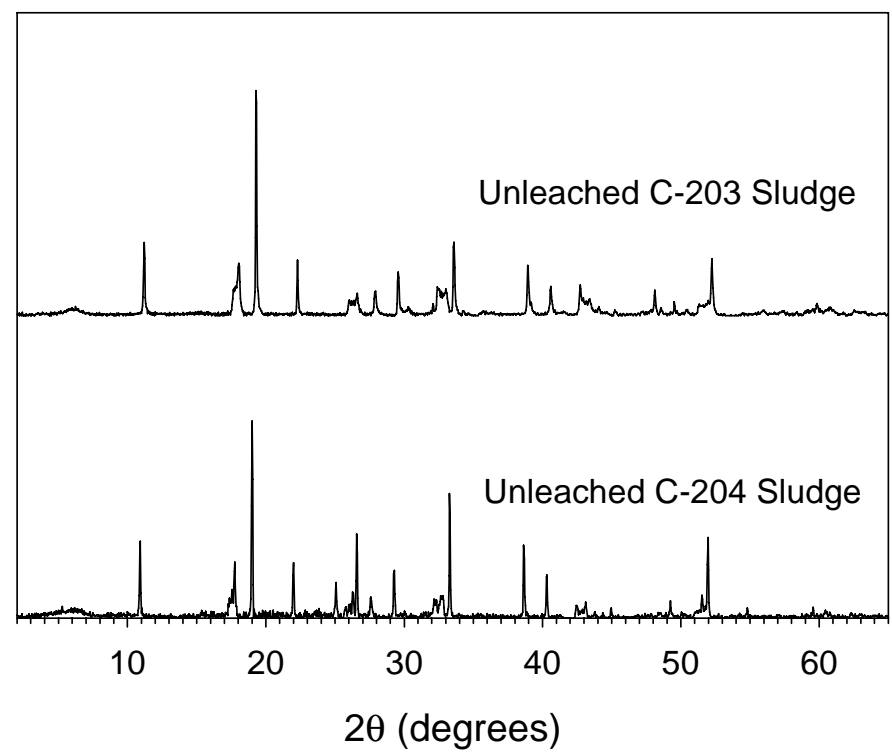

Figure 3.9. Background-Subtracted XRD Patterns for the Unleached C-203 (top) and C-204 (bottom) Sludge Samples

first documented occurrence of this particular uranium solid phase in tank sludges from DOE sites. The Uranium Recovery Technical Manual (GE 1951) briefly discusses the presence of "a dense, hard agglomerate of crystalline carbonate material" in hard tank sludge. This report states that this carbonate material was "believed to be mainly $\left[\mathrm{Na}_{4}\left(\mathrm{UO}_{2}\right)\left(\mathrm{CO}_{3}\right)_{3}\right.$," but presents no evidence for its identification in the portion of the report available to us. Given the long history of nuclear operations and related waste disposal at the AEC/DOE complex, čejkaite or its trigonal polymorph may have been physically identified and 
documented in old classified or unclassified reports. More recently, čejkaite has been identified as a secondary mineral at a uranium ore deposit in the Czech Republic (Ondruš et al. 2003), and possibly as an alteration product of the silicate lava that solidified from the destruction of the Chernobyl reactor core (Burakov et al. 1997).

Except for the identification of quartz in the two-week water-leached C-204 residual tank waste, the XRD patterns for the two-week water-leached C-203 (Figure 3.5) and C-204 (Figure 3.7) sludge samples were also nearly identical. The reflections for čejkaite were absent from both of these XRD patterns, which indicate that čejkaite is highly soluble and the majority of it dissolved during the two-week waterleach test. The background-subtracted XRD pattern suggests that a small amount of possibly poorly crystalline form of clarkeite might be present in the C-203 material. SEM/EDS results discussed in the next section will also show that such a phase probably exists in both the unleached and water-leached samples of C-203 and C-204 sludge materials.

\subsection{SEM/EDS Results}

This section discusses the results of the SEM/EDS analyses for C-203 (jar 19649) and C-204 (jar 19650) residual tank waste samples and natural specimen of čejkaite $\left[\mathrm{Na}_{4}\left(\mathrm{UO}_{2}\right)\left(\mathrm{CO}_{3}\right)_{3}\right]$. The SEM micrographs presented in this section show the typical morphologies, sizes, and surface textures of particles in each of these samples. A complete set of SEM micrographs and EDS spectra for C-203 and C-204 sludge and the čejkaite mineral specimen are given the following appendixes:

- Appendix B - SEM micrographs and EDS spectra for samples of the unleached, unleached yellownugget material, water-leached, and reaction products remaining after the 1:1 solubility experiments for C-203 (jar 19649) sludge

- Appendix C-SEM micrographs and EDS spectra for samples of the unleached (raw), waterleached, and reaction products remaining after various extraction tests for C-204 (jar 19650) sludge

- Appendix D - SEM micrographs and EDS spectra recorded for the natural specimen of čejkaite from the Svornost Mine at Jáchymov in the Czech Republic.

Each micrograph that follow shows the name of the SEM digital image file, sample identification number, and a size scale bar, respectively, at the bottom left, center, and right of each image. Micrographs labeled with "bse" to the immediate right of the digital image file name indicate that the micrograph was collected with backscattered electrons. Areas labeled by "eds" identify locations of particles for which EDS spectra were recorded and presented in the appendixes. The micrographs presented in this section are typically reproduced at reduced size to conserve page space. To get a more detailed view of these micrographs, the reader is referred to Appendixes B through D, where the micrographs are shown at a larger size. 


\subsubsection{C-203 Sludge Samples}

\subsubsection{Unleached C-203 Bulk Sludge}

Figure 3.10 shows SEM micrographs for typical particles identified in the unleached C-203 sludge. The unleached sludge contains large quantities of hexagonal, acicular (i.e., needle-like) crystals, either as

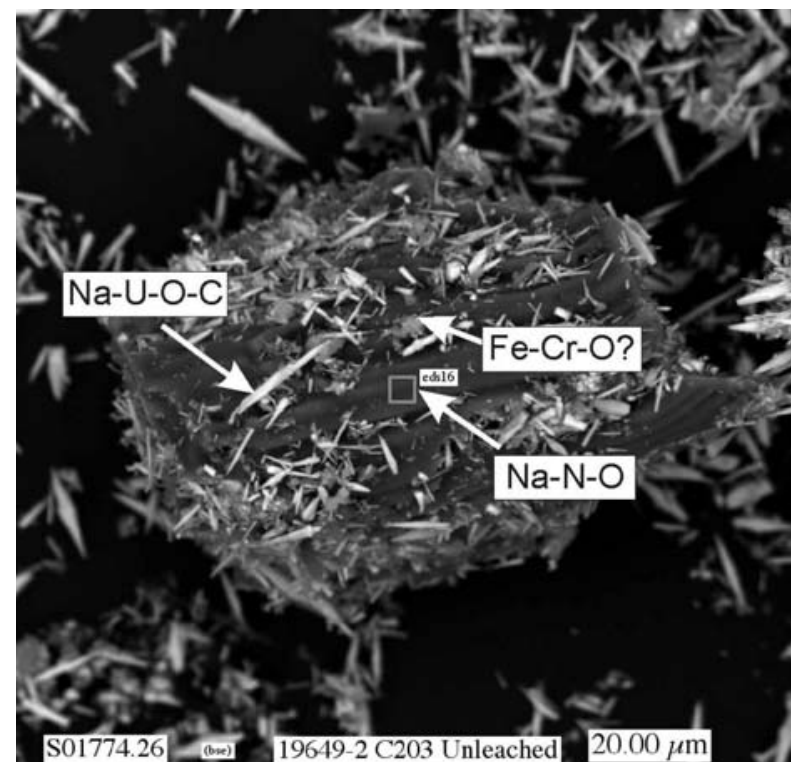

A

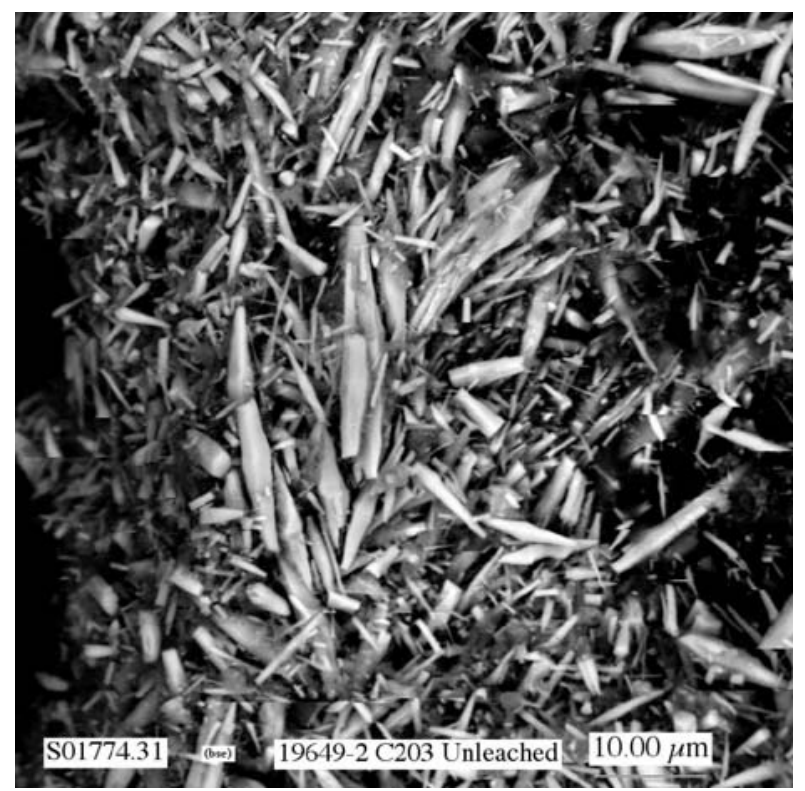

C

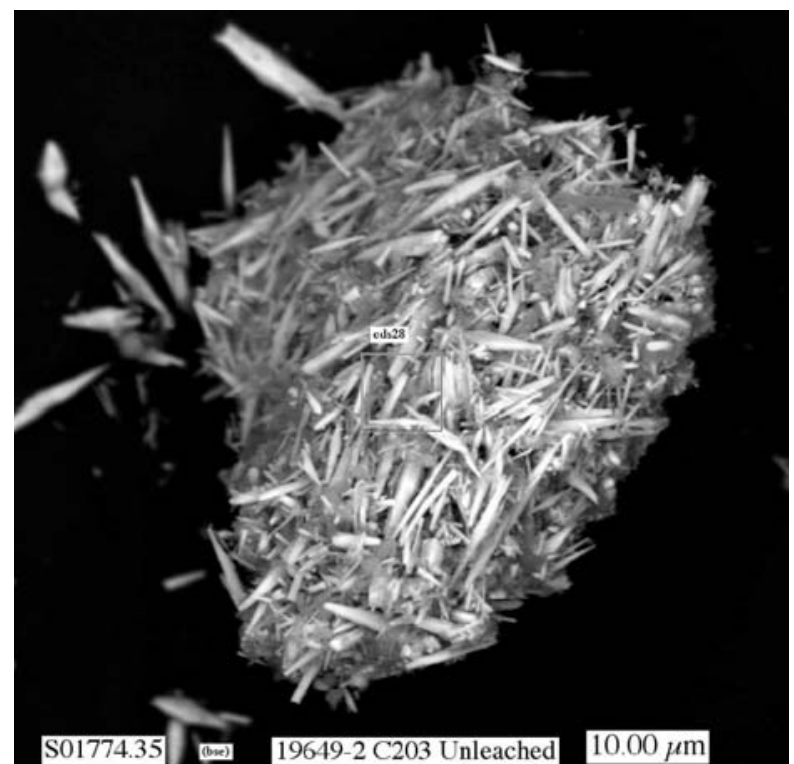

B

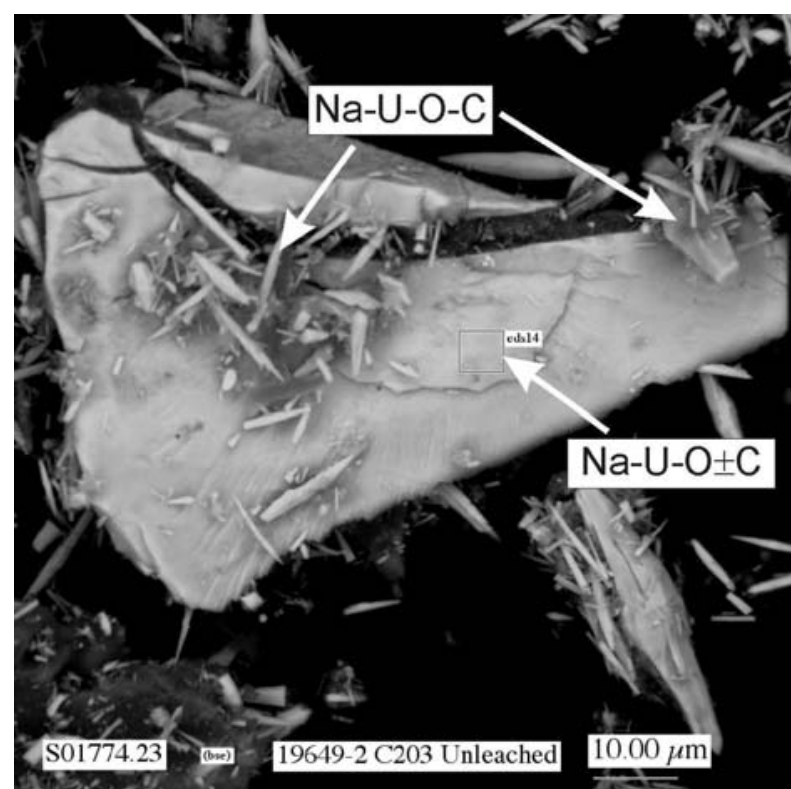

D

Figure 3.10. SEM Micrographs Showing Typical Particles Present in the Unleached C-203 Bulk Sludge 
single crystals (micrograph $\mathrm{C}$ in Figure 3.10) or aggregates of crystals (micrograph B in Figure 3.10), that are composed of $\mathrm{Na}, \mathrm{U}, \mathrm{O}$, and $\mathrm{C}$ as determined by EDS. Based on their morphologies and EDS compositions, these results are consistent with the XRD results (Section 3.4.1), which indicate that this material is composed primarily of the crystalline phase čejkaite. Many of the particle aggregates (for example, see micrograph A in Figure 3.10) appear to be a random intergrowth of needles and rods of čejkaite intergrown in a matrix of a nondescript phase composed of $\mathrm{Na}-\mathrm{O} \pm \mathrm{N}$ (possibly nitrate $) \pm \mathrm{C}$. This phase would be consistent with the possible presence of an amorphous phase or nitratine, which were suggested by the XRD results. The large, smooth, bright particle in micrograph D in Figure 3.10 is also composed of $\mathrm{Na}, \mathrm{U}, \mathrm{O}$, and possibly $\mathrm{C}$. Because its morphology is distinctly different from the acicular and rod-shaped crystals of čejkaite, this may represent a second uranium-containing solid phase such as $\mathrm{Na}_{2} \mathrm{U}_{2} \mathrm{O}_{7}$ and clarkeite $\mathrm{Na}\left[\left(\mathrm{UO}_{2}\right) \mathrm{O}(\mathrm{OH})\right]\left(\mathrm{H}_{2} \mathrm{O}\right)_{0-1}$ present in the $\mathrm{C}-203$ sludge.

\subsubsection{Yellow Nugget Material from Unleached C-203 Bulk Sludge}

As noted in Section 2.1, large yellow particles (nuggets) were discovered embedded in the matrix of the unleached (raw) C-203 sludge sample. The SEM/EDS analyses of this material are consistent with the XRD results, which indicate that this nugget material is composed primarily of the crystalline phase čejkaite, and possible presence of nitratine (soda niter, $\mathrm{NaNO}_{3}$ ). Micrograph $\mathrm{A}$ in Figure 3.11 shows the yellow nugget material, like the particle aggregates observed in the unleached C-203 bulk sludge in the previous section, to be primarily a random intergrowth of needles and rods of a solid composed of $\mathrm{Na}, \mathrm{U}$, $\mathrm{O}$, and $\mathrm{C}$ (probably $\mathrm{CO}_{3}$ ). The morphologies and EDS spectra determined by SEM for these crystals are identical to those for čejkaite observed in samples of the unleached C-203 sludge (subsection 3.5.1.1) and, as will be discussed in a later section, of the unleached C-204 sludge (subsection 3.5.2.1) and natural čejkaite specimen (Section 3.5.3). Close inspection of the micrographs also indicates that a significant

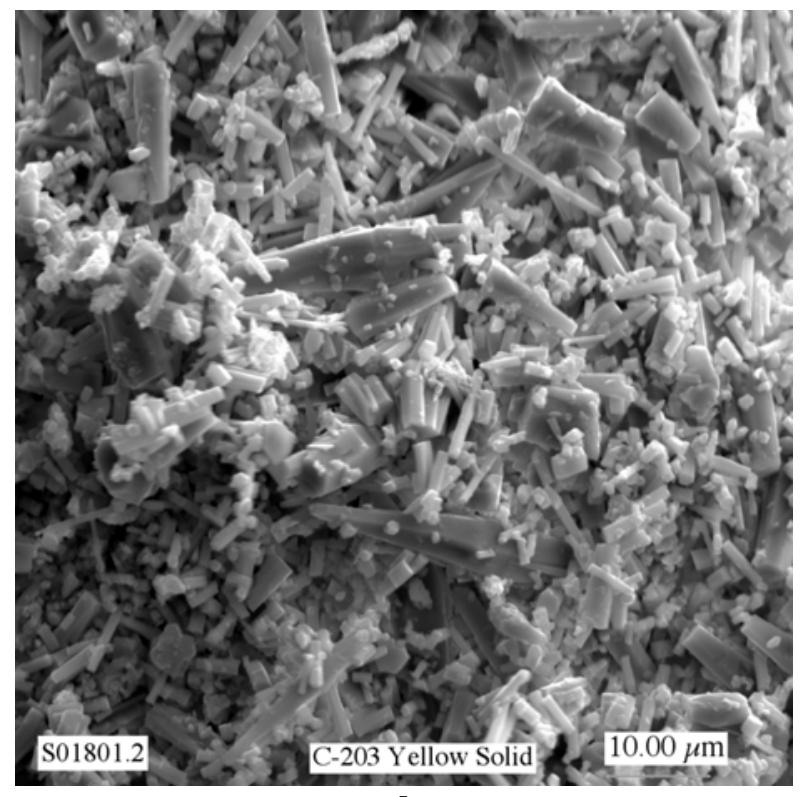

A

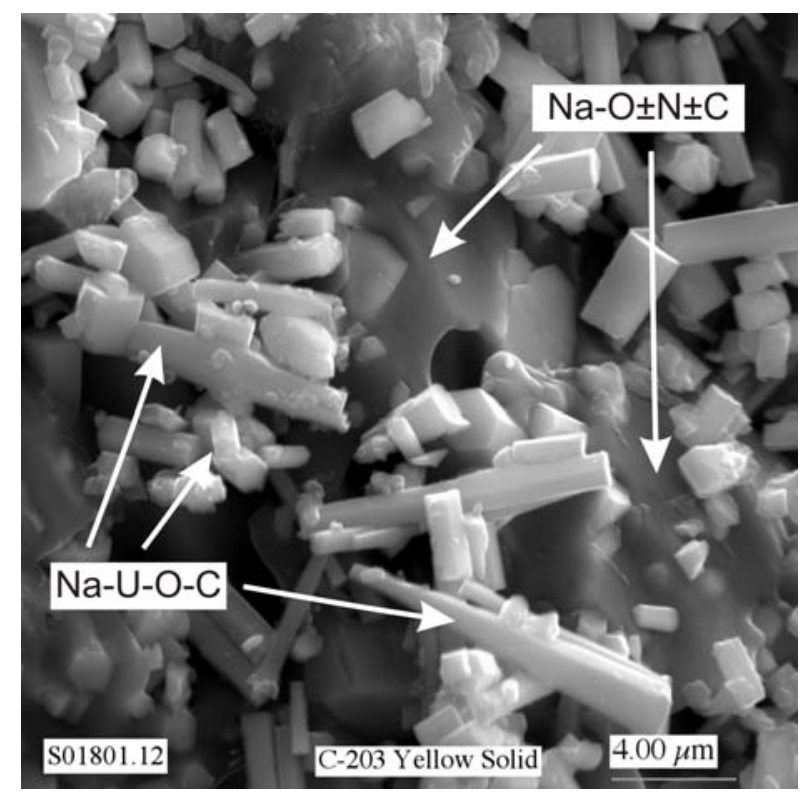

B

Figure 3.11. Secondary-Electron SEM Micrographs of Yellow Nugget Material from Unleached C-203 Bulk Sludge Sample 
amount of the interstitial areas under and between the čejkaite crystals (e.g., see crystals labeled by "Na-U-O-C" in micrograph B in Figure 3.11) are composed of a nondescript phase (e.g., see interstitial areas labeled by "Na-O $\pm \mathrm{N} \pm \mathrm{C}$ " in micrograph $\mathrm{B}$ in Figure 3.11). This material likely corresponds to the amorphous component and possibly nitratine determined by XRD.

\subsubsection{Water-Leached C-203 Sludge}

Figure 3.12 shows SEM micrographs of typical particles remaining in the two-week water-leached C-203 bulk sludge. The acicular crystals of čejkaite observed in the samples of unleached C-203 bulk sludge and yellow nugget material are absent in the water-leached material, which is an indication of the high solubility and rapid dissolution rate of čejkaite. The two-week water-leached material contains a variety of rounded and pitted particles and aggregates of particles with various compositions, as noted in Figure 3.12. Except for the U-containing phase, most of these phases were not observed in the SEM analyses of unleached C-203 sludge. One possible explanation for this difference is that the particles observed in the water-leached sludge were present in the unleached material but coated with čejkaite crystals and the amorphous-like Na-N-O phase. Particles identical to the large U-containing particle shown in micrograph D in Figure 3.10 are also present (see micrographs A and D in Figure 3.12). This uranium phase likely represents poorly crystalline $\mathrm{Na}_{2} \mathrm{U}_{2} \mathrm{O}_{7}$ /clarkeite, as suggested by the XRD results (Section 3.4.1).

Figure 3.13 shows micrographs of one of the most unusual particles observed in all of the SEM analyses completed in this study. The particle in Figure 3.13 appears to have a surface coating of oriented acicular crystals of čejkaite that have nucleated from its surface. This particular feature was not observed in any of the other unleached or leached C-203 and C-204 sludge samples inspected. Because the čejkaite crystals are otherwise absent from both SEM mounts of the two-week water-leached C-203 sludge, one possible explanation for this unique occurrence of čejkaite is that it had nucleated on an internal fracture surface in one of the large, rounded U-containing particles (e.g., micrographs A and D in 3.12). Water was unable to access this fracture during the water-leaching test, and the čejkaite was preserved. During preparation of the SEM mount this particle was fractured, exposing the čejkaite crystals for detection by SEM.

Figure 3.14 shows SEM micrographs of typical particles remaining in the extended two-month waterleached C-203 bulk sludge. There are no apparent major differences between the solid observed in the two week and two month water-leach experiments of the C-203 bulk sludge. However, the large rounded U-containing particles present in the unleached and two-week water-leached C-203 sludge are still present after two months of water leaching. Particles of this U-containing material are present in both micrographs shown in Figure 3.14.

Figure 3.15 shows SEM micrographs of typical particles remaining in the three-month water-leached C-203 bulk sludge. There are no apparent major differences between the solids observed in the twoweek, two-month, and three-month water-leach experiments of the C-203 bulk sludge. The large rounded U-containing particles present in the unleached and the two-week and two-month water-leached C-203 sludge samples are still present after three months of water leaching. These U-containing particles are shown in micrographs A and B (the bright white particles) in Figure 3.15. Many of the small bright particles attached to the surface of the large particle in micrograph $\mathrm{C}$ in Figure 3.15 also contain $\mathrm{U}$. 


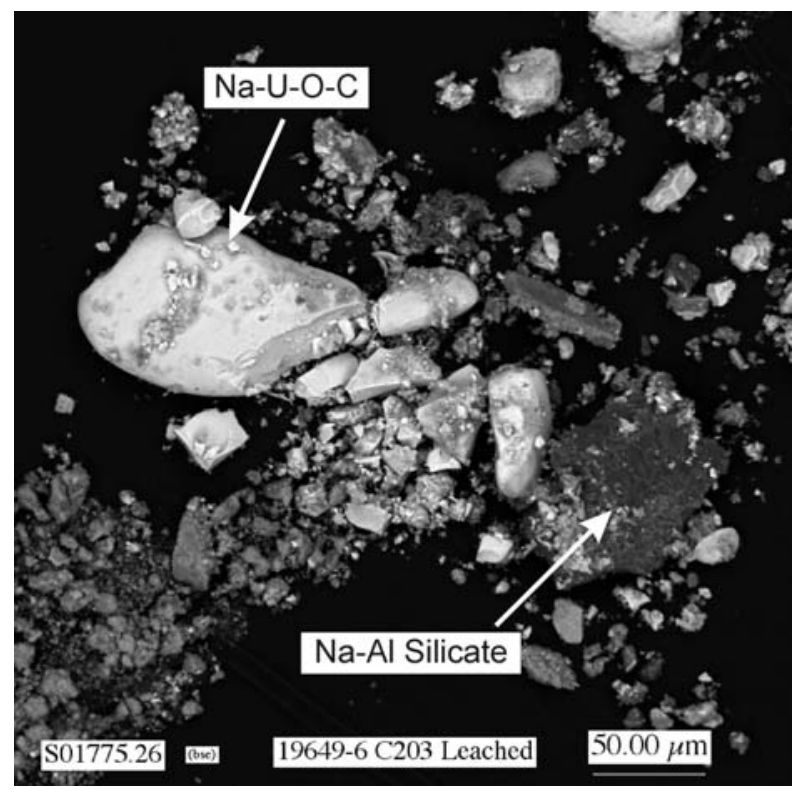

A

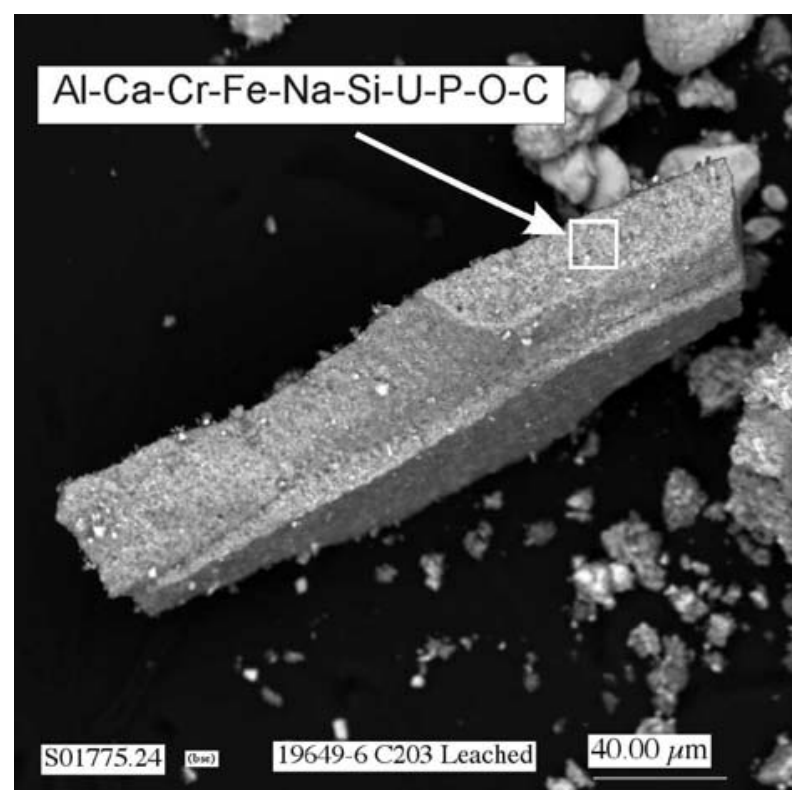

C

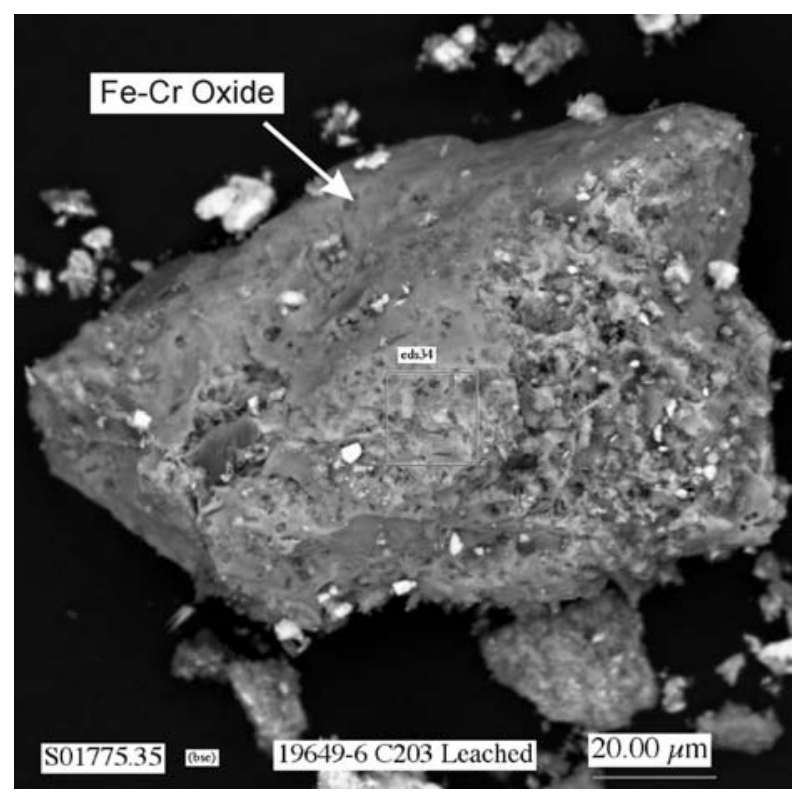

B

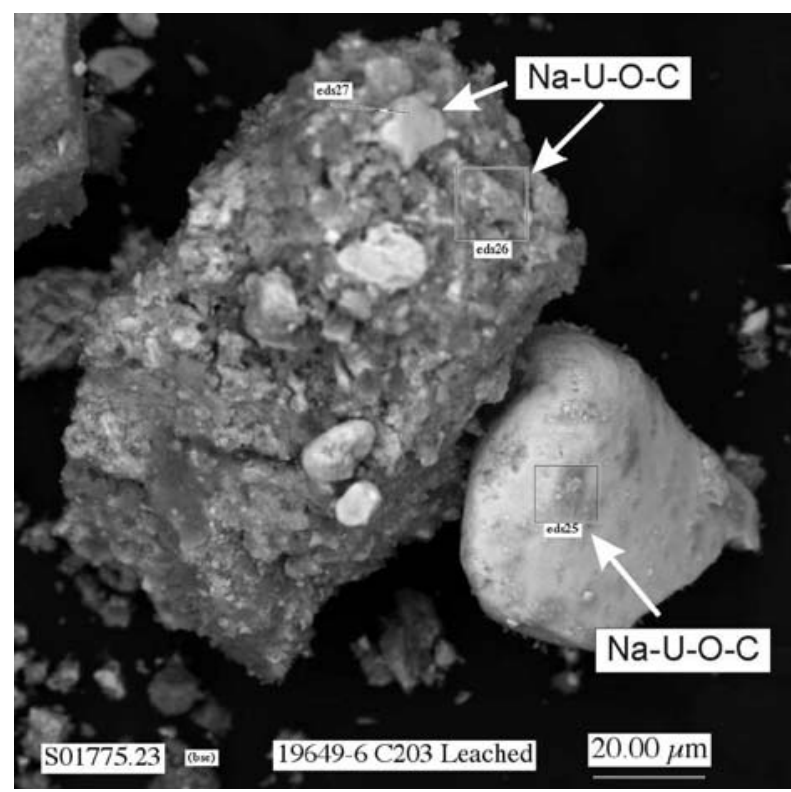

D

Figure 3.12. SEM Micrographs Showing Typical Particles Present in the Two-Week Water-Leached C-203 Bulk Sludge 


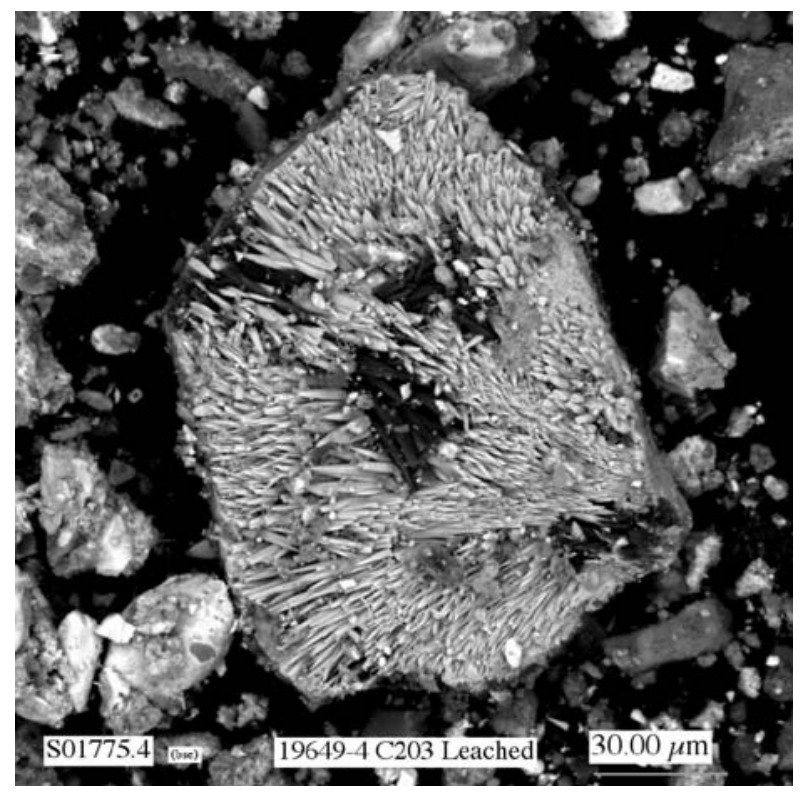

A

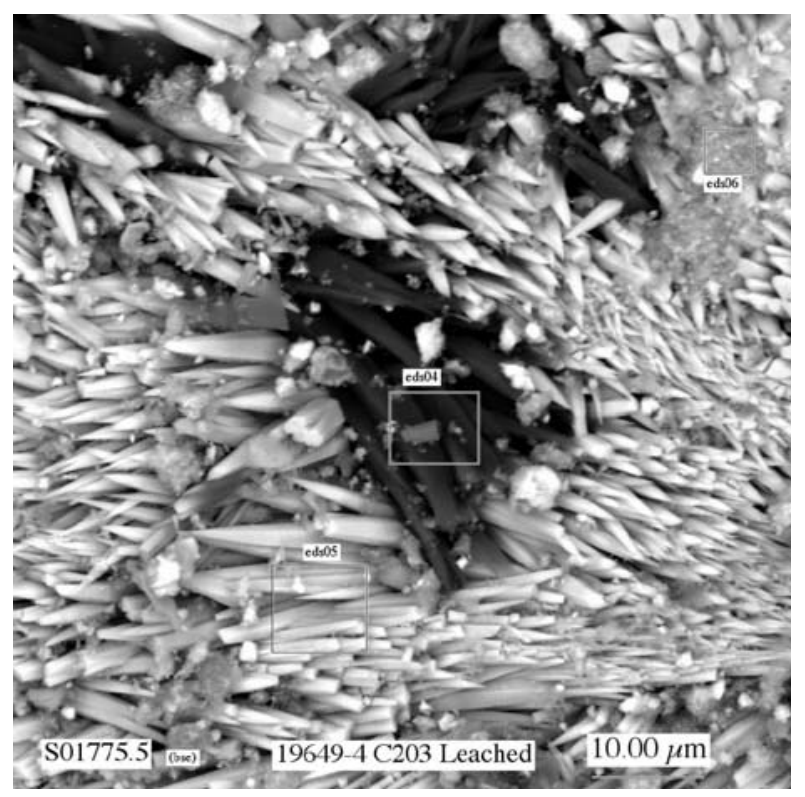

B

Figure 3.13. Micrographs of Unusual Particle in the Sample of Two-Week Water-Leached C-203 Sludge Coated with Oriented Crystals of Čejkaite

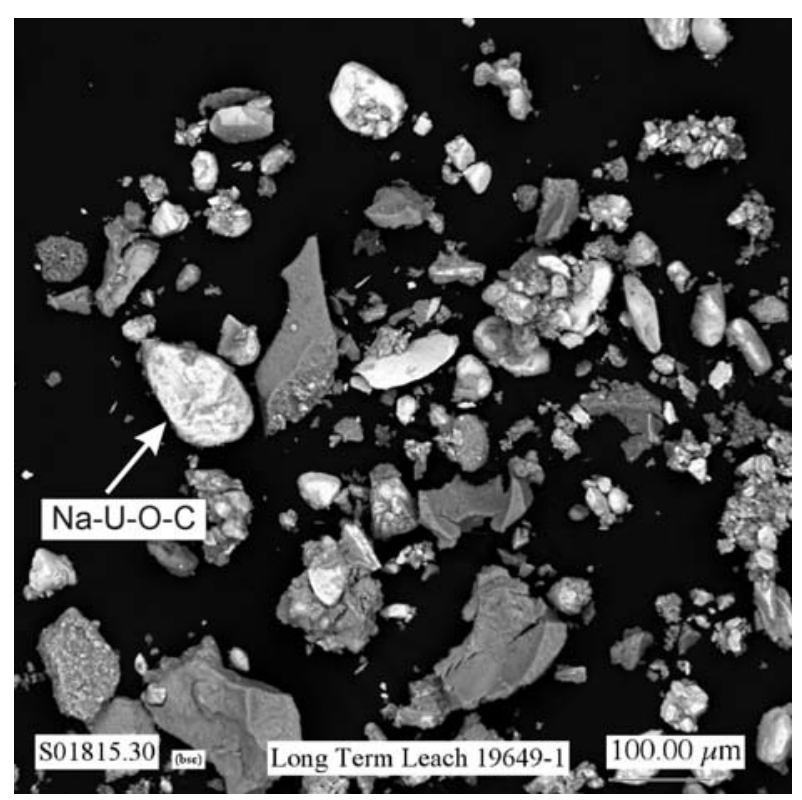

A

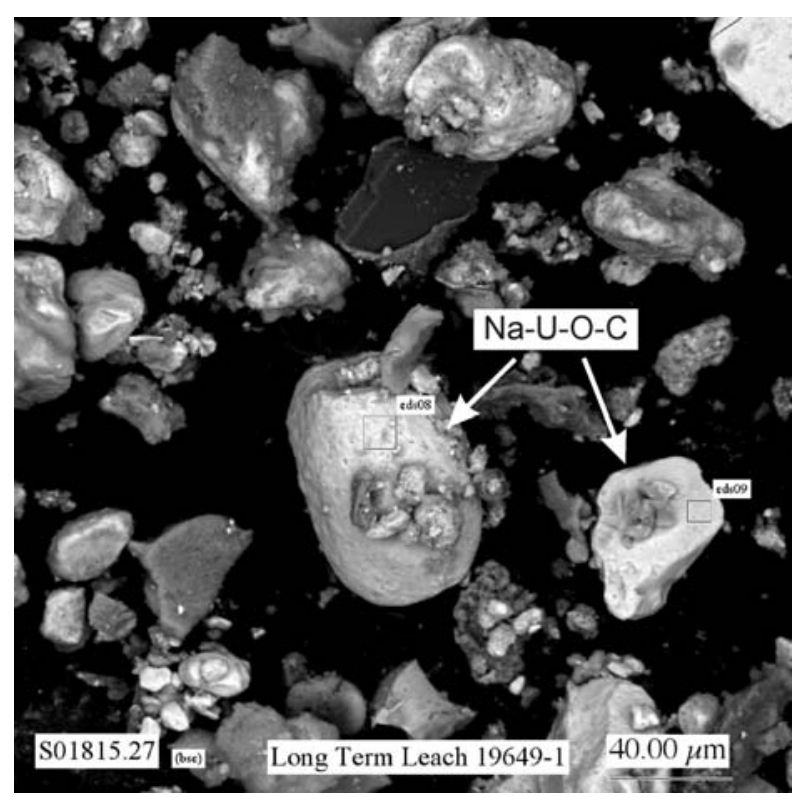

B

Figure 3.14. SEM Micrographs Showing Typical Particles Present in the Two-Month Water-Leached C-203 Bulk Sludge 


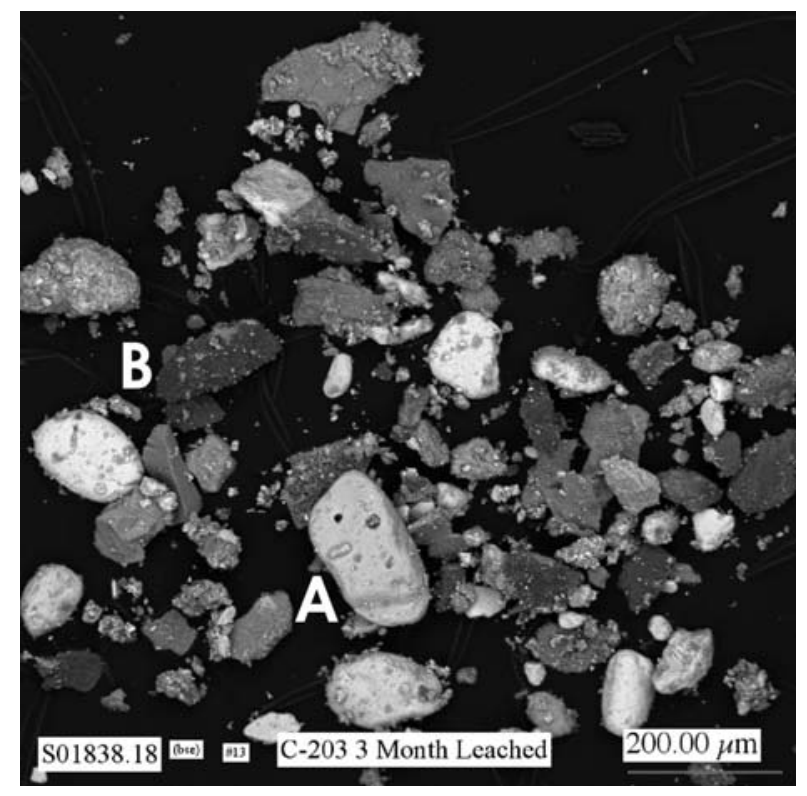

A

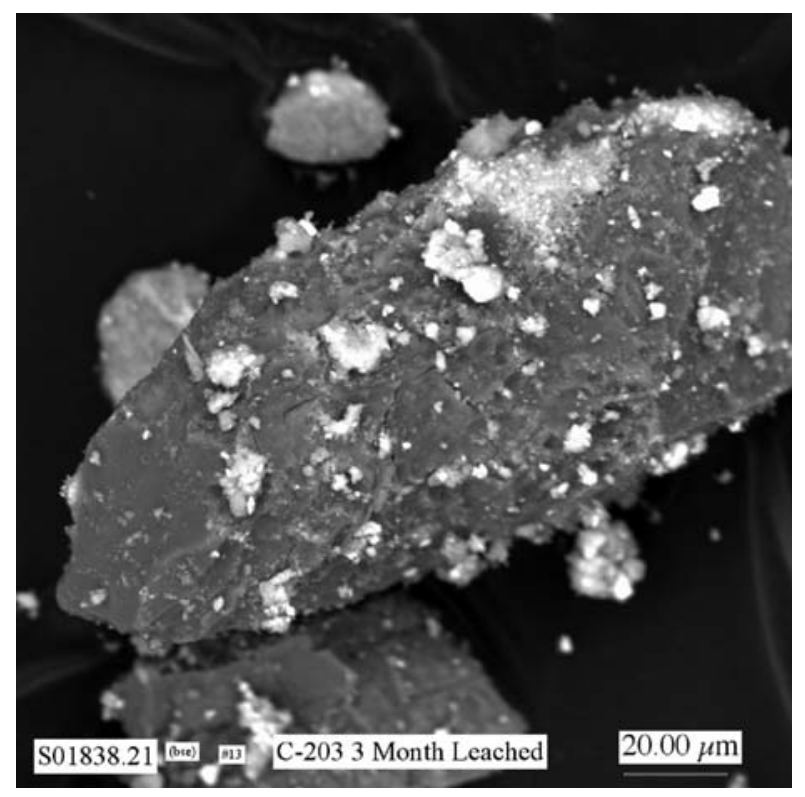

C

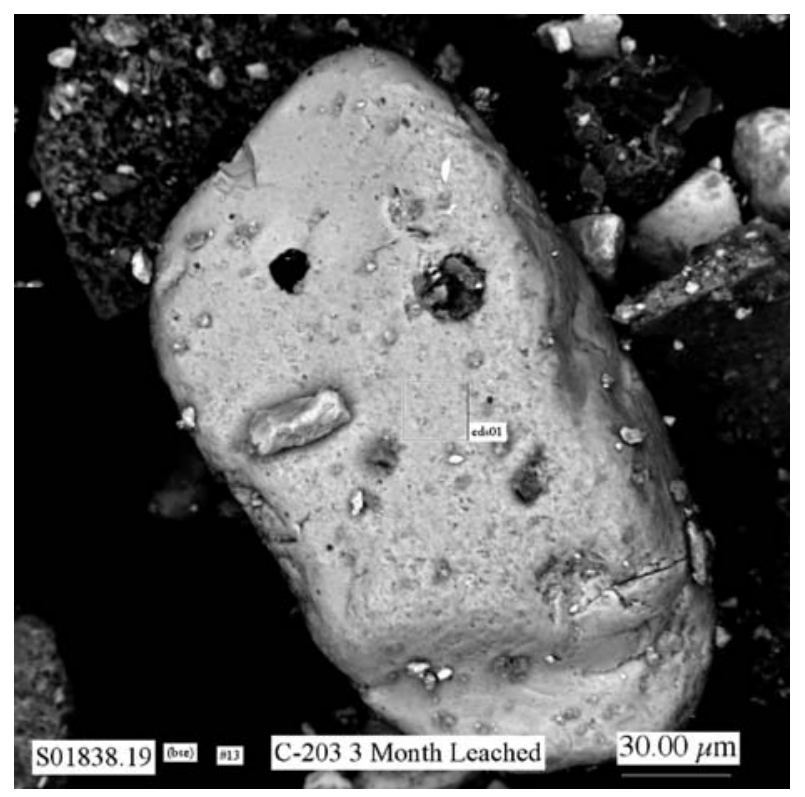

B

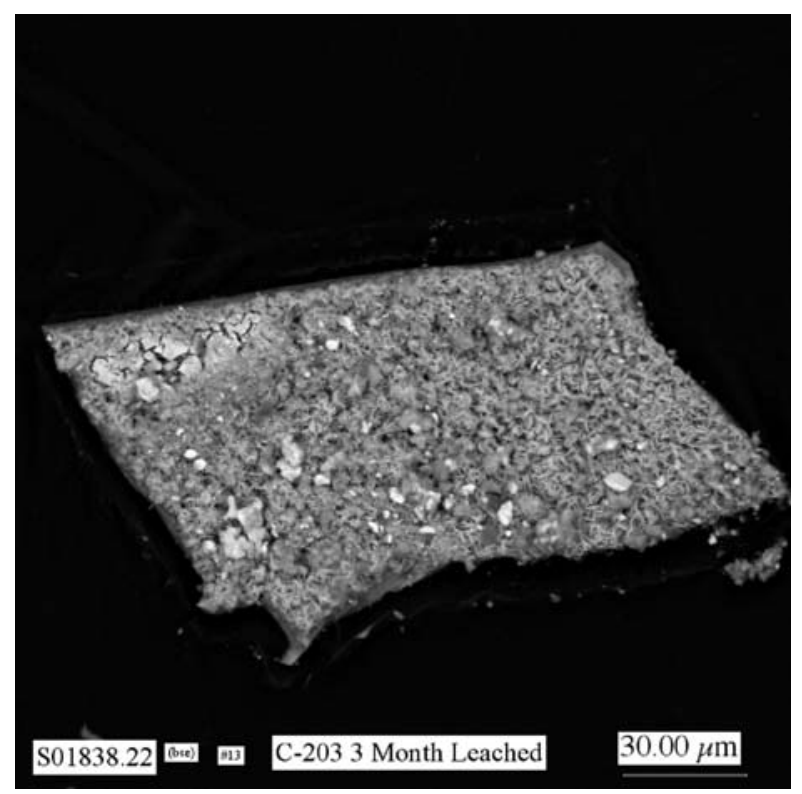

D

Figure 3.15. SEM Micrographs Showing Typical Particles Present in the Three-Month Water Leach of C-203 Bulk Sludge

Based on visual inspection, the quantity of U-containing particles in the fields of view at low SEM magnification in the three-month water-leached sample is similar or possibly greater than in the two-week and two-month water-leached samples. Qualitative comparison of the peak sizes in the EDS spectra indicates that the large U-containing particles (micrographs A and B in Figure 3.15) are composed primarily of $U$, $\mathrm{O}$, and $\mathrm{C}$; lesser amounts of $\mathrm{Ca}, \mathrm{Cr}, \mathrm{Si}, \mathrm{Pb}$, and $\mathrm{P}$; and trace amounts of $\mathrm{Fe}, \mathrm{Na}$, and $\mathrm{Al}$. 


\subsubsection{C-203 Sludge 1:1 Solubility Experiment}

The solid product remaining at the termination of the solubility experiments with the 1:1 sludge-tosolution ratio (Section 3.33) was inspected by SEM/EDS. The SEM/EDS analysis of this product indicates that it still contained large quantities of hexagonal, acicular crystals (Figure 3.16, micrograph A) that are composed of $\mathrm{Na}, \mathrm{U}, \mathrm{O}$, and $\mathrm{C}$. The morphology and EDS-determined compositions of these acicular crystals are shown at higher magnification in Figure 3.16 (micrograph B). These acicular crystals have also been identified in the unleached C-203 bulk sludge (subsection 3.5.1.1) and the yellownugget material found in the C-203 sludge (subsection 3.5.1.2). These acicular crystals have been identified as čejkaite based on XRD studies (Section 3.4) and compositions determined by EDS.

\subsubsection{C-204 Sludge Samples}

\subsubsection{Unleached C-204 Bulk Sludge}

SEM micrographs of typical particles identified in the unleached C-204 sludge are shown in Figure 3.17. Based on these SEM/EDS analyses, the unleached C-204 sludge is composed primarily of hexagonal acicular crystals of čejkaite, as identified previously by XRD and XRD/SEM in the unleached C-203 bulk sludge and yellow nugget material, and an amorphous-like, nondescript solid composed of $\mathrm{Na}, \mathrm{Al}, \mathrm{P}, \mathrm{O}$, and possibly C. Within this mix of čejkaite needles and amorphous Na-Al-P-O phase, there were particles, sometimes as aggregates, of an Fe oxide that often also contained $\mathrm{Cr}$ and $\mathrm{Ni}$. Based on visual inspection, the mass of čejkaite crystals was less in the unleached C-204 sludge than in the unleached C-203 sludge, which is consistent with the relative total concentrations of $U$ measured for these samples. The large rounded particles observed in the unleached and water-leached samples of C-203

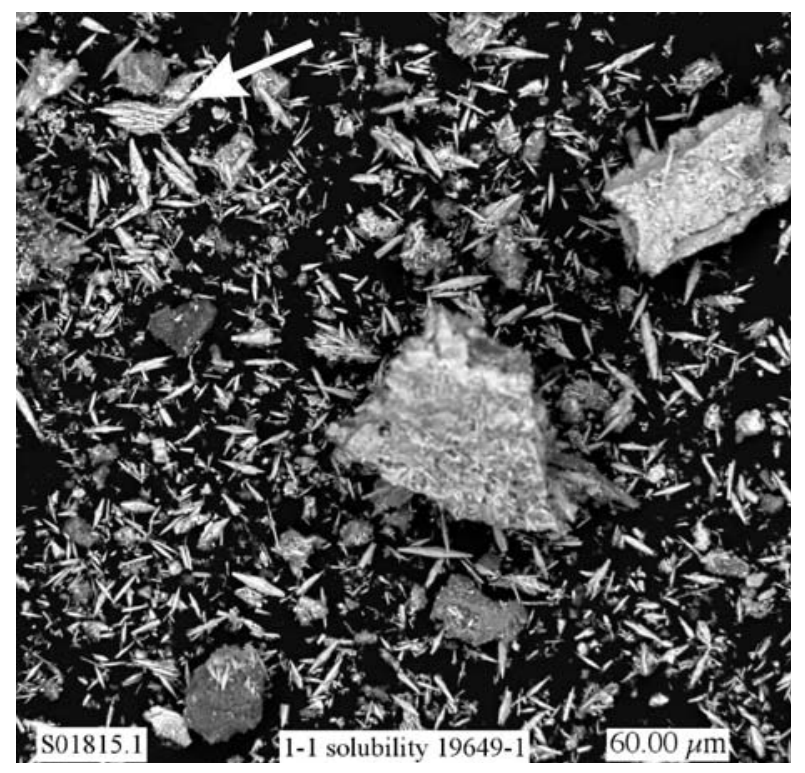

A

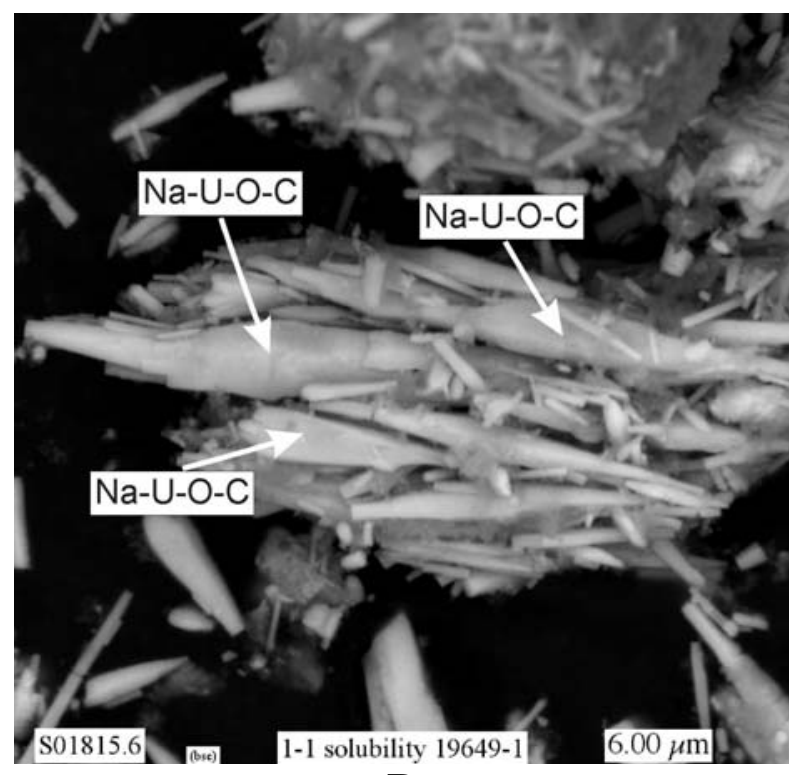

B

Figure 3.16. SEM Micrographs of Solid Products Remaining at the Termination of the 1:1 Solubility Experiments with C-203 Bulk Sludge. (The aggregate indicated by the arrow in micrograph $\mathrm{A}$ is shown at higher magnification in micrograph B.) 

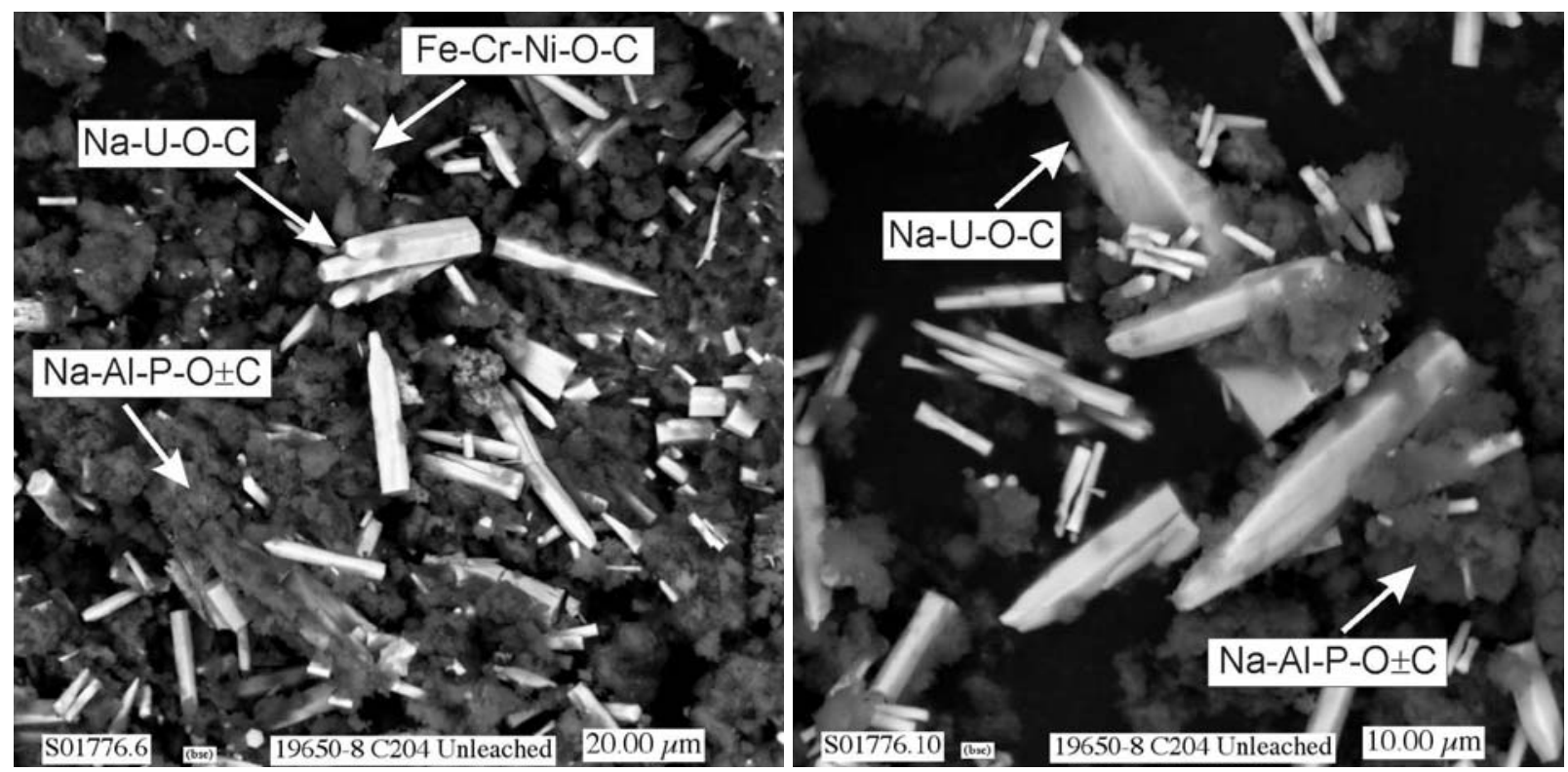

A

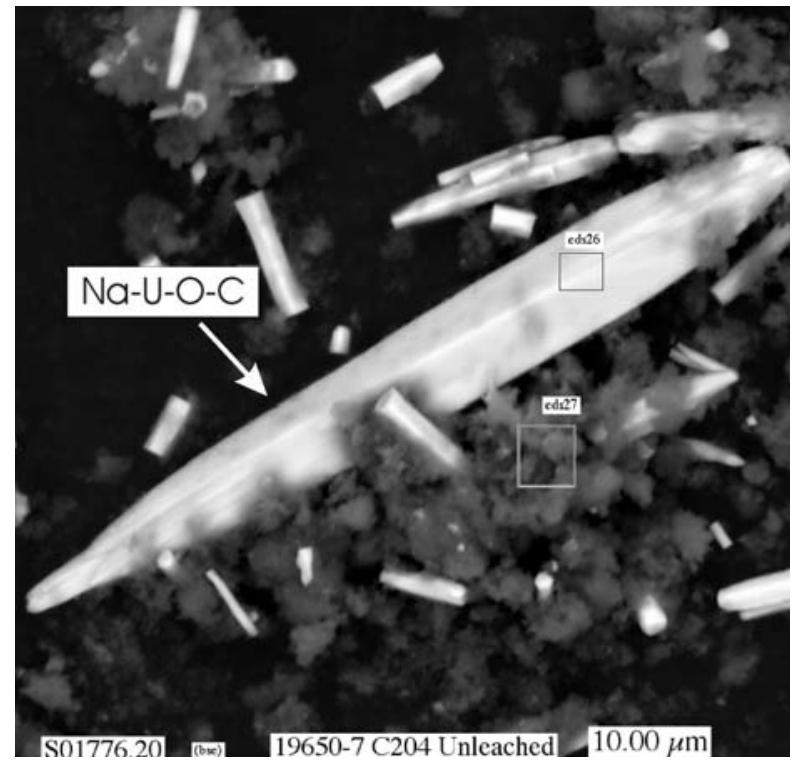

C

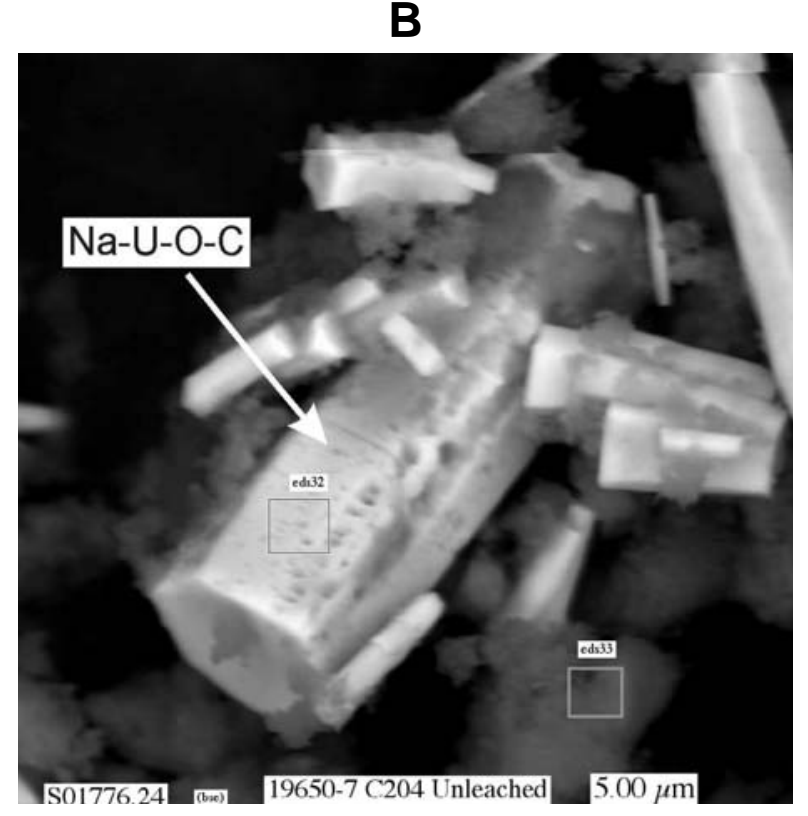

D

Figure 3.17. SEM Micrographs Showing Typical Particles Present in Unleached (raw) C-204 Sludge

sludge (see micrograph D in Figure 3.10, micrographs A and D in Figure 3.12, and micrograph B in Figure 3.14) and identified as possibly a poorly crystalline form of $\mathrm{Na}_{2} \mathrm{U}_{2} \mathrm{O}_{7} /$ clarkeite, were not detected in the SEM mounts of the unleached C-204 sludge.

\subsubsection{Water-Leached C-204 Sludge}

Figures 3.18 and 3.19 are SEM micrographs of typical particles observed in the samples of two-week and two-month water-leached experiments of C-204 residual tank waste. There are no significant 


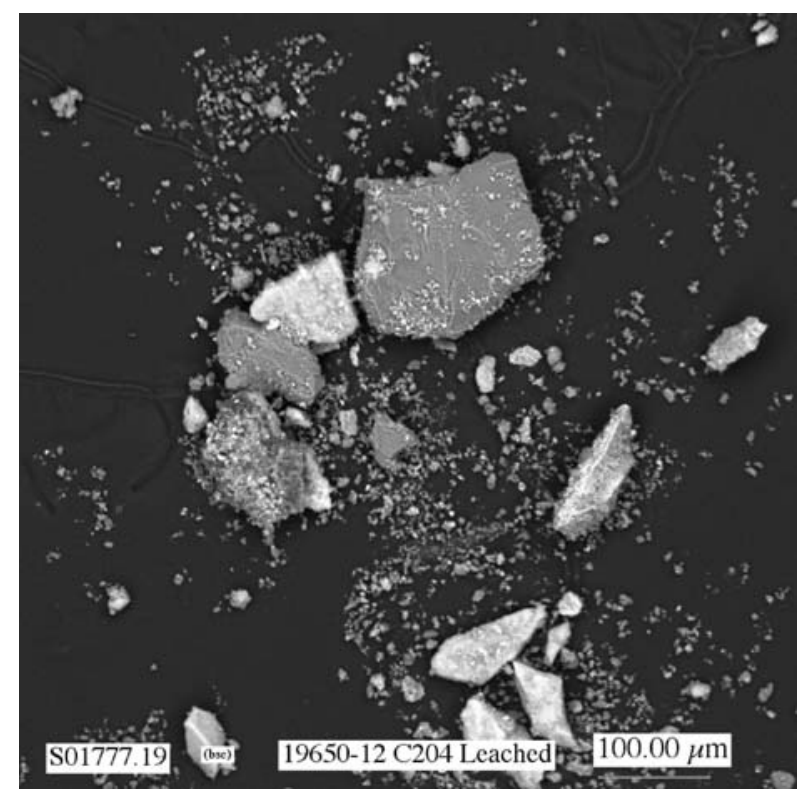

A

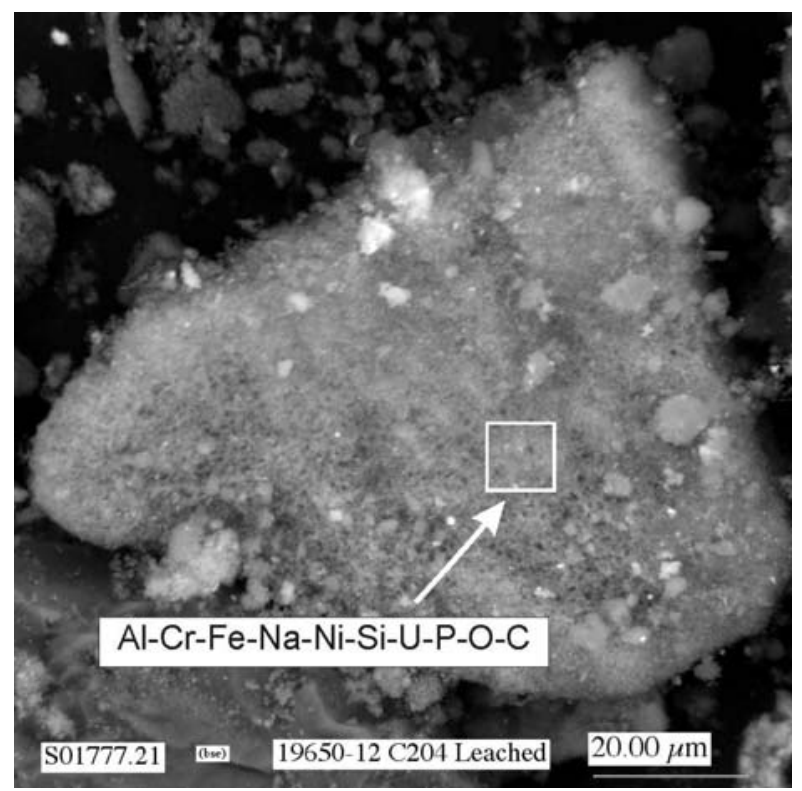

C

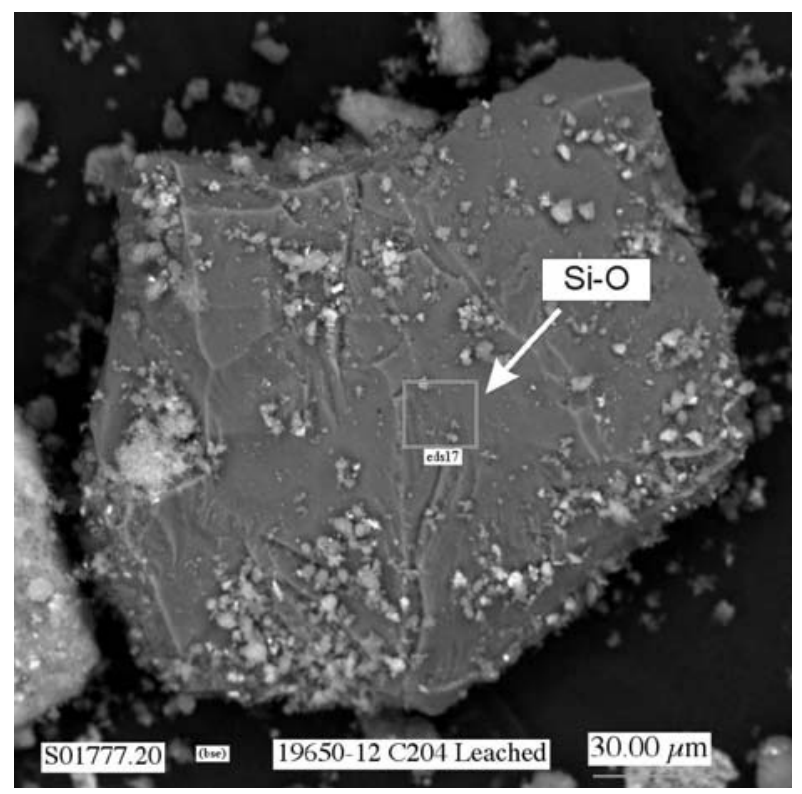

B

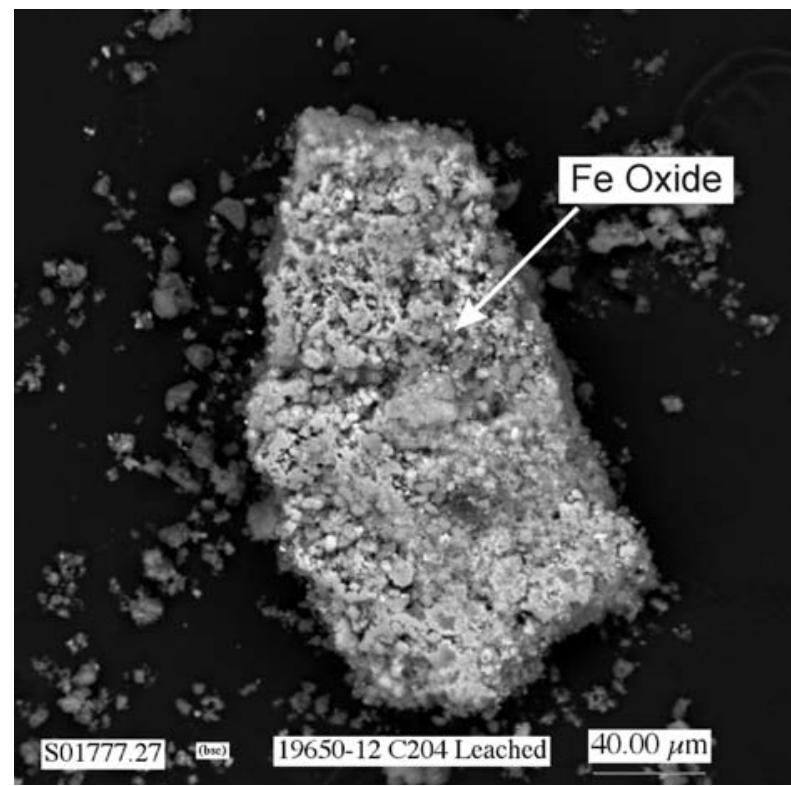

D

Figure 3.18. SEM Micrographs Showing Typical Particles Present in Two-Week Water-Leached C-204 Sludge

differences in the characteristics of particles in these two samples. The numerous acicular crystals of čejkaite and ubiquitous presence of the amorphous Na-Al-P-O phase that were observed in the unleached C-204 sludge are totally absent in all samples of water-leached C-204 sludge. The water-leached samples contain a variety of nondescript particles, many of which have pitted, altered surfaces. These particles 


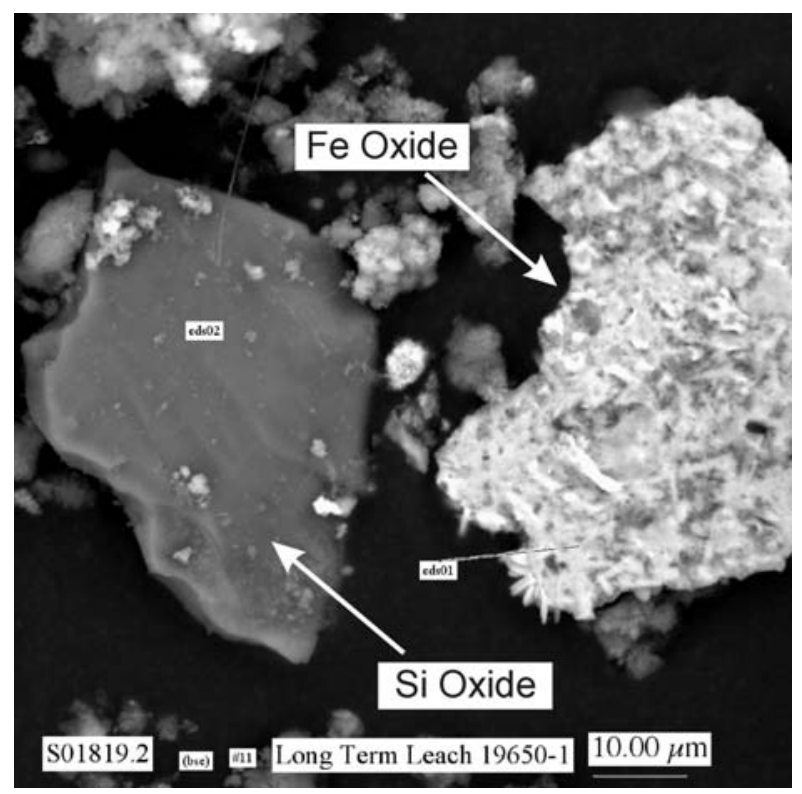

A

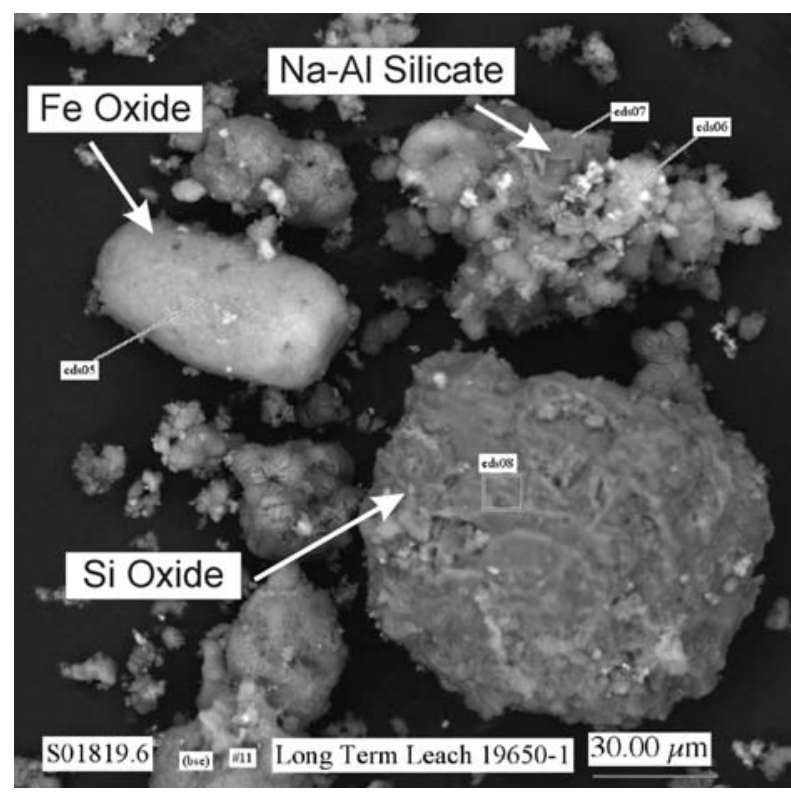

B

Figure 3.19. SEM Micrographs Showing Typical Particles Present in Two-Month Water-Leached C-204 Sludge

include a phase composed of Si oxide (probably quartz) (which is consistent with the XRD results), $\mathrm{Fe}$ oxide (often as globular or botryoidal aggregates), Na-Al silicate, and a porous-looking material (or an aggregate of sub-micrometer particles) that typically contained $\mathrm{Al}, \mathrm{Cr}, \mathrm{Fe}, \mathrm{Na}, \mathrm{Ni}, \mathrm{Si}, \mathrm{U}, \mathrm{P}, \mathrm{O}$, and $\mathrm{C}$.

Two interesting dissolution characteristics not previously observed were seen in the SEM micrographs of C-204 sludge solids remaining after the two-month leach tests. These characteristics may have potential implications in aqueous dissolution rates of sludge materials and subsequent release of contaminants. The SEM micrographs in Figure 3.20 show preferential dissolution cavities (i.e., fossils) (such as those marked by arrows in micrograph B) in an aggregate particle of botryoidal Fe oxide in C-204 sludge. These dissolution cavities wee not observed in our previous studies of AY-102, BX-101, C-203, or C-204 sludge samples, and the composition of the phase (or phases) that had existed in these cavities could not be determined. The dissolution cavities shown in Figure 3.20 suggest that some contaminant solids can become encapsulated during precipitation of iron oxides and thus become partially isolated from fluids used to dissolve the tank sludge during retrieval. Future water percolating through the sludge will dissolve the iron oxides to some extent and expose the contaminant solids to dissolution. As discussed in the technetium release model (Section 4.2), this process is used to simulate the release of the more recalcitrant ${ }^{99} \mathrm{Tc}$ from the tank sludges.

Figure 3.21 shows an aggregate of Na-Al-P-O (probably phosphate) particles partially covered by a coating of Fe oxide observed in extended, two-month leach test of the C-204 sludge. Based on previous SEM analyses of the unleached and two-week water-leach samples, these Fe-oxide coatings likely existed in the unleached sludge but appeared in those materials as particles composed entirely of Fe oxide. However, continual dissolution during the extended leach tests apparently decreased the extent of the coatings 


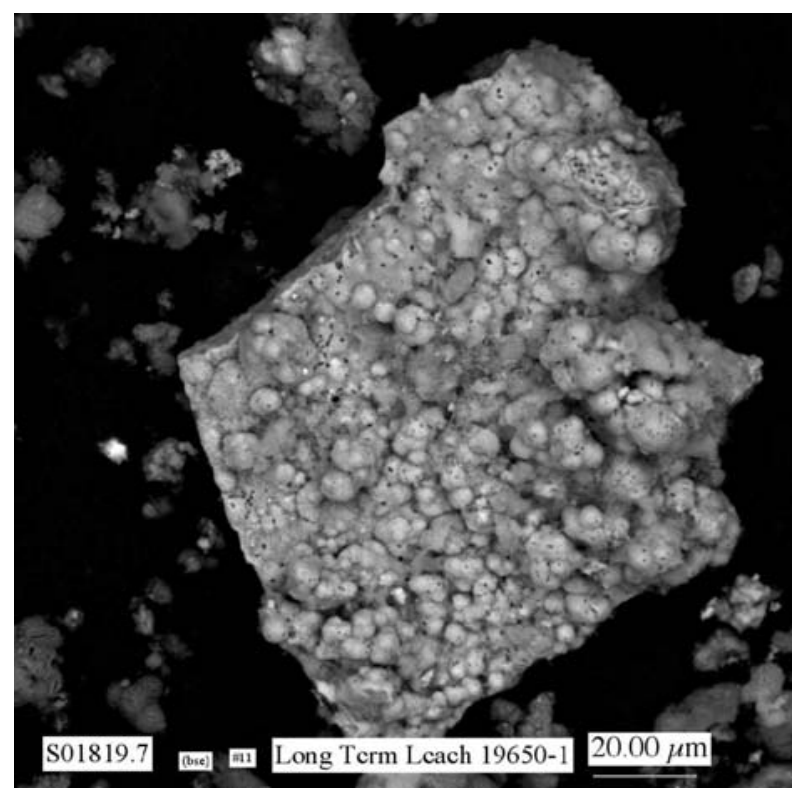

A

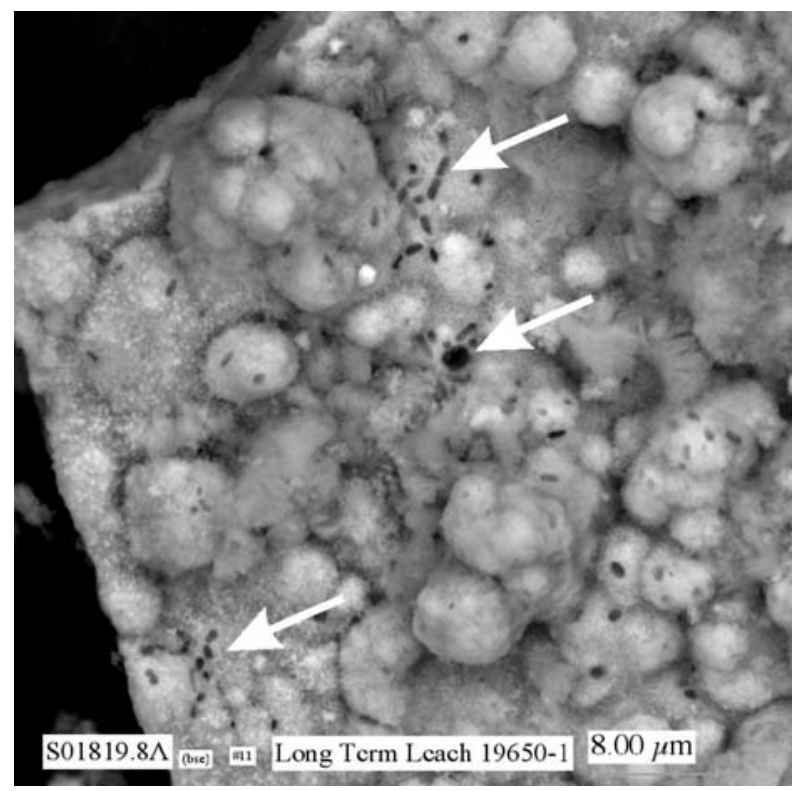

B

Figure 3.20. SEM Micrographs of Botryoidal Aggregates of Fe Oxide with Preferential Dissolution Pits from the Two-Month Water Leach of C-204 Sludge. (Arrows in B show locations of preferential dissolution cavities.)

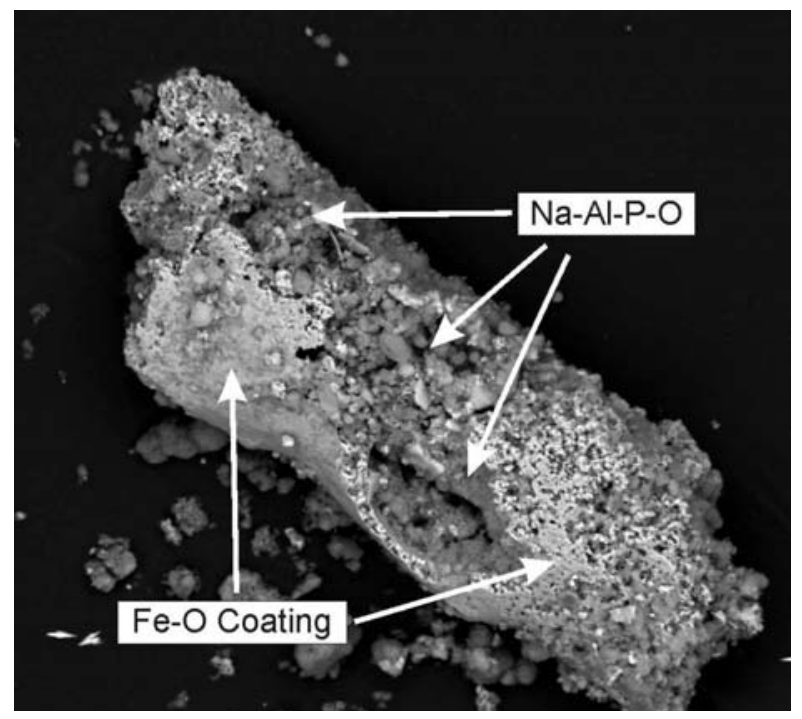

A

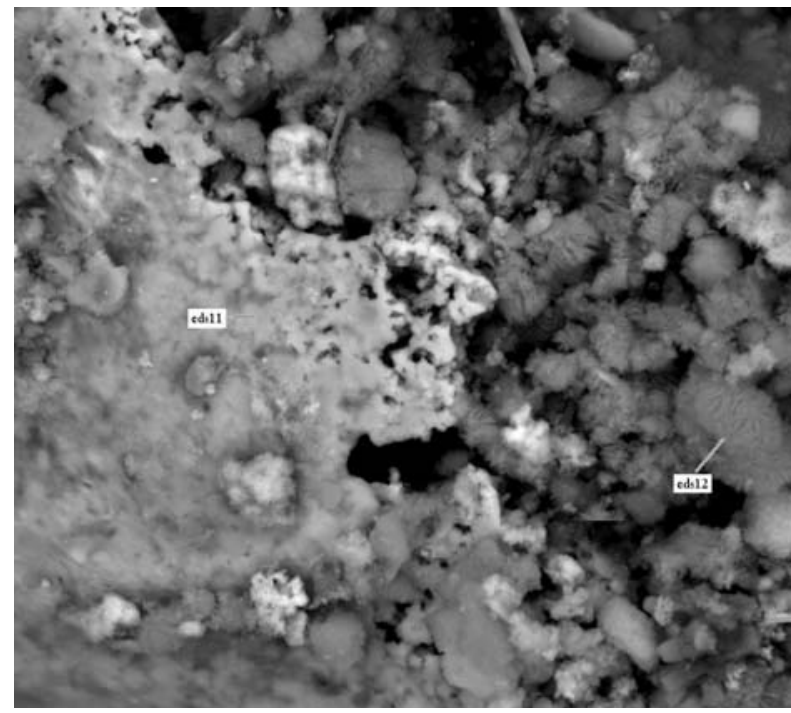

B

Figure 3.21. SEM Micrographs Showing Dissolution of an Fe Oxide Coating on a Large Particle of Possibly Na-Al-P-O from the Two-Month Water Leach of C-204 Sludge 
and exposed the underlying matrix phase(s). These SEM results suggest that dissolution of some soluble sludge phases could be delayed until coatings, such as that in Figure 3.21, have dissolved sufficiently to expose the matrix to contact with the leachate.

\subsubsection{C-204 Material from Selective Extractions Experiments}

Figures 3.22, 3.23, and 3.24 show typical particles observed in the solids remaining from the water-, acetate-, and ethanol-contact selective extractions of C-204 sludge. These materials are similar to each other and to those analyzed by SEM from the water leaches of C-204 sludge. As in micrograph A in Figure 3.22, a few small, rounded U-containing particles were observed in the solids from the selective extraction tests, but these were not as large or abundant as the rounded, smooth-surface U-containing particles detected by SEM in the water-leached C-203 sludges. Also present in these reaction products were botryoidal aggregates of iron oxide (for example, see micrographs $\mathrm{C}$ and $\mathrm{D}$ [higher magnification of C] in Figure 3.24] like those observed in the water-leached samples of C-204 sludge. The particle shown in micrograph B in Figure 3.24 is unusual and was not observed in any of the other leached or unleached C-203 and C-204 sludge samples. Based on EDS analyses, the particle appears to be an aluminum hydroxide solid containing spheroidal inclusions of Fe with lesser amounts of $\mathrm{Cr}$.

An HF/NaF buffer selective extraction of C-204 sludge was conducted to evaluate the potential sequestration of ${ }^{99} \mathrm{Tc}$ in aluminum hydroxy(oxide) phases (Section 2.6). Samples of solids remaining after three days from the HF/NaF selective extraction of C-204 were analyzed by SEM/EDS. Micrographs of particles from two sample mounts from the three-day $\mathrm{HF} / \mathrm{NaF}$ sequential extraction are shown

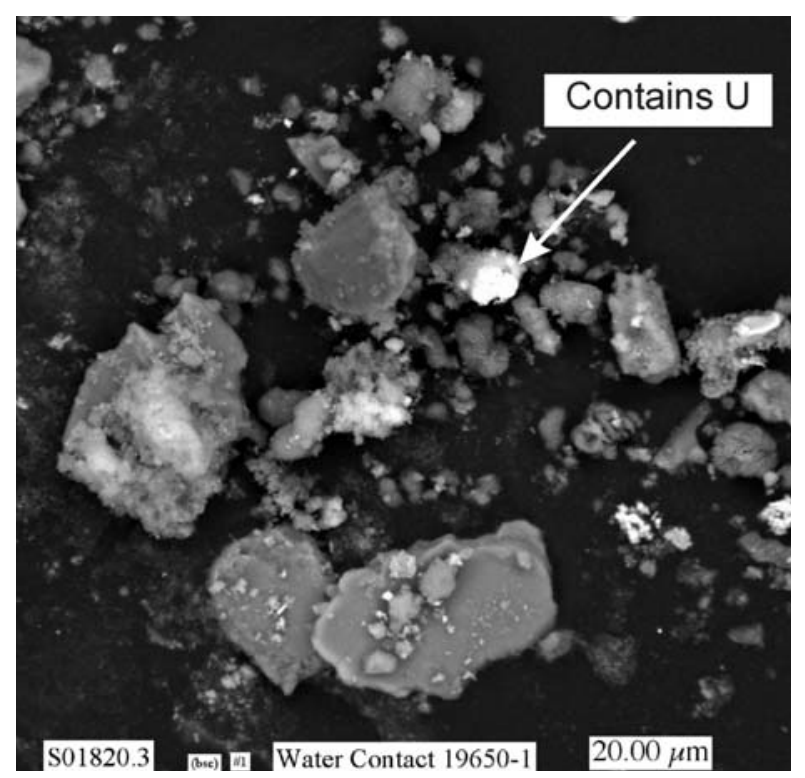

A

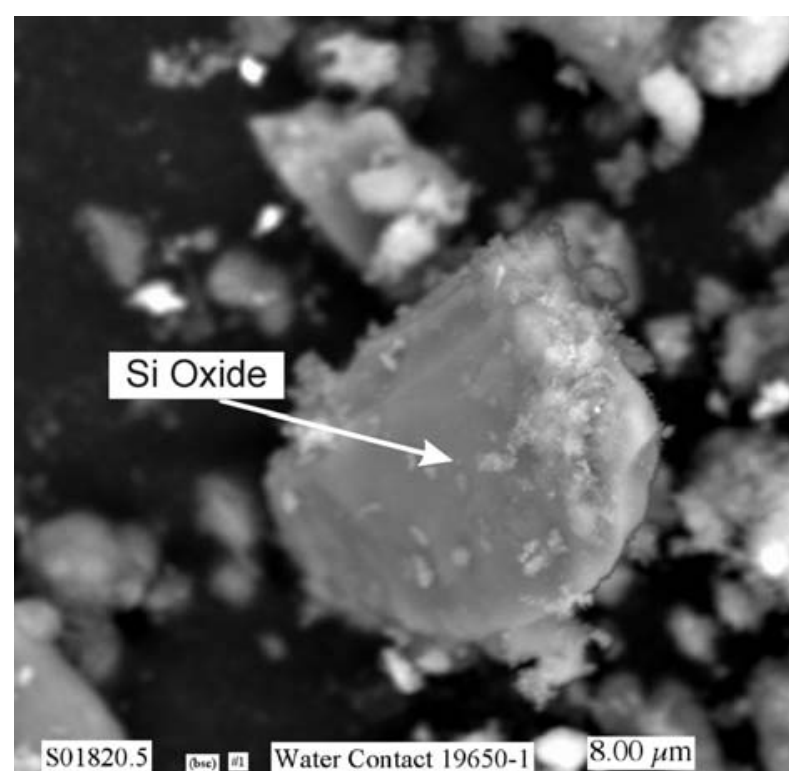

B

Figure 3.22. SEM Micrographs of Typical Particles in Water-Contact Selective Extraction of C-204 Sludge 


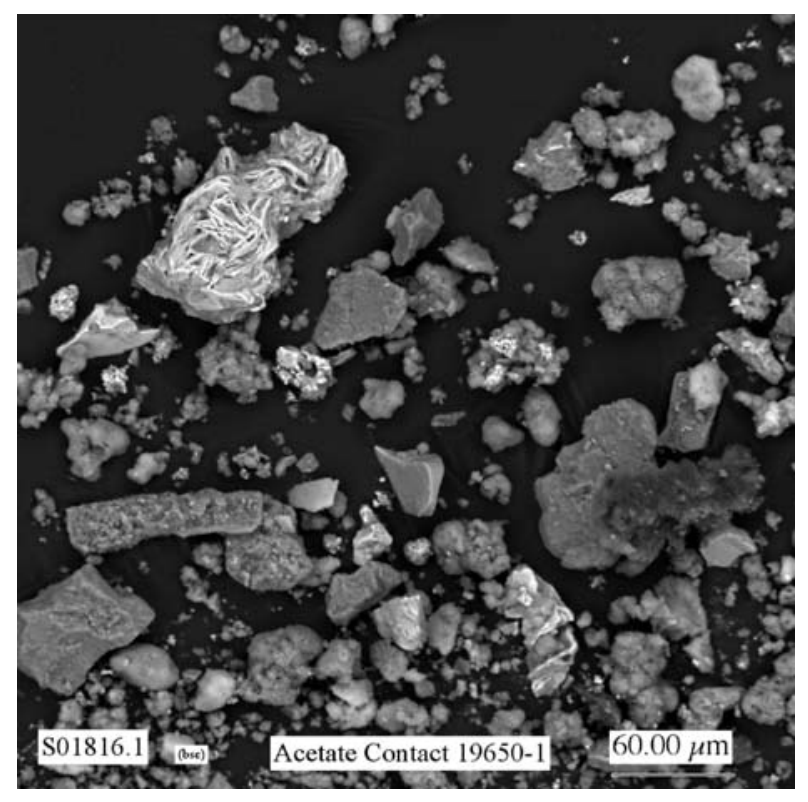

A

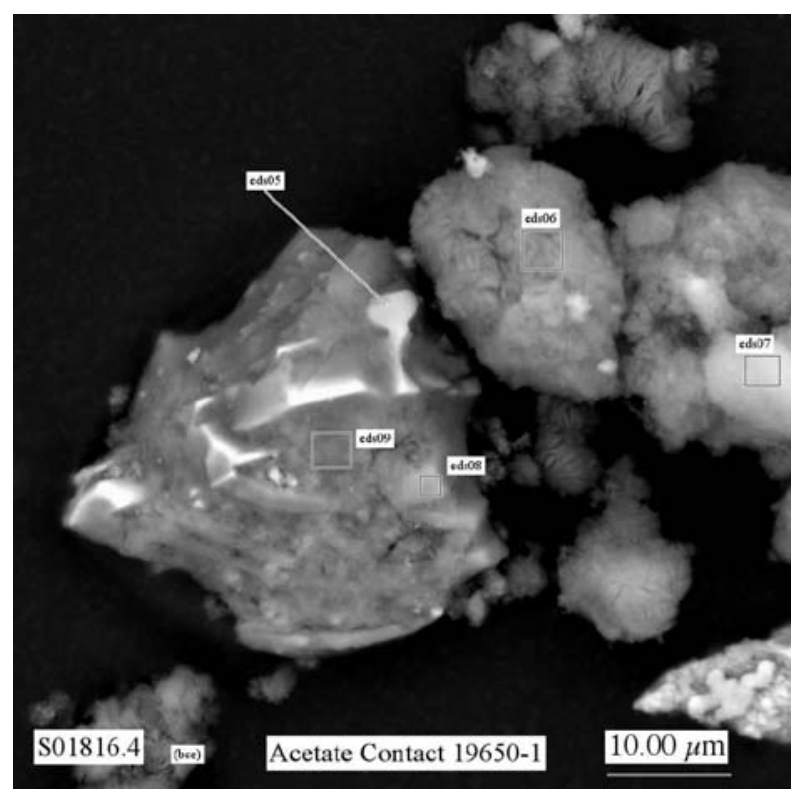

B

Figure 3.23. SEM Micrographs of Typical Particles in Acetate-Contact Selective Extraction of C-204 Sludge

in Figures 3.25 and 3.26. Except for a few occurrences of some unique U-containing, platy crystals not previously seen in any of the unleached or reacted samples of C-203 or C-204 sludge samples, the residues from the HF/NaF did not contain any needles of čejkaite or any of the large, rounded U-containing particles previously seen in these sludges. Many of the particles in the residue exhibited pitted, reacted surfaces like the large bright particles in the four micrographs in Figure 3.25. Several of these particles, such as the large particle (contains $\mathrm{Fe}, \mathrm{Cr}, \mathrm{P}, \mathrm{Al}, \mathrm{Si}, \mathrm{O}$, and $\mathrm{C}$ ) on the right side of micrograph $\mathrm{C}$ and the large particle (contains $\mathrm{Fe}$ and $\mathrm{O}$ ) at the center of micrograph $\mathrm{D}$, show preferential dissolution features suggesting that these particles had originally contained one or more other phases that were more soluble than the Fe-containing matrix in $\mathrm{HF} / \mathrm{NaF}$ extractant. Appendix D contains micrographs that show at higher magnification the surface structures of the matrices of these two reacted particles. The darker particles with the clean-appearing surfaces in Figure 3.25 were typically silicates that contained Si and O (probably quartz) (see grain with label eds 15 micrograph B) or $\mathrm{Si}, \mathrm{Al}, \mathrm{Na}, \mathrm{Ca}$, and $\mathrm{O}$ (probably feldspar) (see grains with labels eds07 in micrograph A and eds16 in micrograph B). Quartz and feldspar are two of the most common minerals found in Hanford sediments.

As mentioned above, SEM analysis of residue from the HF/NaF buffer sequential extraction of C-204 sludge also identified a few occurrences of U-containing platy crystals (see micrographs in Figure 3.26) that had nucleated on some particle surfaces. Micrographs B and $\mathrm{C}$ show at higher magnification the bright particles labeled A and B in micrograph A in Figure 3.26. These platy crystals had not previously been observed in any of the unleached or reacted samples of C-203 or C-204 sludge samples. The EDS analysis indicated these platy crystals contained primarily $\mathrm{U}, \mathrm{P}, \mathrm{O}$, and possibly $\mathrm{C}$. The platy morphology of these crystals and EDS-based composition are consistent with $\mathrm{U}(\mathrm{VI})$ phosphate minerals in the autunite group, such as chernikovite $\left[\left(\mathrm{H}_{3} \mathrm{O}\right)_{2}\left(\mathrm{UO}_{2}\right)_{2}\left(\mathrm{PO}_{4}\right)_{2} \cdot 6 \mathrm{H}_{2} \mathrm{O}\right]$. Although the EDS spectra also suggested that 


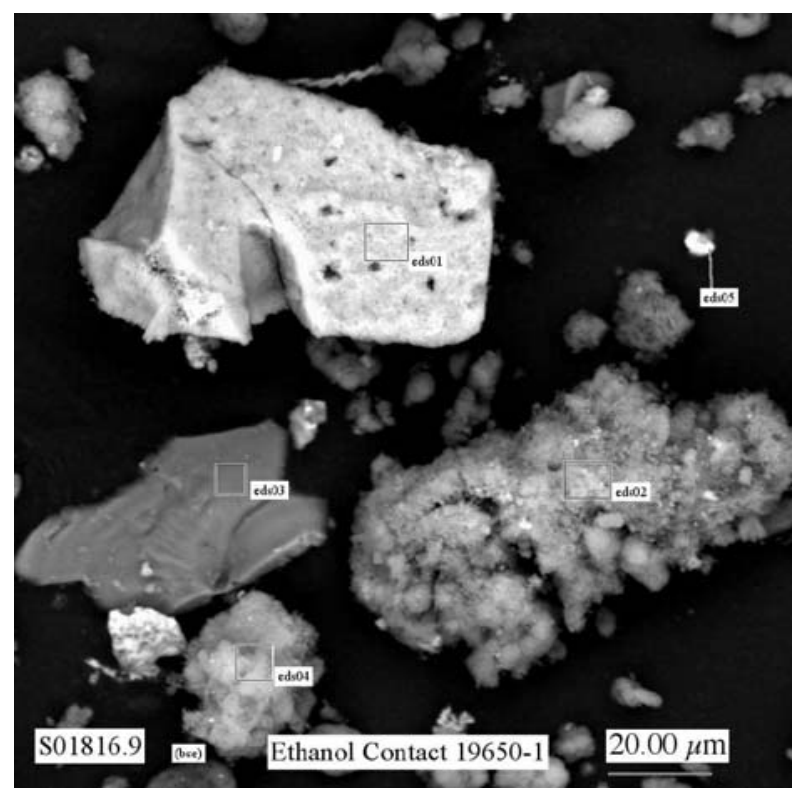

A

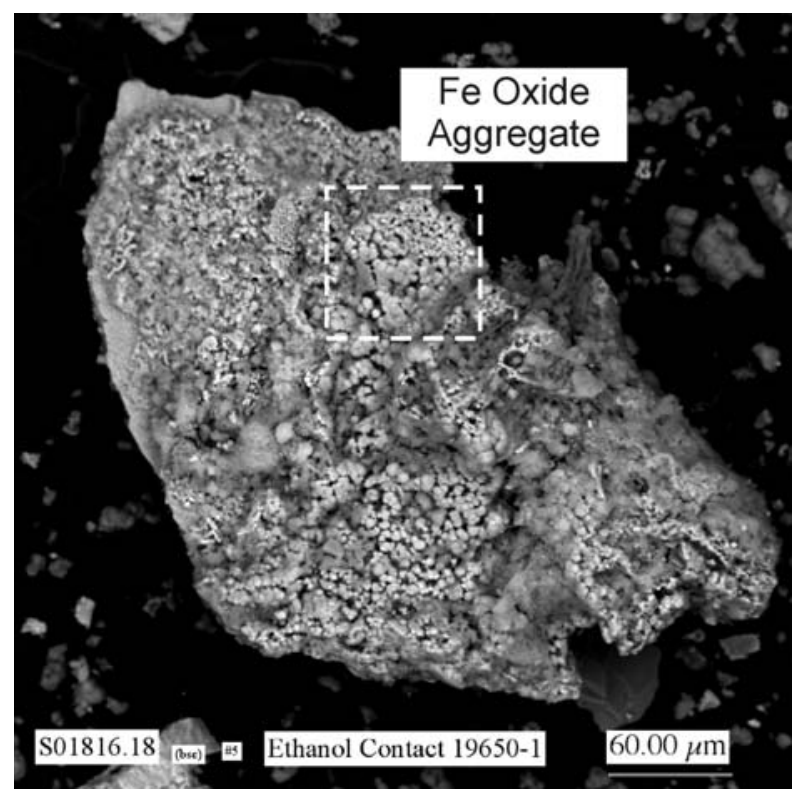

C

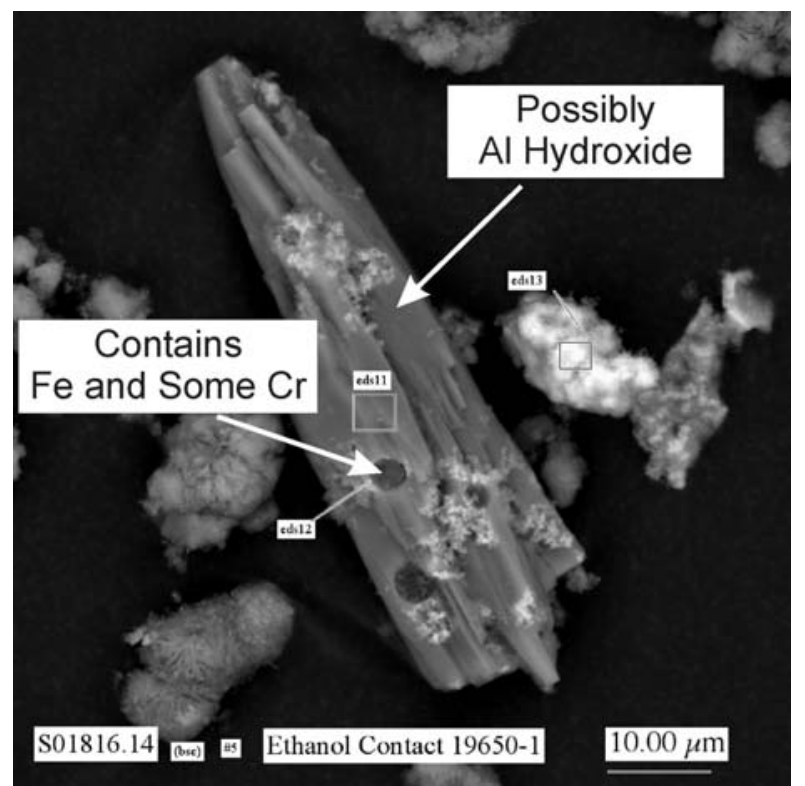

B

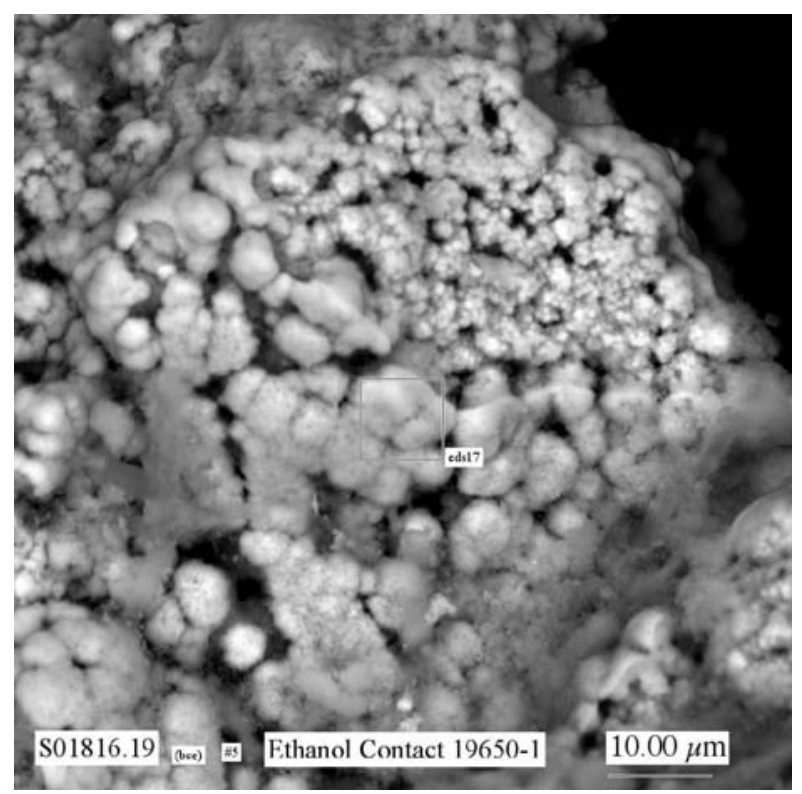

D

Figure 3.24. SEM Micrographs of Typical Particles in Ethanol-Contact Selective Extraction of C-204 Sludge. (Area indicated by box in $\mathrm{C}$ is shown at higher magnification in D.)

these crystals possibly also contained $\mathrm{Fe}, \mathrm{Ni}, \mathrm{Si}, \mathrm{Al}$, and $\mathrm{Cr}$, the $\mathrm{X}$-ray signals for these latter elements likely originated from the particles that serve as the substrate for these platy crystals. Because these crystals had not been observed in any of the other C-203 and C-204 samples, it is possible they formed during $\mathrm{HF} / \mathrm{NaF}$ sequential extraction or from drying the samples during preparation of the SEM mounts. 


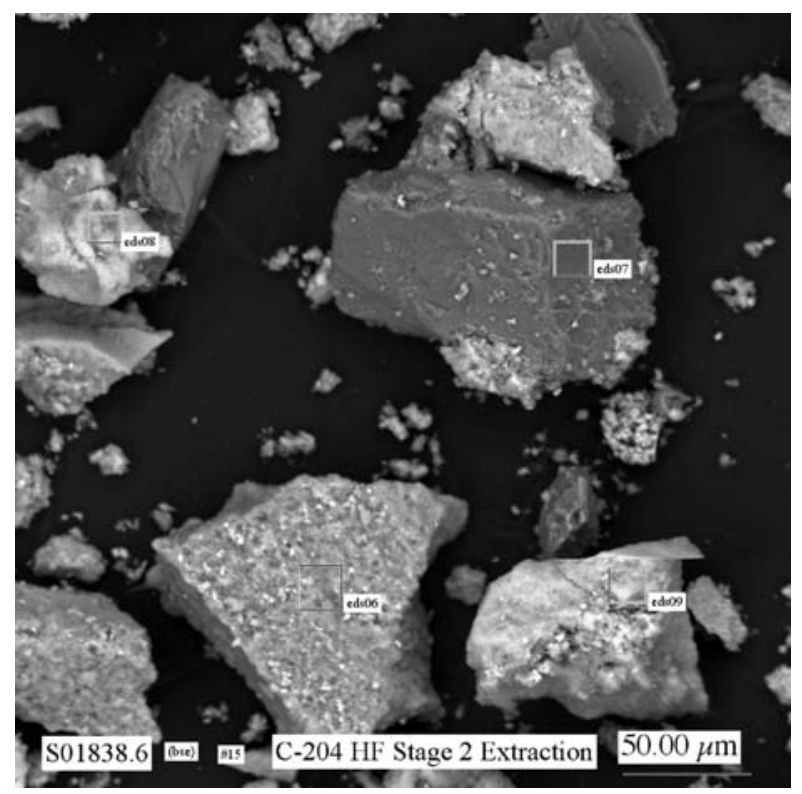

A

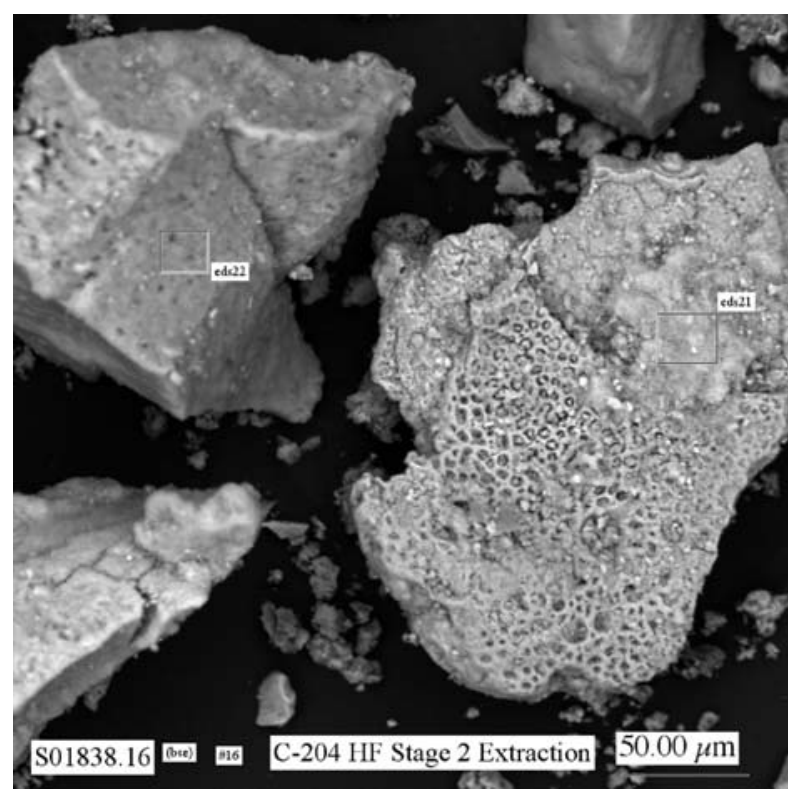

C

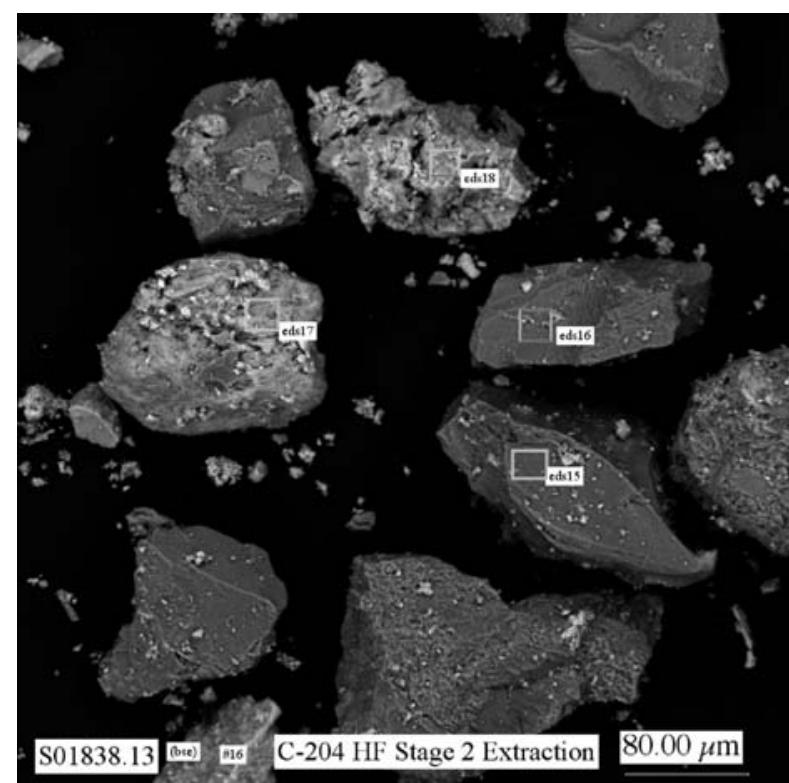

B

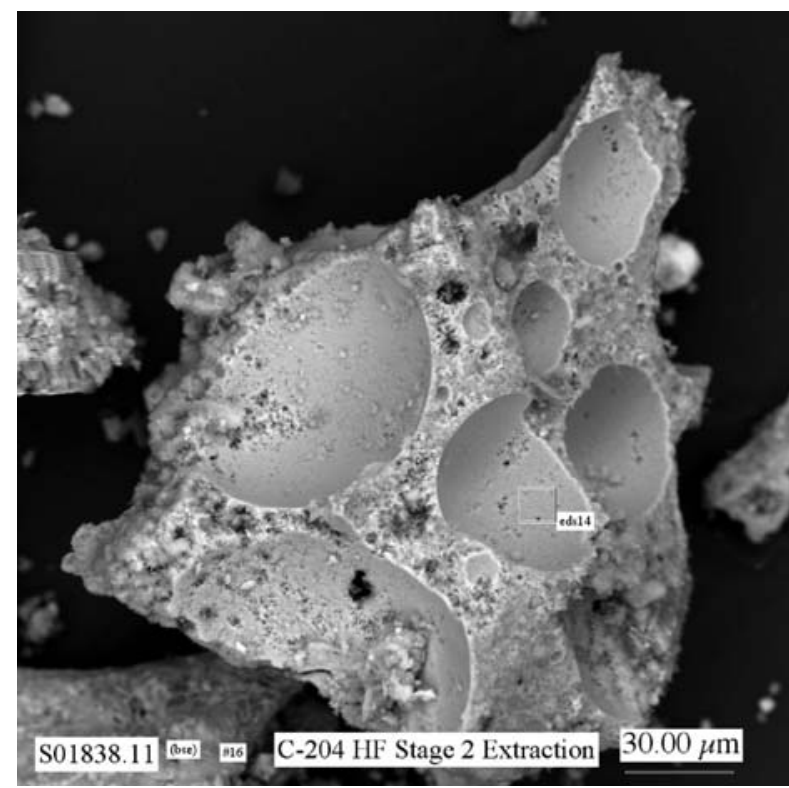

D

Figure 3.25. SEM Micrographs Showing the Morphology of Typical Particles in Material Remaining from the Three-Day HF/Na Sequential Extraction of C-204 Sludge 


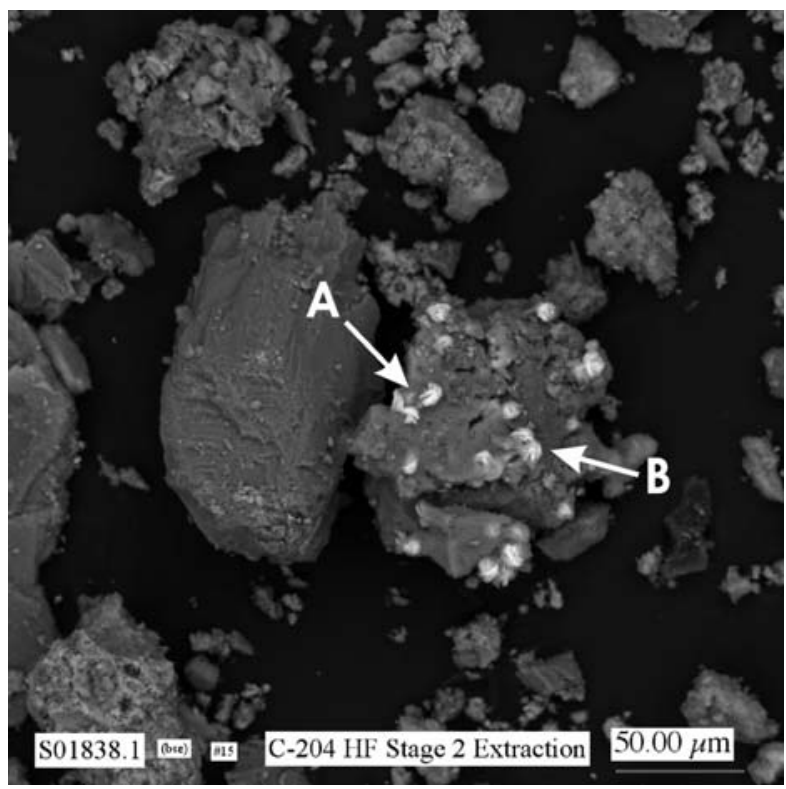

A

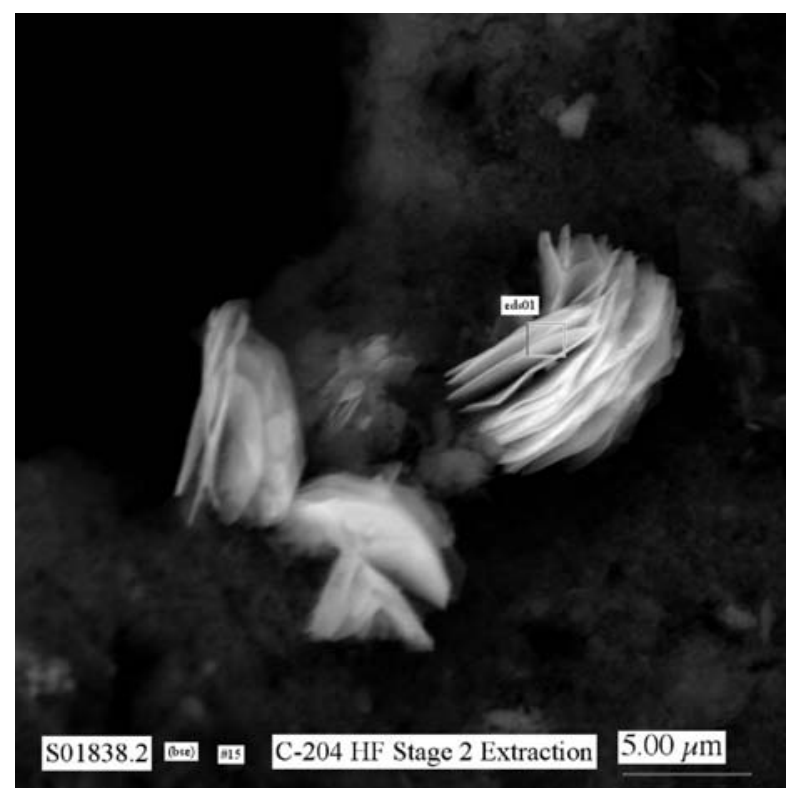

B

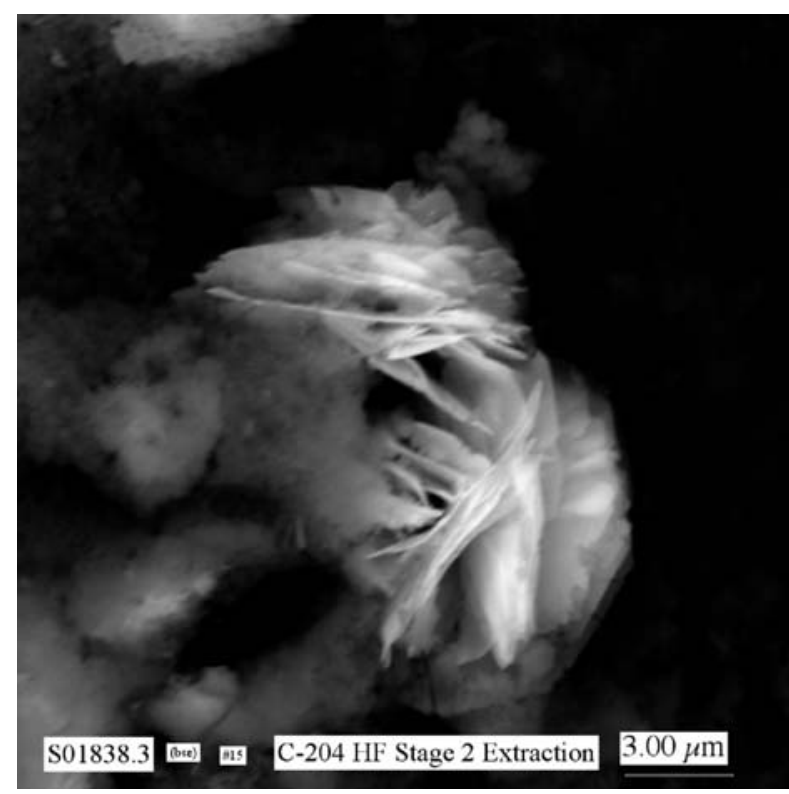

C

Figure 3.26. SEM Micrographs Showing the Morphology of U-Containing Platy Particles Observed on the Surfaces of a Few Grains Present in Residue from the Three-Day HF/Na Sequential Extraction of C-204 Sludge 


\subsubsection{Natural Specimen of Čejkaite}

Figure 3.27 shows typical SEM micrographs of hexagonal, acicular (i.e., needle-like) crystals composed of $\mathrm{Na}, \mathrm{U}, \mathrm{O}$, and $\mathrm{C}$ (probably $\mathrm{CO}_{3}$ ) that were present in the natural specimen of čejkaite. The morphology and EDS-determined compositions for these acicular crystals are essentially identical to those observed by SEM/EDS in the bulk solid and yellow nugget material in the unleached C-203 sludge (subsections 3.5.1.1 and 3.5.1.2) and the unleached C-204 sludge (Section 3.5.2.1). These characteristics are consistent with these crystals being čejkaite.

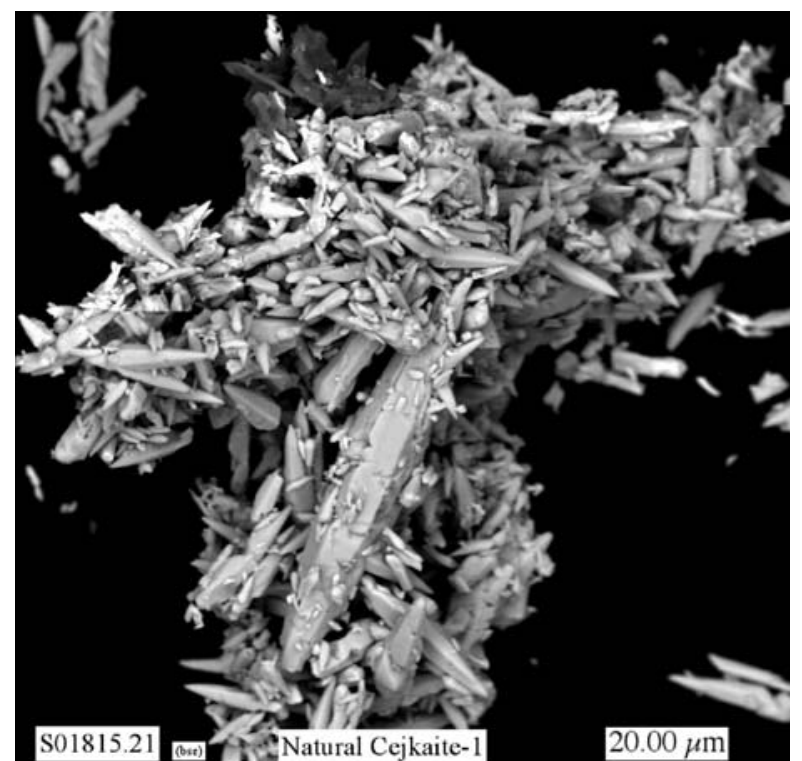

A

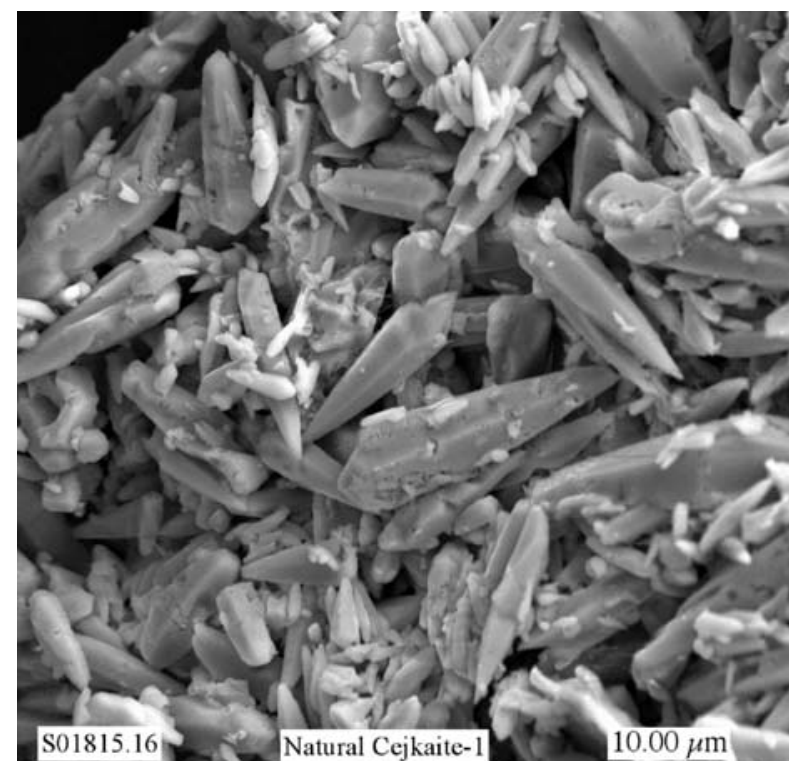

B

Figure 3.27. SEM Micrographs of Typical Crystals Present in the Natural Mineral Specimen of Čejkaite

\subsection{Selective Extraction Results}

Selected results of the first set of selective extraction experiments (SE1) for C-203 and C-204 sludge samples are shown in Table 3.35. Data for ${ }^{99} \mathrm{Tc}, \mathrm{U}, \mathrm{Fe}$, and $\mathrm{Al}$ are tabulated. Results from two ethanol extracts (SE1-203-S4, SE1-203-S5, SE1-204-S4, and SE1-203-S5) are not included because they resulted in very little release of the metals of interest. Also included in Table 3.35 for comparison are the total concentrations of ${ }^{99} \mathrm{Tc}, \mathrm{U}, \mathrm{Fe}$, and $\mathrm{Al}$ determined from the acid extract and the fusion methods. Results displayed in parentheses are less than the lowest instrument EQL but greater than a zero instrument signal. These values may reflect real concentrations but have larger associated uncertainties. Values with a "<" sign are instrument values less than zero. The number indicated is the EQL. To facilitate easier evaluation of these data, the samples and duplicates were averaged and tabulated as a percentage of the fusion concentrations. These data are shown in Table 3.36. Also included in this table are totals determined by addition of the results from each extraction step. These total values were determined by assuming any less-than number was zero. For the C-203 samples, the ${ }^{99} \mathrm{Tc}$ results are rather uncertain. This is due primarily to the very low ${ }^{99} \mathrm{Tc}$ concentrations in these samples, which are mostly at or below the EQL (see Table 3.35). 
Table 3.35. Selective Extraction Experiment Results for C-203 (Jar 19649) and C-204 (Jar 19650) Sludge Samples

\begin{tabular}{|c|c|c|c|c|c|}
\hline Sample Number & Extractant & 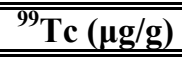 & $\mathrm{U}(\mu \mathrm{g} / \mathrm{g})$ & $\mathrm{Fe}(\mu \mathrm{g} / \mathrm{g})$ & $\mathrm{Al}(\mu \mathrm{g} / \mathrm{g})$ \\
\hline \multicolumn{6}{|c|}{ C-203 (Jar 19649) } \\
\hline SE1-203-S1 & Deionized Water & $9.53 \mathrm{E}-02$ & $1.60 \mathrm{E}+05$ & $1.7 \mathrm{E}+03$ & $(1.6 \mathrm{E}+03)$ \\
\hline SE1-203-S1-dup & Deionized Water & $7.01 \mathrm{E}-02$ & $1.53 \mathrm{E}+05$ & $9.7 \mathrm{E}+02$ & $(8.9 \mathrm{E}+02)$ \\
\hline SE1-203-S2 & Deionized Water & $<6.9 \mathrm{E}-02$ & $2.54 \mathrm{E}+03$ & $3.6 \mathrm{E}+02$ & $(6.3 \mathrm{E}+02)$ \\
\hline SE1-203-S2-dup & Deionized Water & $<7.0 \mathrm{E}-02$ & $4.10 \mathrm{E}+03$ & $2.1 \mathrm{E}+03$ & $(1.7 \mathrm{E}+03)$ \\
\hline SE1-203-S3 & Acetate Buffer & $<6.9 \mathrm{E}-02$ & $5.37 \mathrm{E}+04$ & $(1.6 \mathrm{E}+02)$ & $(1.0 \mathrm{E}+03)$ \\
\hline SE1-203-S3-dup & Acetate Buffer & $(7.0 \mathrm{E}-03)$ & $6.23 \mathrm{E}+04$ & $3.6 \mathrm{E}+02$ & $(9.4 \mathrm{E}+02)$ \\
\hline SE1-203-S6 & $8 \mathrm{M} \mathrm{HNO}_{3}$ & $(1.4 \mathrm{E}-02)$ & $1.64 \mathrm{E}+04$ & $1.7 \mathrm{E}+04$ & $(8.5 \mathrm{E}+02)$ \\
\hline SE1-203-S6-dup & $8 \mathrm{M} \mathrm{HNO}_{3}$ & $<7.0 \mathrm{E}-02$ & $1.55 \mathrm{E}+04$ & $2.4 \mathrm{E}+04$ & $(7.0 \mathrm{E}+02)$ \\
\hline SE1-203-S7 & Hot Conc. $\mathrm{HNO}_{3}$ & $<1.4 \mathrm{E}-01$ & $2.50 \mathrm{E}+02$ & $1.9 \mathrm{E}+04$ & $7.3 \mathrm{E}+03$ \\
\hline SE1-203-S7-dup & Hot Conc. $\mathrm{HNO}_{3}$ & $(3.5 \mathrm{E}-02)$ & $3.79 \mathrm{E}+02$ & $6.6 \mathrm{E}+04$ & $(1.2 \mathrm{E}+03)$ \\
\hline Acid Ext. (Ave) & - & $8.81 \mathrm{E}-02$ & $1.95 \mathrm{E}+05$ & $5.28 \mathrm{E}+04$ & $9.81 \mathrm{E}+02$ \\
\hline Fusion & - & $1.04 \mathrm{E}-01$ & $2.18 \mathrm{E}+05$ & $3.87 \mathrm{E}+04$ & $1.34 \mathrm{E}+03$ \\
\hline \multicolumn{6}{|c|}{ C-204 (Jar 19650) } \\
\hline SE1-204-S1 & Deionized Water & $8.69 \mathrm{E}-02$ & $5.65 \mathrm{E}+04$ & $1.7 \mathrm{E}+03$ & $2.1 \mathrm{E}+03$ \\
\hline SE1-204-S1-dup & Deionized Water & $1.03 \mathrm{E}-01$ & $7.54 \mathrm{E}+04$ & $1.3 \mathrm{E}+03$ & $1.8 \mathrm{E}+03$ \\
\hline SE1-204-S2 & Deionized Water & $<3.2 \mathrm{E}-02$ & $1.43 \mathrm{E}+03$ & $2.8 \mathrm{E}+03$ & $2.6 \mathrm{E}+03$ \\
\hline SE1-204-S2-dup & Deionized Water & $<3.0 \mathrm{E}-02$ & $2.16 \mathrm{E}+03$ & $1.6 \mathrm{E}+03$ & $1.9 \mathrm{E}+03$ \\
\hline SE1-204-S3 & Acetate Buffer & $<3.2 \mathrm{E}-02$ & $1.12 \mathrm{E}+04$ & $(1.3 \mathrm{E}+02)$ & $(8.8 \mathrm{E}+02)$ \\
\hline SE1-204-S3-dup & Acetate Buffer & $<3.0 \mathrm{E}-02$ & $1.17 \mathrm{E}+04$ & $(1.7 \mathrm{E}+02)$ & $(8.8 \mathrm{E}+02)$ \\
\hline SE1-204-S6 & $8 \mathrm{M} \mathrm{HNO}_{3}$ & $3.06 \mathrm{E}-01$ & $7.53 \mathrm{E}+03$ & $7.8 \mathrm{E}+04$ & $1.8 \mathrm{E}+04$ \\
\hline SE1-204-S6-dup & $8 \mathrm{M} \mathrm{HNO}_{3}$ & $1.65 \mathrm{E}-01$ & $6.41 \mathrm{E}+03$ & $5.7 \mathrm{E}+04$ & $1.7 \mathrm{E}+04$ \\
\hline SE1-204-S7 & Hot Conc. $\mathrm{HNO}_{3}$ & $(3.2 \mathrm{E}-02)$ & $5.34 \mathrm{E}+02$ & $2.3 \mathrm{E}+04$ & $(1.3 \mathrm{E}+03)$ \\
\hline SE1-204-S7-dup & Hot Conc. $\mathrm{HNO}_{3}$ & 4.99E-02 & $4.65 \mathrm{E}+02$ & $2.8 \mathrm{E}+04$ & $(1.3 \mathrm{E}+03)$ \\
\hline Acid Ext. (Ave) & - & $2.06 \mathrm{E}-01$ & $3.31 \mathrm{E}+04$ & $1.95 \mathrm{E}+05$ & $1.56 \mathrm{E}+04$ \\
\hline Fusion & - & $3.87 \mathrm{E}-01$ & $8.02 \mathrm{E}+04$ & $1.27 \mathrm{E}+05$ & $2.59 \mathrm{E}+04$ \\
\hline
\end{tabular}

Table 3.36. Average and Total Selective Extraction Results as a Percentage of the Fusion Results for C-203 (Jar 19649) and C-204 (Jar 19650) Sludge Samples

\begin{tabular}{|c|c|c|c|c|c|}
\hline Sample Number & Extractant & 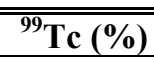 & 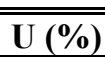 & Fe (\%) & Al (\%) \\
\hline \multicolumn{6}{|c|}{ C-203 (Jar 19649) } \\
\hline SE1-203-S1 & Deionized Water & 80 & 72 & 3.5 & (93) \\
\hline SE1-203-S2 & Deionized Water & $<67$ & 1.5 & 3.2 & $(86)$ \\
\hline SE1-203-S3 & Acetate Buffer & (36) & 27 & $(0.7)$ & (72) \\
\hline SE1-203-S6 & $8 \mathrm{M} \mathrm{HNO}_{3}$ & $<40$ & 7.3 & 54 & $(58)$ \\
\hline SE1-203-S7 & Hot Conc. $\mathrm{HNO}_{3}$ & $<72$ & 0.1 & 109 & $(318)$ \\
\hline Total & & 80 & 108 & 170 & $\mathrm{NA}$ \\
\hline \multicolumn{6}{|c|}{ C-204 (Jar 19650) } \\
\hline SE1-204-S1 & Deionized Water & 25 & 82 & 1.2 & 7.6 \\
\hline SE1-204-S2 & Deionized Water & $<8.0$ & 2.2 & 1.6 & 8.6 \\
\hline SE1-204-S3 & Acetate Buffer & $<8.0$ & 14 & $(0.1)$ & (3.4) \\
\hline SE1-204-S6 & $8 \mathrm{M} \mathrm{HNO}_{3}$ & 61 & 8.7 & 53 & 67 \\
\hline SE1-204-S7 & Hot Conc. $\mathrm{HNO}_{3}$ & 11 & 0.6 & 20 & (4.9) \\
\hline Total & & 97 & 108 & 76 & 92 \\
\hline
\end{tabular}


The ${ }^{99} \mathrm{Tc}$ results from the $\mathrm{C}-204$ sample indicate that a small fraction of the ${ }^{99} \mathrm{Tc}$ is readily water soluble and most of the ${ }^{99} \mathrm{Tc}$ can only be mobilized by acid extraction. This suggests that a major fraction of the ${ }^{99} \mathrm{Tc}$ is incorporated into recalcitrant phases such as the iron/aluminum oxyhydroxides. Despite the uncertainties of the ${ }^{99} \mathrm{Tc}$ results, these water extracts compare well with the previous single-contact waterleaching results conducted for one day, two weeks and four weeks. These results indicated a range in the percent leached for ${ }^{99} \mathrm{Tc}$ of 56 to $71 \%$ for the C-203 samples and 28 to $34 \%$ for the C-204 samples.

Uranium release during the selective extractions followed similar patterns for both tank sludges. For the C-203 sludge, approximately $73 \%$ of the uranium was released by the two water leaches, while for the C-204 sludge approximately $84 \%$ was released. Nearly all the uranium that dissolved in the two water extractions was released during the first extraction. These results also compare well with the singlecontact water-leaching experiments. A significant amount of uranium also dissolved during the acetate buffer extraction (27\% for C-203 and 14\% for C-204). An additional amount of uranium was dissolved during the $8 \mathrm{M} \mathrm{HNO}_{3}$ extraction (7\% for C-203 and 9\% for C-204). These results suggest that release of uranium from C-203 and C-204 sludges is not likely to be controlled by the solubility of čejkaite alone. One or more additional uranium phases of lower solubility than čejkaite likely occur in these sludges.

The iron data for the C-203 sludge is generally consistent with its occurrence as relatively insoluble oxyhydroxides. The aluminum data for the C-203 sludge cannot be meaningfully interpreted, due to the large uncertainties associated with this data. The extraction results for both the iron and aluminum in the C-204 samples are generally consistent with their existence as relatively insoluble oxyhydroxides; however, a surprisingly large amount of the aluminum (16\%) dissolved during the deionized water extractions. This suggests that some of the aluminum occurs as a relatively soluble phase; however, no evidence was found for the presence of such a phase.

To determine whether recalcitrant ${ }^{99} \mathrm{Tc}$ was being held in an aluminum oxide or hydroxide phase, a second series of sequential extractions specifically targeted the removal of aluminum oxide or hydroxide phases and minimized dissolution of iron oxyhydroxides. These extractions were conducted only on C-204 sludge because of the very low aluminum concentrations in C-203 sludge. The quantities of several major metal elements and ${ }^{99} \mathrm{Tc}$ mobilized during the extractions are compiled in Table 3.37. For easier analysis of these data, the percentage extracted was calculated for each of these constituents and presented in Table 3.38. The fusion results were used for the total concentrations for these calculations.

During the first extraction, 35 to $40 \%$ of the aluminum was dissolved. Essentially none of the ${ }^{99} \mathrm{Tc}$ was released during this first extraction. These results suggest that the recalcitrant ${ }^{99} \mathrm{Tc}$ in C-204 sludge is not associated with aluminum oxyhydroxides. During the second extraction, an additional 7 to $13 \%$ aluminum dissolved along with 7 to $9 \%$ of the iron and 12 to $18 \%$ of the chromium in the sludge. In addition, 2 to $3 \%$ of the ${ }^{99} \mathrm{Tc}$ dissolved. The release of ${ }^{99} \mathrm{Tc}$ to the solution is most likely a result of the dissolution of the iron solid. More iron and chromium dissolved in the second addition of the $\mathrm{HF} / \mathrm{NaF}$ solution because less of the soluble aluminum solid was available to neutralize the acid. The lower $\mathrm{pH}$ of the second extraction ( $\mathrm{pH} 3.3$ ) versus the first extraction $(\mathrm{pH} 4.0)$ enhanced the solubility of the iron and chromium solids. Chromium may be present in these sludges as a component of the iron oxyhydroxide solids and/or as a separate chromium hydroxide solid. The relatively low percentage of Si released suggests that the majority of the aluminum in this sludge is not associated with aluminosilicates. 
Table 3.37. Extracted Concentrations of Selected Elements from C-204 Sludge by $0.02 \mathrm{M}$ Hydrofluoric Acid/0.01 Sodium Fluoride Buffer Solution

\begin{tabular}{|l|c|c|c|c|c||}
\hline \hline Sample ID & $\begin{array}{c}\mathbf{A l} \\
\boldsymbol{\mu g} / \mathbf{g}\end{array}$ & $\begin{array}{c}\mathbf{C r} \\
\boldsymbol{\mu g} / \mathbf{g}\end{array}$ & \multicolumn{1}{c}{$\begin{array}{c}\mathbf{F e} \\
\boldsymbol{\mu g} / \mathbf{g}\end{array}$} & \multicolumn{1}{c|}{$\begin{array}{c}\mathbf{S i} / \mathbf{g} \\
\mathbf{\mu g} / \mathbf{g}\end{array}$} \\
\hline \hline C-204-1 & $8.9 \mathrm{E}+03$ & $6.1 \mathrm{E}+01$ & $4.9 \mathrm{E}+01$ & $1.0 \mathrm{E}+03$ & $<2.55 \mathrm{E}-03$ \\
\hline C-204-1 dup & $1.0 \mathrm{E}+04$ & $1.4 \mathrm{E}+02$ & $1.4 \mathrm{E}+02$ & $1.2 \mathrm{E}+03$ & $(1.16 \mathrm{E}-03)$ \\
\hline C-204-2 & $3.4 \mathrm{E}+03$ & $1.0 \mathrm{E}+03$ & $8.4 \mathrm{E}+03$ & $1.0 \mathrm{E}+03$ & $6.64 \mathrm{E}-03$ \\
\hline C-204-2 dup & $1.8 \mathrm{E}+03$ & $1.6 \mathrm{E}+03$ & $1.2 \mathrm{E}+04$ & $8.1 \mathrm{E}+02$ & $1.18 \mathrm{E}-02$ \\
\hline \hline
\end{tabular}

Table 3.38. Percent Extracted for Selected Elements from C-204 Sludge by 0.02 M Hydrofluoric Acid/0.01 Sodium Fluoride Buffer Solution

\begin{tabular}{||l|c|c|c|c|c||}
\hline \hline Sample ID & Al \% & Cr \% & Fe \% & Si\% & ${ }^{99}$ Tc \% \\
\hline \hline C-204-1 & 34.5 & 0.7 & 0.0 & 2.8 & $<0.7$ \\
\hline C-204-1 dup & 39.8 & 1.5 & 0.1 & 3.4 & 0.0 \\
\hline C-204-2 & 13.3 & 11.6 & 6.6 & 2.8 & 1.7 \\
\hline C-204-2 dup & 7.1 & 18.2 & 9.4 & 2.3 & 3.0 \\
\hline
\end{tabular}




\subsection{Contaminant Release Model}

The primary objective of this project is to develop source release models for contaminants of concern present in residual tank waste. As shown in Figure 4.1, this consists of laboratory testing to produce contaminant release data and a conceptual source release model. The release model can then be incorporated into a fate and transport model as part of a long-term performance assessment for the closed tank. This section describes the conceptual release models developed for ${ }^{238} \mathrm{U}$ and ${ }^{99} \mathrm{Tc}$ from the laboratory data and the requirements of a fate and transport model to appropriately simulate release of these contaminants from residual sludge in Tanks C-203 and C-204.

The contaminant release models for these tanks are based on the solubility of minerals that contain the contaminant. Mineral solubility is defined as the amount of a mineral or other solid phase that will dissolve in solution under the geochemical conditions of the system. Solubility is based on thermodynamic equilibrium between the phases; however, the amount of a solid that dissolves to reach equilibrium (its solubility) is strongly influenced by site (system) conditions (e.g., pH, Eh, ionic strength, presence/concentration of complexing species, etc.). For this reason, the release models described in this section apply only to expected tank conditions at closure and will be modified as additional information becomes available.

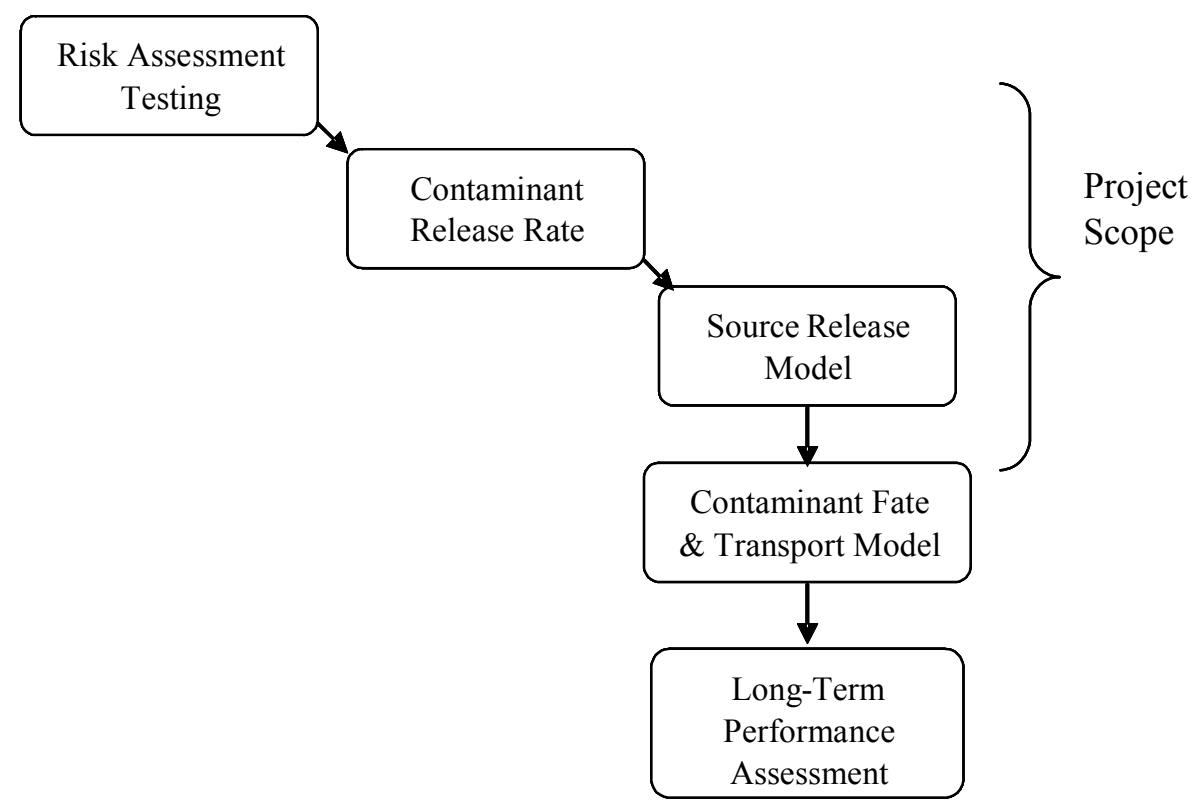

Figure 4.1. Source Release Model Development for Long-Term Performance Assessments

\subsection{Uranium Release}

It is clear from the analyses described in Section 3.2.3 that uranium release from C-203 and C-204 sludges will initially be controlled by the solubility of čejkaite $\left[\mathrm{Na}_{4} \mathrm{UO}_{2}\left(\mathrm{CO}_{3}\right)_{3}\right]$. Because of the common ion effect (Equation 3.2) and the relatively high concentrations of sodium nitrate in the sludges, the initial 
solubility of čejkaite in C-203 and C-204 sludges will be suppressed until the readily soluble sodium salts have dissolved and have been transported in solution out of the tank sludge. After this, the čejkaite solubility will increase and remain high until all the remaining čejkaite has dissolved. Based on the selective extraction results, it appears that approximately 70 to $85 \%$ of the uranium in Tanks C-203 and C-204 is in the form of čejkaite. The rest of the uranium appears to occur in another phase or phases with a lower solubility than čejkaite. As a result, once the čejkaite has completely dissolved, this other phase (or phases) is likely to lower the solution concentration of uranium being released from these sludges.

Based on these factors, the suggested solubility parameters to be used in the performance assessment modeling for Tanks C-203 and C-204 are as follows. The initial solubility limit for uranium is estimated to be $8 \times 10^{-4} \mathrm{M}(0.19 \mathrm{~g} / \mathrm{L})$. This estimated value is applicable for a solution containing a dissolved $\mathrm{NaNO}_{3}$ concentration of $7.4 \mathrm{~mol} / \mathrm{L}$. This value was determined by first calculating a conditional solubility constant $\left(\mathrm{K}_{\mathrm{sp}}\right)$ :

$$
\mathrm{K}_{\mathrm{sp}}^{\prime}=\left[\mathrm{UO}_{2}{ }^{2+}\right]_{\mathrm{T}}\left[\mathrm{Na}^{+}\right]^{4}
$$

where $\left[\mathrm{UO}_{2}{ }^{2+}\right]_{\mathrm{T}}$ is the total dissolved uranium concentration. Values for $\left[\mathrm{UO}_{2}{ }^{2+}\right]_{\mathrm{T}}$ and $\left[\mathrm{Na}^{+}\right]$from sample C-203(1:1)-1 (Table 3.34) were used to calculate a $\mathrm{K}_{\mathrm{sp}}^{\prime}$ of 2.37. This $\mathrm{K}_{\mathrm{sp}}^{\prime}$ value was then used to calculate the equilibrium $\left[\mathrm{UO}_{2}{ }^{2+}\right]_{\mathrm{T}}$ concentration for a $\left[\mathrm{Na}^{+}\right]$concentration of $7.4 \mathrm{M}$ (in equilibrium with $\mathrm{NaNO}_{3}$ ). To make this calculation, it was assumed that there is no significant difference in the activity coefficients between the solution used to calculate $\mathrm{K}_{\mathrm{sp}}^{\prime}$ (sample $\mathrm{C}-203(1: 1)-1$ ) and a $7.4 \mathrm{M} \mathrm{NaNO}_{3}$ solution. The calculation also assumes that essentially all the dissolved $\mathrm{UO}_{2}{ }^{2+}$ is in the form of the $\mathrm{UO}_{2}\left(\mathrm{CO}_{3}\right)_{3}{ }^{4-}$ complex in both solutions (Equation 3.2). Given the number of assumptions needed to estimate this solubility value, it should be considered relatively uncertain. Ongoing solubility studies being conducted under the Environmental Management Science Program at PNNL (AR Felmy, principle investigator) may provide a more reliable value for čejkaite solubility in 7.4 $\mathrm{M} \mathrm{NaNO}_{3}$.

The current best-estimate čejkaite solubility in $7.4 \mathrm{M} \mathrm{NaNO}_{3}$ is used until all the $\mathrm{NaNO}_{3}$ has dissolved. The duration of this stage of the release model is a function of the estimated mass of $\mathrm{NaNO}_{3}$ in the sludge, its solubility of $7.4 \mathrm{M}$, and the flux of water through the sludge. Tank C-203 contains $0.22 \mathrm{~g}$ $\mathrm{NaNO}_{3} /$ g-sludge, and Tank C-204 contains $0.04 \mathrm{~g} \mathrm{NaNO} /$-g-sludge. The solubility of $\mathrm{NaNO}_{3}$ in water is $629 \mathrm{~g} / \mathrm{L}$. Combining this information with the total mass of sludge in the tank and the water infiltration rate completes the input data required to calculate how long $\mathrm{NaNO}_{3}$ will control the solubility of čejkaite.

After the $\mathrm{NaNO}_{3}$ has completely dissolved, the dissolved uranium will increase to $0.29 \mathrm{M}(69 \mathrm{~g} / \mathrm{L})$ for the remaining čejkaite. The uranium that is not in the form of čejkaite (27\% for C-203 and 16\% for C 204) is assumed to be in a less-soluble phase (see Section 3.6). At this time, the identity of this lower solubility phase(s) has not been determined, and its solubility has not been quantified. Because the solubility of this remaining uranium phase (perhaps clarkeite) cannot be determined at this time, it has been estimated conservatively as the concentration of uranium extracted in the acetate buffer selective extractions (Section 3.5). The acetate-extracted uranium concentrations were significantly higher in the C-203 samples than in the C-204 samples (Table 3.35). As a result, the higher C-203 extraction results were used to provide a conservative (from a groundwater standpoint) upper limit for the solubility of the remaining uranium solid. A summary of all the uranium release model data is provided in Table 4.1. 
Table 4.1. Summary of Uranium Release Model Data

\begin{tabular}{||l|l|l|c|l||}
\hline \hline Tank & Release Form & \multicolumn{1}{c|}{ Sludge Conc. } & Release Conc. & Release Control \\
\hline \hline C-203 & čejkaite & $0.16 \mathrm{~g} \mathrm{U} / \mathrm{g}$-sludge & $0.19 \mathrm{~g} / \mathrm{L}$ & čejkaite/NaNO $\mathrm{NaN}_{3}$ \\
\hline C-203 & čejkaite & calculated & $69.00 \mathrm{~g} / \mathrm{L}$ & čejkaite \\
\hline C-203 & Non-čejkaite-U & $0.058 \mathrm{~g} \mathrm{U} / \mathrm{g}$-sludge & $0.42 \mathrm{~g} / \mathrm{L}$ & unknown U phase \\
\hline \hline C-204 & čejkaite & $0.068 \mathrm{~g} \mathrm{U} / \mathrm{g}$-sludge & $0.19 \mathrm{~g} / \mathrm{L}$ & čejkaite $/ \mathrm{NaNO}_{3}$ \\
\hline C-204 & čejkaite & calculated & $69.00 \mathrm{~g} / \mathrm{L}$ & čejkaite \\
\hline C-204 & Non-čejkaite-U & $0.013 \mathrm{~g} \mathrm{U} / \mathrm{g}$-sludge & $0.42 \mathrm{~g} / \mathrm{L}$ & unknown U phase \\
\hline
\end{tabular}

These suggested solubility limits are based on contact with water that resembles natural infiltration (i.e., rainwater). Water modified by grout placed in the tank or any other amendments that could significantly alter the solubility of čejkaite would require different solubility limits for the release model.

\subsection{Technetium Release}

The selective extraction results presented in Table 3.36 indicate that the readily water-soluble ${ }^{99} \mathrm{Tc}$ is approximately $80 \%$ of the total for C-203 sludge and $25 \%$ for C-204 sludge. Results from the one-day, two-week, and one-month water-leach experiments indicate a range of $56 \%$ to $71 \%$ water-leachable ${ }^{99} \mathrm{Tc}$ in C-203 sludge and 28 to 34\% in C-204 sludge. For the conceptual release model, it is assumed that the one-month water-leach results are the most correct values for the readily soluble fraction of ${ }^{99} \mathrm{Tc}$ in the C-203 and C-204 sludges. It is possible that some fraction of readily water-soluble ${ }^{99} \mathrm{Tc}$ attributed to the sludge may have actually been dissolved in aqueous solution entrained within the sludge samples.

Because it is not possible to distinguish between these two pools of ${ }^{99} \mathrm{Tc}$, it has been assumed that all the readily soluble ${ }^{99} \mathrm{Tc}$ is actually associated with the sludge. The fusion results are assumed to provide the best estimates for the total concentrations of ${ }^{99} \mathrm{Tc}$ in these sludges and are used in release model calculations.

For the readily soluble portion of ${ }^{99} \mathrm{Tc}$ in the sludge, it is assumed that release of ${ }^{99} \mathrm{Tc}$ is controlled by the solubility of $\mathrm{NaTcO}_{4}$ listed in Rard et al. 1999. The solubility of this phase was determined to be $7.14 \mathrm{~mol} / \mathrm{L}\left(706 \mathrm{~g}{ }^{99} \mathrm{Tc} / \mathrm{L}\right)$ at $25^{\circ} \mathrm{C}$ by Guerman (reported in Rard et al. 1999). To evaluate the possibility that this very soluble compound could have become incorporated within the čejkaite or $\mathrm{NaNO}_{3}$ phases in the sludge, the čejkaite solubility extracts were analyzed for ${ }^{99} \mathrm{Tc}$ (C-203 experiments only). The ${ }^{99} \mathrm{Tc}$ and ${ }^{238} \mathrm{U}$ results are shown in Table 4.2. The large percentages of ${ }^{99} \mathrm{Tc}$ compared with ${ }^{238} \mathrm{U}$ in the first two extractions strongly suggest that ${ }^{99} \mathrm{Tc}$ and ${ }^{238} \mathrm{U}$ are in separate phases. The dominant phase, čejkaite, clearly contains ${ }^{238} \mathrm{U}$, requiring another primary ${ }^{99} \mathrm{Tc}$ phase to be present.

Based on results from the selective extraction experiments, the recalcitrant fraction of ${ }^{99} \mathrm{Tc}$ in the C-203 and C-204 sludges is believed to be incorporated into an iron oxyhydroxide solid phase. The current conceptual model for ${ }^{99} \mathrm{Tc}$ release from this phase is that the ${ }^{99} \mathrm{Tc}$ will be released in proportion to the dissolution of the iron solid. The exact nature of the iron oxyhydroxide phase (or phases) is not known at this time, but these phases have been observed by SEM (Figures 3.12b, 3.17d, 3.18b, 3.19a,b). 
Table 4.2. $\quad{ }^{99} \mathrm{Tc}$ Concentrations Measured in Čejkaite Solubility Extracts

\begin{tabular}{||l|c|c|c||}
\hline \multicolumn{1}{|c|}{ Sample ID } & ${ }^{\mathbf{9 9}} \mathbf{T c}(\boldsymbol{\mu g} / \mathbf{m L})$ & ${ }^{\mathbf{9 9}} \mathbf{T c} \%$ & Cumulative \% U Dissolved \\
\hline \hline C-203 (1:1)-1 & 0.0660 & 64 & 3.4 \\
\hline C-203 (1:1)-2 & 0.0253 & 24 & 13.2 \\
\hline C-203 (1:1)-3 & 0.0090 & 8.7 & 27.6 \\
\hline C-203 (1:1)-4 & 0.0046 & 4.4 & 47.1 \\
\hline Total & 0.105 & 101 & 1.8 \\
\hline \hline C-203 (2:1)-1 & 0.0643 & 62 & 6.0 \\
\hline C-203 (2:1)-2 & 0.0255 & 25 & 13.8 \\
\hline C-203 (2:1)-3 & 0.0102 & 10 & 23.4 \\
\hline C-203 (2:1)-4 & 0.0043 & 4 & \\
\hline Total & 0.104 & 100 & \\
\hline
\end{tabular}

The solubility of the iron oxyhydroxide phase(s) will be modeled as ferrihydrite, the most soluble iron oxyhydroxide phase that is likely to occur in the tanks. As a result, this approach is considered conservative (from a groundwater impact perspective). The solubility of ferrihydrite was calculated for a $\mathrm{pH}$ of 8.2 and an ionic strength of 0.01 using the chemical equilibrium code MINEQL+ (Schecher and McAvoy 1998). The solubility of ferrihydrite under these conditions is $6.6 \times 10^{-9} \mathrm{~mol} / \mathrm{L}(0.37 \mu \mathrm{g} \mathrm{Fe} / \mathrm{L})$. Using the ratios of ${ }^{99} \mathrm{Tc}$ to $\mathrm{Fe}$ in the $\mathrm{C}-203$ and $\mathrm{C}-204$ sludges, the release of the recalcitrant portion of ${ }^{99} \mathrm{Tc}$ from these sludges was calculated to be $2.8 \times 10^{-13} \mathrm{~g} / \mathrm{L}(0.28 \mathrm{pg} / \mathrm{L})$ for C-203 sludge and $7.4 \times 10^{-13}$ $\mathrm{g} / \mathrm{L}(0.74 \mathrm{pg} / \mathrm{L})$ for $\mathrm{C}-204$ sludge. These extremely low release concentrations for the recalcitrant portion of ${ }^{99} \mathrm{Tc}$ indicate that it is reasonable to assume that this portion of ${ }^{99} \mathrm{Tc}$ is essentially immobile.

After closure, initial contact of water with the sludge will result in very high salt concentrations $\left(\mathrm{NaNO}_{3}\right.$ in particular) until these salts have been completely dissolved and transported away from the sludge. The initial high salt concentrations will affect ferrihydrite solubility. This effect has been neglected because the duration for which this will influence ferrihydrite solubility is relatively small. During this time the $\mathrm{TcO}_{4}{ }^{-}$concentrations leaching from the sludge will be dominated by the readilysoluble fraction of ${ }^{99} \mathrm{Tc}$ in the sludge. A summary of the release model data for ${ }^{99} \mathrm{Tc}$ is provided in Table 4.3. Included are data for ${ }^{99} \mathrm{Tc}$ and iron, listing the release form, concentrations in the sludge, concentrations in equilibrium with infiltration contacting the sludge, and the release control mechanism used for the conceptual model.

Table 4.3. Summary of ${ }^{99}$ Tc Release Model Data for C-203 and C-204 Sludge

\begin{tabular}{||l|l|l|l|l||}
\hline \multicolumn{1}{|c|}{ Tank } & \multicolumn{1}{|c|}{ Release Form } & \multicolumn{1}{c|}{ Sludge Conc. } & \multicolumn{1}{c|}{ Release Conc. } & \multicolumn{1}{c||}{ Release Control } \\
\hline \hline $\mathrm{C}-203$ & $\mathrm{NaTcO}_{4}$ & $0.074 \mu \mathrm{g} \mathrm{Tc} / \mathrm{g}$-sludge & $706 \mathrm{~g}^{99} \mathrm{Tc} / \mathrm{L}$ & $\mathrm{NaTcO}_{4}$ solubility \\
\hline $\mathrm{C}-203$ & $\mathrm{Fe}(\mathrm{OH})_{3}(\mathrm{~s})$ & $0.039 \mathrm{~g} \mathrm{Fe} / \mathrm{g}$-sludge & $0.37 \mu \mathrm{g} \mathrm{Fe} / \mathrm{L}$ & $\mathrm{Fe}(\mathrm{OH})_{3}(\mathrm{~s})$ solubility \\
\hline $\mathrm{C}-203$ & $\mathrm{TcO}_{4}{ }^{-}$in $\mathrm{Fe}(\mathrm{OH})_{3}(\mathrm{~s})$ & $0.030 \mu \mathrm{g} \mathrm{Tc} / \mathrm{g}$-sludge & $0.28 \mathrm{pg}{ }^{99} \mathrm{Tc} / \mathrm{L}$ & $\mathrm{Fe}(\mathrm{OH})_{3}(\mathrm{~s})$ solubility \\
\hline \hline $\mathrm{C}-204$ & $\mathrm{NaTcO}_{4}$ & $0.128 \mu \mathrm{g} \mathrm{Tc} / \mathrm{g}$-sludge & $706 \mathrm{~g}^{99} \mathrm{Tc} / \mathrm{L}$ & $\mathrm{NaTcO}_{4}$ solubility \\
\hline $\mathrm{C}-204$ & $\mathrm{Fe}(\mathrm{OH})_{3}(\mathrm{~s})$ & $0.13 \mathrm{~g} \mathrm{Fe} / \mathrm{g}$-sludge & $0.37 \mu \mathrm{g} \mathrm{Fe} / \mathrm{L}$ & $\mathrm{Fe}(\mathrm{OH})_{3}(\mathrm{~s})$ solubility \\
\hline $\mathrm{C}-204$ & $\mathrm{TcO}_{4}{ }^{-}$in $\mathrm{Fe}(\mathrm{OH})_{3}(\mathrm{~s})$ & $0.259 \mu \mathrm{g} \mathrm{Tc} / \mathrm{g}$-sludge & $0.74 \mathrm{pg}{ }^{99} \mathrm{Tc} / \mathrm{L}$ & $\mathrm{Fe}(\mathrm{OH})_{3}(\mathrm{~s})$ solubility \\
\hline
\end{tabular}




\subsection{Integration of C-203 and C-204 Release Data with Fate and Transport Modeling Codes}

The contaminant release models for ${ }^{238} \mathrm{U}$ and ${ }^{99} \mathrm{Tc}$ described in Sections 4.1 and 4.2 are based on the solubilities of minerals containing those contaminants. For the ${ }^{99} \mathrm{Tc}$-containing solids, equilibrium solubility is assumed constant during release; whereas, for the ${ }^{238} \mathrm{U}$-containing minerals the solubility is not constant. For both contaminants, more than one solid limits release to water during different stages of the conceptual model. Table 4.4 shows the conceptual model that must be incorporated into transport modeling codes to simulate the releases observed in the laboratory testing of the tank sludges. The stages are similar for both tanks, but the inventories of the contaminants and minerals are different, as shown in Tables 4.1 and 4.3. Also, the duration of the stages for ${ }^{238} \mathrm{U}$ and ${ }^{99} \mathrm{Tc}$ do not coincide. Because of the very soluble nature of the stage- 1 technetium solid compared with the stage- 1 uranium mineral, this stage will last longer for uranium than technetium. Alternatively, stage 2 for technetium release will last much longer than stages 2 and 3 for uranium release because of the low solubility of the technetium-containing mineral (modeled as ferrihydrite) at this stage. As a consequence of the complexity of the release of these contaminants, the transport code must have the flexibility of handling multiple minerals containing contaminants, and the code must have the capability of varying the solubilities of those minerals.

Table 4.4. Conceptual Contaminant Release Model for Tanks C-203 and C-204

\begin{tabular}{|c|l|l||}
\hline Stage of Release & \multicolumn{1}{|c||}{${ }^{238} \mathbf{U}$} & \multicolumn{1}{|c|}{ Tc } \\
\hline \hline 1 & $\begin{array}{l}\text { Čejkaite solubility limited until all } \\
\mathrm{NaNO}_{3} \text { dissolves }\end{array}$ & Very soluble ${ }^{99} \mathrm{Tc}$ mineral dissolves \\
\hline 2 & $\begin{array}{l}\text { Čejkaite solubility increases to } \\
\text { maximum value }\end{array}$ & $\begin{array}{l}\text { Very insoluble iron mineral controls } \\
\text { release }\end{array}$ \\
\hline 3 & $\begin{array}{l}\text { Non-čejkaite uranium mineral controls } \\
\text { release }\end{array}$ & \\
\hline
\end{tabular}




\subsection{Conclusions}

This report provides the results of laboratory tests on sludge samples from Hanford Tanks C-203 and C-204 and describes the development of source term release models for the primary contaminants of concern. The major conclusions from this work are discussed in this section.

The ${ }^{99} \mathrm{Tc}$ release model for C-203 and C-204 sludges is based on the concentrations and solubilities of technetium-bearing solids in contact with pore water migrating through the sludges. There are two stages of technetium release to solution:

- Initially, part of the ${ }^{99} \mathrm{Tc}$ is present in the sludge as a highly soluble solid phase. The composition of this solid is not known, but $\mathrm{NaTcO}_{4}$ has been used as a surrogate for this solid. The concentration of this solid is $0.074 \mu \mathrm{g}{ }^{99} \mathrm{Tc} / \mathrm{g}$-sludge in C-203 and $0.128 \mu \mathrm{g}{ }^{99} \mathrm{Tc} / \mathrm{g}$-sludge in C-204. The solubility of this solid for both tanks is $706 \mathrm{~g}{ }^{99} \mathrm{Tc} / \mathrm{L}$. The high solubility effectively allows all the ${ }^{99} \mathrm{Tc}$ from this source to dissolve in a very small quantity of water.

- After the soluble ${ }^{99} \mathrm{Tc}$ mineral is removed from the waste by dissolution, the remaining ${ }^{99} \mathrm{Tc}$ is recalcitrant because it is incorporated into a very insoluble iron mineral, which is assumed to be ferrihydrite for modeling purposes. The residual concentration of ${ }^{99} \mathrm{Tc}$ in $\mathrm{C}-203$ is $0.030 \mu \mathrm{g}$ ${ }^{99} \mathrm{Tc} / \mathrm{g}$-sludge; it is $0.259 \mu \mathrm{g}{ }^{99} \mathrm{Tc} / \mathrm{g}$-sludge in C-204. In this stage of release, the ferrihydrite must dissolve to release the trace amounts of ${ }^{99} \mathrm{Tc}$ found in its structure. Based on the concentration ratios of ${ }^{99} \mathrm{Tc}$ in the sludge/ferrihydrite and a calculated solubility of ferrihydrite for tank conditions, the release of ${ }^{99} \mathrm{Tc}$ from Tank C-203 during this stage is $0.28 \mathrm{pg}{ }^{99} \mathrm{Tc} / \mathrm{L}$ and for Tank C-204 it is $0.74 \mathrm{pg}$ ${ }^{99} \mathrm{Tc} / \mathrm{L}$. These low dissolved concentrations effectively eliminate movement of ${ }^{99} \mathrm{Tc}$ from these tanks at this stage.

Section 4.2 discusses the assumptions and uncertainties in these calculations.

The ${ }^{238} \mathrm{U}$ release model for C-203 and C-204 sludges is based on the concentrations and solubilities of uranium- and sodium-bearing minerals in contact with pore water migrating through the sludges. There are three stages of uranium release to solution:

- Initially, soluble čejkaite $\left[\mathrm{Na}_{4}\left(\mathrm{UO}_{2}\right)\left(\mathrm{CO}_{3}\right)_{3}\right]$ and sodium nitrate are present in the sludges at concentrations of $0.16 \mathrm{~g} \mathrm{U} / \mathrm{g}$-sludge and $0.22 \mathrm{~g} \mathrm{NaNO}_{3} / \mathrm{g}$-sludge for C-203 and $0.068 \mathrm{~g} \mathrm{U} / \mathrm{g}$-sludge and $0.04 \mathrm{~g} \mathrm{NaNO}_{3} / \mathrm{g}$-sludge for $\mathrm{C}-204$. The common ion effect due to $\mathrm{Na}^{+}$limits the solubility of čejkaite to $0.19 \mathrm{~g} \mathrm{U} / \mathrm{L}$ until all the $\mathrm{NaNO}_{3}$ is dissolved. The solubility of $\mathrm{NaNO}_{3}$ is constant at $629 \mathrm{~g} / \mathrm{L}$.

- After all the $\mathrm{NaNO}_{3}$ has dissolved, the solubility of čejkaite increases to $69 \mathrm{~g} \mathrm{U} / \mathrm{L}$ and dissolves the remaining čejkaite.

- A residual non-čejkaite uranium mineral present at a concentration of $0.058 \mathrm{~g} \mathrm{U} / \mathrm{g}$-sludge in C-203 and $0.013 \mathrm{~g} \mathrm{U} / \mathrm{g}$-sludge in C-204 controls the final release of uranium to pore water. The solubility of this solid is estimated at $0.42 \mathrm{~g} \mathrm{U} / \mathrm{L}$. 
Section 4.1 discusses the assumptions and uncertainties in these calculations.

- ${ }^{129}$ I was not measured above the estimated quantitation limit of $71.1 \mathrm{pCi} / \mathrm{g}$ in C-203 sludge using a modified $\mathrm{KOH}: \mathrm{KNO}_{3}$ water fusion extraction method. However, this extraction method was not successful at dissolving the entire sludge sample; therefore, the ${ }^{129}$ I concentration of the sludge has not been adequately determined. ${ }^{129}$ I was also analyzed in the water leaches from the single-contact tests. In all cases, ${ }^{129}$ I was not measured above the estimated quantitation limits, which were in the range of 18.7 to $30.6 \mathrm{pCi} / \mathrm{g}$-sludge. Because of the general lack of measurable ${ }^{129} \mathrm{I}$ in the sludge or water extracts, a release model was not developed for this potential contaminant.

- The concentrations of ${ }^{99} \mathrm{Tc}$ in C-203 sludge were $0.104 \mu \mathrm{g} / \mathrm{g}$ (fusion extraction) and $0.088 \mu \mathrm{g} / \mathrm{g}$ (acid digestion). ${ }^{238} \mathrm{U}$ concentrations in C-203 sludge were $218,000 \mu \mathrm{g} / \mathrm{g}$ (fusion extraction) and $195,000 \mu \mathrm{g} / \mathrm{g}$ (acid digestion). The concentrations of ${ }^{99} \mathrm{Tc}$ in C-204 sludge were $0.387 \mu \mathrm{g} / \mathrm{g}$ (fusion extraction) and $0.206 \mu \mathrm{g} / \mathrm{g}$ (acid digestion). ${ }^{238} \mathrm{U}$ concentrations in this tank were 80,200 $\mu \mathrm{g} / \mathrm{g}$ (fusion extraction) and 33,100 $\mu \mathrm{g} / \mathrm{g}$ (acid digestion). For these tank solids, it appears that the fusion extraction method provides a more complete quantitation of total concentrations.

- The sum of the ${ }^{239} \mathrm{Pu}$ and ${ }^{241} \mathrm{Am}$ isotopes in C-203 sludge measured by the fusion method was $4,039 \mathrm{nCi} / \mathrm{g}$, and by the EPA acid digestion method it was $2,470 \mathrm{nCi} / \mathrm{g}$. This would classify the sludge in Tank C-203 as TRU based on the DOE definition $(100 \mathrm{nCi} / \mathrm{g})$. The sum of the ${ }^{239} \mathrm{Pu}$ and ${ }^{241} \mathrm{Am}$ isotopes in C-204 sludge measured by the fusion method was $13.8 \mathrm{nCi} / \mathrm{g}$, and by the EPA acid digestion method it was $5.73 \mathrm{nCi} / \mathrm{g}$. These measurements are considered minimum values for C-204 and should not be used to classify the waste in this tank. The TRU values may be higher than measured because the TBP present in the waste was not completely digested during the measurements. TBP may have retained some of the TRU components.

- The predominant metals measured in C-203 sludge are ${ }^{238} \mathrm{U}(21.8 \mathrm{wt} \%), \mathrm{Na}(17 \mathrm{wt} \%), \mathrm{Fe}(3.9 \mathrm{wt} \%)$, and $\mathrm{Cr}(2.4 \mathrm{wt} \%)$. The predominant anions in this sludge are carbonate $(17.1 \mathrm{wt} \%)$, nitrate $(16.3 \mathrm{wt} \%)$, oxalate $(2.54 \mathrm{wt} \%)$, and nitrite $(0.8 \mathrm{wt} \%)$. The predominant metals in $\mathrm{C}-204$ sludge are $\mathrm{Fe}(12.7 \mathrm{wt} \%), \mathrm{Na}(9.1 \mathrm{wt} \%),{ }^{238} \mathrm{U}(8 \mathrm{wt} \%), \mathrm{Si}(3.6 \mathrm{wt} \%)$, and $\mathrm{Al}(2.8 \mathrm{wt} \%)$. The predominant anions in this sludge are carbonate $(8.32 \mathrm{wt} \%)$, nitrate $(2.93 \mathrm{wt} \%)$, and nitrite $(1.94 \mathrm{wt} \%)$. A major component of the $\mathrm{C}-204$ sludge is the organic compound TBP $(28.3 \mathrm{wt} \%)$.

- The water leachable amount of ${ }^{99} \mathrm{Tc}$ in $\mathrm{C}-203$ sludge ranged from 56.3 to $71.3 \%$ of the total ${ }^{99} \mathrm{Tc}$ in the sludge for the single-contact batch tests. The leachable percentage of ${ }^{99} \mathrm{Tc}$ increases with contact time. For Tank C-204, the water-leachable ${ }^{99} \mathrm{Tc}$ ranged from 28.0 to $33.9 \%$ of the total ${ }^{99} \mathrm{Tc}$. The lower leachability of ${ }^{99} \mathrm{Tc}$ in Tank C-204 may be associated with the higher Fe concentration (12.7 wt \%) in this tank compared with Tank C-203 (3.9 wt\% Fe). The lowest percentage of ${ }^{99} \mathrm{Tc}$ was released in the one-day contact test $(28 \%)$. Similar amounts were released at contact times of two weeks $(33.9 \%)$ and one month $(32.9 \%)$. For the water leach tests in which the water was periodically replaced with fresh water, most of the leachable ${ }^{99} \mathrm{Tc}$ occurred in the first contact stage. During subsequent stages, low percentages (below detection to $2.9 \%$ ) of ${ }^{99} \mathrm{Tc}$ were water leachable from the sludge. The recalcitrant nature of some of the ${ }^{99} \mathrm{Tc}(29$ to $72 \%)$ in Hanford tank sludges has 
been documented in previous water leach studies of sludge from Tank AY-102 (Lindberg and Deutsch 2003; Krupka et al. 2004).

- The water leachable amount of ${ }^{238} \mathrm{U}$ in C-203 sludge from the single-contact batch tests ranged from 70.4 to $75.8 \%$ of the total ${ }^{238} \mathrm{U}$ in the sludge and was generally insensitive to the leaching time. In the periodic water replenishment tests, there did appear to be a time dependence on ${ }^{238} U$ leachability. For the first five stages, in which contact time was two to three days per stage, the leachable amount decreased in the order $74.2 \%, 2.4 \%, 0.8 \%, 0.2 \%, 0.1 \%$; however, in stage $6 \mathrm{a}$, where the contact time was 65 days, the amount leachable increased to $0.8 \%$, and in stage $6 \mathrm{~b}$ ( 86 day contact) the value was $3.2 \%$. This suggests the presence of at least two uranium minerals (čejkaite plus possibly clarkeite) with different solubilities and dissolution rates in the C-203 sludge.

- The water leachable amount of ${ }^{238} \mathrm{U}$ in C-204 sludge for the single-contact batch tests ranged from 76.0 to $92.1 \%$ of the available ${ }^{238} \mathrm{U}$. These levels are within the range of analytical precision for these measurements suggesting that there is no time dependence for uranium leaching in the singlecontacting testing. For the periodic water-replenishment tests, almost all of the ${ }^{238} \mathrm{U}$ is leached in the first stage and there is a similar, although smaller, increase in stages $6 \mathrm{a}$ and $6 \mathrm{~b}$, as observed in testing C-203 sludge. However, as described above, the uranium release model for these two sludges is a three-stage process that is controlled by the solubilities of two uranium solids. Therefore, time (or pore water infiltration rate) is an important factor in uranium release.

- If a wet retrieval method is used for the sludge in these tanks, it is likely that a large fraction of the contaminants in the soluble portion of the sludge will be removed by the retrieval process. A wet sludge retrieval method could remove as much as $73 \%$ of the uranium in Tank C-203 and $84 \%$ of the uranium in C-204. This method would also remove as much as $52 \%$ of the ${ }^{99} \mathrm{Tc}$ in Tank $\mathrm{C}-203$ and $25 \%$ of the ${ }^{99} \mathrm{Tc}$ in $\mathrm{C}-204$.

- Sodium is the only metal that appears to be almost completely water leachable from both sludge samples. Phosphorus also appears to be highly leachable (52.5 to 66\%) from C-204 sludge. Other elements that have water leachabilities greater than $10 \%$ in one or more of the tests are $\mathrm{Al}, \mathrm{Ca}, \mathrm{Cr}$, $\mathrm{Si}$, and $\mathrm{Sr}$. Elements with lower water leachabilities are $\mathrm{Fe}, \mathrm{Mn}, \mathrm{Ni}$, and $\mathrm{Pb}$.

- The solubility of čejkaite in water in contact with the tank sludges was found to be strongly influenced by the dissolution of other sludge solids (primarily sodium nitrate and sodium carbonate) that provide common ions ( $\mathrm{Na}$ and $\mathrm{CO}_{3}{ }^{2-}$ ) to the solution. Čejkaite solubility increased by a factor of six (from 0.03 to $0.18 \mathrm{~mol} / \mathrm{L}$ ) as the other sodium and carbonate minerals were dissolved and removed from the system. The common ion effect is important from a contaminant release standpoint because it can suppress the solubility of minerals containing contaminants, thereby limiting their release to solution.

- Čejkaite $\left[\mathrm{Na}_{4}\left(\mathrm{UO}_{2}\right)\left(\mathrm{CO}_{3}\right)_{3}\right]$ is the dominant crystalline phase identified by XRD analysis of the sludges from Tank C-203. If all the uranium in the sludge $(\sim 218,000 \mathrm{ppm})$ is attributed to čejkaite, then this mineral forms about $50 \%$ of the C-203 sludge solids. The yellow nugget material separated from the C-203 sludge was also found to be predominantly čejkaite; however, the XRD pattern showed the possible presence of nitratine (soda niter, $\mathrm{NaNO}_{3}$ ) in the nuggets. The lack of a čjkaite 
pattern in the XRD analysis of the solids after two weeks of leaching with water shows the high solubility of čejkaite in water. The XRD pattern for the water-leached sludge suggests the presence of a small amount of poorly crystalline clarkeite $\left[\mathrm{Na}\left[\left(\mathrm{UO}_{2}\right) \mathrm{O}(\mathrm{OH})\right]\left(\mathrm{H}_{2} \mathrm{O}\right)_{0-1}\right]$ in the residual solid.

- Čejkaite $\left[\mathrm{Na}_{4}\left(\mathrm{UO}_{2}\right)\left(\mathrm{CO}_{3}\right)_{3}\right]$ is also the dominant crystalline phase identified by XRD analysis of the sludges from Tank C-204. If all the uranium in the sludge $(\sim 80,000 \mathrm{ppm})$ is attributed to čejkaite, this mineral forms about $18 \%$ of the C-204 sludge solids. As for Tank C-203 sludge, all of the čejkaite dissolved in the water leach tests, where the solid:solution ratio was 1:100. The XRD pattern for the water-leached sludge showed the presence of quartz and feldspar in the residual solid. No clarkeite was detected in the C-204 material.

- SEM/EDS analysis of C-203 sludge showed the presence of predominantly čejkaite, which has distinctive acicular and rod-shaped crystals in this sludge. Some of the čejkaite crystals were bound in a matrix with a sodium nitrate solid, possibly nitratine $\left(\mathrm{NaNO}_{3}\right)$. The yellow nugget material found in this sludge was a combination of čejkaite and this sodium nitrate phase. A second uranium mineral with a smooth surface was identified at lower concentration in this sludge. This mineral may be represented by the composition $\mathrm{Na}_{2} \mathrm{U}_{2} \mathrm{O}_{7}$ or clarkeite $\mathrm{Na}\left[\left(\mathrm{UO}_{2}\right) \mathrm{O}(\mathrm{OH})\right]\left(\mathrm{H}_{2} \mathrm{O}\right)_{0-1}$. Micrographs of the water-leached sludge did not show the readily soluble čejkaite but did show the presence of the apparently less soluble/reactive clarkeite.

- SEM/EDS analysis of C-204 sludge showed that it is composed of čejkaite and an amorphous solid composed of $\mathrm{Na}, \mathrm{Al}, \mathrm{P}, \mathrm{O}$, and possibly $\mathrm{C}$. (A separate organic analysis of this sludge showed it to have a TBP concentration of $28 \%$, which probably accounts for much of this amorphous material.) Within this mix of čejkaite needles and the amorphous phase, there were particles, sometimes aggregates, of an Fe oxide that often also contained $\mathrm{Cr}$ and $\mathrm{Ni}$. $\mathrm{Na}_{2} \mathrm{U}_{2} \mathrm{O}_{7} /$ clarkeite was not detected in the SEM mounts of the water leached C-204 sludge. Water leaching completely eliminated the čejkaite crystals from this sludge. The remaining solid consisted of a variety of nondescript particles, many of which had pitted and altered surfaces. These particles include phases composed of Si oxide (probably quartz, which is consistent with the XRD results), Fe oxide (often as globular or botryoidal aggregates), Na-Al silicate, and a porous-looking material (or aggregate of sub-micrometer particles) that typically contained $\mathrm{Al}, \mathrm{Cr}, \mathrm{Fe}, \mathrm{Na}, \mathrm{Ni}, \mathrm{Si}, \mathrm{U}, \mathrm{P}, \mathrm{O}$, and $\mathrm{C}$. Cavities were found on the surface of the iron oxides. The cavities likely represent the locations of solids that preferentially dissolved in the water. These solids had been trapped in the iron mineral during its precipitation. If these solids contained contaminants, the release of these contaminants to water would be limited by dissolution of the low solubility iron oxides in future infiltrating water. This process likely accounts for at least some of the release of the recalcitrant ${ }^{99} \mathrm{Tc}$ found in these sludges.

Testing of sludges from Tanks C-203 and C-204 has shown the need for future development of analytical techniques and release models. These future developments include:

- Improved ${ }^{129}$ I extraction and measurement techniques

- Evaluation of actinide partitioning in TBP and extraction methods for analysis of total actinides in sludge 
- Testing of contaminant release from sludge under environmental conditions other than fresh water infiltration (e.g., cement grout/sludge system)

- Release model for chromium from residual sludge. 


\subsection{References}

Agnew SF, P Baca, R Corbin, K Jurgensen, and B Young. 1995a. Tank Layer Model (TLM). LA-UR94-4269 Rev. 1, Los Alamos National Laboratory, Los Alamos, NM.

Agnew SF, P Baca, R Corbin, T Duran, and K Jurgensen. 1995b. Waste Status and Transaction Record Summary for the Northeast Quadrant. WHC-SD=WM-TI-615 Rev. 2, Los Alamos National Laboratory, Los Alamos, NM.

Agnew SF, J Boyer, RA Borbin, TB Duran, JR FitzPatrick, KA Jurgensen, TP Ortiz, and BL Young. 1996. Hanford Tank Chemical and Radionuclide Compositions: HDW Model Rev. 3. LA-UR-96-858, Los Alamos National Laboratory, Los Alamos, NM.

ASTM. 1998. D2216-98 Standard Test Method for Laboratory Determination of Water (Moisture) Content of Soil and Rock by Mass. American Society for Testing and Materials, West Conshohocken, PA.

ASTM. 1999. D3987-85 Standard Test Method for Shake Extraction of Solid Waste with Water. American Society for Testing and Materials, West Conshohocken, PA.

Blake CA, CF Coleman, KB Brown, DG Hill, RS Lowrie, and JM Schmitt. 1956. "Studies in the Carbonate-Uranium System.” J. Am. Chem. Soc., 78: 5978-5983.

Brevick CH, LA Gaddis, and WW Pickett. 1994. Historical Tank Content Estimate for the Northeast Quadrant of the Hanford 200 East Area. WHC-SD-WM-ER-349 Rev 0A, ICF Kaiser Hanford Company, Richland, WA.

Brown CF, KN Geiszler, MJ Lindberg, and WJ Deutsch. 2004. "Analysis of 129I by Inductively Coupled Plasma Mass Spectrometry: A Comparison of Analytical Methods and Techniques." 227th National Meeting of the American Chemical Society, Anaheim, CA. PNNL-SA-41108, Pacific Northwest National Laboratory, Richland, WA.

Burakov BE, EE Strykanova, and EB Anderson. 1997. "Secondary Uranium Minerals on the Surface of Chernobyl 'Lava'." Scientific Basis for Nuclear Waste Management XX, WJ Gray and IR Triay (eds.), Vol. 465, pp. 1309-1311. Materials Research Society, Pittsburgh, PA.

Cantrell KJ, RJ Serne, and GV Last. 2003. Hanford Contaminant Distribution Coefficient Database and Users Guide. PNNL-13895 Rev. 1, Pacific Northwest National Laboratory, Richland, WA.

Clesceri LS, AE Greenberg, and AD Eaton. 1998. Standard Methods for the Examination of Water and Wastewater, 20th Edition. American Public Health Association, American Water Works Association, and Water Environment Federation, Washington, DC.

Conner JM. 1996. Tank Characterization Report for Single-Shell Tank 241-C-204. WHC-SD-WM-ER-479 Rev. 0, Westinghouse Hanford Company, Richland, WA. 
De Lorenzo, DS, AT DiCenso, DB Hiller, KW Johnson, JH Rutherford, DJ Smith, and BC Simpson. 1994. Tank Characterization Reference Guide. WHC-SD-WM-TI-648 REV 0, prepared for Westinghouse Hanford Company by Los Alamos Technical Associates, Kennewick, WA.

EPA (U.S. Environmental Protection Agency). 2000. "Method 3050B. Acid Digestion of Sediments, Sludges, and Soils," Rev. 2. Test Methods for Evaluating Solid Wastes: Physical/Chemical Methods. EPA SW-846, Third Ed., Vol. I, Section A, Chapter 3 (Inorganic Analytes), pp. 3050B-1-3050B-12. U.S. Environmental Protection Agency, Office of Solid Waste and Emergency Response, Washington, DC. Available at: http://www.epa.gov/epaoswer/hazwaste/test/pdfs/3050b.pdf.

Finch RJ, and RC Ewing. 1997. "Clarkeite: New Chemical and Structural Data." American Mineralogist, 82:607-619.

Fiskum SK, CJ Barinaga, JP Bramson, KJ Carson, and JR DesChane. 2000. Inorganic and Radiochemical Analysis of 241-C-104 Tank Waste. PNNL-13364 (WTP-RPT-007-Rev. 0) (formerly BNFL-RPT-043), Pacific Northwest National Laboratory, Richland, WA.

General Electric Company (GE). 1951. Uranium Recovery Technical Manual. HW-19140. General Electric Company, Richland, WA.

Herting DL, RW Warrant, and GA Cooke. 2002. Identification of Solid Phases in Saltcake from Hanford Site Waste Tanks. HNF-11585, Rev. 0 (HNF-EDC-02-12376), Fluor Hanford, Inc., Richland, WA.

Johnson ME. 2003. Origin of Wastes in C-200 Series Single-Shell Tanks. RPP-15408, CH2M HILL Hanford Group, Richland WA.

Krupka KM, WJ Deutsch, MJ Lindberg, KJ Cantrell, NJ Hess, HT Schaef, and BW Arey. 2004. Hanford Tanks 241-AY-102 and 241-BX-101: Sludge Composition and Contaminant Release Data. PNNL-14614, Pacific Northwest National Laboratory, Richland, WA.

Lindberg MJ and WJ Deutsch. 2003. Tank 241-AY-102 Data Report. PNNL-14344, Pacific Northwest National Laboratory, Richland, WA.

Ondruš P, R Skála, F Veselovský, J Sejkora, and C Vitti. 2003. “Čejkaite, the Triclinic Polymorph of $\mathrm{Na}_{4}\left(\mathrm{UO}_{2}\right)\left(\mathrm{CO}_{3}\right)_{3}$ - A New Mineral from Jáchymov, Czech Republic.” Amer. Mineral., 88(4):686-693.

Ondruš P, F Veselovský, R Skála, I Císarová, J Hlousek, J Fryda, I Vavrín, J Čejka, and A Gabašová. 1997. "New Naturally Occurring Phases of Secondary Origin from Jáchymov (Joachimsthal)." J. Czech Geol. Soc., 42:77-108.

Oosterhof H, RM Geertman, GJ Wikamp, and GM van Rosmalen. 1999. "The growth of sodium nitrate from mixtures of water and isopropoxyethanol.” J. Crystal Growth, 198/199:754-759.

Rapko BM and GJ Lumetta. 2000. Status Report on Phase Identification in Hanford Tank Sludges. PNNL-13394, Pacific Northwest National Laboratory, Richland, WA. 
Rard JA, MH Rand, G Anderegg, H Wanner. 1999. Chemical Thermodynamics of Technetium, MCA Sandino and E Osthols, eds. Elsevier, New York.

Schecher WD and DC McAvoy. 1998. MINEQL+ A Chemical Equilibrium Modeling System, Version 4.0 for Windows, User's Manual. Environmental Research Software, Hallowell, ME.

Schulz WW, LL Burger and JD Nauratil. 1984. Science and Technology of Tributyl Phosphate, Vol. III. Applications of Tributyl Phosphate in Nuclear Fuel Processing. CRC Press, Inc., Boca Raton, FL.

Simpson BC. 1994. Tank 241-T-111 Characterization Report. WHC-EP-0806, Westinghouse Hanford Company, Richland, WA.

Smith GL, DJ Bates, RW Goles, LR Greenwood, RC Lettau, GF Piepel, MJ Schweiger, HD Smith, MW Urie, and JJ Wagner. 2001. Vitrification and Product Testing of C-104 and AZ-102 Pretreated Sludge Mixed with Flowsheet Quantities of Secondary Wastes. PNNL-13452, Pacific Northwest National Laboratory, Richland, WA.

Strachan DM, HT Schaef, MJ Schweiger, KL Simmons, LJ Woodcock, and MK Krouse. 2003. "A Versatile and Inexpensive XRD Specimen Holder for Highly Radioactive or Hazardous Specimens." Powder Diffraction, 18 (1):23-28.

Temer DJ and R Villarreal. 1995. Sludge Washing and Alkaline Leaching Tests on Actual Hanford Tank Sludge: A Status Report. LAUR-95-2070, Los Alamos National Laboratory, Los Alamos, NM.

Temer DJ and R Villarreal. 1996. Sludge Washing and Alkaline Leaching Tests on Actual Hanford Tank Sludge: FY 1996 Results. LAUR-96-2839, Los Alamos National Laboratory, Los Alamos, NM.

Temer DJ and R Villarreal. 1997. Sludge Washing and Alkaline Leaching Tests on Actual Hanford Tank Sludge: FY 1997 Results. LAUR-97-2889, Los Alamos National Laboratory, Los Alamos, NM.

Traina SJ, P Grandinetti, GE Brown Jr, CC Ainsworth, JE Szecsody, I Yamakawa, S Prasad, J Warner, Y He, and J Catalano. 2001. Immobilization of Radionuclides in the Hanford Vadose Zone by Incorporation in Solid Phases. 2001 Progress Report. Environmental Management Science Program (EMSP), Washington, DC. Available at: http://emsp.em.doe.gov/EMSPprojects1996_2002/Subsurface/700812001.pdf

Um W, RJ Serne, and KM Krupka. 2004. "Linearity and Reversibility of Iodide Adsorption on Sediments from Hanford, Washington, Under Water-Saturated Conditions." Water Research, 38:20092016. 


\section{Appendix A}

\section{X-Ray Diffraction Patterns for Sludge Samples and Natural Specimen of Čejkaite}




\section{Appendix A}

\section{X-Ray Diffraction Patterns for Sludge Samples and Natural Specimen of Čejkaite}

This appendix presents the as-measured and background-subtracted X-ray powder diffraction (XRD) patterns for the unleached (raw) and water-leached C-203 (jar 19649) and C-204 (jar 19650) sludge samples, solids remaining at the end of certain extraction tests and solubility experiments (see Table 2.3), and čejkaite $\left[\mathrm{Na}_{4}\left(\mathrm{UO}_{2}\right)\left(\mathrm{CO}_{3}\right)_{3}\right]$ particles removed from a natural mineral specimen. The instrumentation and procedures used for measuring, subtracting background, and interpreting the XRD patterns for these materials are described in the main report. The vertical axis in each of the following patterns represents the intensity of the XRD peaks. For comparison to the background signal in the as-measured XRD patterns included in this appendix, Figure A.1 shows the XRD pattern for collodion film measured in the absence of any sludge material.

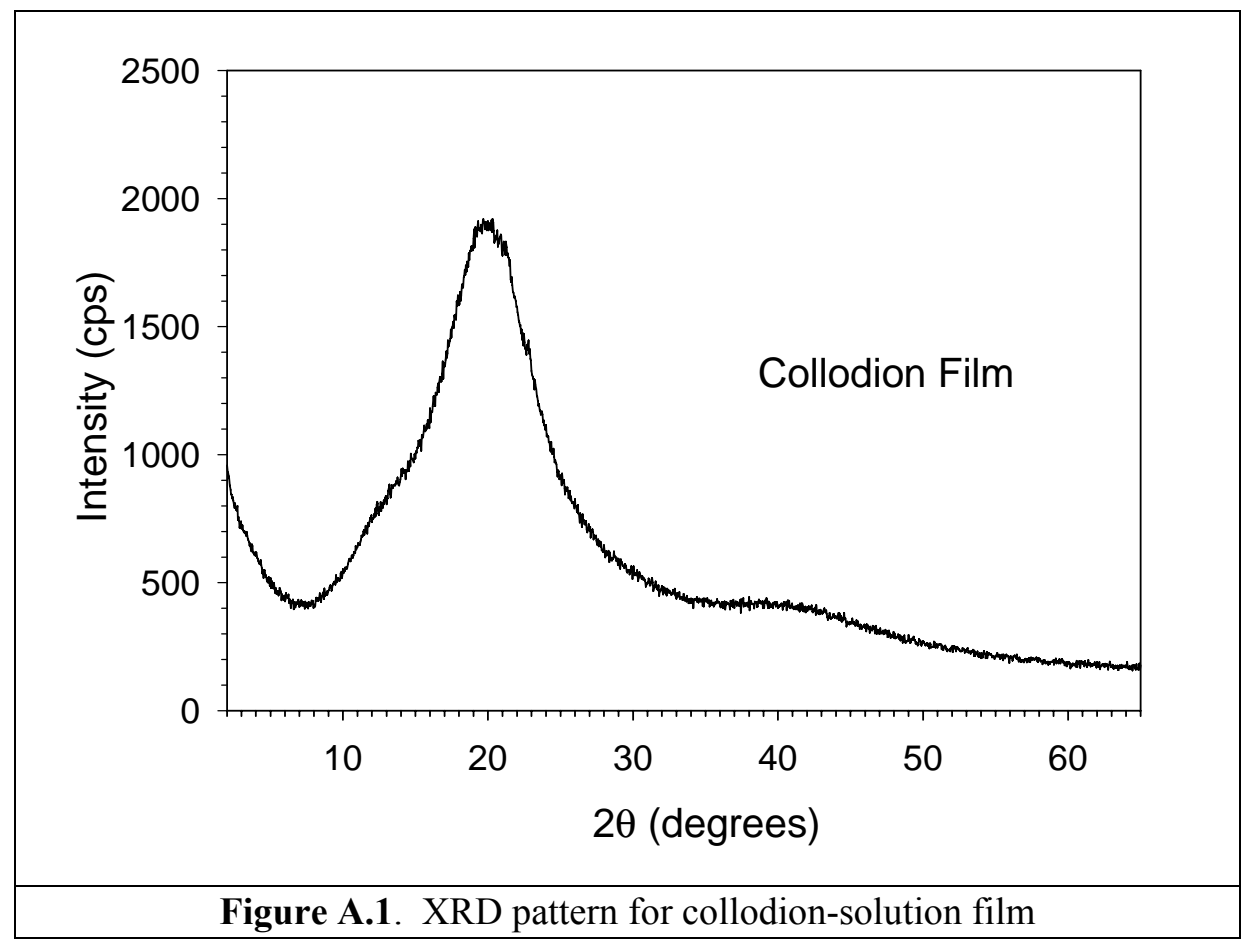

A. 1 


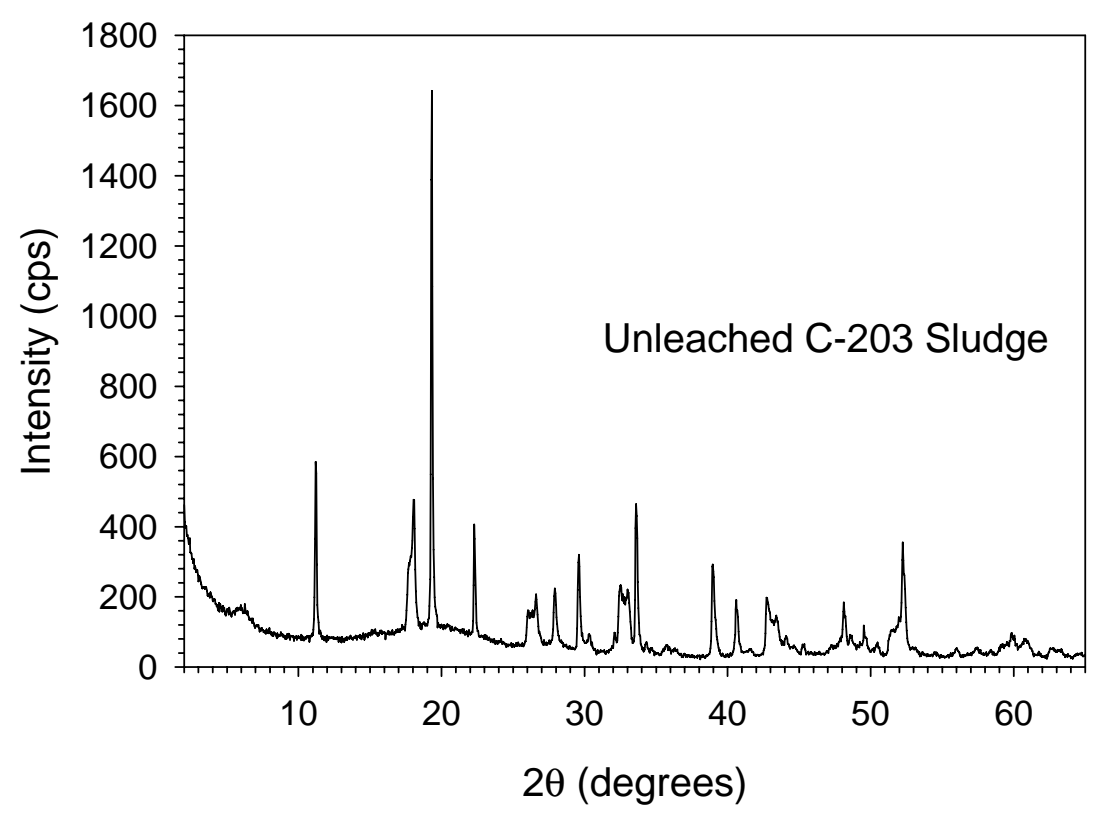

Figure A.2. As-measured XRD pattern (without background subtraction) for unleached C-203 (jar 19649) sludge

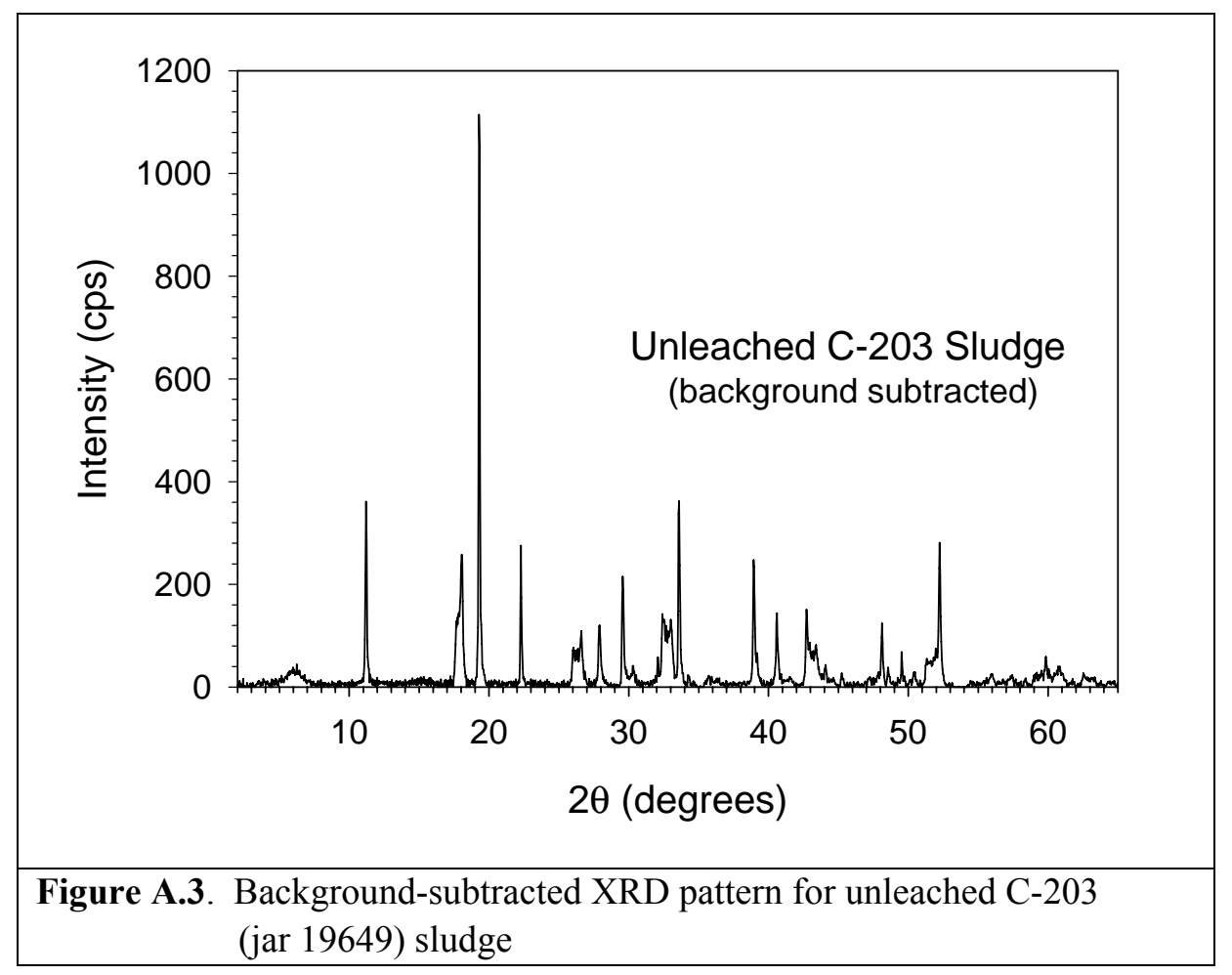

A. 2 


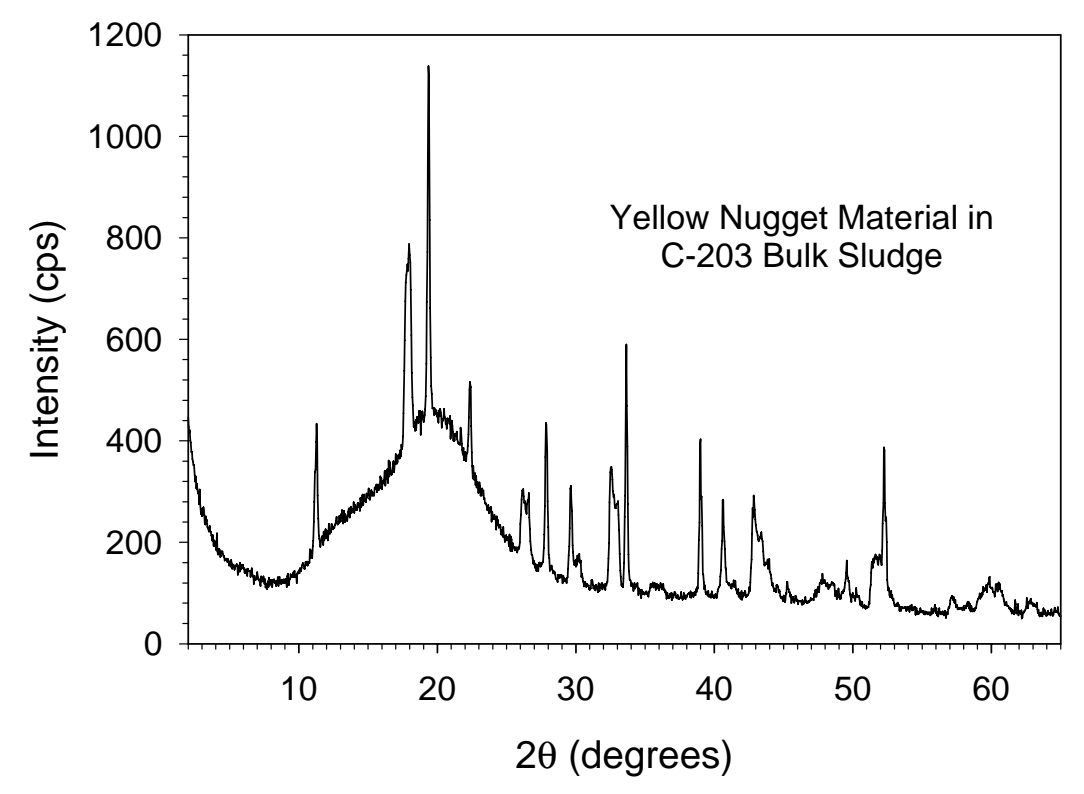

Figure A.4. As-measured XRD pattern (without background subtraction) for unleached yellow nuggets from C-203 (jar 19649) sludge

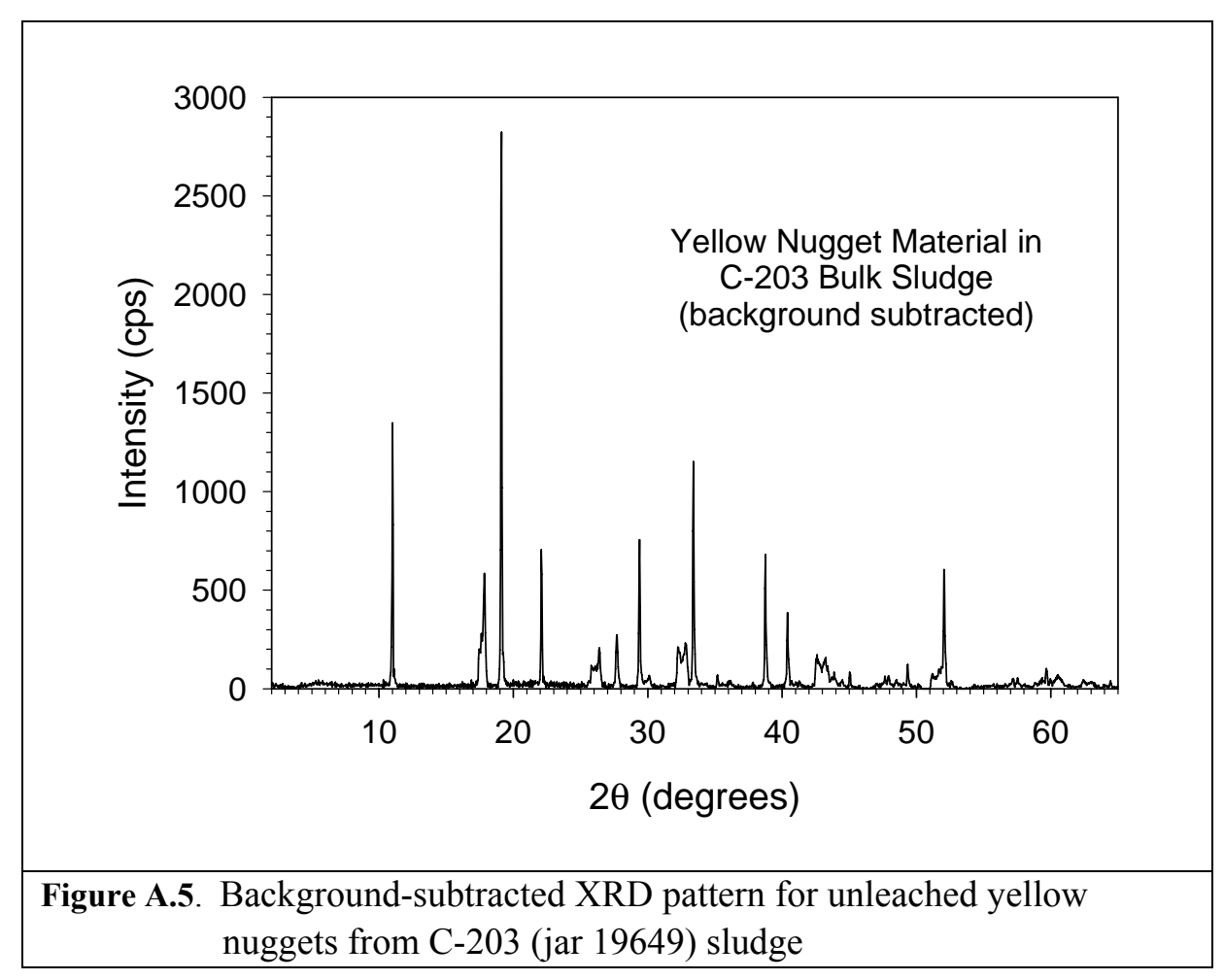

A.3 


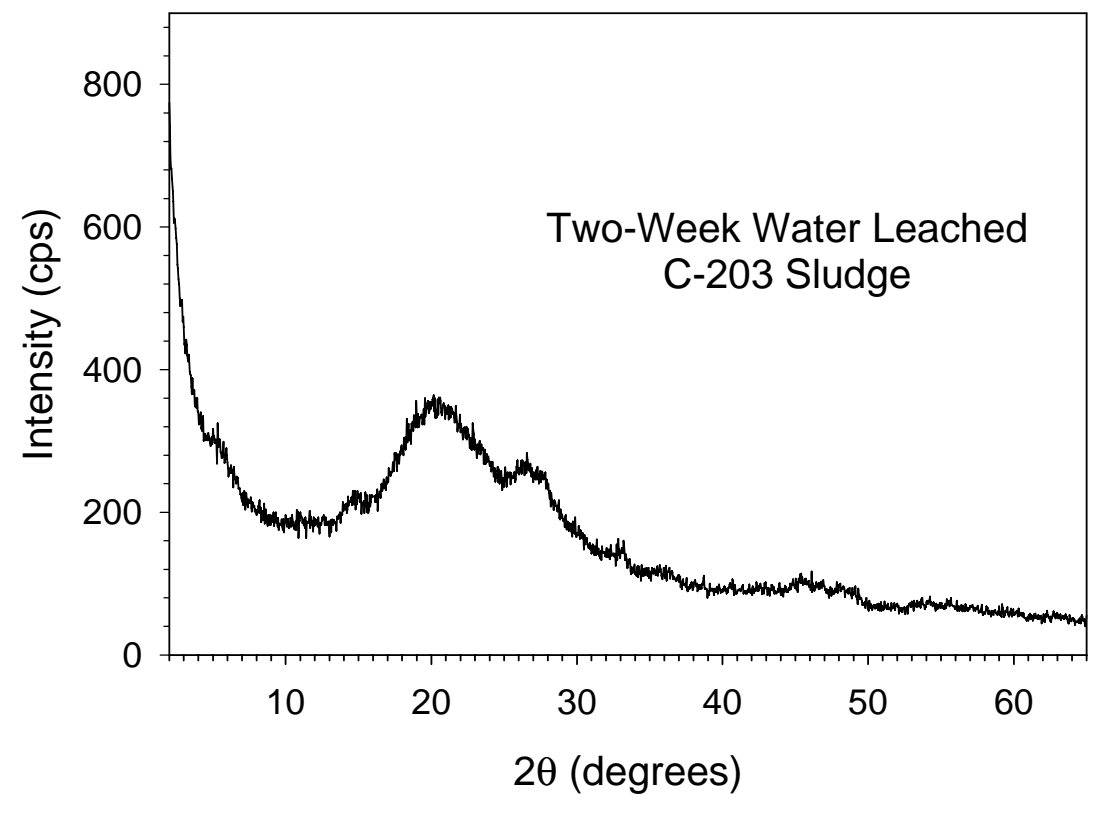

Figure A.6. As-measured XRD pattern (without background subtraction) for 2-week water leached C-203 (jar 19649) sludge

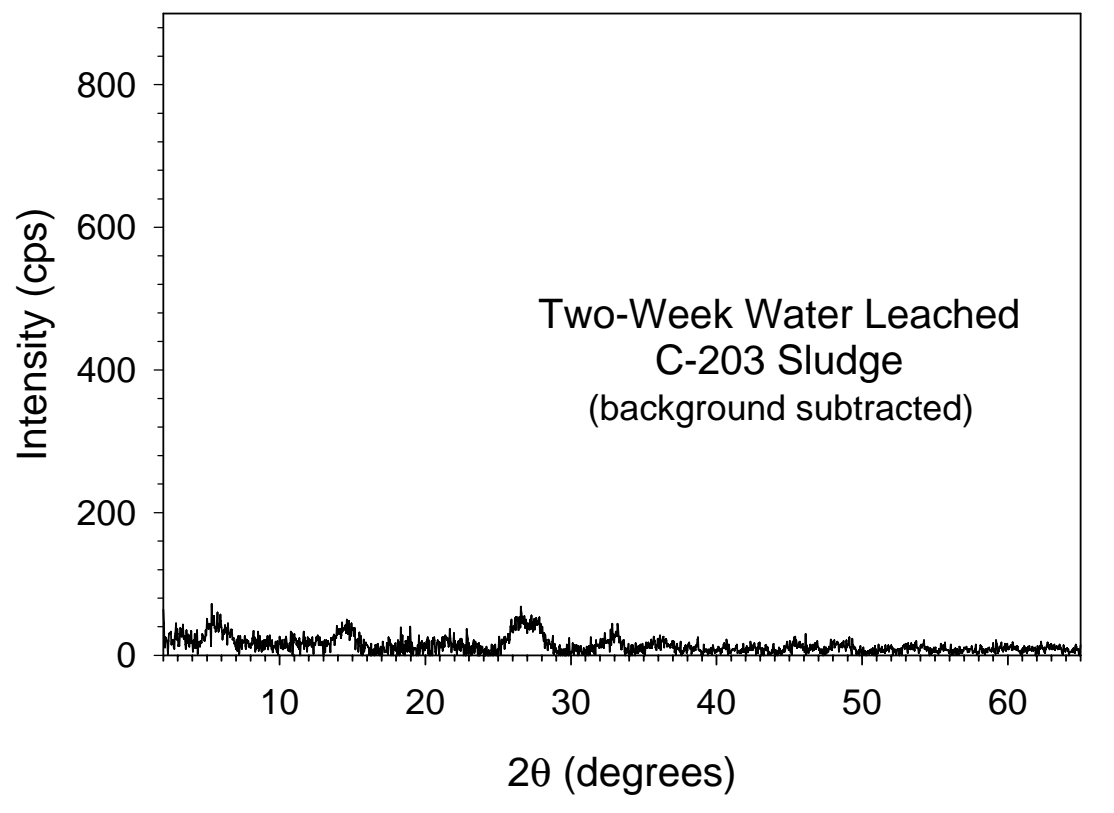

Figure A.7. Background-subtracted XRD pattern for 2-week water leached C-203 (jar 19649) sludge 


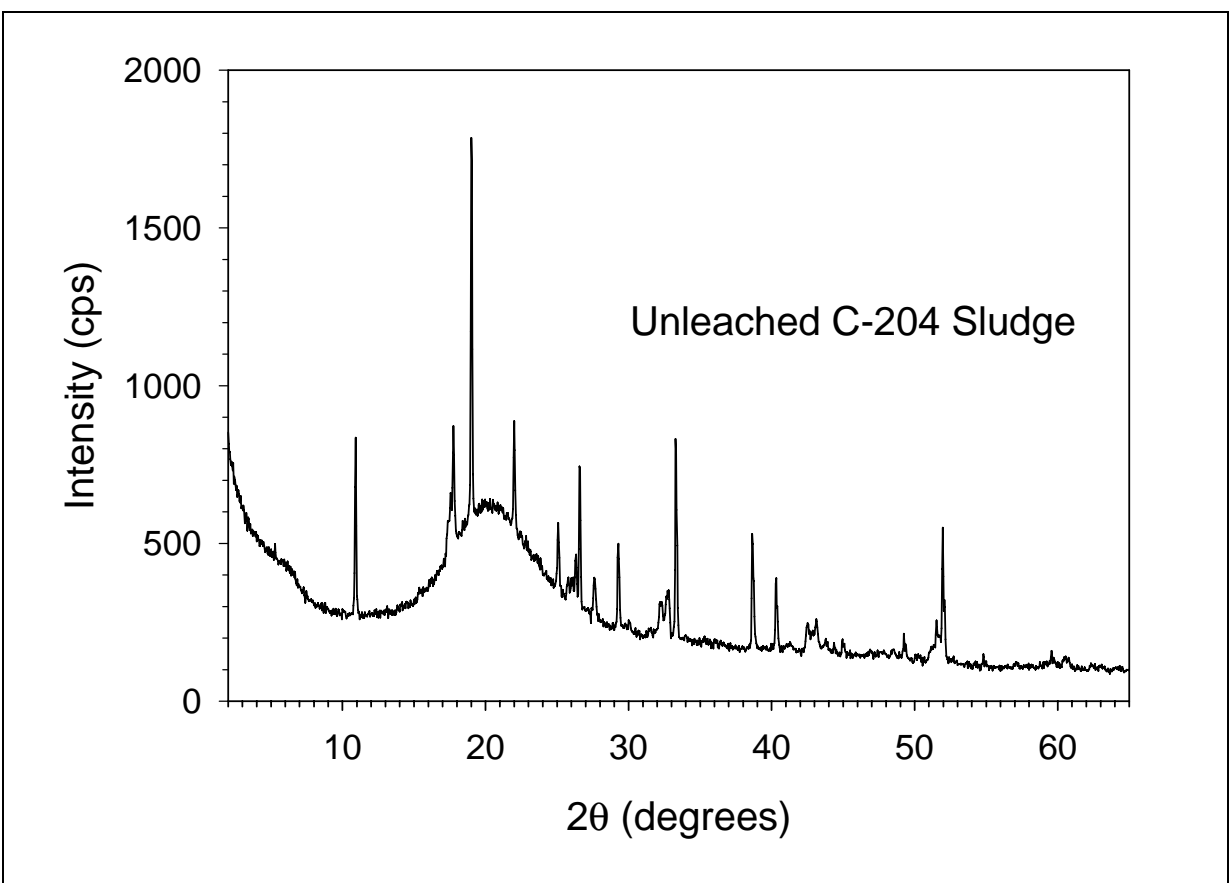

Figure A.8. As-measured XRD pattern (without background subtraction) for unleached C-204 (jar 19650) sludge

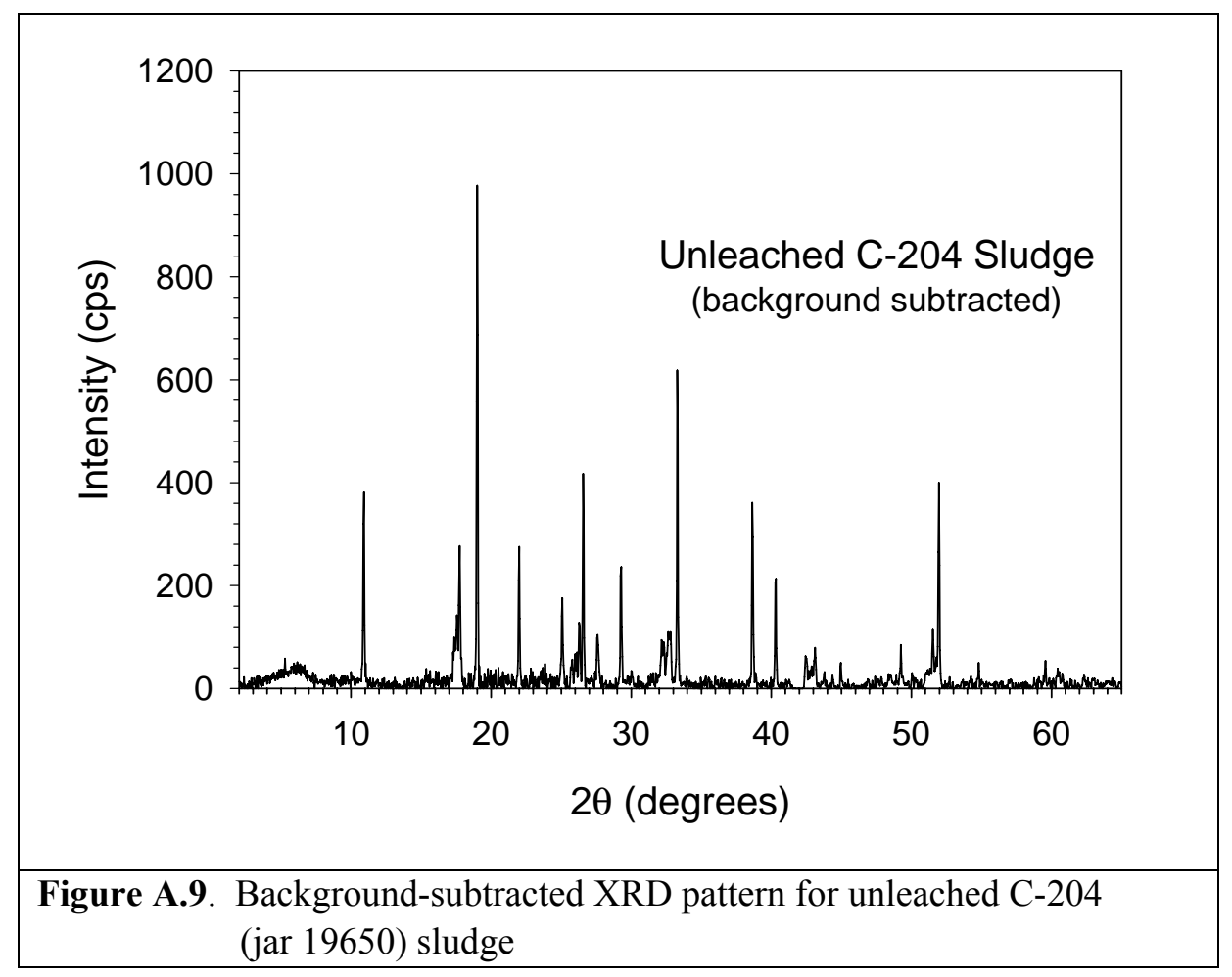

A.5 


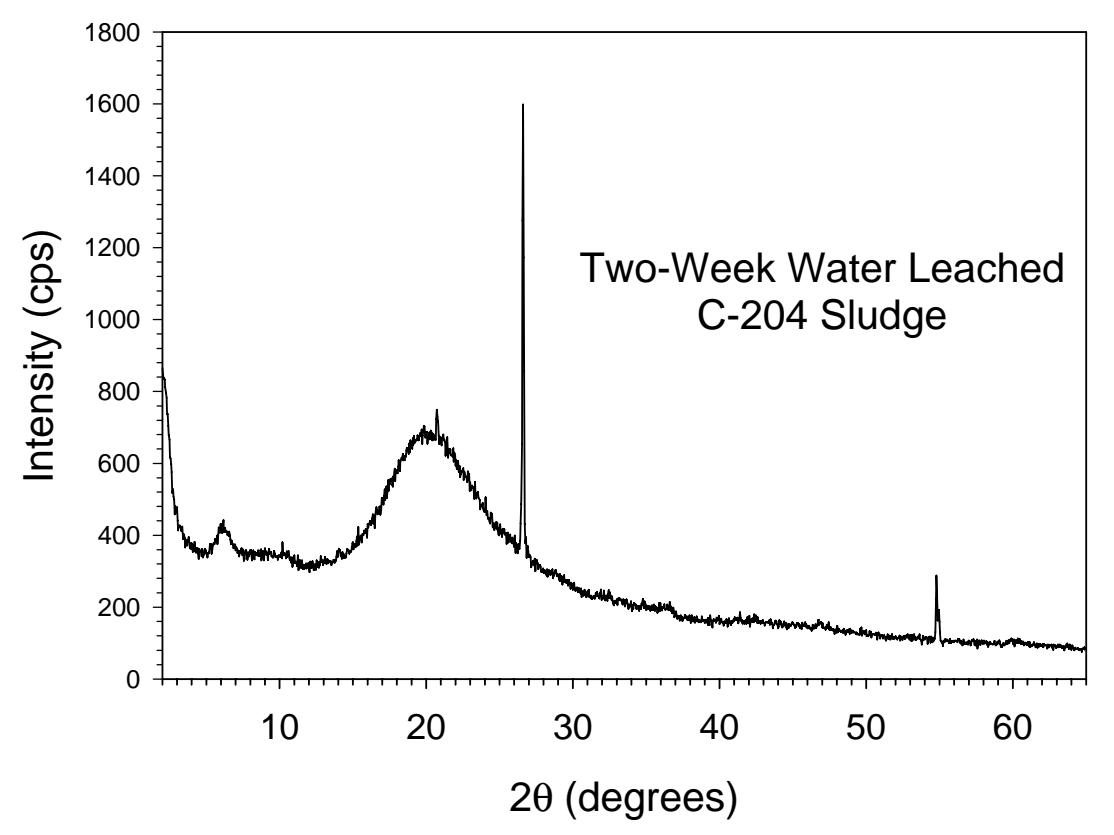

Figure A.10. As-measured XRD pattern (without background subtraction) for 2-week water leached C-204 (jar 19650) sludge

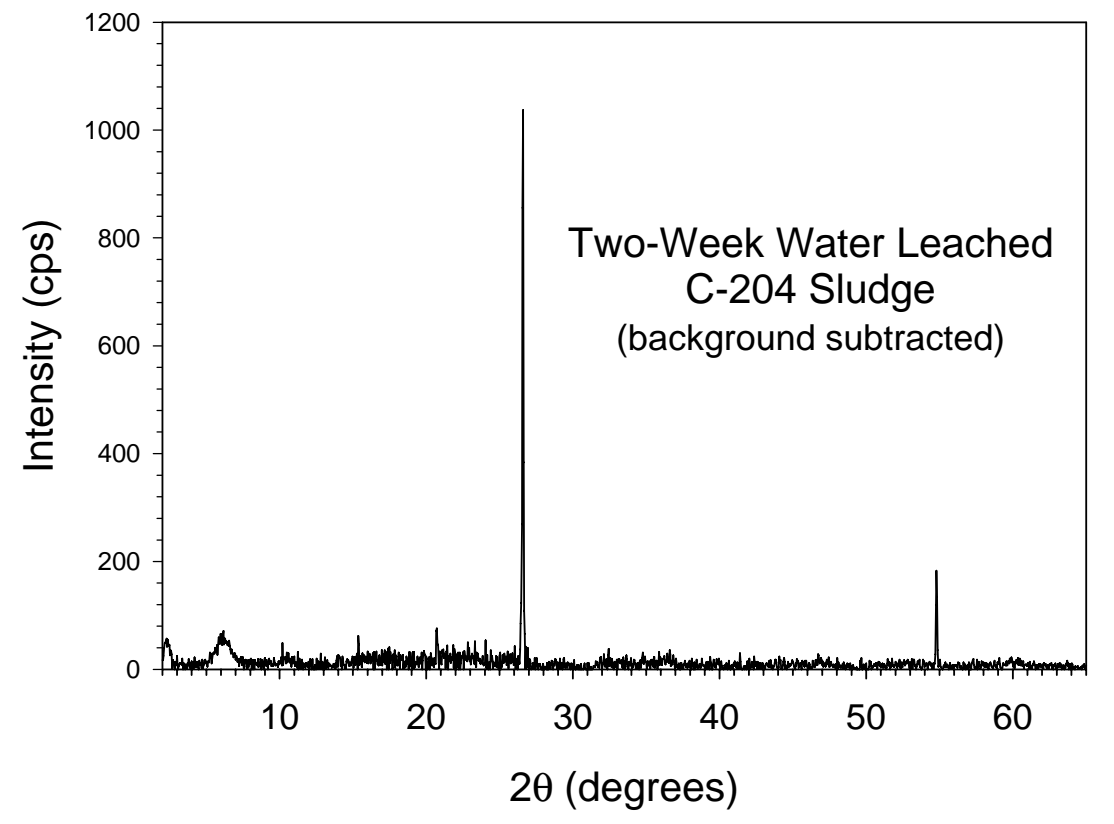

Figure A.11. Background-subtracted XRD pattern for 2-week water leached C-204 (jar 19650) sludge 


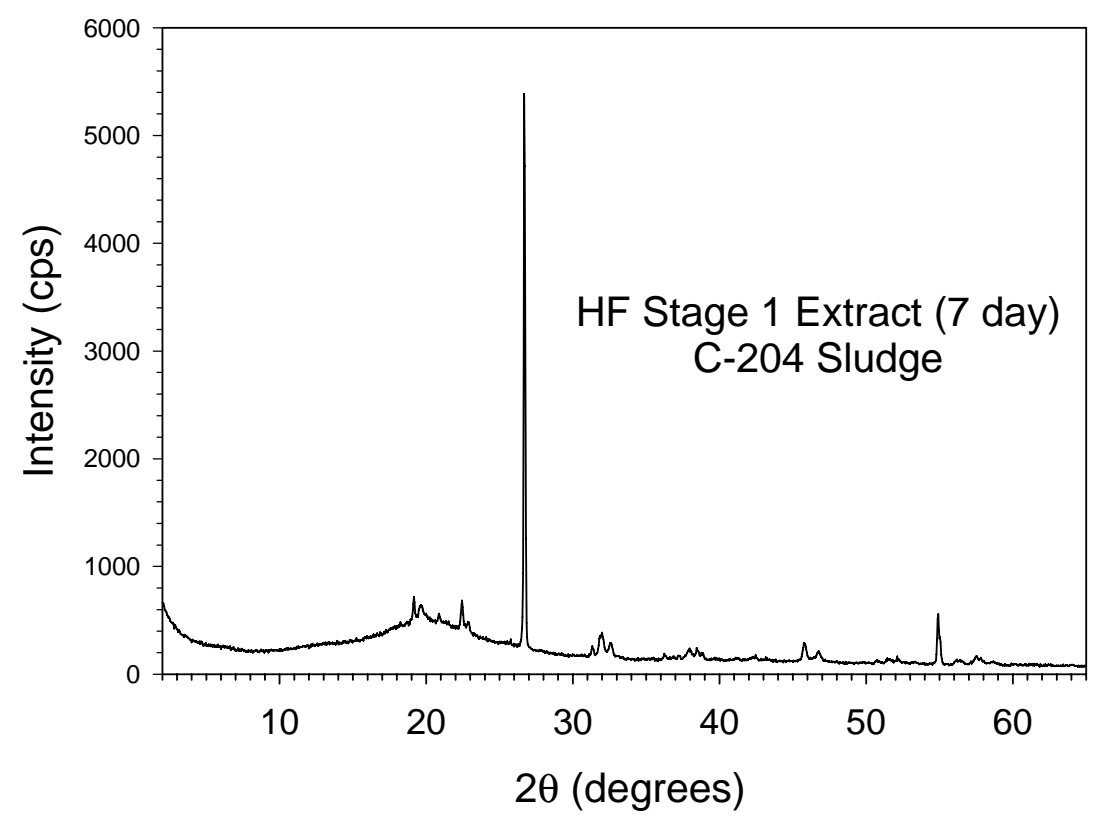

Figure A.12. As-measured XRD pattern (without background subtraction) for solid from HF Stage 1 extraction (7 day) C-204 (jar 19650) sludge

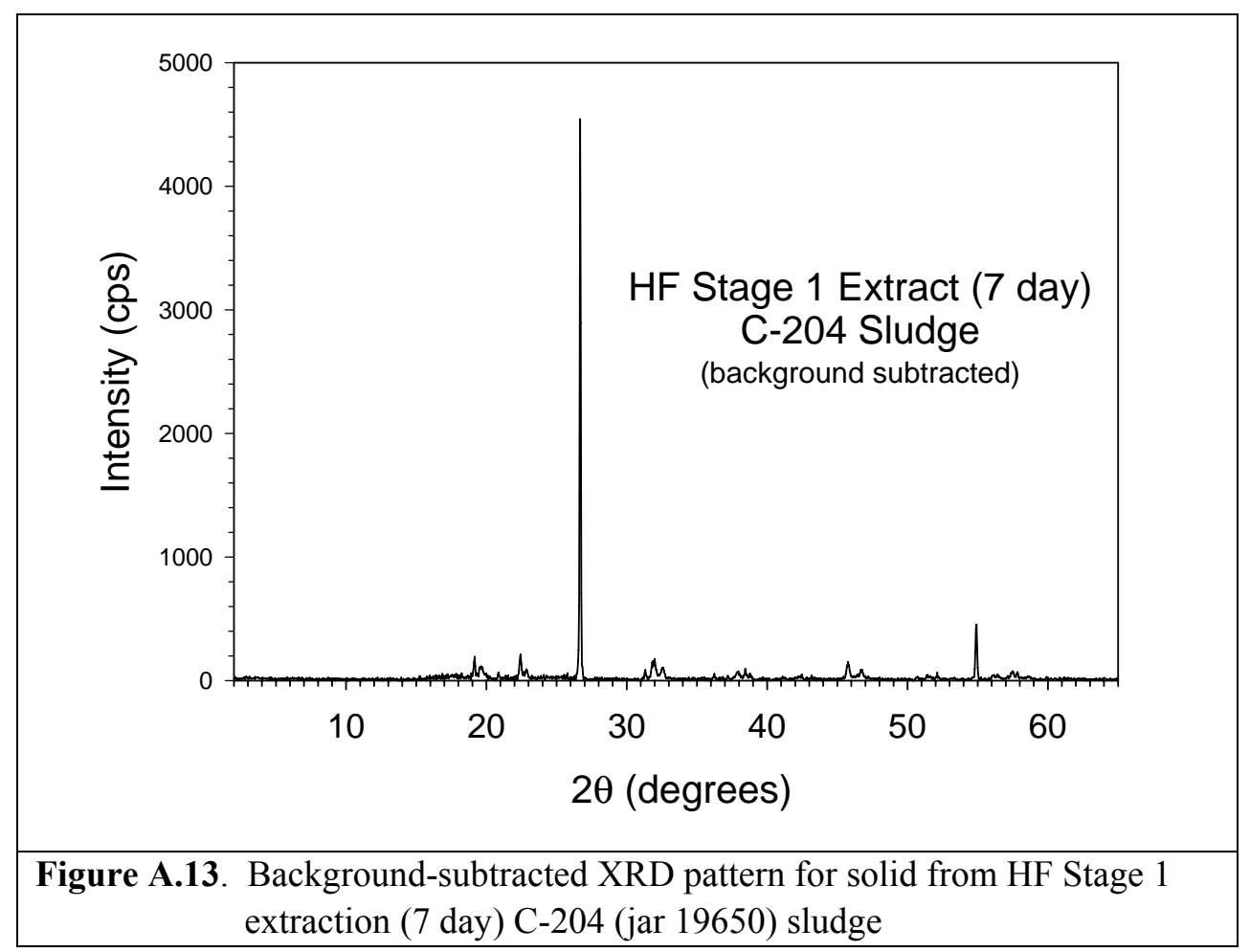

A. 7 


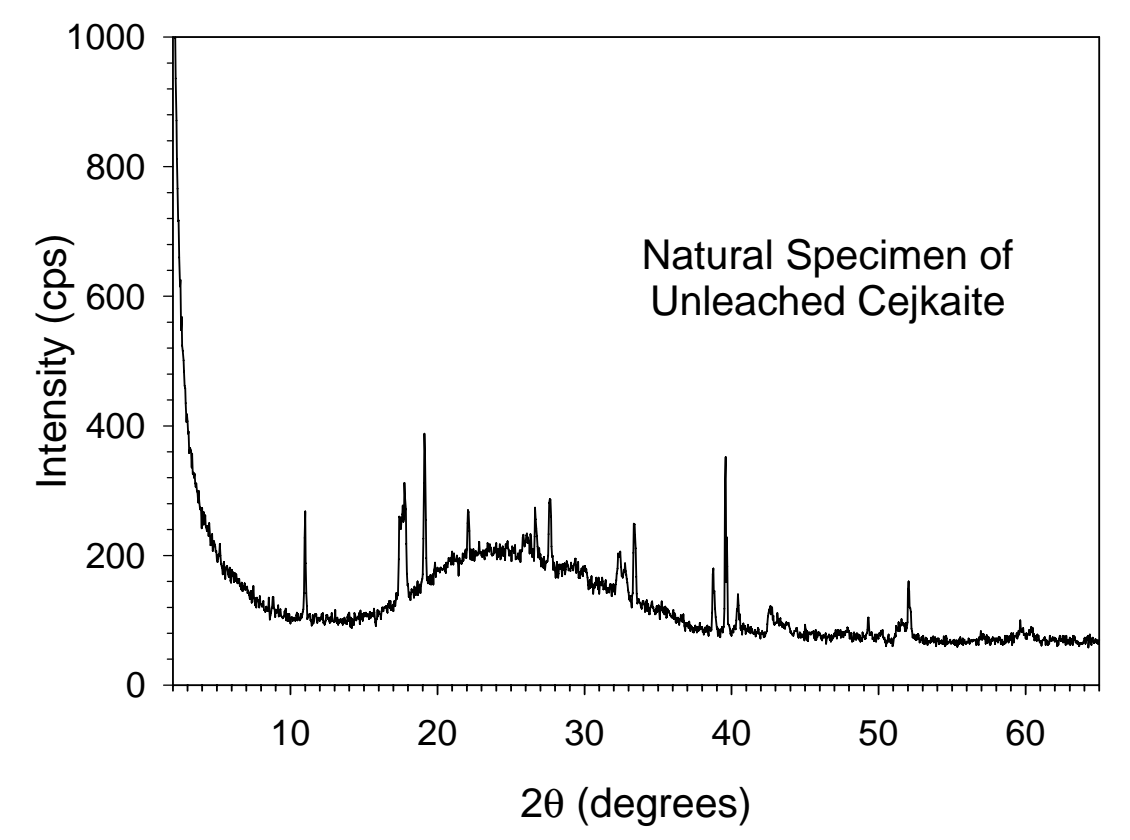

Figure A.14. As-measured XRD pattern (without background subtraction) for unleached natural specimen of čejkaite

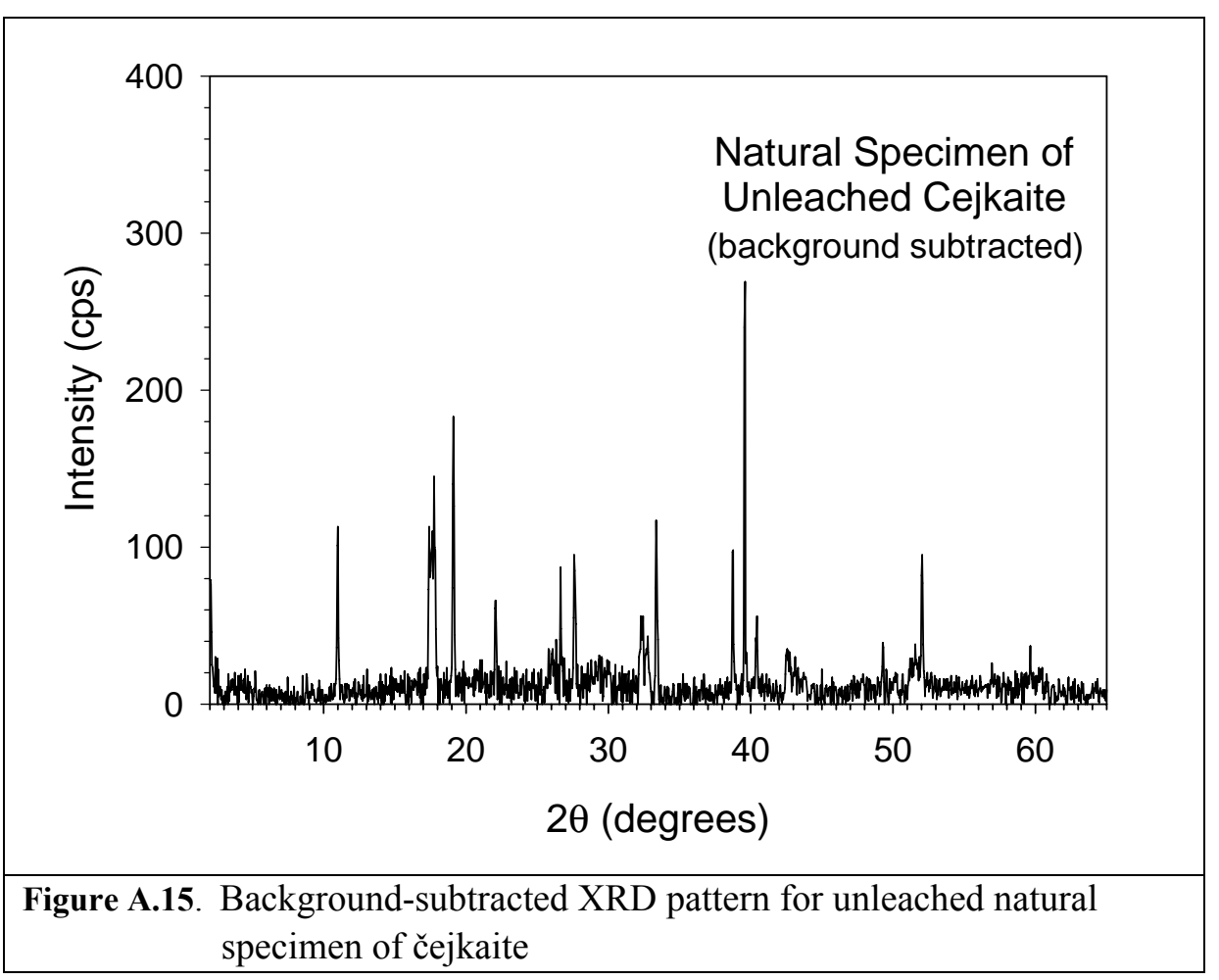




\section{Appendix B}

SEM Micrographs and EDS Spectra for C-203 Sludge Samples 


\section{Appendix B}

\section{SEM Micrographs and EDS Spectra for C-203 Sludge}

This appendix includes the scanning electron microscope (SEM) micrographs and the energydispersive X-ray spectrometry (EDS) spectra and composition summary tables for samples of the unleached (raw), unleached yellow-nugget material, water-leached, and reaction products remaining the 1:1 solubility experiments for C-203 (jar 19649) residual tank waste. The EDS composition summary tables list the qualitative compositions calculated with and without inclusion of the emission peak for carbon for the unleached and two-week water leached C-203 sludge samples. The operating conditions for the SEM and procedures used for mounting the SEM samples are described in Section 2.4 of the main report.

The name of each SEM digital image file, sample identification number, and a size scale bar are given, respectively, at the bottom left, center, and right of each SEM micrograph in this appendix. Micrographs labeled by "bse" to the immediate right of the digital image file name indicate that the micrograph was collected with backscattered electrons. Areas identified by a letter and/or outlined by a dashed-line square in a micrograph designate sample material that was imaged at higher magnification, which is typically shown in figure(s) that immediately follow in the series for that sample.

Areas labeled by "eds" in the following SEM micrographs in this appendix identify locations of particles for which EDS spectra were recorded. The "eds" label given with each EDS spectrum correspond to the same "EDS" label used in the SEM micrographs for this sample.

\section{B.1 Unleached C-203 Bulk Sludge}

Two mounts of unleached (raw) of C-203 (jar 19649) bulk residual tank waste were analyzed by SEM/EDS. The SEM micrographs for the first mount (19649-1) of C-203 sludge are shown in Figures B.1 through B.8. The EDS spectra for this mount are given in Figures B.9 through B.11. The SEM micrographs for the second mount (19649-2) of C-203 sludge are shown in Figures B.12 through B.23, and the EDS spectra for the second mount are given in Figures B.24 through B.26. 


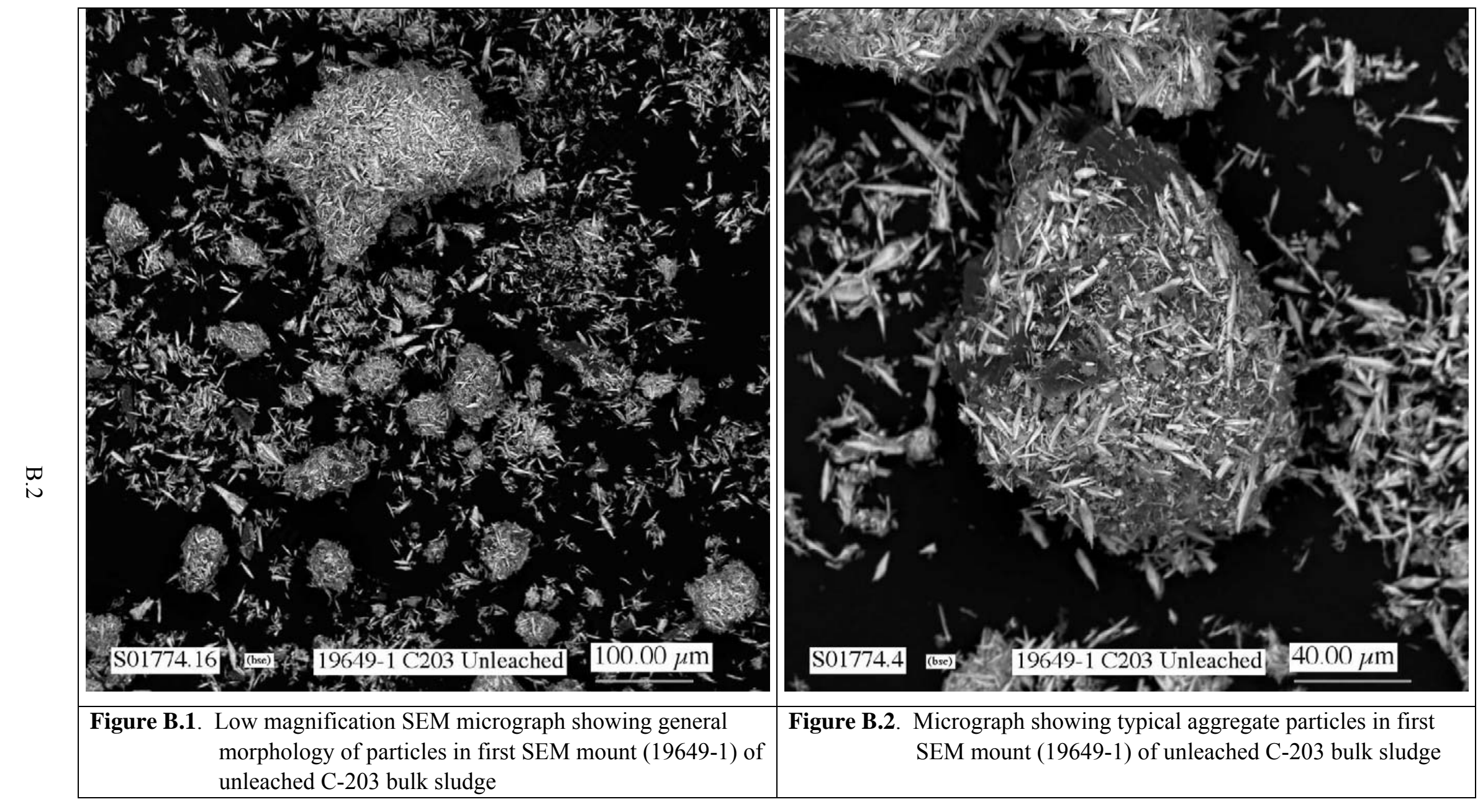




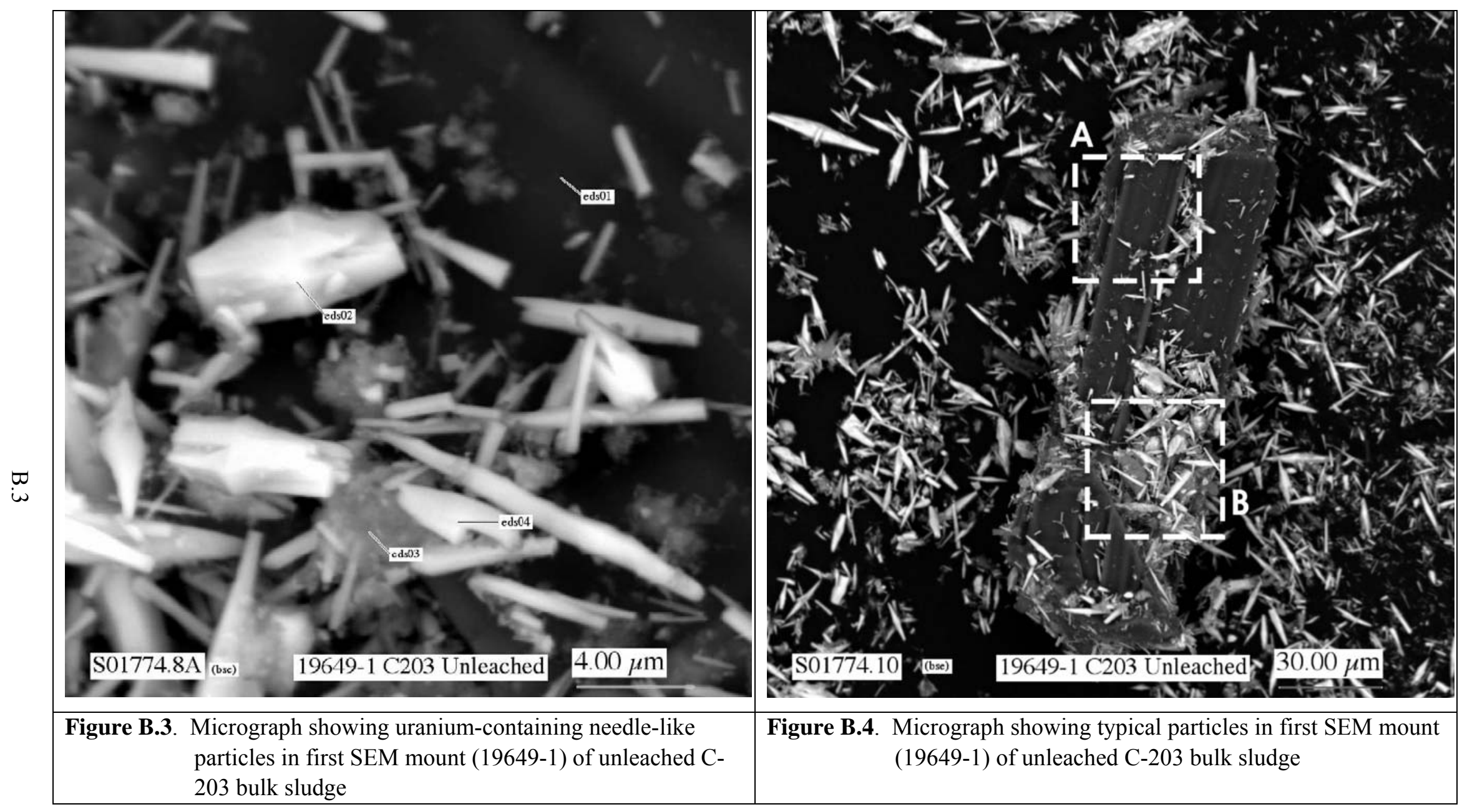




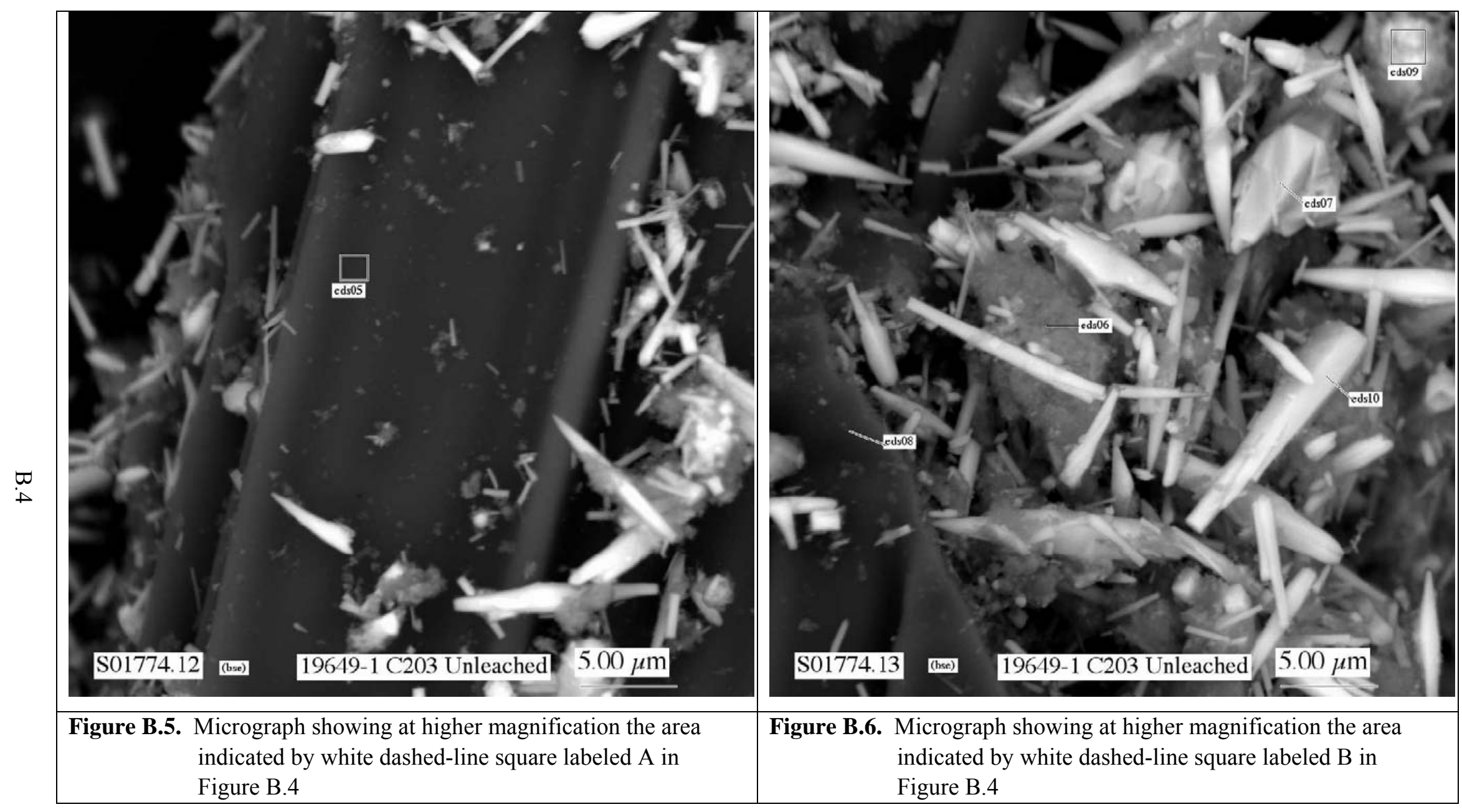




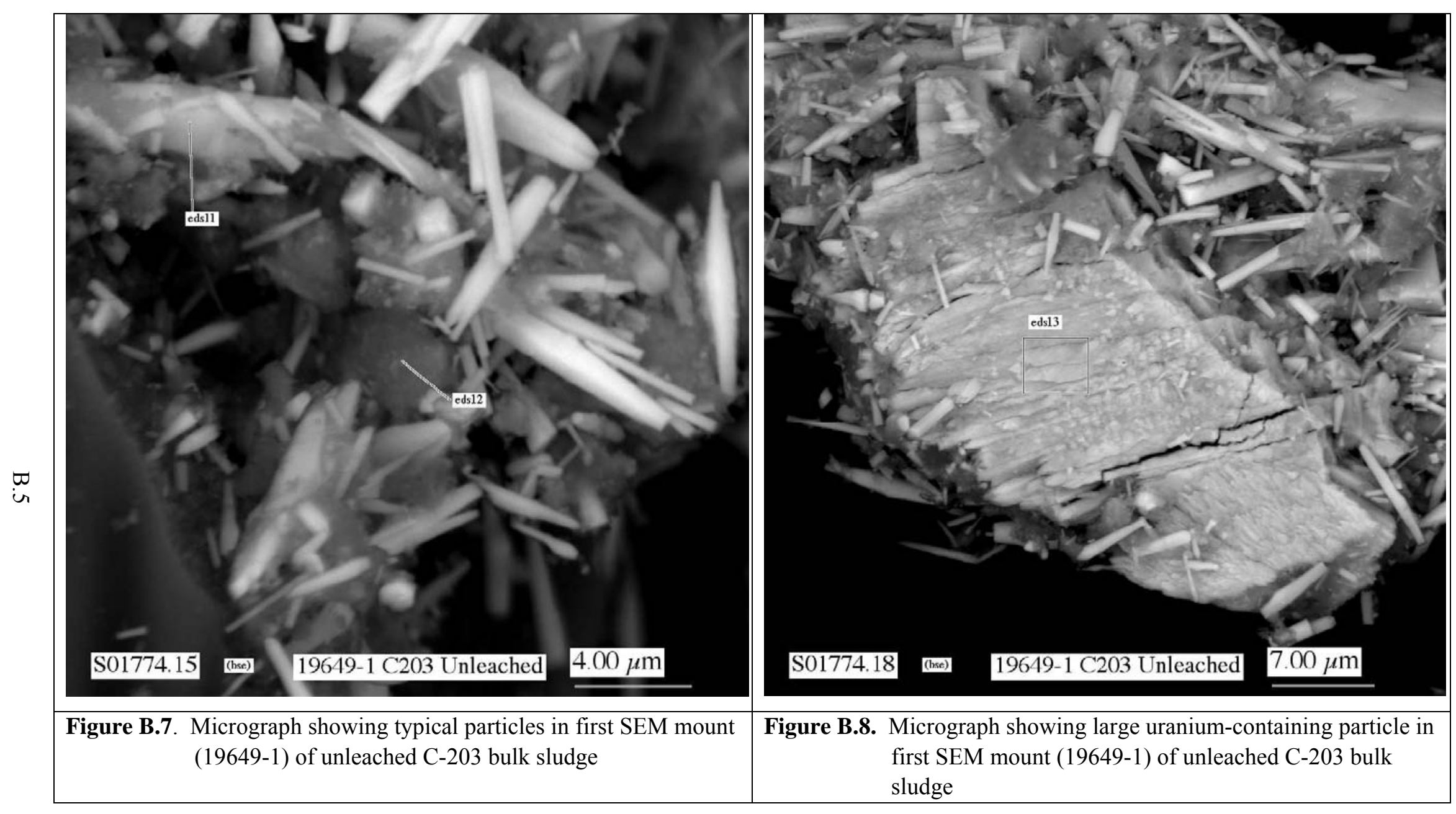




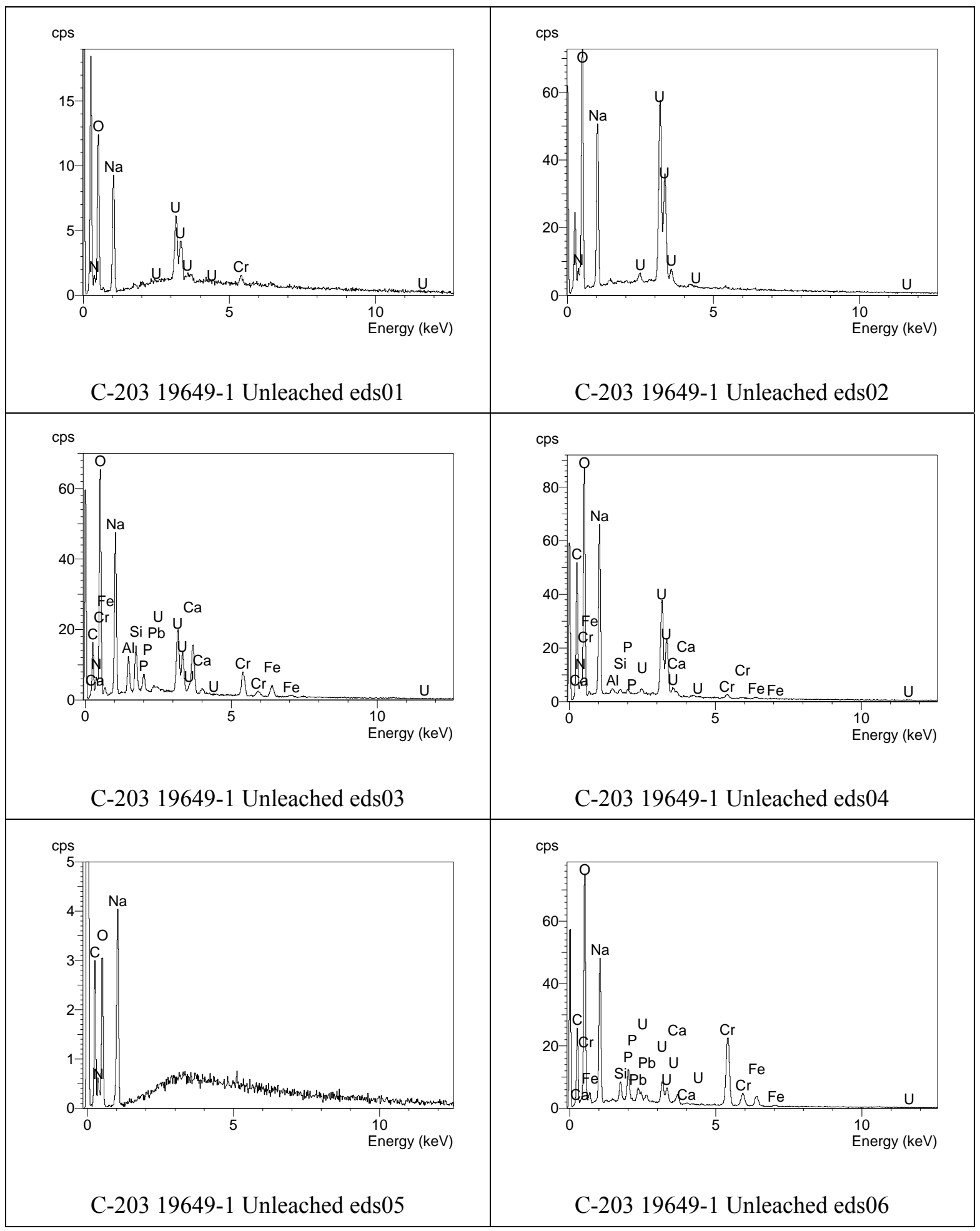

Figure B.9. EDS spectra for analyses eds01 through eds06 for particles in the first SEM mount (19649-1) of unleached C-203 bulk sludge 


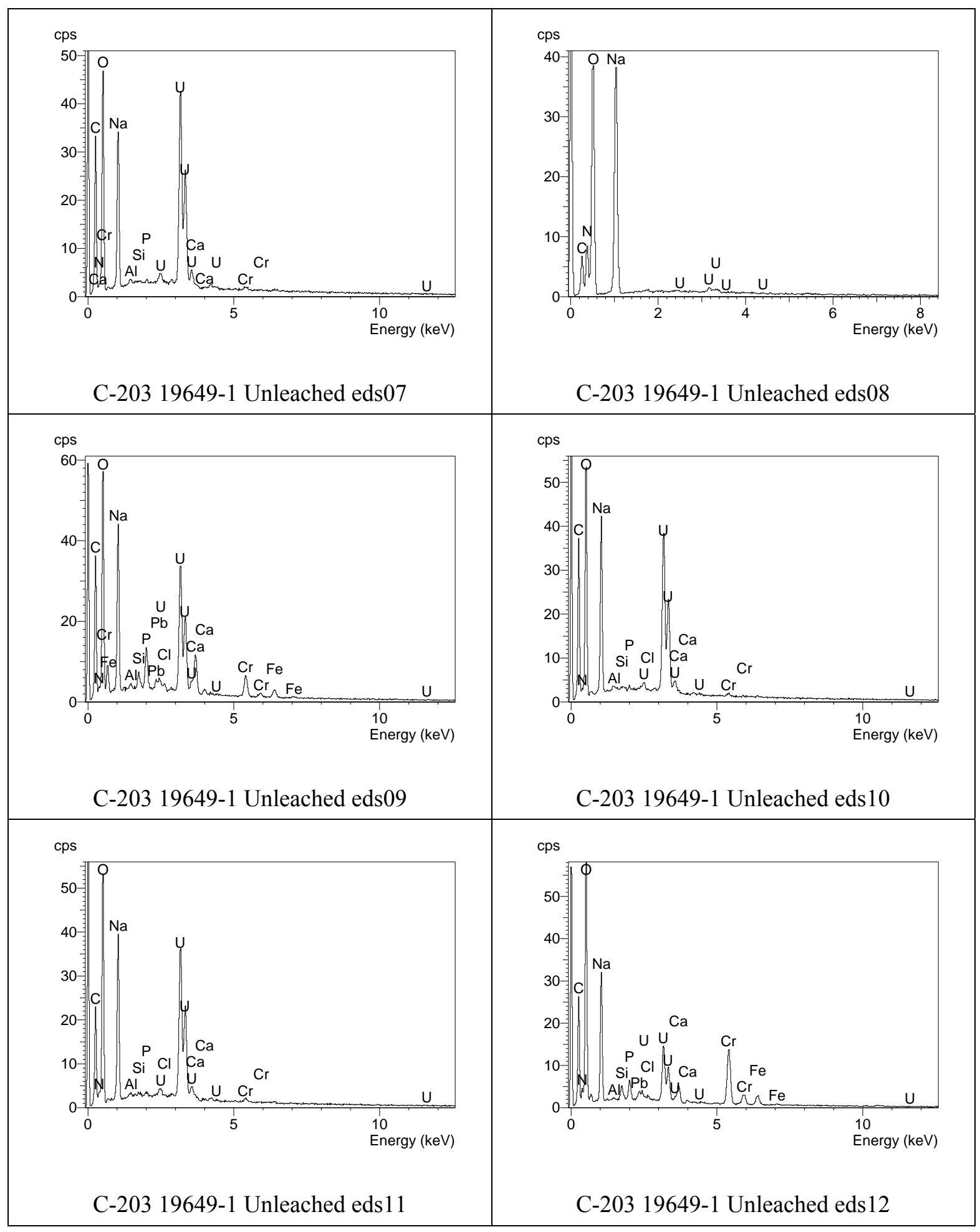

Figure B.10. EDS spectra for analyses eds07 through eds 12 for particles in the first SEM mount (19649-1) of unleached C-203 bulk sludge

B.7 


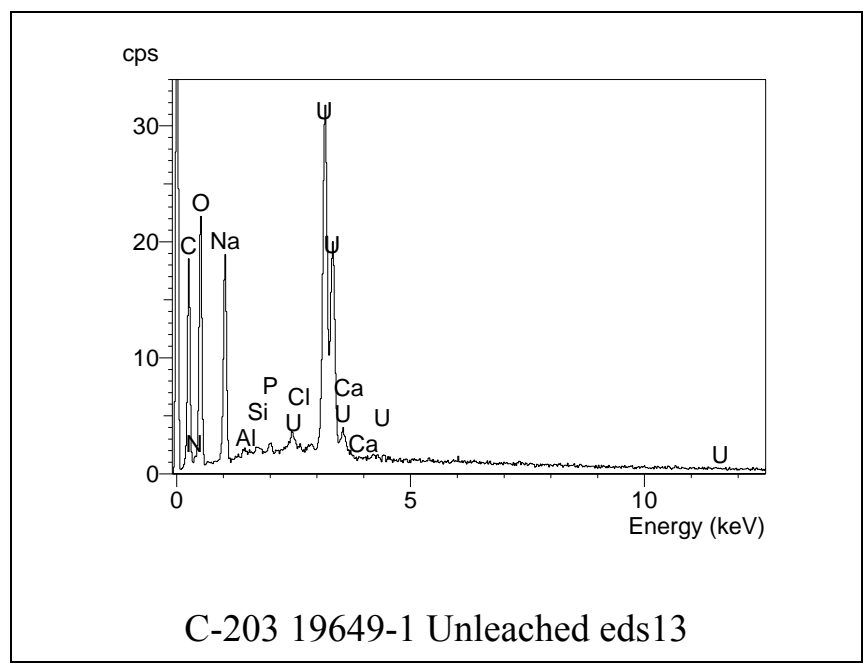

Figure B.11. EDS spectrum for analysis eds 13 for a particle in the first SEM mount (19649-1) of unleached C-203 bulk sludge 


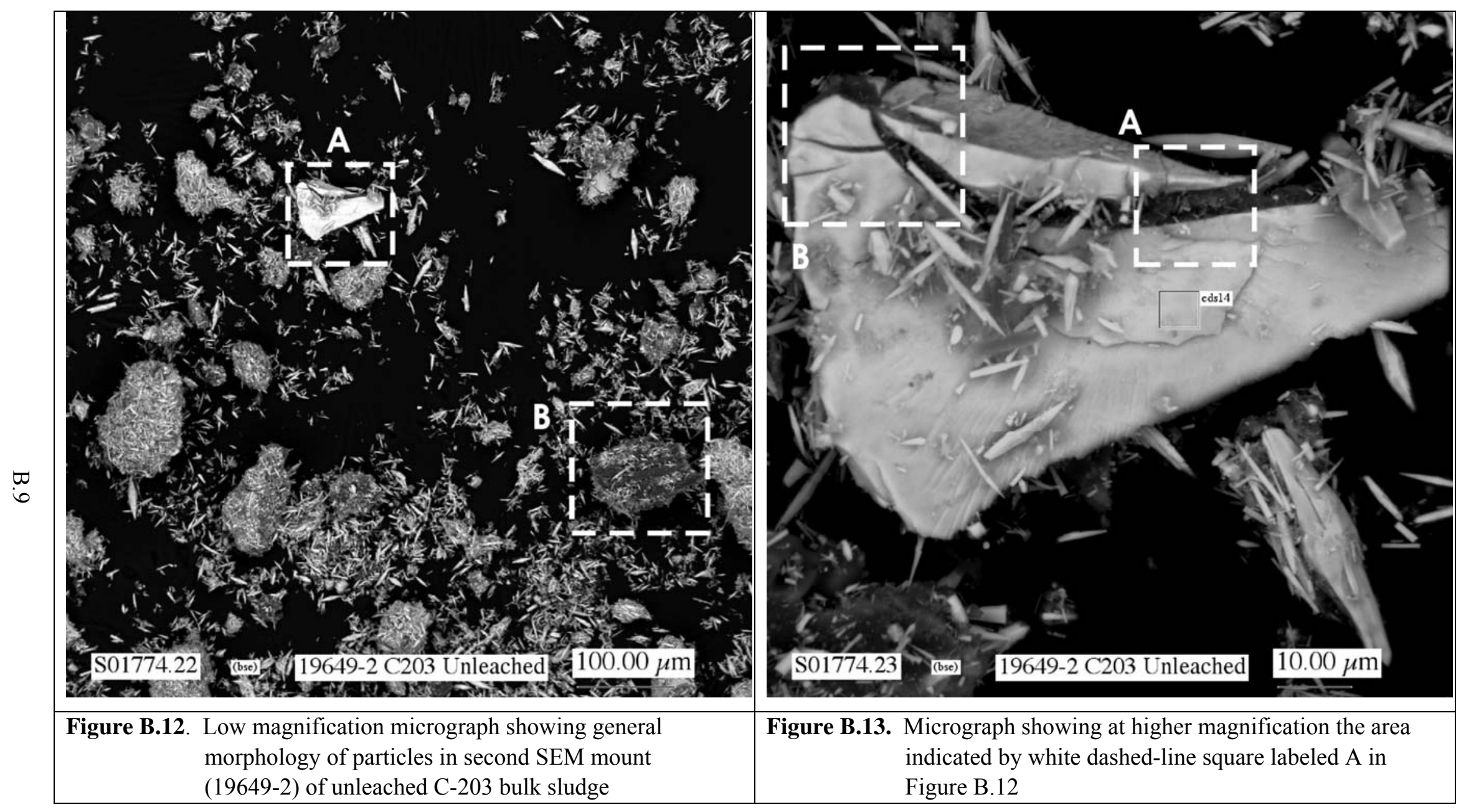




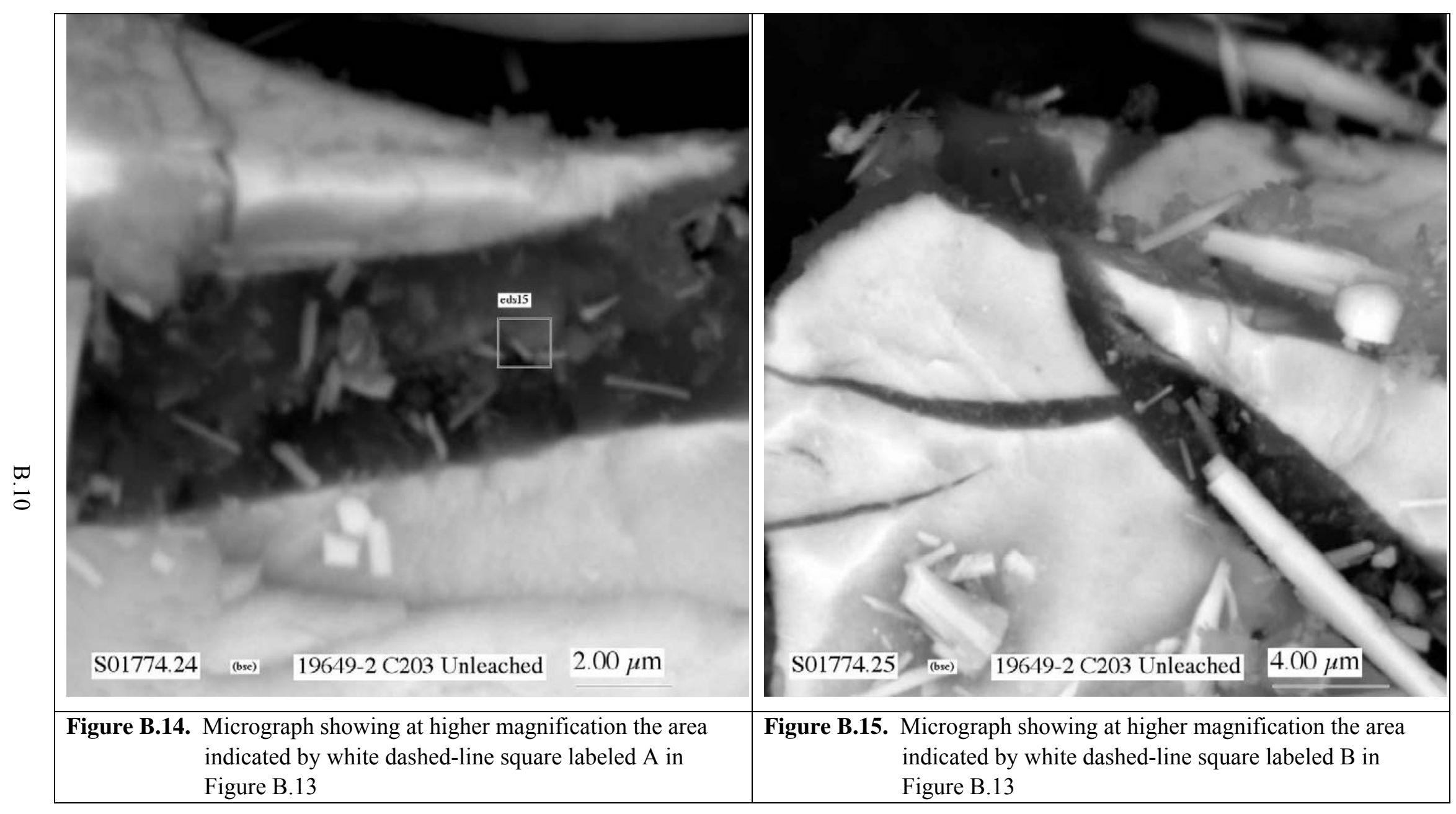




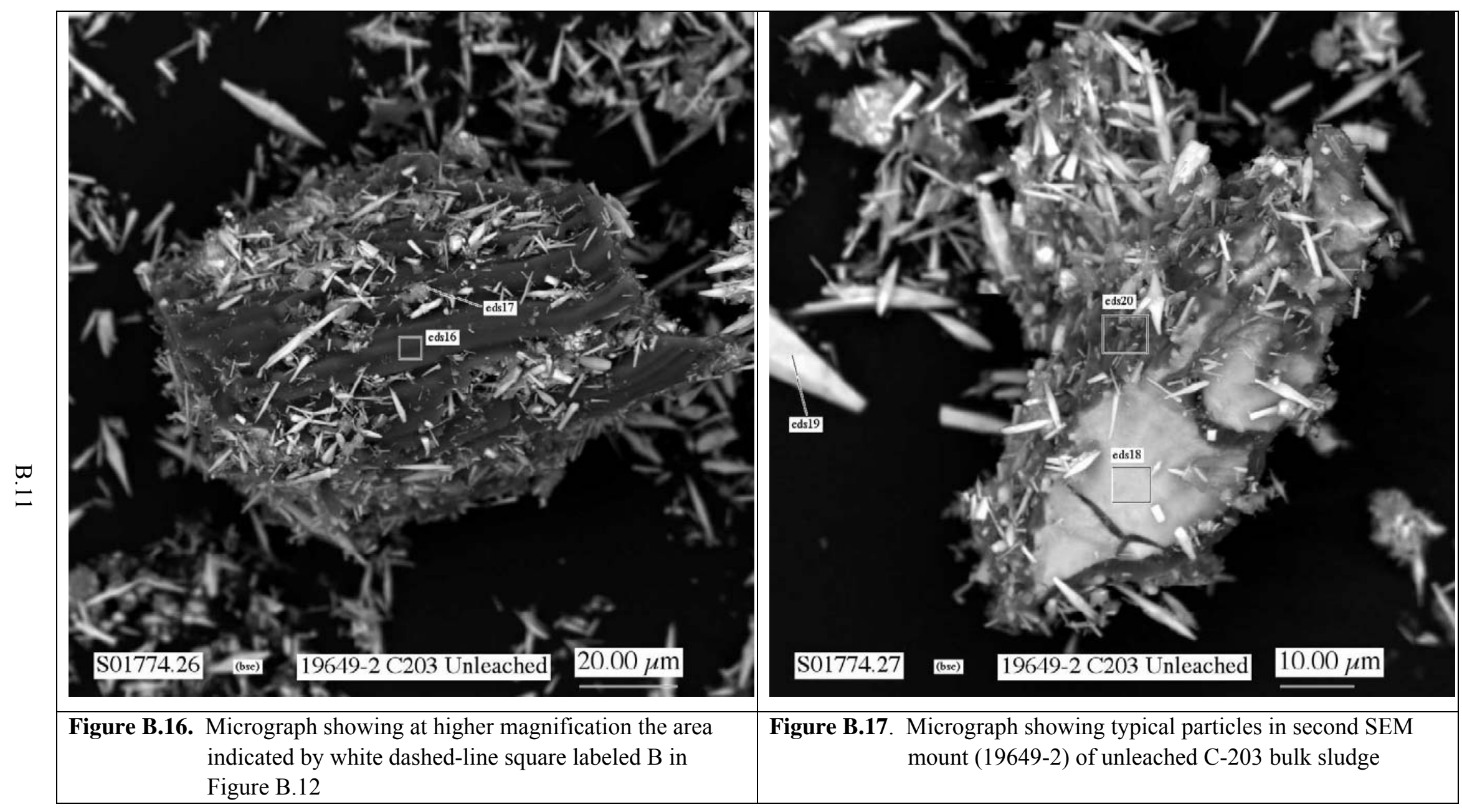



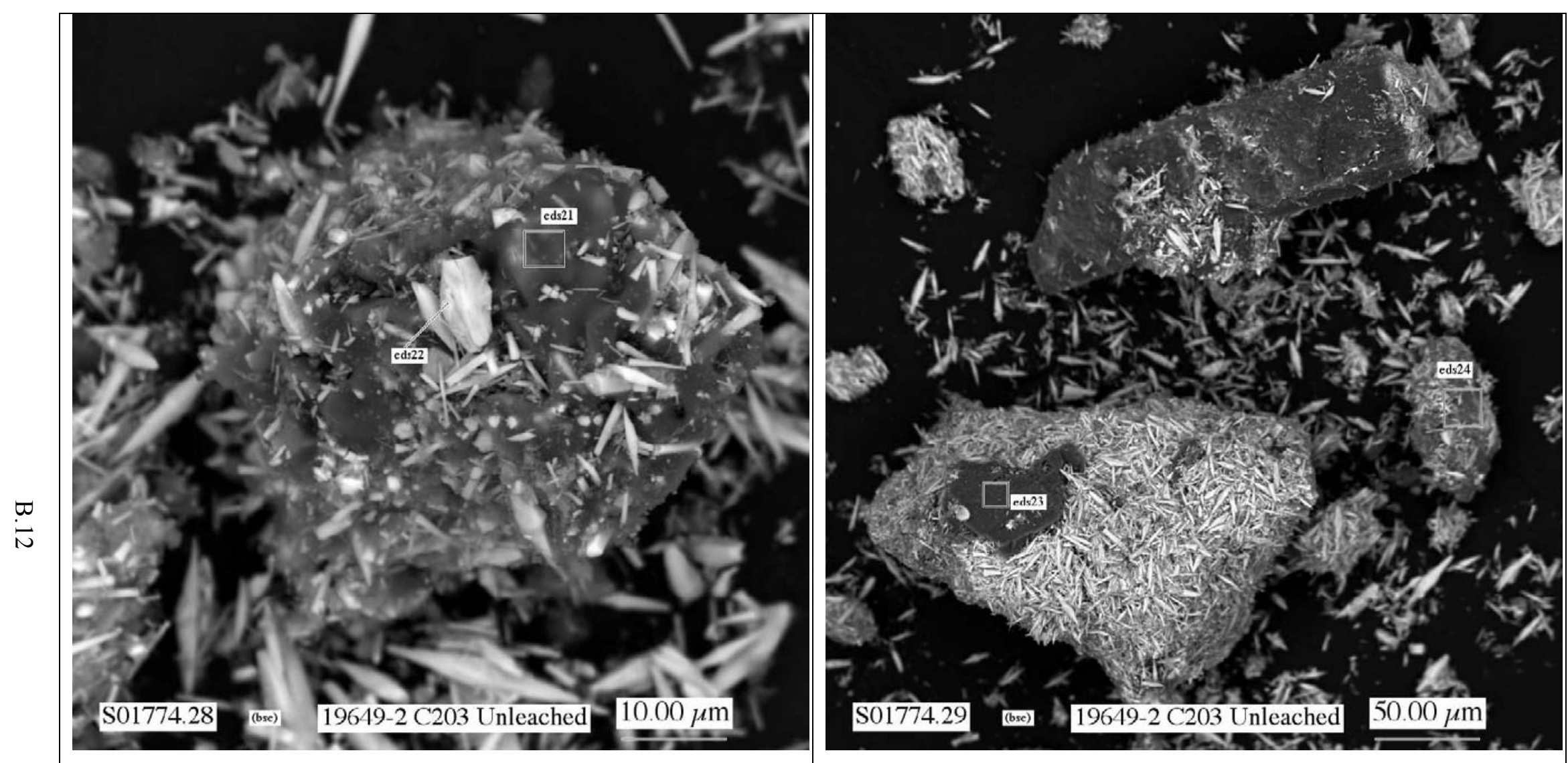

Figure B.18. Micrograph showing typical particles in second SEM mount (19649-2) of unleached C-203 bulk sludge

Figure B.19. Micrograph showing typical particles in second SEM mount (19649-2) of unleached C-203 bulk sludge 


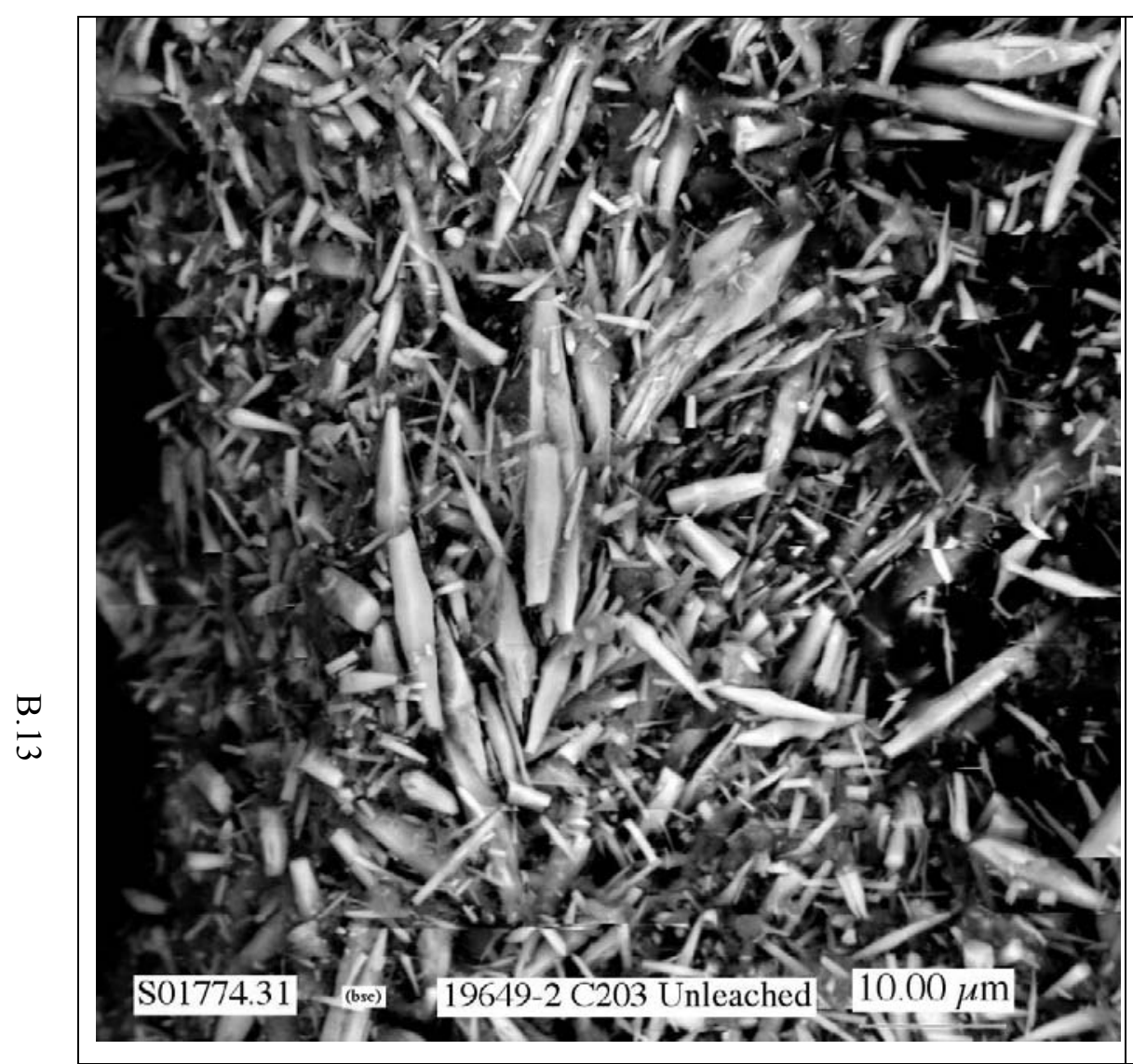

Figure B.20. Micrograph showing typical particles in second SEM mount (19649-2) of unleached C-203 bulk sludge

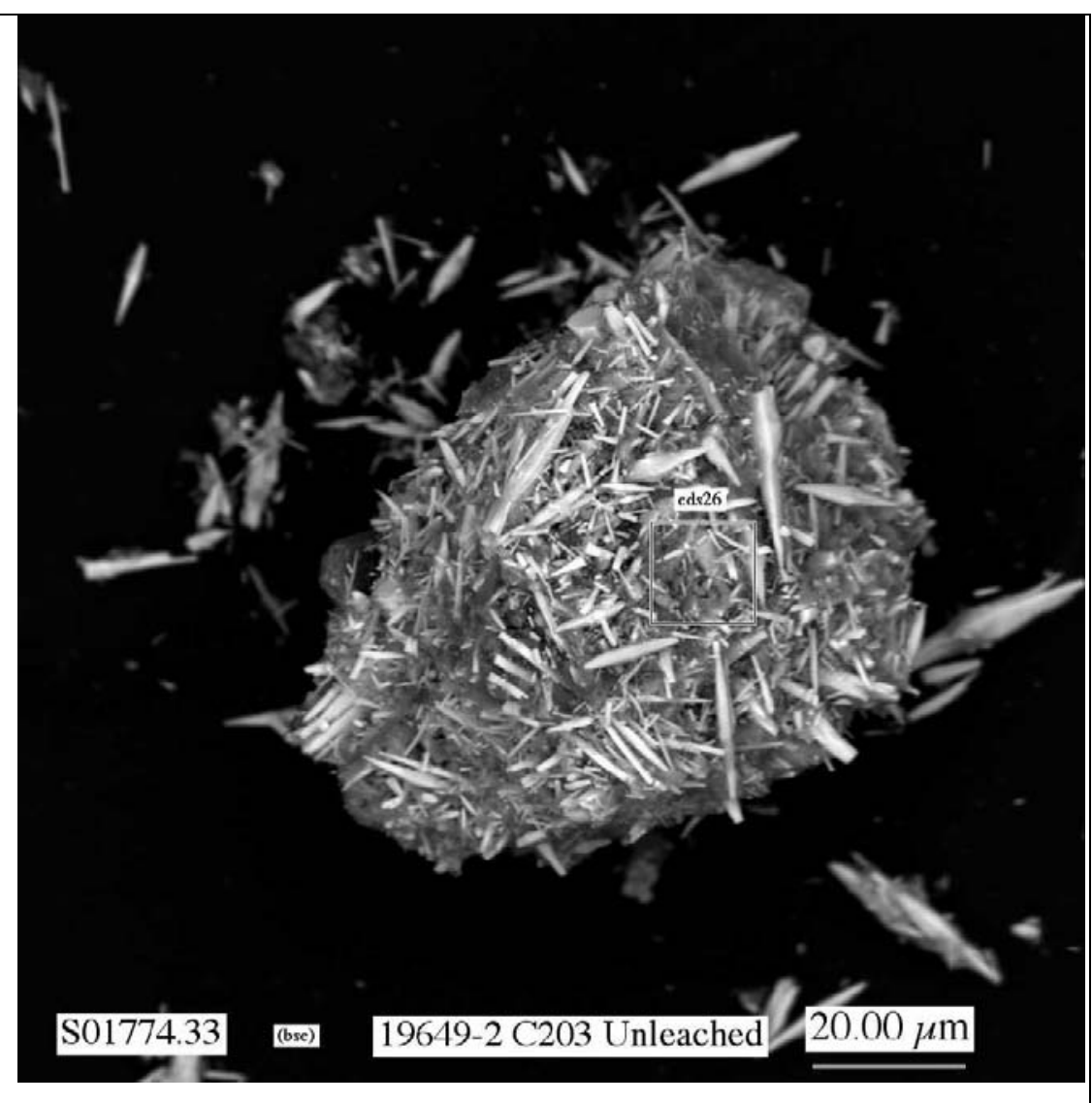

Figure B.21. Micrograph showing typical particles in second SEM mount (19649-2) of unleached C-203 bulk sludge 


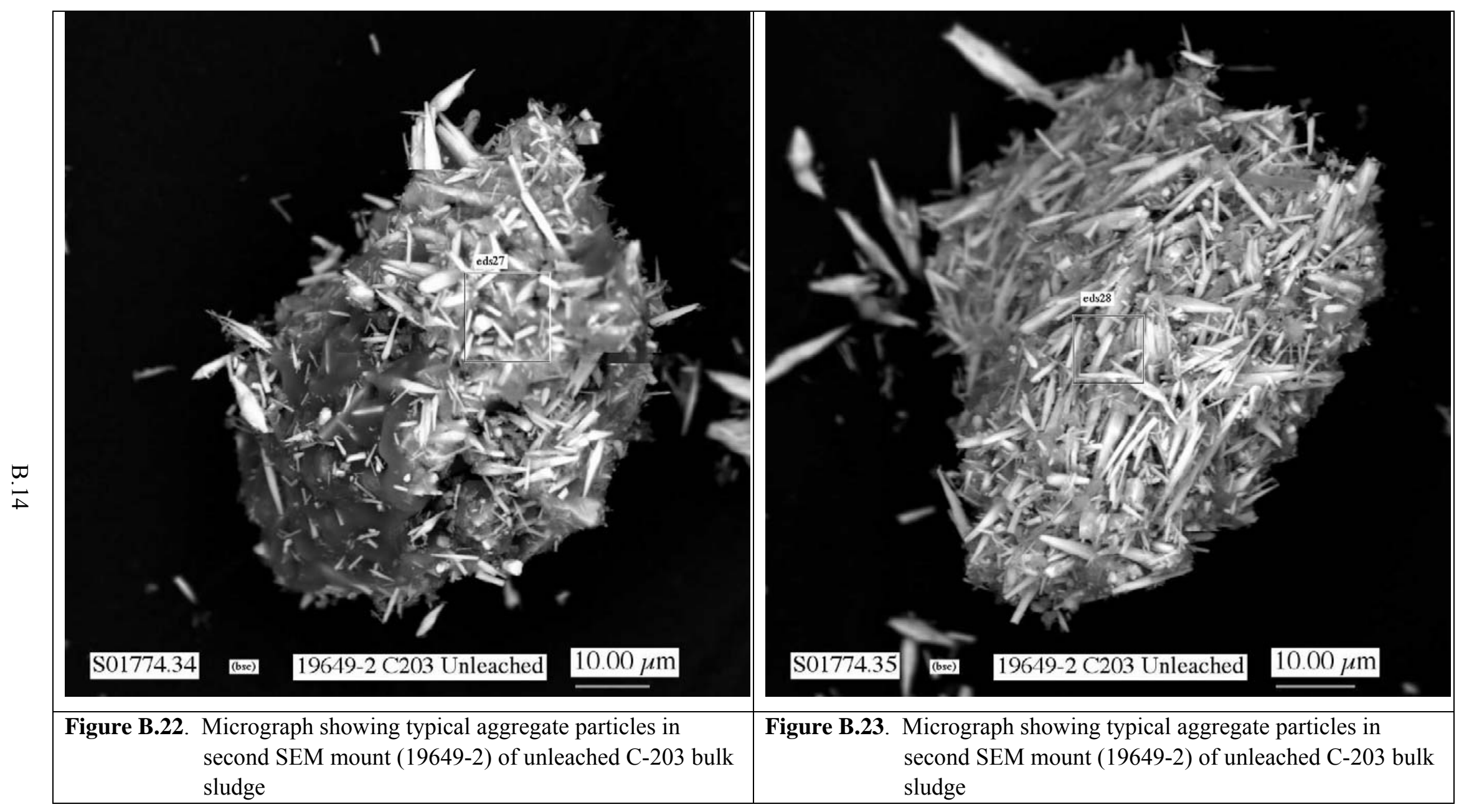




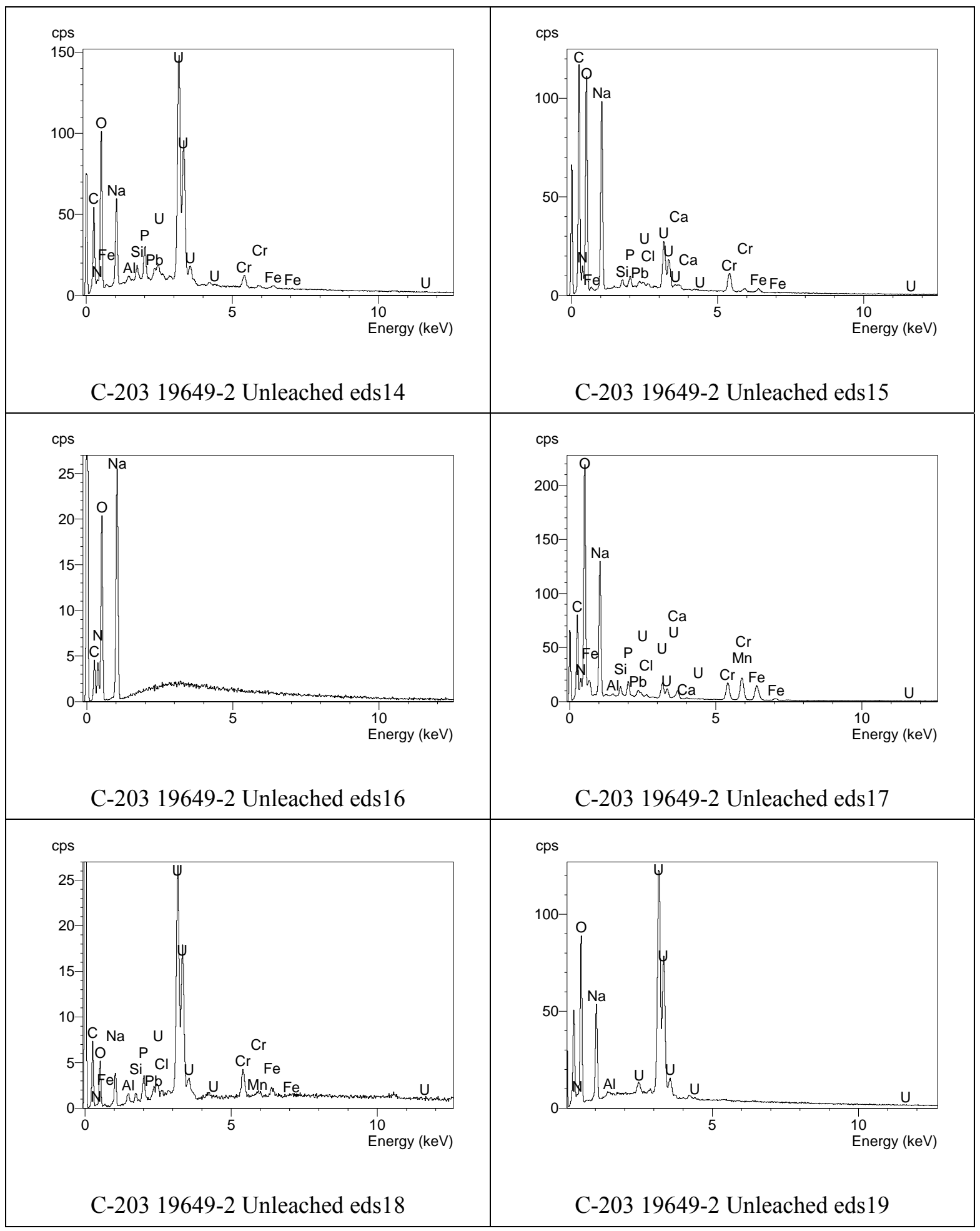

Figure B.24. EDS spectra for analyses eds14 through eds 19 for particles in the second SEM mount (19649-2) of unleached C-203 bulk sludge 


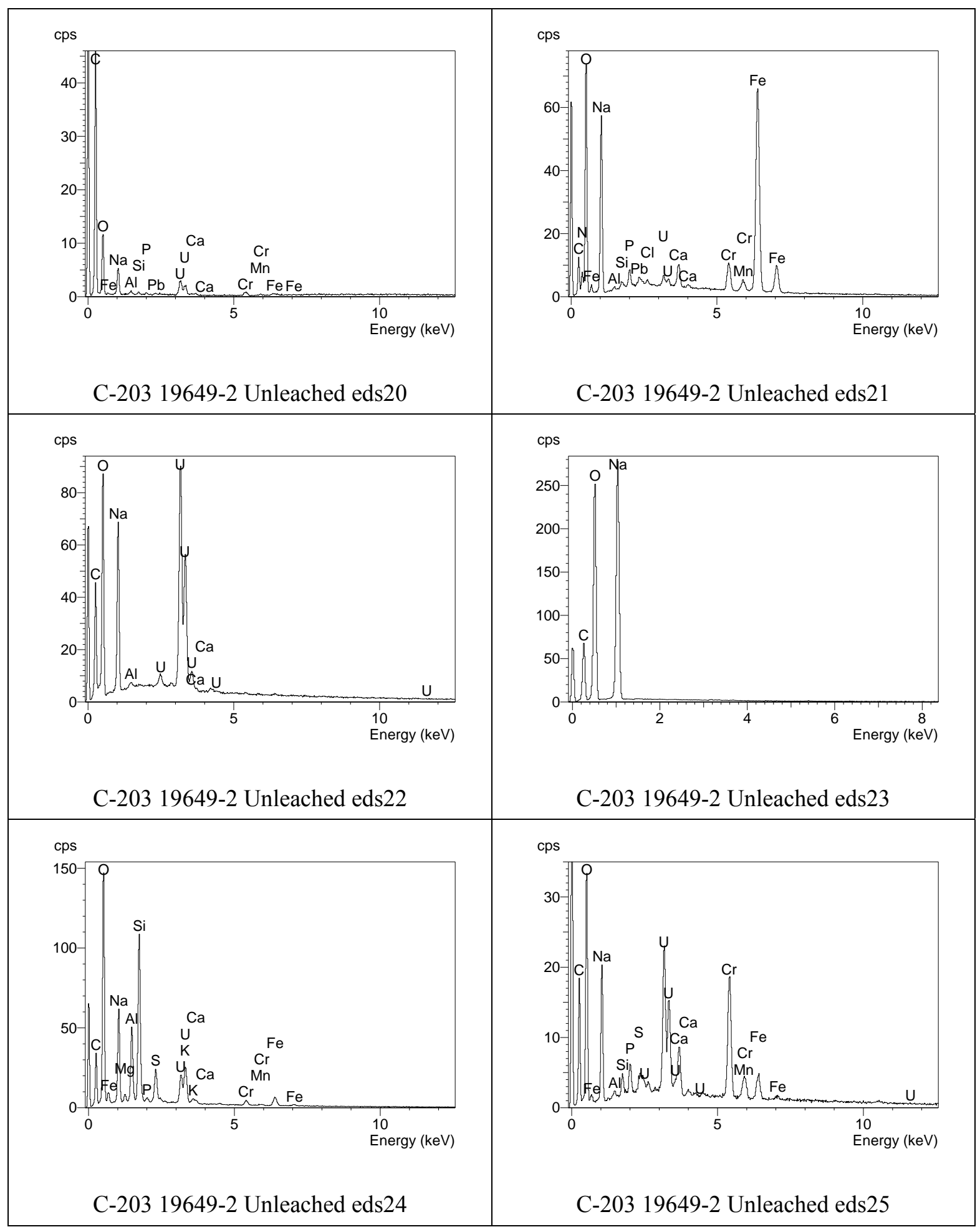

Figure B.25. EDS spectra for analyses eds20 through eds25 for particles in the second SEM mount (19649-2) of unleached C-203 bulk sludge 


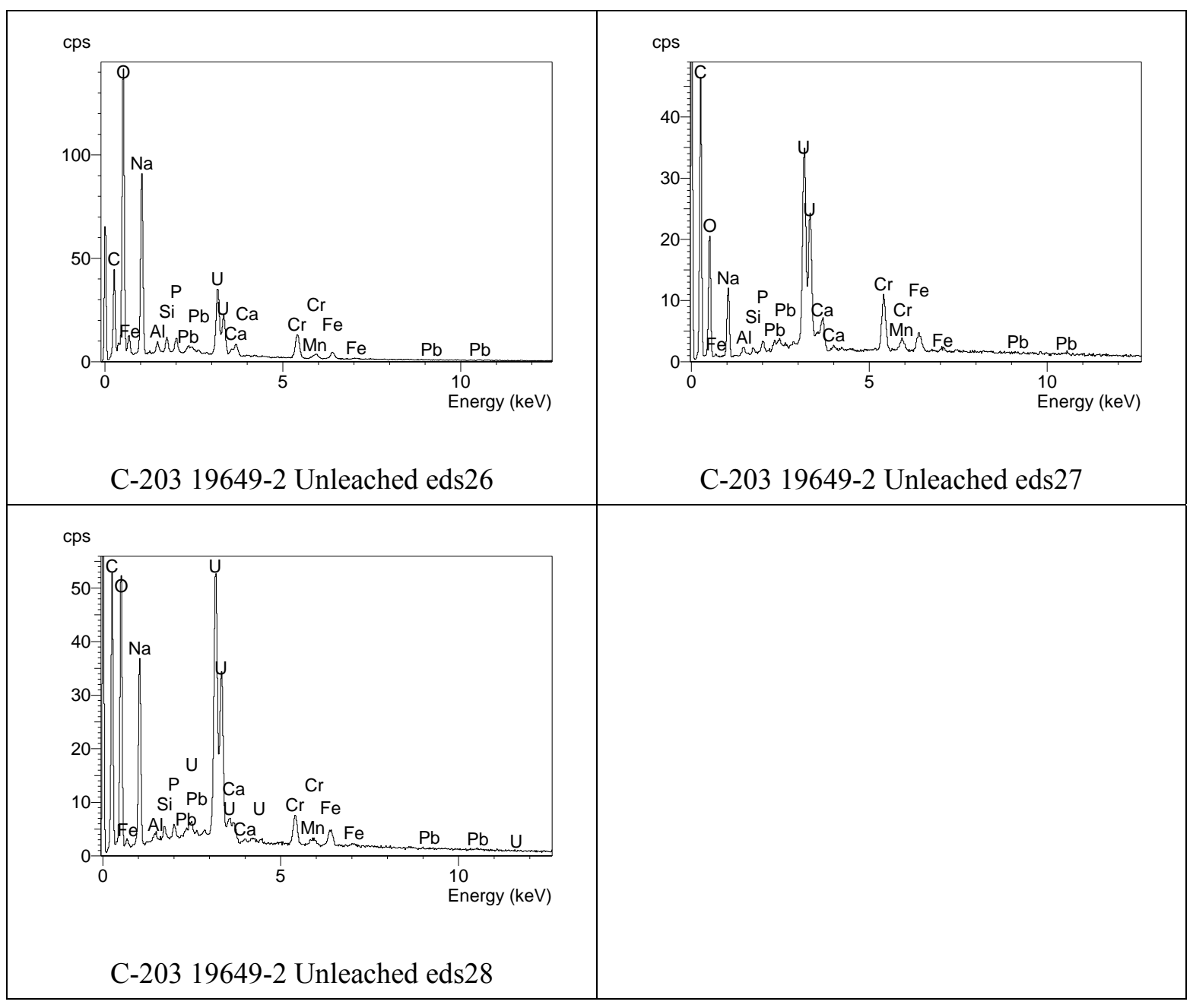

Figure B.26. EDS spectra for analyses eds 26 through eds 28 for particles in the second SEM mount (19649-2) of unleached C-203 bulk sludge 


\section{B.2 Yellow Nugget Material from C-203 Bulk Sludge}

Two mounts of yellow nugget material from the unleached (raw) of C-203 (jar 19649) bulk residual tank waste were analyzed by SEM/EDS. The SEM micrographs for the first mount of yellow nugget material are shown in Figures B.27 through B.38. The EDS spectra for this mount are given in Figures B.39 through B.40. The SEM micrographs for the second mount ("Yellow Solid-2") of yellow nugget material are shown in Figures B.41 through B.46, and the EDS spectra for the second mount are given in Figure B.47. 


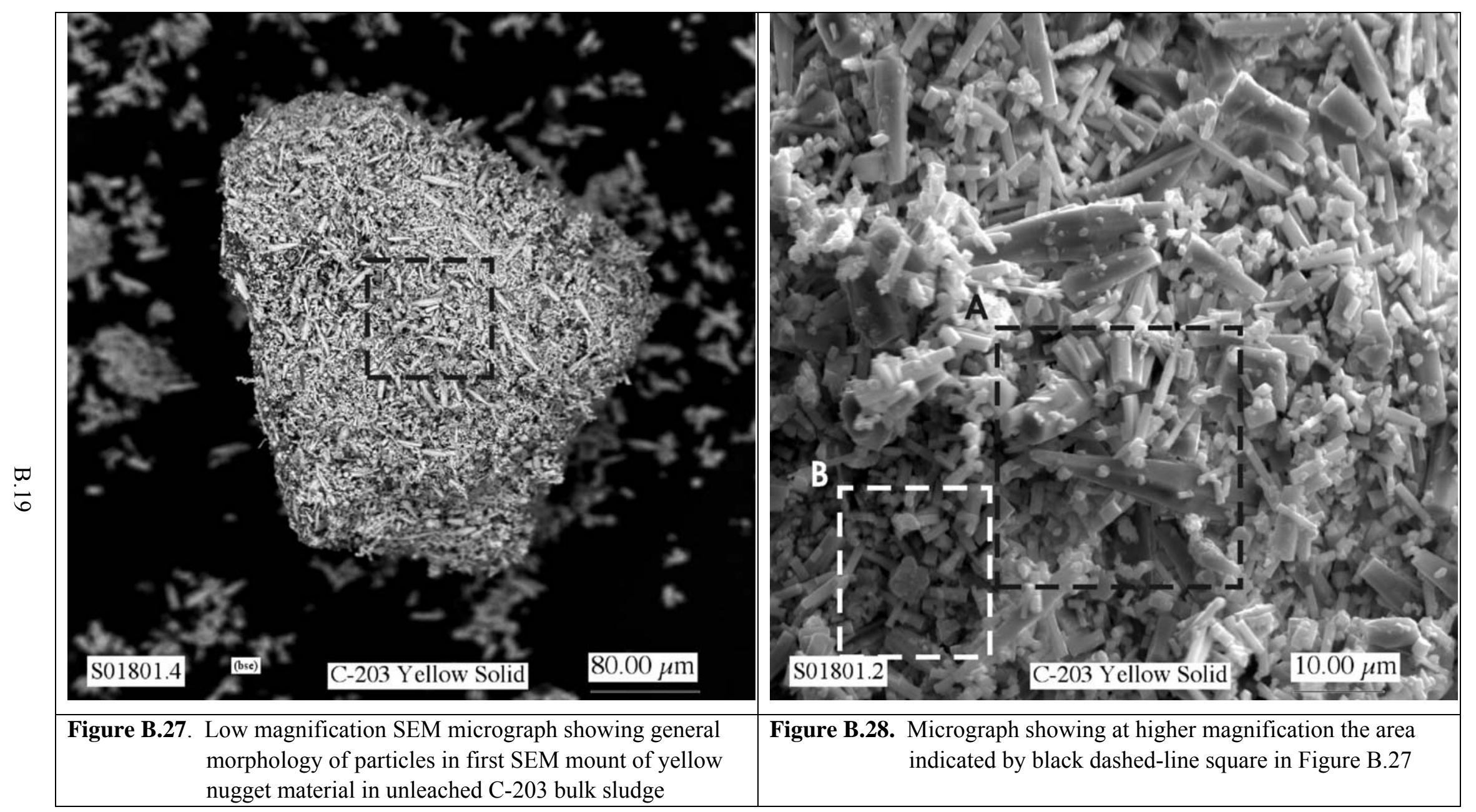




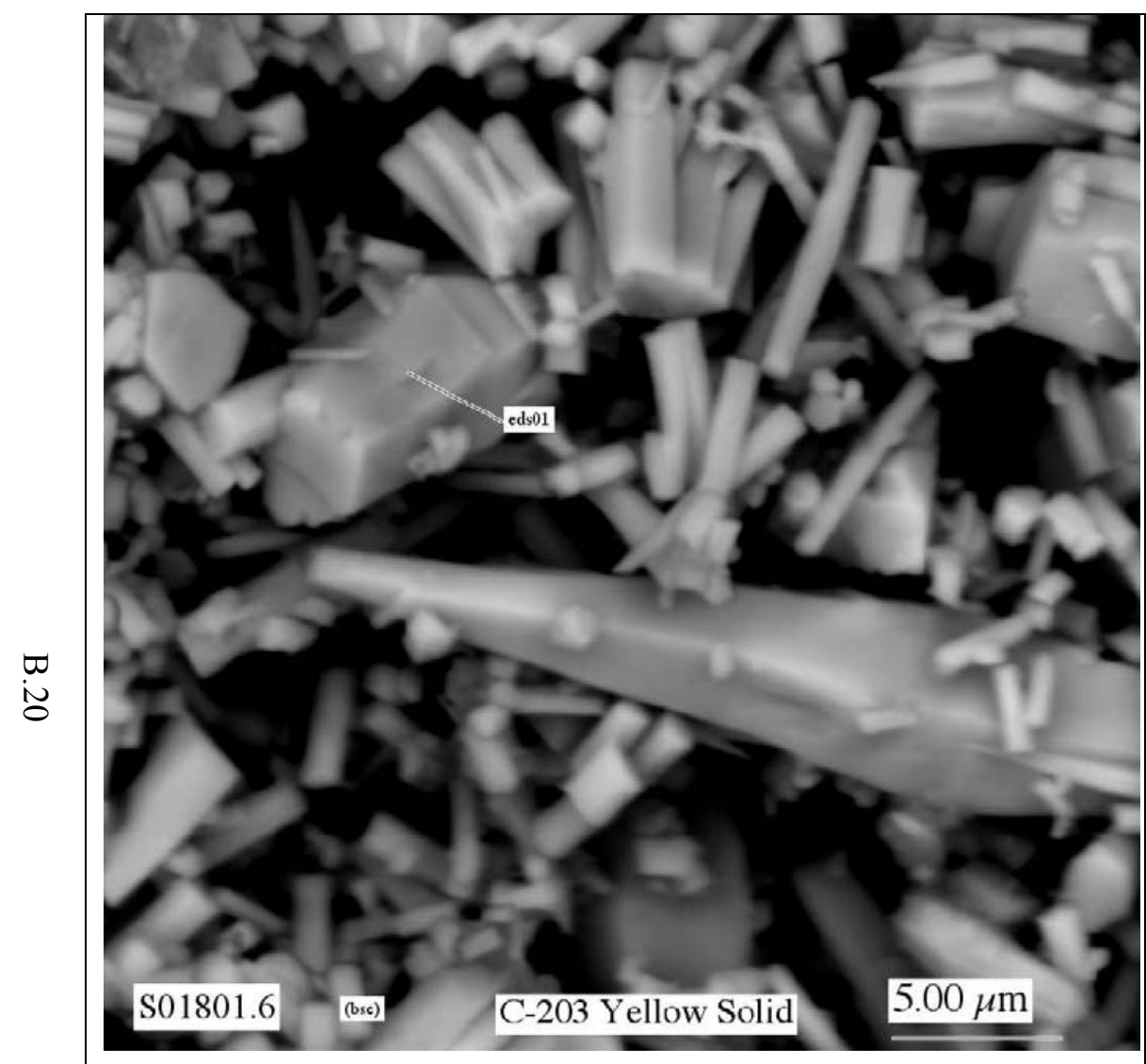

Figure B.29. Micrograph showing at higher magnification the area indicated by black dashed-line square labeled $\mathrm{A}$ in Figure B.28

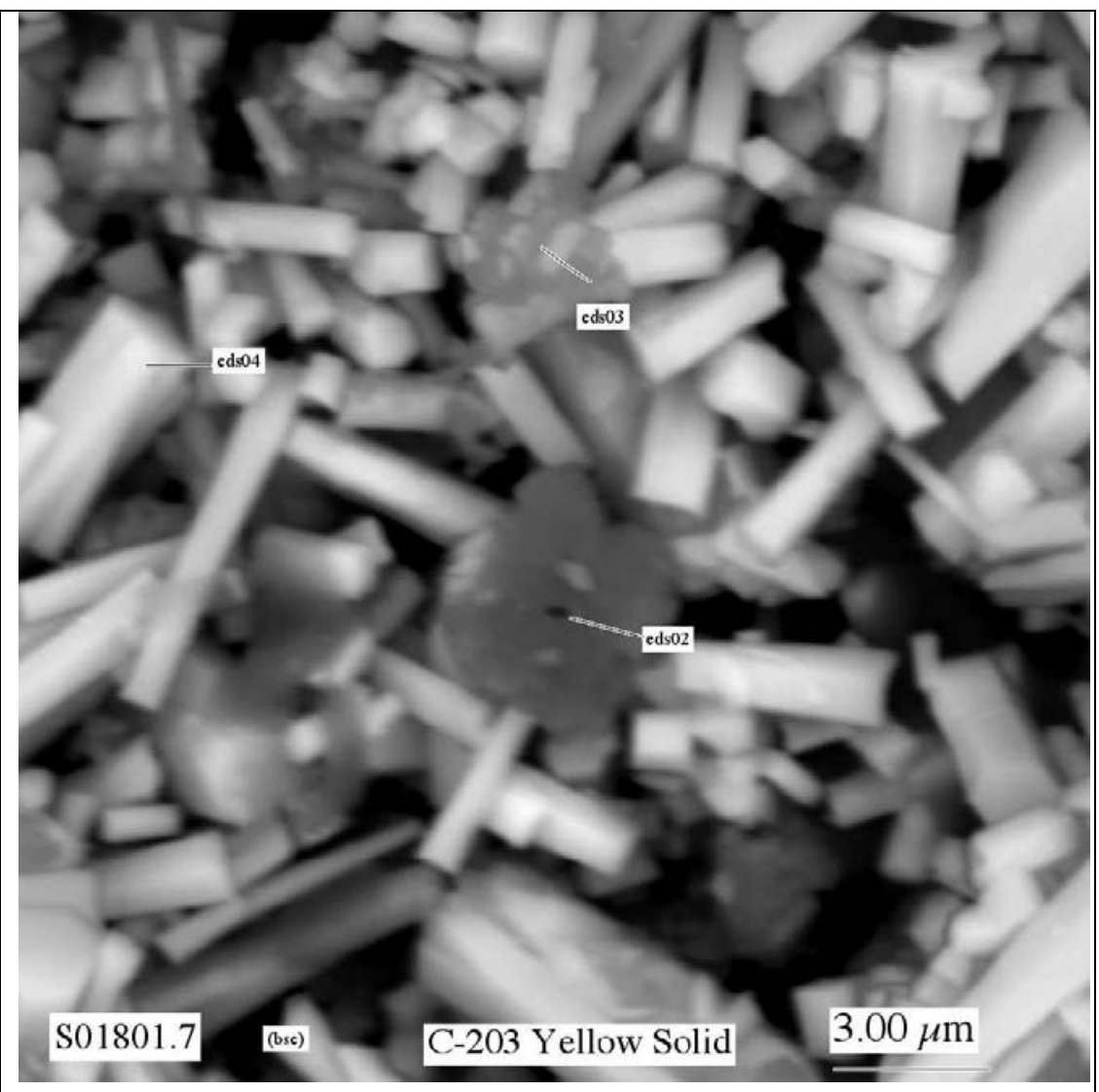

Figure B.30. Micrograph showing at higher magnification the area indicated by white dashed-line square labeled B in Figure B.28 


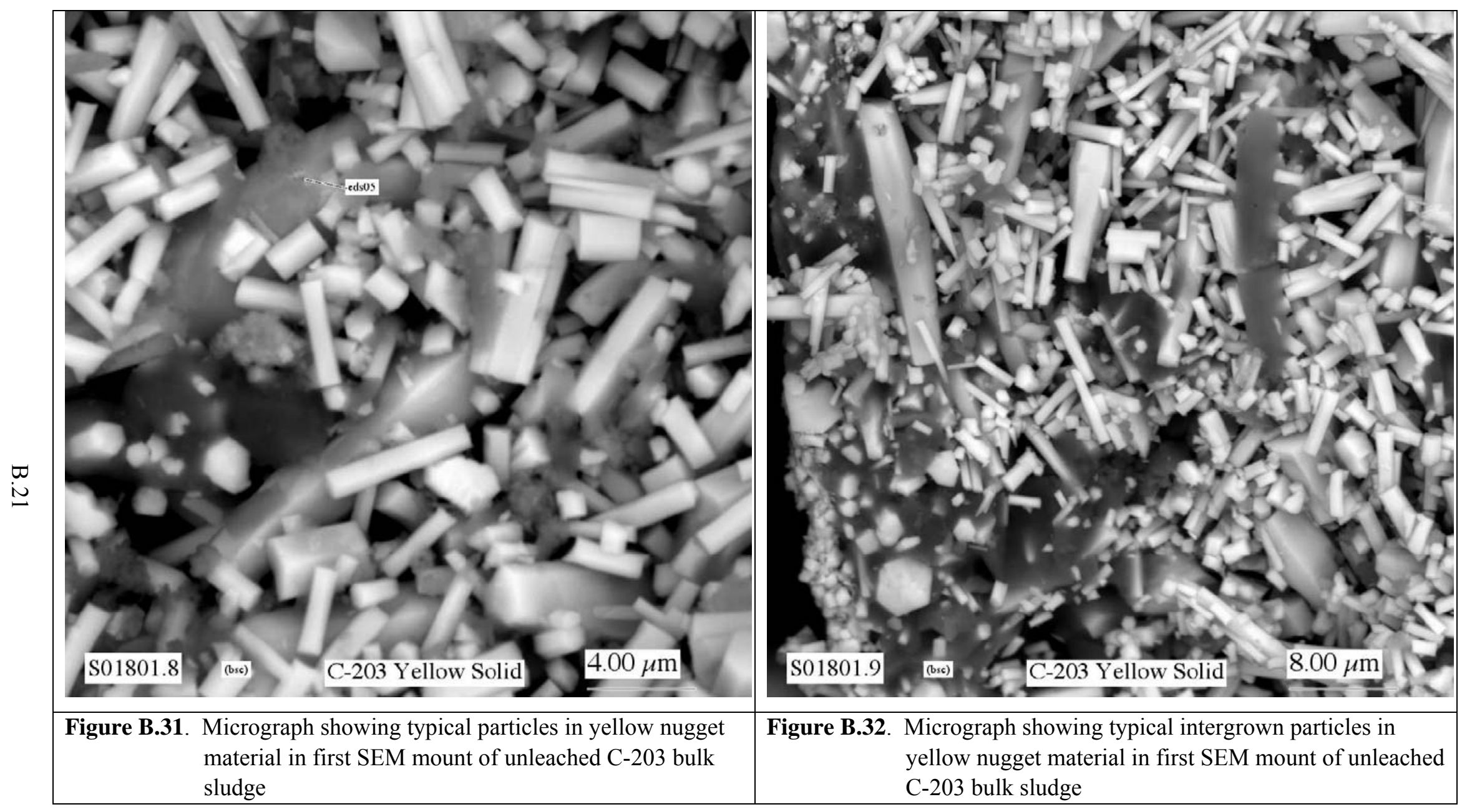




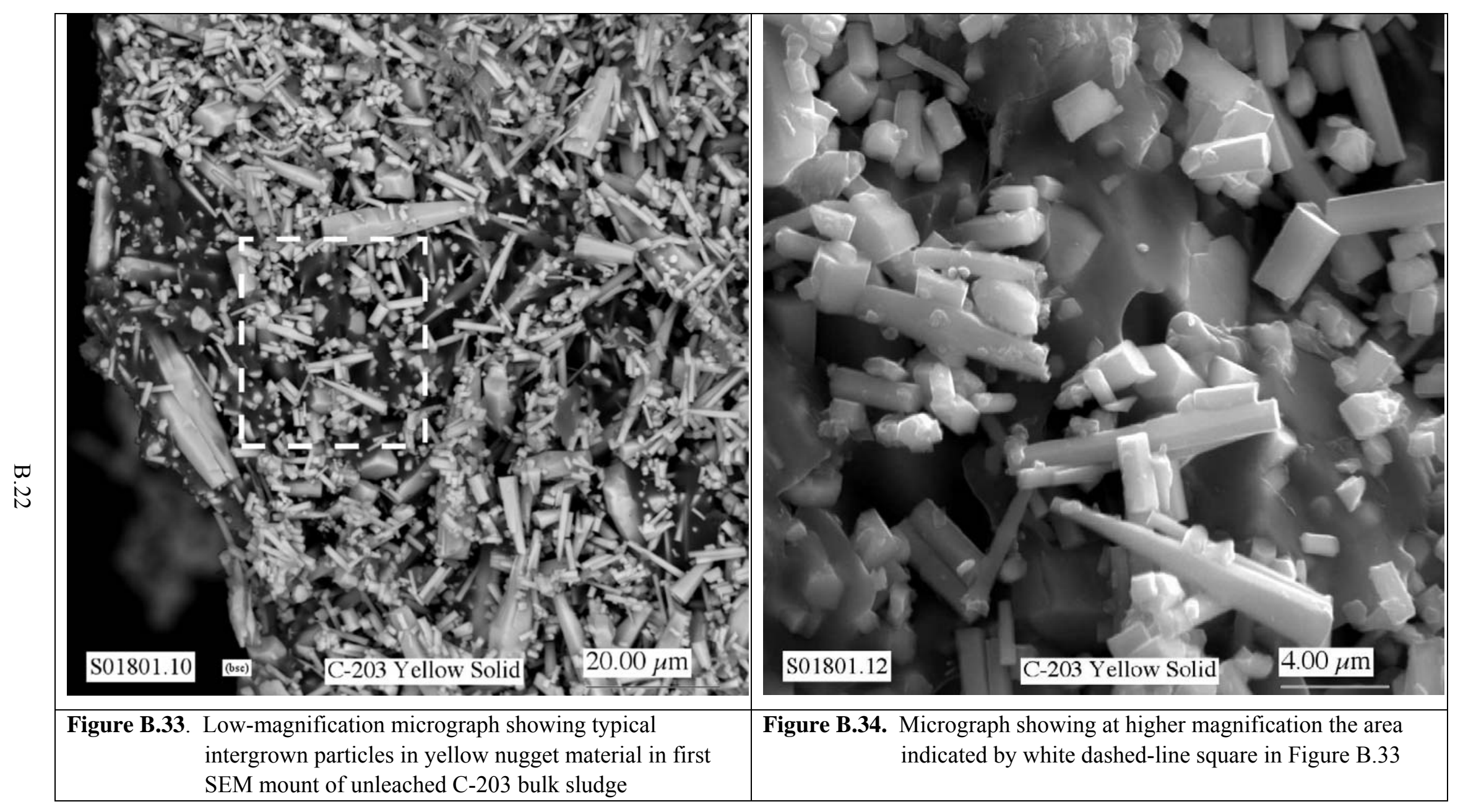




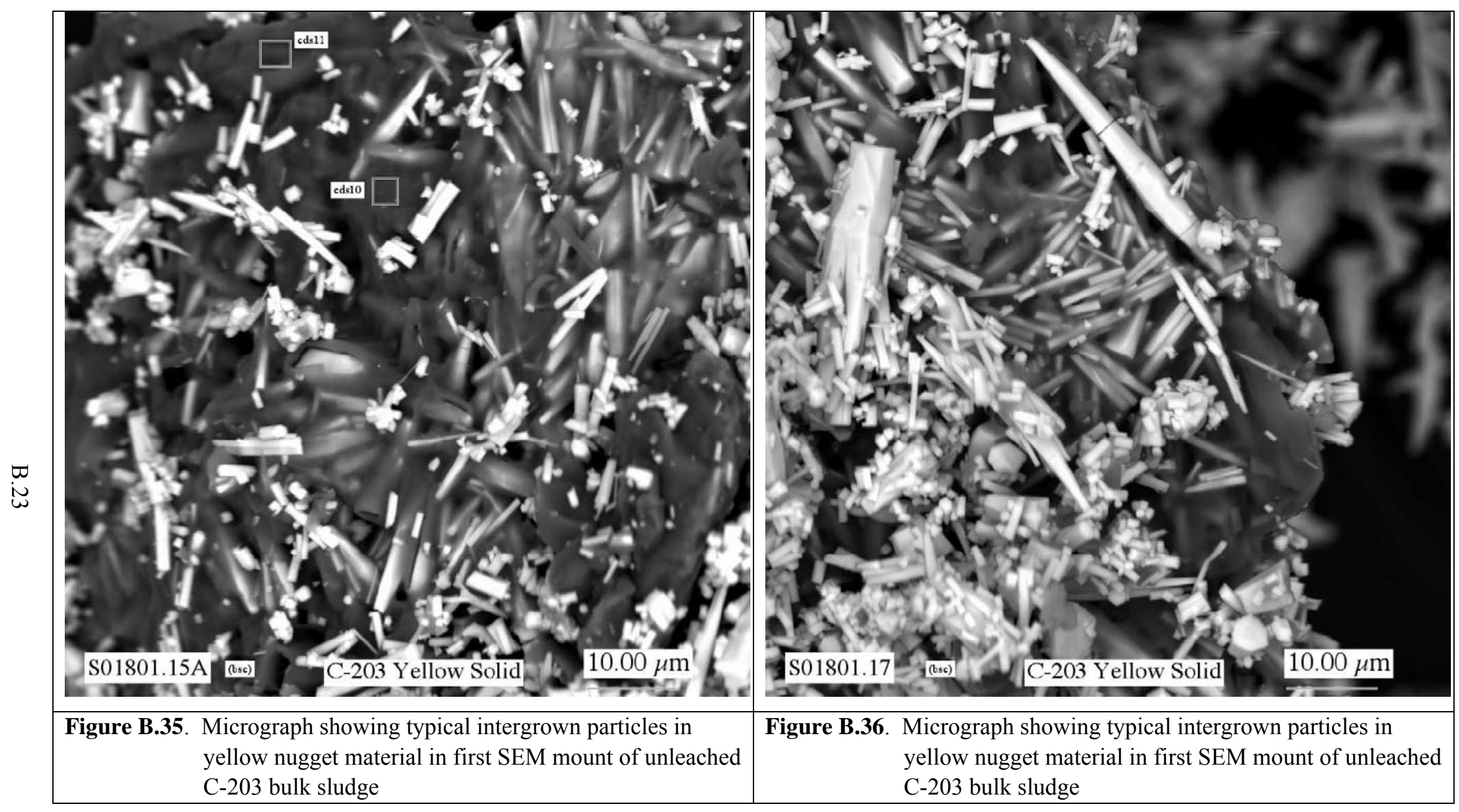




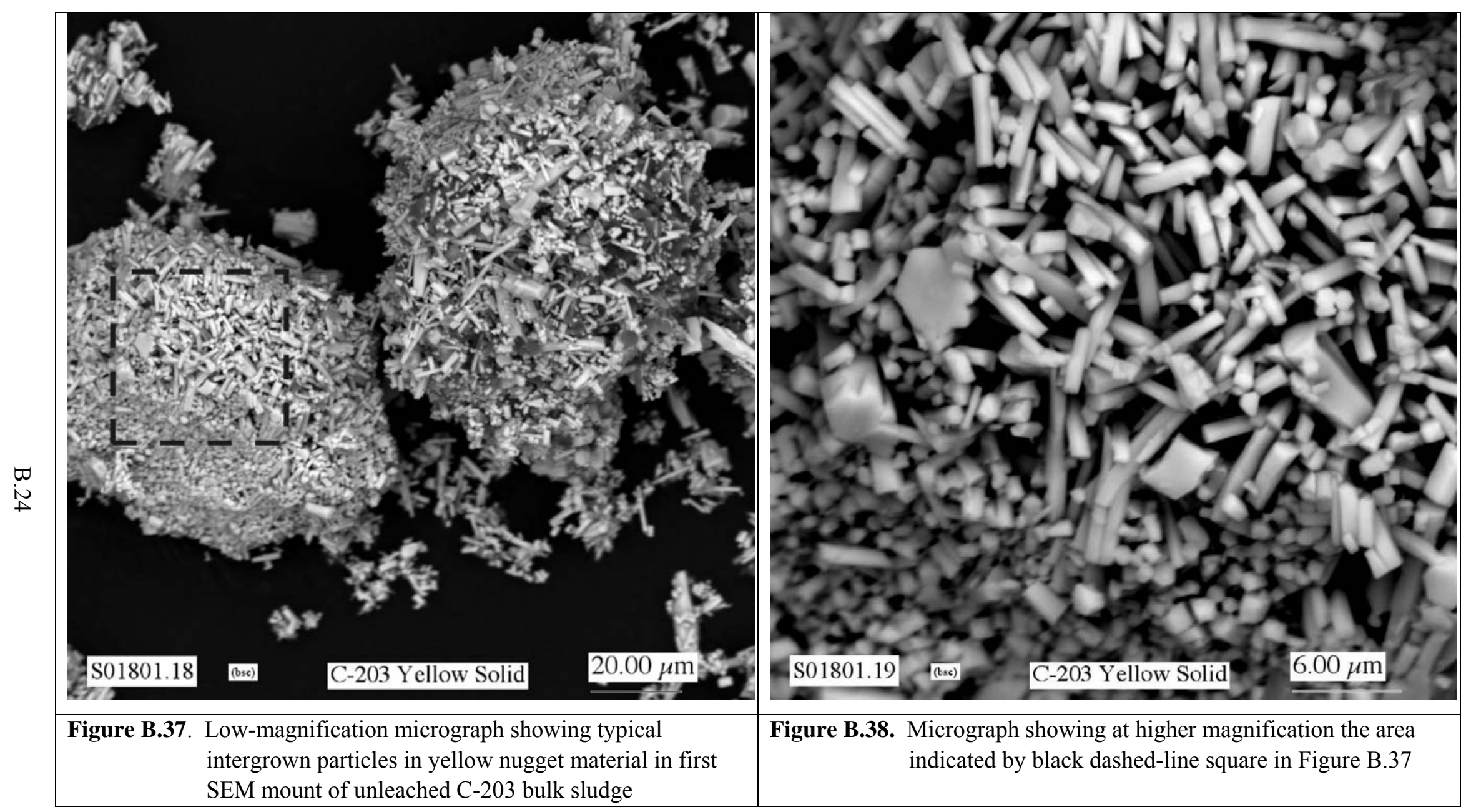




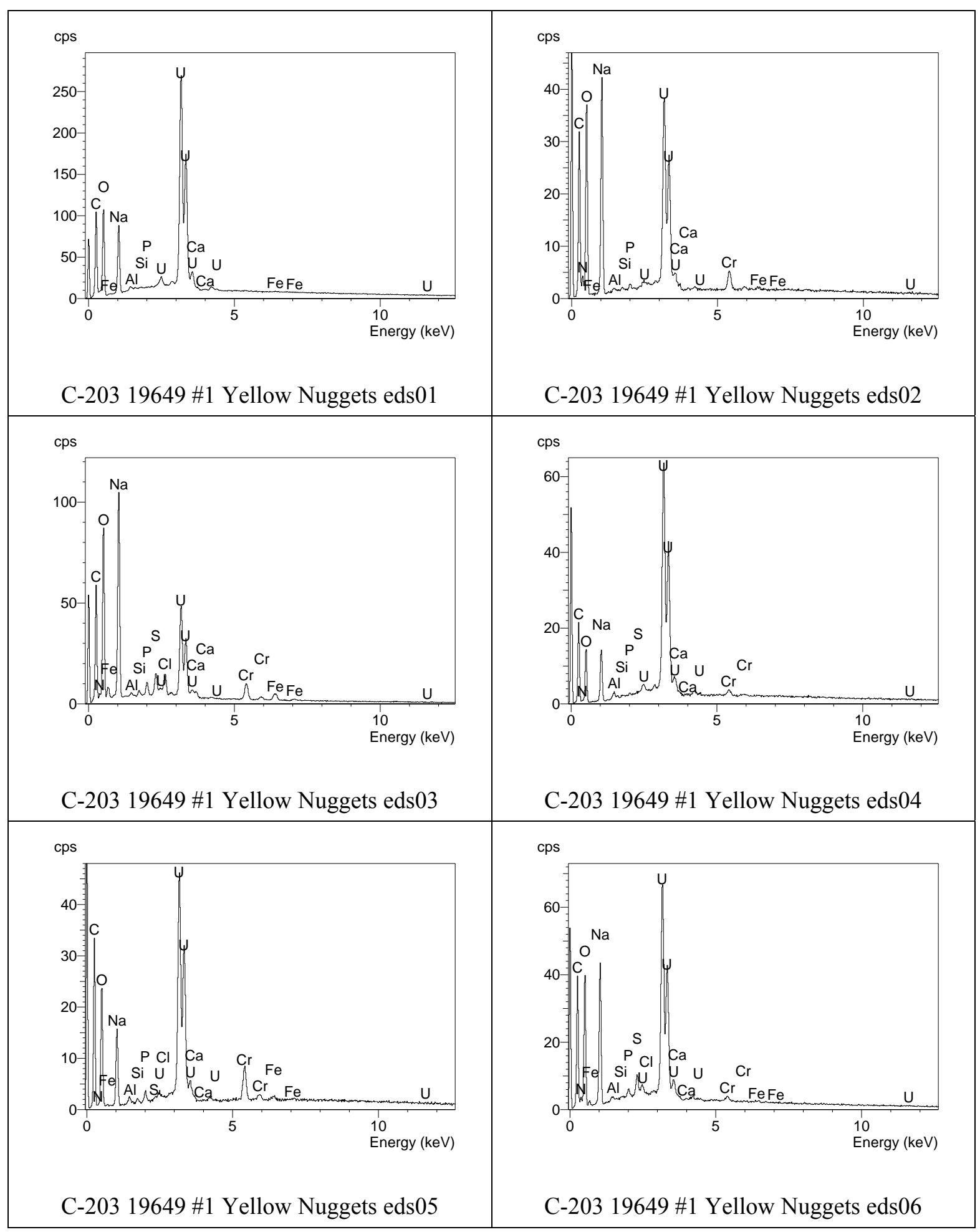

Figure B.39. EDS spectra for analyses eds01 through eds 06 for particles in the first SEM mount in yellow nugget material present in first SEM mount of unleached C-203 bulk sludge 


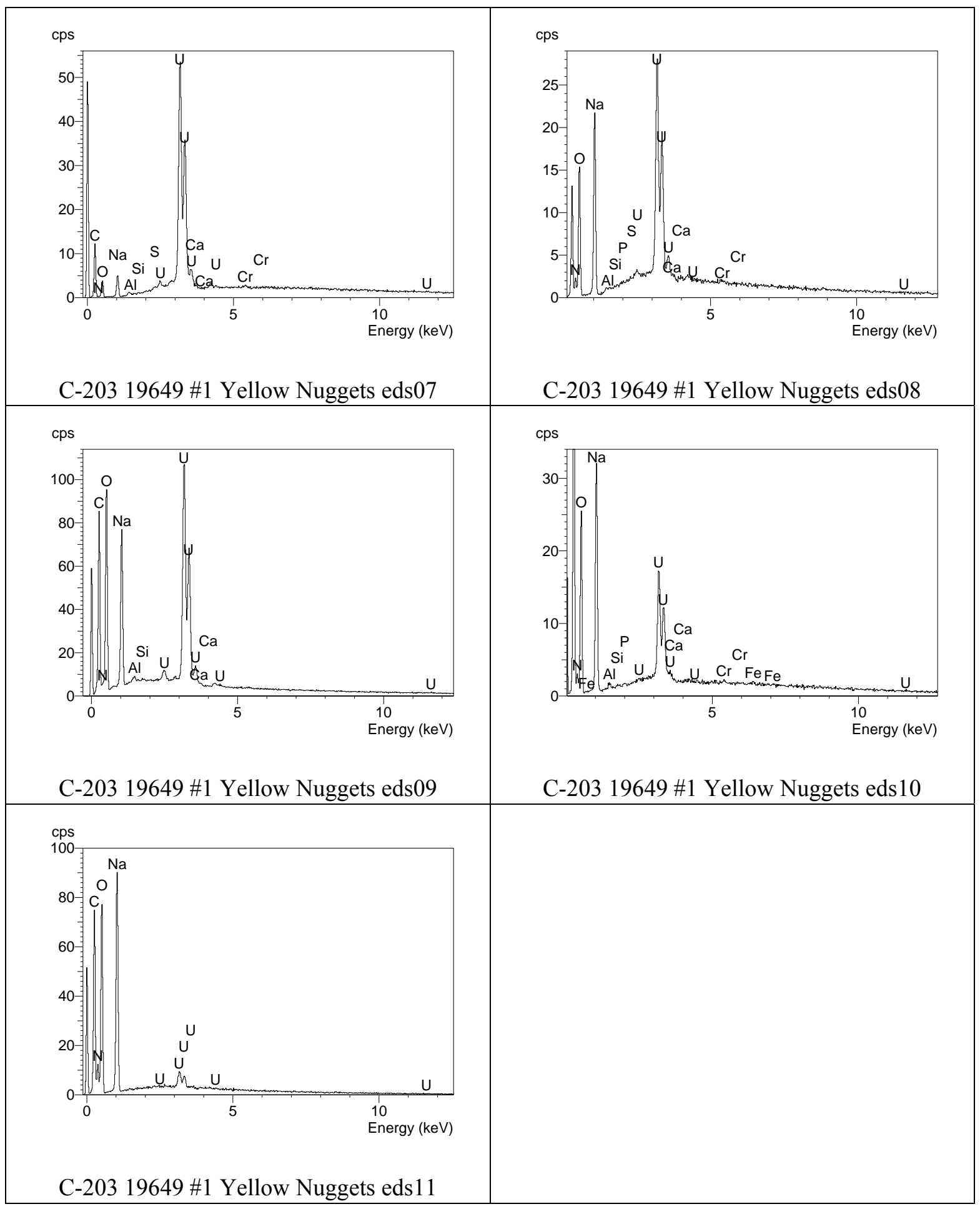

Figure B.40. EDS spectra for analyses eds07 through eds 11 for particles in the first SEM mount in yellow nugget material present in first SEM mount of unleached C-203 bulk sludge 


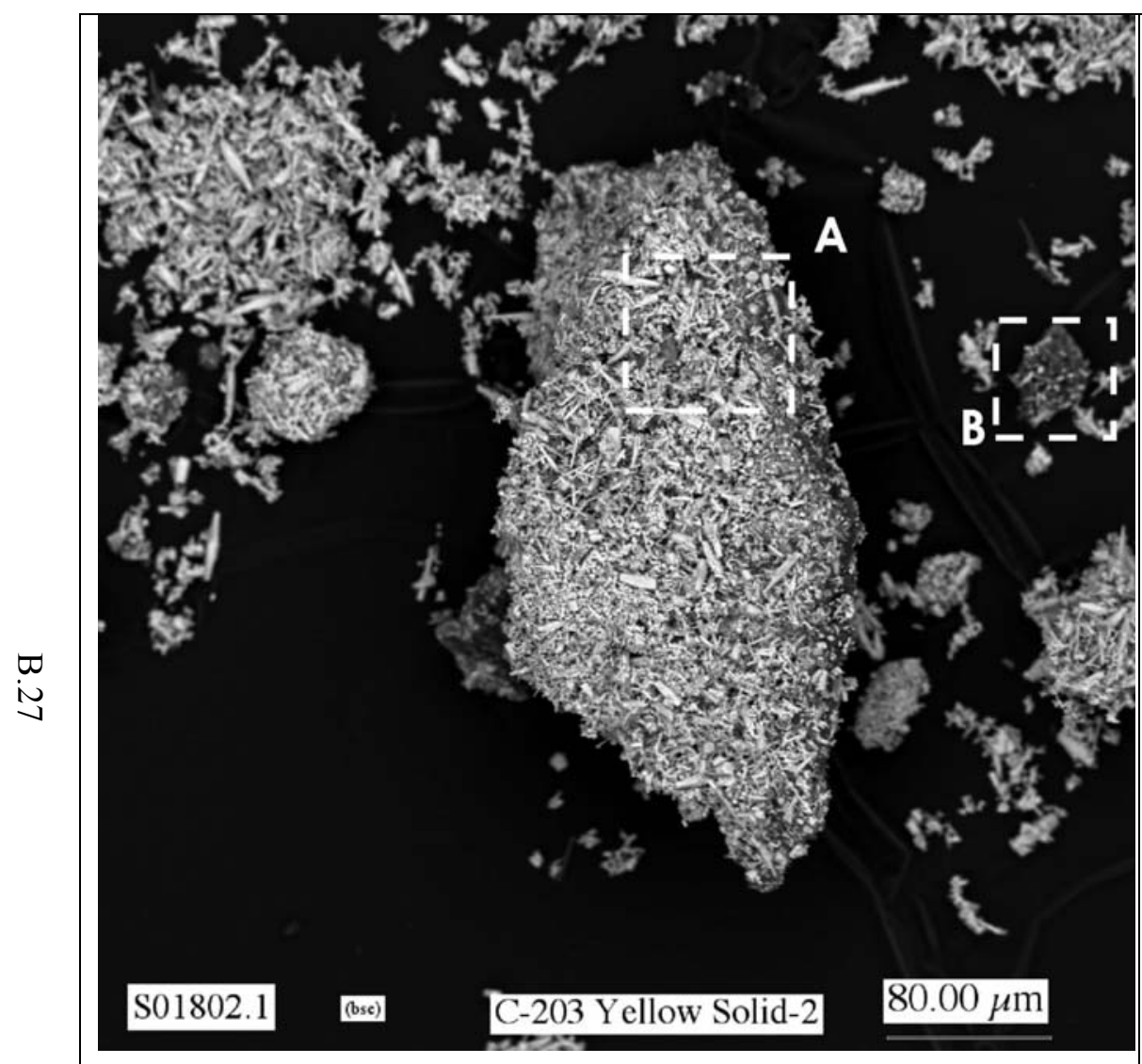

Figure B.41. Low magnification SEM micrograph showing general morphology of particles in second SEM mount of yellow nugget material in unleached C-203 bulk sludge

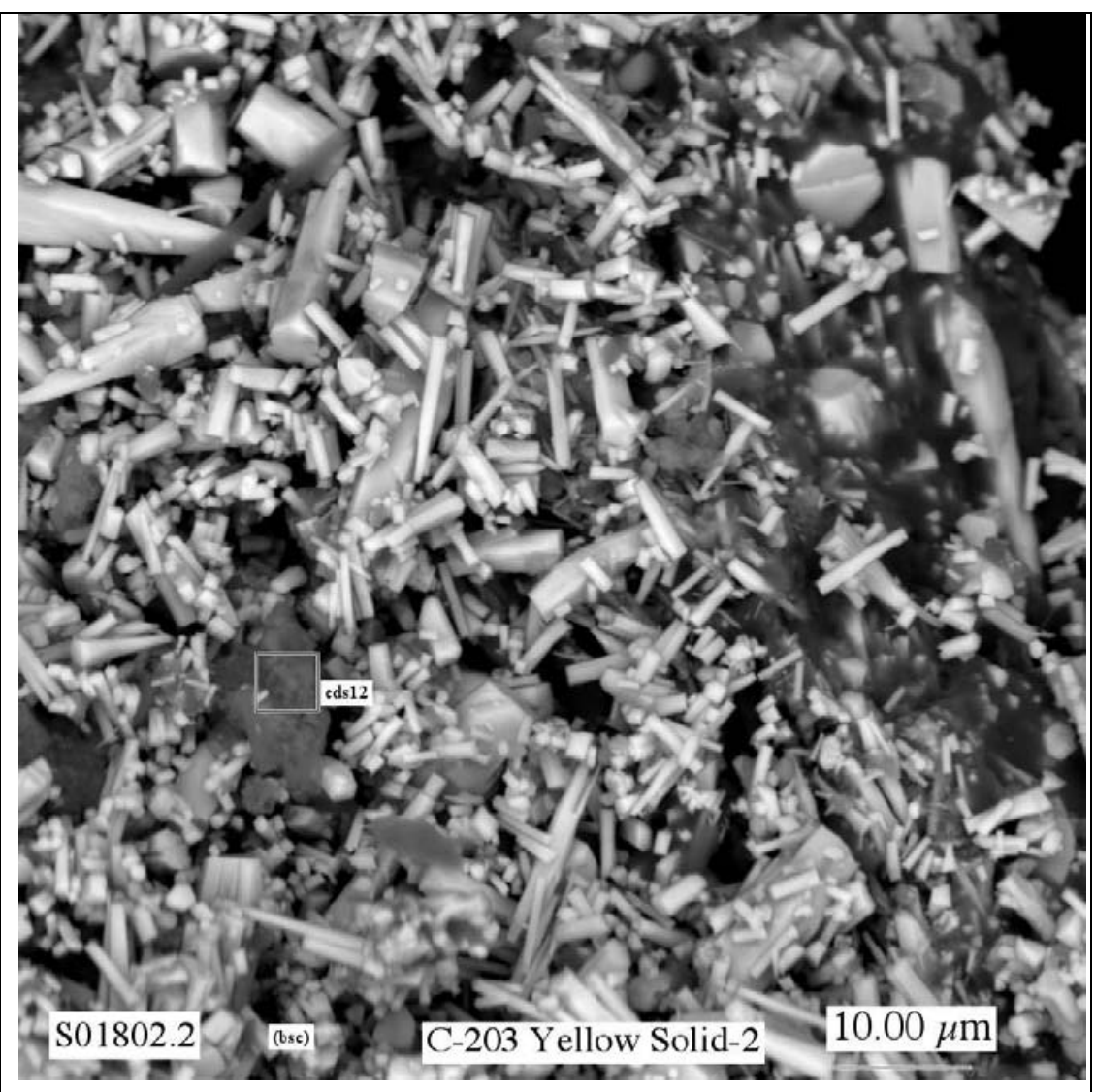

Figure B.42. Micrograph showing at higher magnification the area indicated by white dashed-line square labeled $\mathrm{A}$ in Figure B.41 


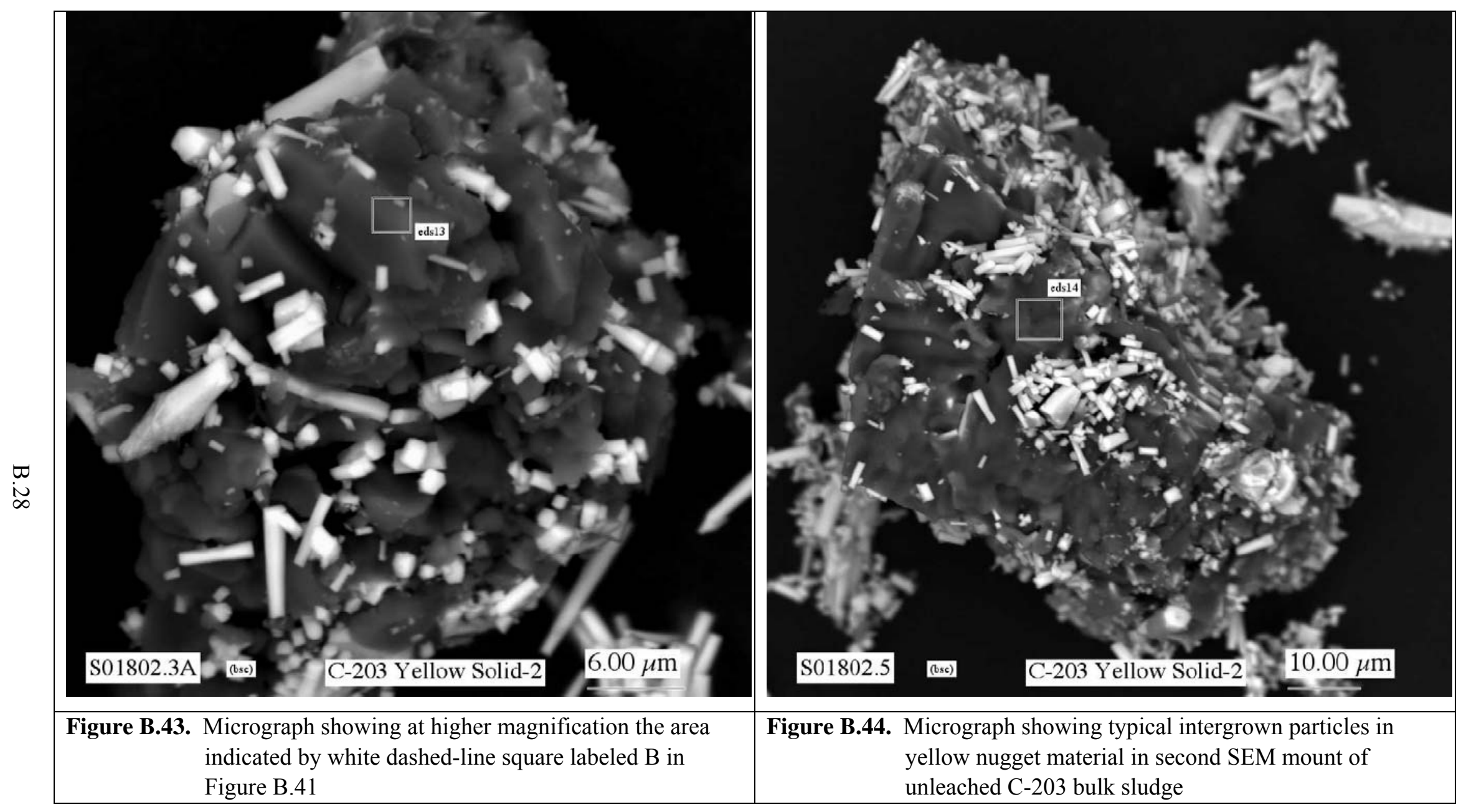




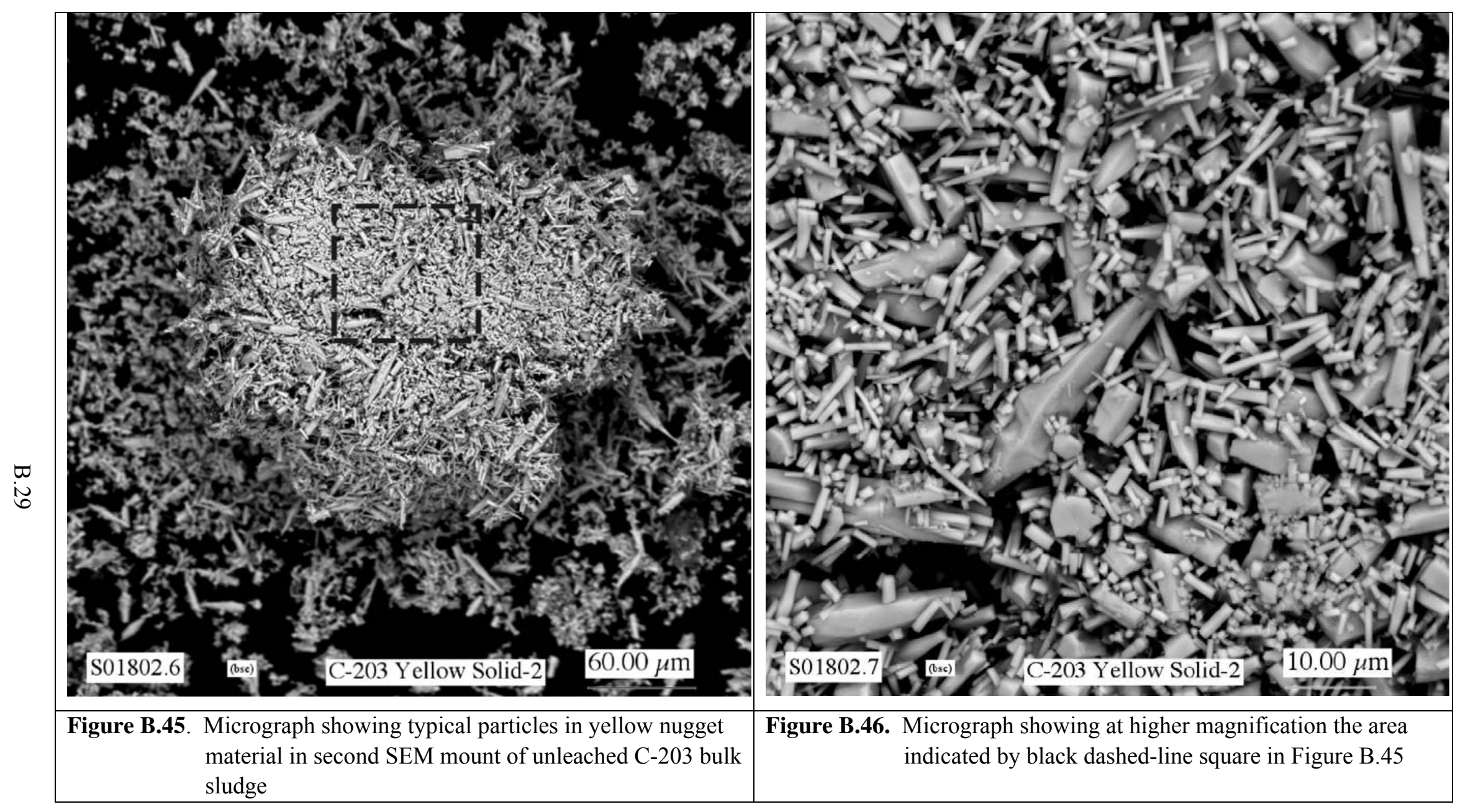




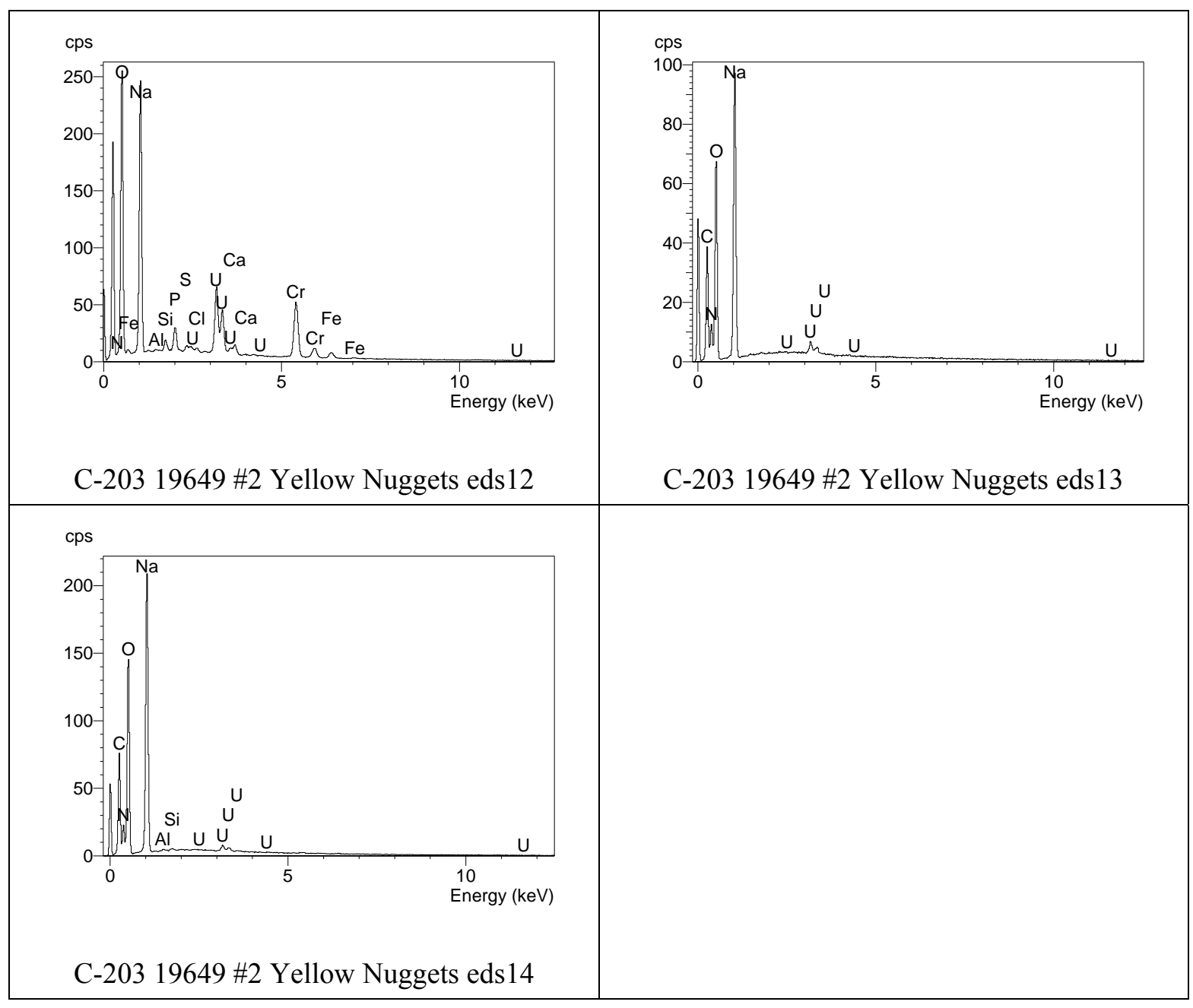

Figure B.47. EDS spectra for analyses eds 12 through eds 14 for particles in the second SEM mount in yellow nugget material present in sound SEM mount of unleached C-203 bulk sludge 


\section{B.3 Water-Leached (two weeks) C-203 Sludge}

Two mounts of water-leached (two weeks) C-203 (jar 19649) bulk residual tank waste were analyzed by SEM/EDS. The SEM micrographs for the first mount (19649-4) of C-203 sludge are shown in Figures B.48 through B.57. The EDS spectra for this mount are given in Figures B.58 through B.62. The SEM micrographs for the second mount (19649-6) of C-203 sludge are shown in Figures B.63 through B.74, and the EDS spectra for the second mount are given in Figures B.75 through B.77. 


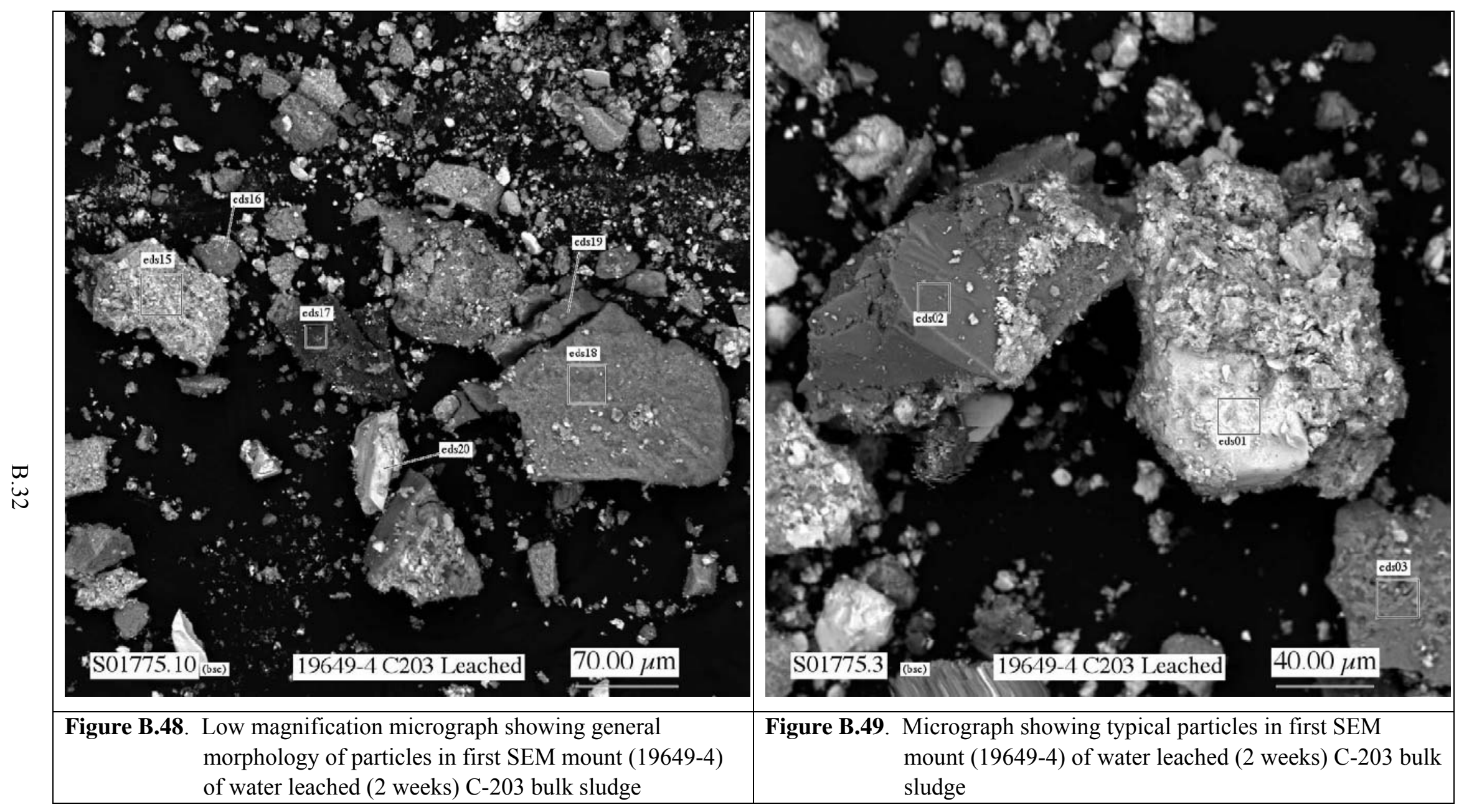




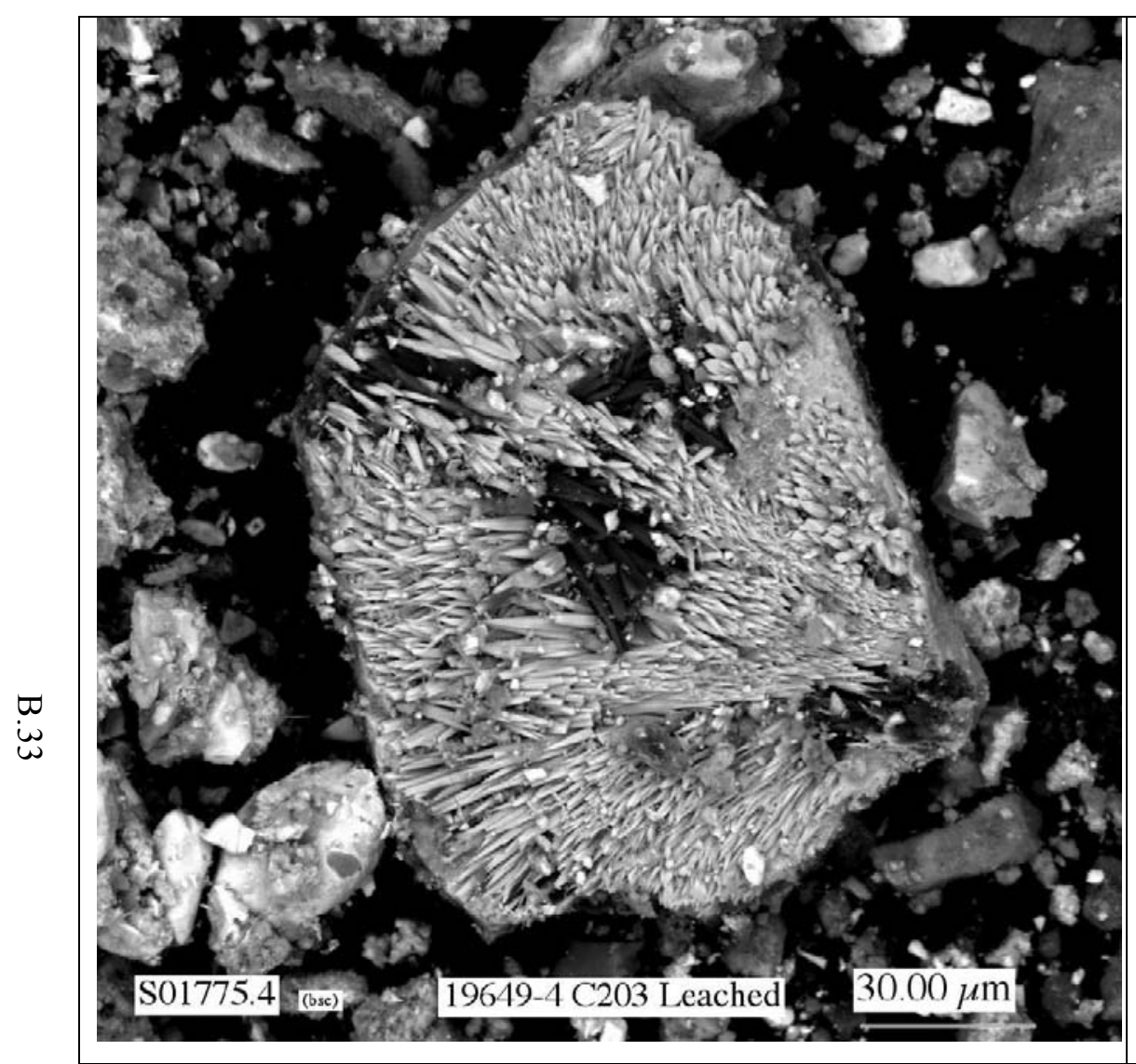

Figure B.50. Micrograph showing unusual particle coated with oriented uranium-containing needle-like crystals in first SEM mount (19649-4) of water leached (2 weeks) C203 bulk sludge

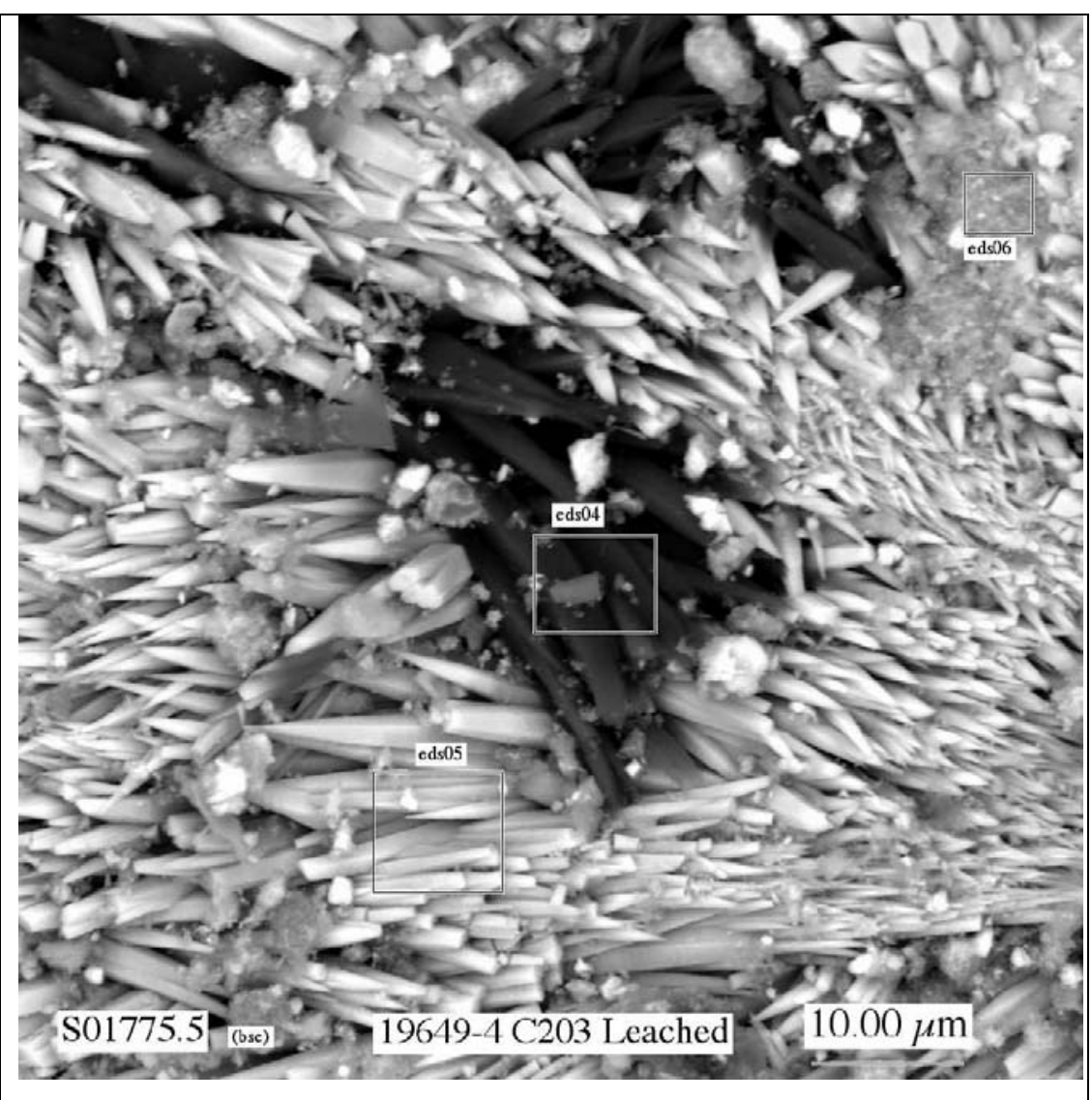

Figure B.51. Micrograph showing at higher magnification the area in the center of Figure B.50 


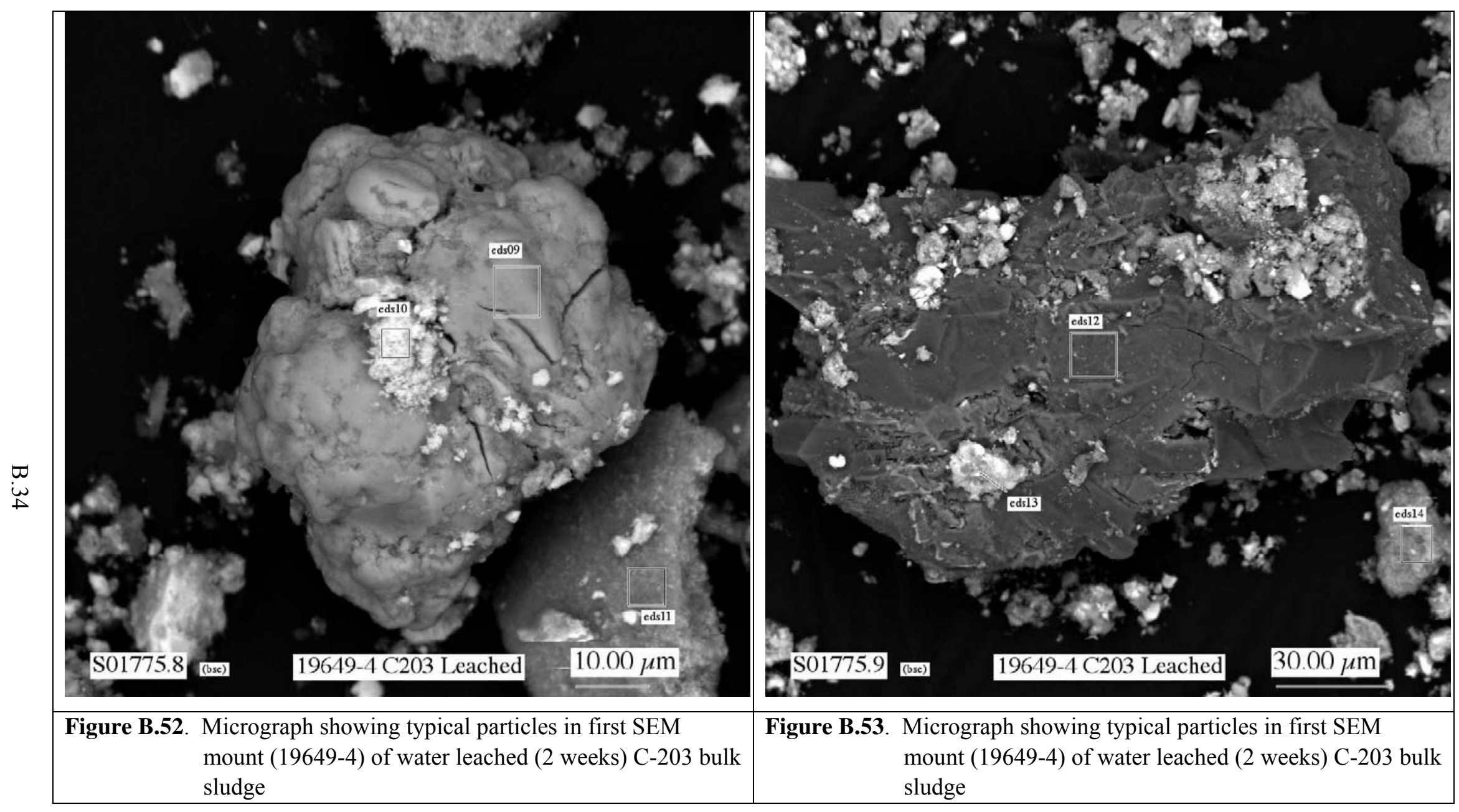




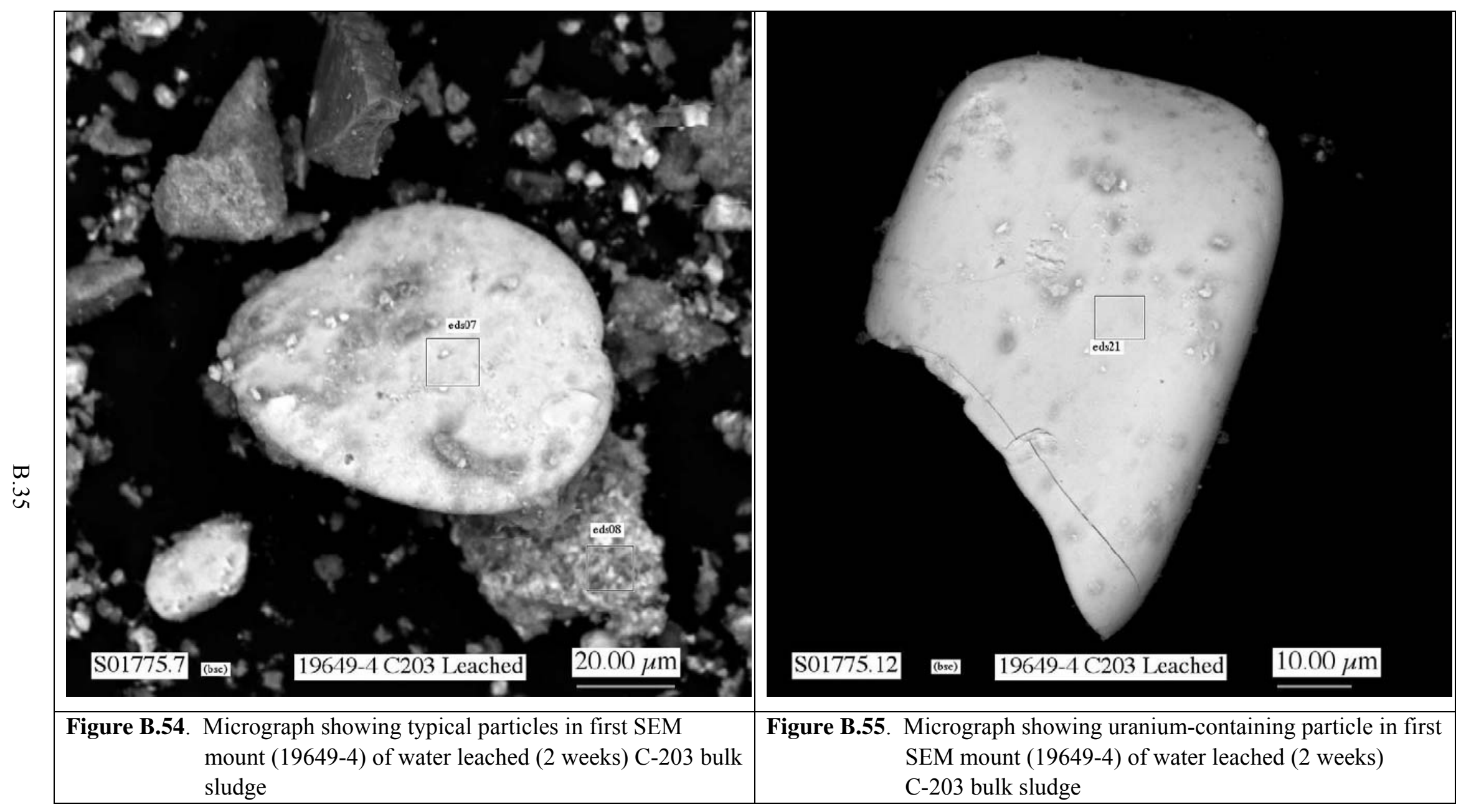




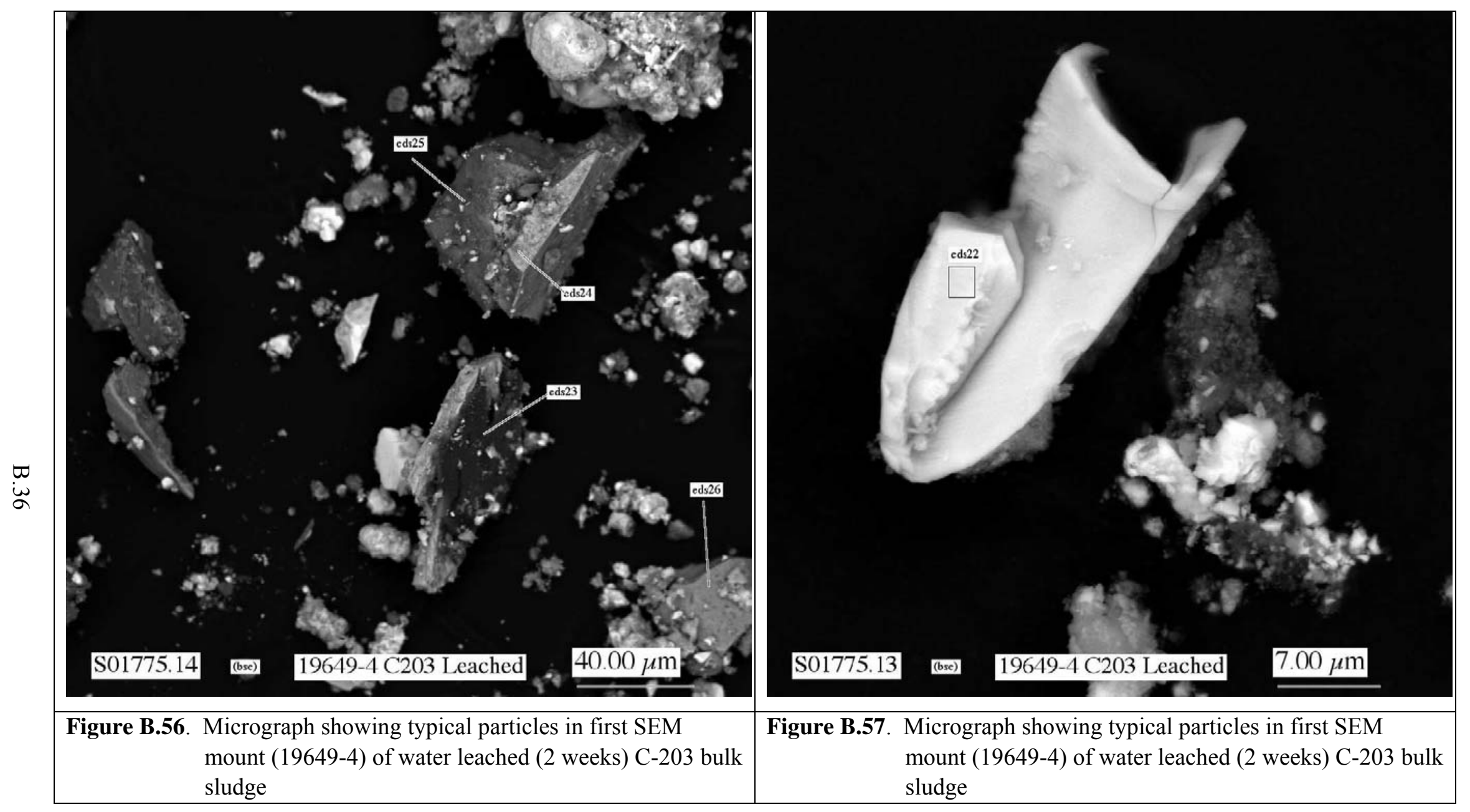




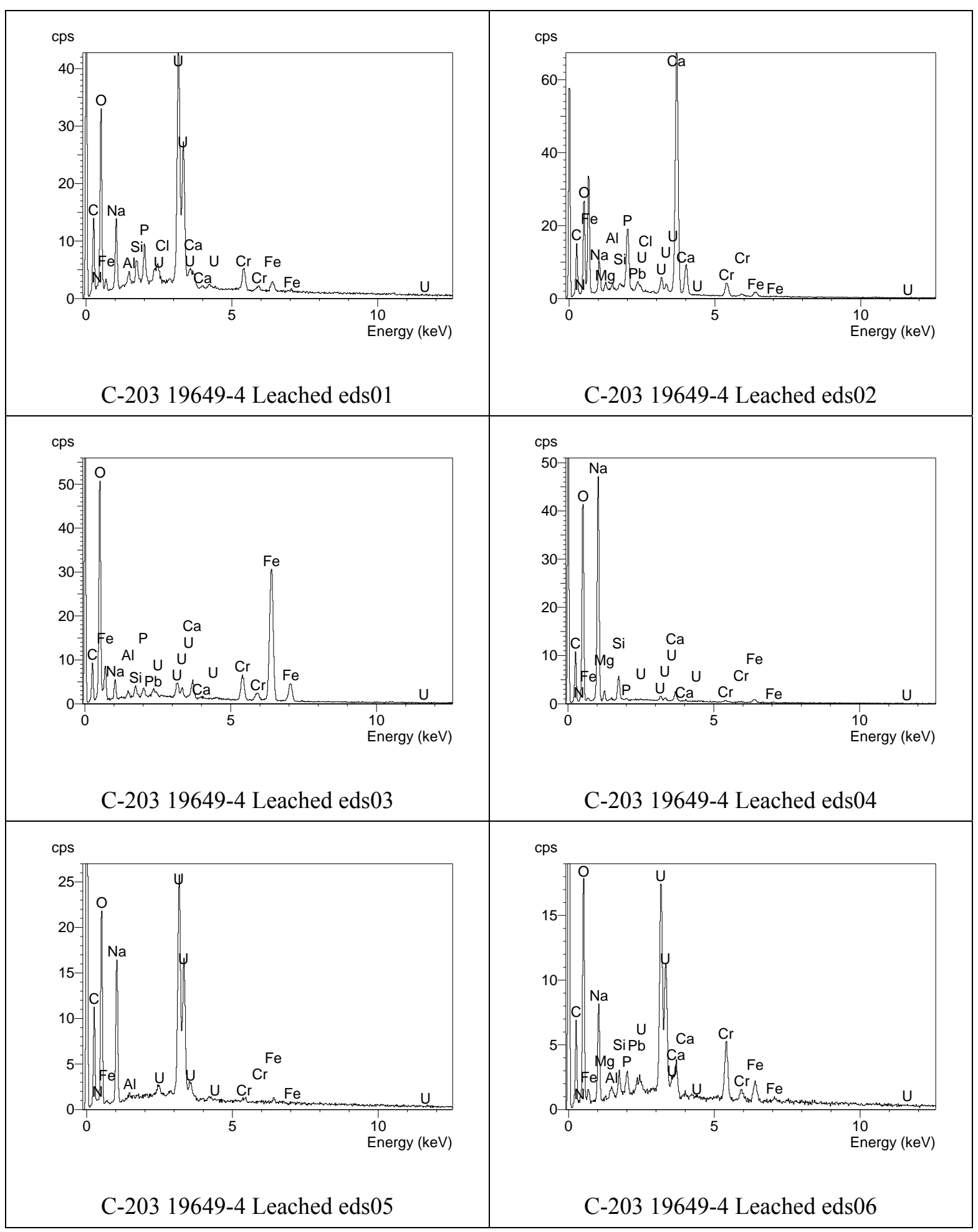

Figure B.58. EDS spectra for analyses eds01 through eds06 for particles in the first SEM mount (19649-4) of water leached (2 weeks) C-203 bulk sludge 


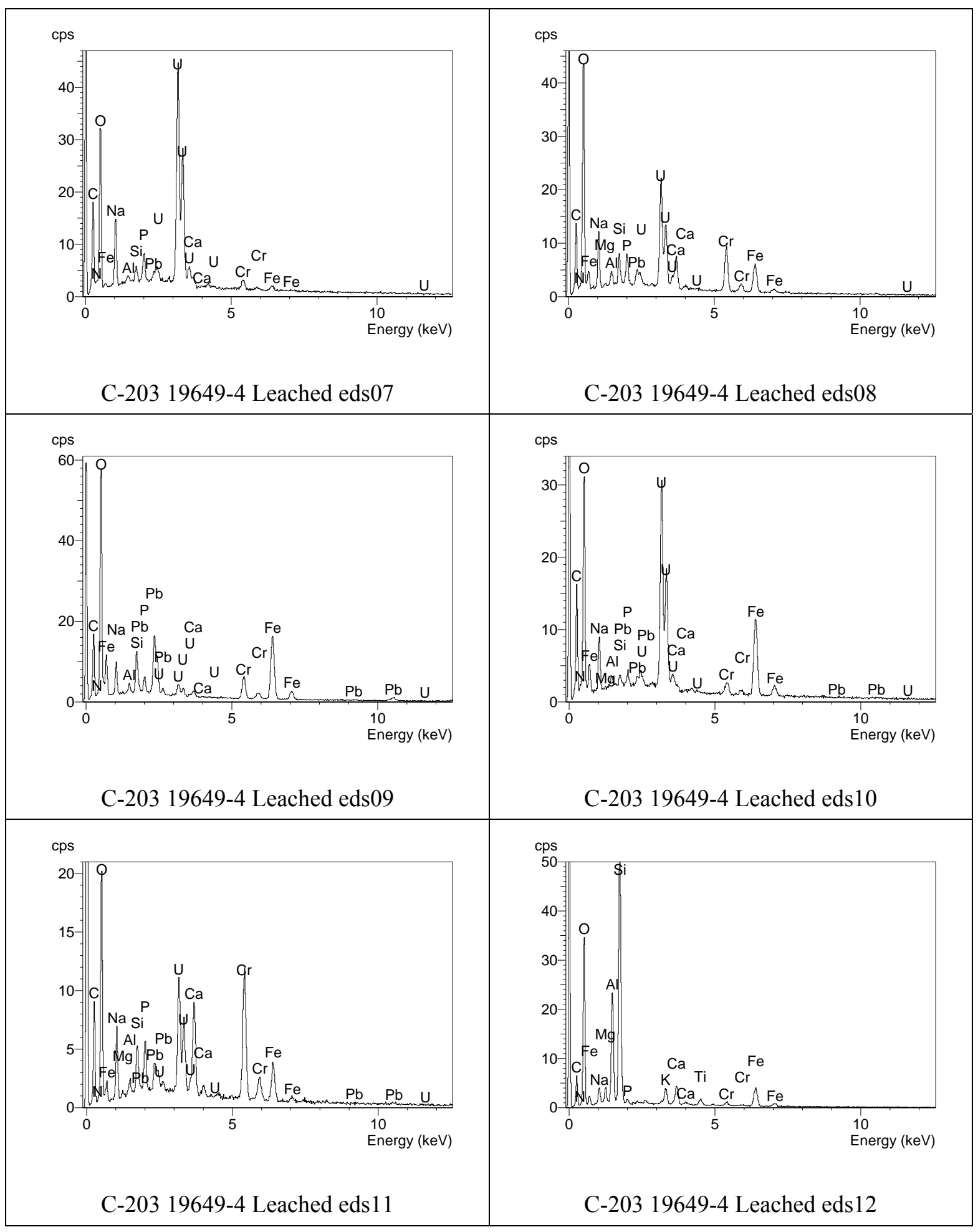

Figure B.59. EDS spectra for analyses eds07 through eds 12 for particles in the first SEM mount (19649-4) of water leached (2 weeks) C-203 bulk sludge 


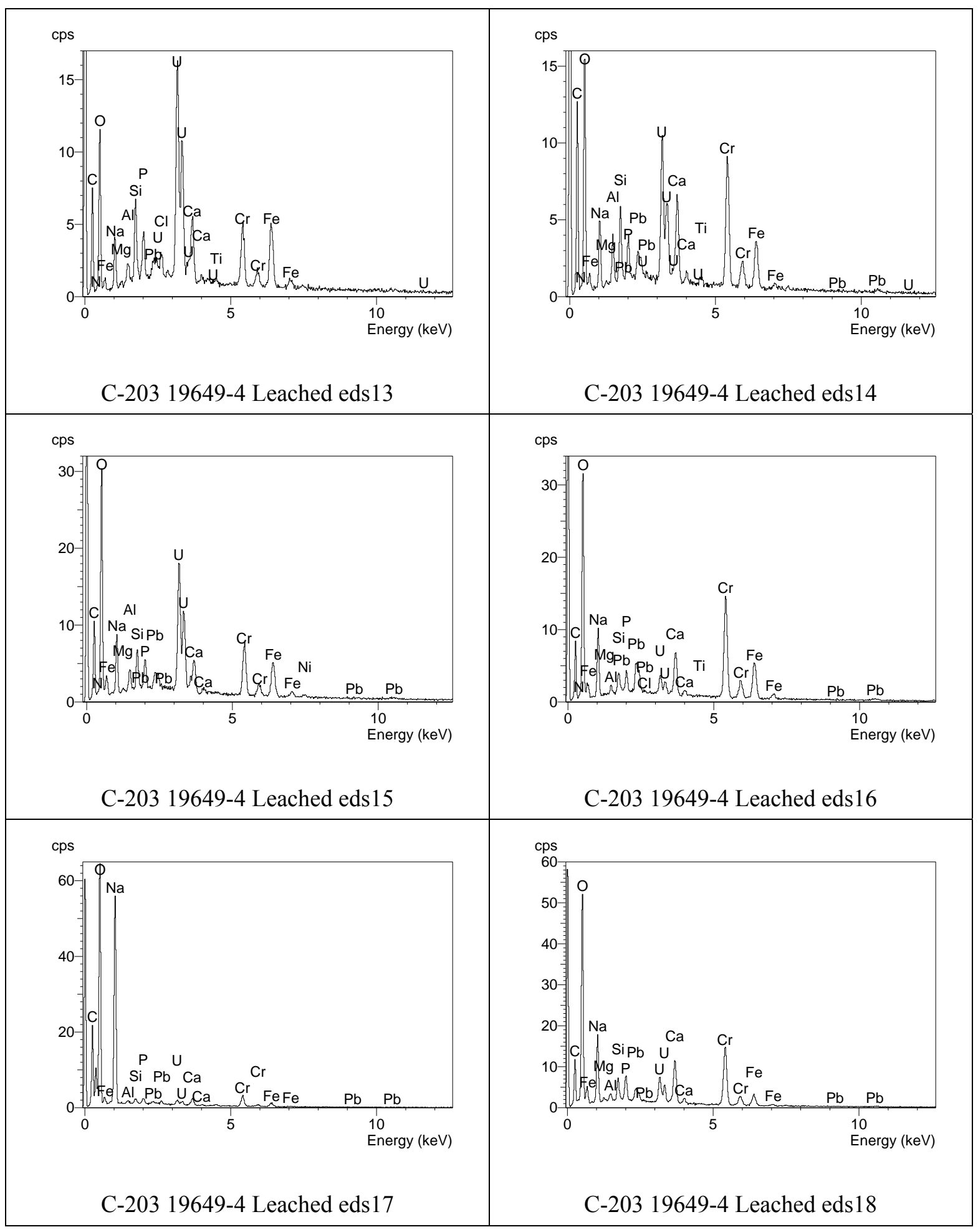

Figure B.60. EDS spectra for analyses eds 13 through eds 18 for particles in the first SEM mount (19649-4) of water leached (2 weeks) C-203 bulk sludge 


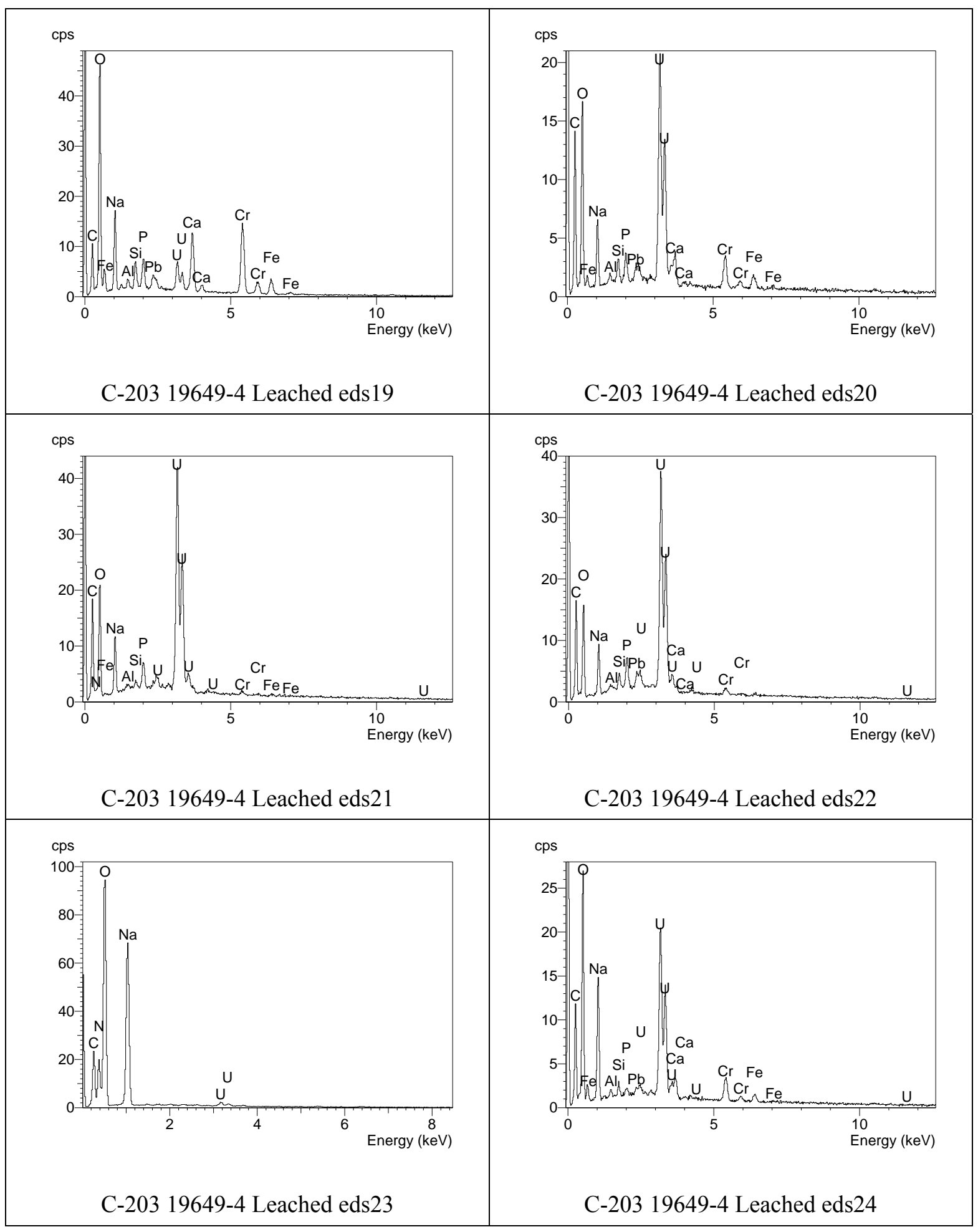

Figure B.61. EDS spectra for analyses eds 19 through eds24 for particles in the first SEM mount (19649-4) of water leached (2 weeks) C-203 bulk sludge 


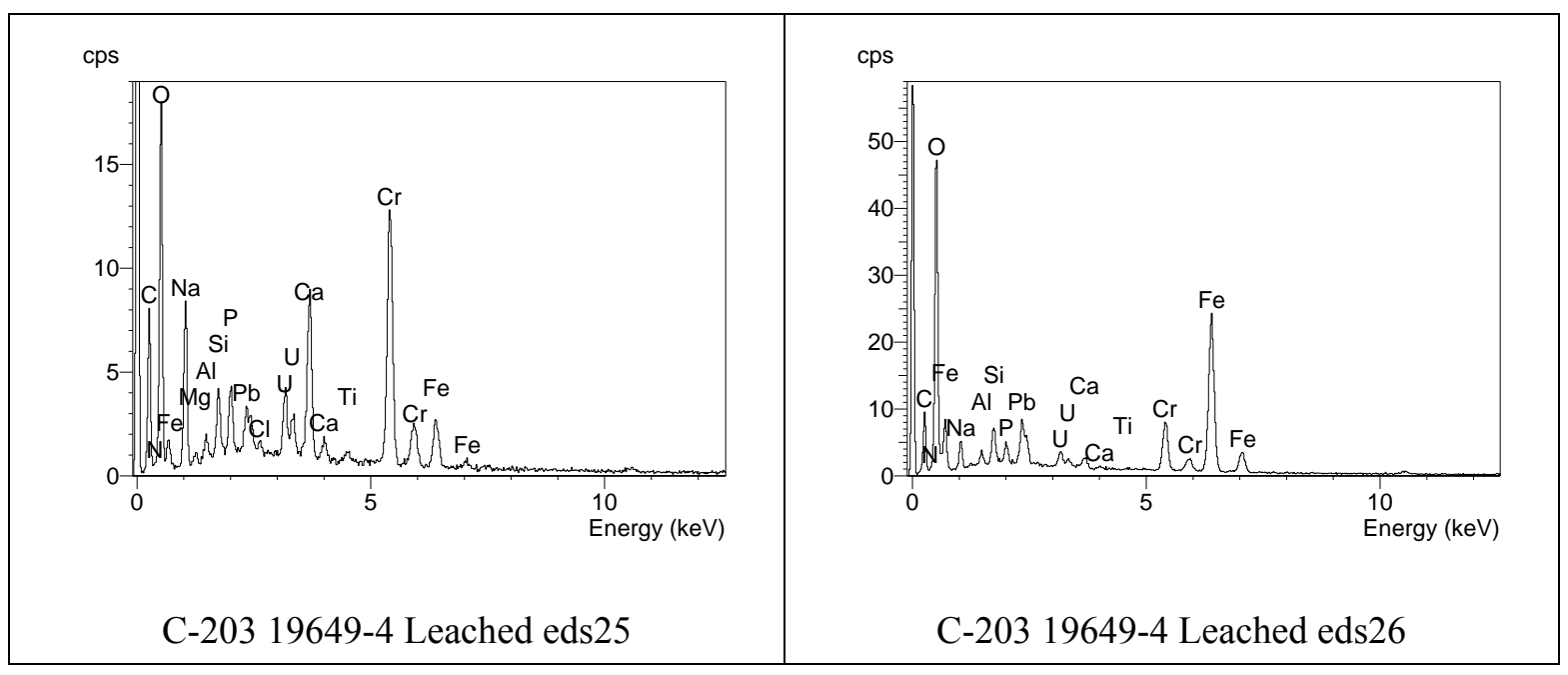

Figure B.62. EDS spectra for analyses eds 25 and eds 26 for particles in the first SEM mount (19649-4) of water leached (2 weeks) C-203 bulk sludge 


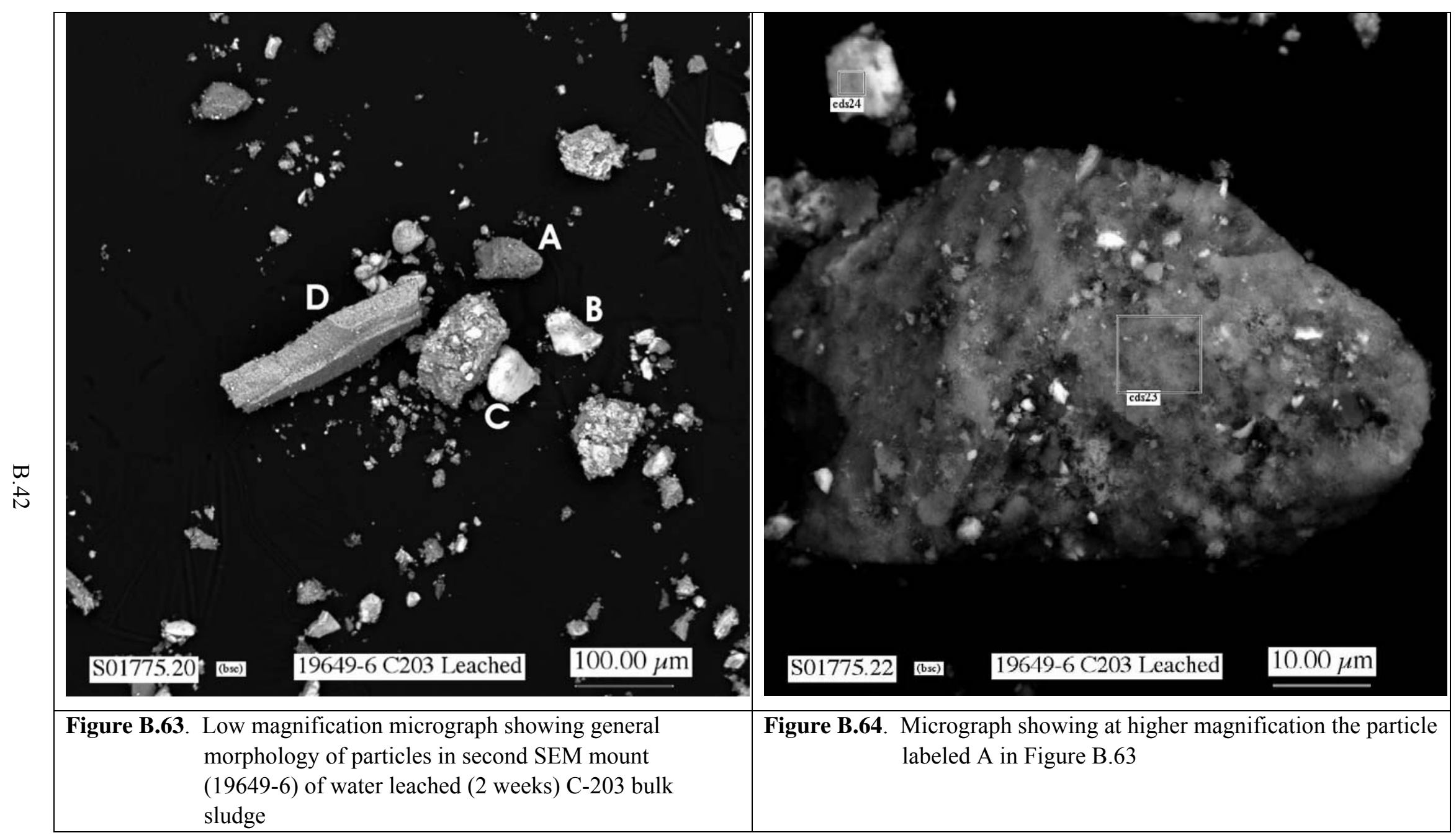




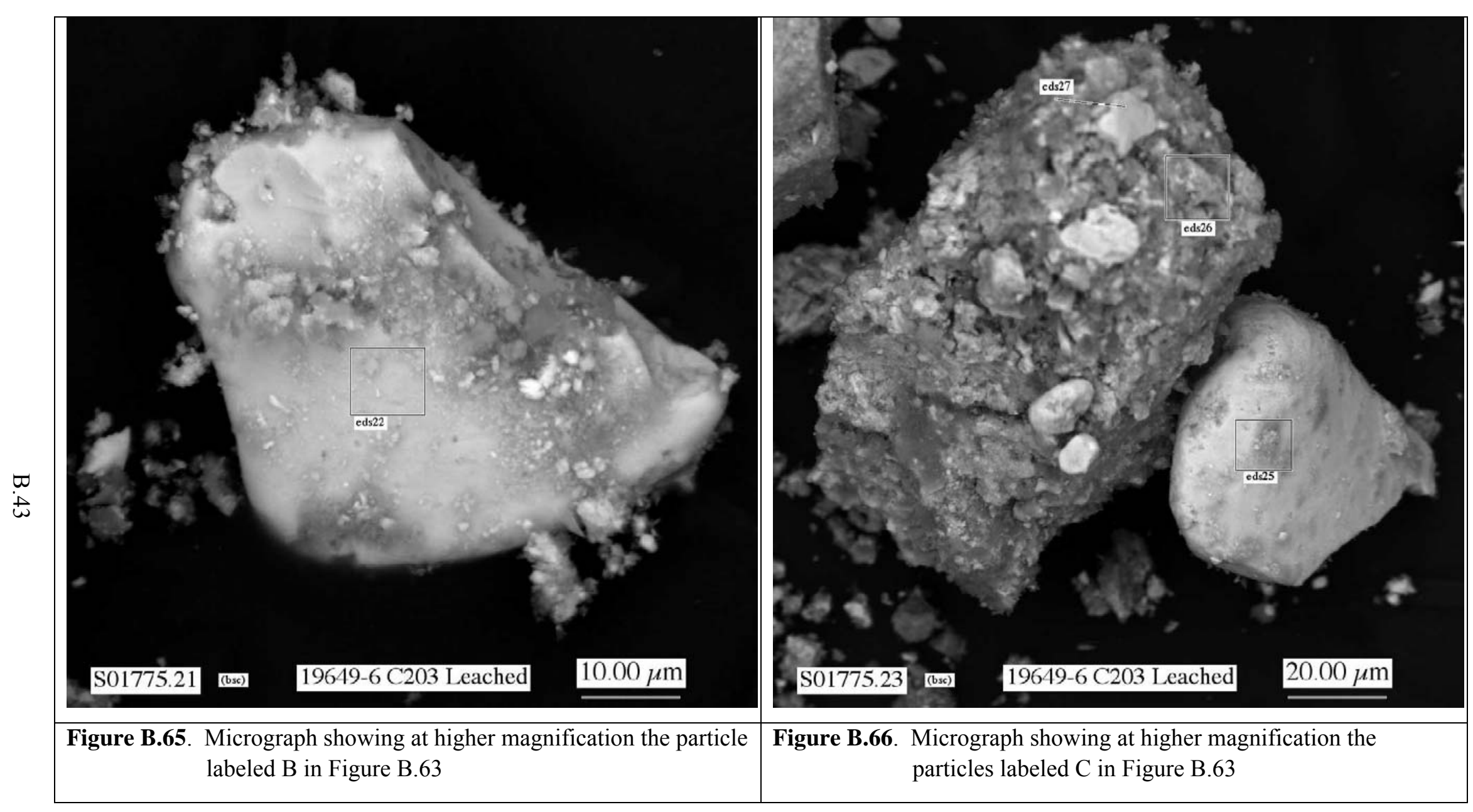




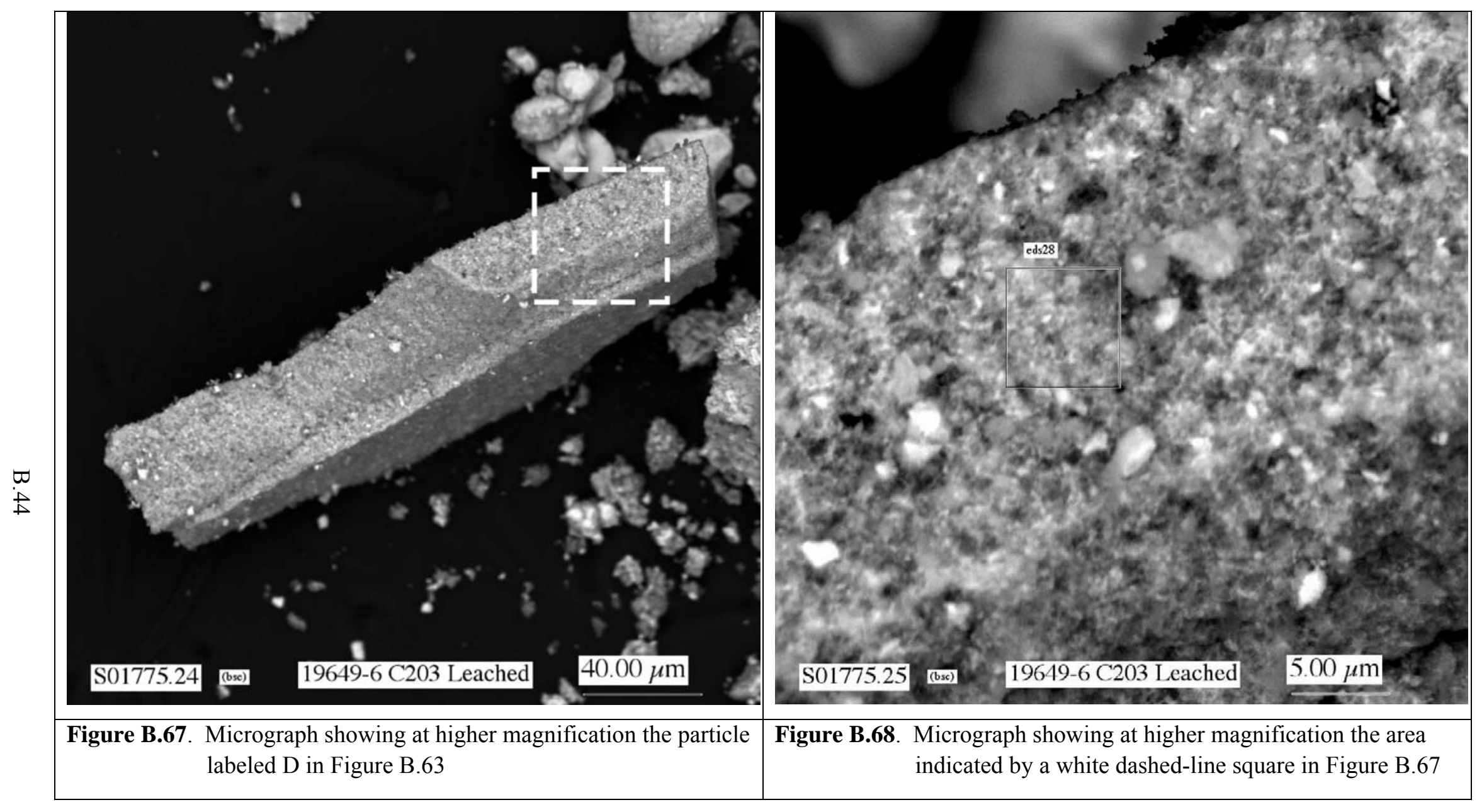




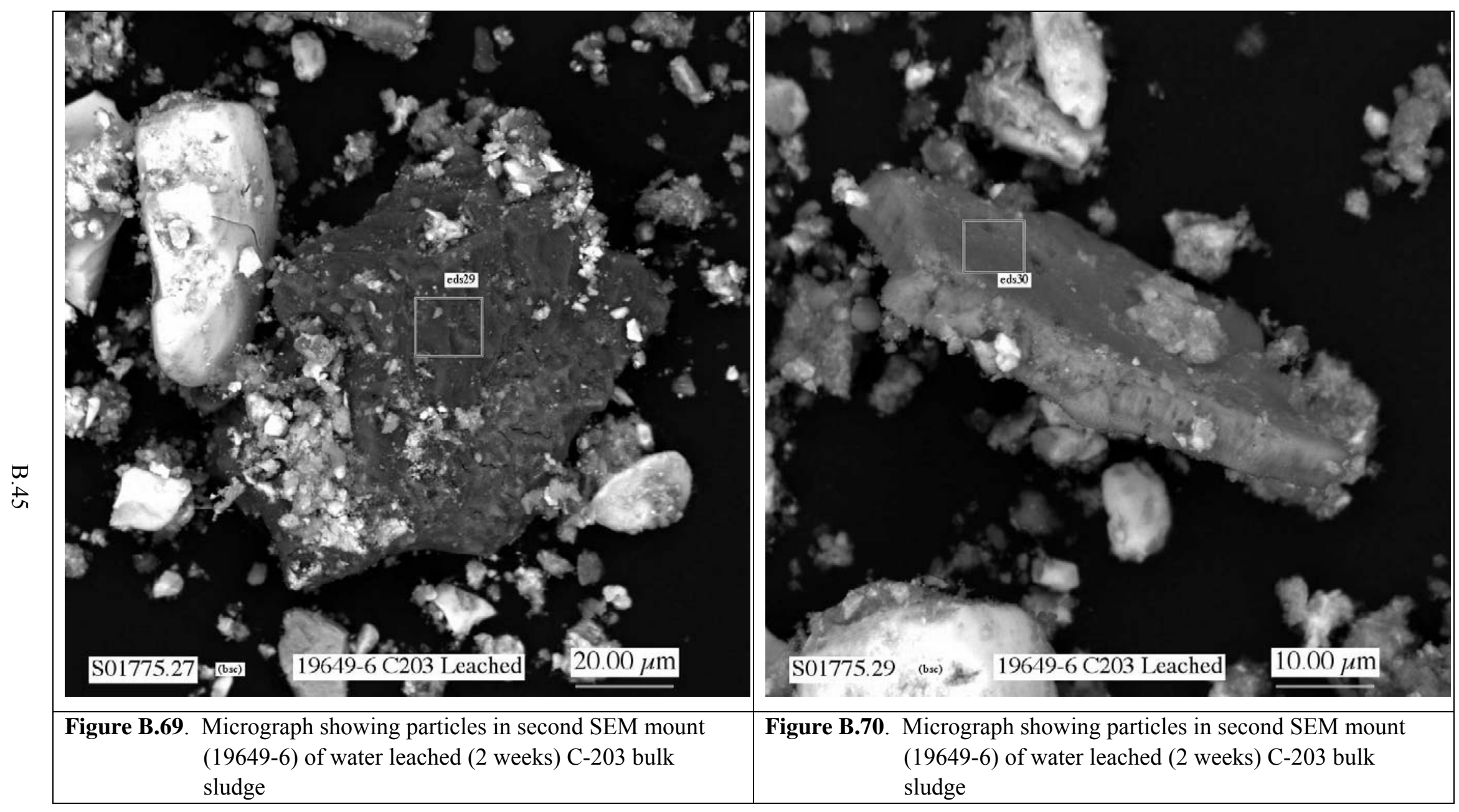




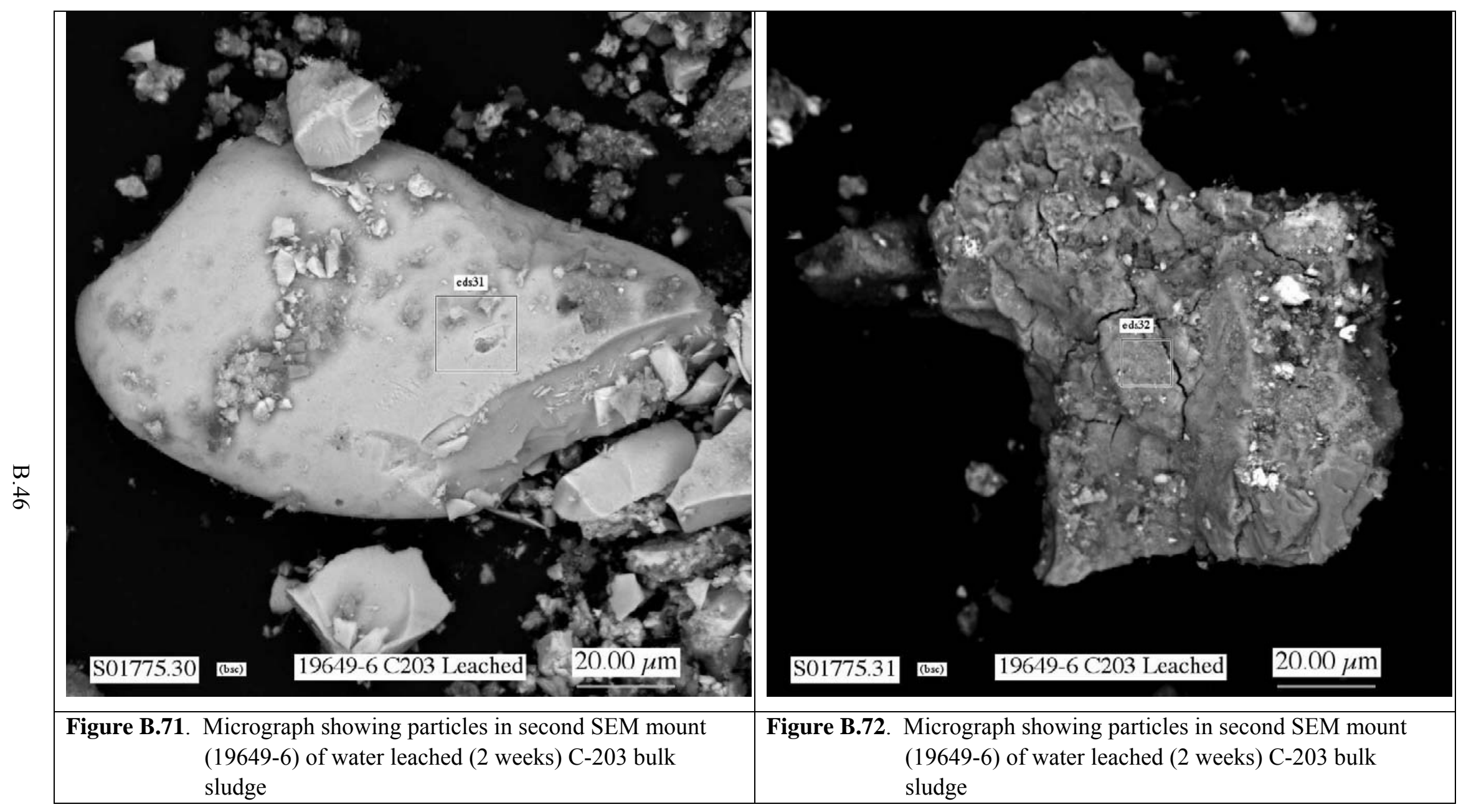




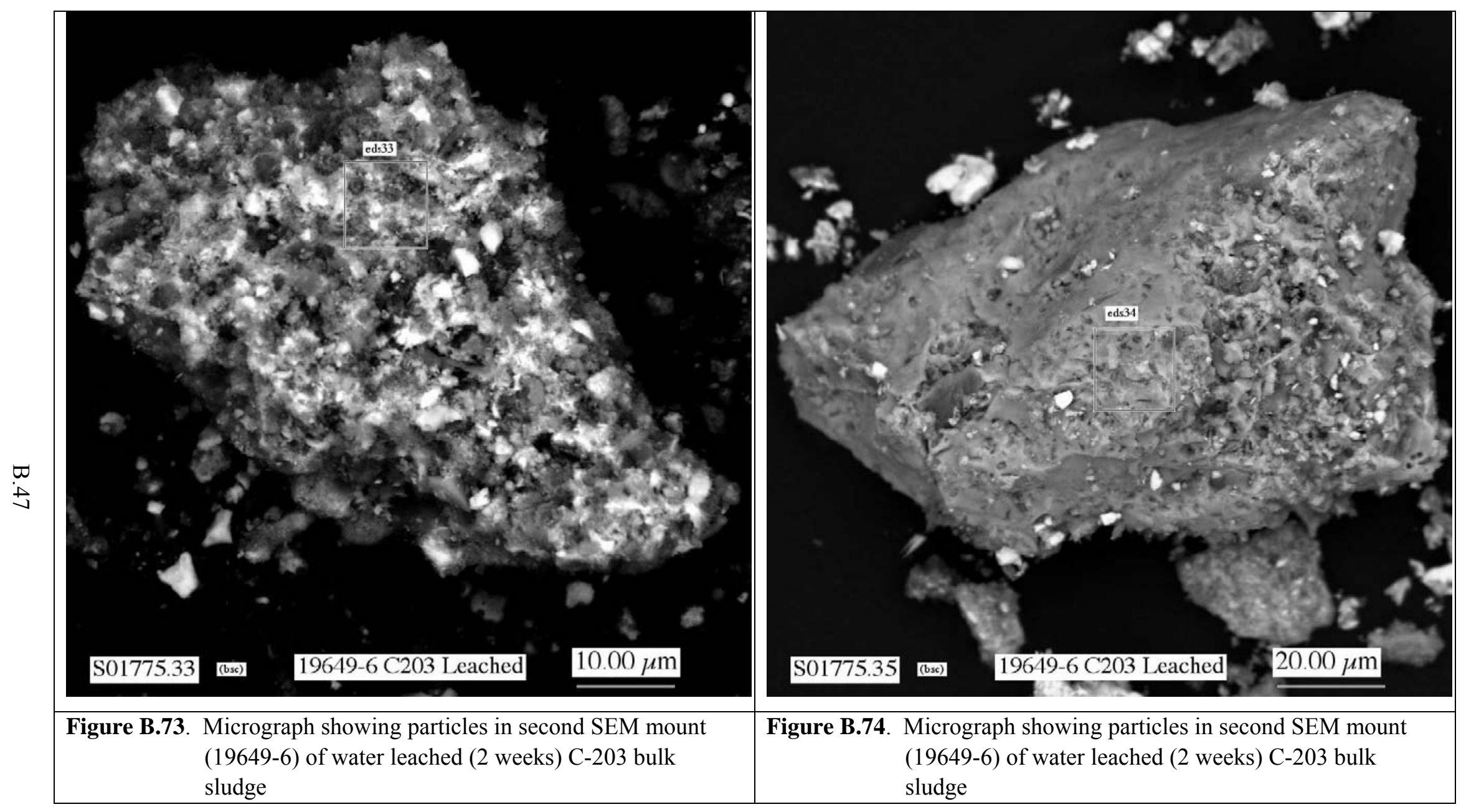




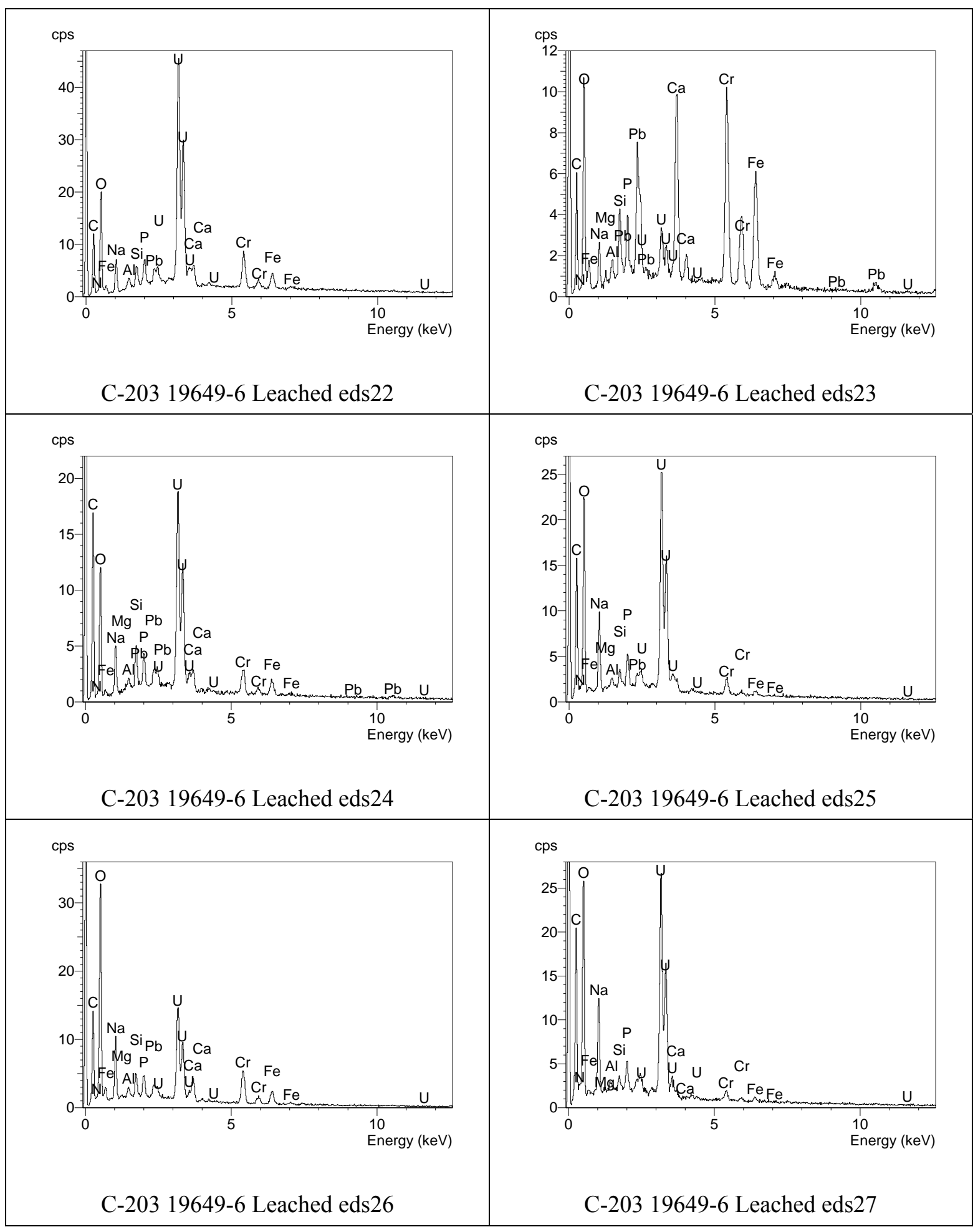

Figure B.75. EDS spectra for analyses eds22 through eds27 for particles in the second SEM mount (19649-6) of water leached (2 weeks) C-203 bulk sludge 


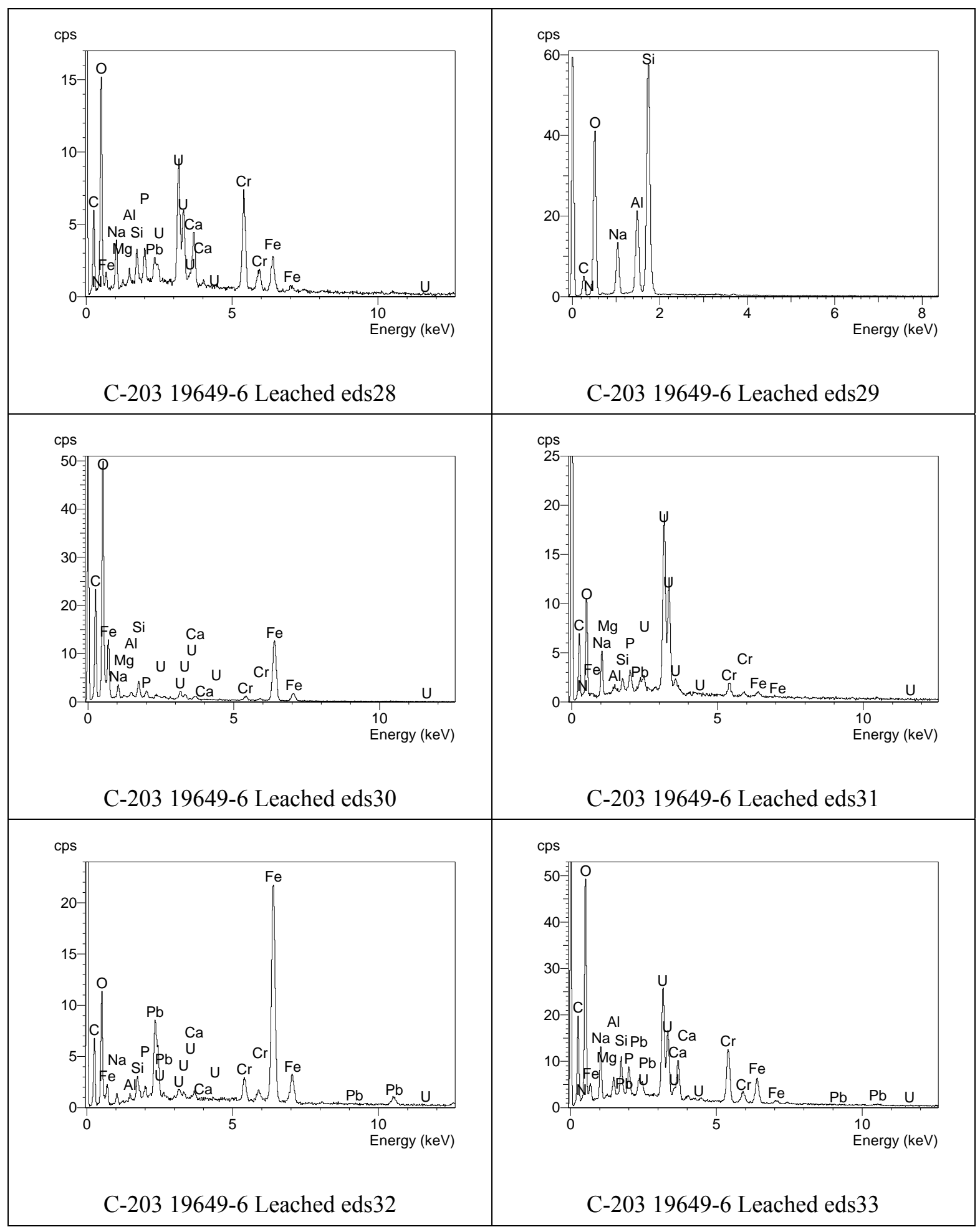

Figure B.76. EDS spectra for analyses eds 28 through eds 33 for particles in the second SEM mount (19649-6) of water leached (2 weeks) C-203 bulk sludge 


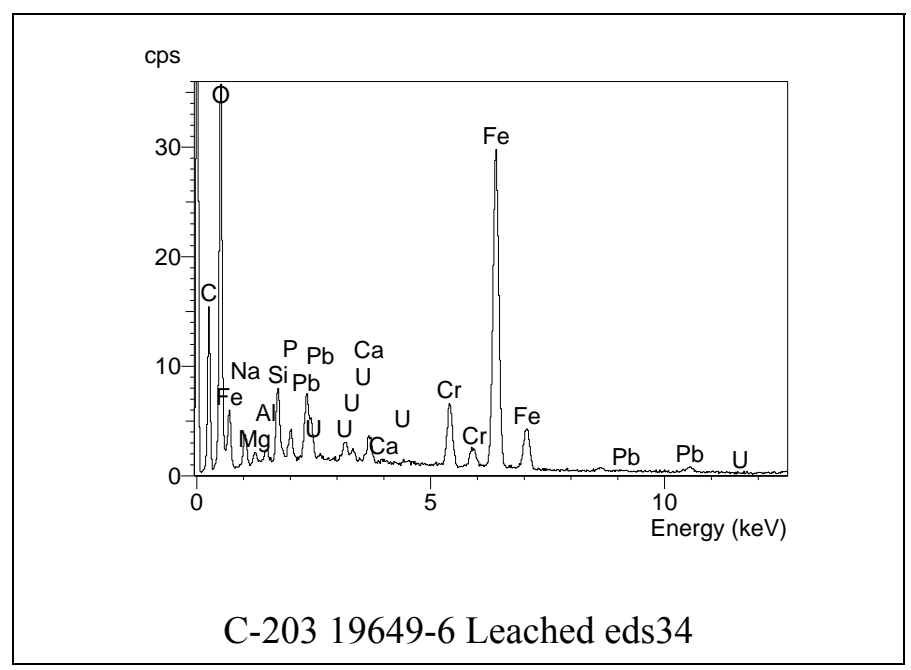

Figure B.77. EDS spectra for analysis eds 34 for a particle in the second SEM mount (19649-6) of water leached (2 weeks) C-203 bulk sludge 


\section{B.4 Water-Leached (two months) C-203 Sludge}

Only one mount of long-term water-leached (two months) C-203 (jar 19649) bulk residual tank waste was analyzed by SEM/EDS. The SEM micrographs for this sample of C-203 sludge are shown in Figures B.77 through B.87. The EDS spectra for this sample are given in Figures B.88 through B.90. 


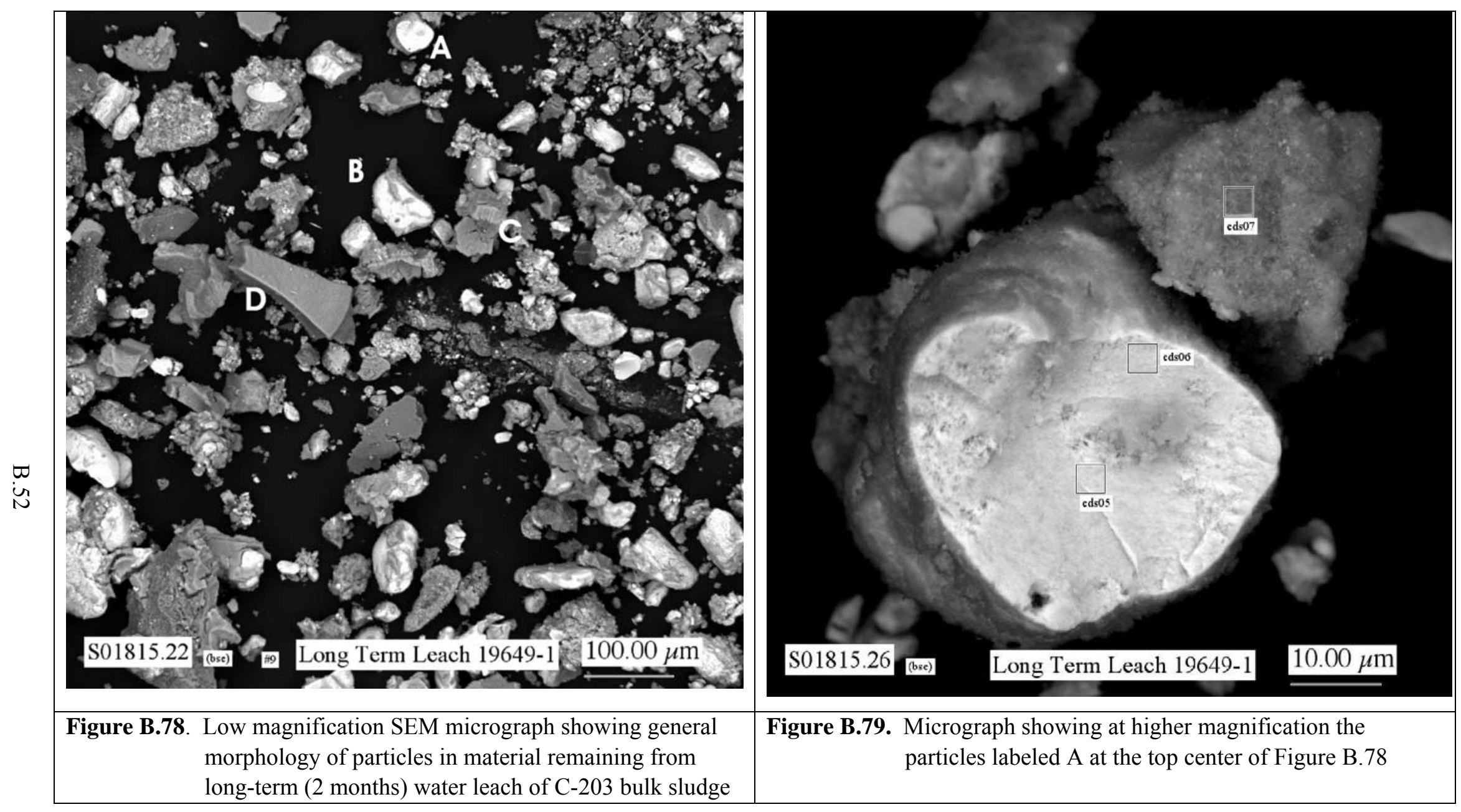




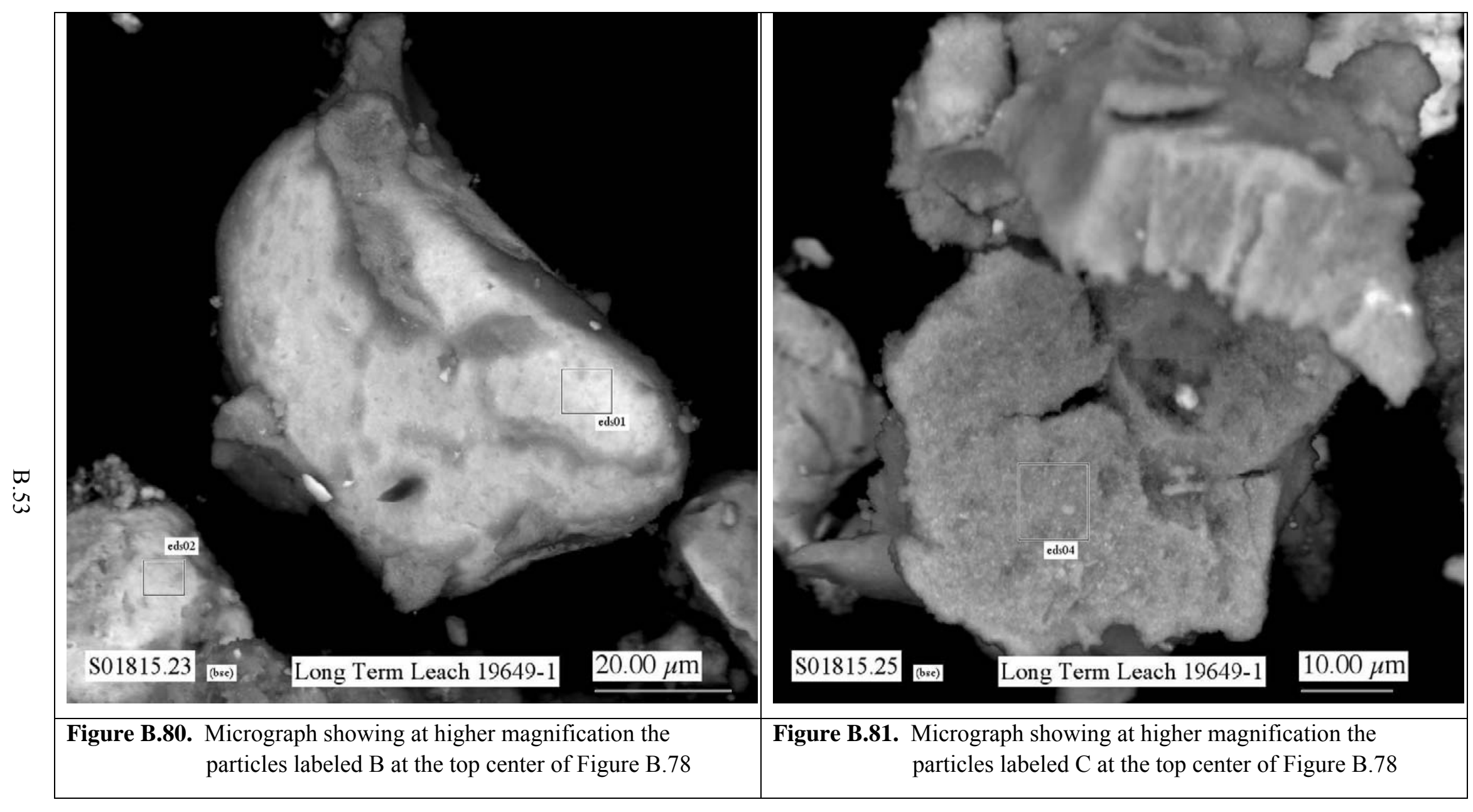




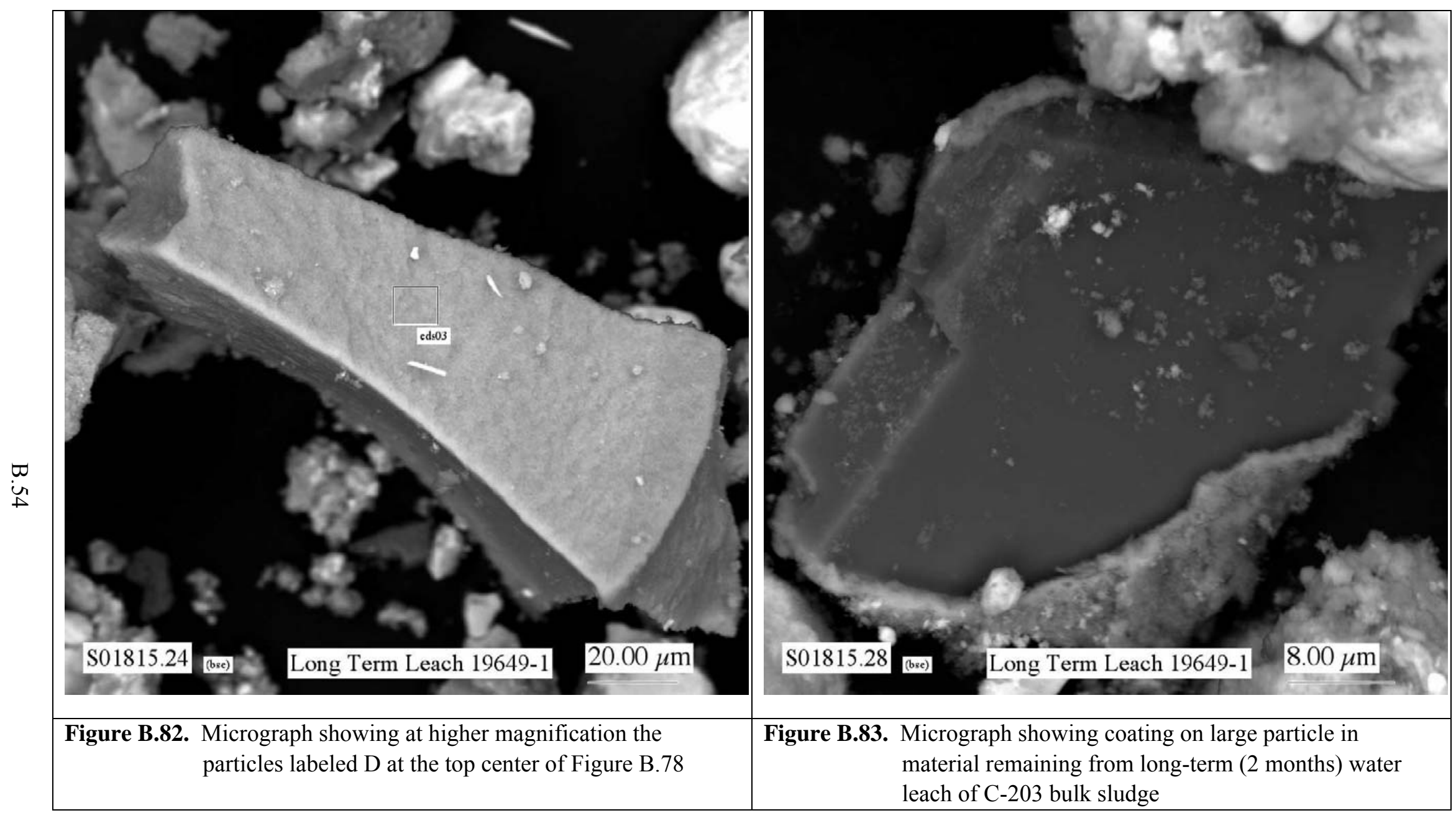




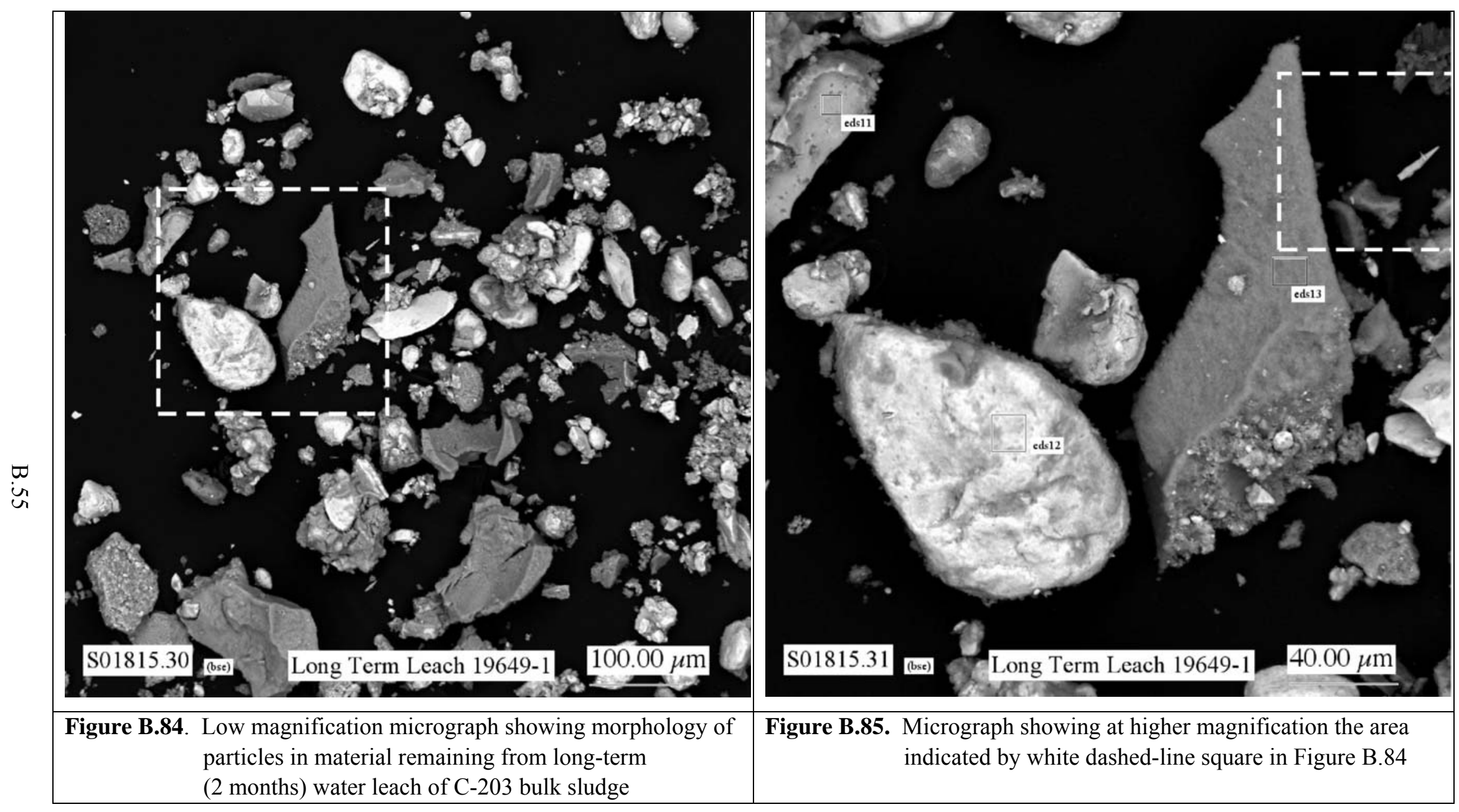




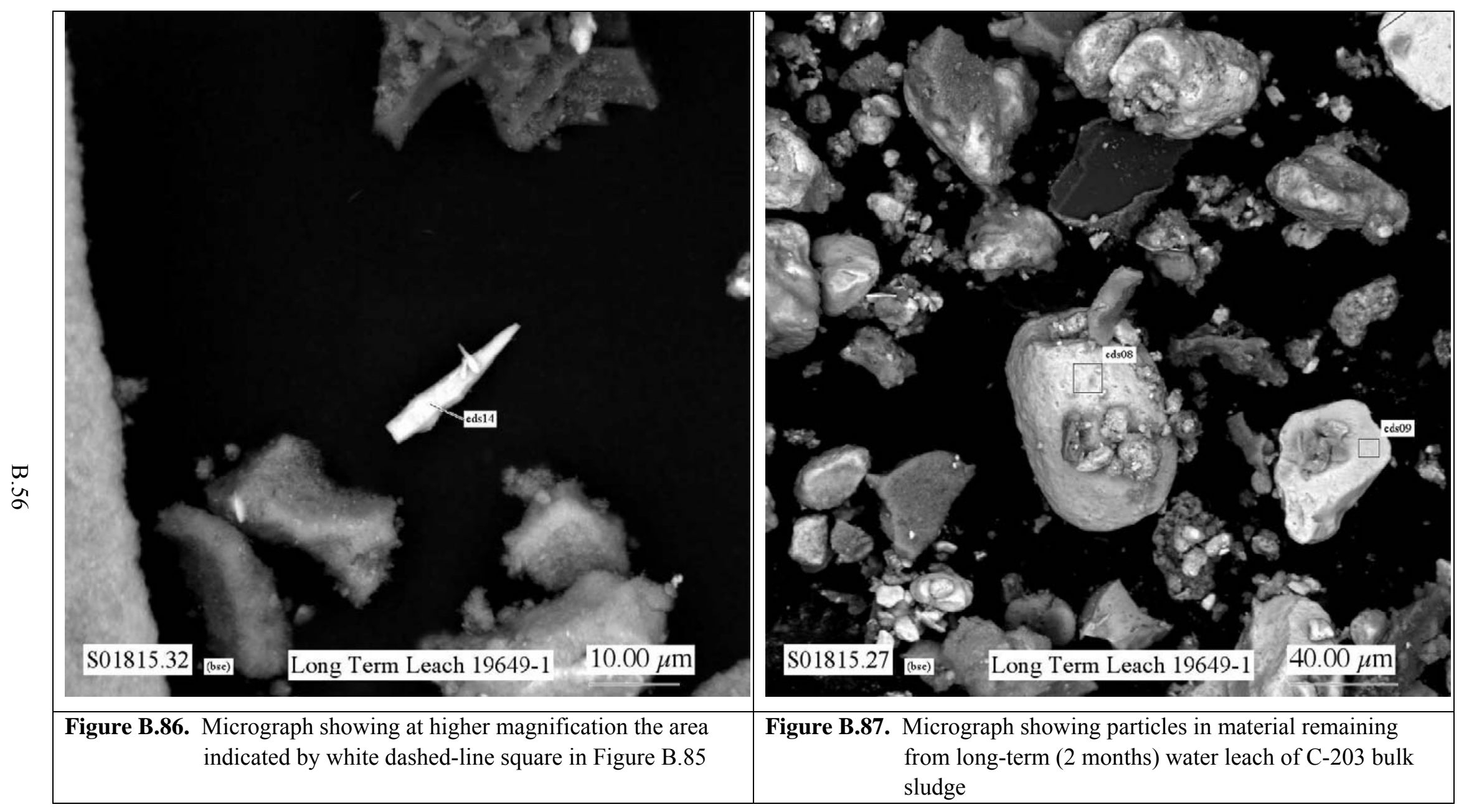




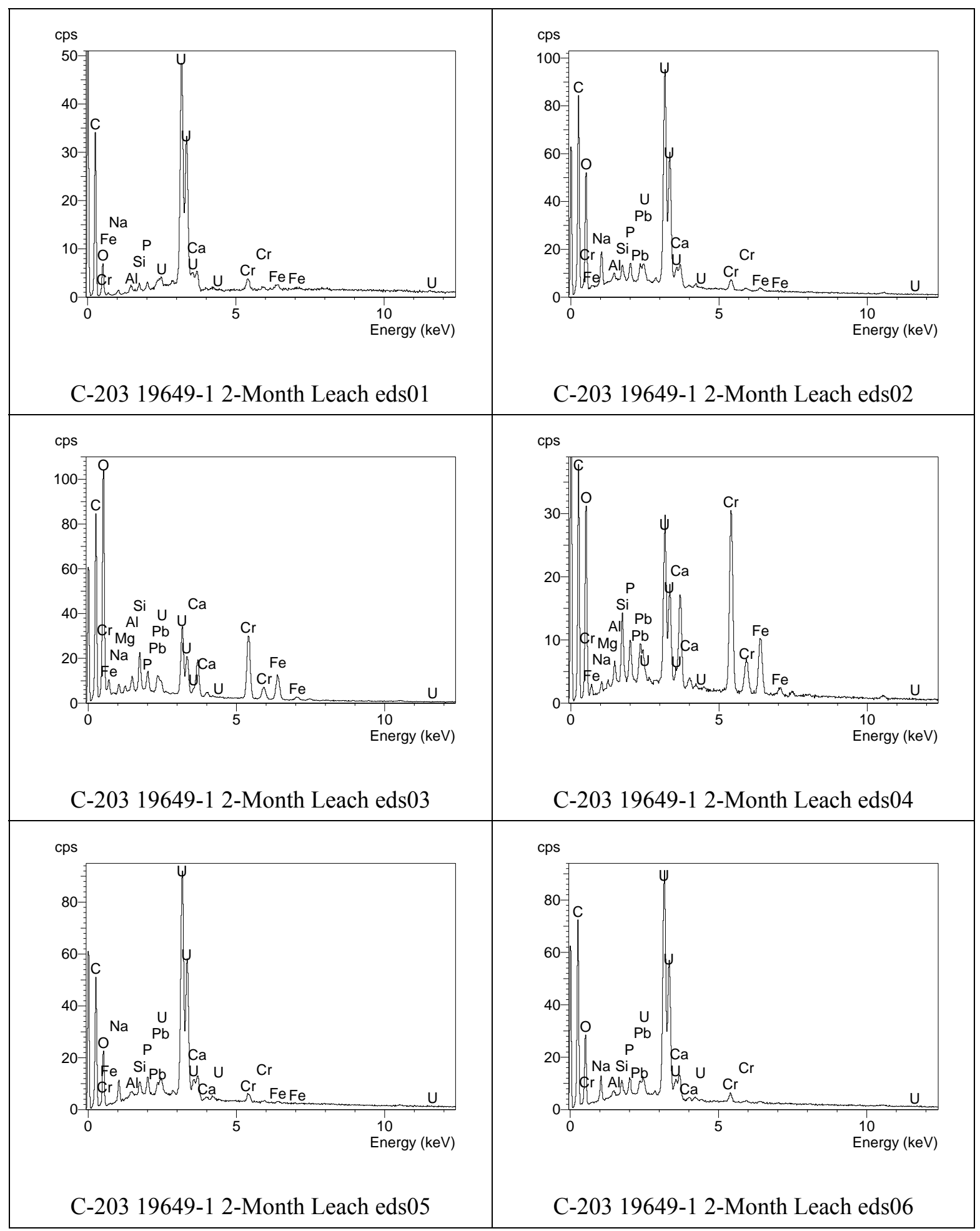

Figure B.88. EDS spectra for analyses eds01 through eds06 for particles from long-term (2 month) water leach of C-203 bulk sludge 


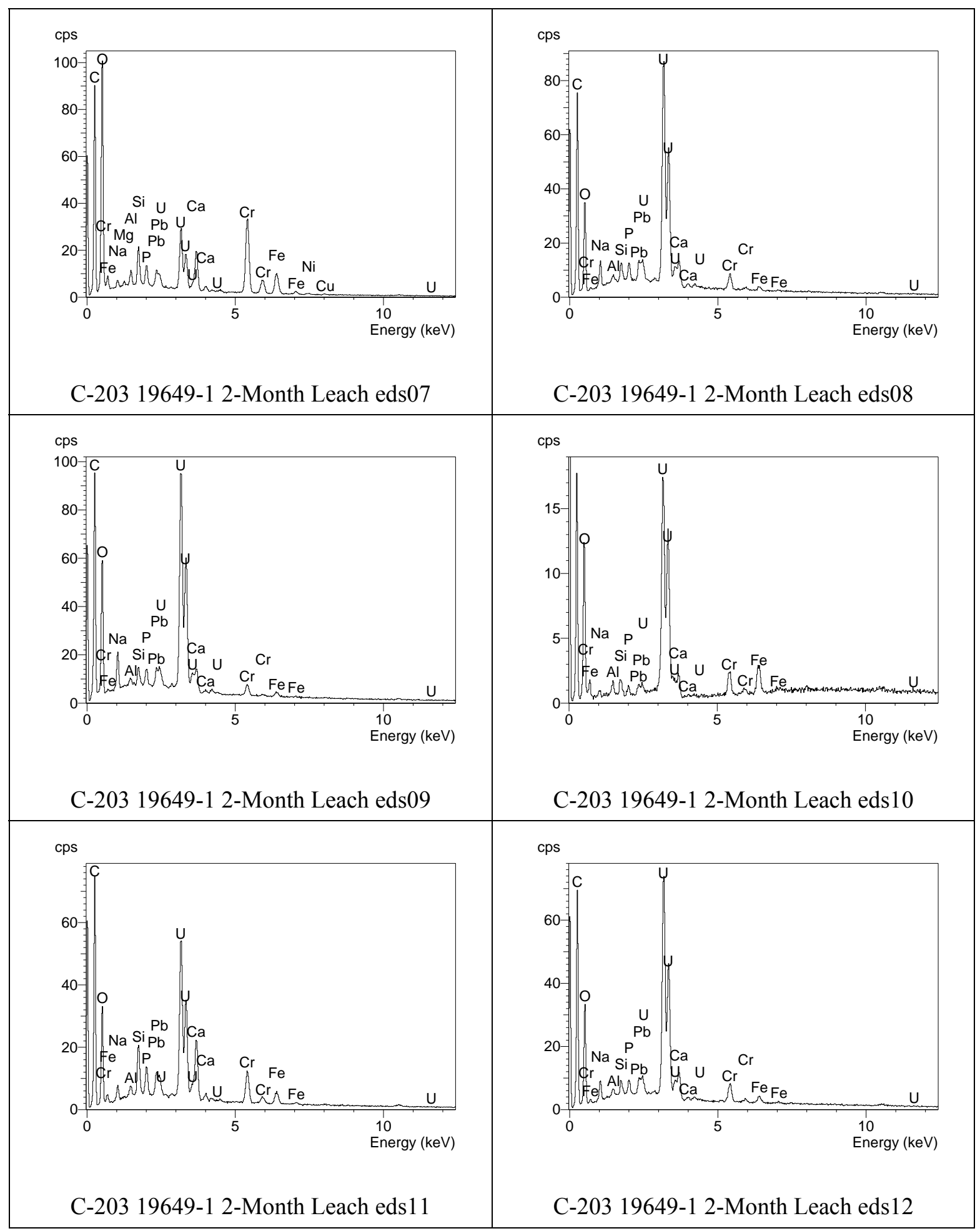

Figure B.89. EDS spectra for analyses eds 07 through eds 12 for particles from long-term (2-month) water leach of C-203 bulk sludge 


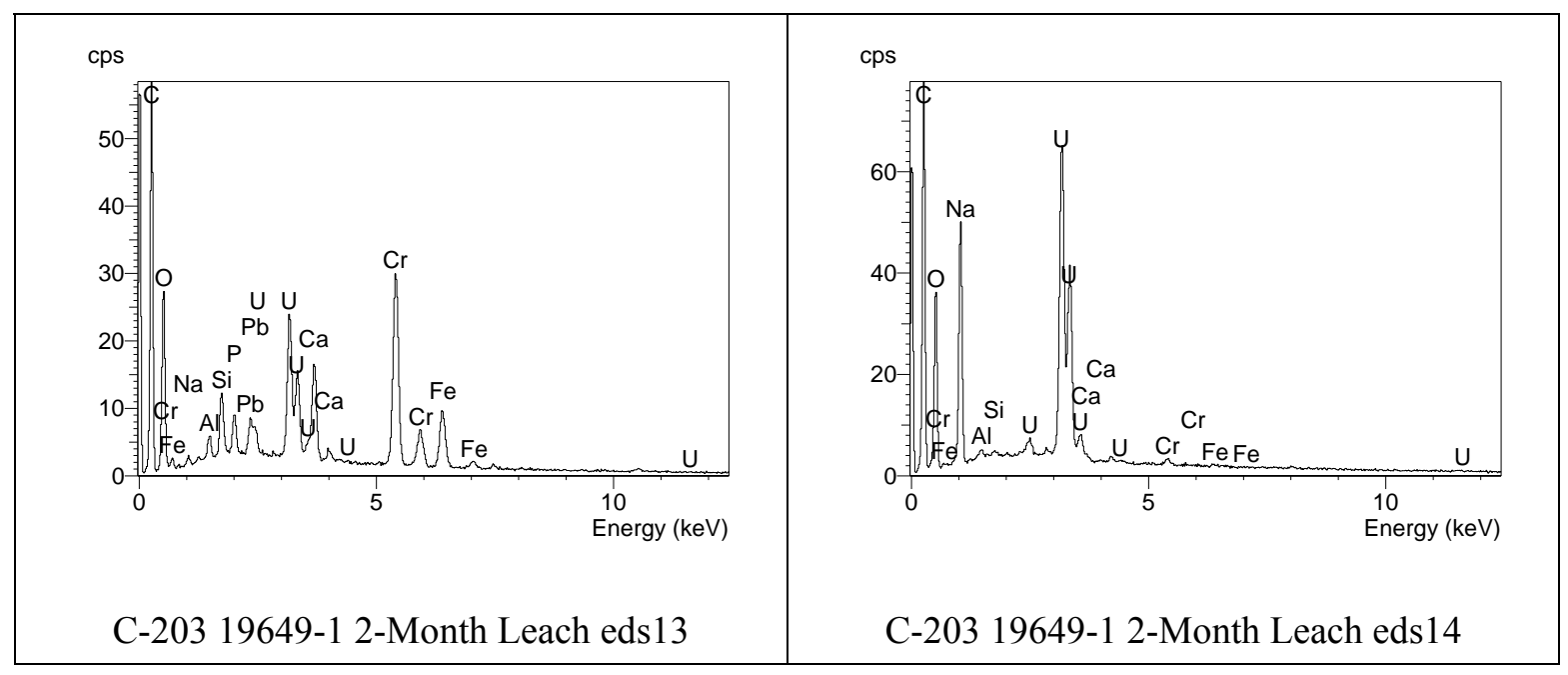

Figure B.90. EDS spectra for analyses eds 13 through eds 14 for particles from long-term (2 month) water leach of C-203 bulk sludge 


\section{B.5 Water-Leached (three months) C-203 Sludge}

Only one mount of the three-month water-leached C-203 (jar 19649) bulk residual tank waste was analyzed by SEM/EDS. The SEM micrographs for this sample of C-203 sludge are shown in Figures B.91 through B.98. Figures B.91 and B.92 are noteworthy in that they show the large number of U-containing particles (very bright particles) that still remain in the residue after the three month leach test. Unfortunately, the contrast between bright and dark particles in Figure B.91 is poor due to the large area (i.e., carbon mounting tape) containing no particles in the field view. The EDS spectra for this sample are given in Figures B.99 through B.100. 


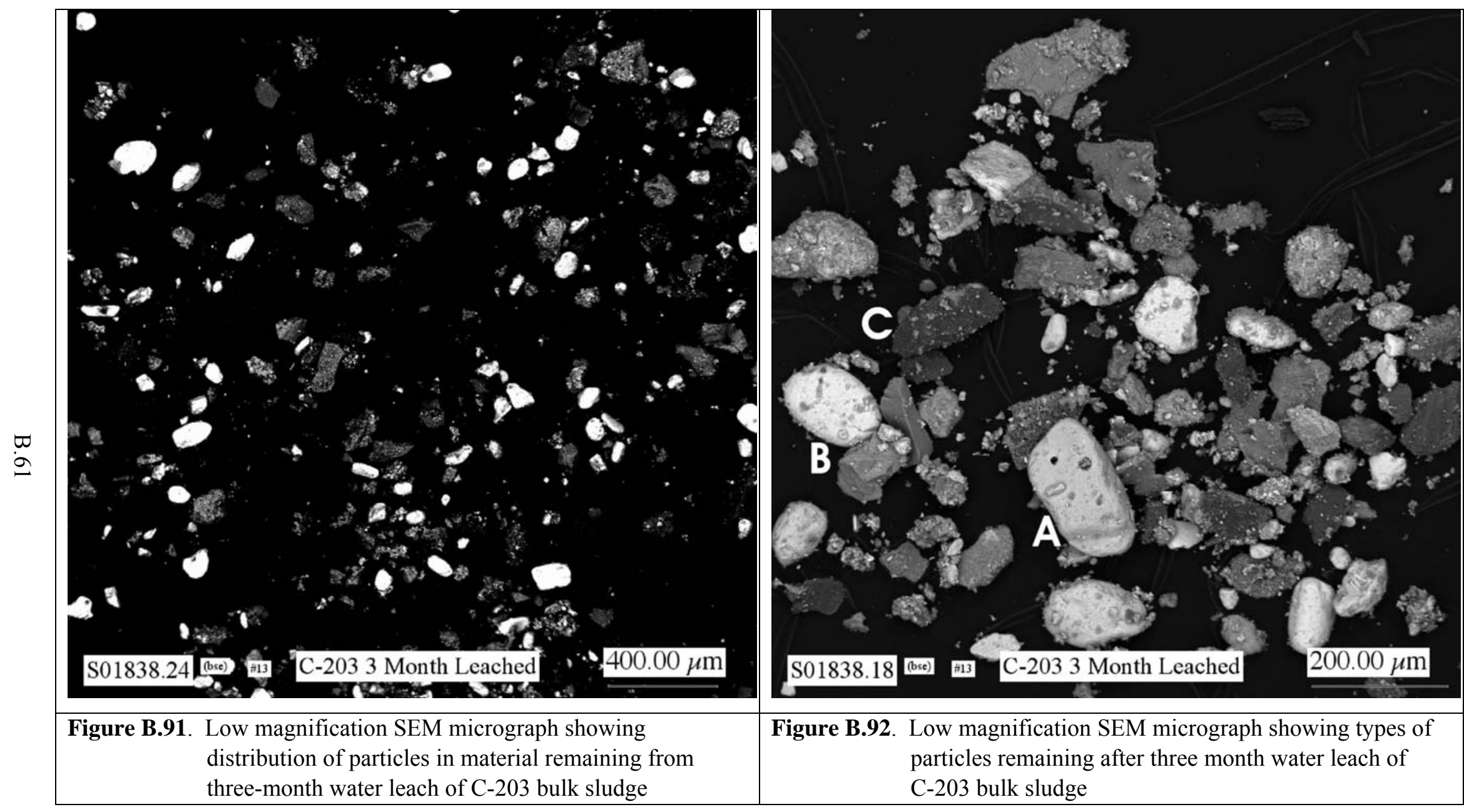




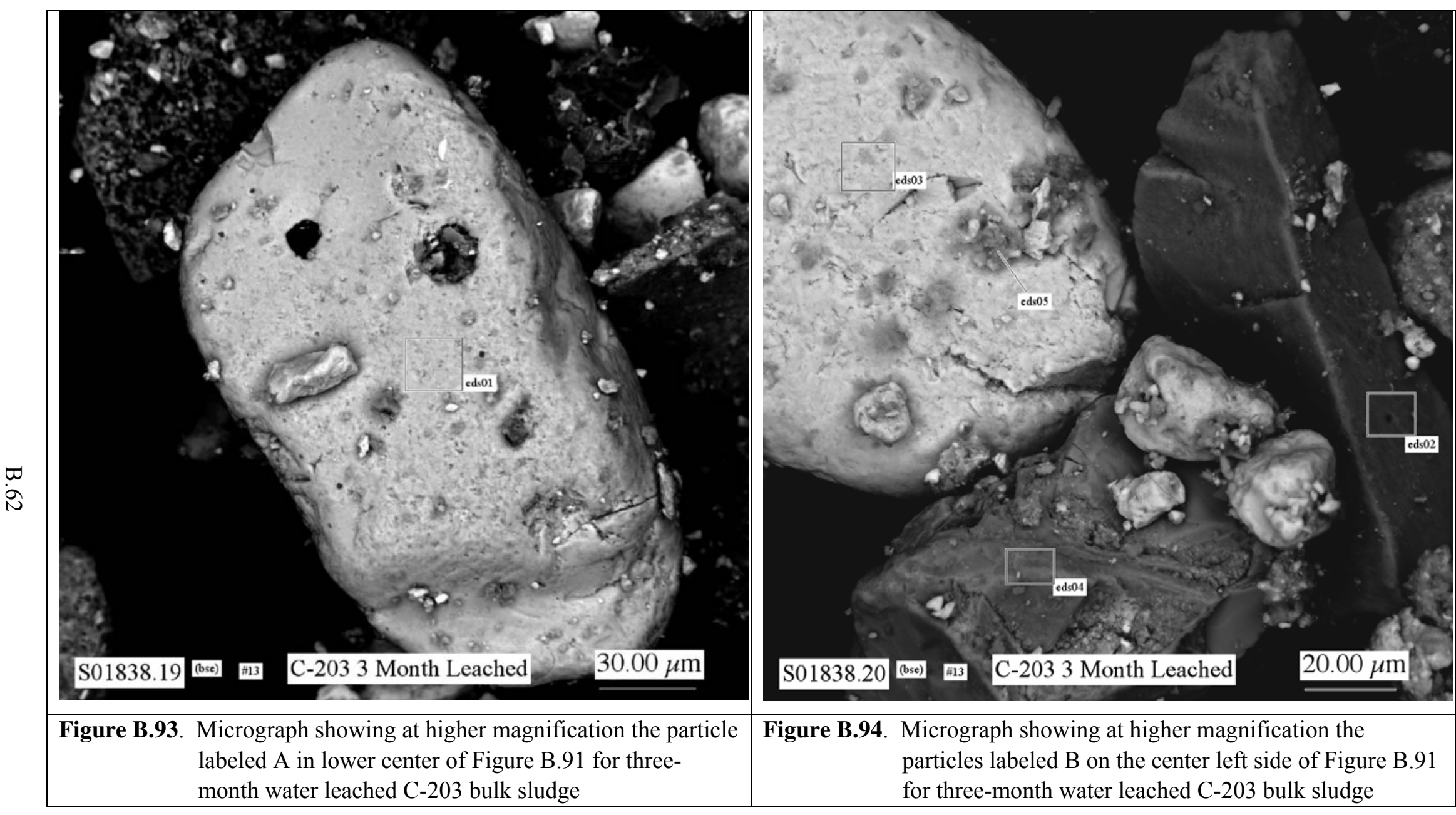




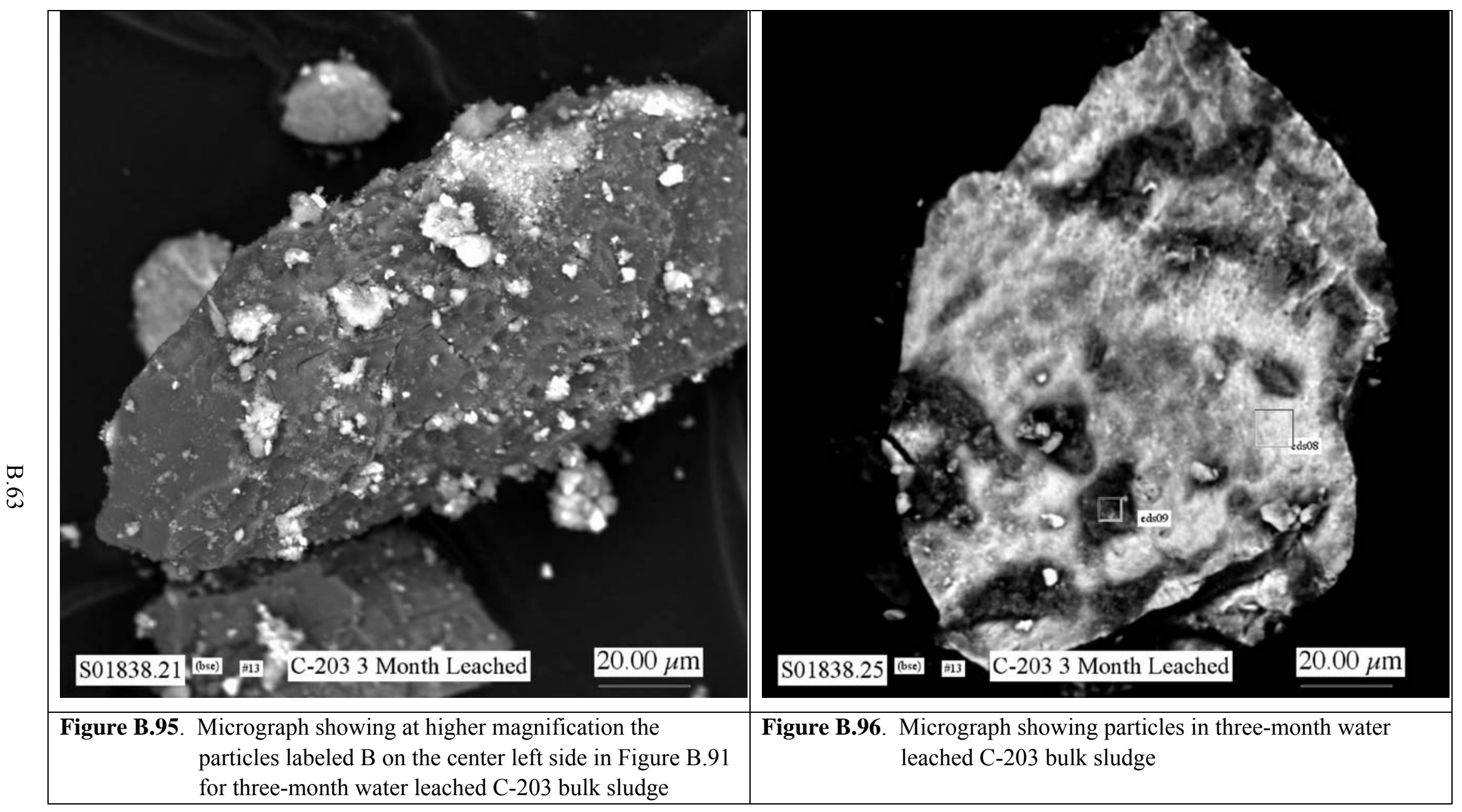




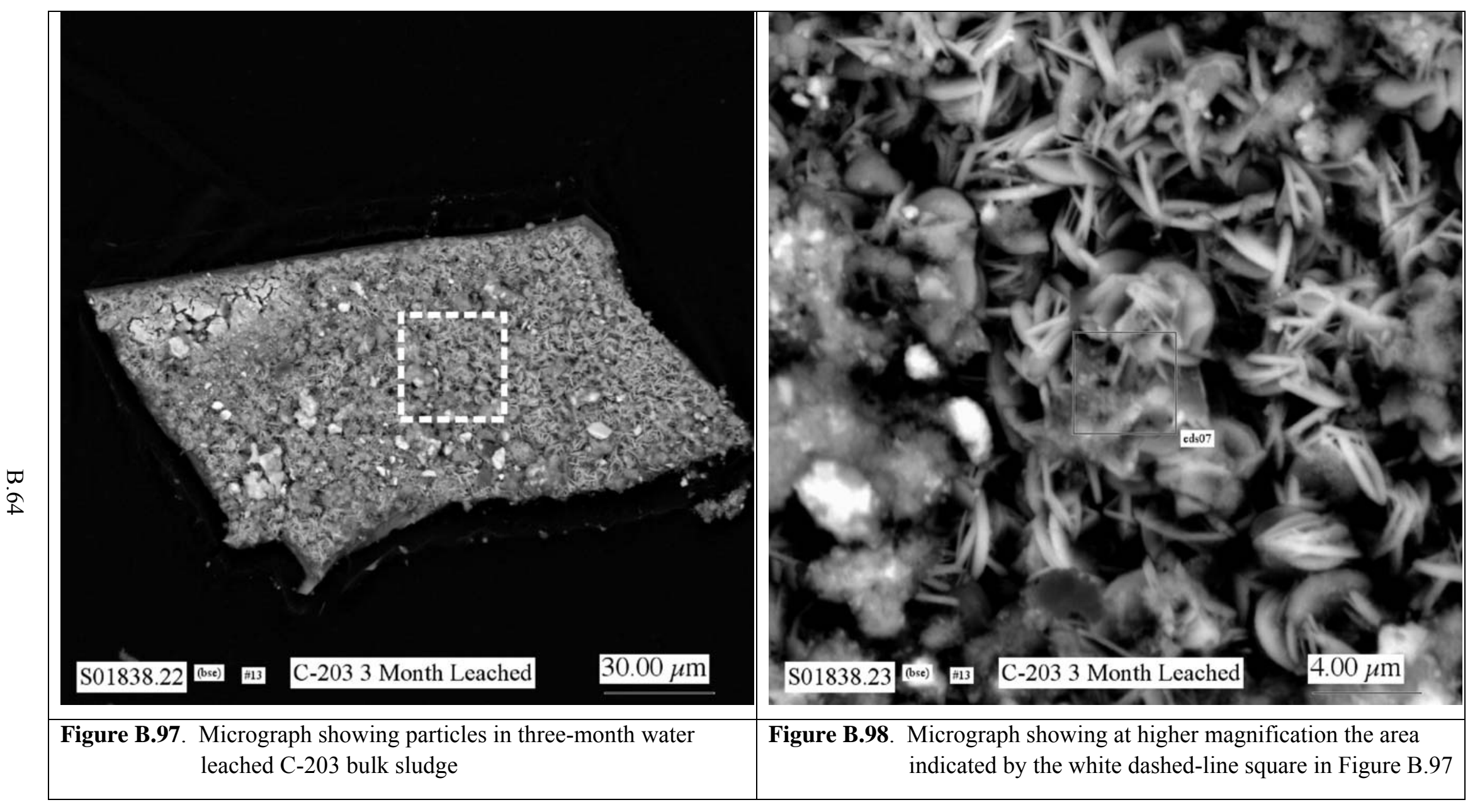




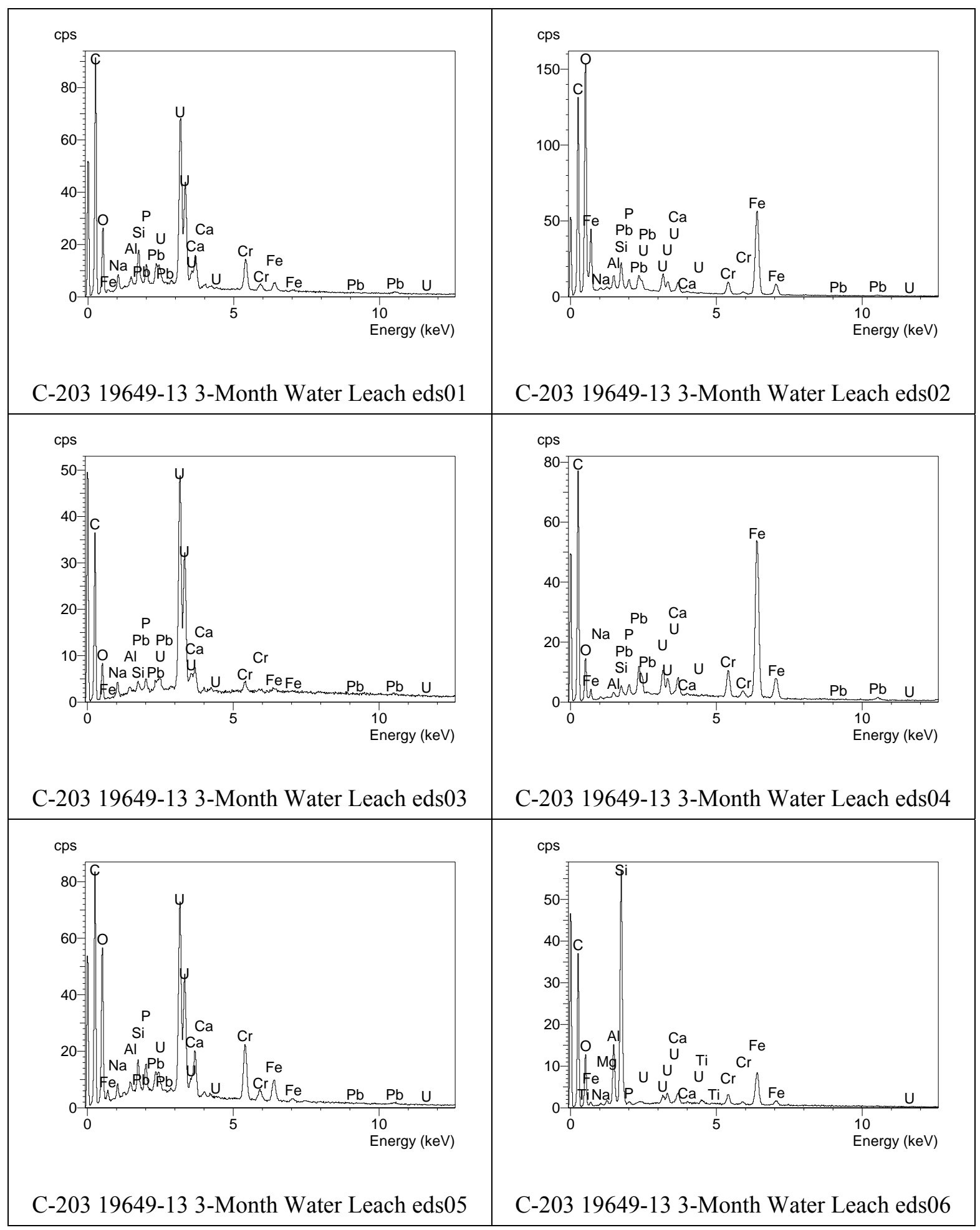

Figure B.99. EDS spectra for analyses eds 01 through eds06 for particles from three-month water leach of C-203 bulk sludge 


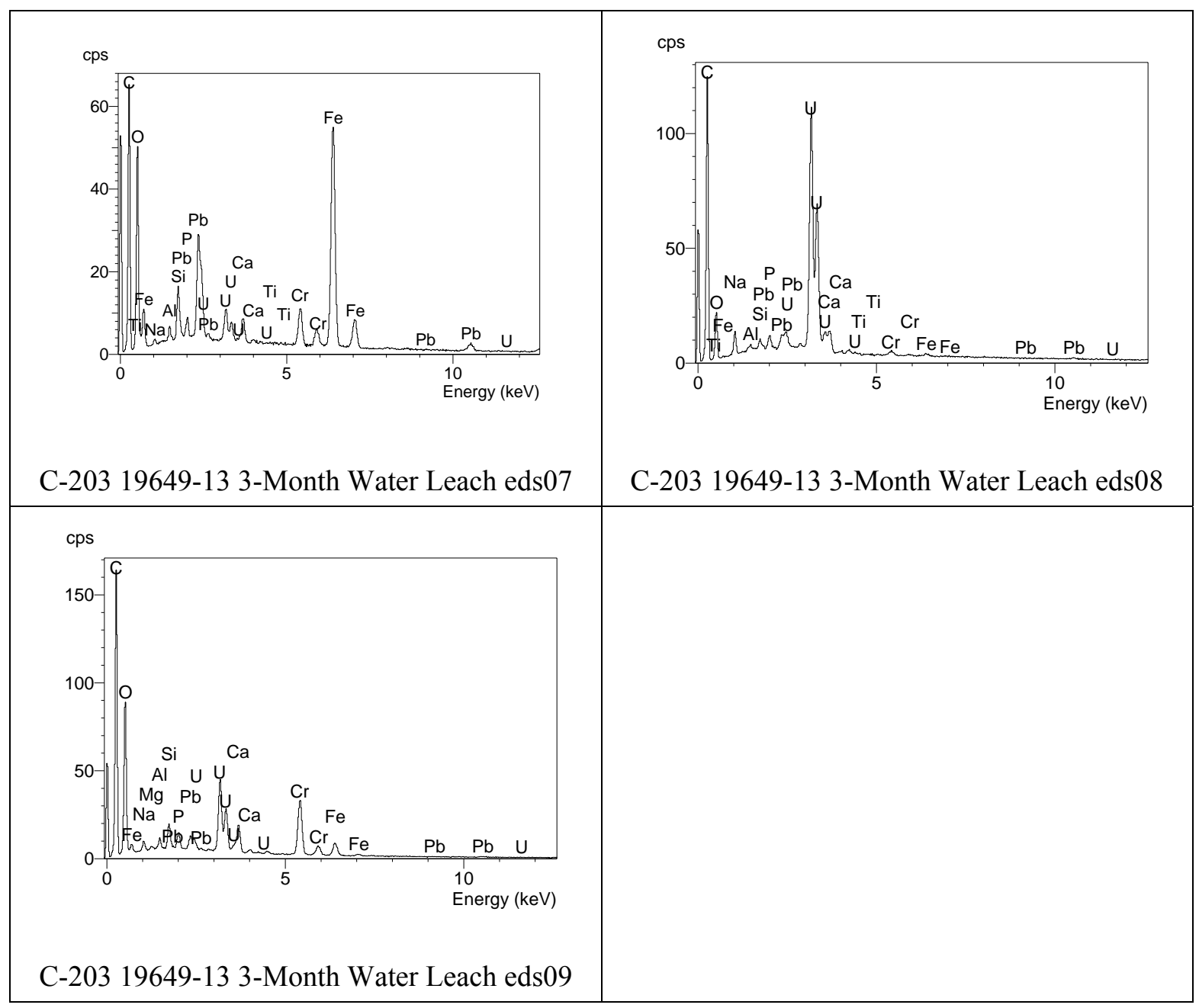

Figure B.100. EDS spectra for analyses eds 07 through eds 09 for particles from three-month water leach of C-203 bulk sludge 


\section{B.6 Residual Solid from 1:1 Solubility Experiments with C-203 Sludge}

Only one mount of material from the 1:1 solubility experiments with C-203 (jar 19649) bulk residual tank waste was analyzed by SEM/EDS. The SEM micrographs for this sample of reaction product from the 1:1 solubility experiments for C-203 are shown in Figures B.101 through B.110. The EDS spectra for this sample are given in Figures B.111 through B.112. 


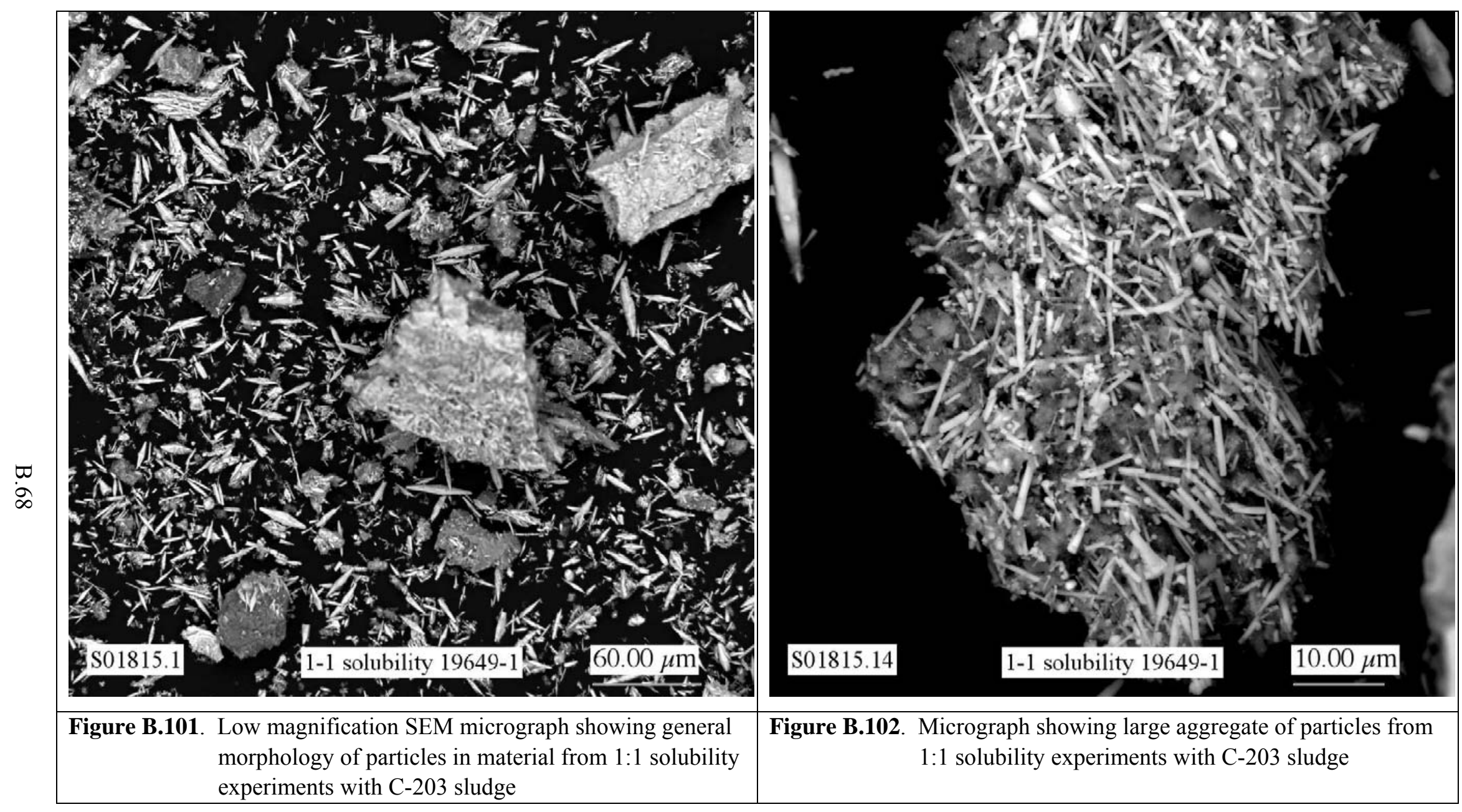




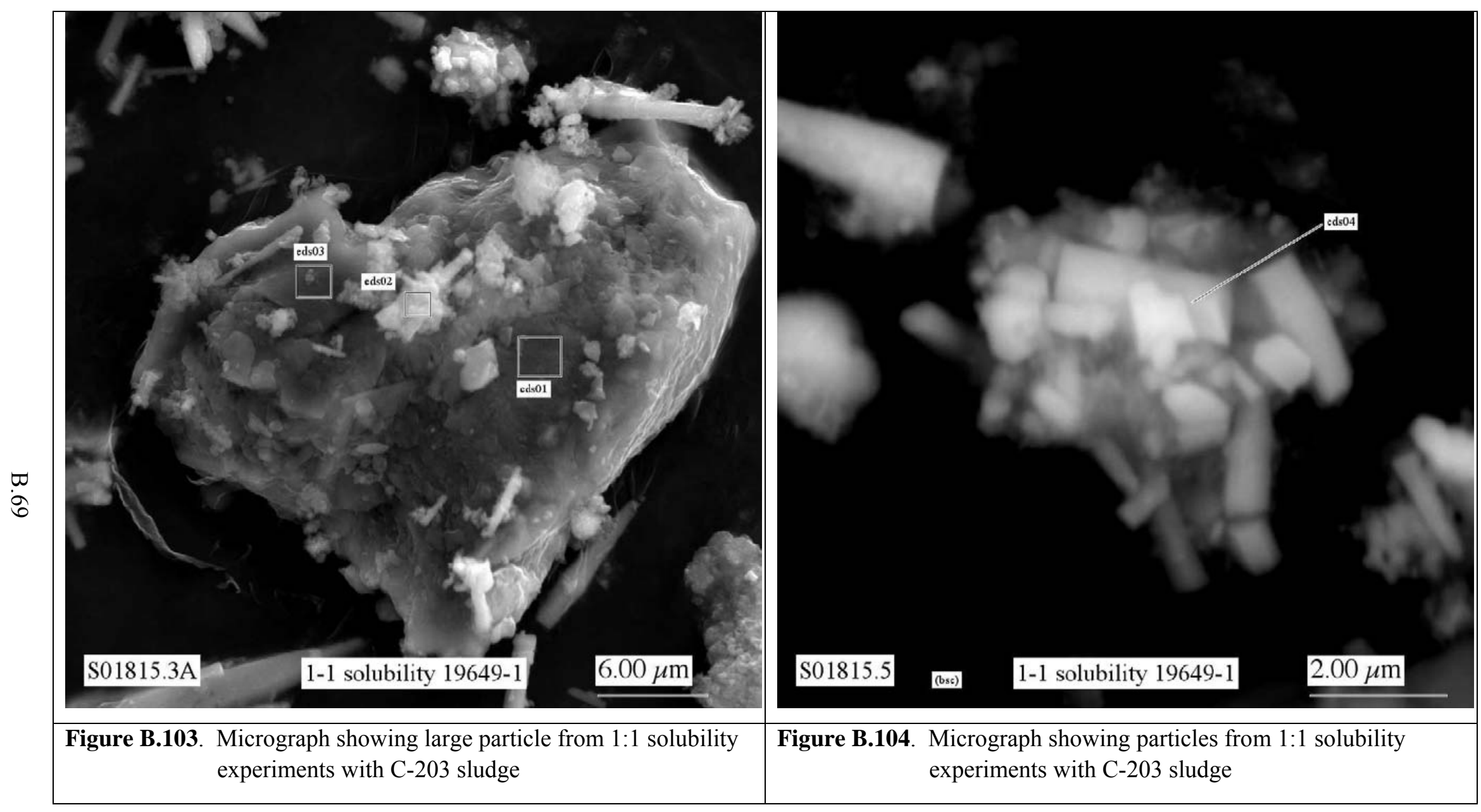



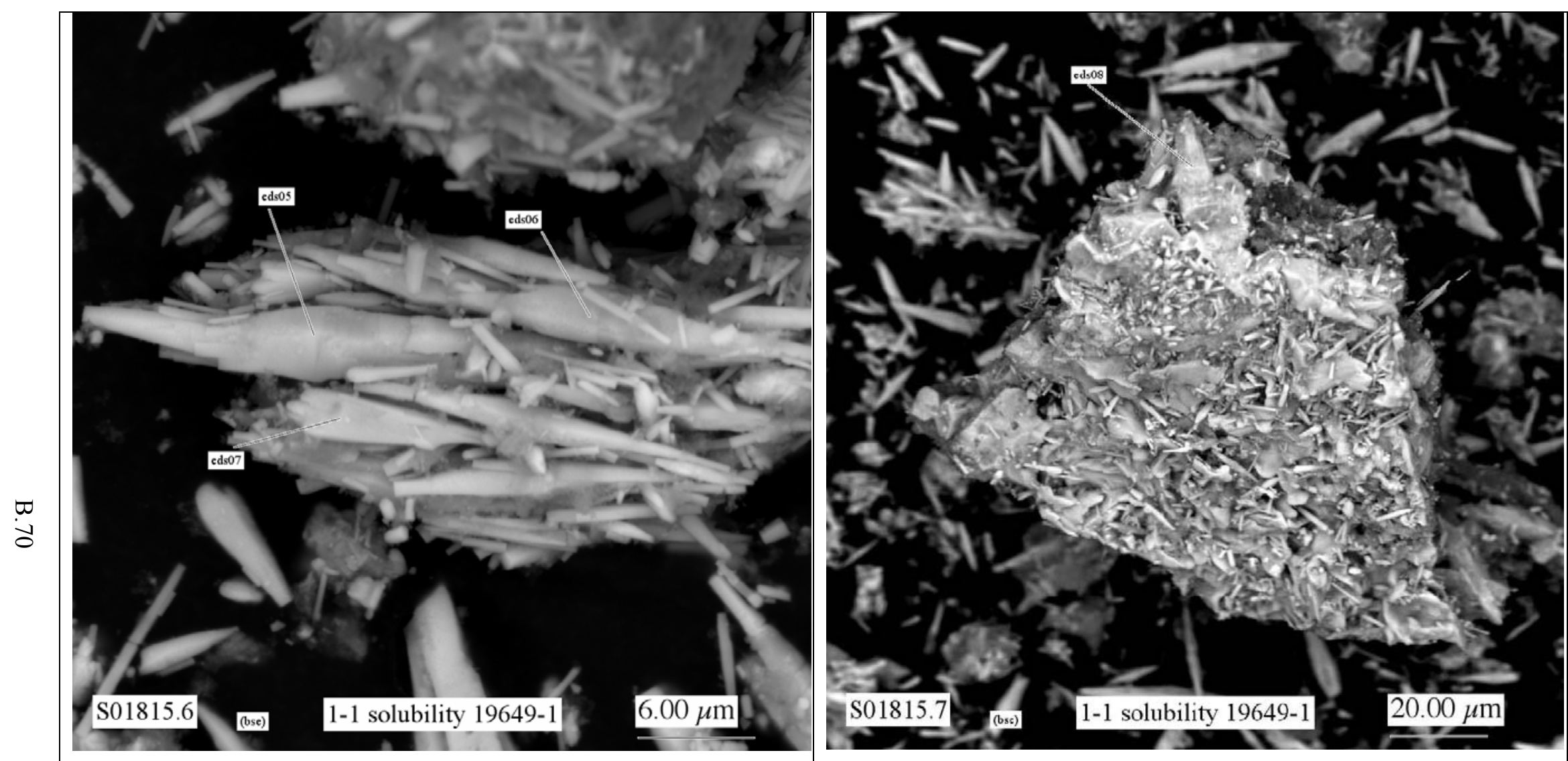

Figure B.105. Micrograph showing aggregate of particles from 1:1

Figure B.106. Micrograph showing large aggregate of particles from solubility experiments with C-203 sludge 1:1 solubility experiments with C-203 sludge 


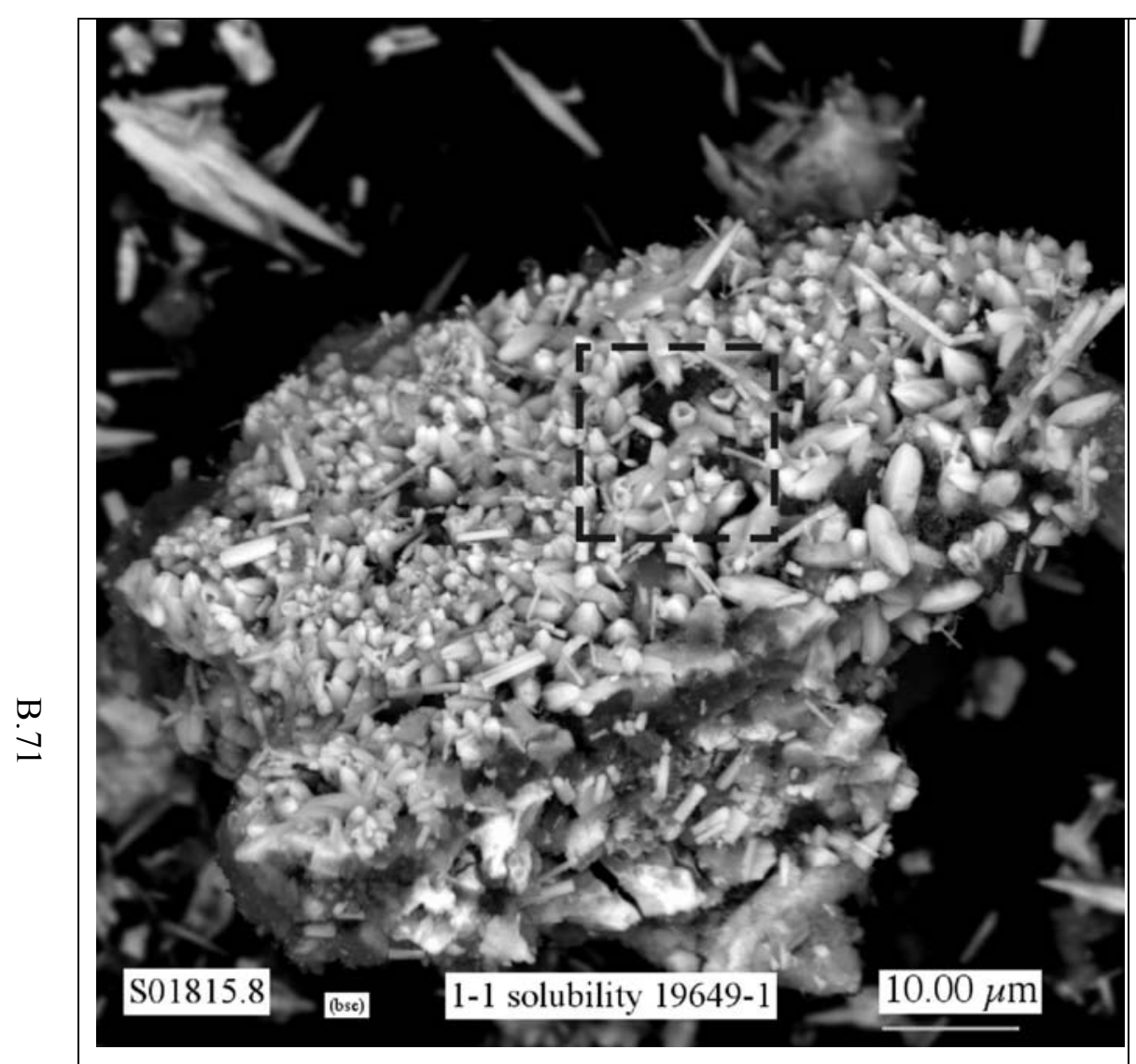

Figure B.107. Micrograph showing large aggregate of particles from 1:1 solubility experiments with C-203 sludge

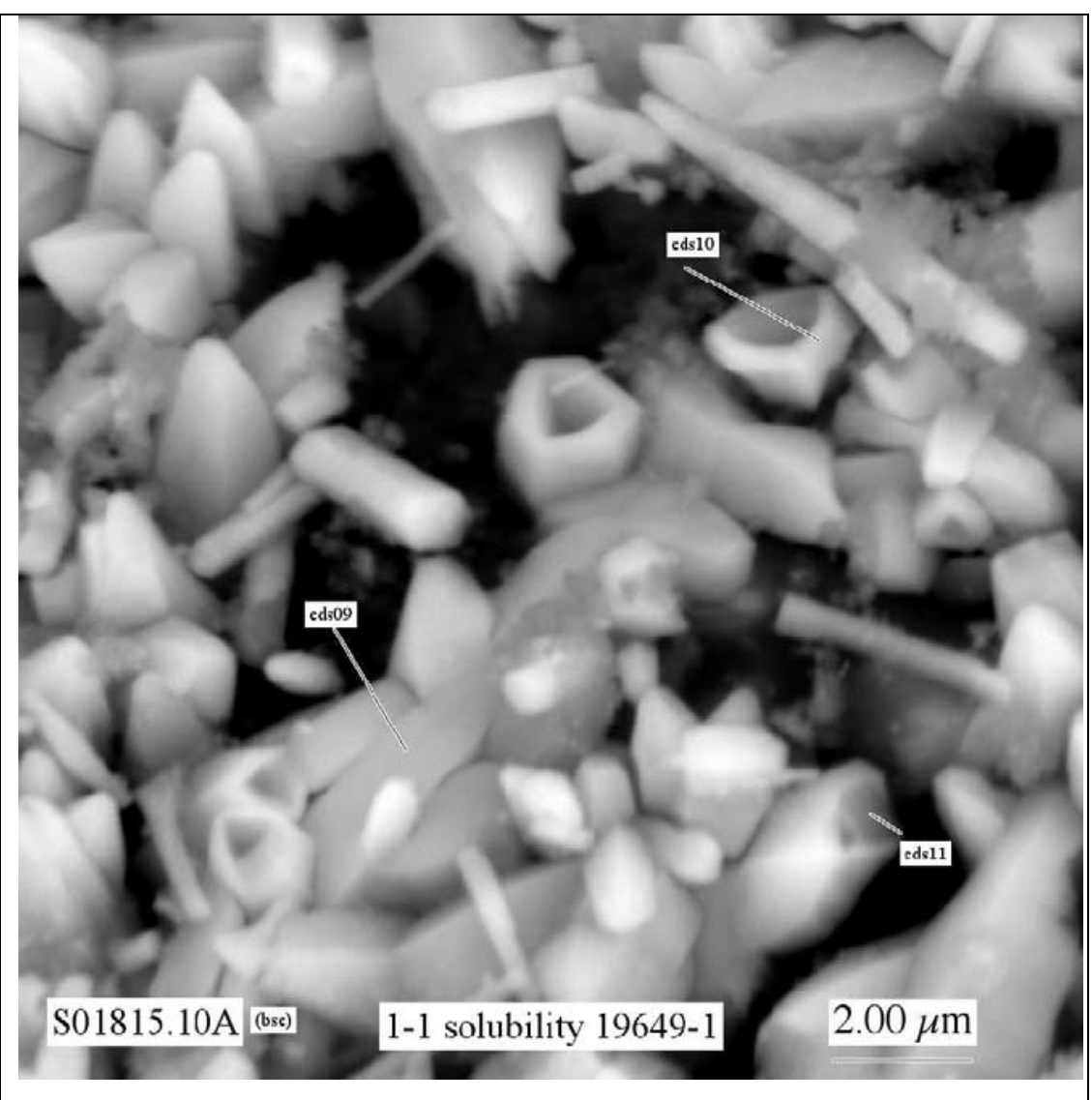

Figure B.108. Micrograph showing at higher magnification the area indicated by the black dashed-line square in Figure B.107 


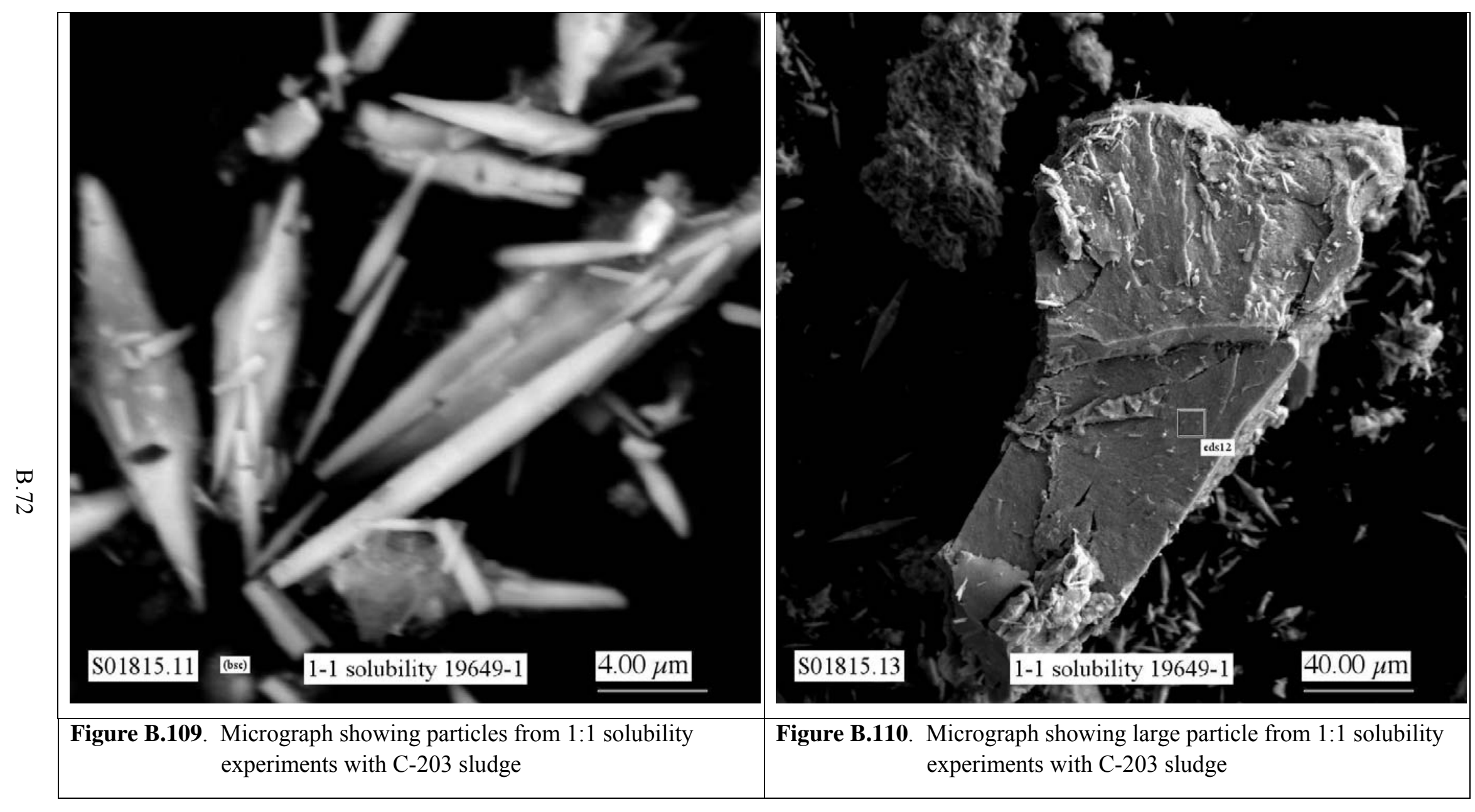




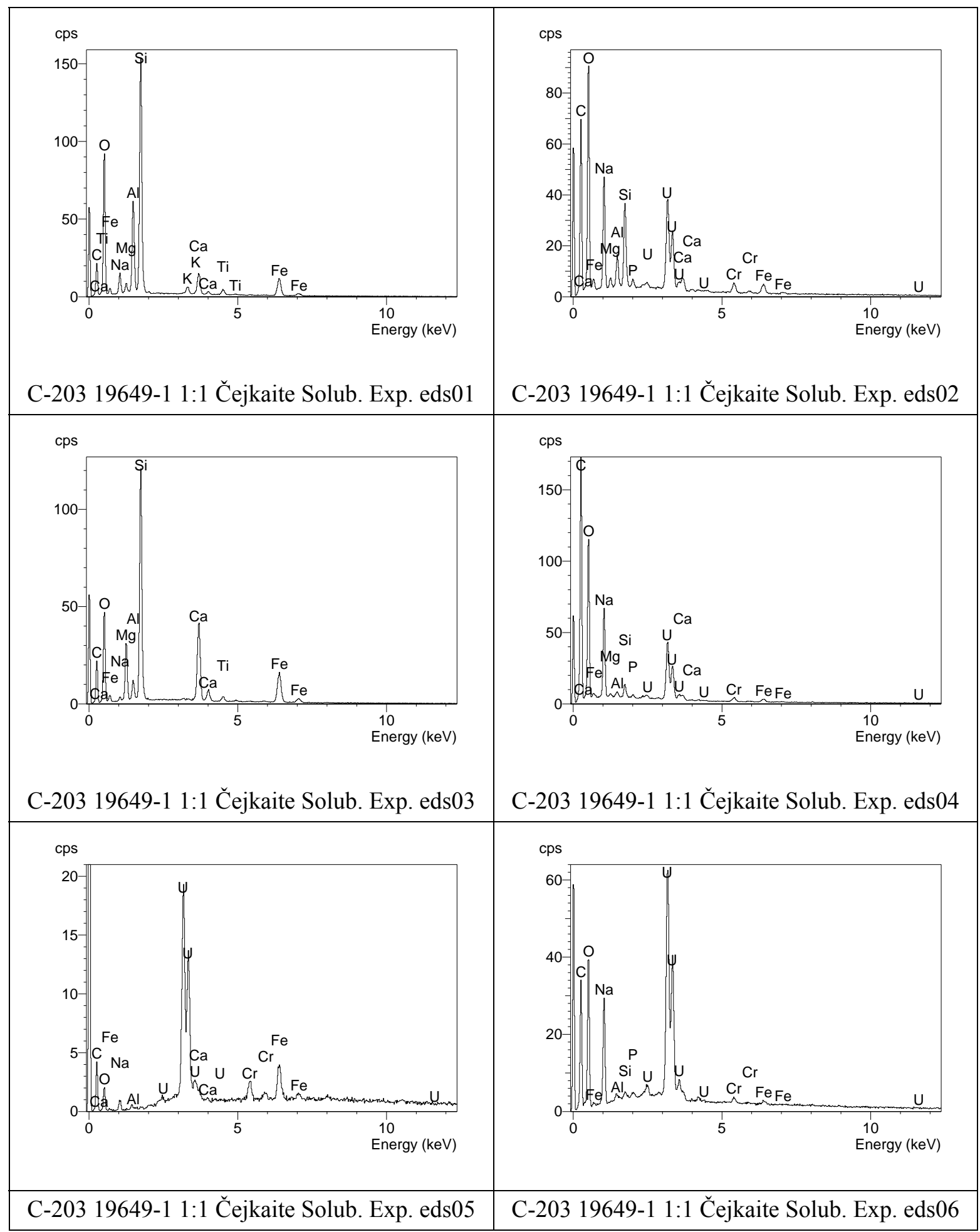

Figure B.111. EDS spectra for analyses eds 01 through eds 06 for particles from 1:1 solubility experiment with C-203 sludge 


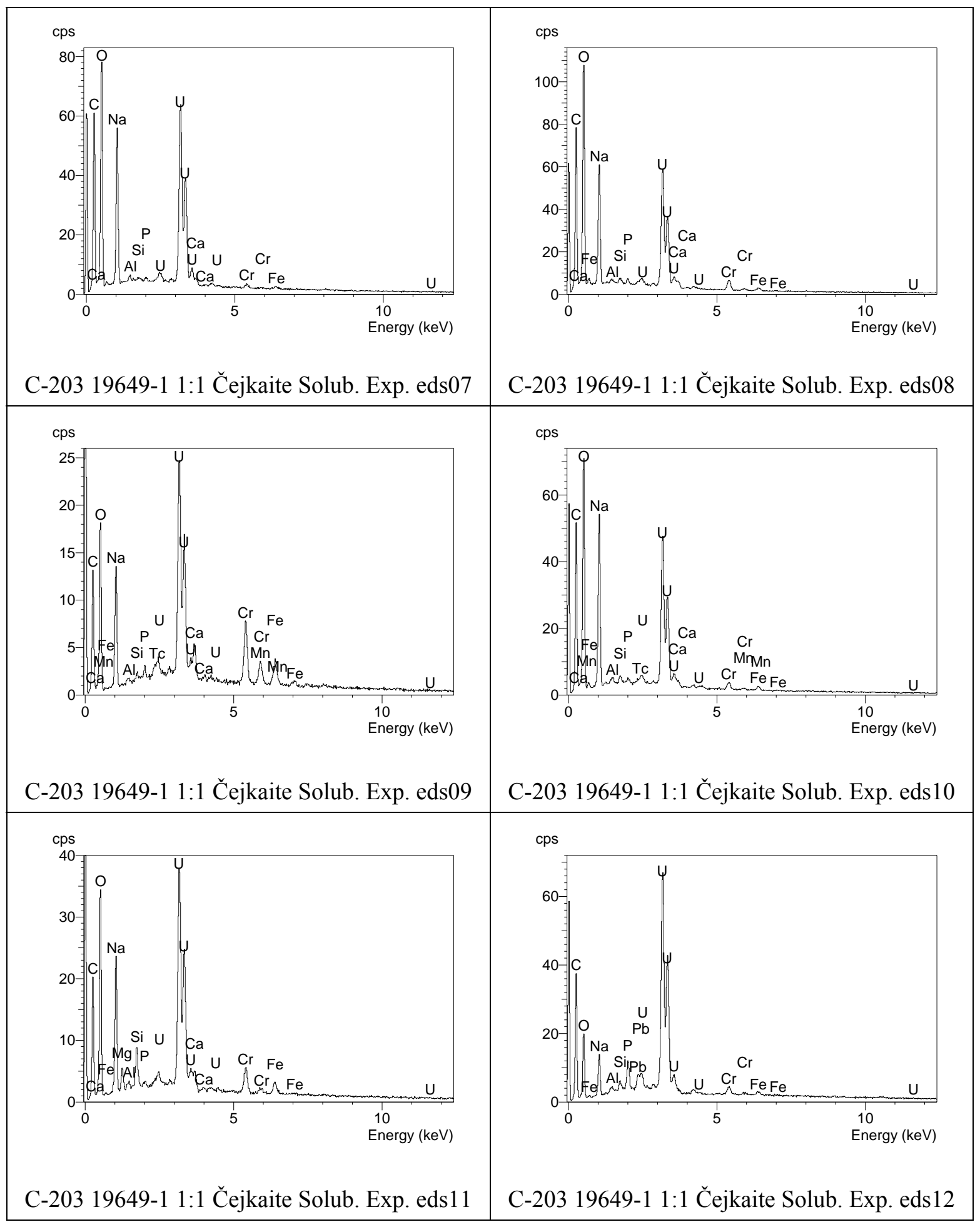

Figure B.112. EDS spectra for analyses eds 07 through eds 12 for particles from 1:1 solubility experiment with $\mathrm{C}-203$ sludge 


\section{Appendix C}

SEM Micrographs and EDS Spectra for C-204 Sludge Samples 


\section{Appendix C}

\section{SEM Micrographs and EDS Spectra for C-204 Samples}

This appendix includes the scanning electron microscope (SEM) micrographs and the energydispersive X-ray spectrometry (EDS) spectra and composition summary tables for samples of the unleached (raw), water-leached, and reaction products remaining after various extraction tests for C-204 (jar 19650) residual tank waste. The EDS composition summary tables list the qualitative compositions calculated with and without inclusion of the emission peak for carbon for the unleached and 2-week water leached C-204 sludge samples. The operating conditions for the SEM and procedures used for mounting the SEM samples are described in Section 2.4 of the main report.

The name of each SEM digital image file, sample identification number, and a size scale bar are given, respectively, at the bottom left, center, and right of each SEM micrograph in this appendix. Micrographs labeled by "bse” to the immediate right of the digital image file name indicate that the micrograph was collected with backscattered electrons. Areas identified by a letter and/or outlined by a white dashed-line square in a micrograph designate sample material that was imaged at higher magnification, which is typically shown in figure(s) that immediately follow in the series for that sample.

Areas labeled by "eds" in the following SEM micrographs in this appendix identify locations of particles for which EDS spectra were recorded. The "eds” label given with each EDS spectrum correspond to the same "EDS" label used in the SEM micrographs for this sample.

\section{C.1 Unleached C-204 Sludge}

Two mounts of unleached (raw) of C-204 (jar 19650) bulk residual tank waste were analyzed by SEM/EDS. The SEM micrographs for the first mount (19650-7) of C-204 sludge are shown in Figures C.1 through C.10. The EDS spectra for this mount are given in Figures C.11 through C.13. The SEM micrographs for the second mount (19650-8) of C-204 sludge are shown in Figures C.14 through C.21, and the EDS spectra for the second mount are given in Figures C.22 through C.25. 


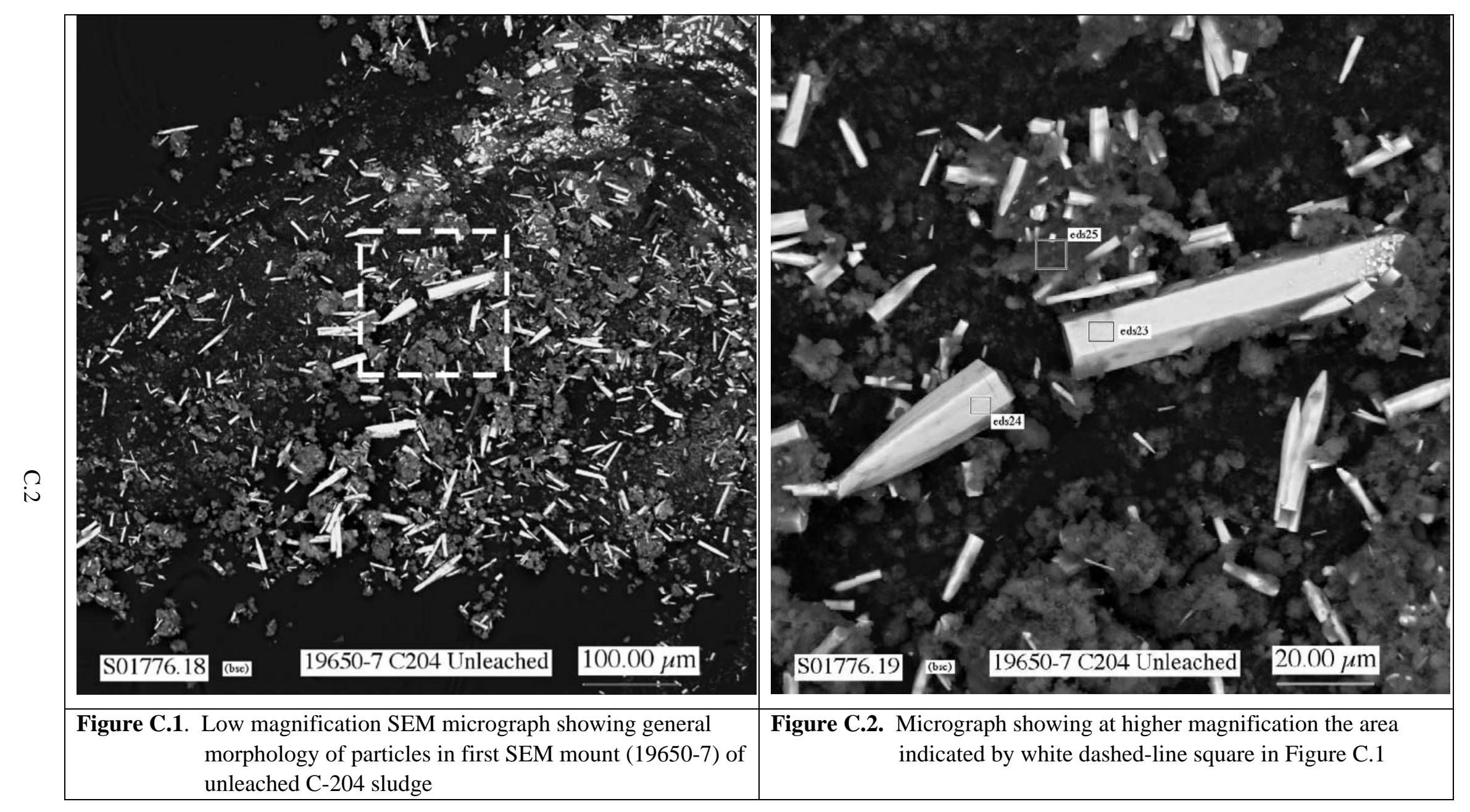




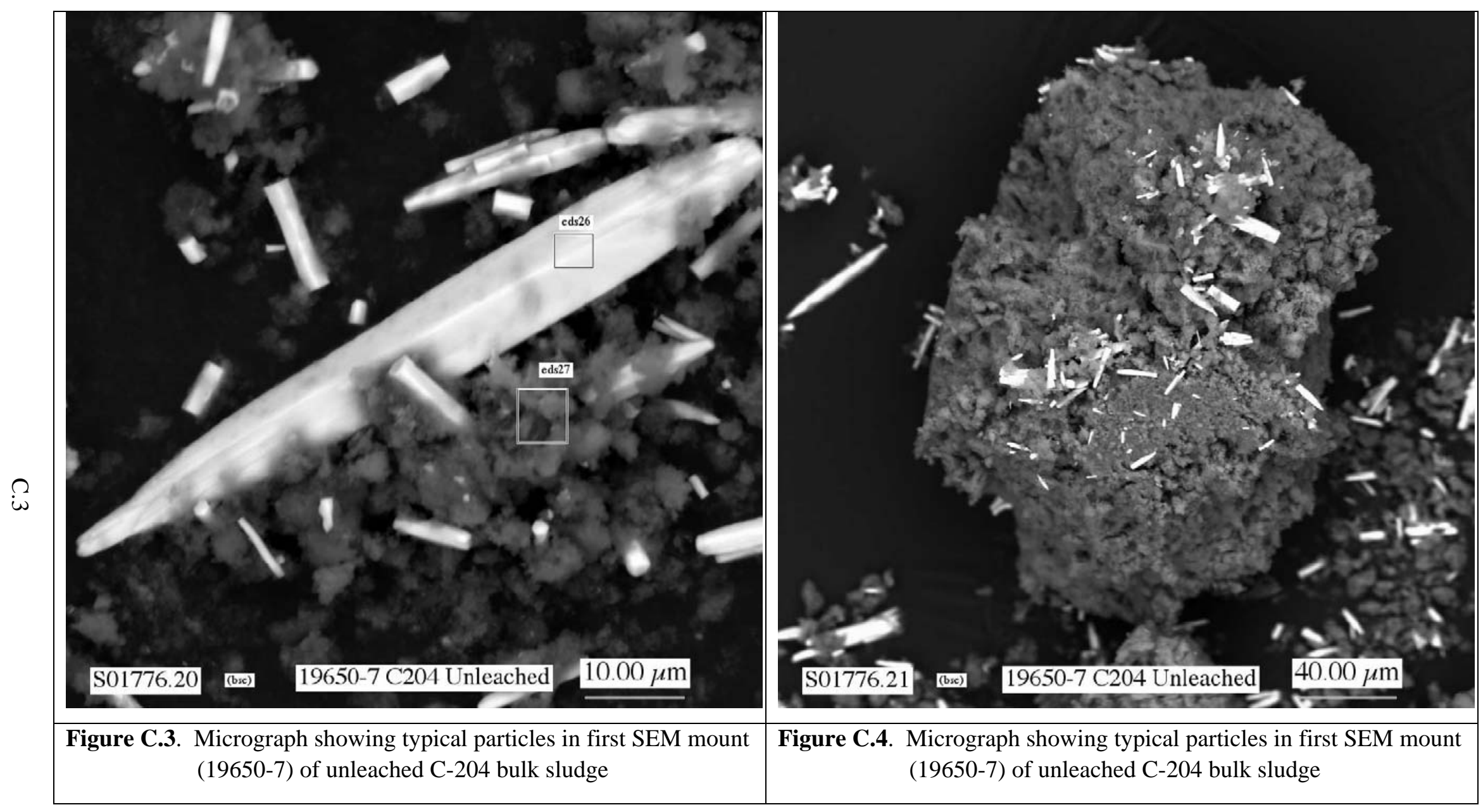




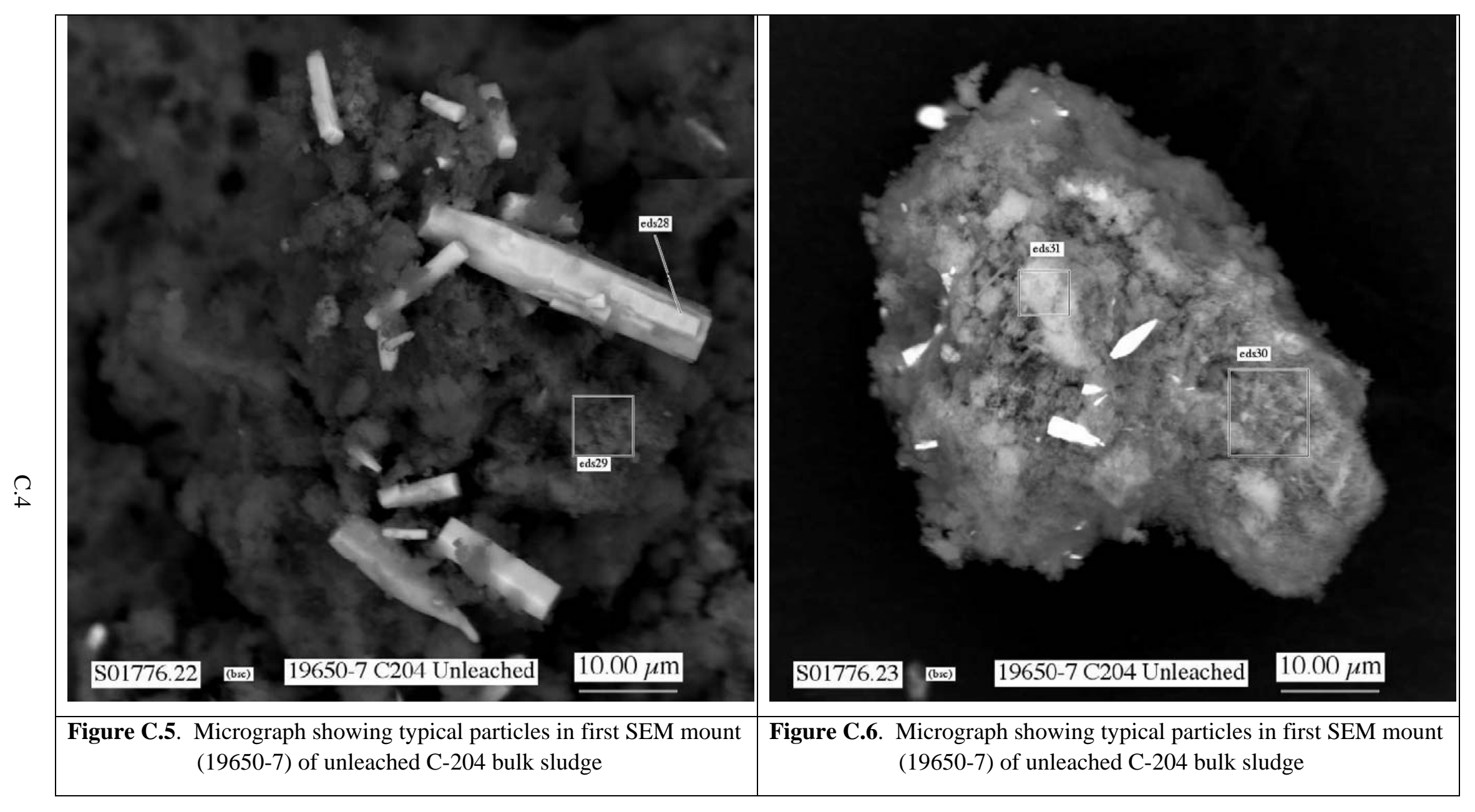




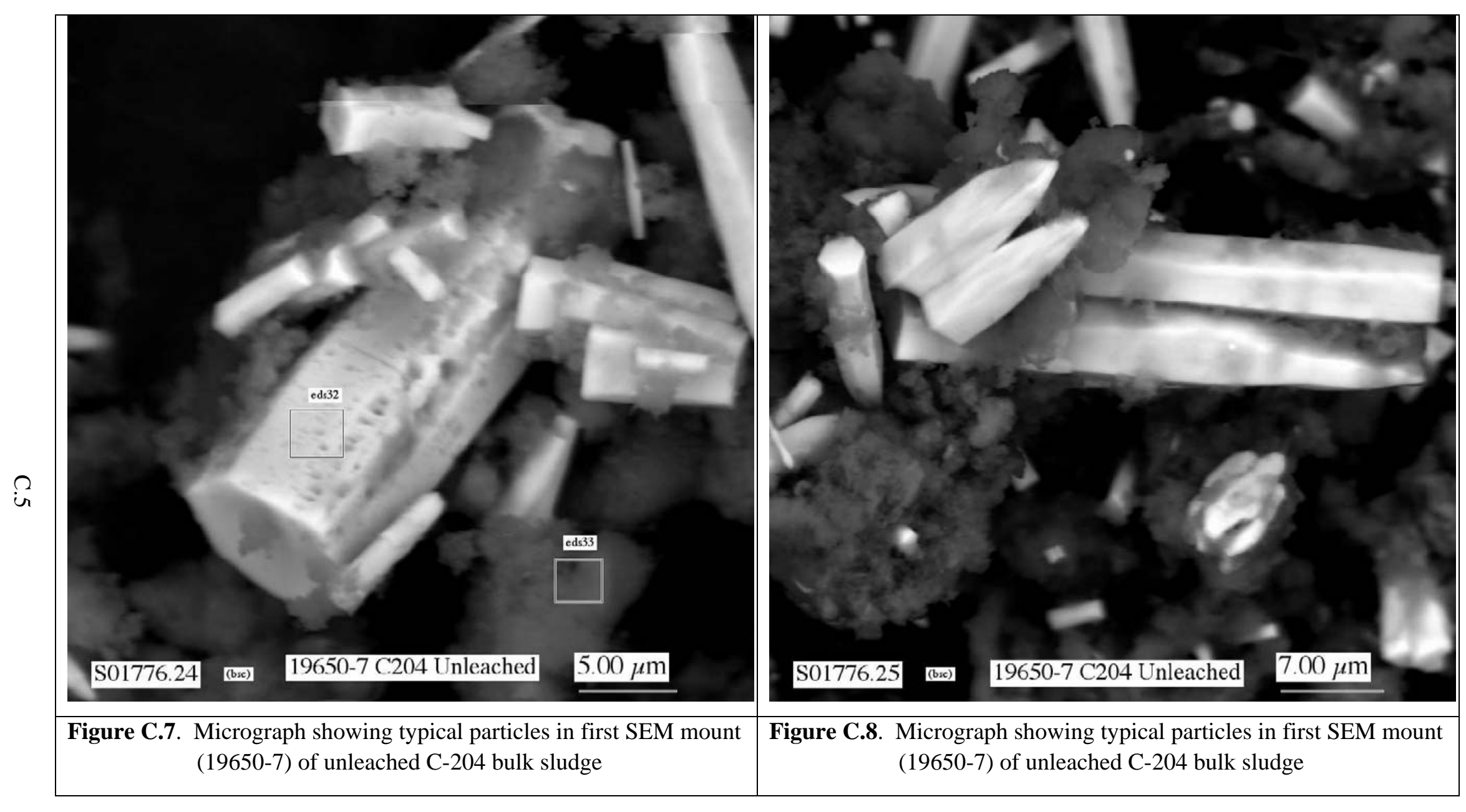




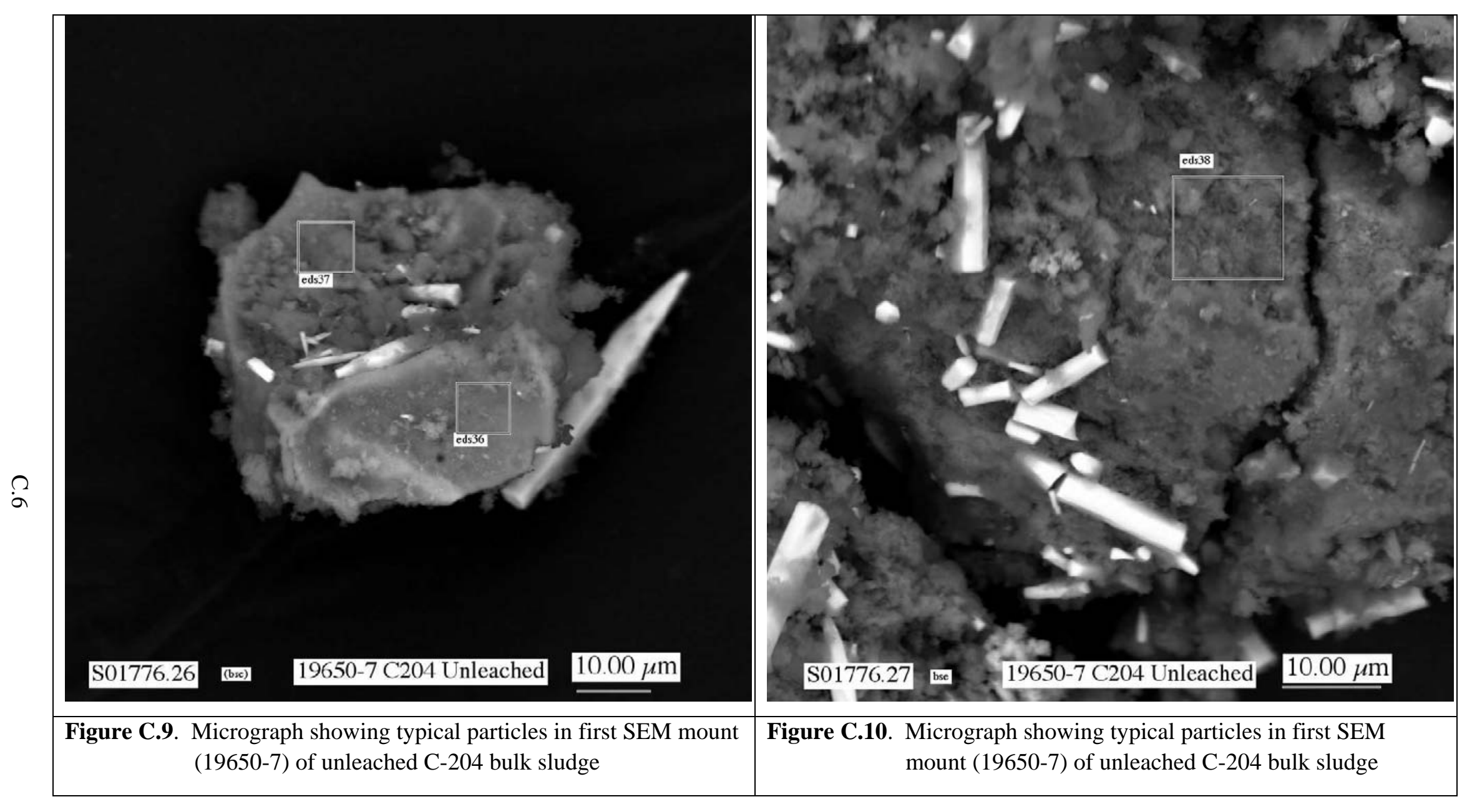




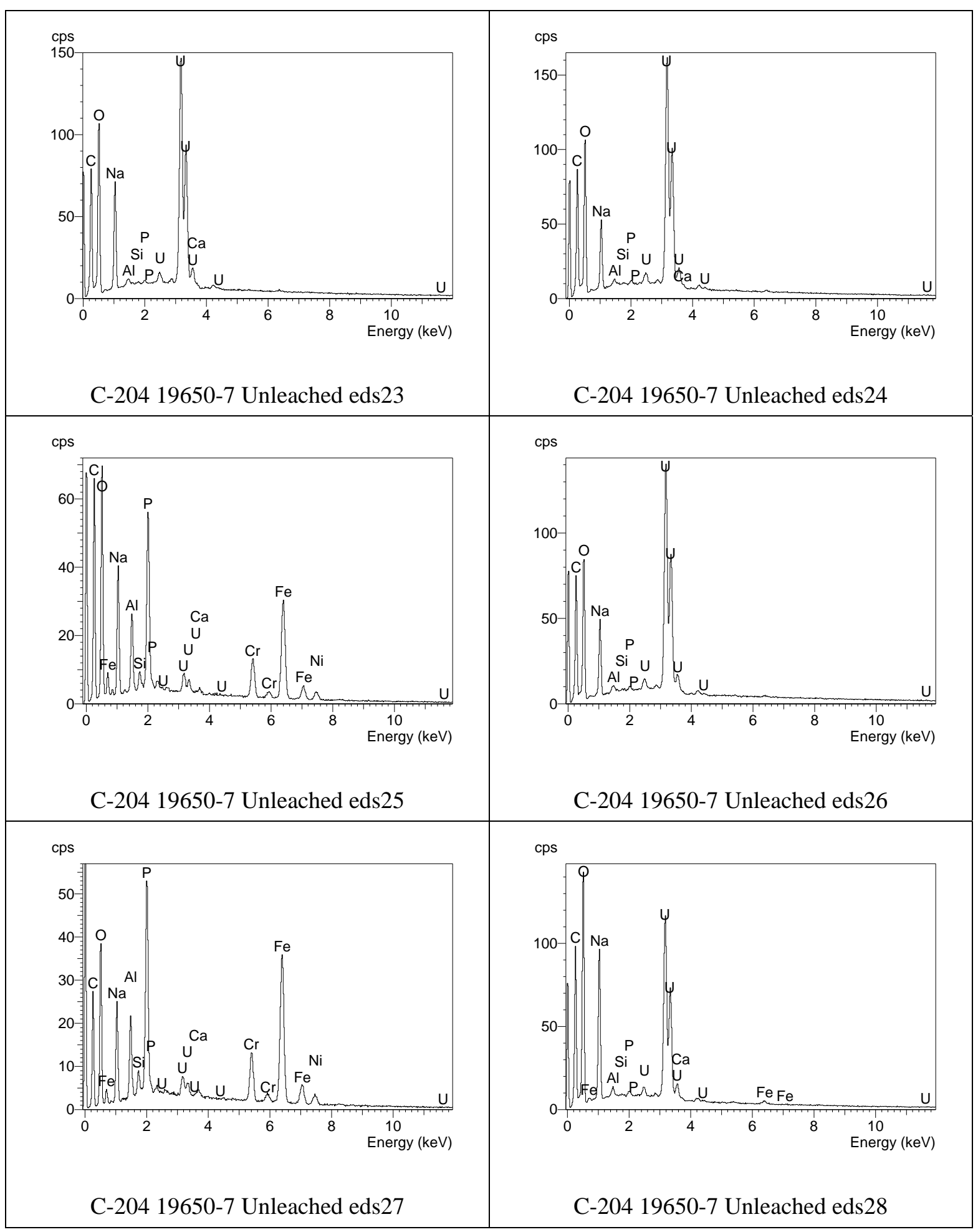

Figure C.11. EDS spectra for analyses eds23 through eds28 for particles in the first SEM mount (19650-7) of unleached C-204 sludge

C.7 


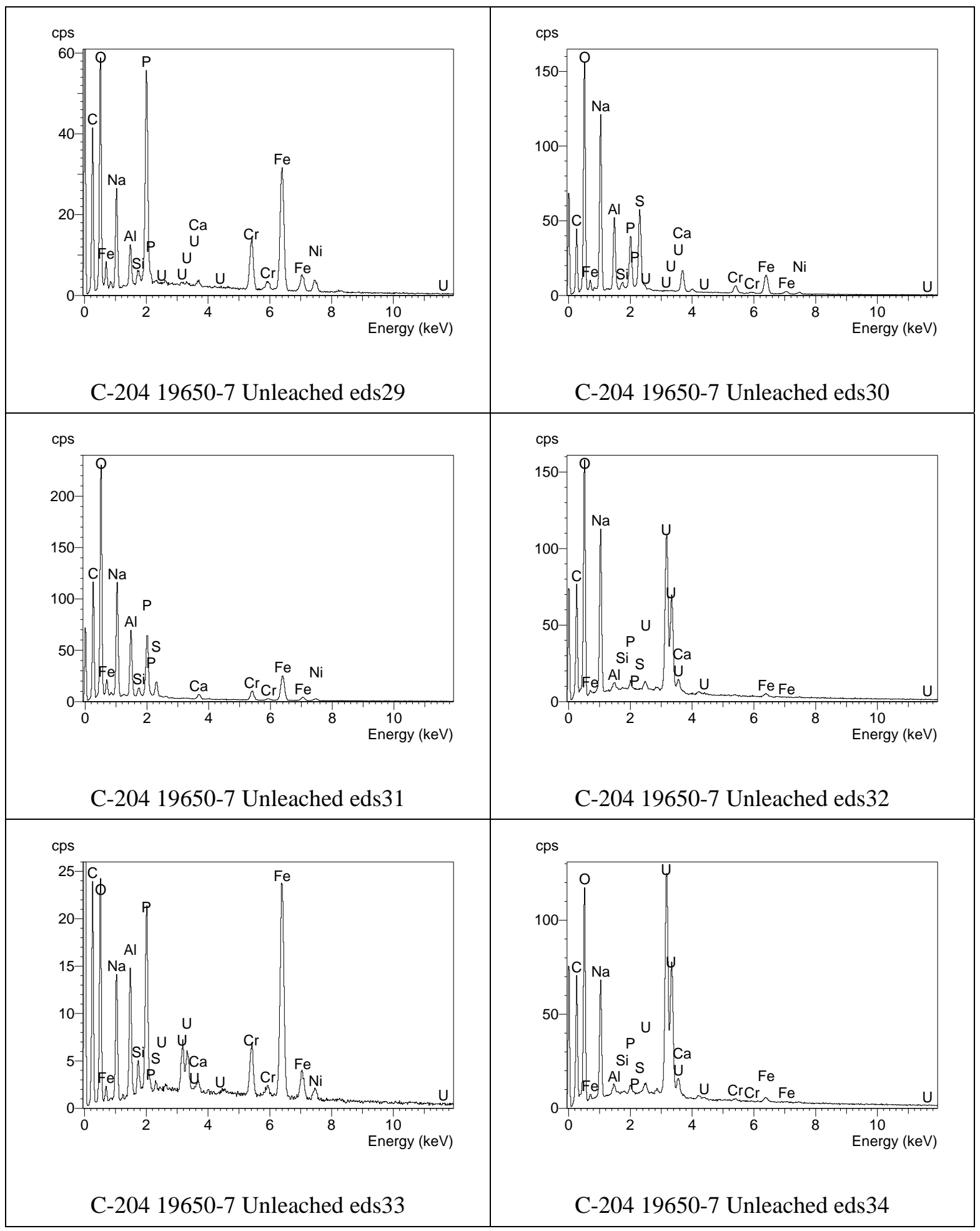

Figure C.12. EDS spectra for analyses eds29 through eds34 for particles in the first SEM mount (19650-7) of unleached C-204 sludge 


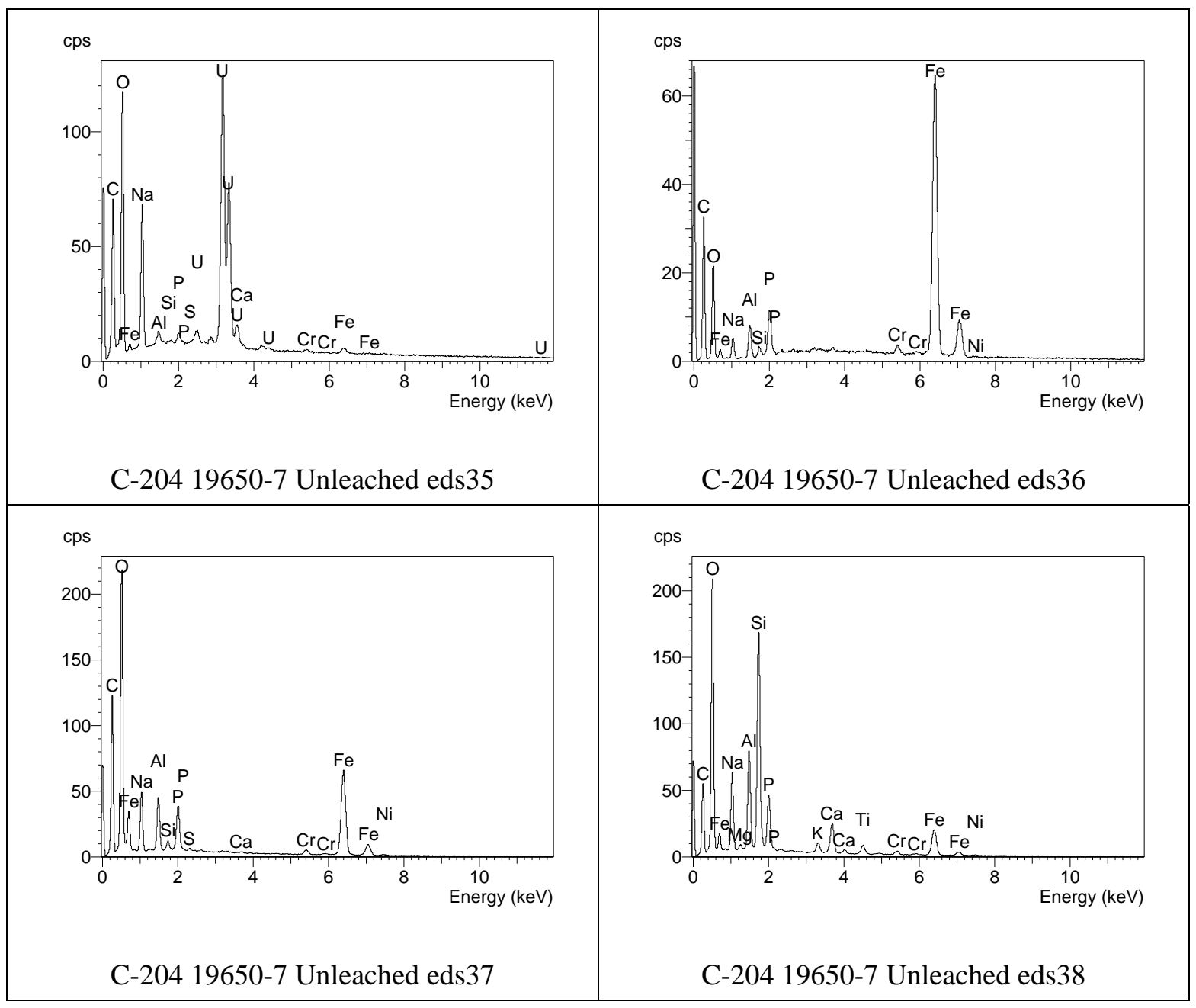

Figure C.13. EDS spectra for analyses eds35 through eds38 for particles in the first SEM mount (19650-7) of unleached C-204 sludge 


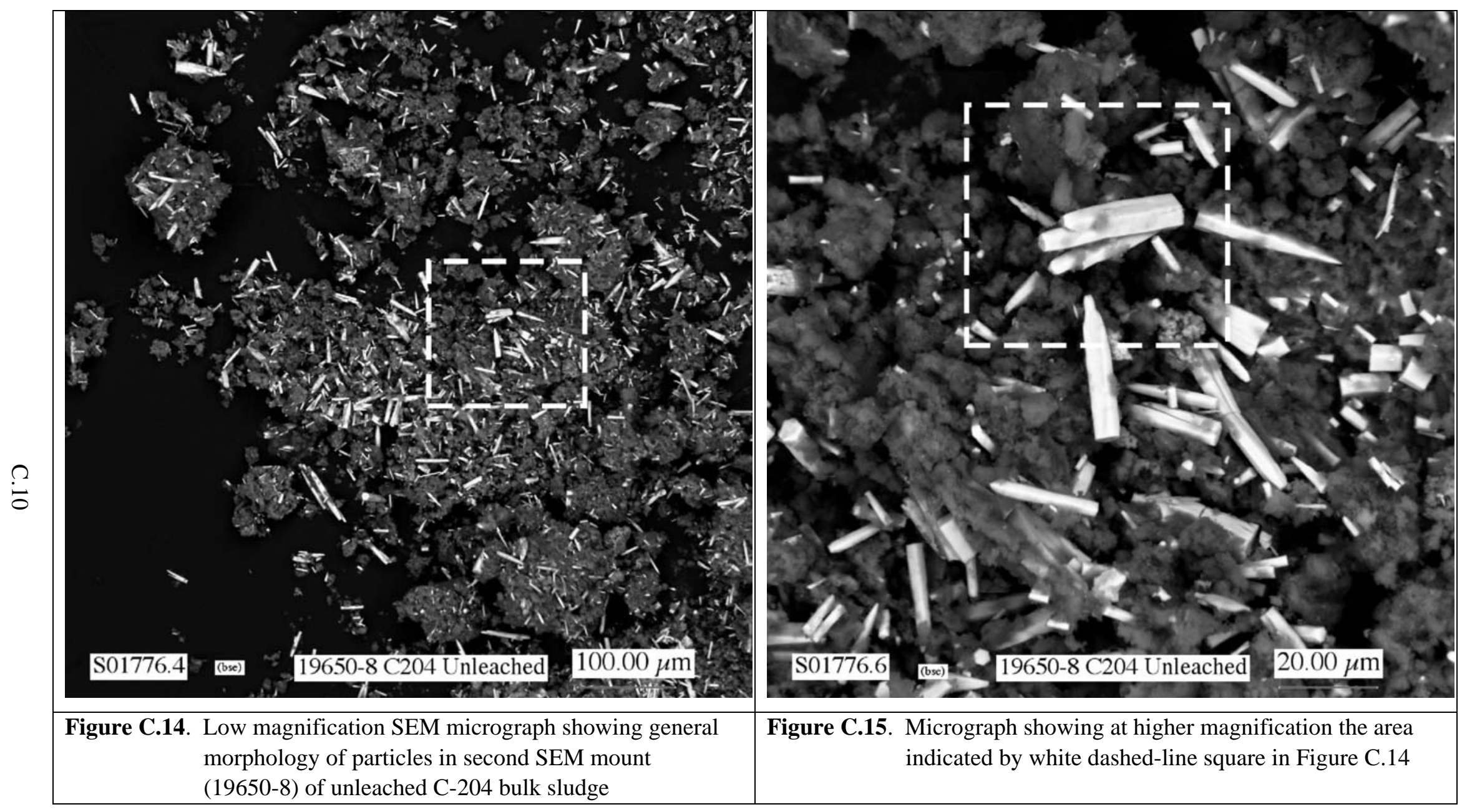




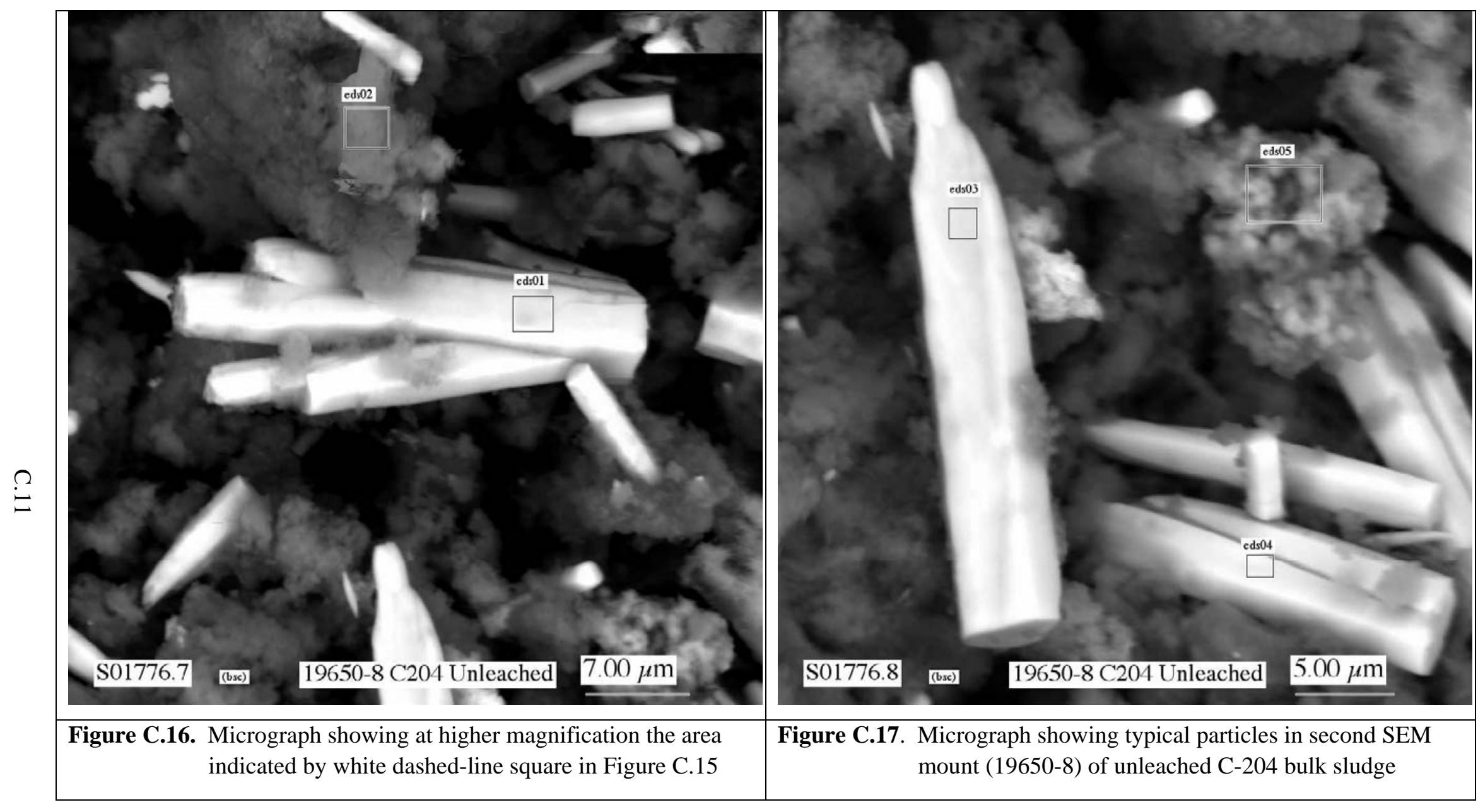




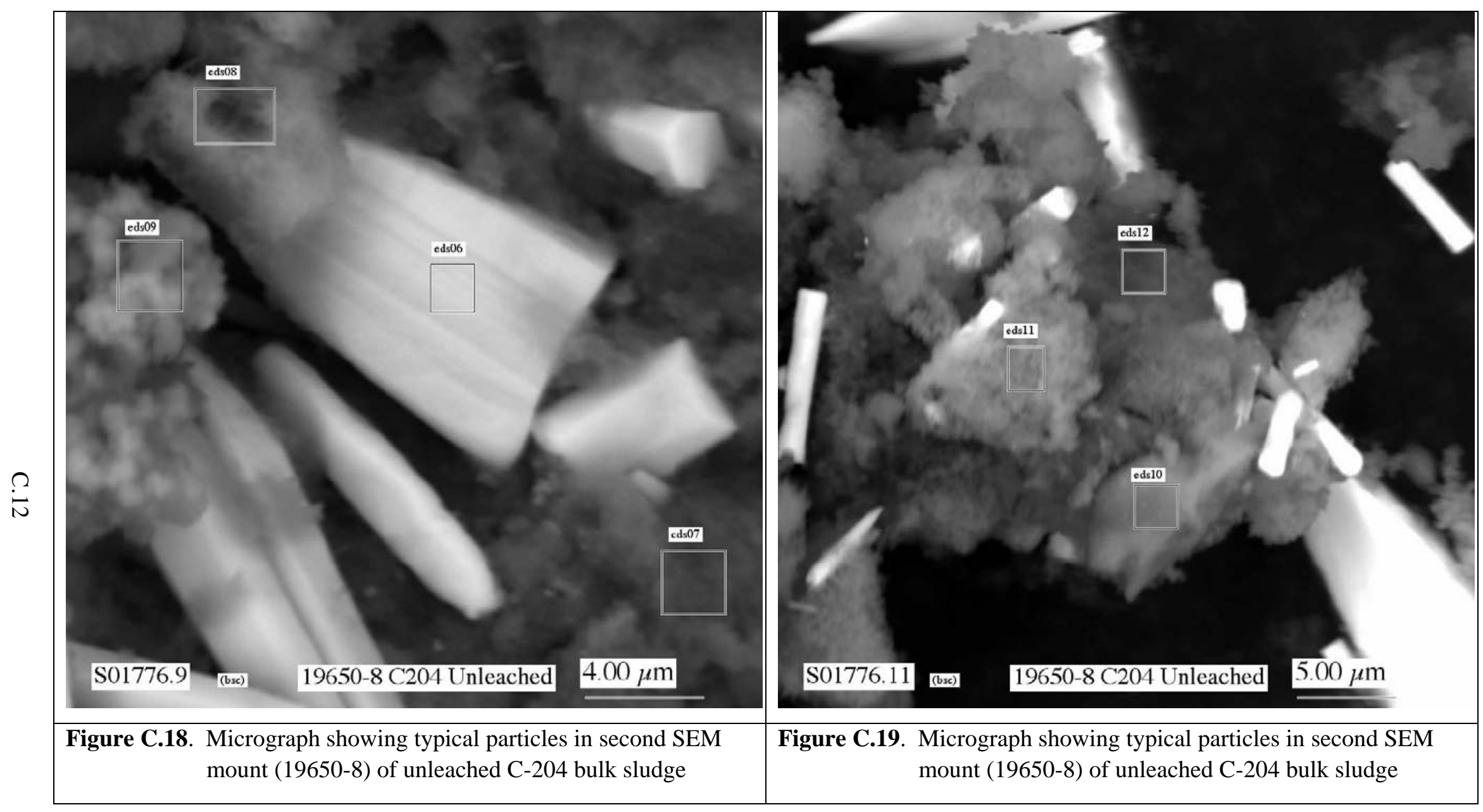




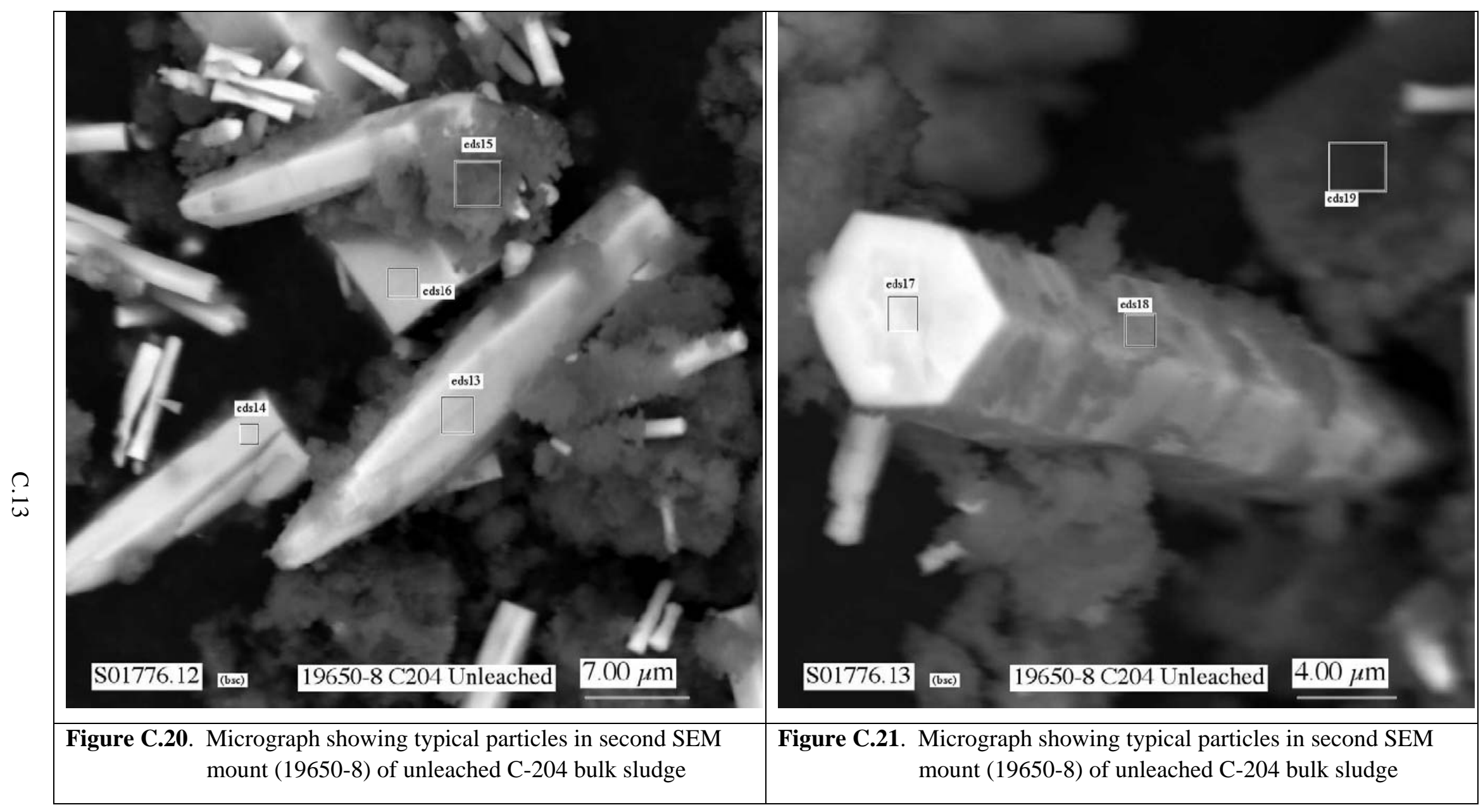




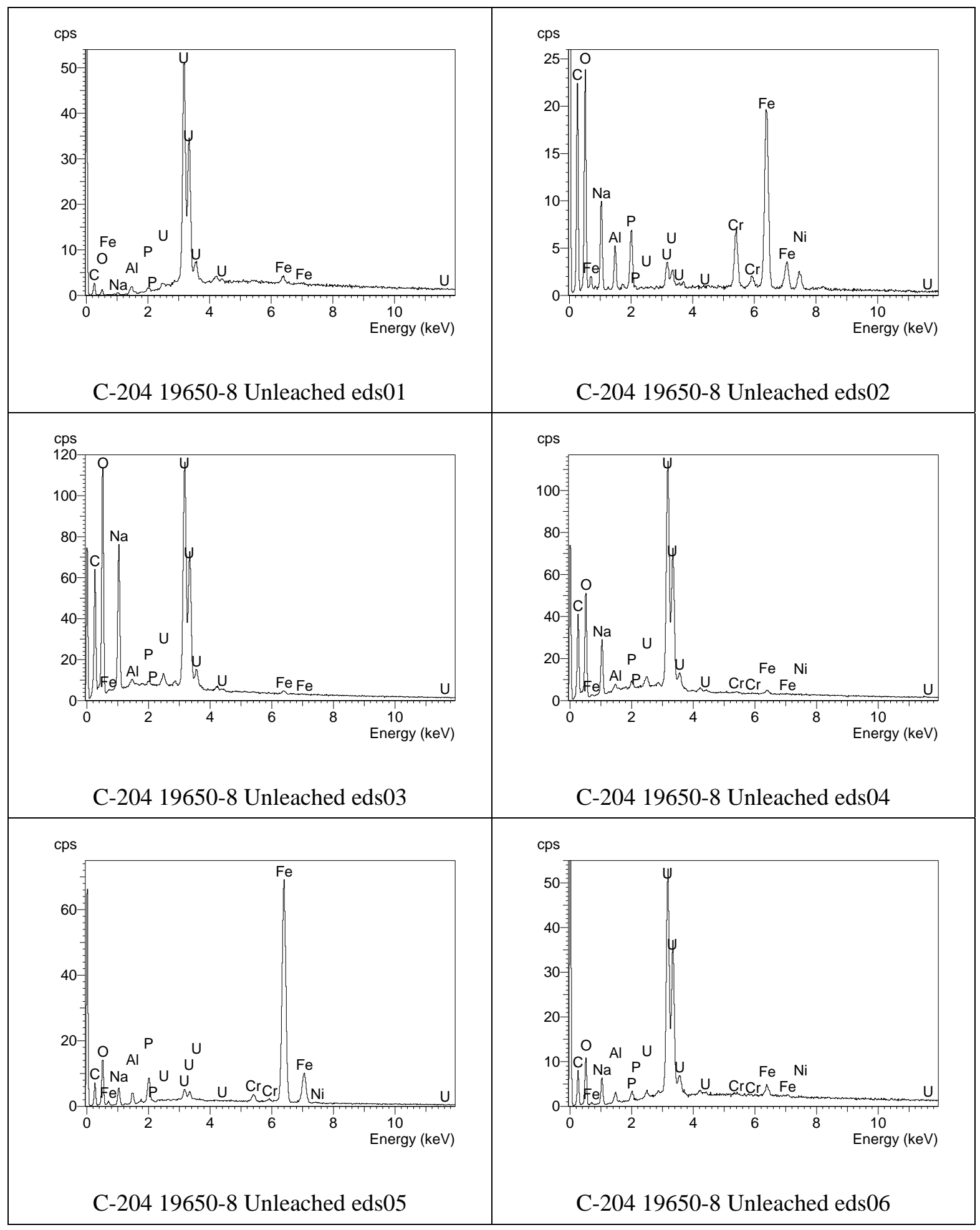

Figure C.22. EDS spectra for analyses eds01 through eds06 for particles in the second SEM mount (19650-8) of unleached C-204 sludge 


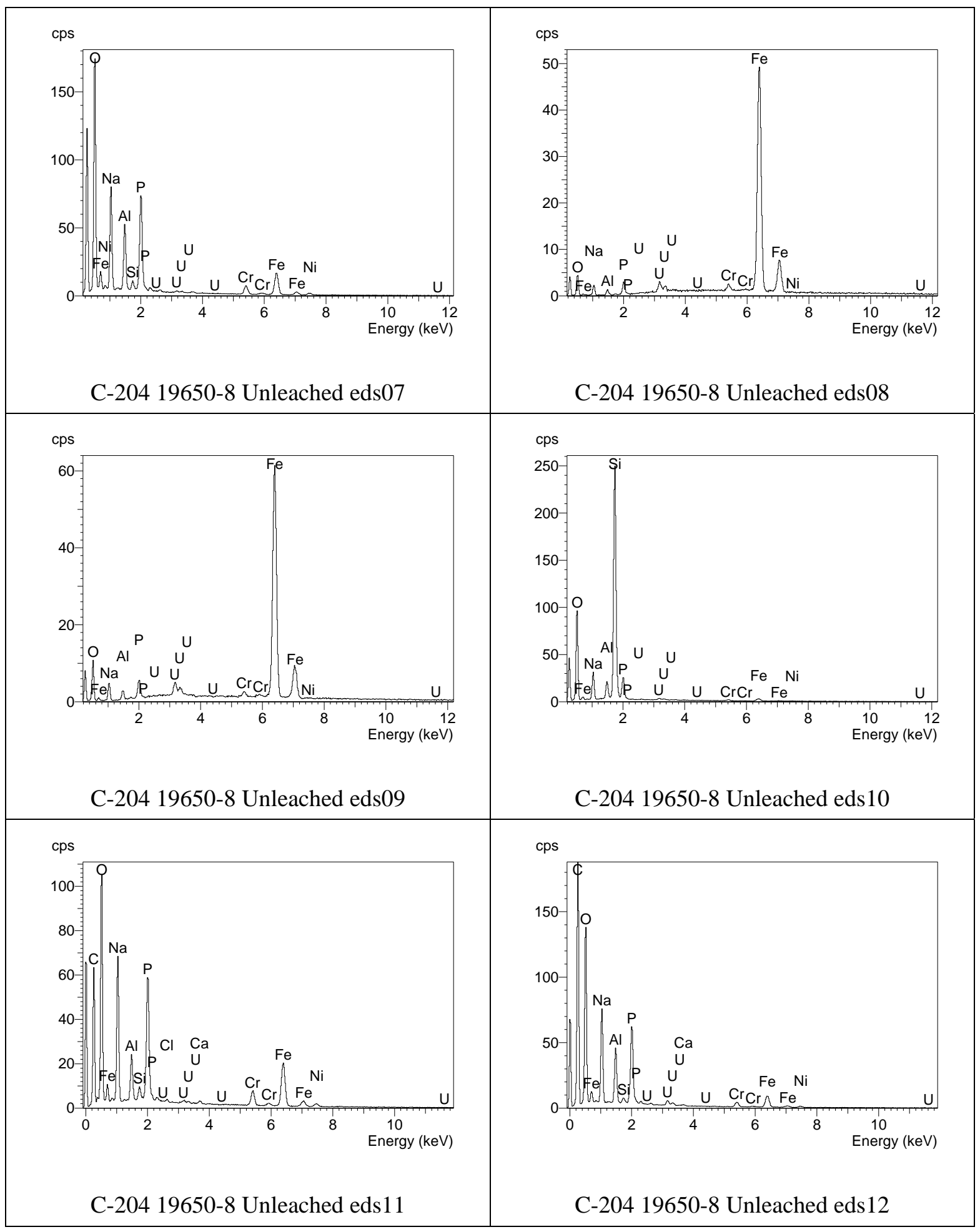

Figure C.23. EDS spectra for analyses eds07 through eds12 for particles in the second SEM mount (19650-8) of unleached C-204 sludge 


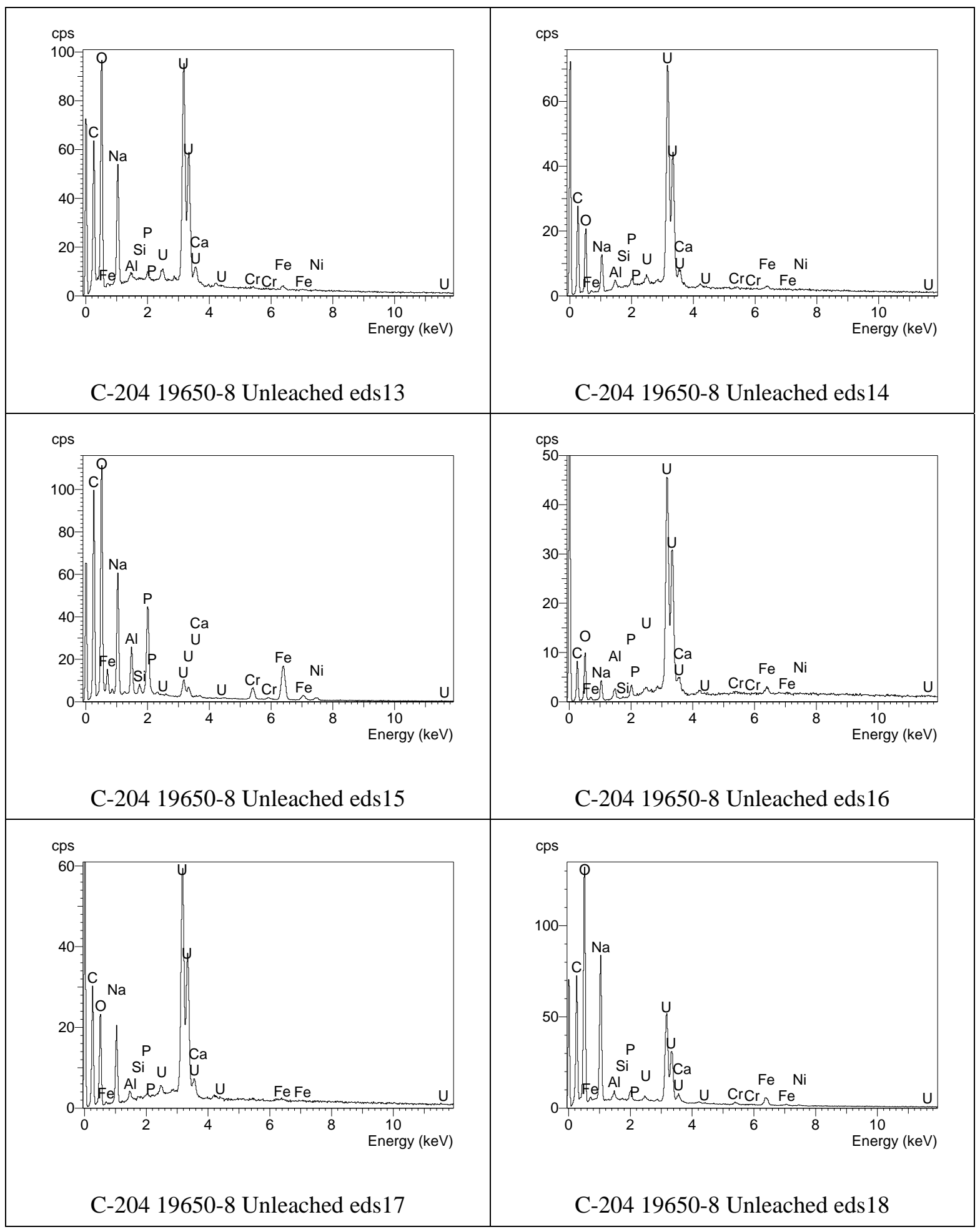

Figure C.24. EDS spectra for analyses eds13 through eds18 for particles in the second SEM mount (19650-8) of unleached C-204 sludge 


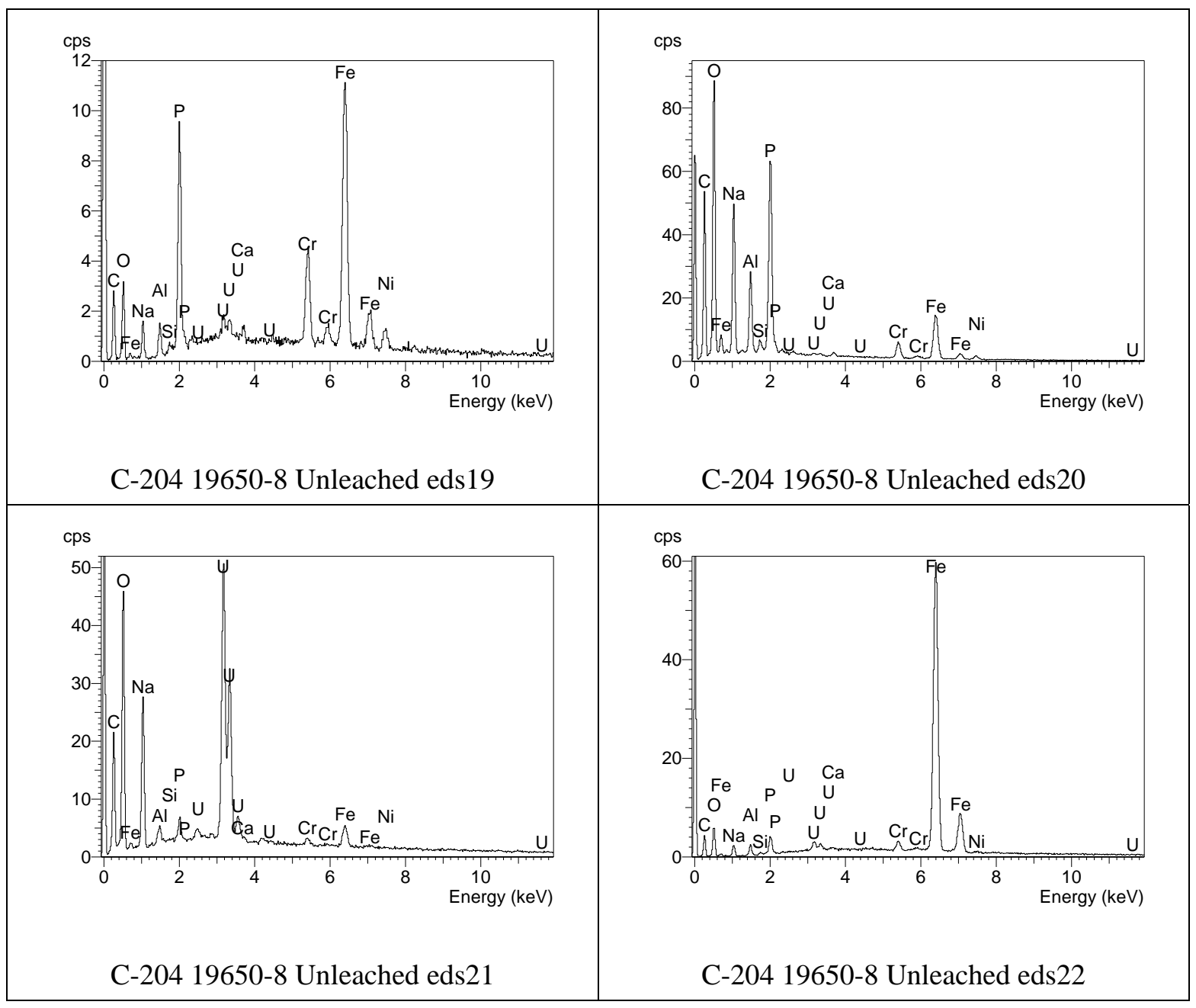

Figure C.25. EDS spectra for analyses eds19 through eds22 for particles in the second SEM mount (19650-8) of unleached C-204 sludge 


\section{C.2 Water-Leached (two weeks) C-204 Sludge}

Two mounts of water-leached (two weeks) C-204 (jar 19650) bulk residual tank waste were analyzed by SEM/EDS. The SEM micrographs for the first mount (19650-11) of C-204 sludge are shown in Figures C.26 through C.37. The EDS spectra for this mount are given in Figures C.38 through C.40. The SEM micrographs for the second mount (19650-11) of C-204 sludge are shown in Figures C.41 through C.54, and the EDS spectra for the second mount are given in Figures C.55 through C.57. 


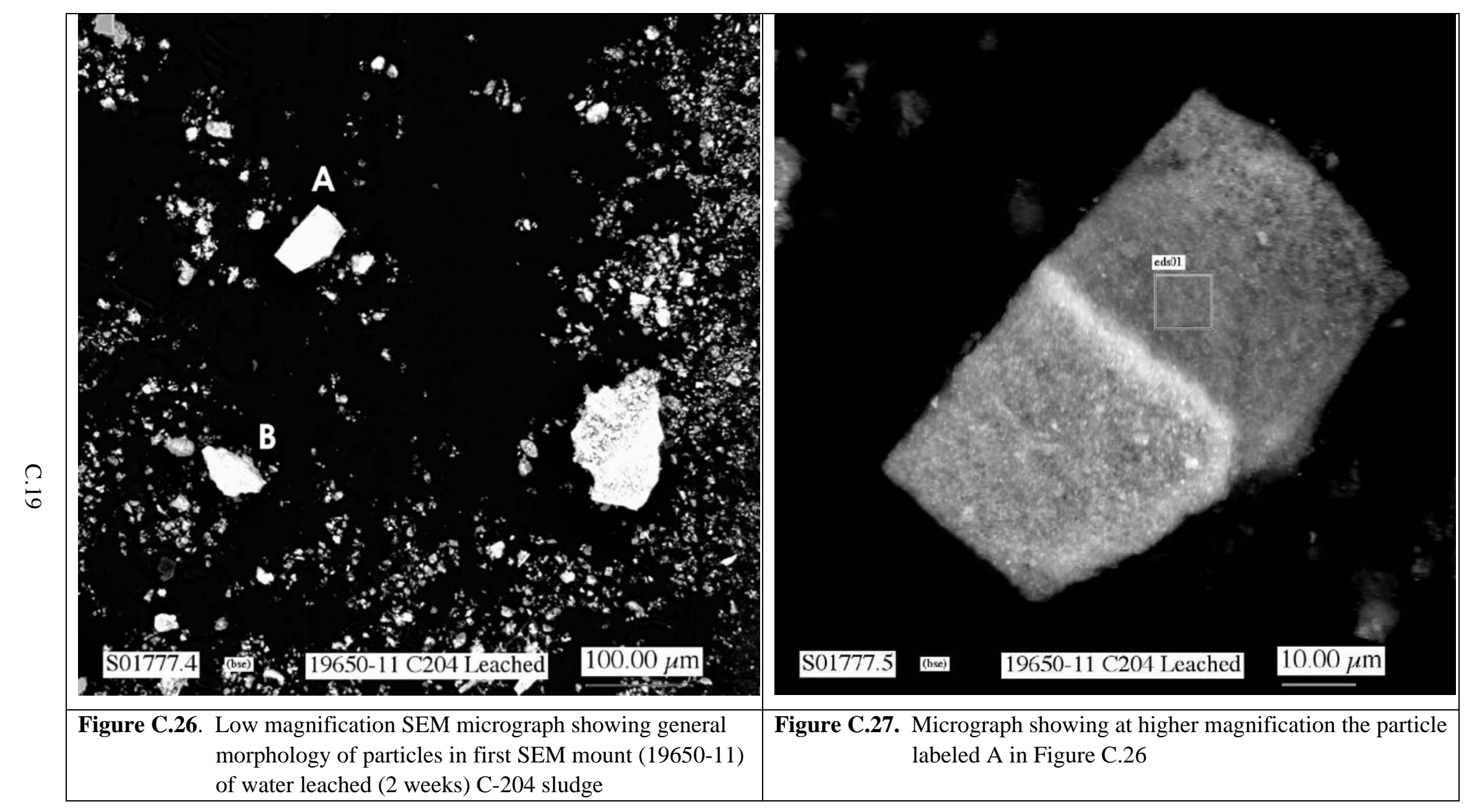




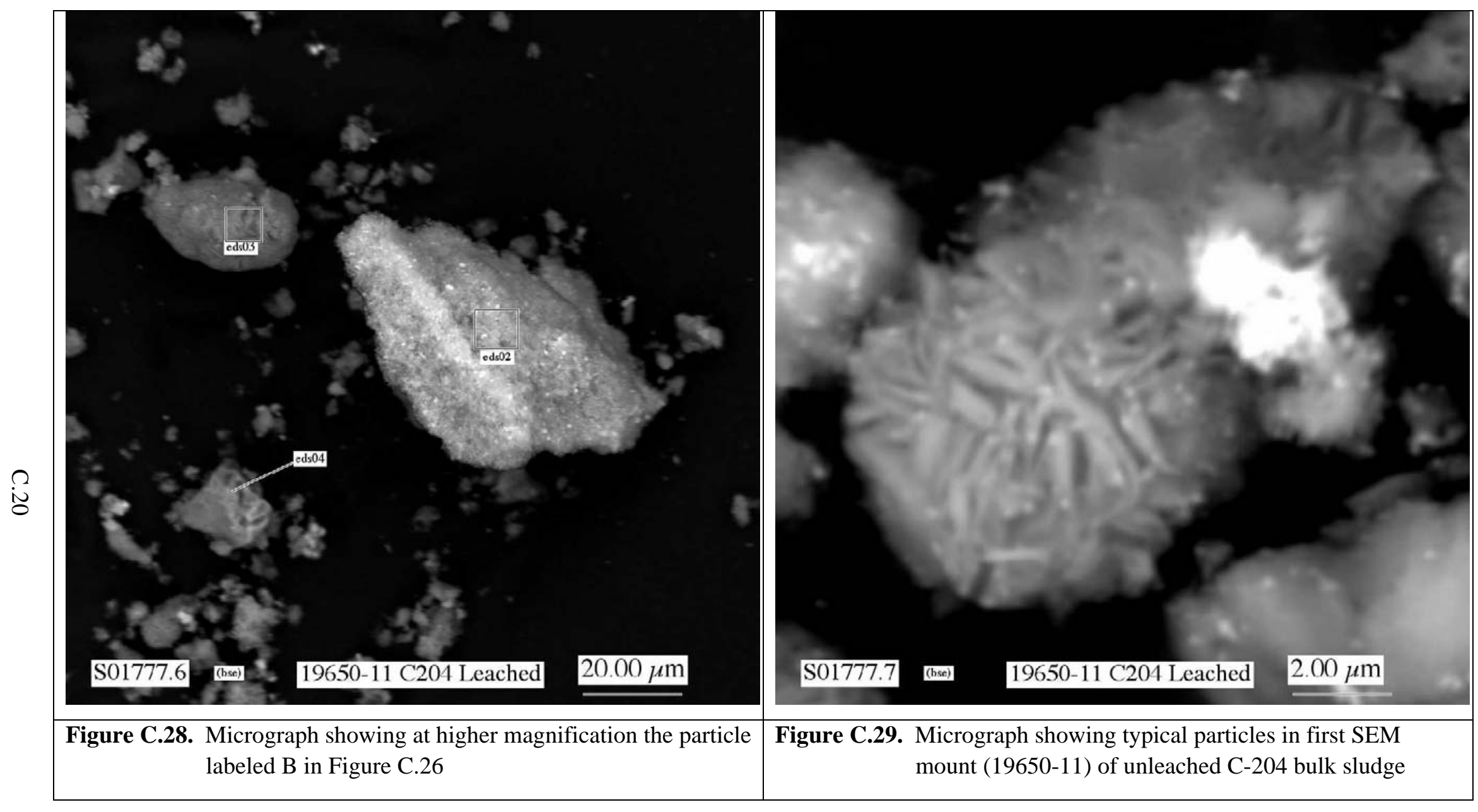




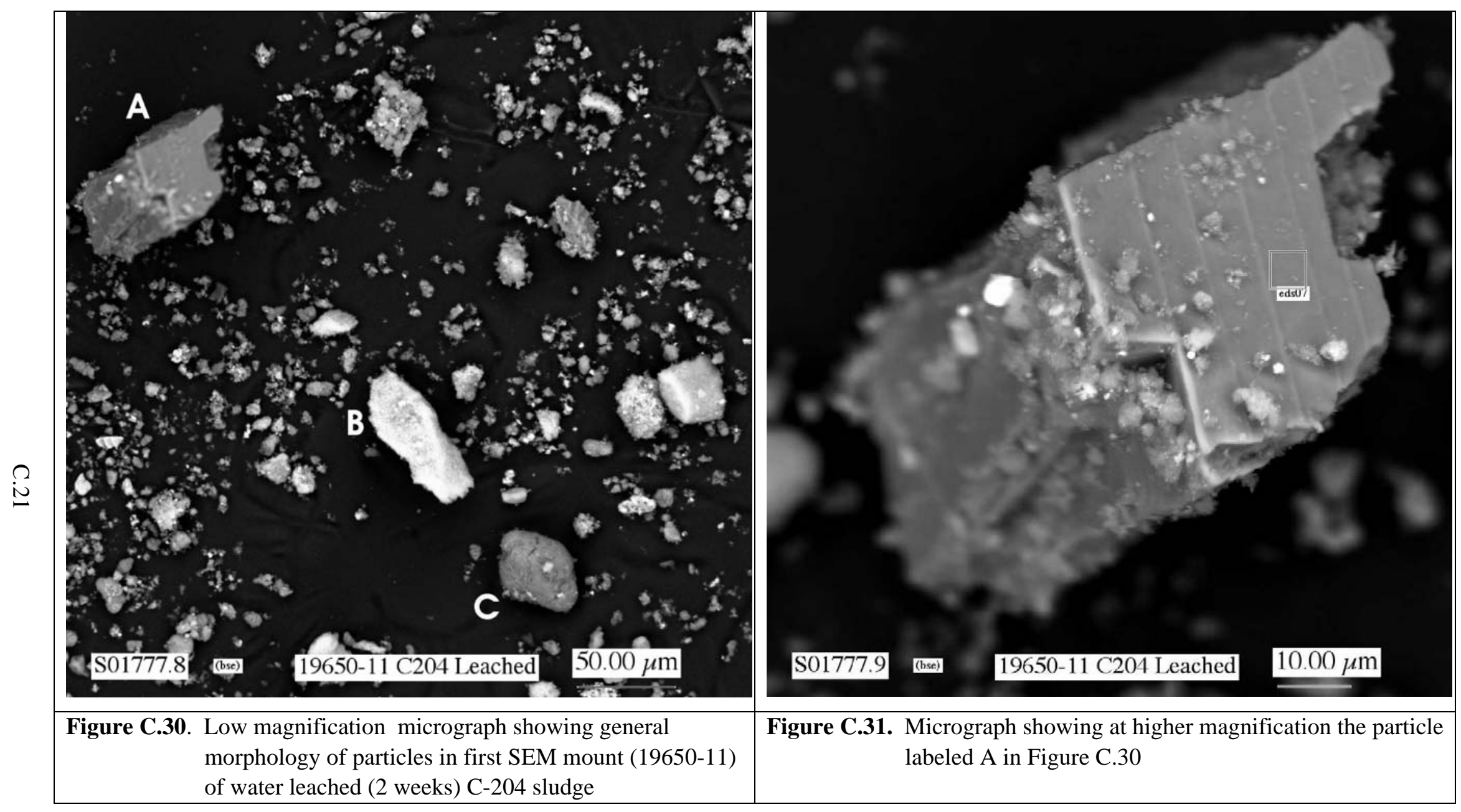




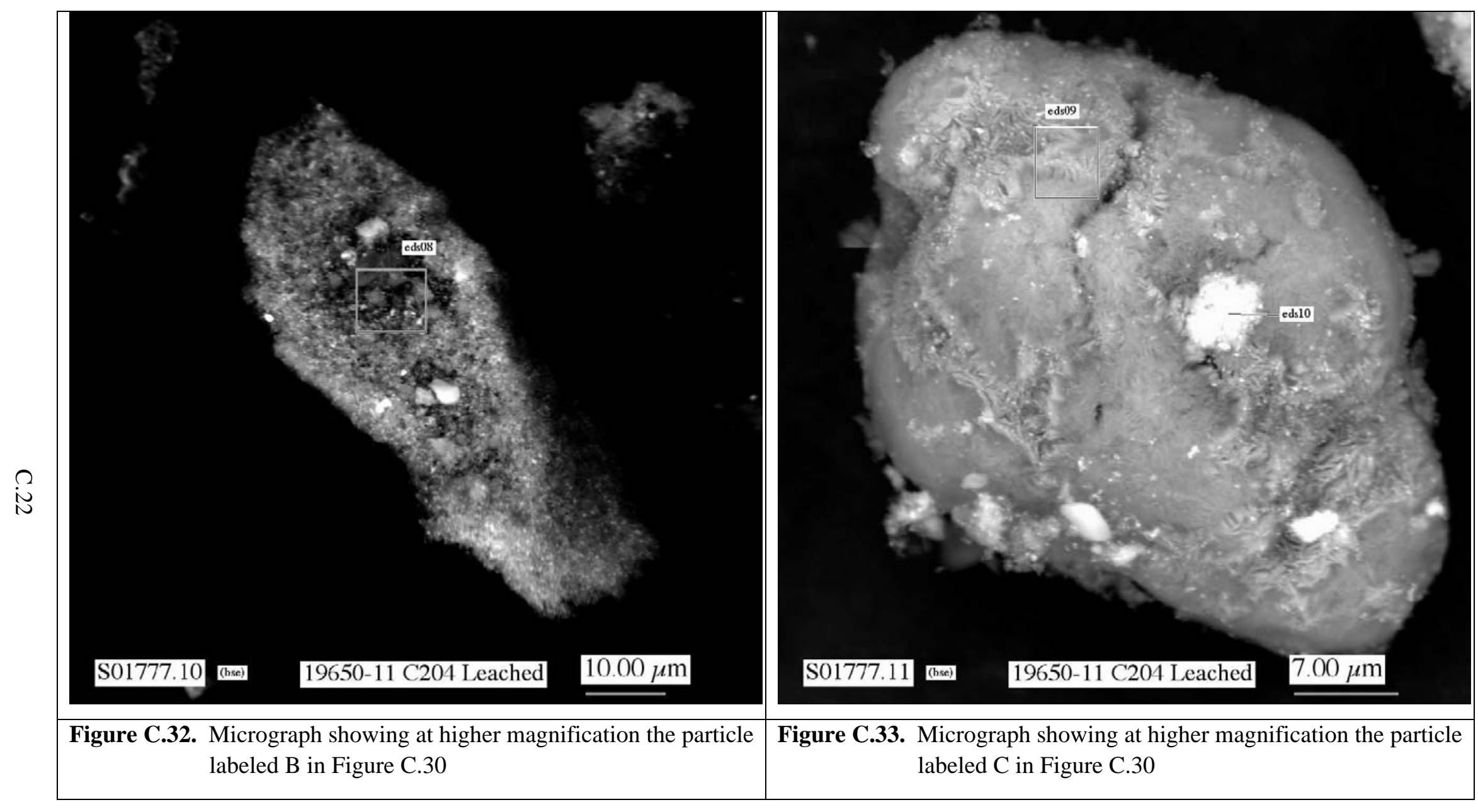




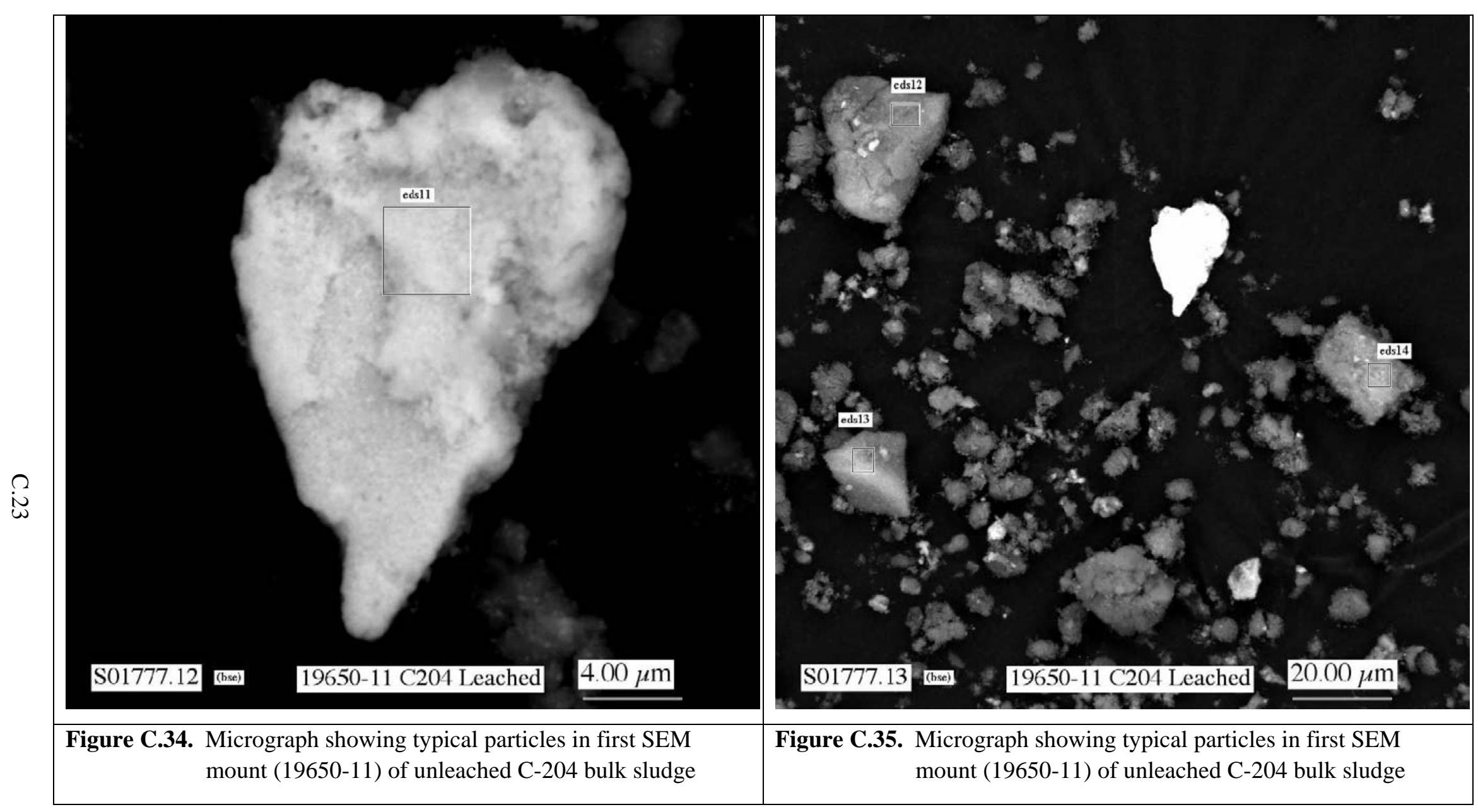




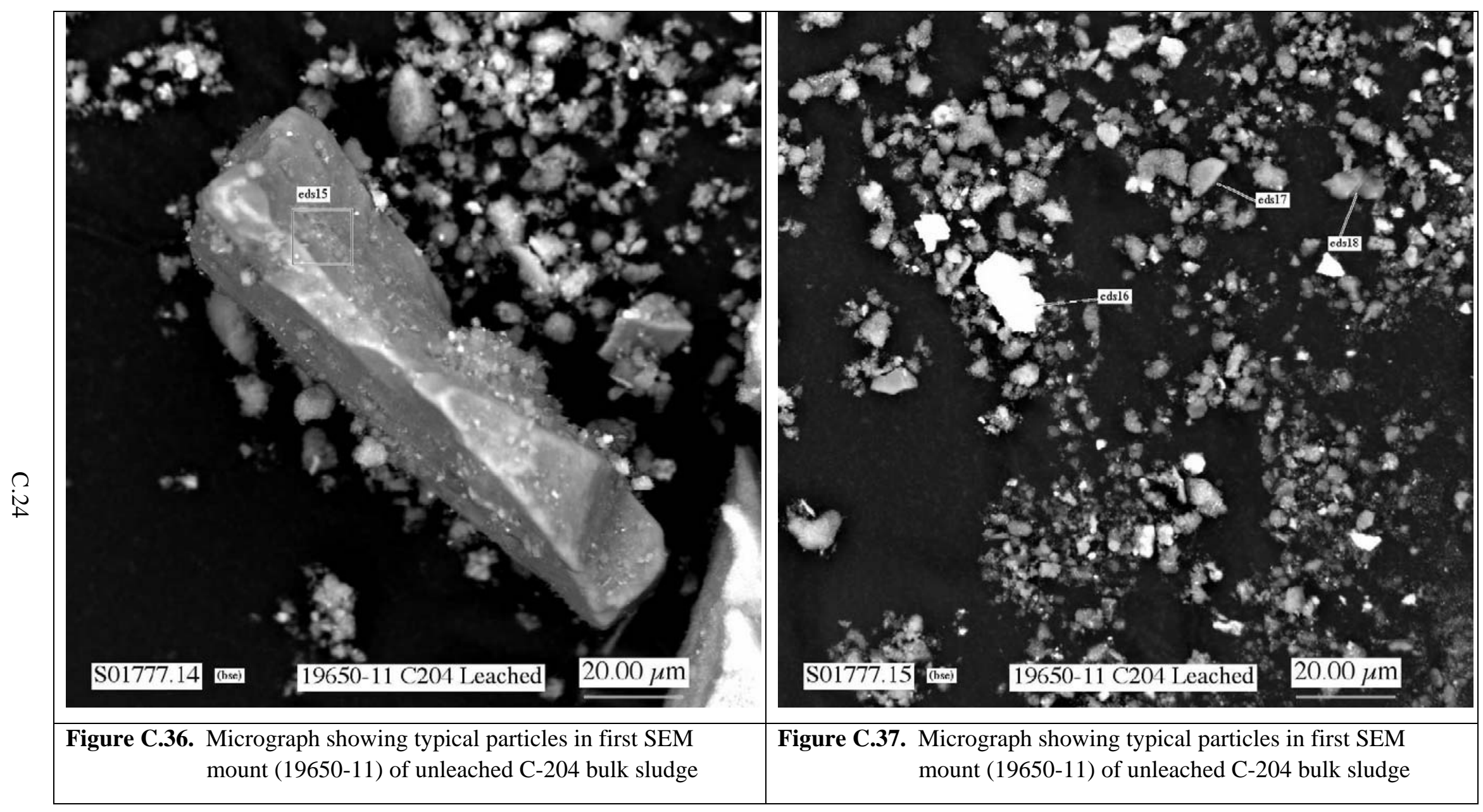




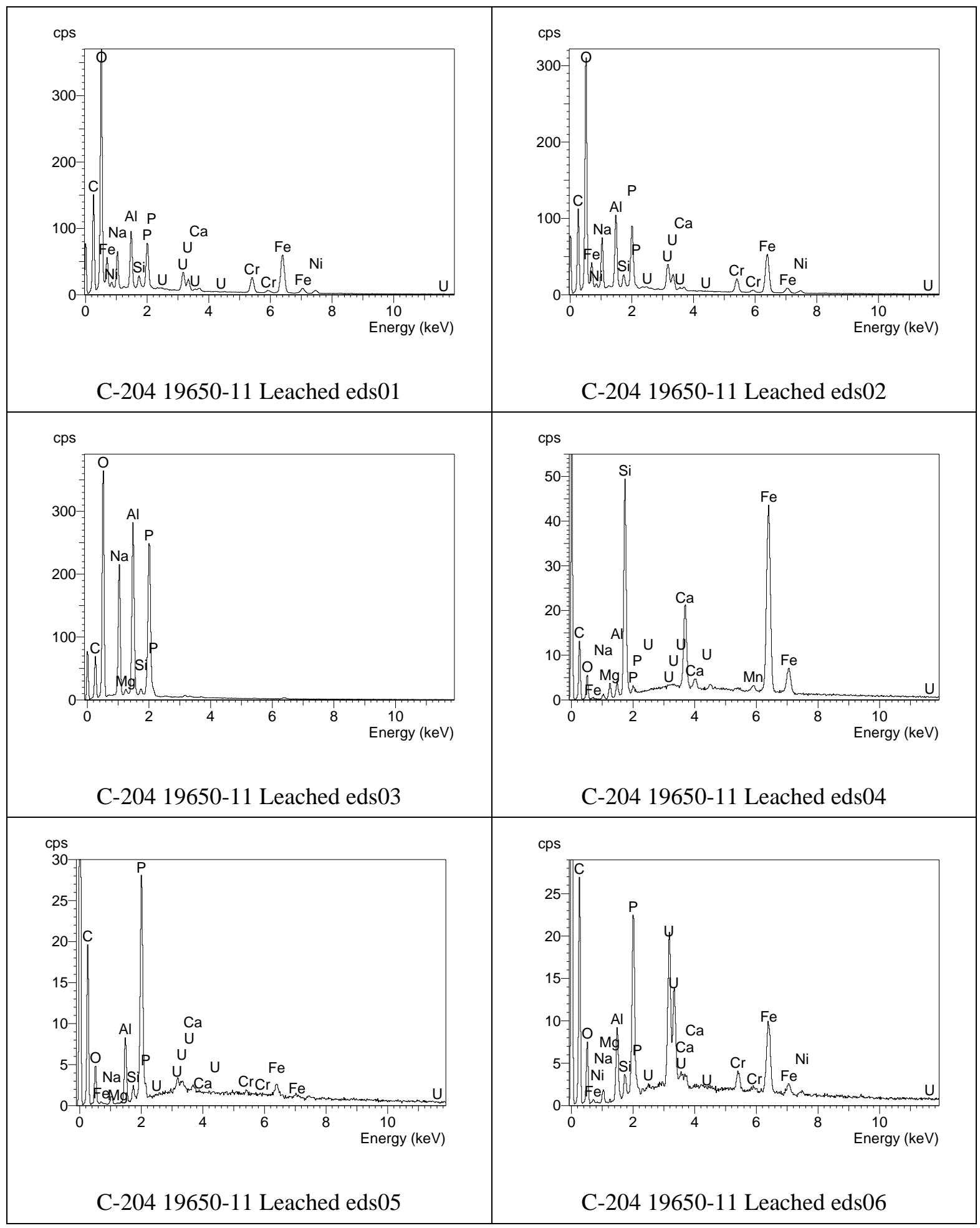

Figure C.38. EDS spectra for analyses eds01 through eds06 for particles in the first SEM mount (19650-11) of water leached (2 weeks) C-204 sludge 


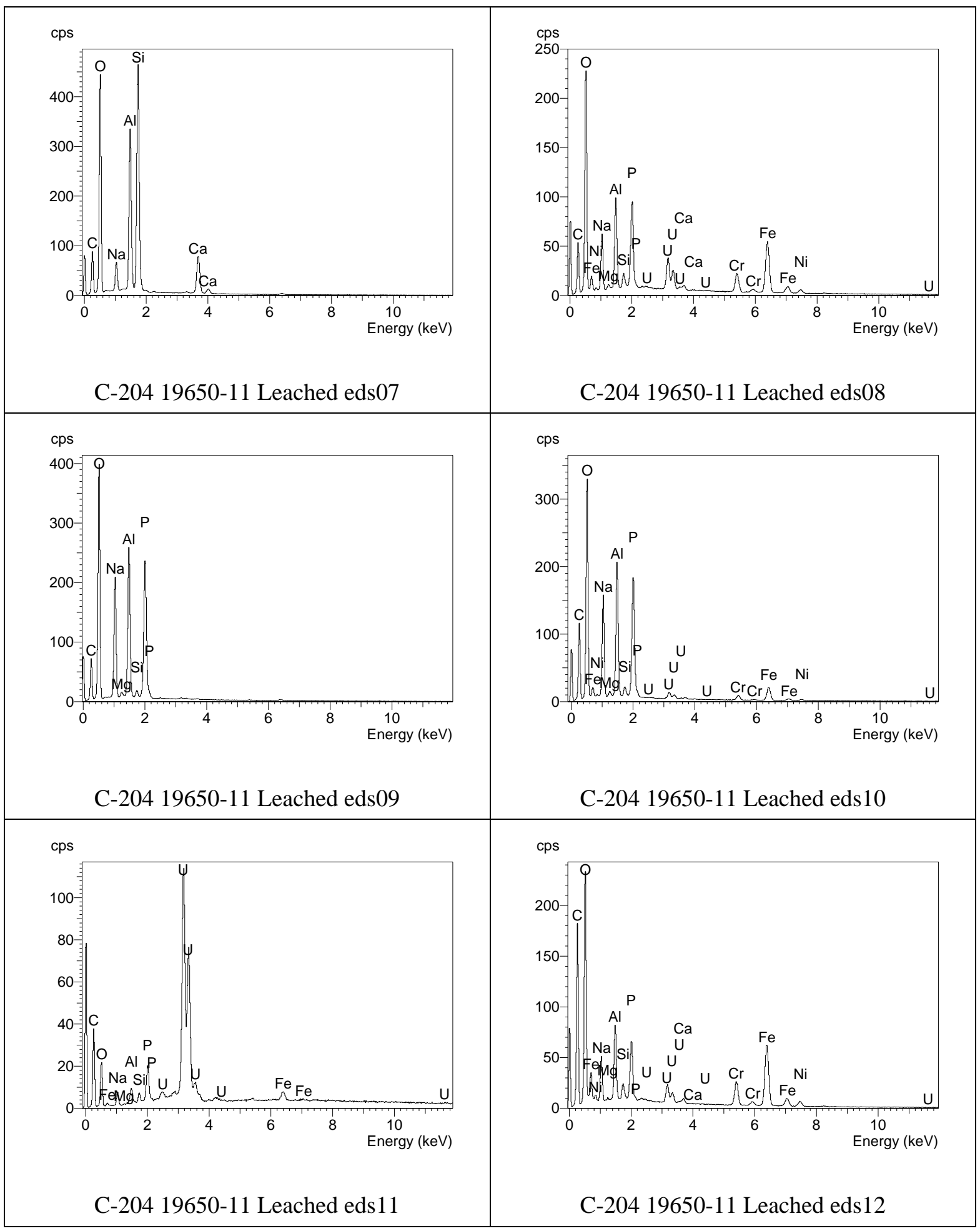

Figure C.39. EDS spectra for analyses eds07 through eds12 for particles in the first SEM mount (19650-11) of water leached (2 weeks) C-204 sludge 


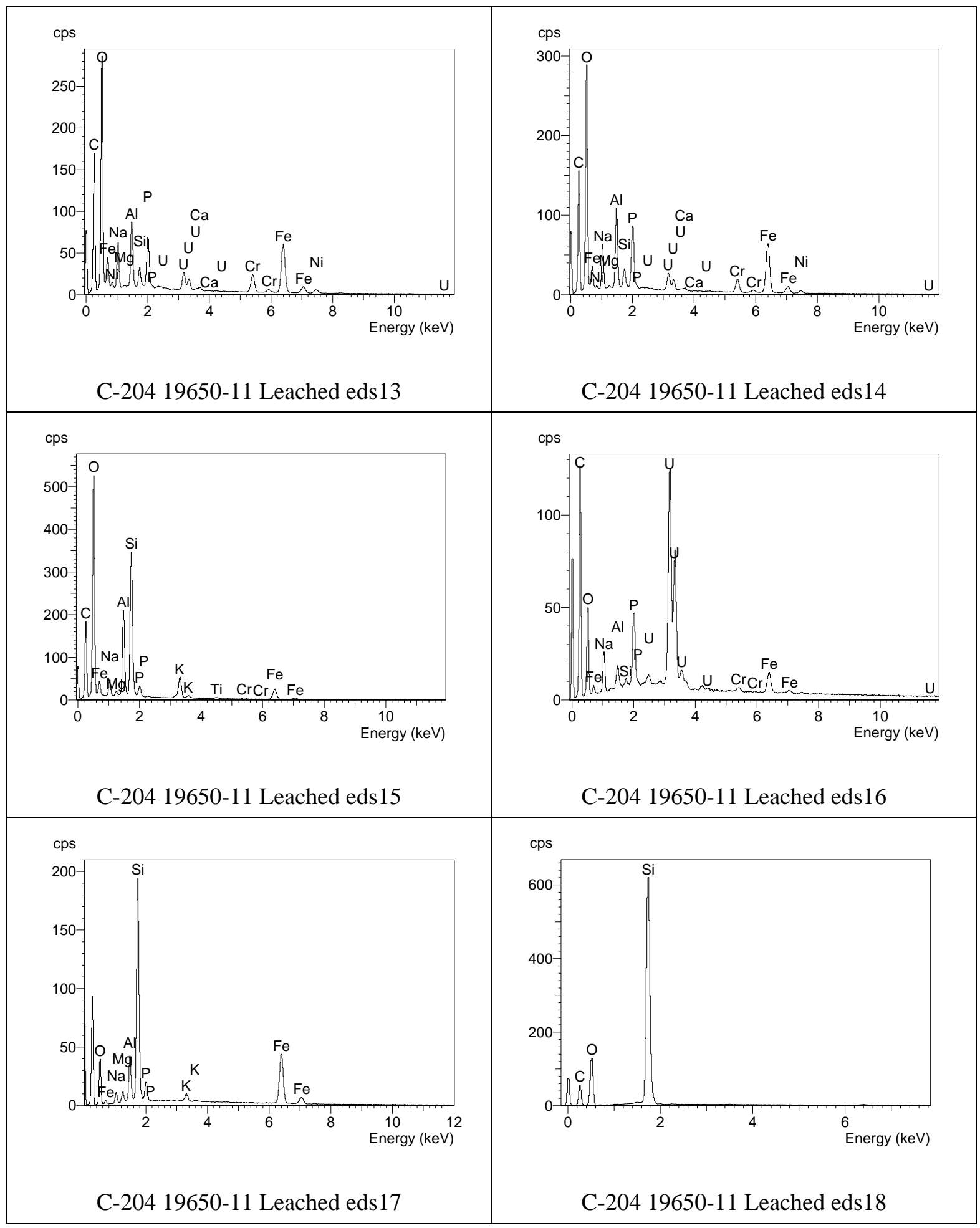

Figure C.40. EDS spectra for analyses eds13 through eds18 for particles in the first SEM mount (19650-11) of water leached (2 weeks) C-204 sludge 


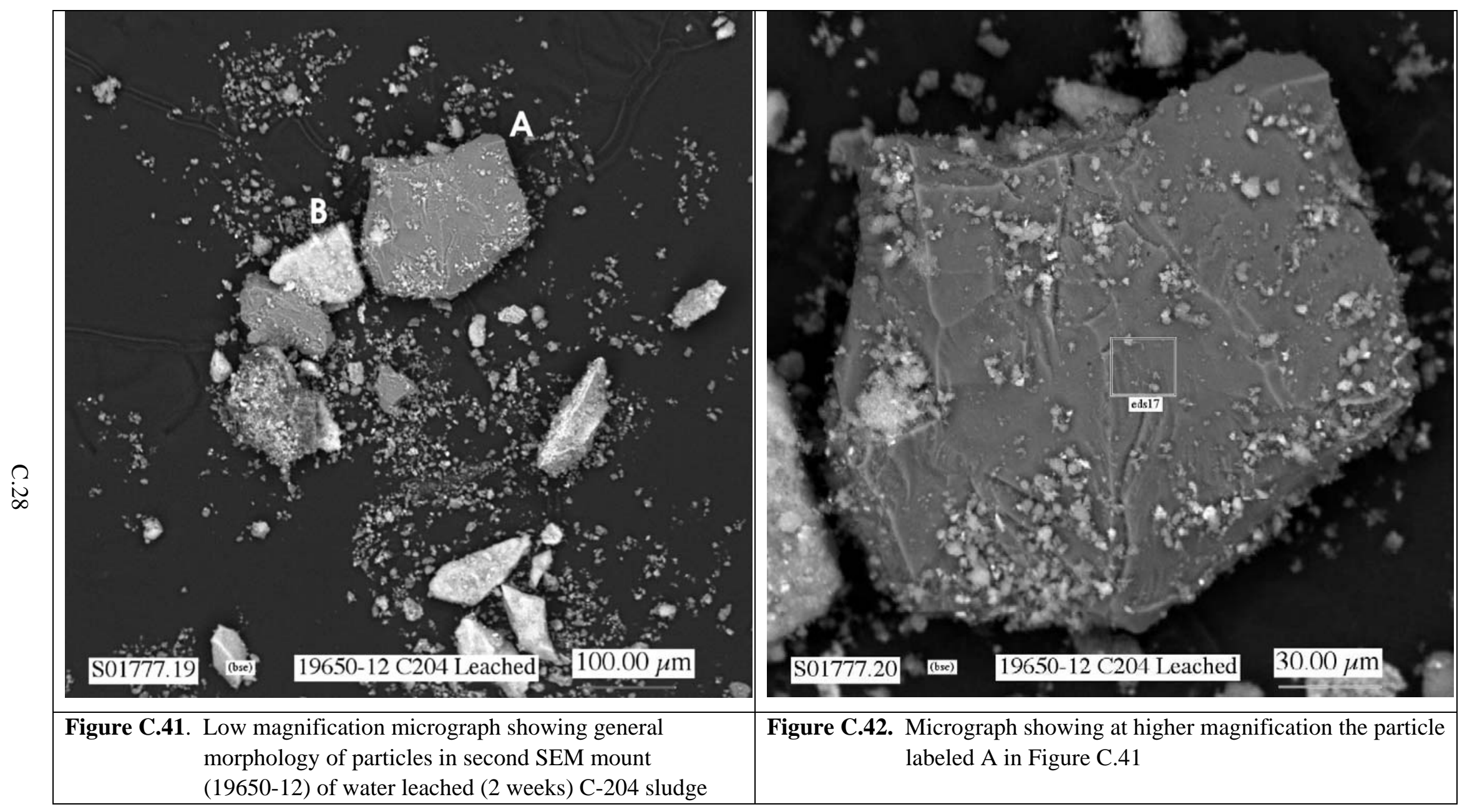




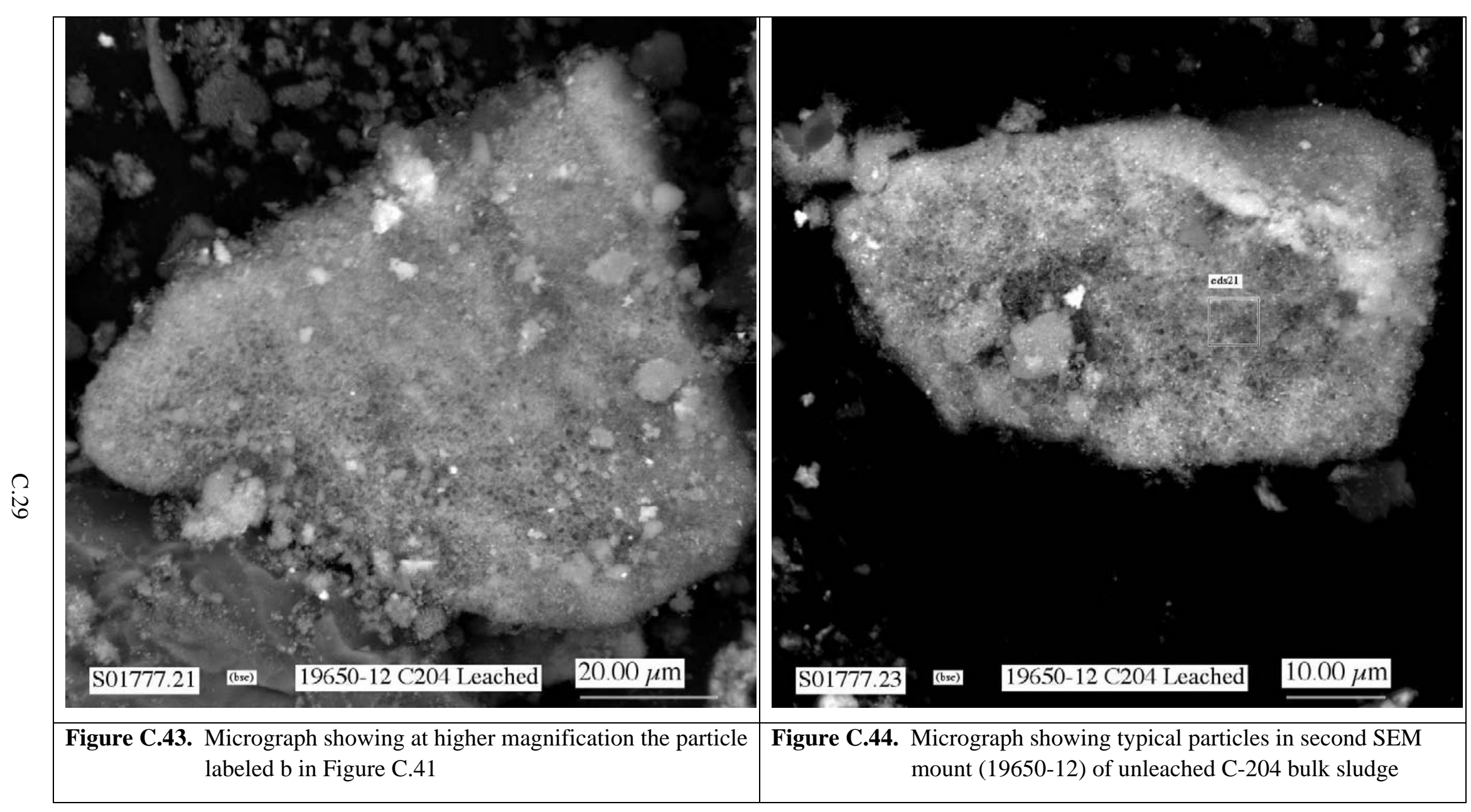




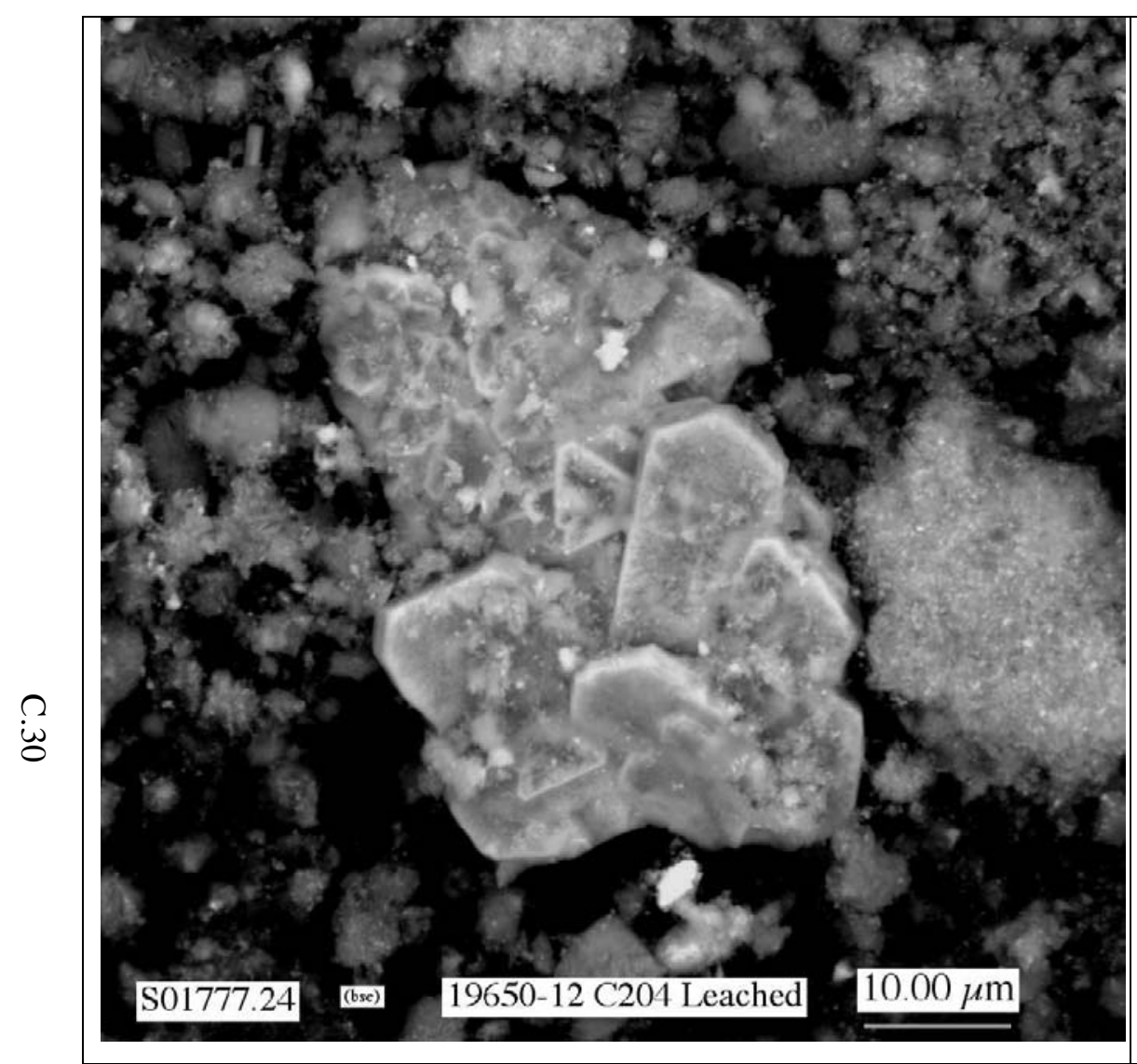

Figure C.45. Micrograph showing typical particles in second SEM mount (19650-12) of unleached C-204 bulk sludge

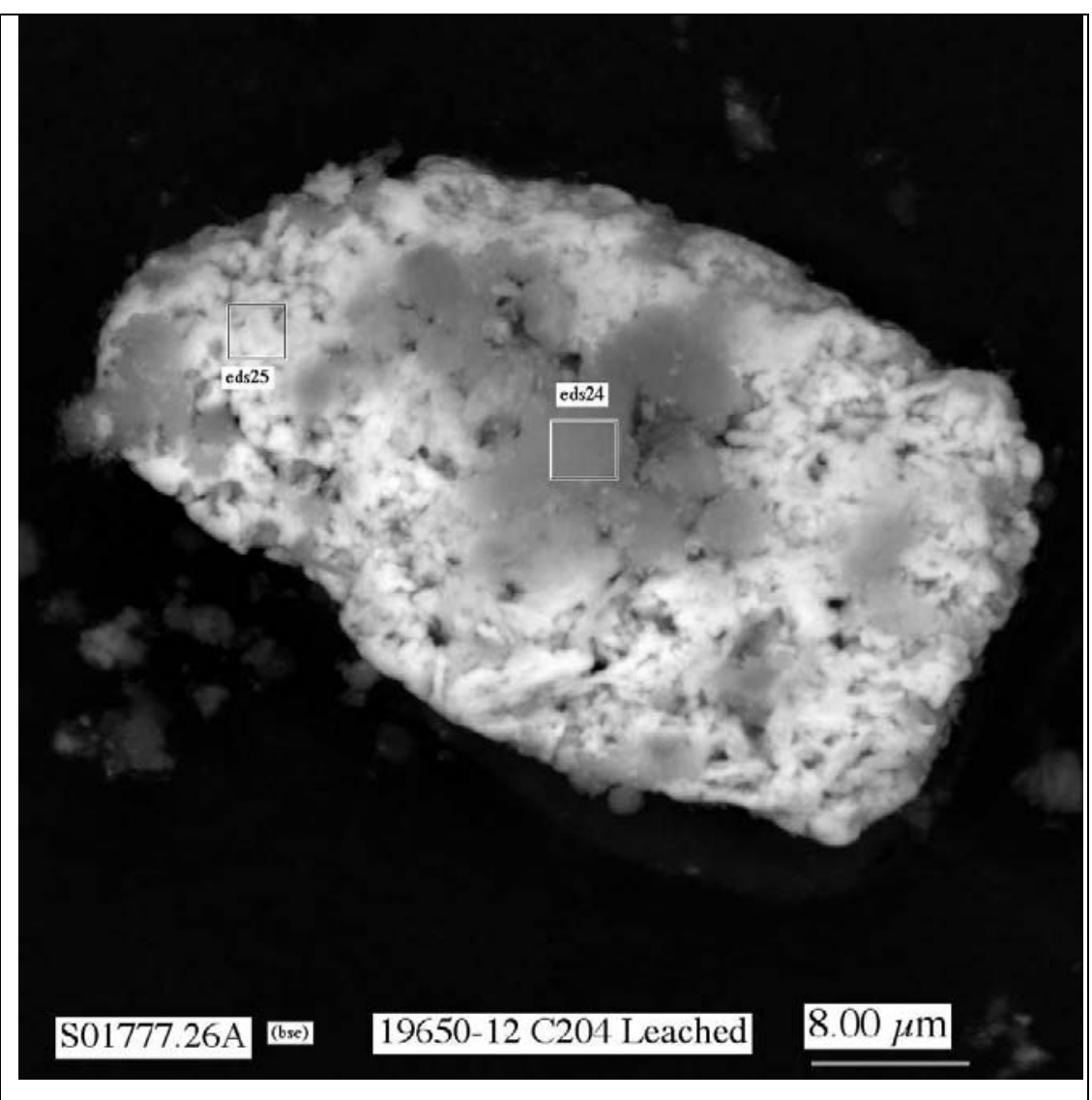

Figure C.46. Micrograph showing typical particles in second SEM mount (19650-12) of unleached C-204 bulk sludge 


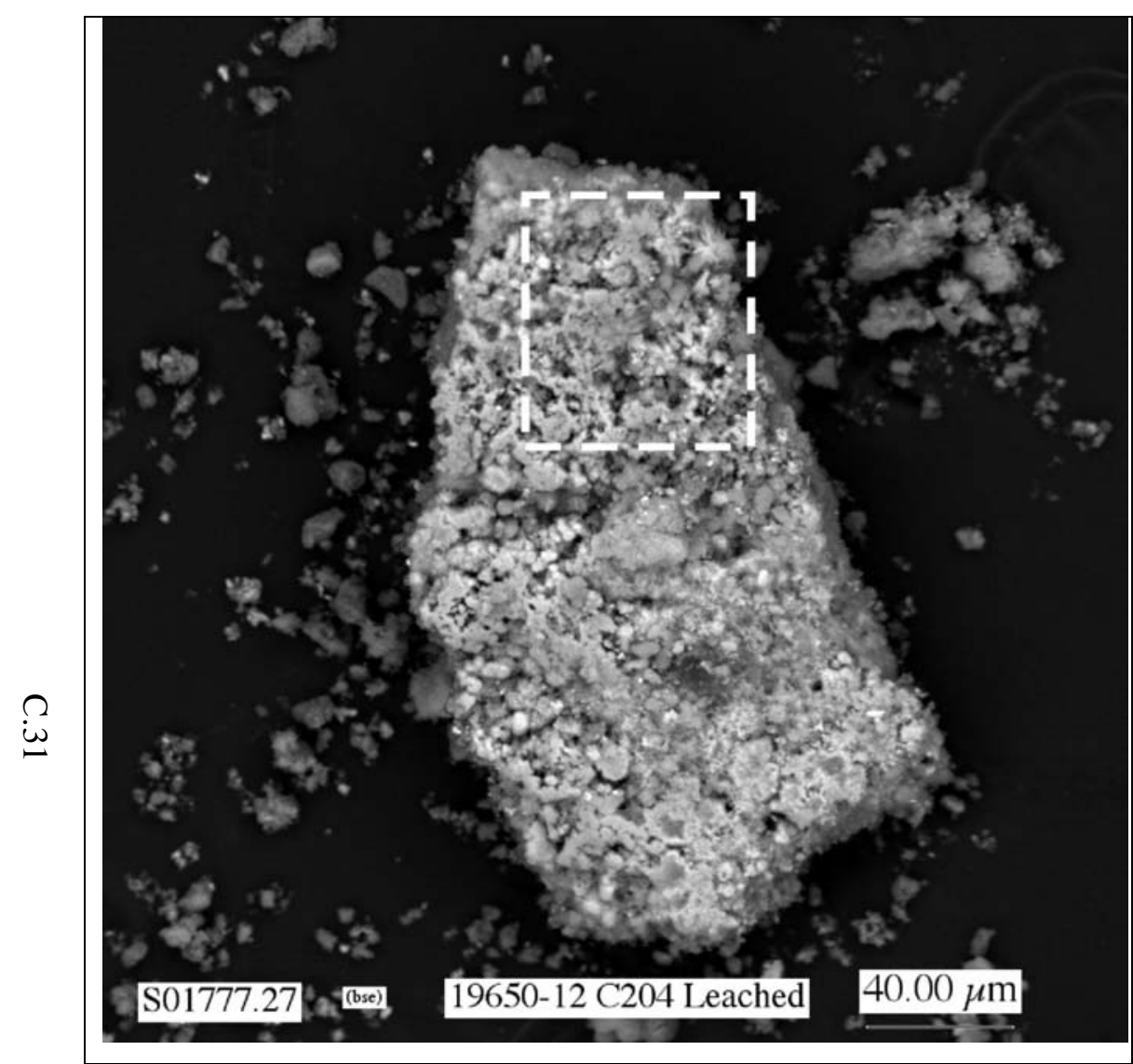

Figure C.47. Micrograph showing typical particles in second SEM mount (19650-12) of unleached C-204 bulk sludge

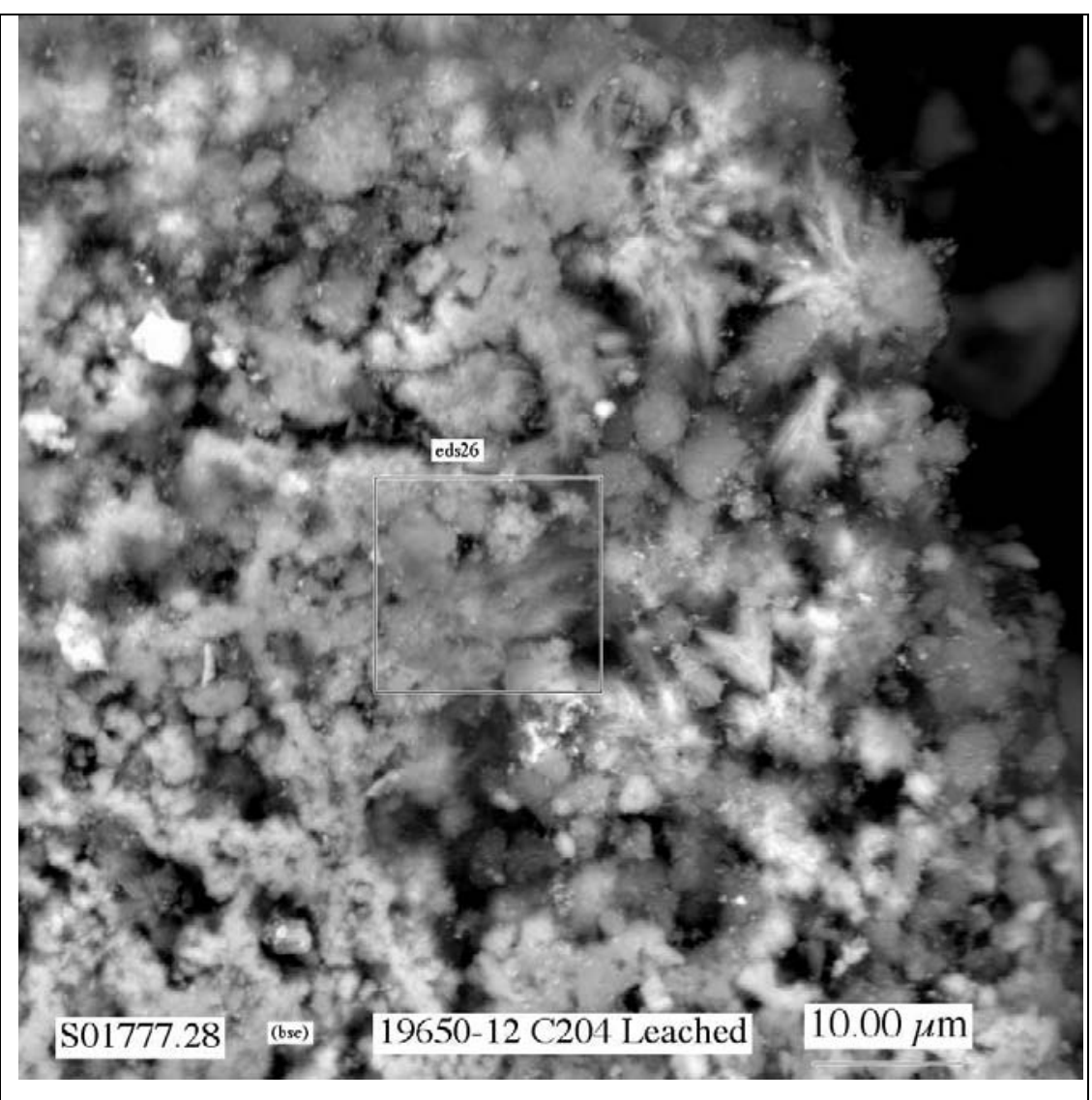

Figure C.48. Micrograph showing at higher magnification area indicated by white dashed-line square in Figure C.47 


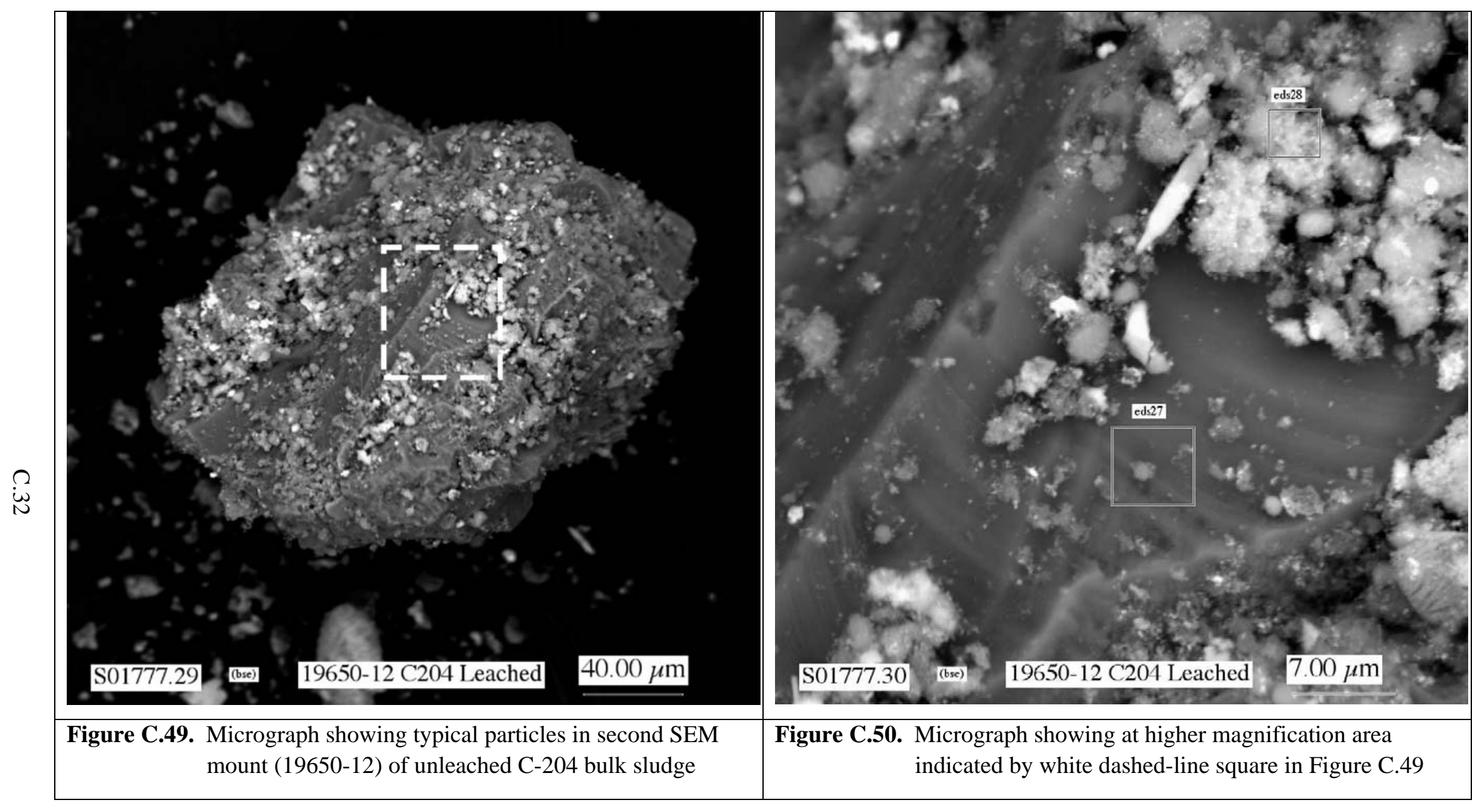




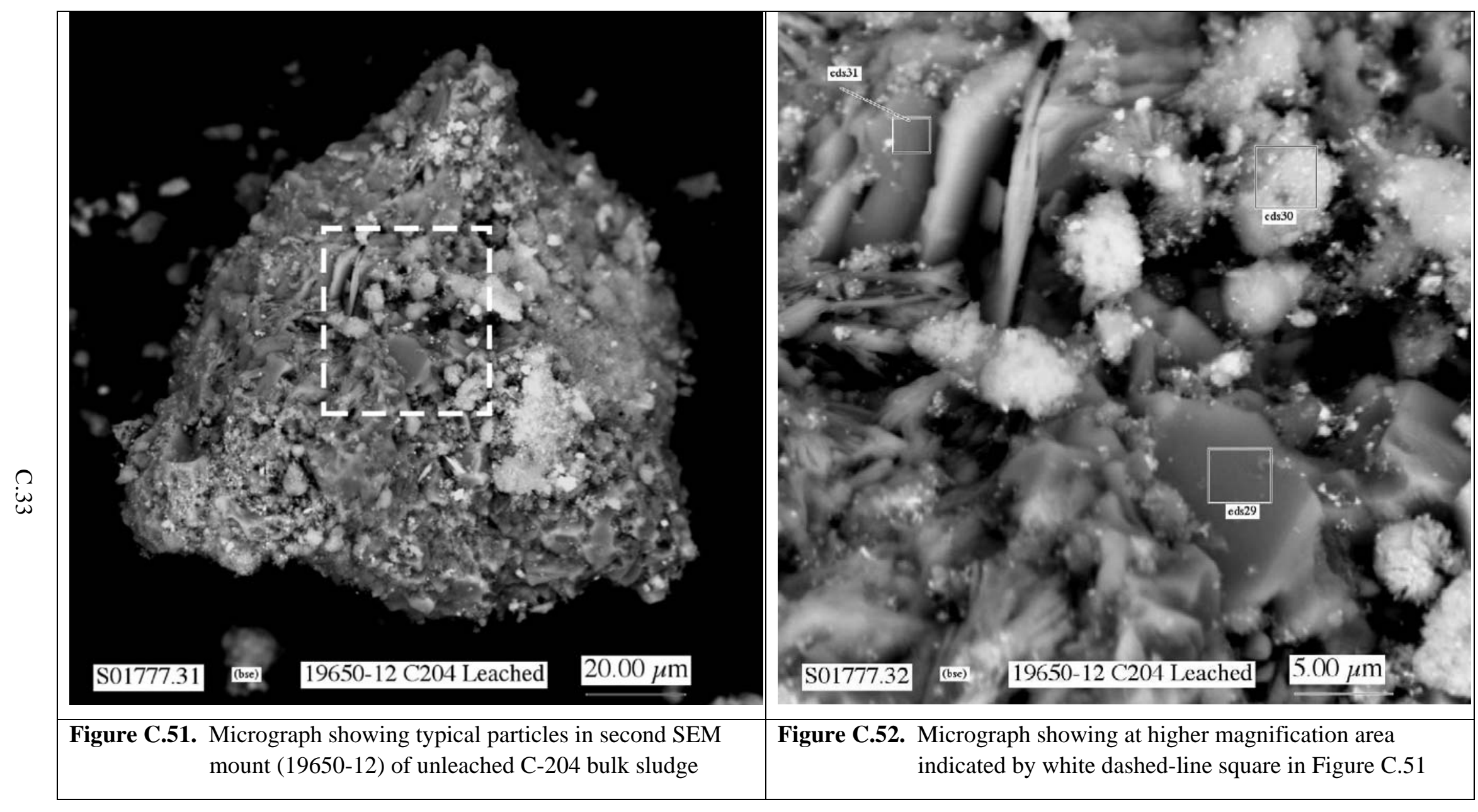




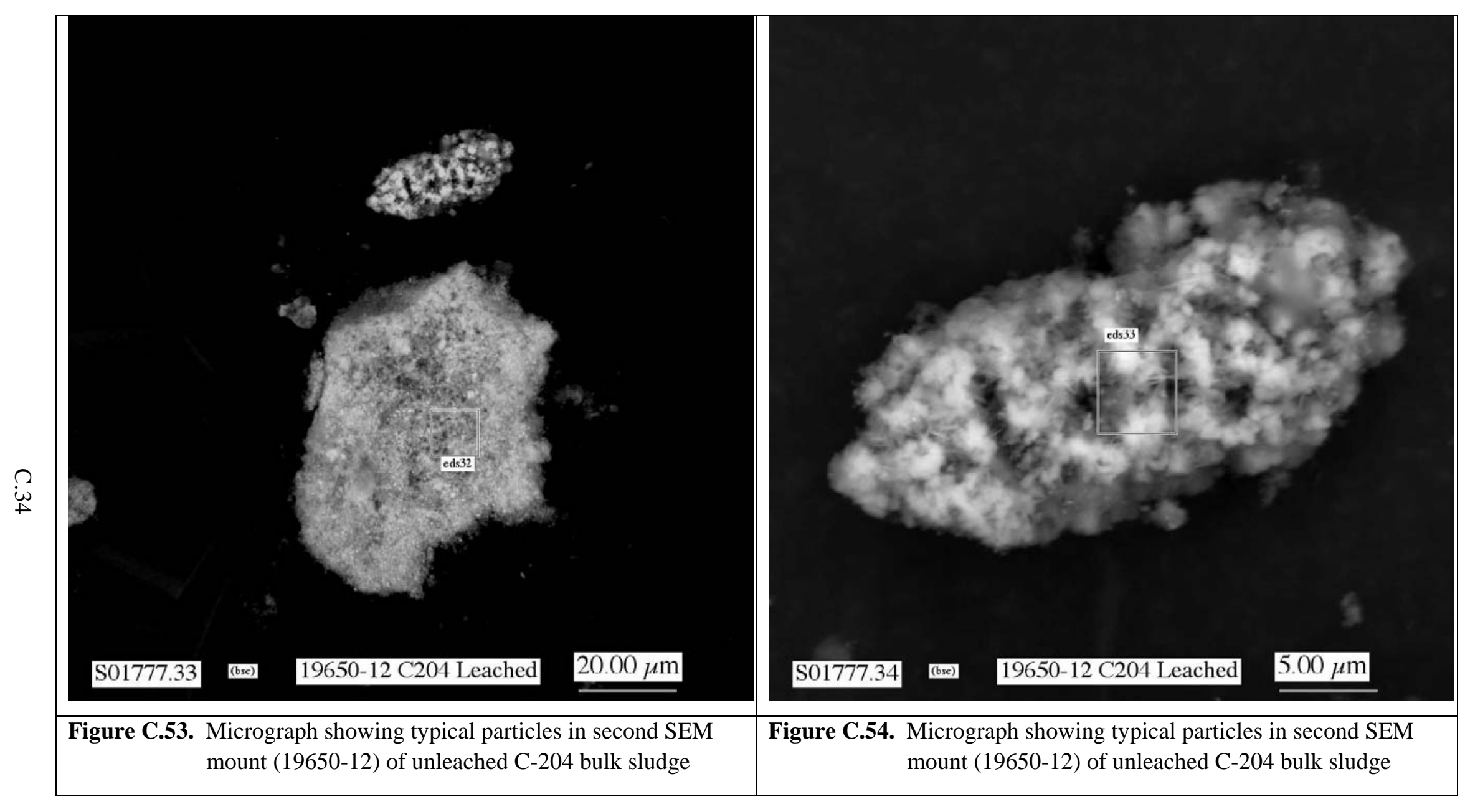




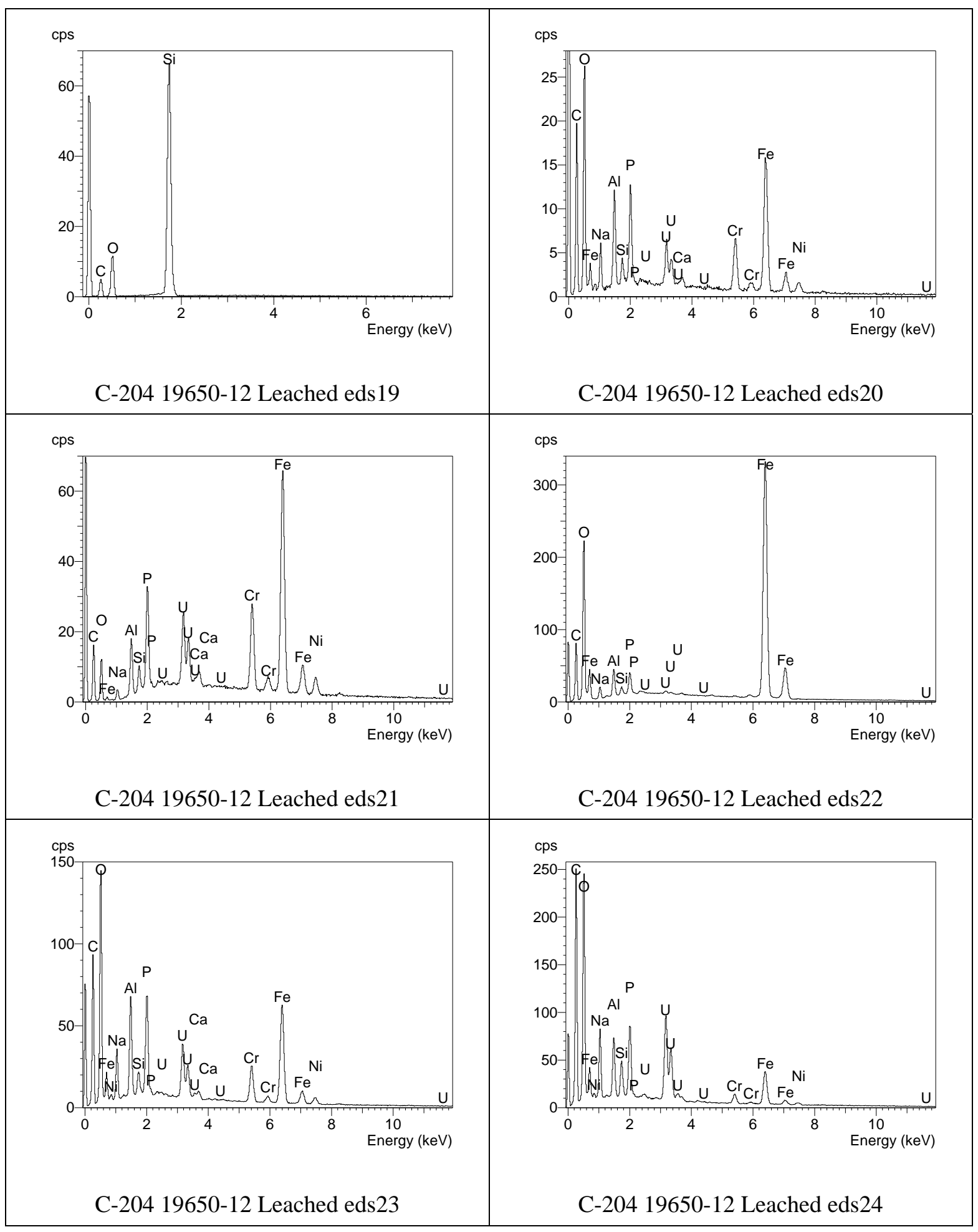

Figure C.55. EDS spectra for analyses eds19 through eds24 for particles in the second SEM mount (19650-12) of water leached (2 weeks) C-204 sludge 


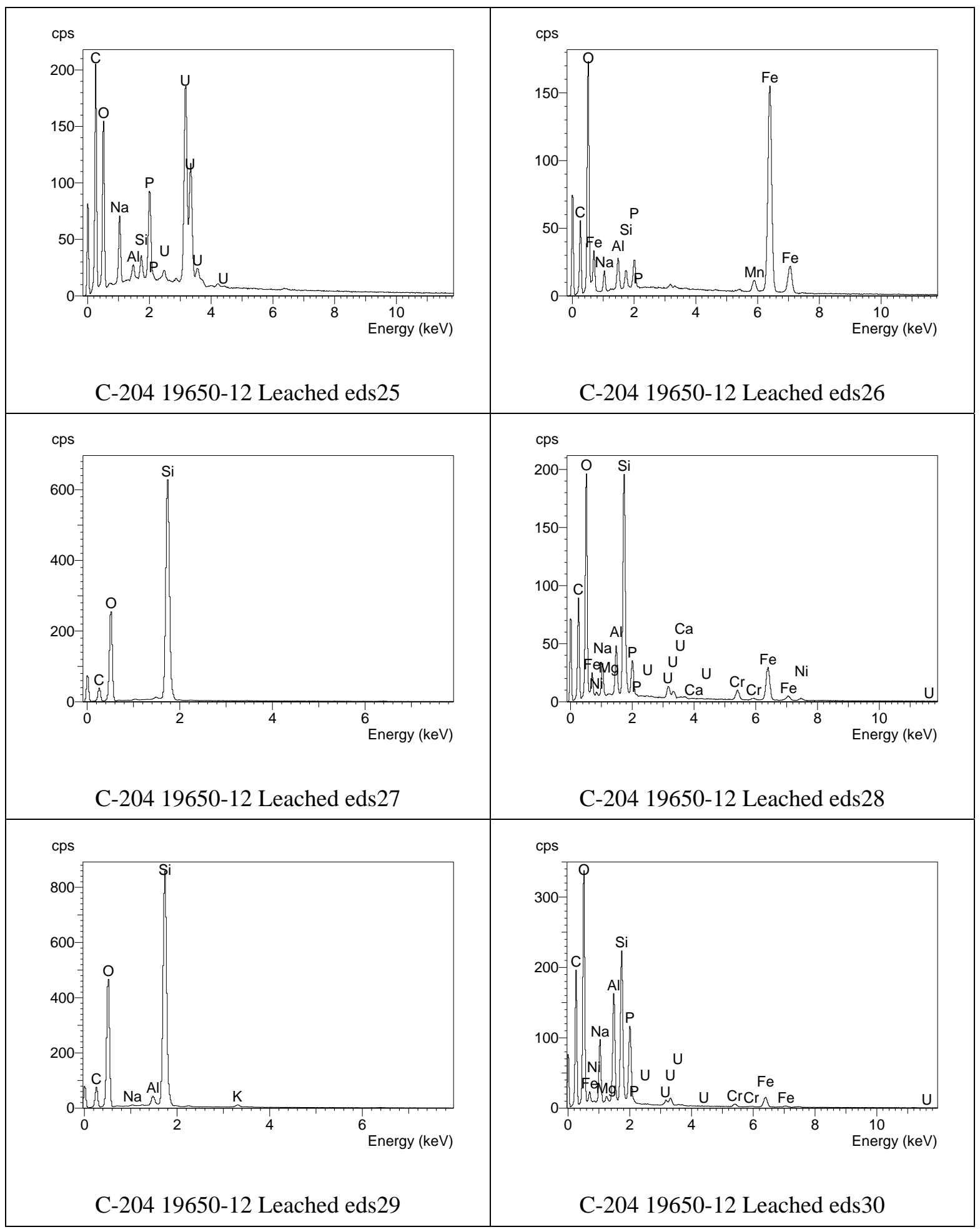

Figure C.56. EDS spectra for analyses eds25 through eds30 for particles in the second SEM mount (19650-12) of water leached (2 weeks) C-204 sludge 


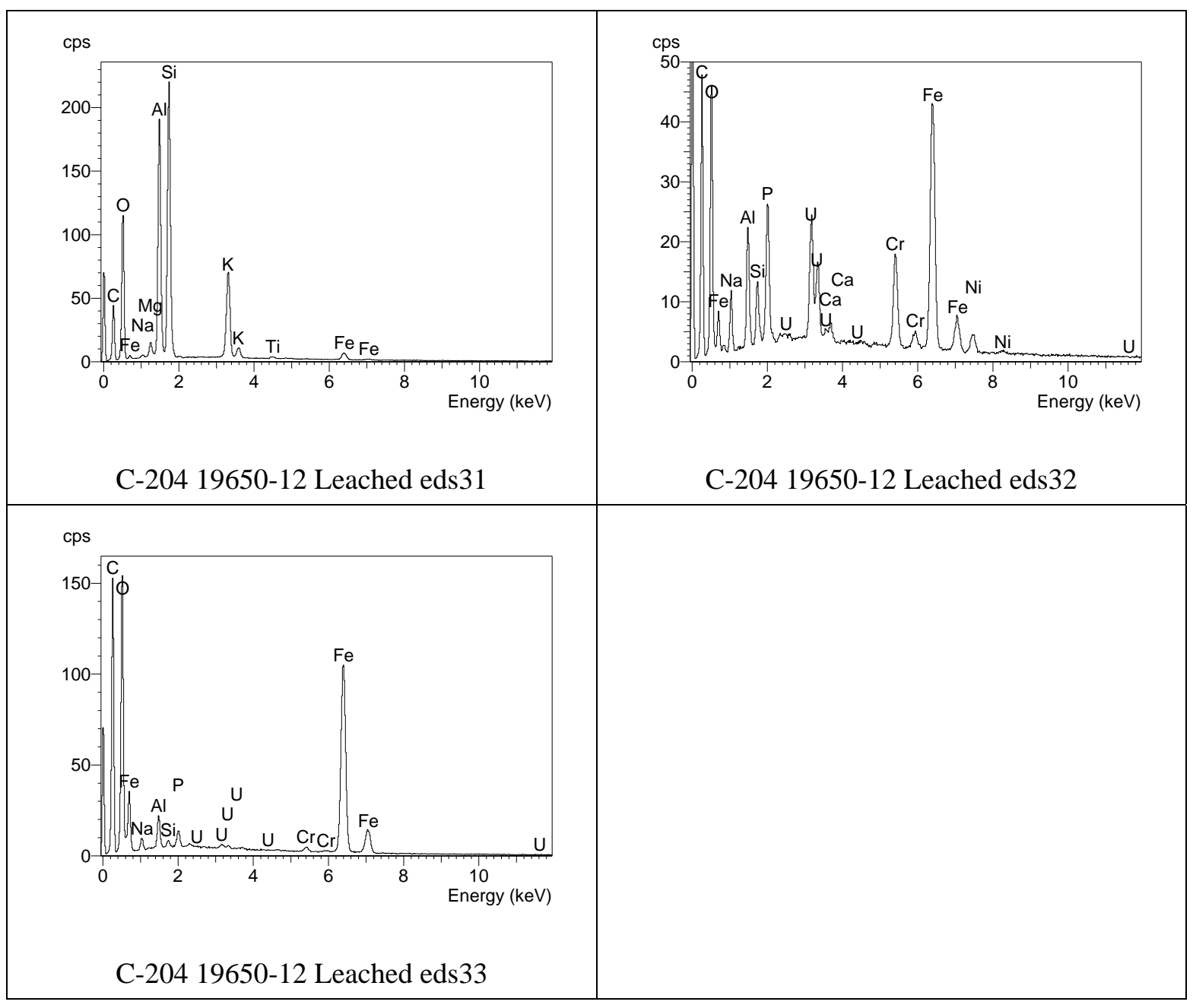

Figure C.57. EDS spectra for analyses eds31 through eds33 for particles in the second SEM mount (19650-12) of water leached (2 weeks) C-204 sludge 


\section{C.3 Water-Leached (two months) C-204 Sludge}

Only one mount of water-leached (two months) C-204 (jar 19650) bulk residual tank waste was analyzed by SEM/EDS. The SEM micrographs for this sample of C-204 sludge are shown in Figures C.58 through C.67. The EDS spectra for this sample are given in Figures C.68 and C.69. 


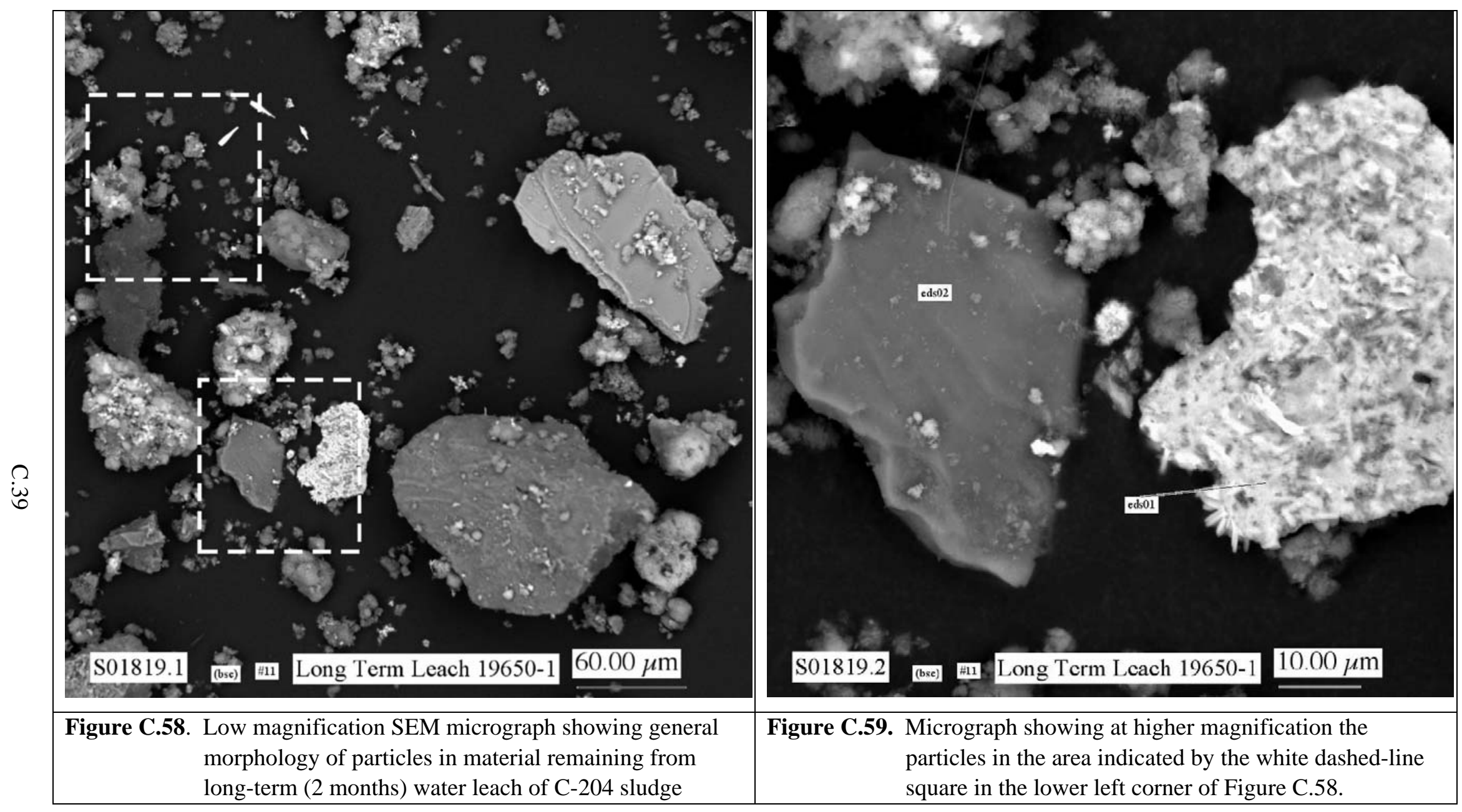




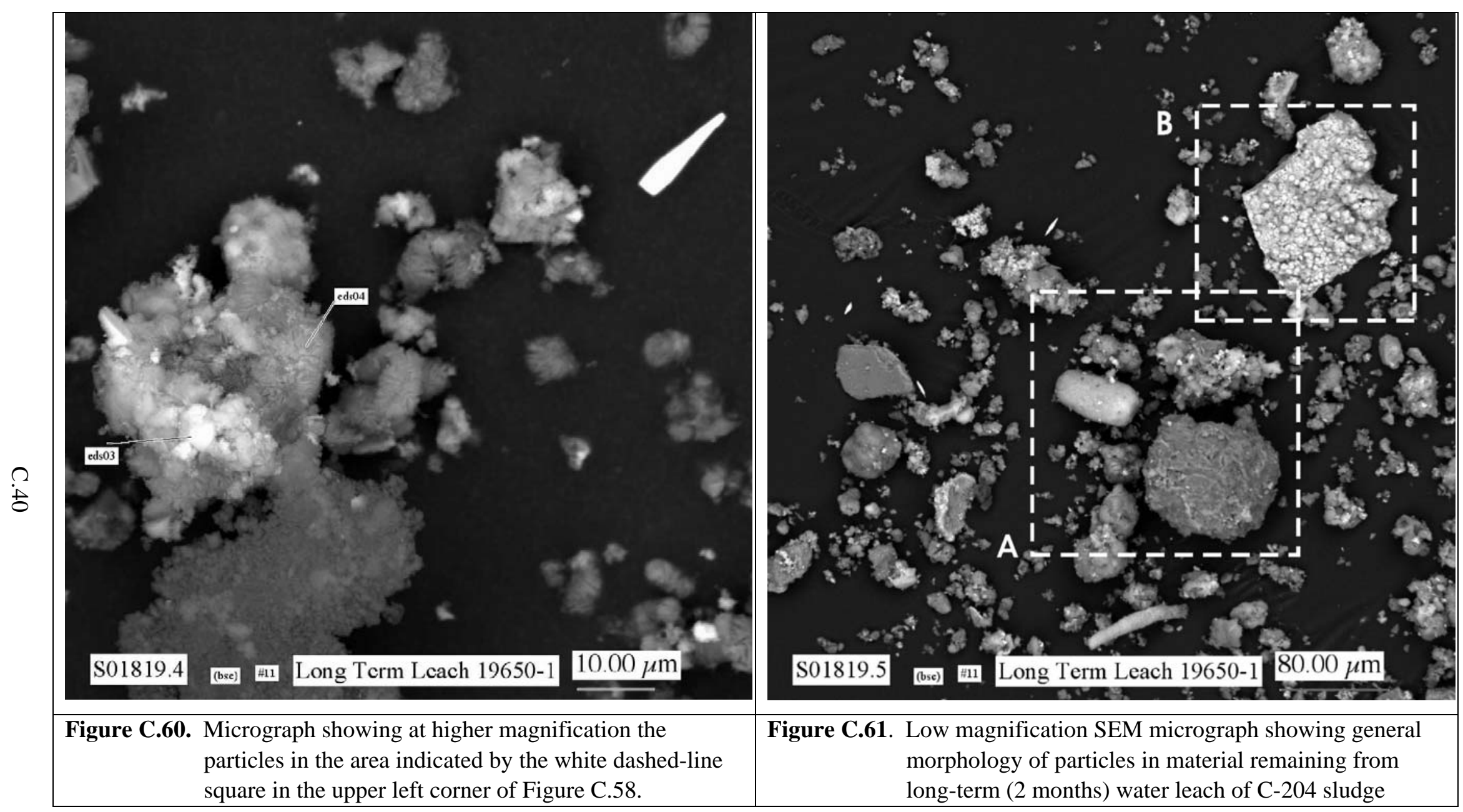




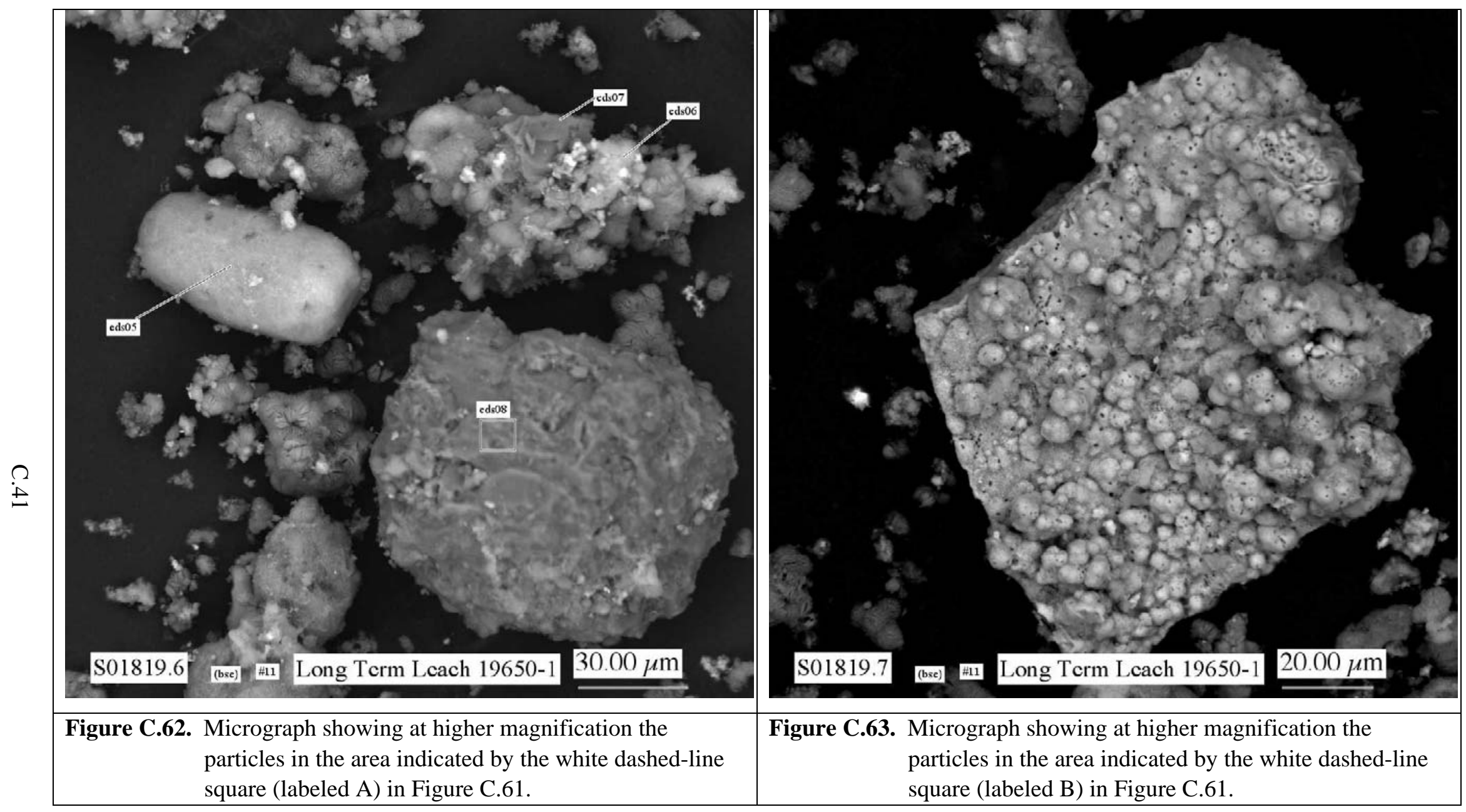




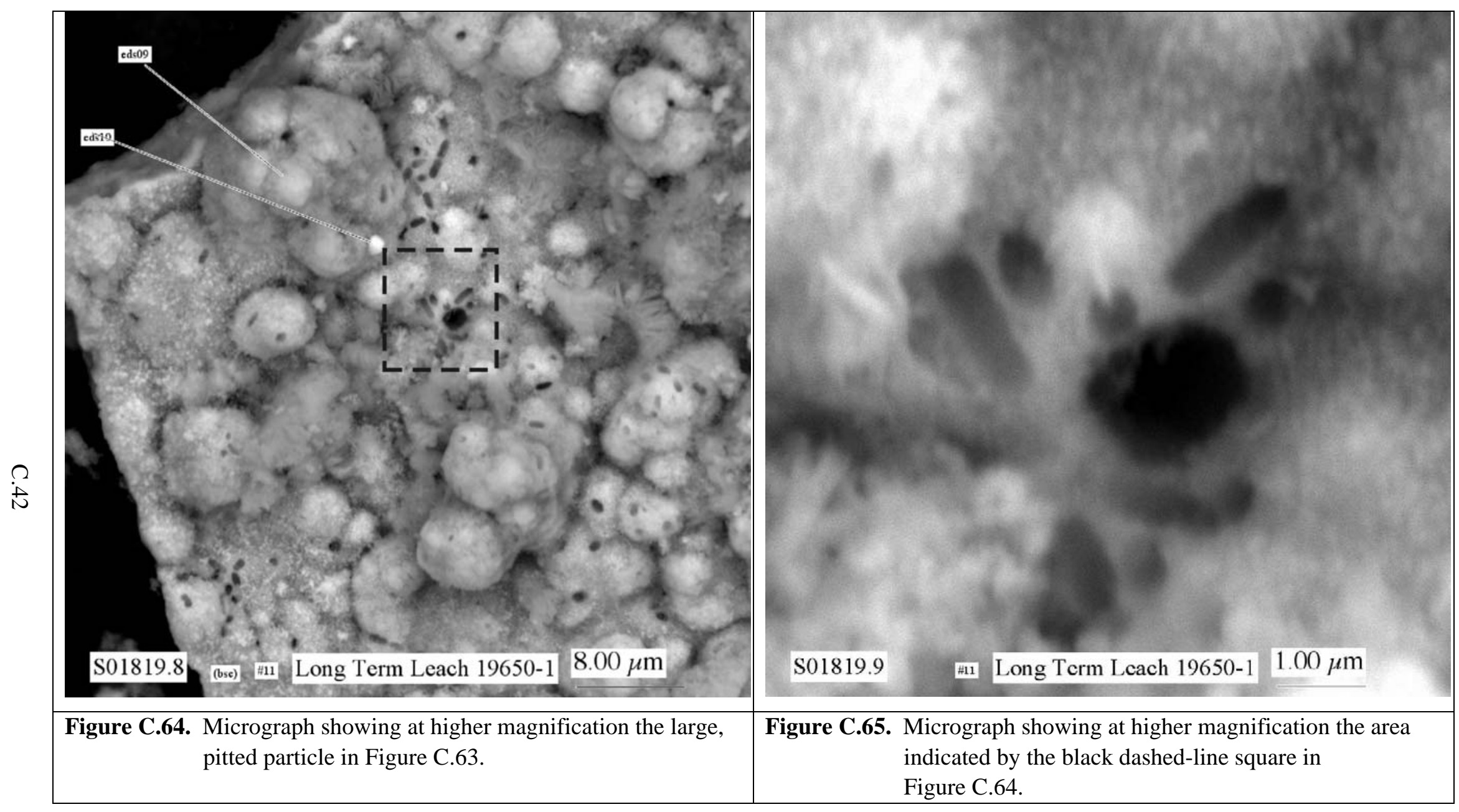




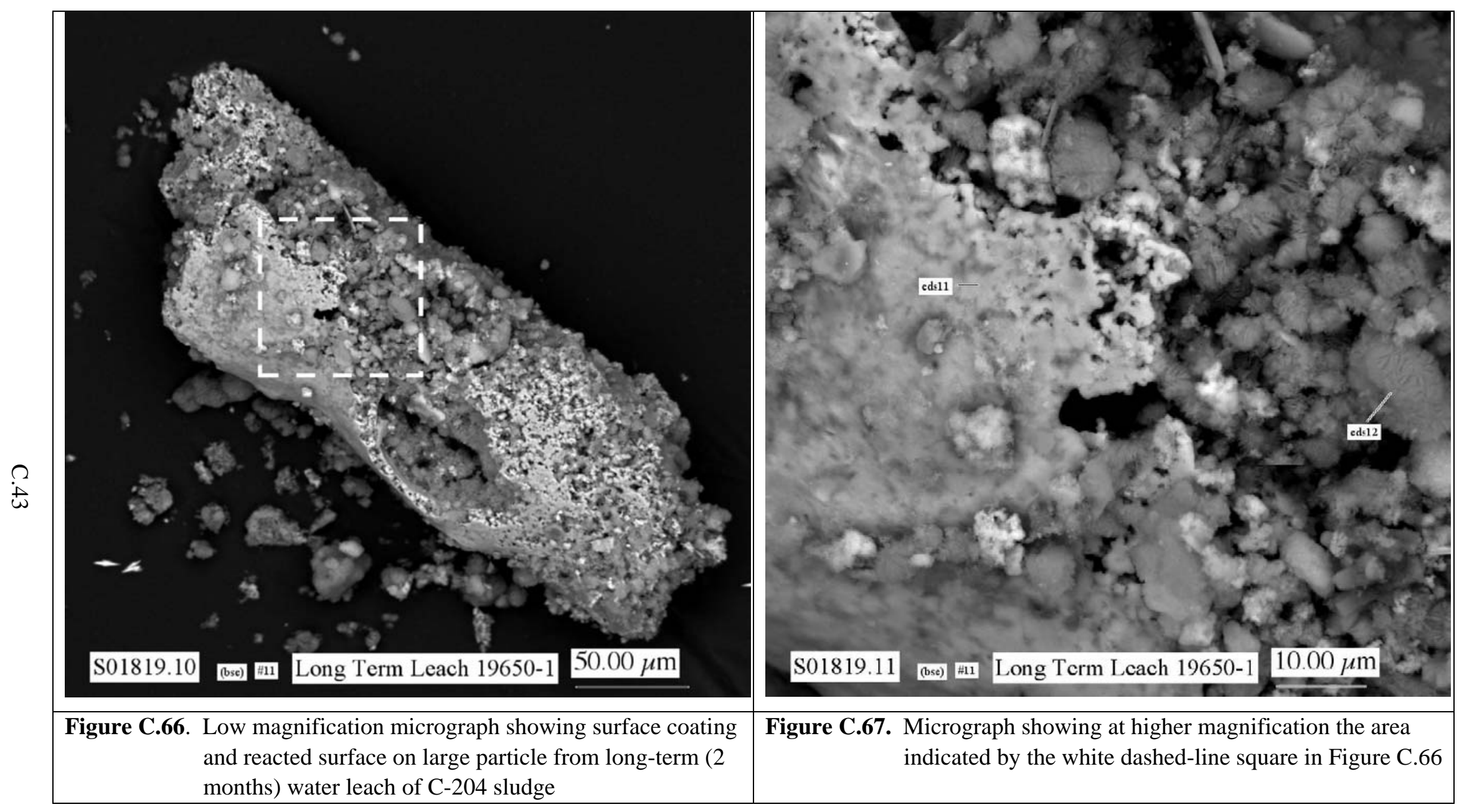




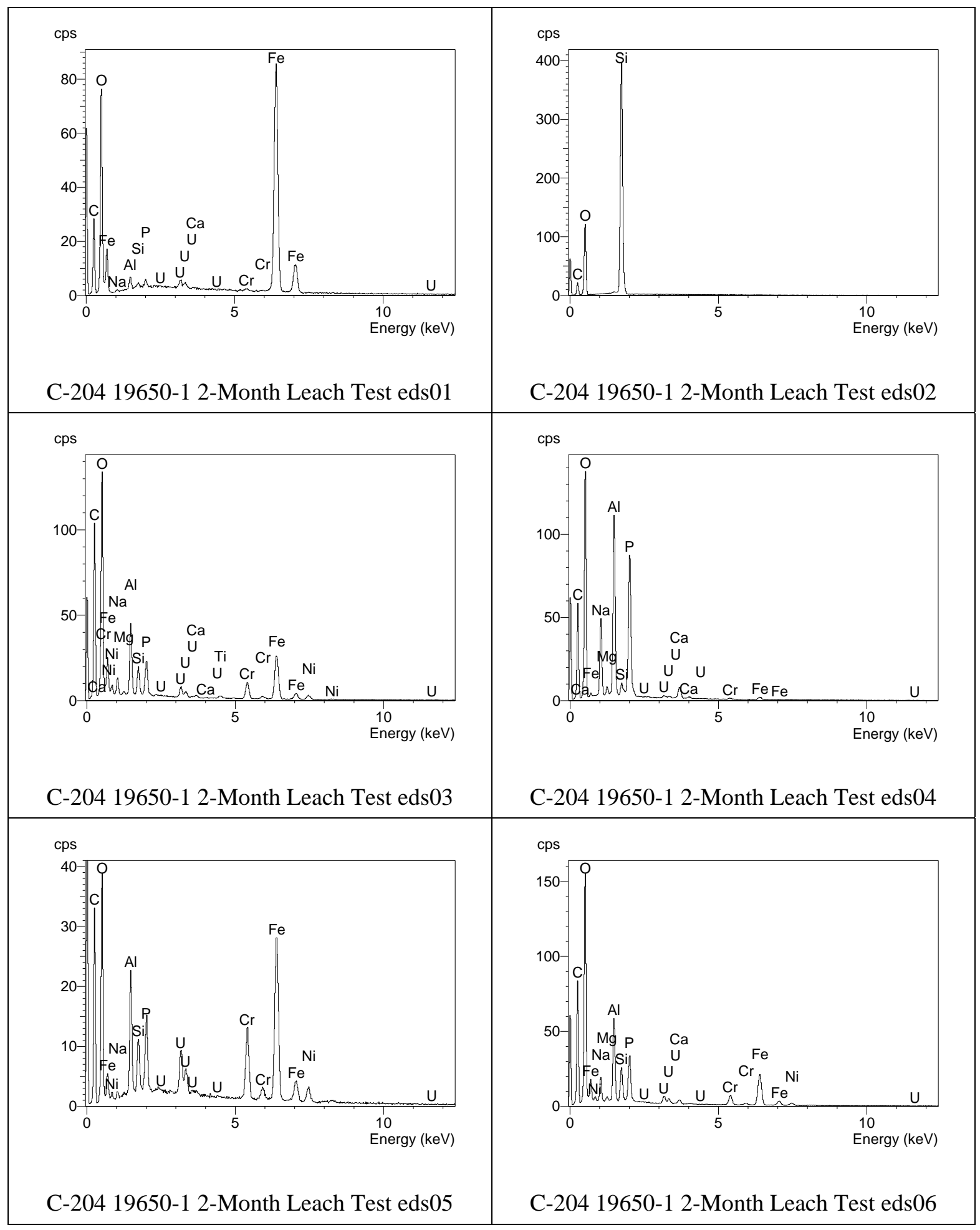

Figure C.68. EDS spectra for analyses eds01 through eds06 for particles in residual solids remaining after the long-term (2 months) water leach of C-204 sludge 


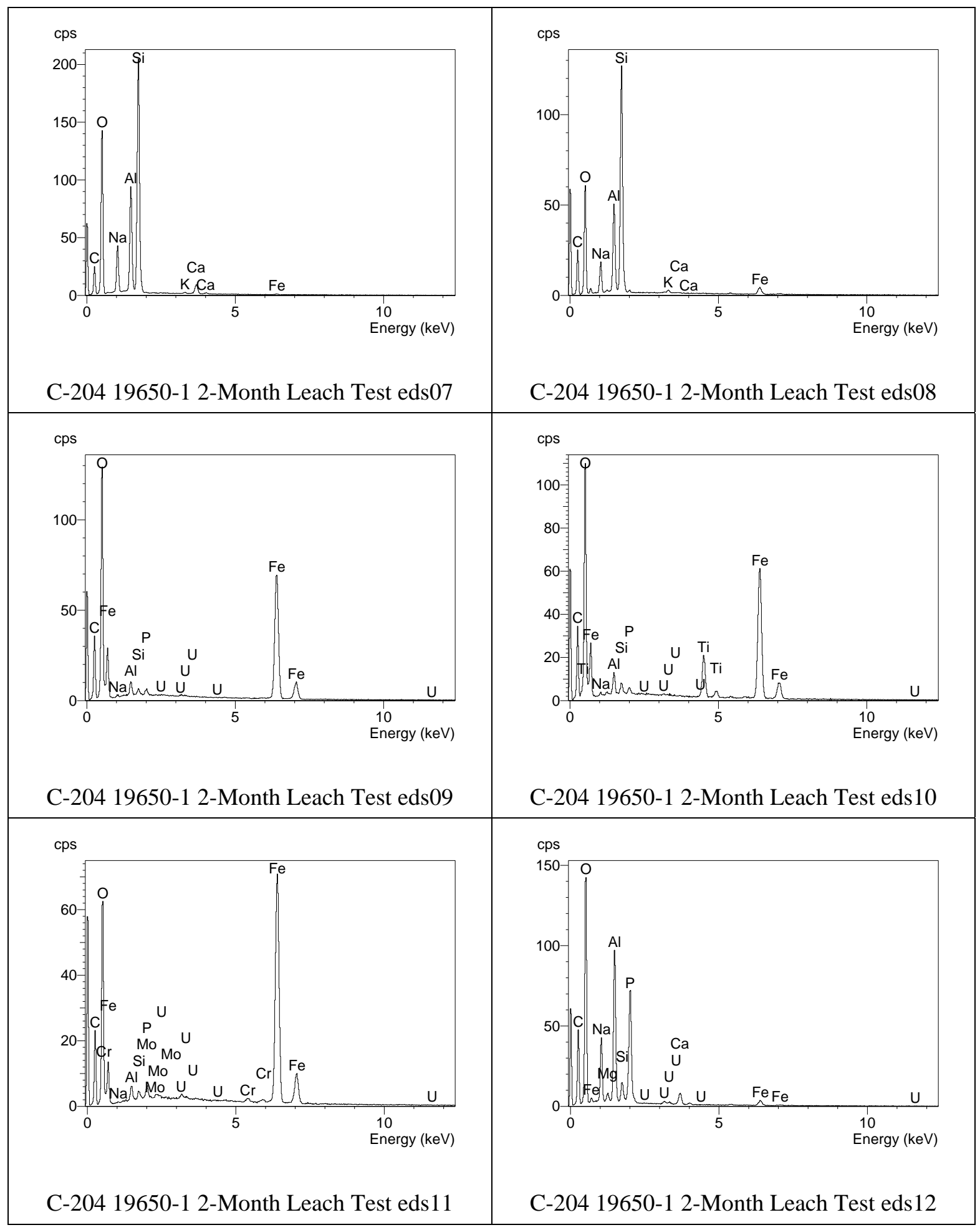

Figure C.69. EDS spectra for analyses eds07 through eds12 for particles in residual solids remaining after the long-term (2 months) water leach of C-204 sludge 


\section{C.4 Residual Solid from Selective Extraction (water contact) of C-204 Sludge}

Only one mount of residual solid from the selective extraction (water contact) of C-204 (jar 19650) residual tank waste was analyzed by SEM/EDS. The SEM micrographs for this sample of C-204 sludge are shown in Figures C.70 through C.81. The EDS spectra for this sample are given in Figures C.82 through C.84. 


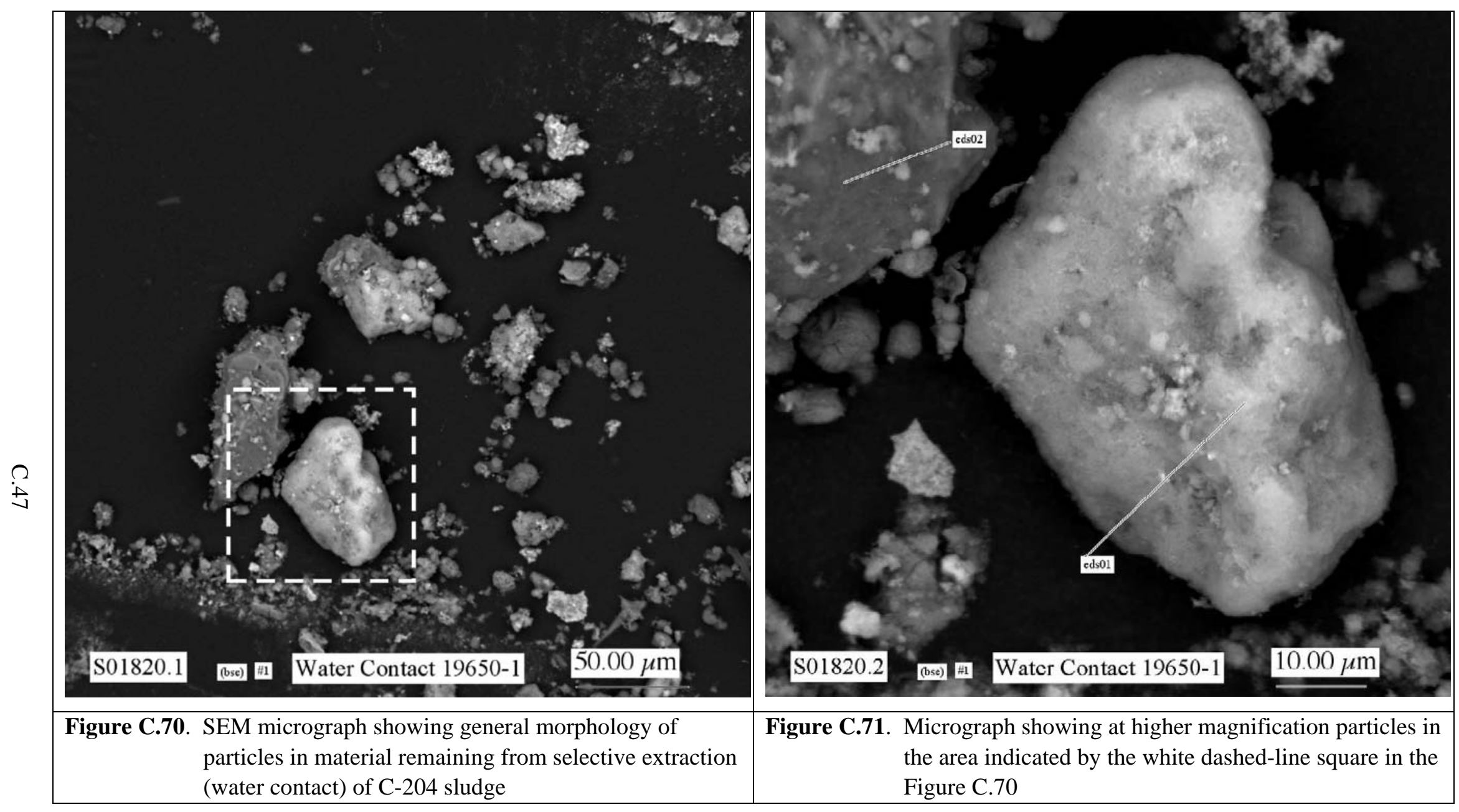




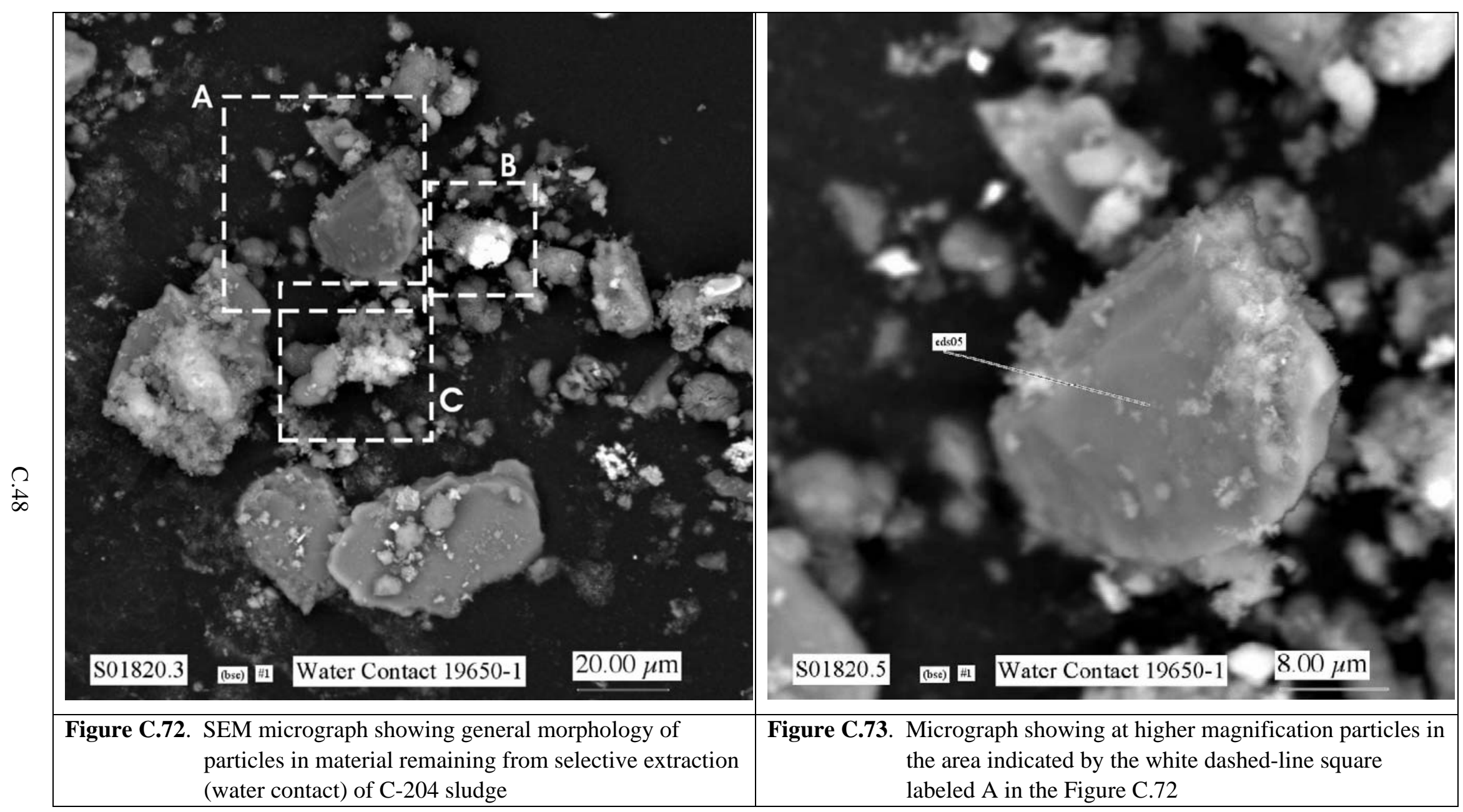




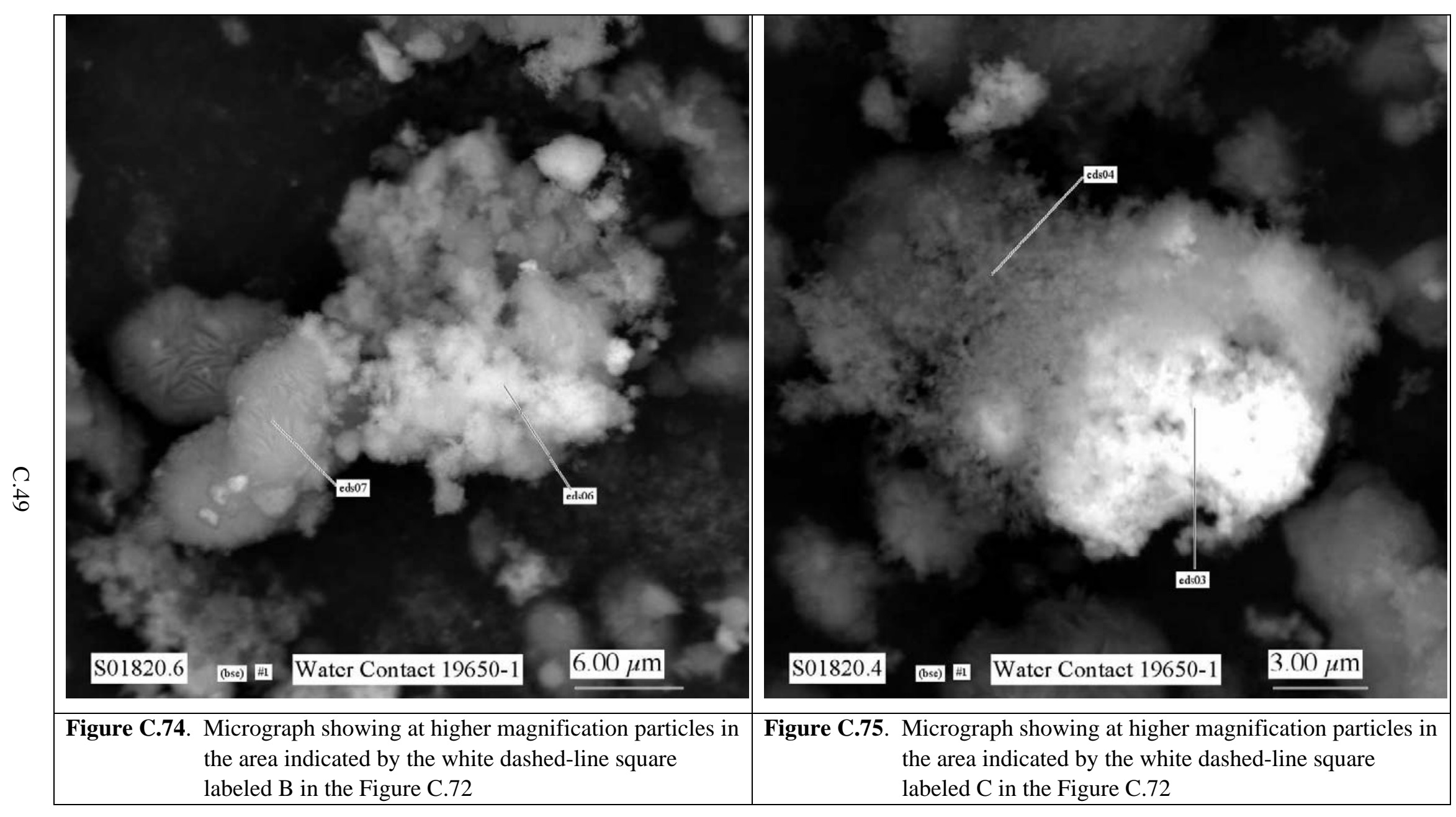




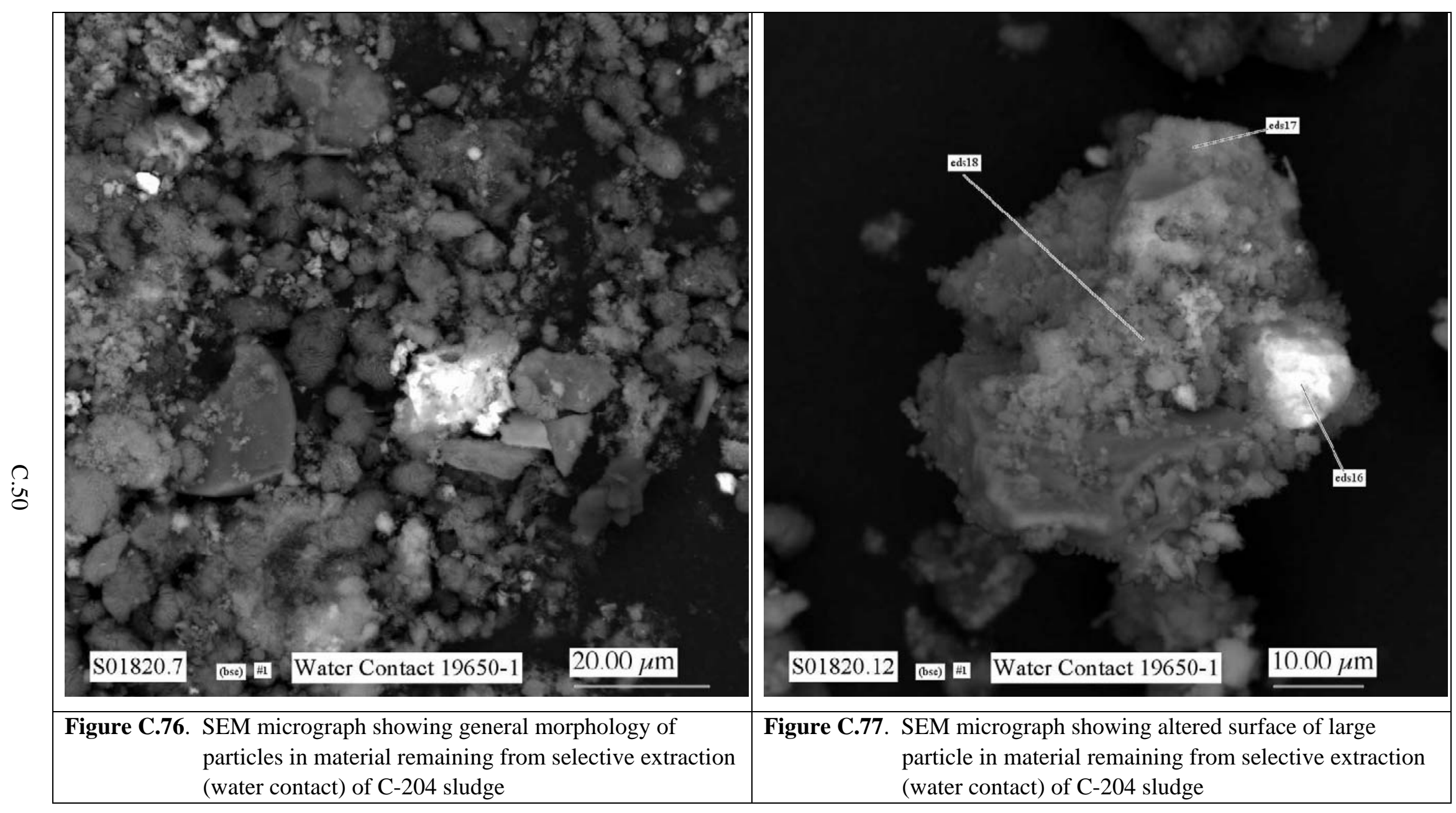




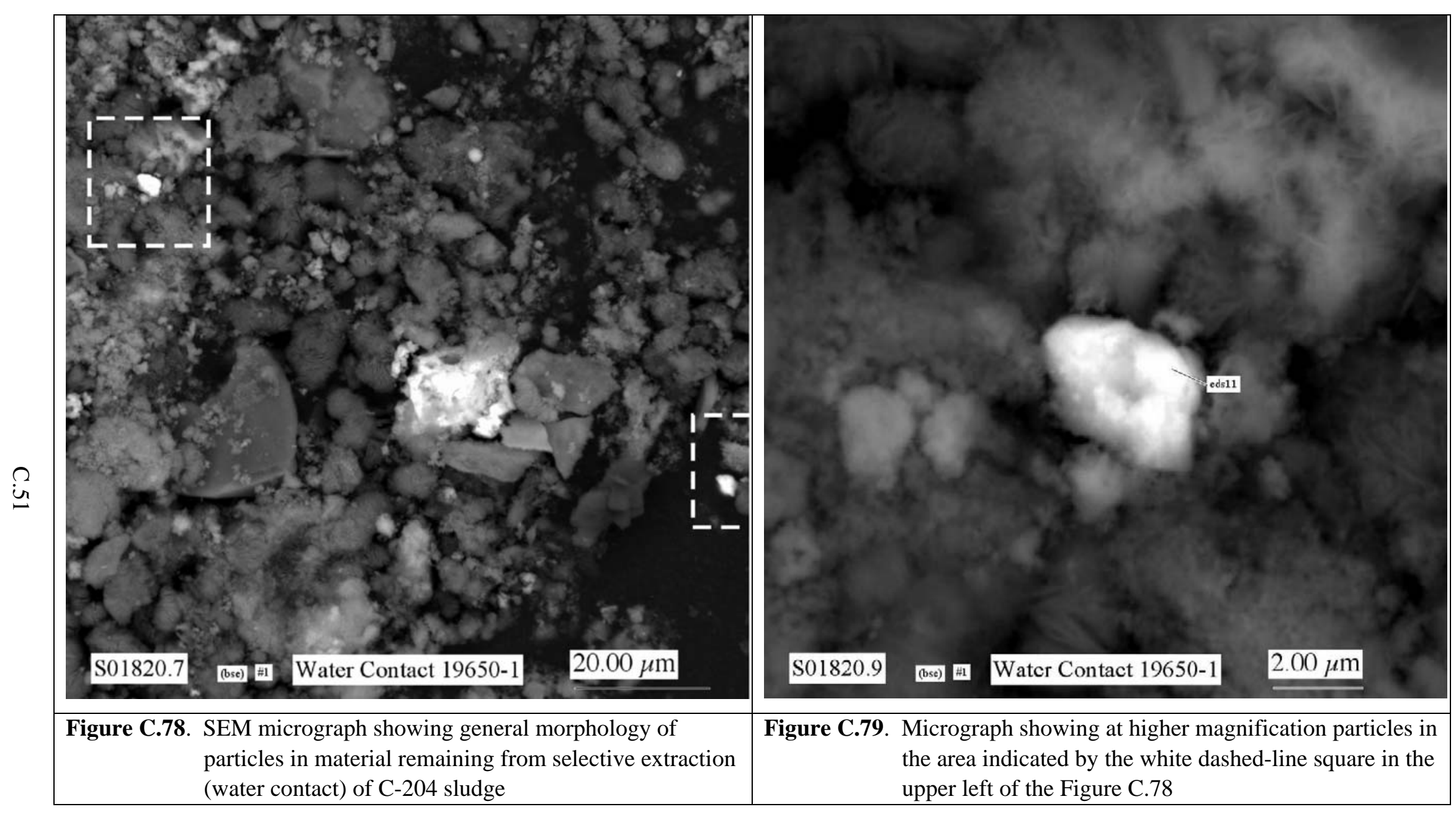




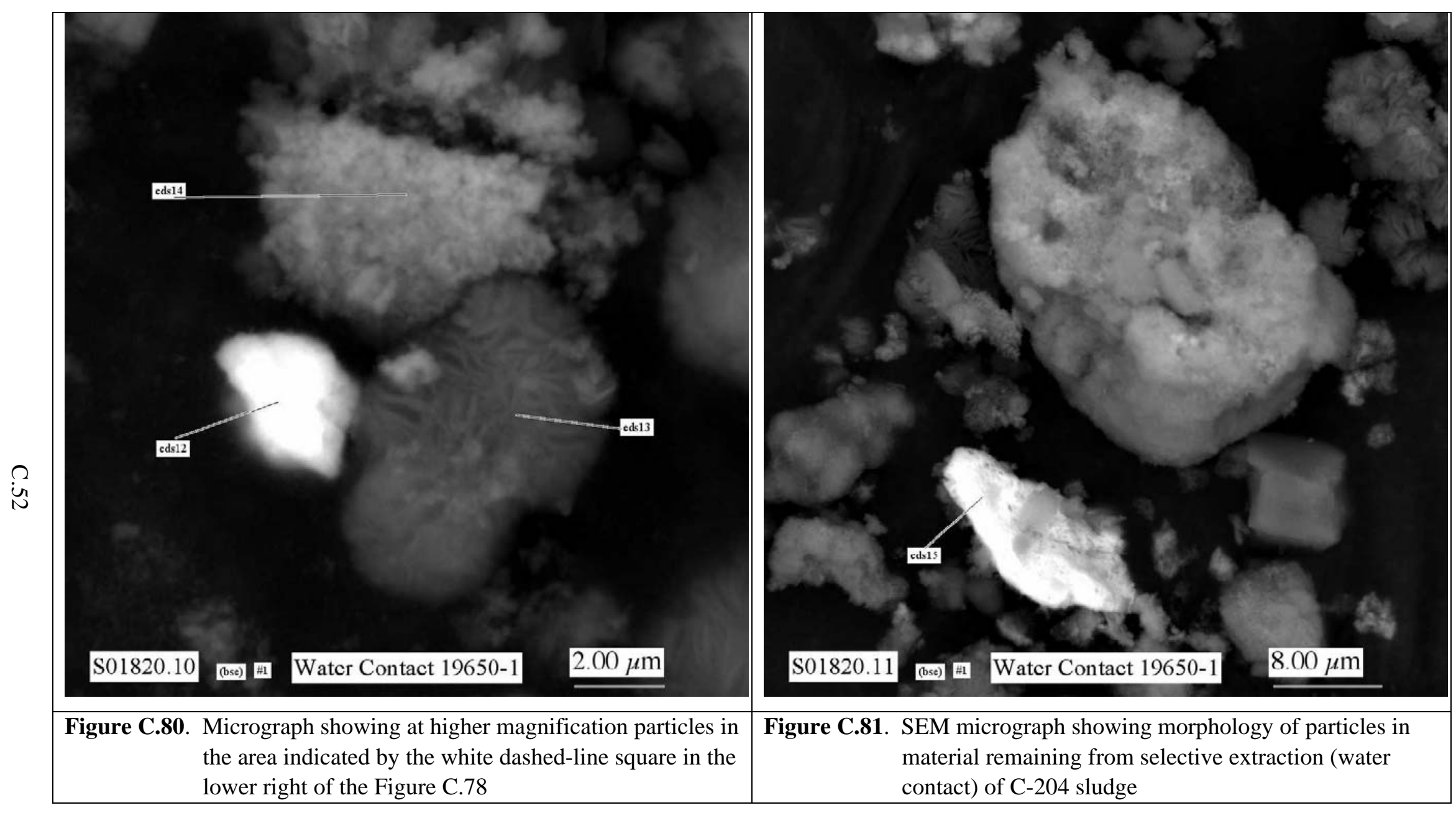




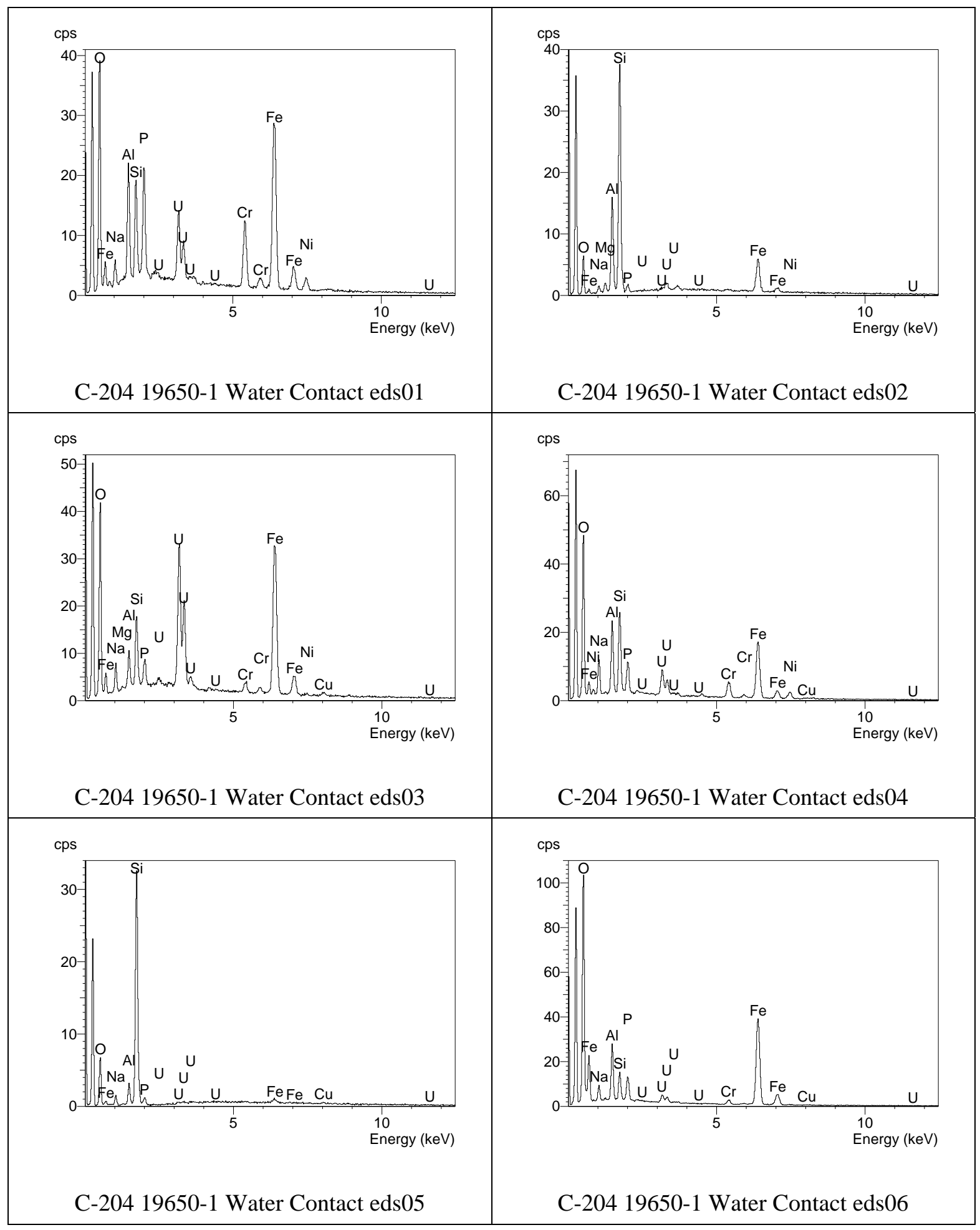

Figure C.82. EDS spectra for analyses eds01 through eds06 for particles in residual solids remaining after the selective extraction (water contact) of C-204 sludge 


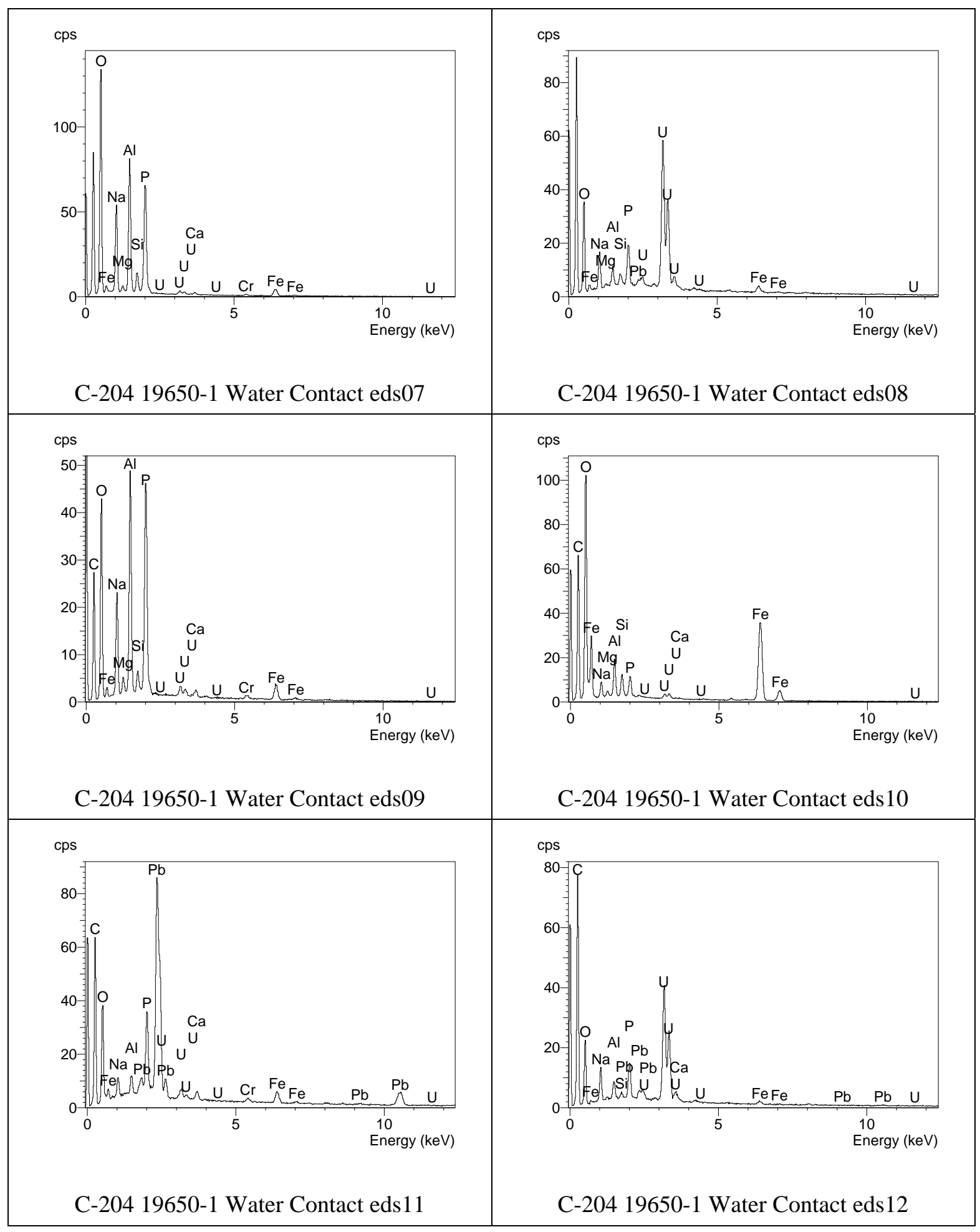

Figure C.83. EDS spectra for analyses eds07 through eds 12 for particles in residual solids remaining after the selective extraction (water contact) of C-204 sludge 


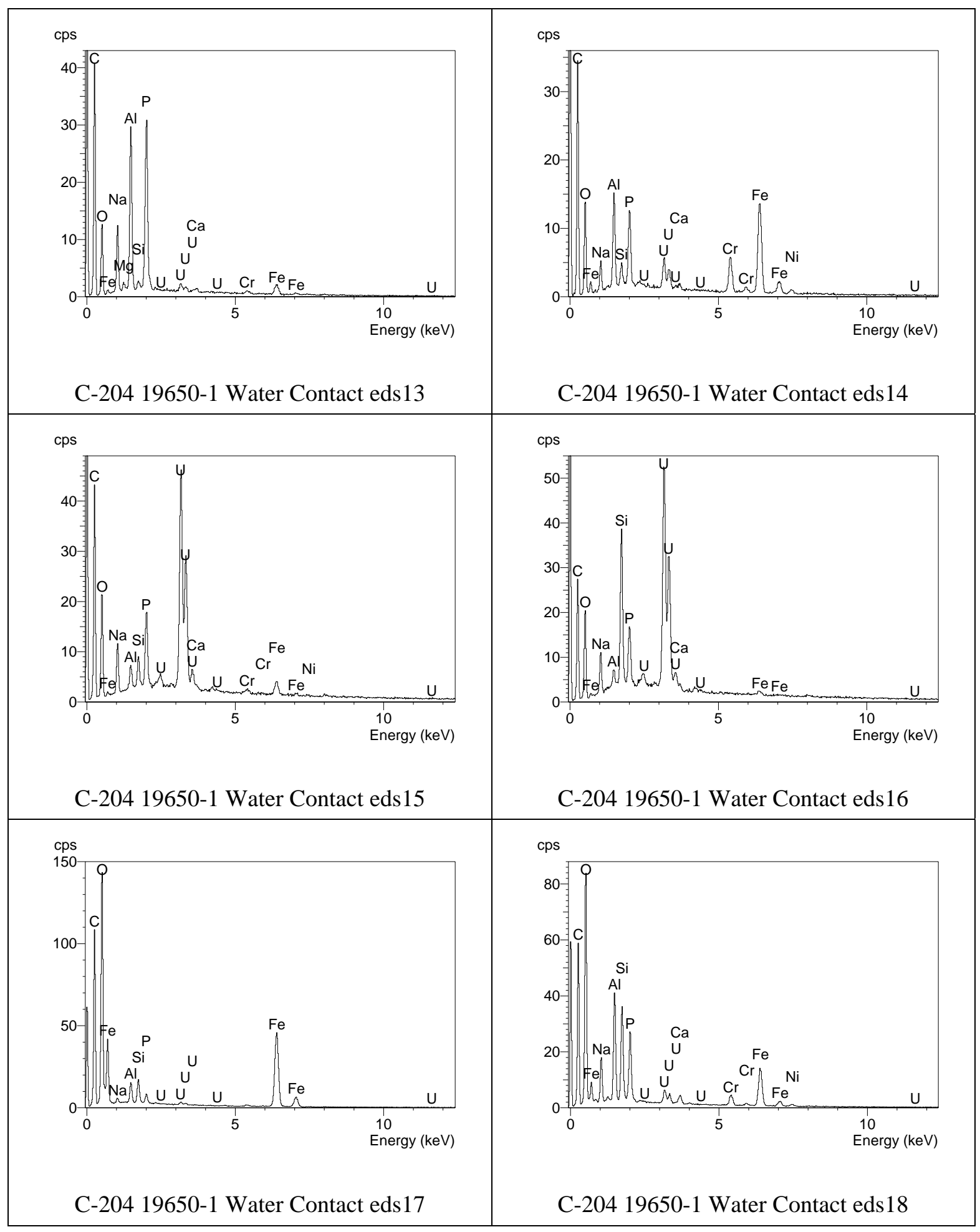

Figure C.84. EDS spectra for analyses eds13 through eds18 for particles in residual solids remaining after the selective extraction (water contact) of C-204 sludge 


\section{C.5 Residual Solid from Selective Extraction (acetate contact) of C-204 Sludge}

Only one mount of residual solid from the selective extraction (acetate contact) of C-204 (jar 19650) residual tank waste was analyzed by SEM/EDS. The SEM micrographs for this sample of C-204 sludge are shown in Figures C.85 through C.90. The EDS spectra for this sample are given in Figures C.91 through C.93. 


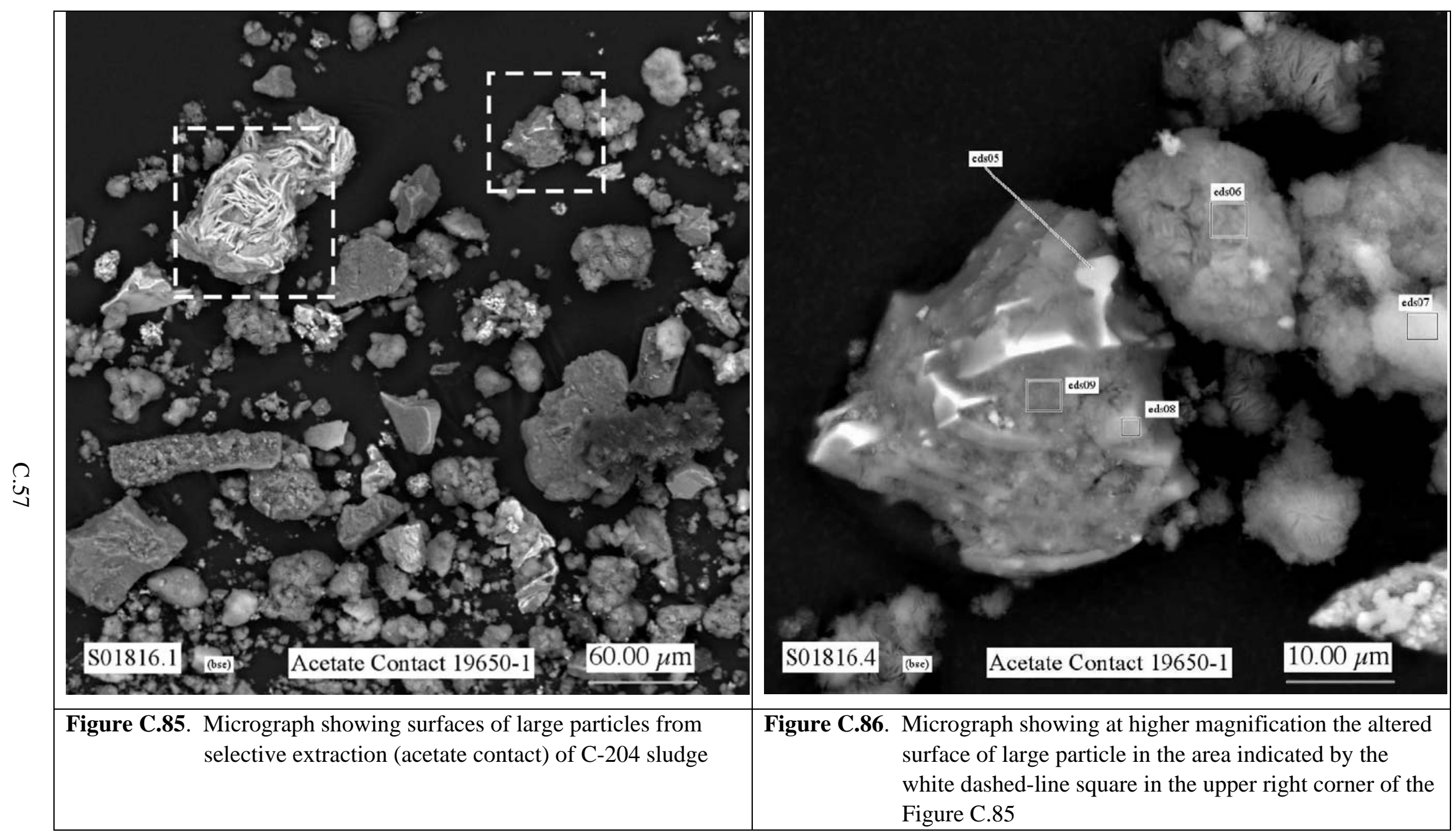




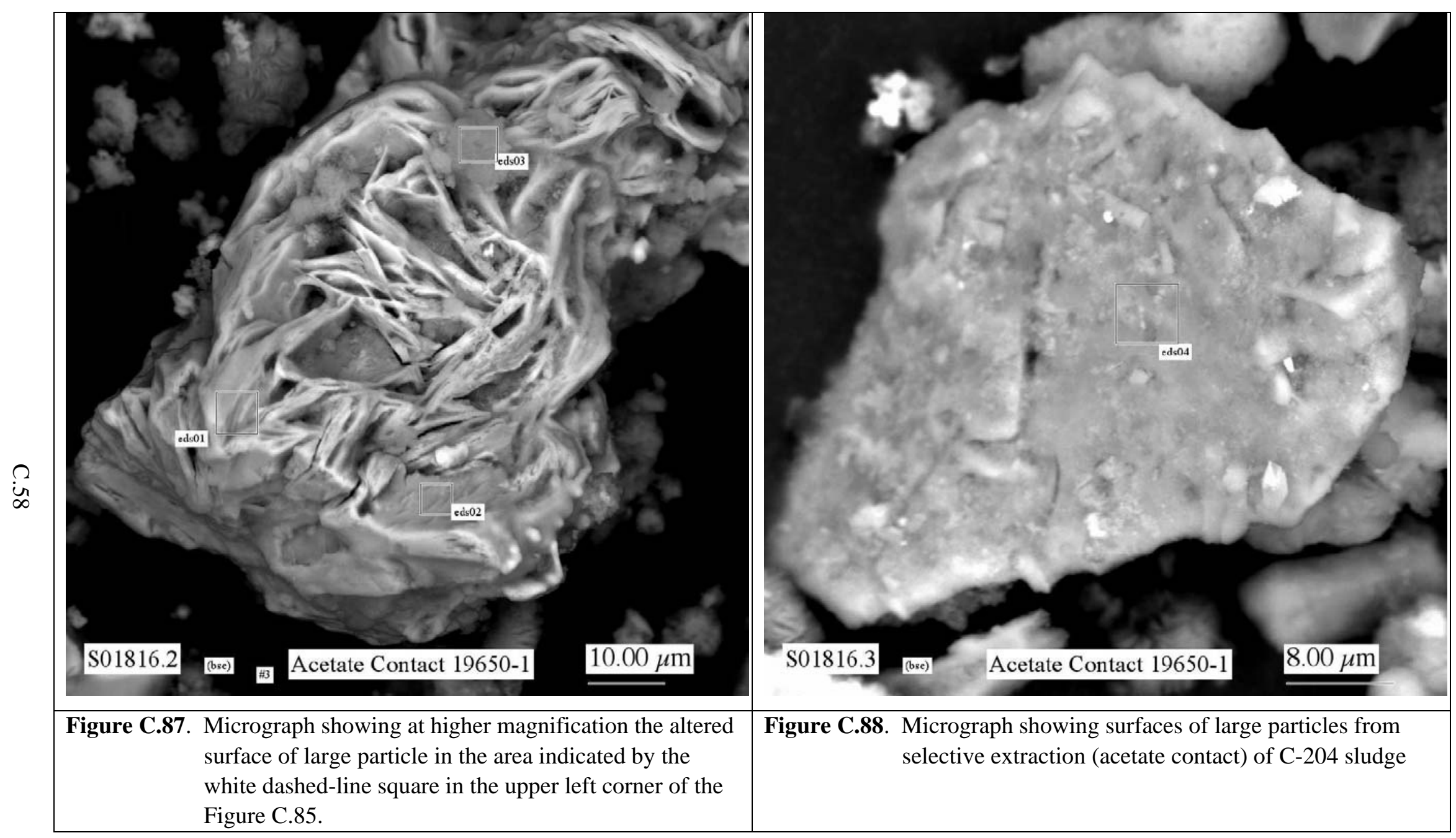




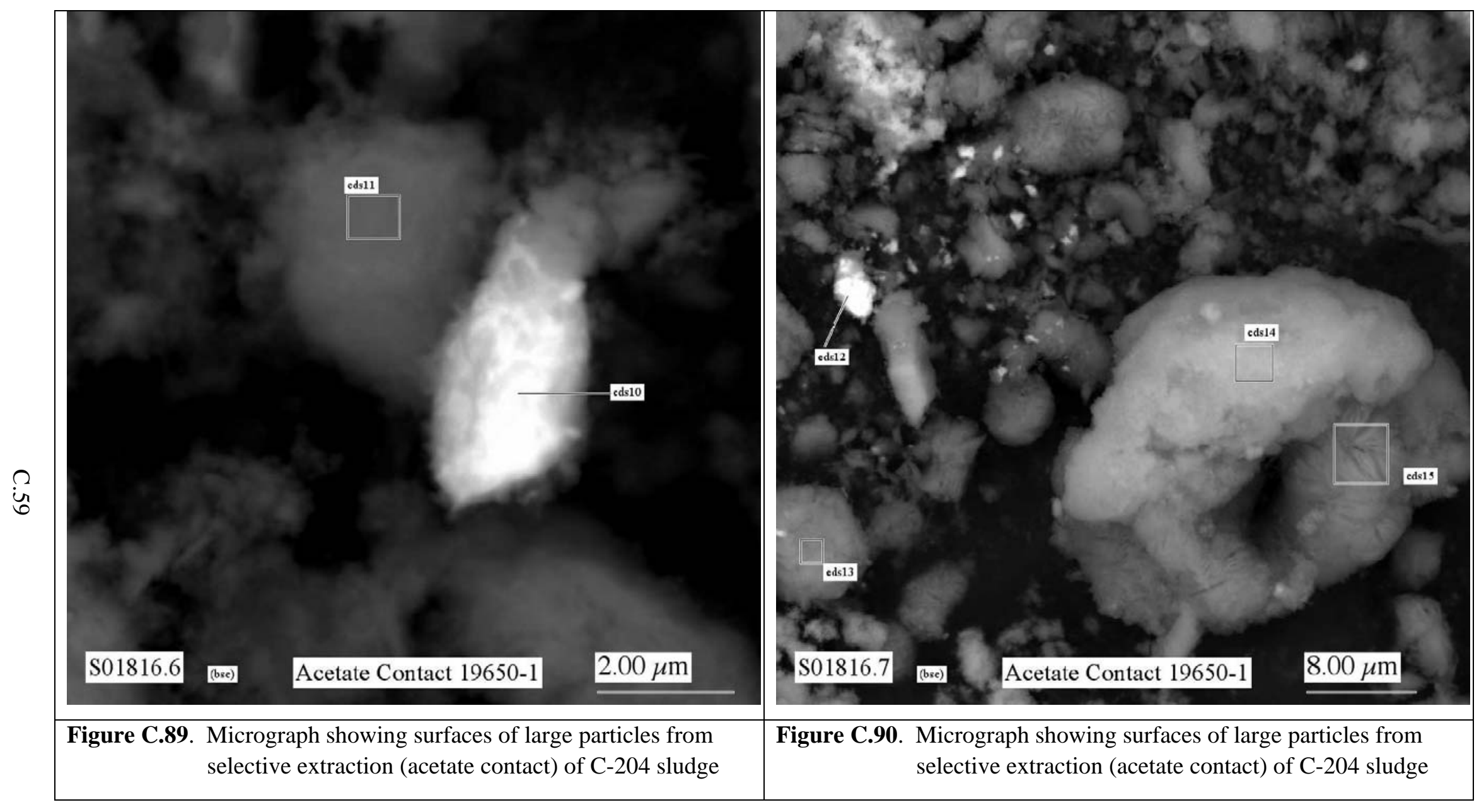




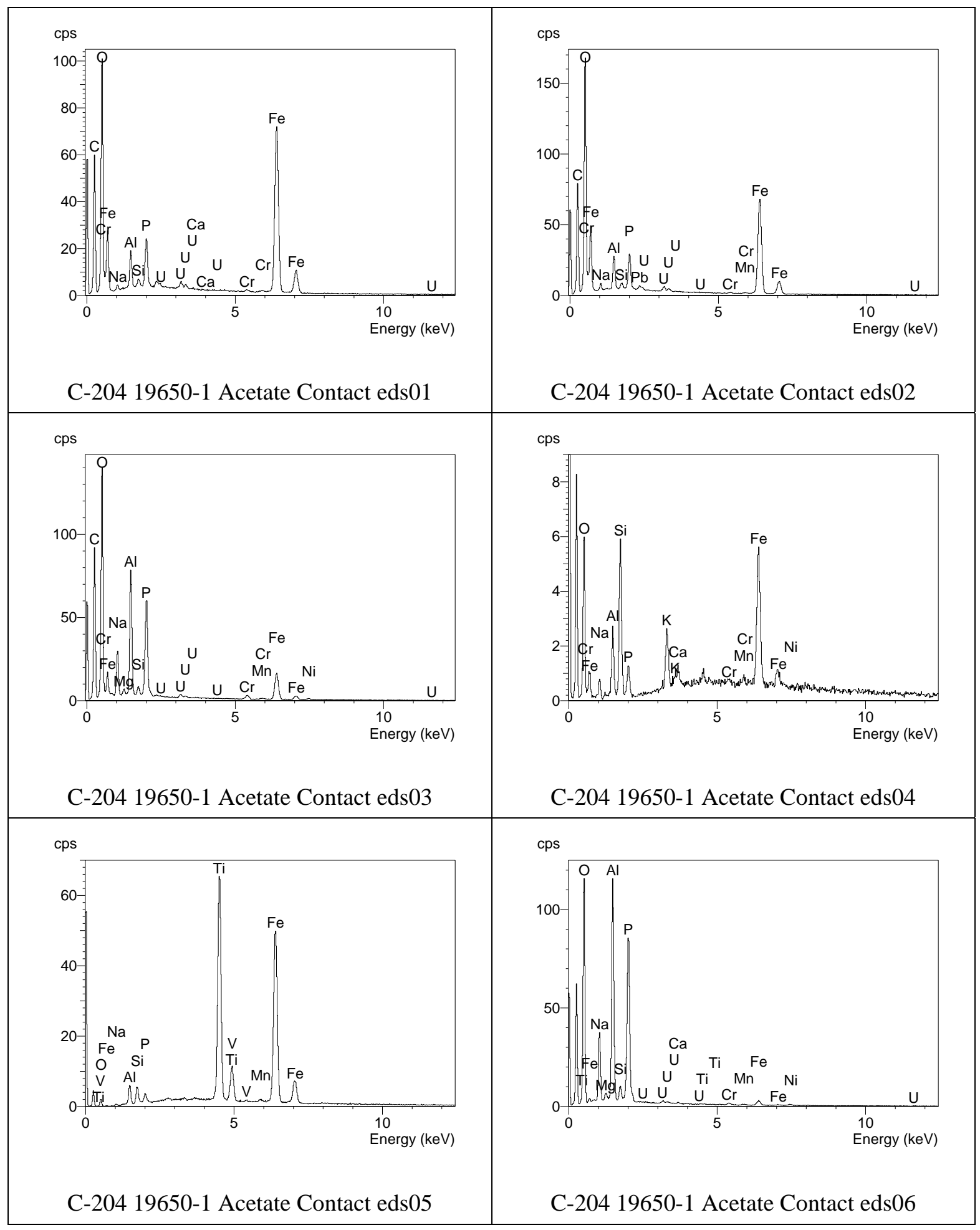

Figure C.91. EDS spectra for analyses eds01 through eds06 for particles in residual solids remaining after the selective extraction (acetate contact) of C-204 sludge 


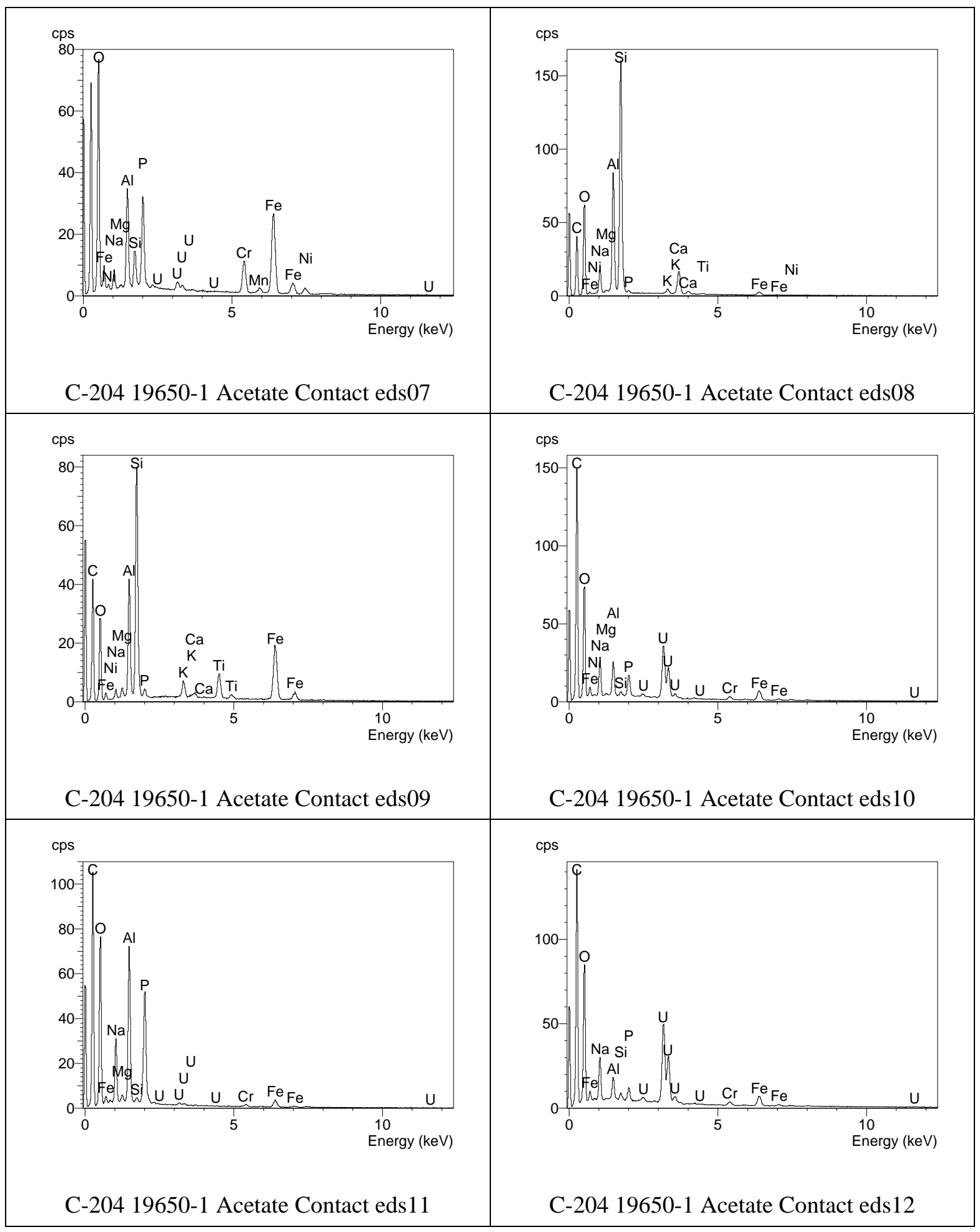

Figure C.92. EDS spectra for analyses eds07 through eds12 for particles in residual solids remaining after the selective extraction (acetate contact) of C-204 sludge 


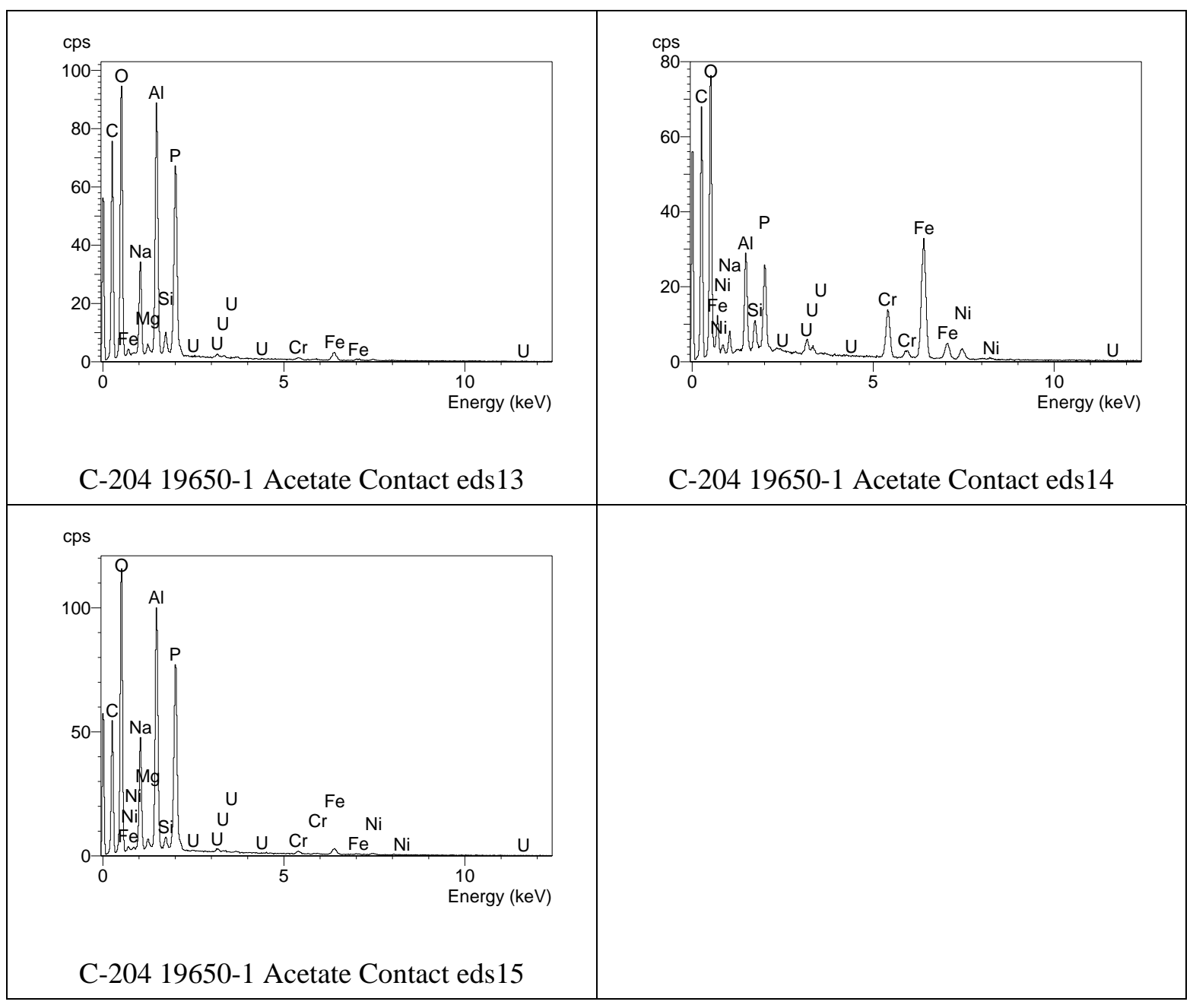

Figure C.93. EDS spectra for analyses eds13 through eds15 for particles in residual solids remaining after the selective extraction (acetate contact) of C-204 sludge 


\section{C.6 Residual Solid from Selective Extraction (ethanol contact) of C-204 Sludge}

Only one mount of residual solid from the selective extraction (ethanol contact) of C-204 (jar 19650) residual tank waste was analyzed by SEM/EDS. The SEM micrographs for this sample of C-204 sludge are shown in Figures C.94 through C.101. The EDS spectra for this sample are given in Figures C.102 through C.104. 


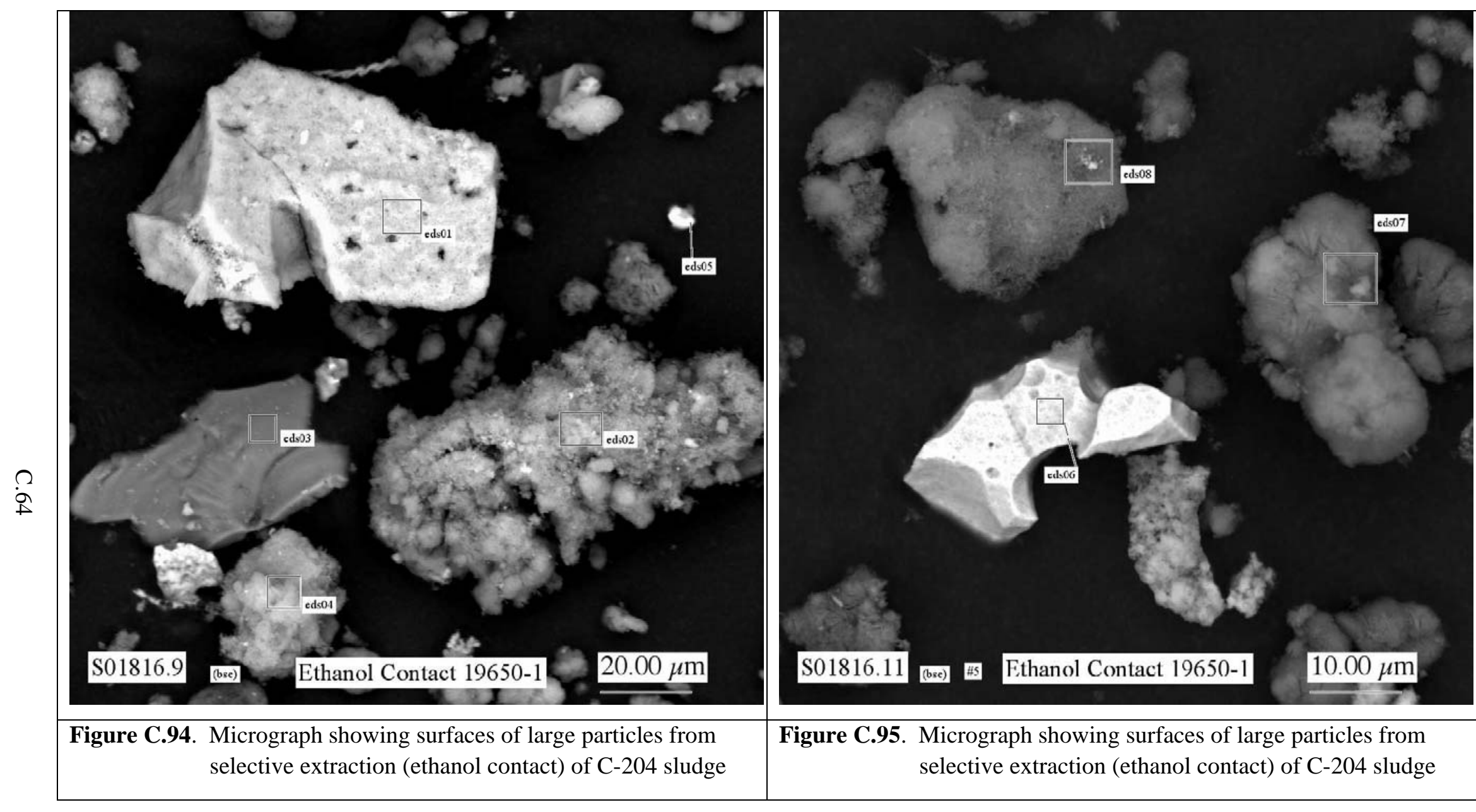




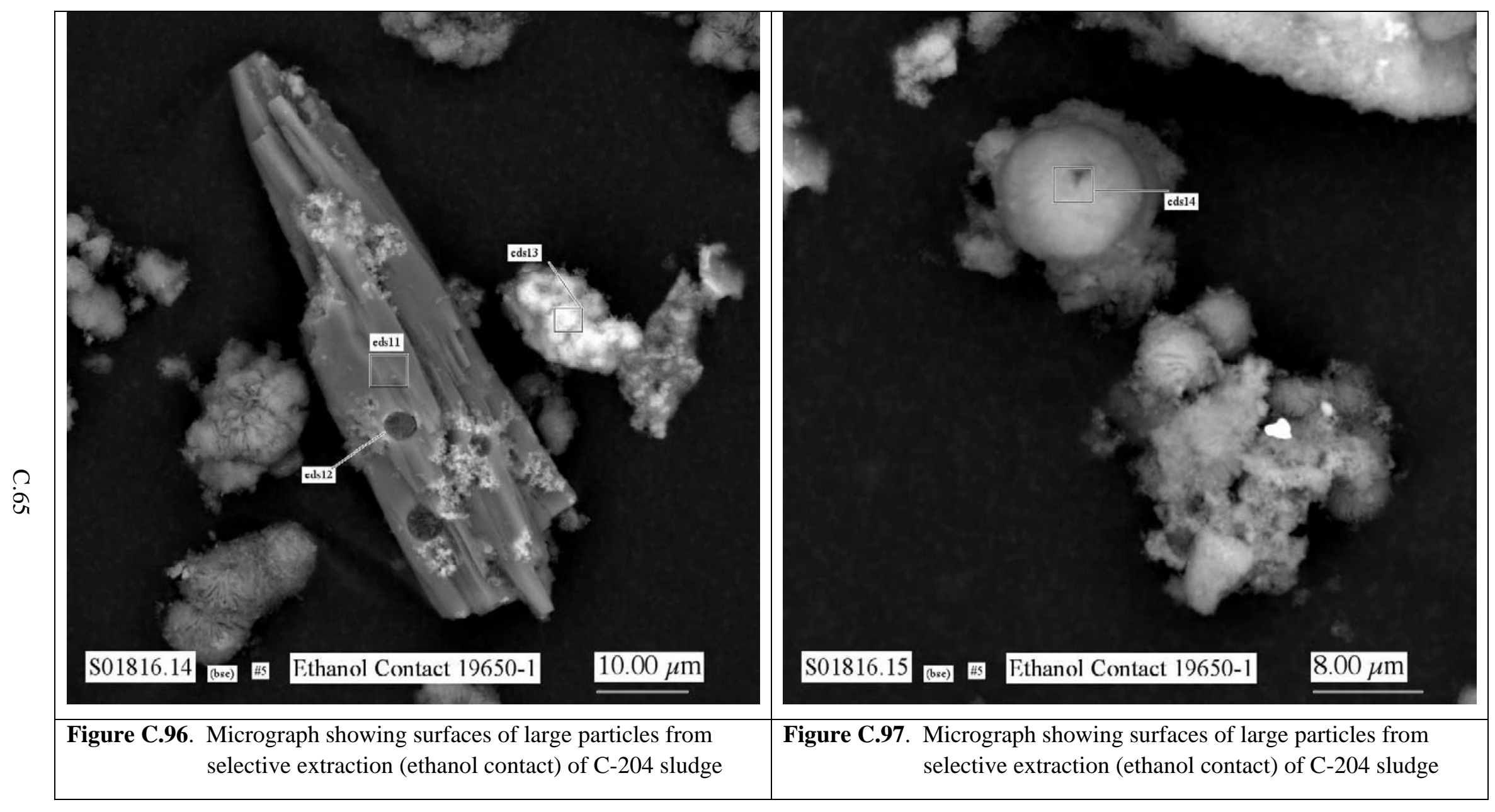




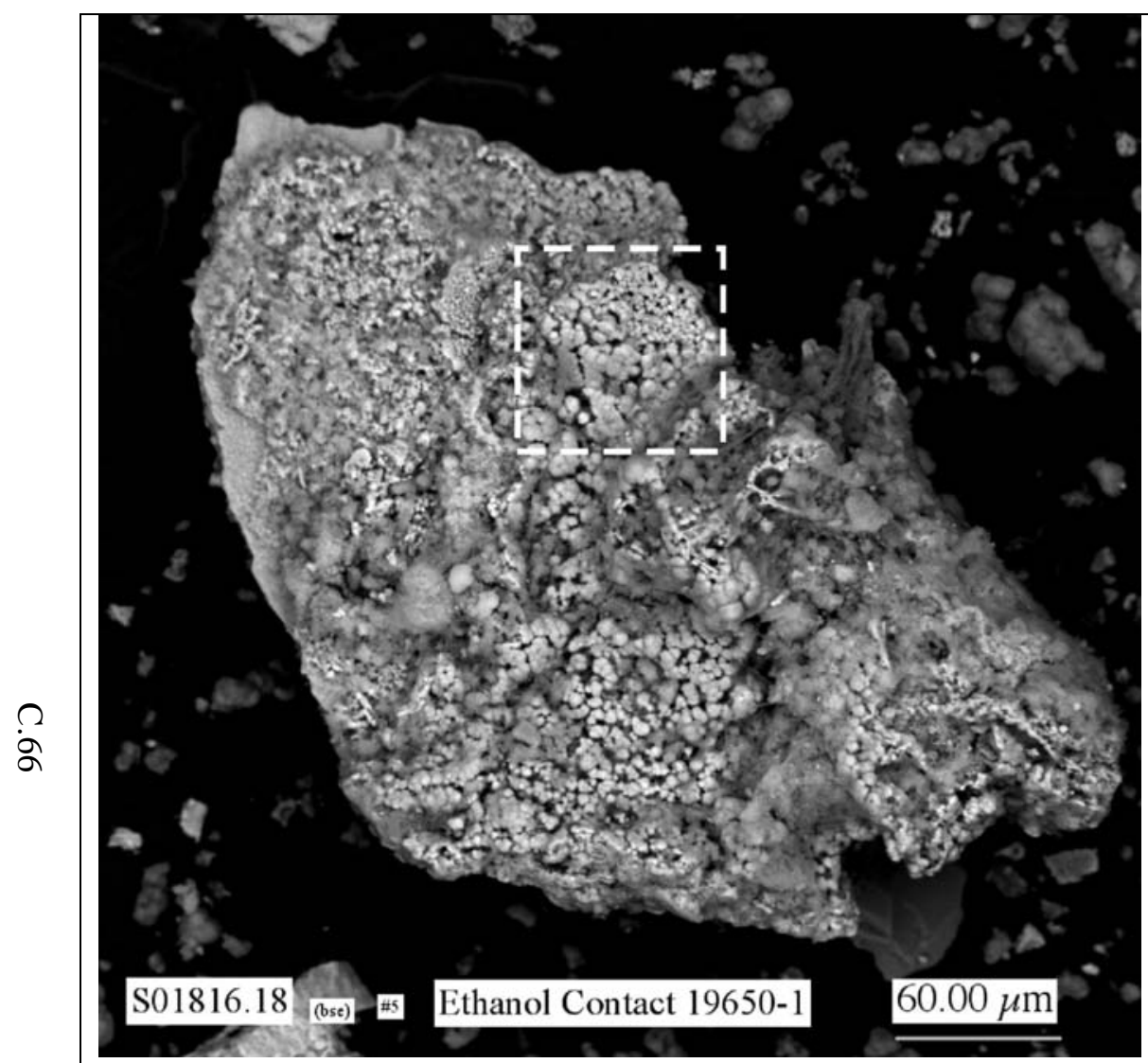

Figure C.98. Micrograph showing reacted surface of large particle from selective extraction (ethanol contact) of C-204 sludge

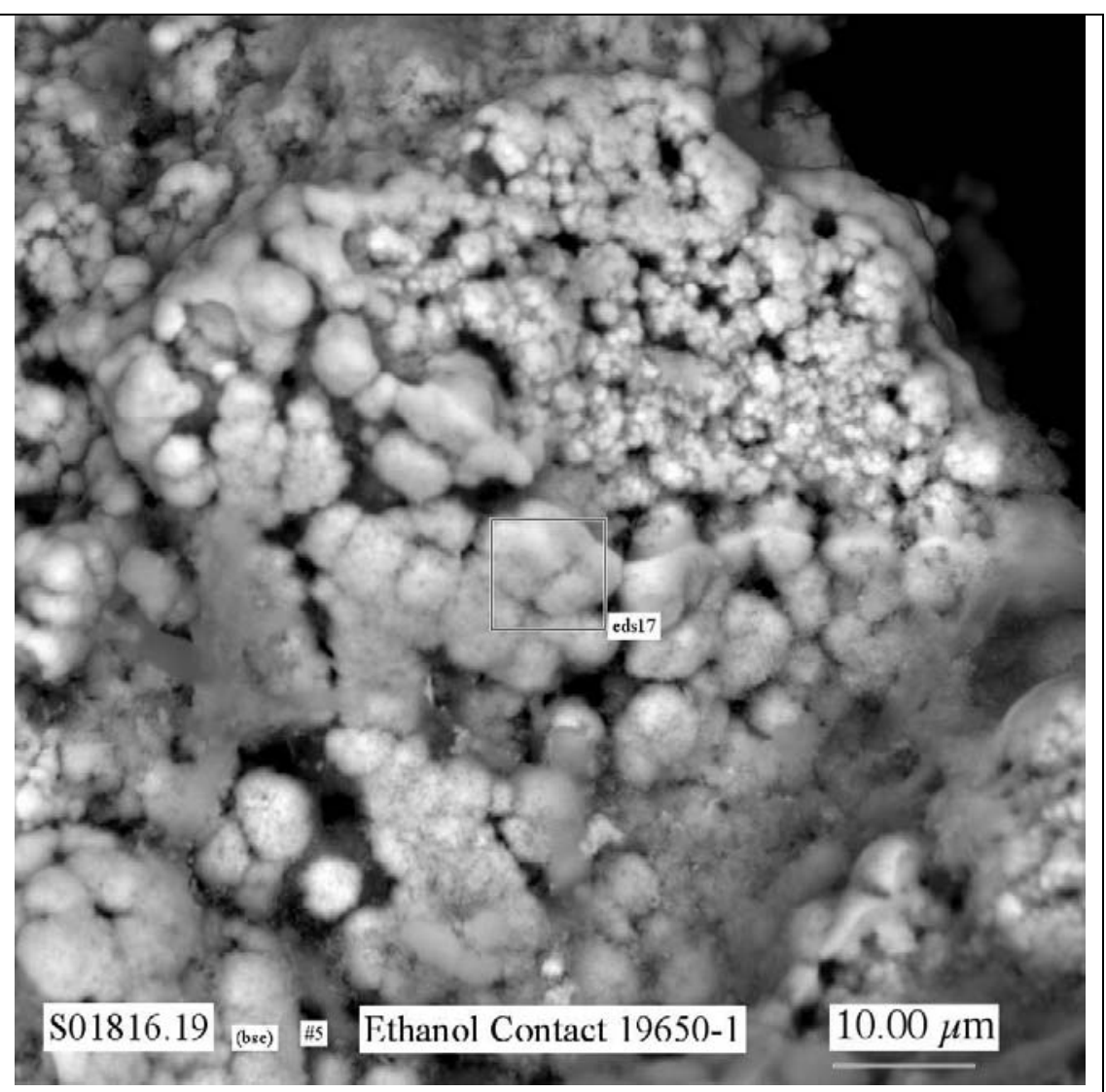

Figure C.99. Micrograph showing at higher magnification the altered surface in the area indicated by the white dashed-line square in the Figure C.98. 


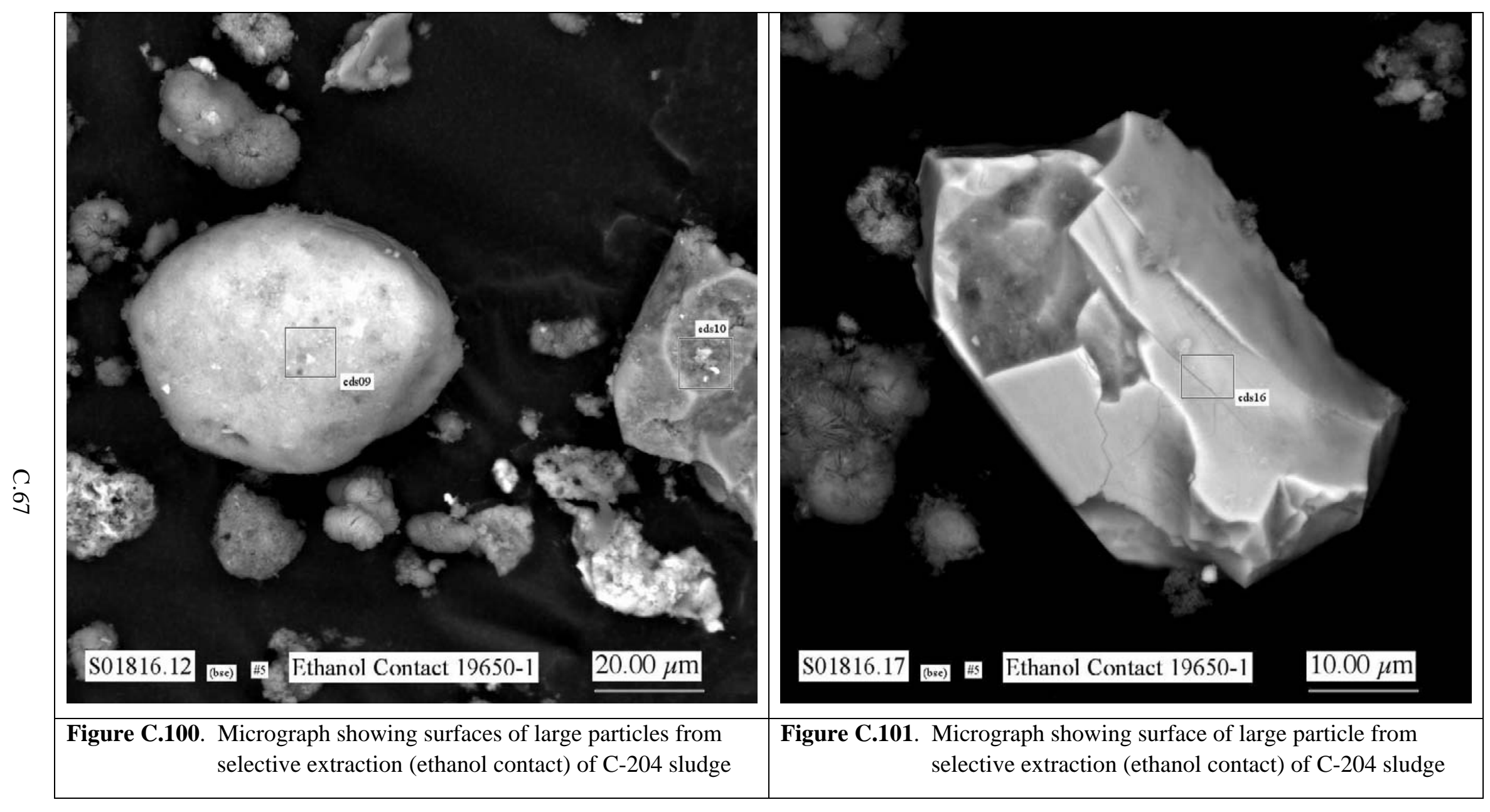




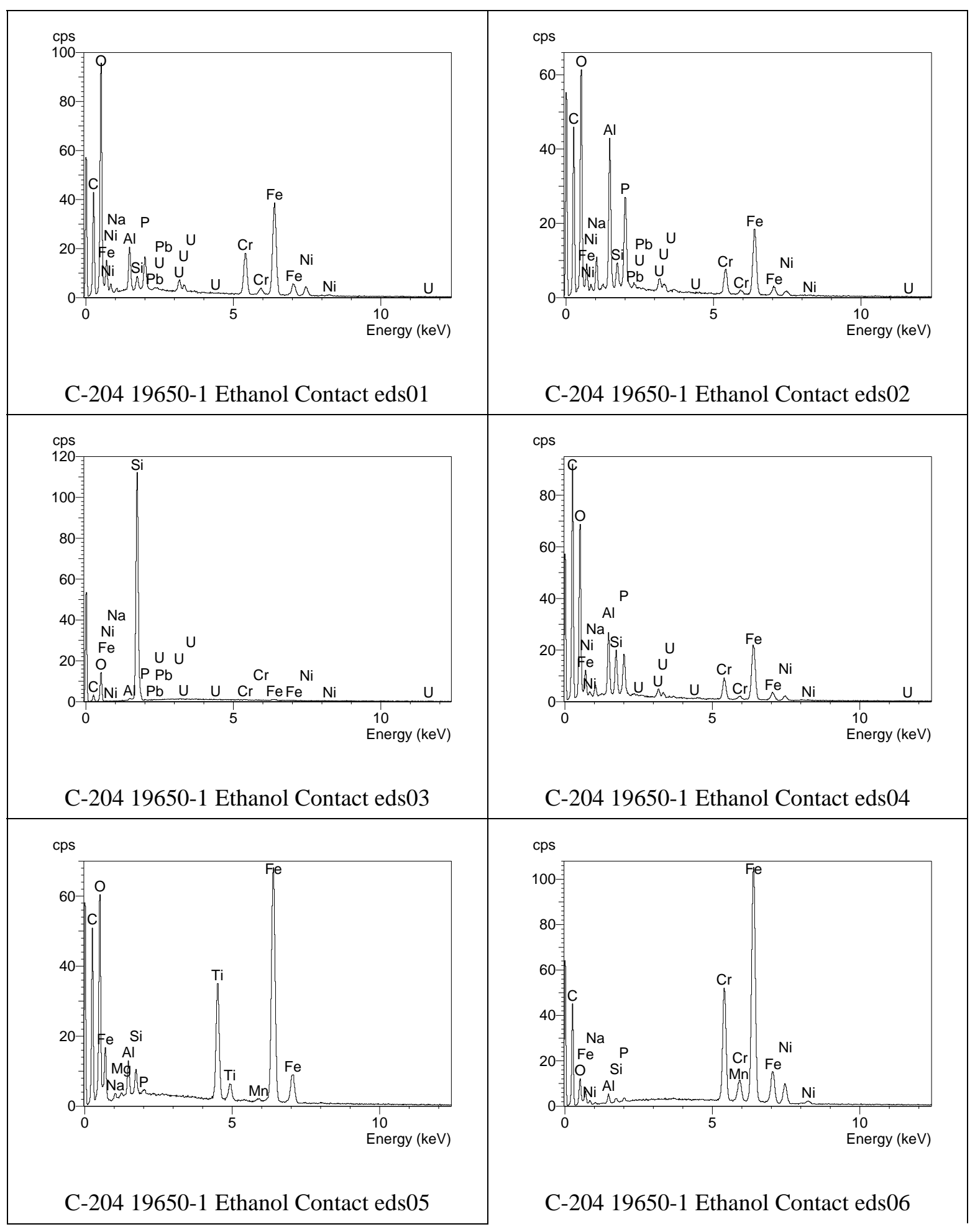

Figure C.102. EDS spectra for analyses eds01 through eds06 for particles in residual solids remaining after the selective extraction (ethanol contact) of C-204 sludge 


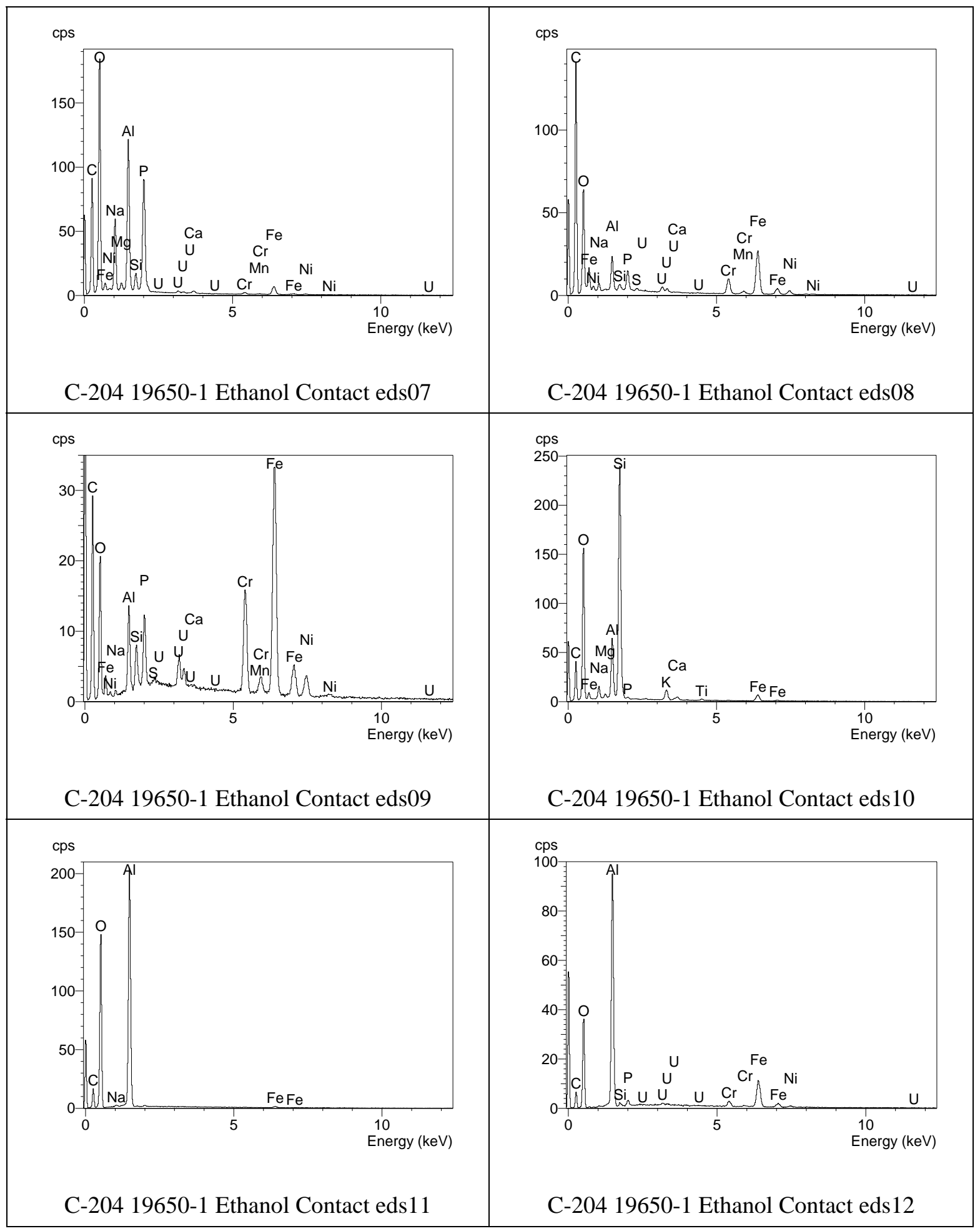

Figure C.103. EDS spectra for analyses eds07 through eds12 for particles in residual solids remaining after the selective extraction (ethanol contact) of C-204 sludge 


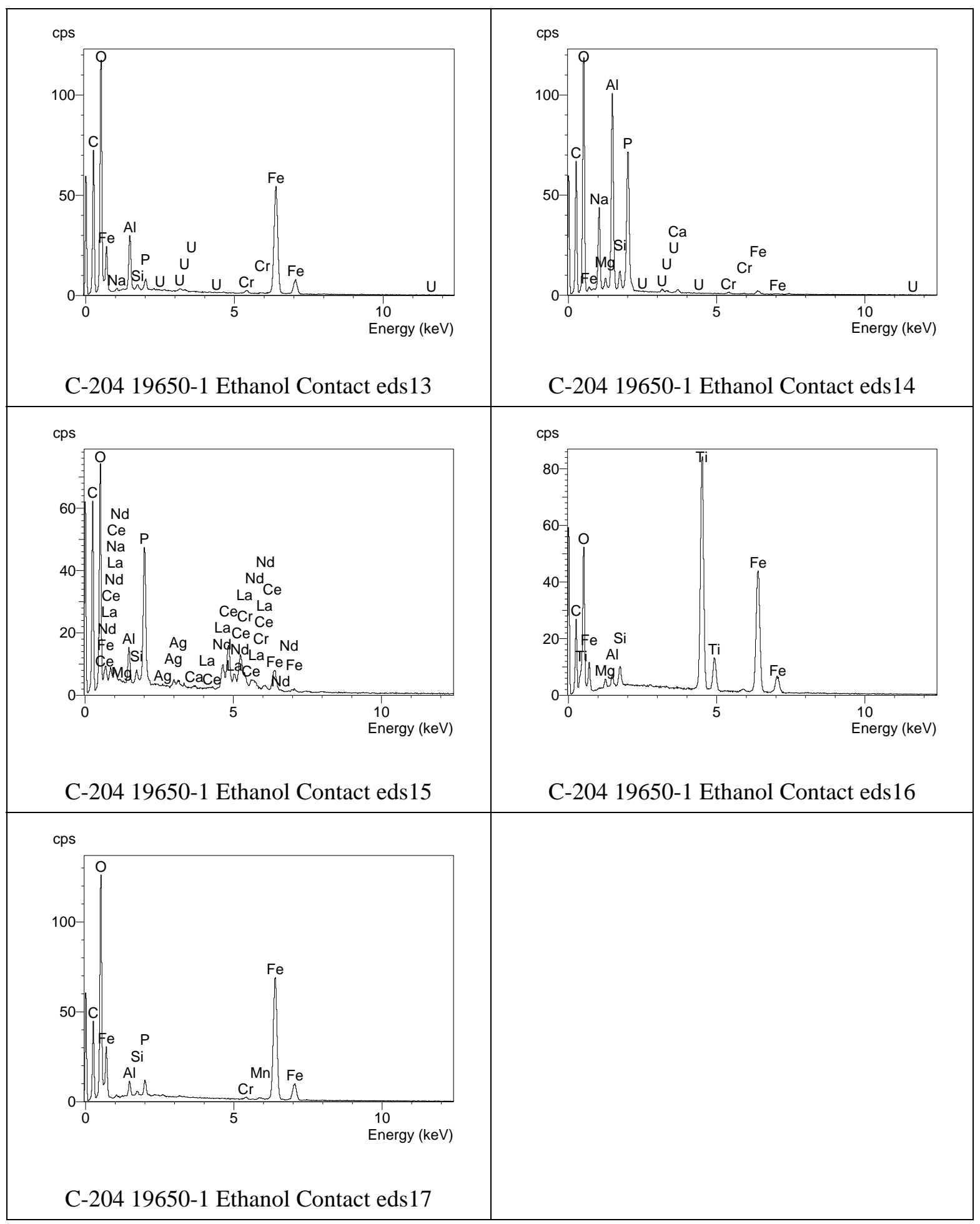

Figure C.104. EDS spectra for analyses eds13 through eds17 for particles in residual solids remaining after the selective extraction (ethanol contact) of C-204 sludge 


\section{C.8 Residual Solid from HF/NaF Sequential Extraction (3 days) of C-204 Sludge}

Two mounts of residual solid from the three-day HF/NaF sequential extraction of C-204 (jar 19650) residual tank waste were analyzed by SEM/EDS. The SEM micrographs for the first mount (19650 -15) of C-204 sludge are shown in Figures C-105 through C-114. The EDS spectra for this mount are given in Figures C-115 through C-117. The SEM micrographs for the second mount (19650 -16) of C-204 sludge are shown in Figures C-118 through C-124, and the EDS spectra for the second mount are given in Figures C-125 and C-126. 

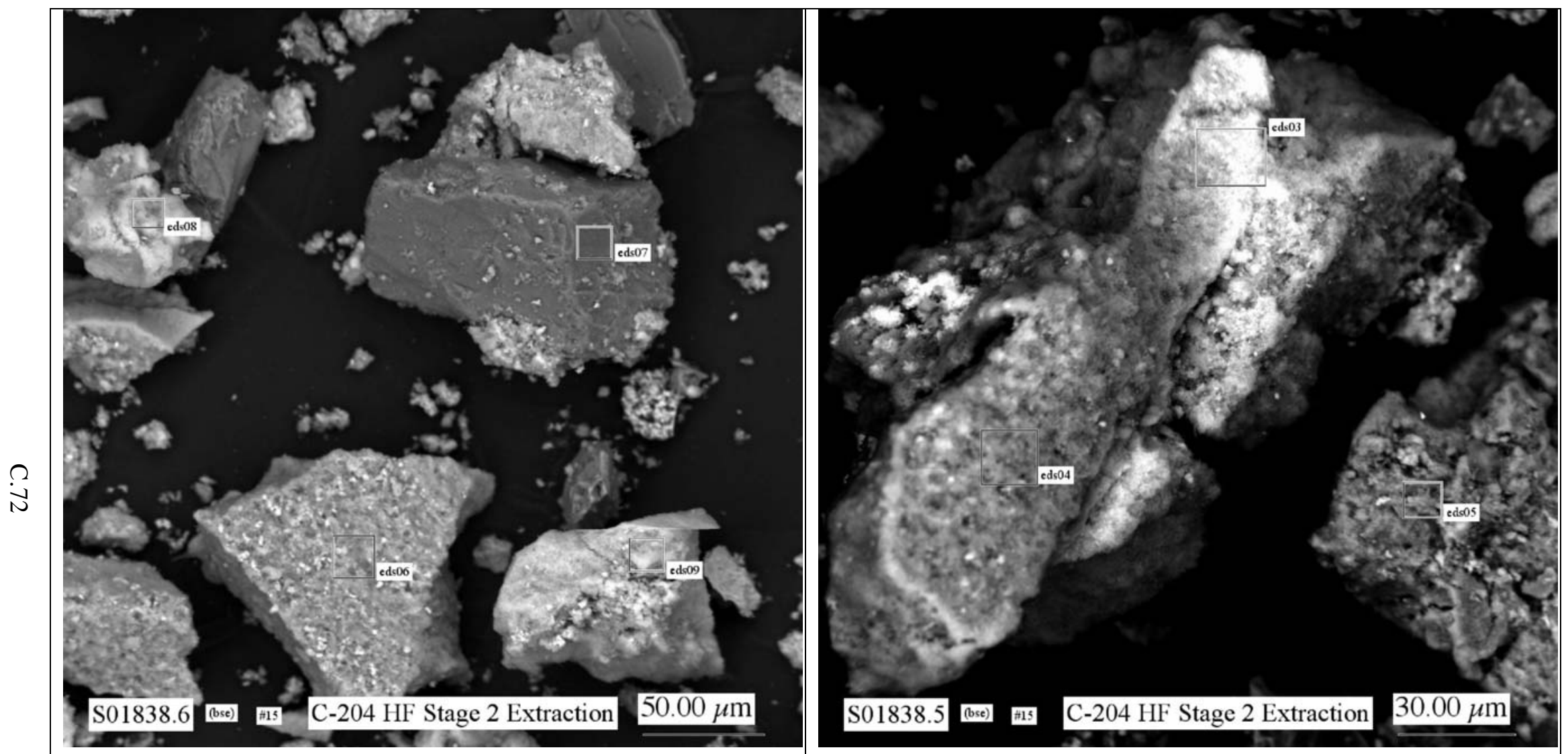

Figure C.105. SEM micrograph for mount 19650-15 showing general morphology of particles in material remaining from

Figure C.106. Micrograph for mount 19650-15 showing general 3-day HF/NaF sequential extraction of C-204 sludge morphology of particles in material remaining from 3-day HF/NaF sequential extraction of C-204 sludge 


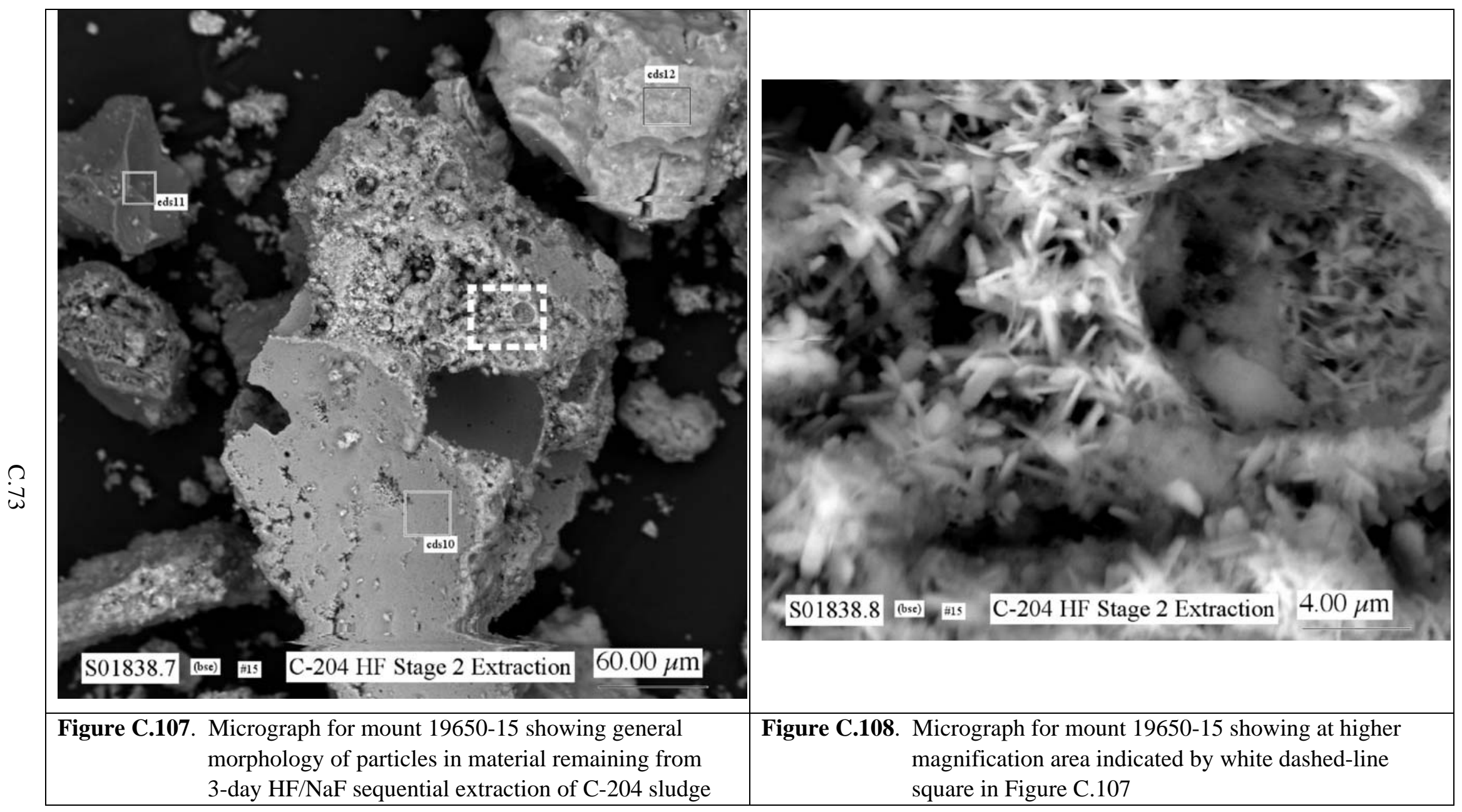




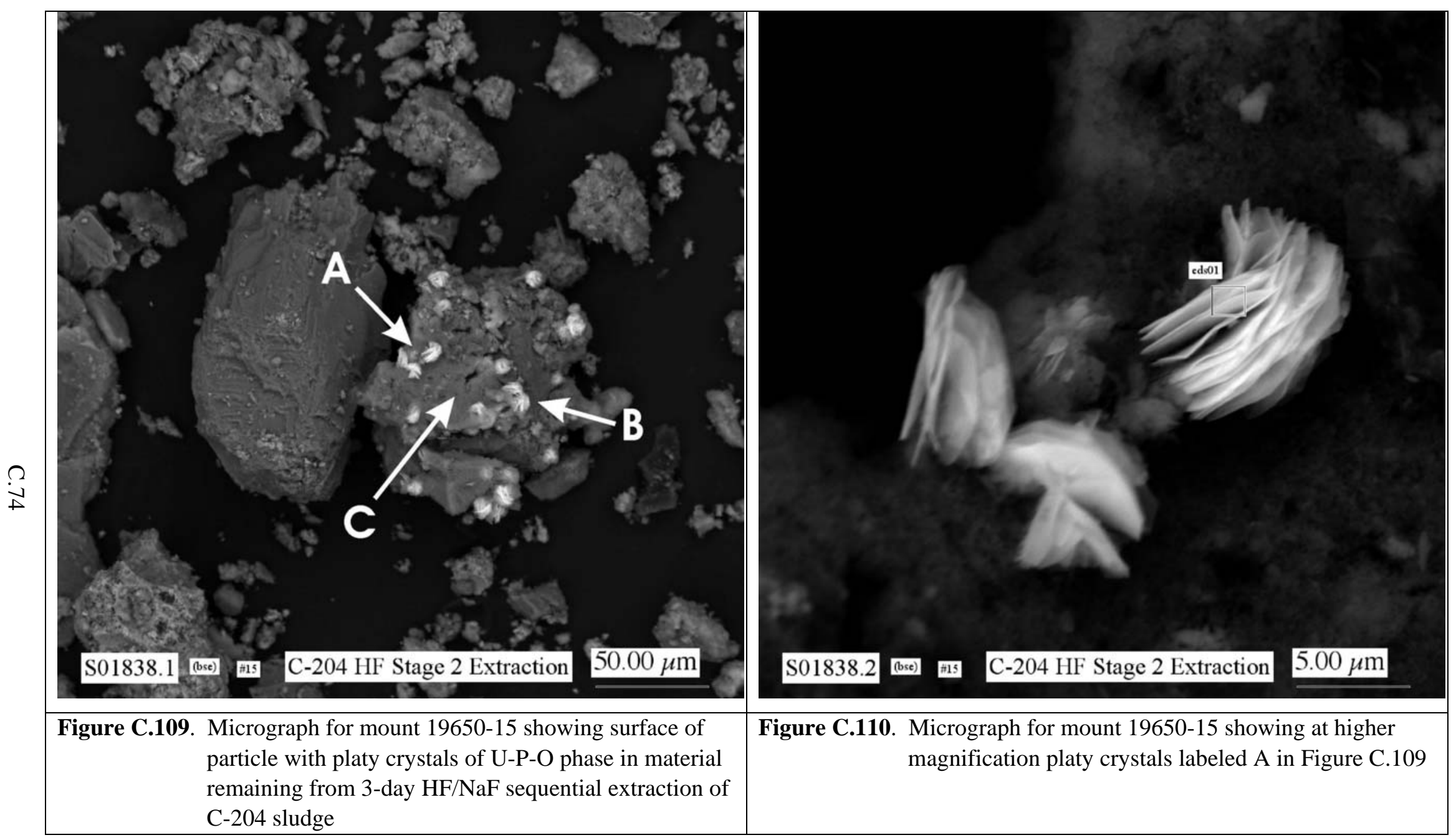




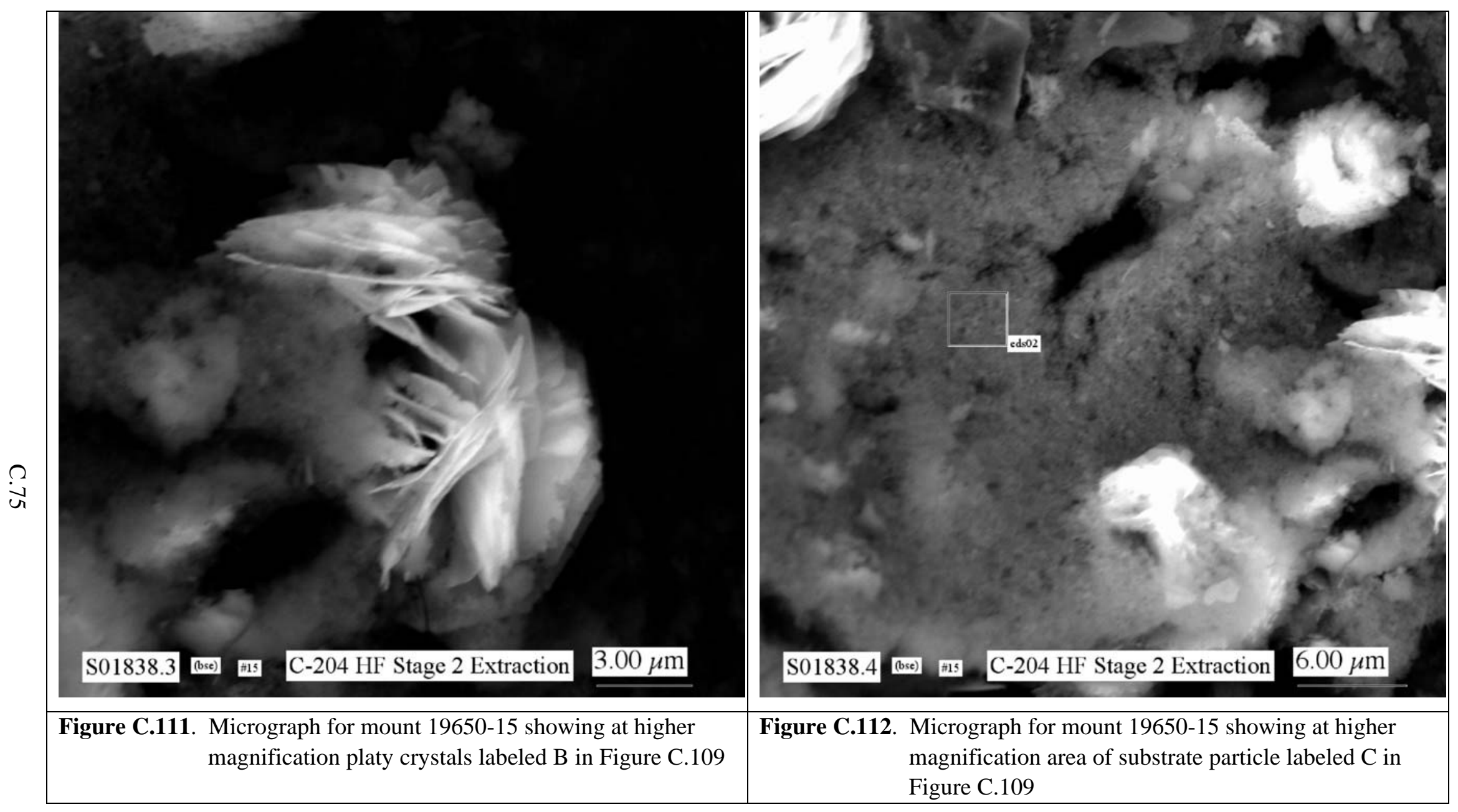




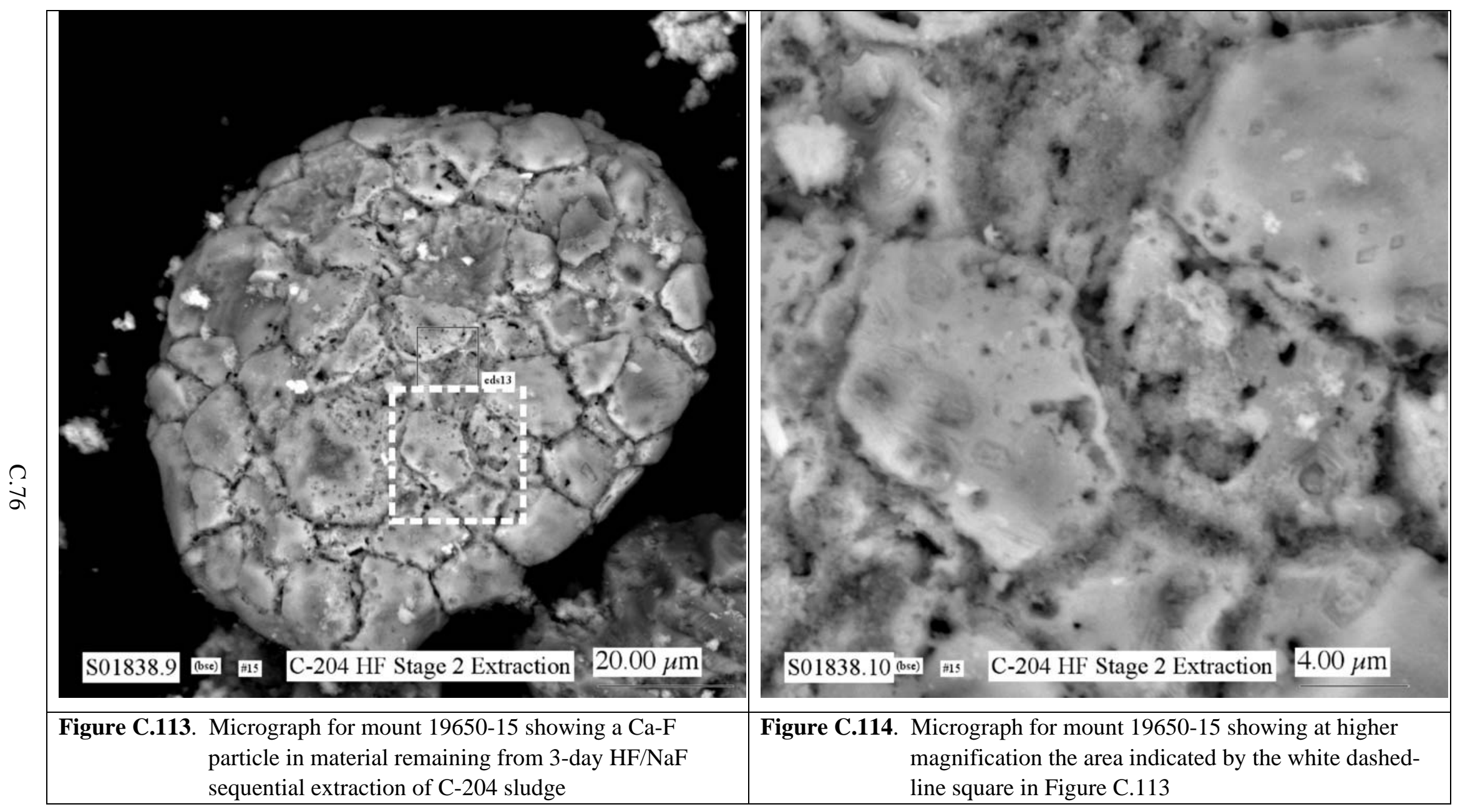




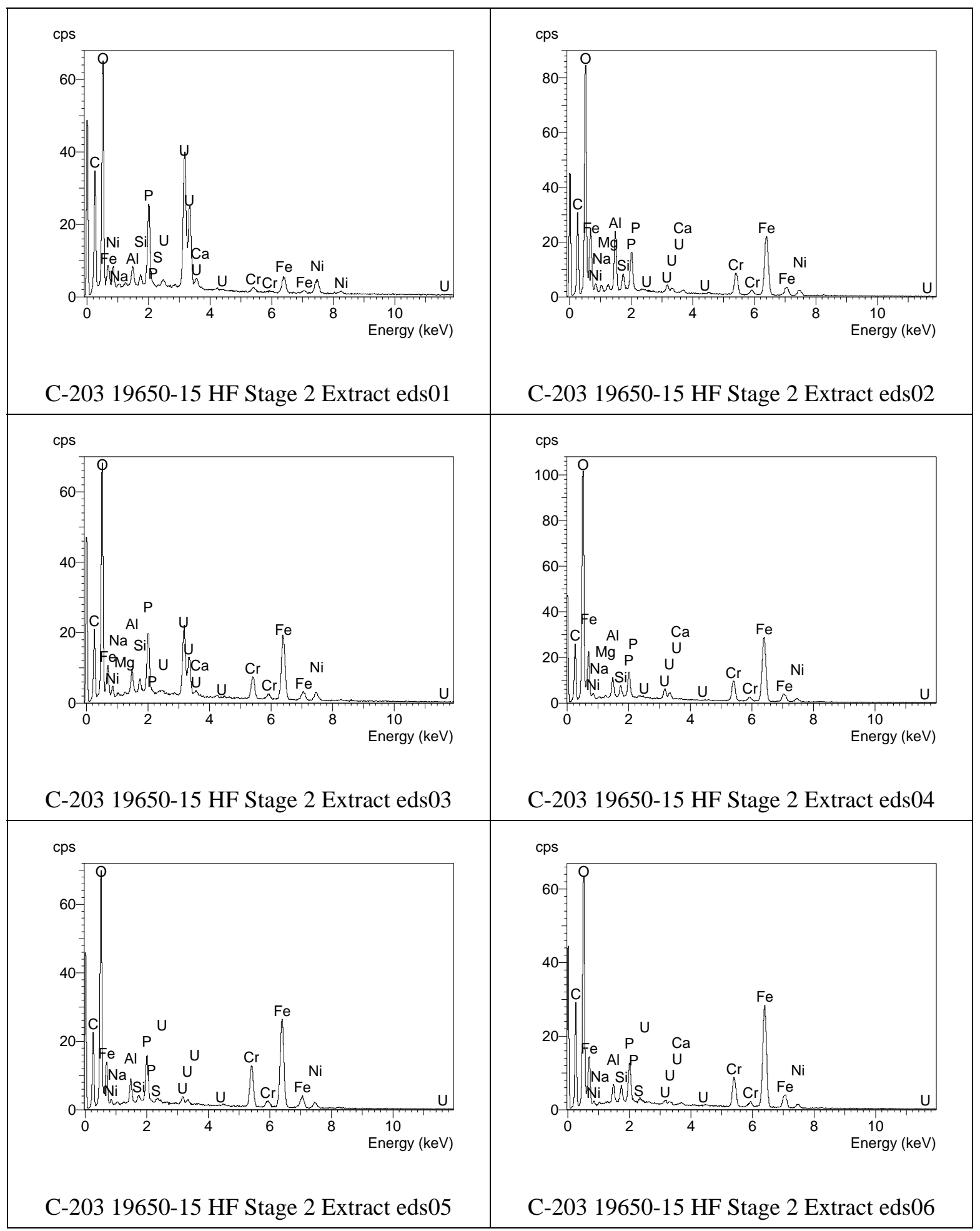

Figure C.115. EDS spectra for analyses eds01 through eds06 for particles in SEM mount 19650-15 of residual solids remaining after the 3-day HF/NaF extraction of C-204 sludge 


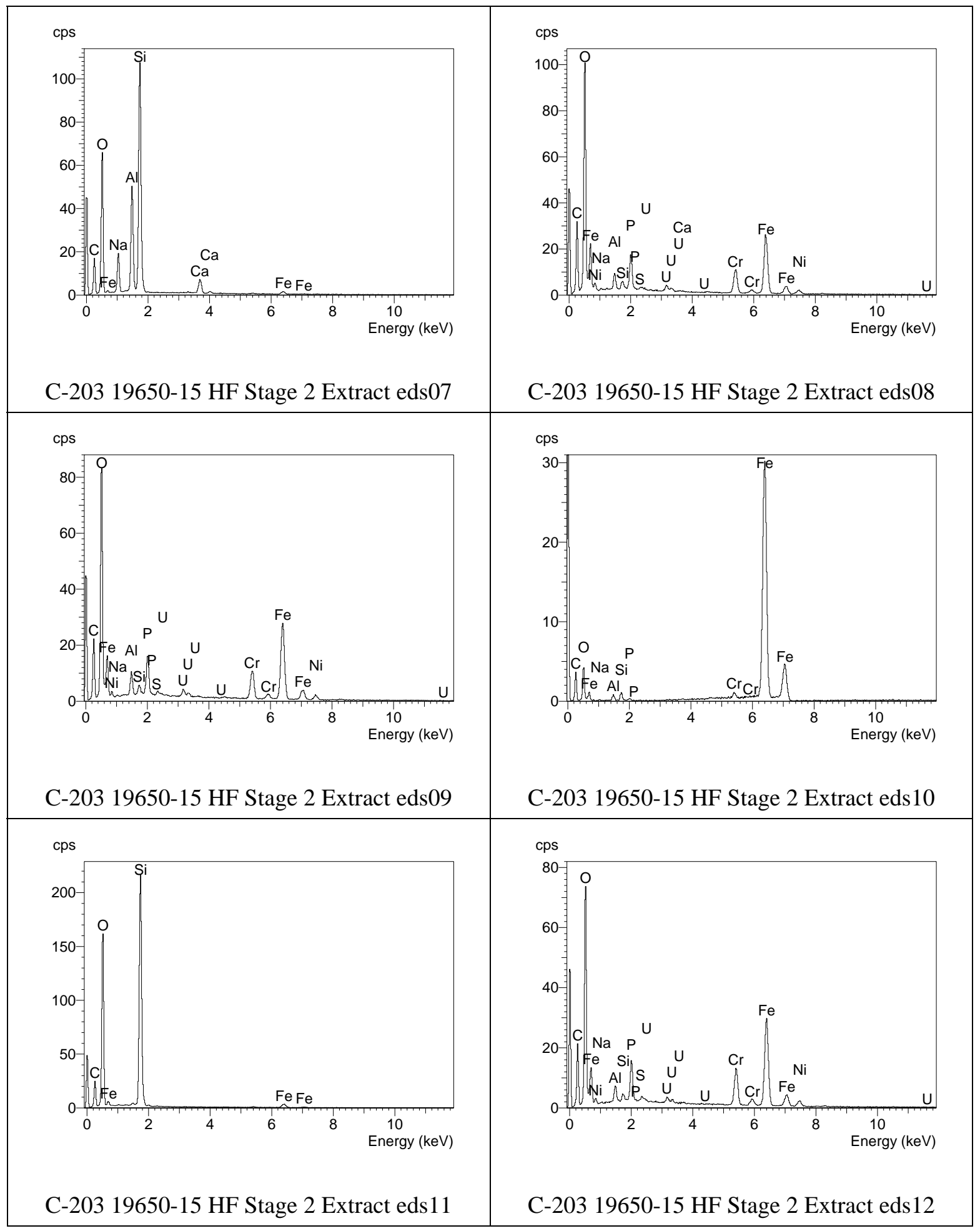

Figure C.116. EDS spectra for analyses eds07 through eds 12 for particles in SEM mount 19650-15 of residual solids remaining after the 3-day HF/NaF extraction of C-204 sludge 


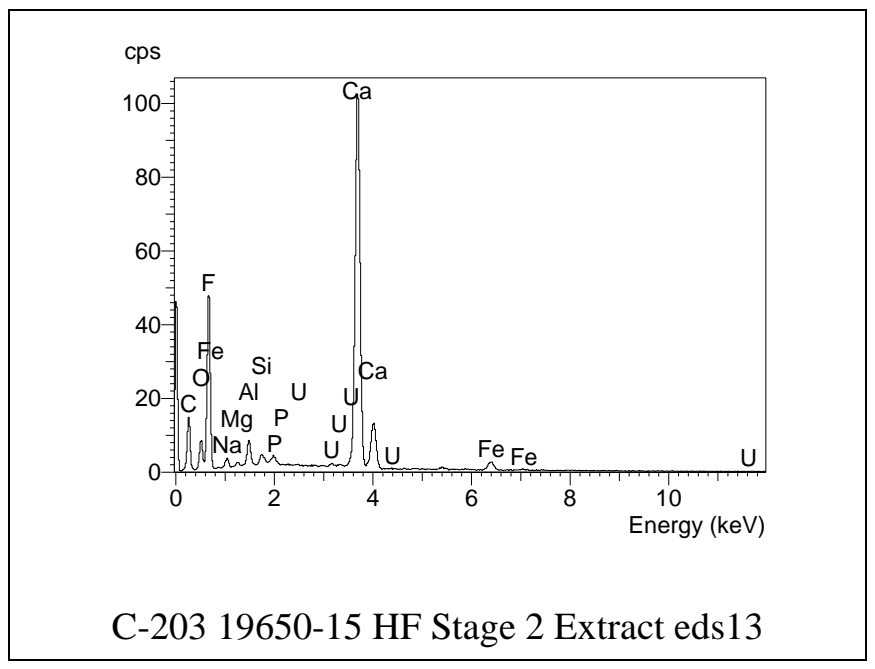

Figure C.117. EDS spectra for analysis eds13 for a particle in SEM mount 19650-15 of residual solids remaining after the 3-day $\mathrm{HF} / \mathrm{NaF}$ extraction of C-204 sludge 


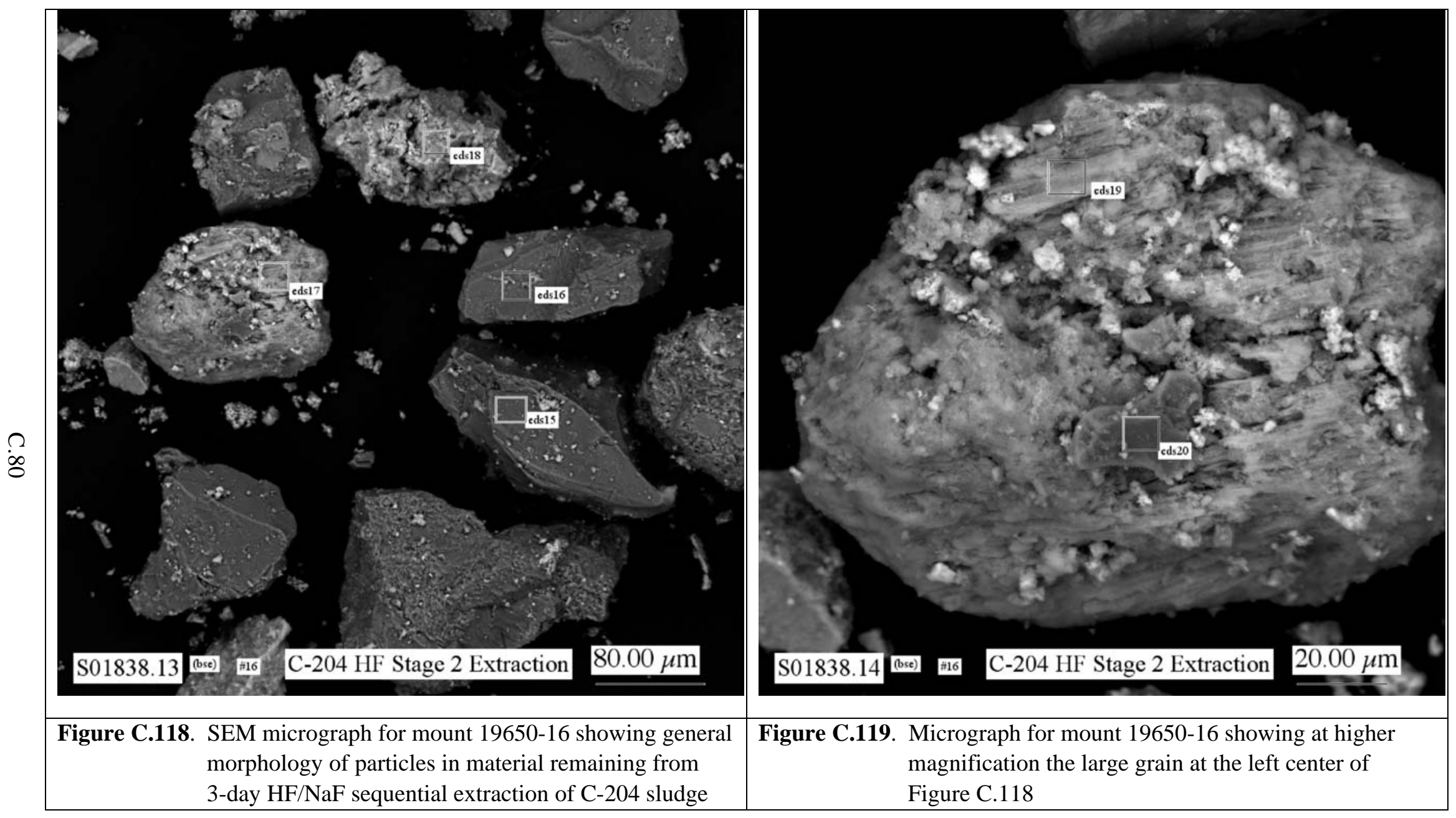




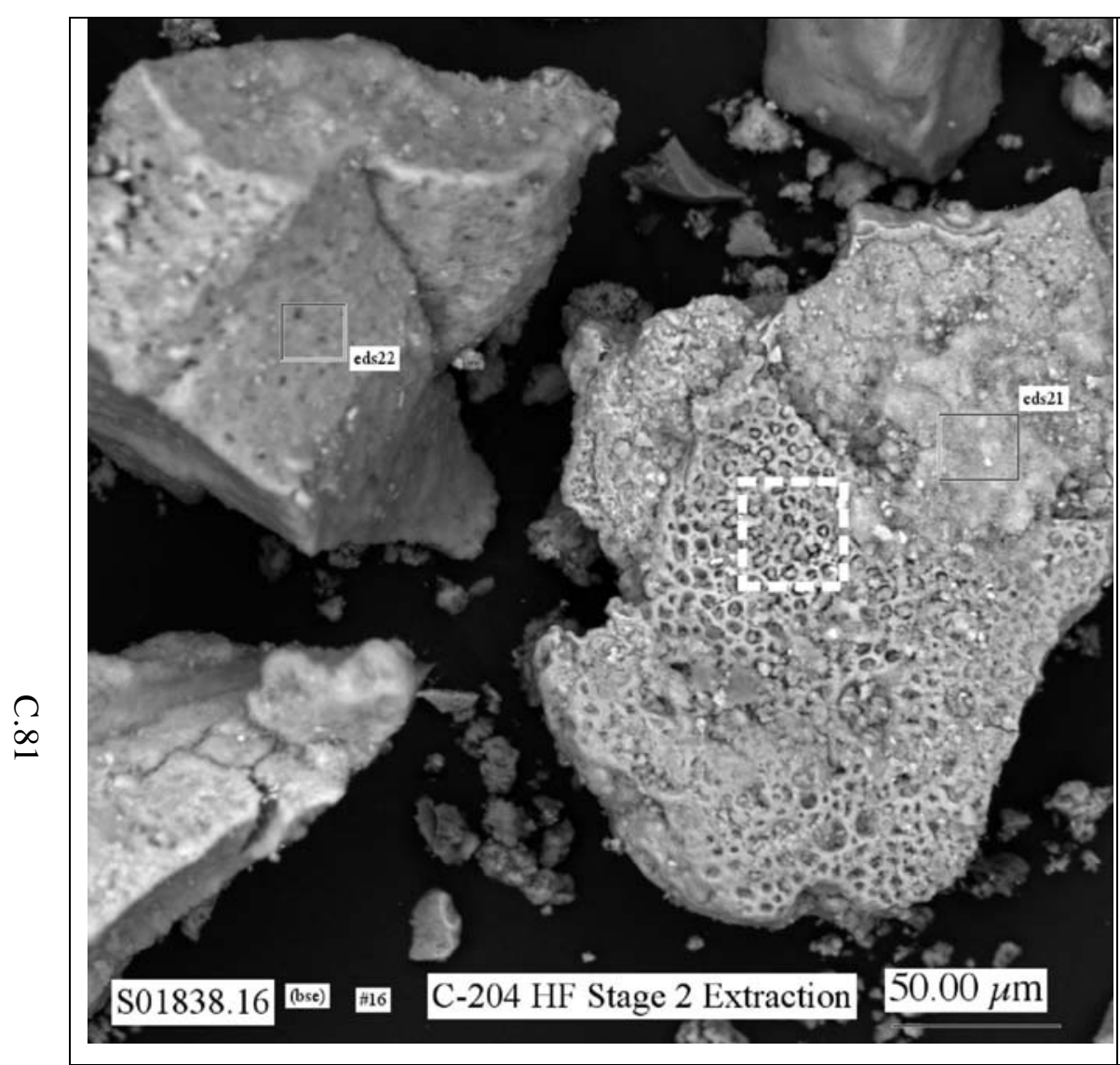

Figure C.120. Micrograph for mount 19650-16 showing typical particles in material remaining from 3-day $\mathrm{HF} / \mathrm{NaF}$ sequential extraction of C-204 sludge

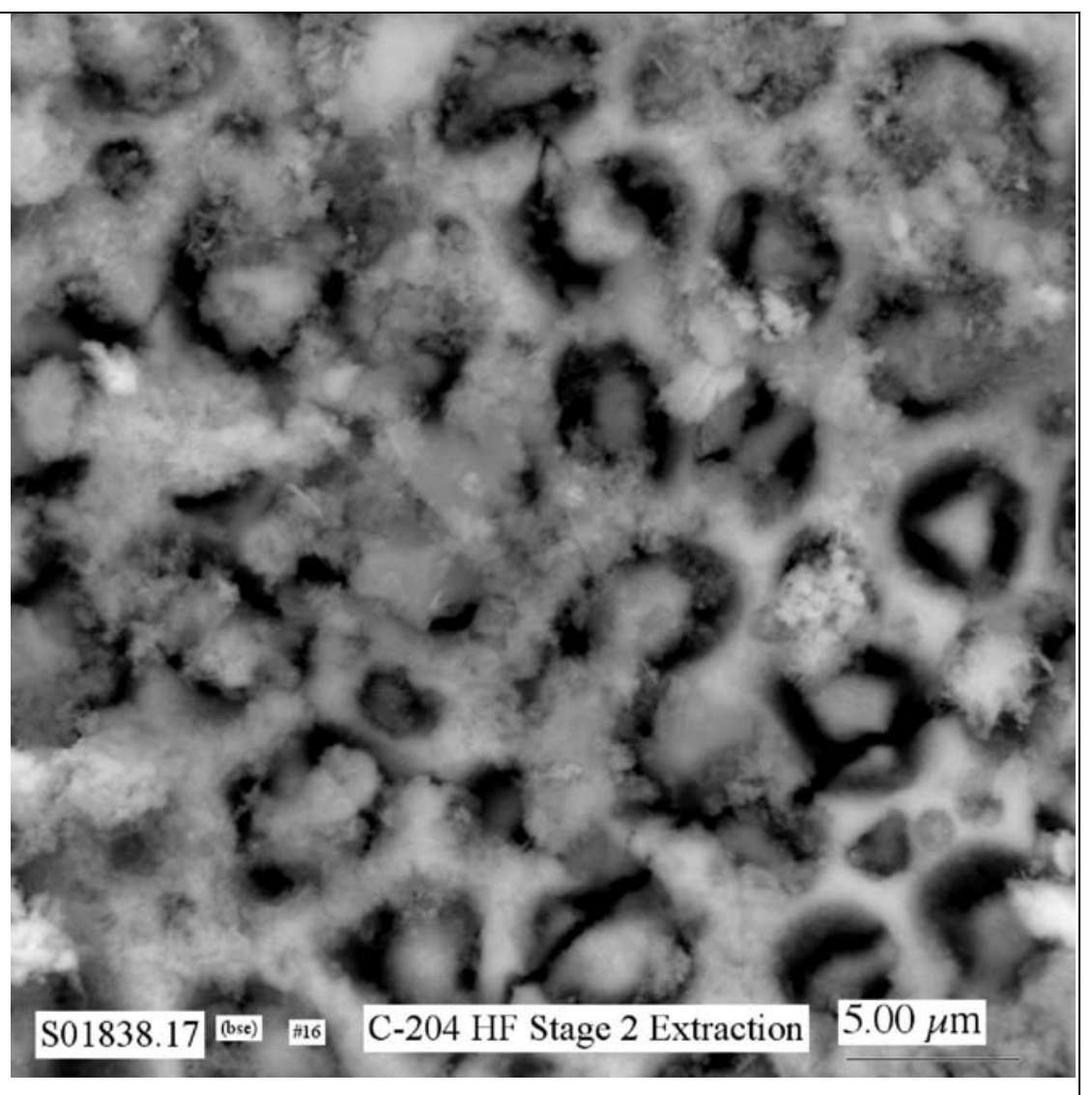

Figure C.121. Micrograph for mount 19650-16 showing at higher magnification area indicated by white dashed-line square in Figure C.120 


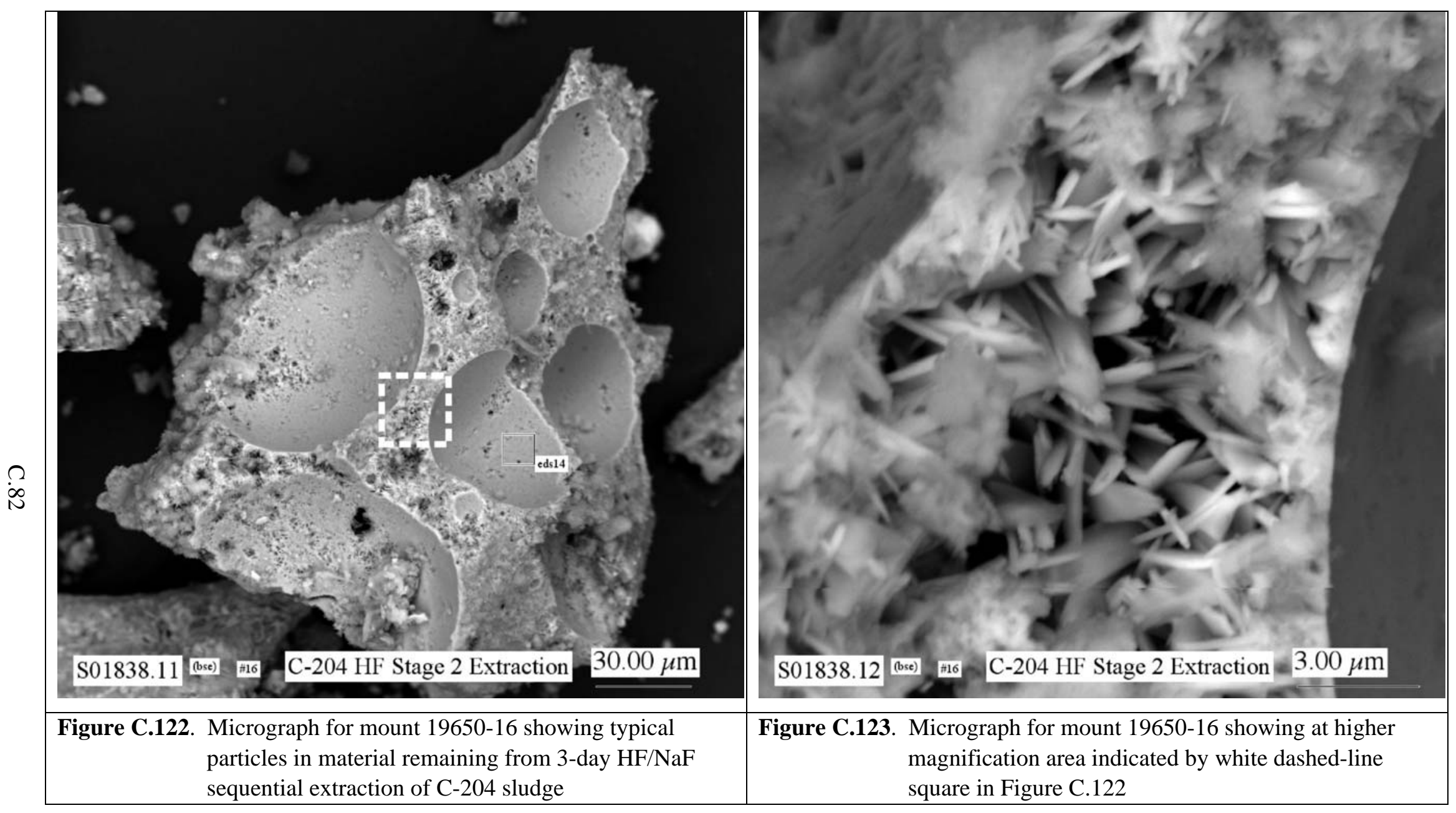




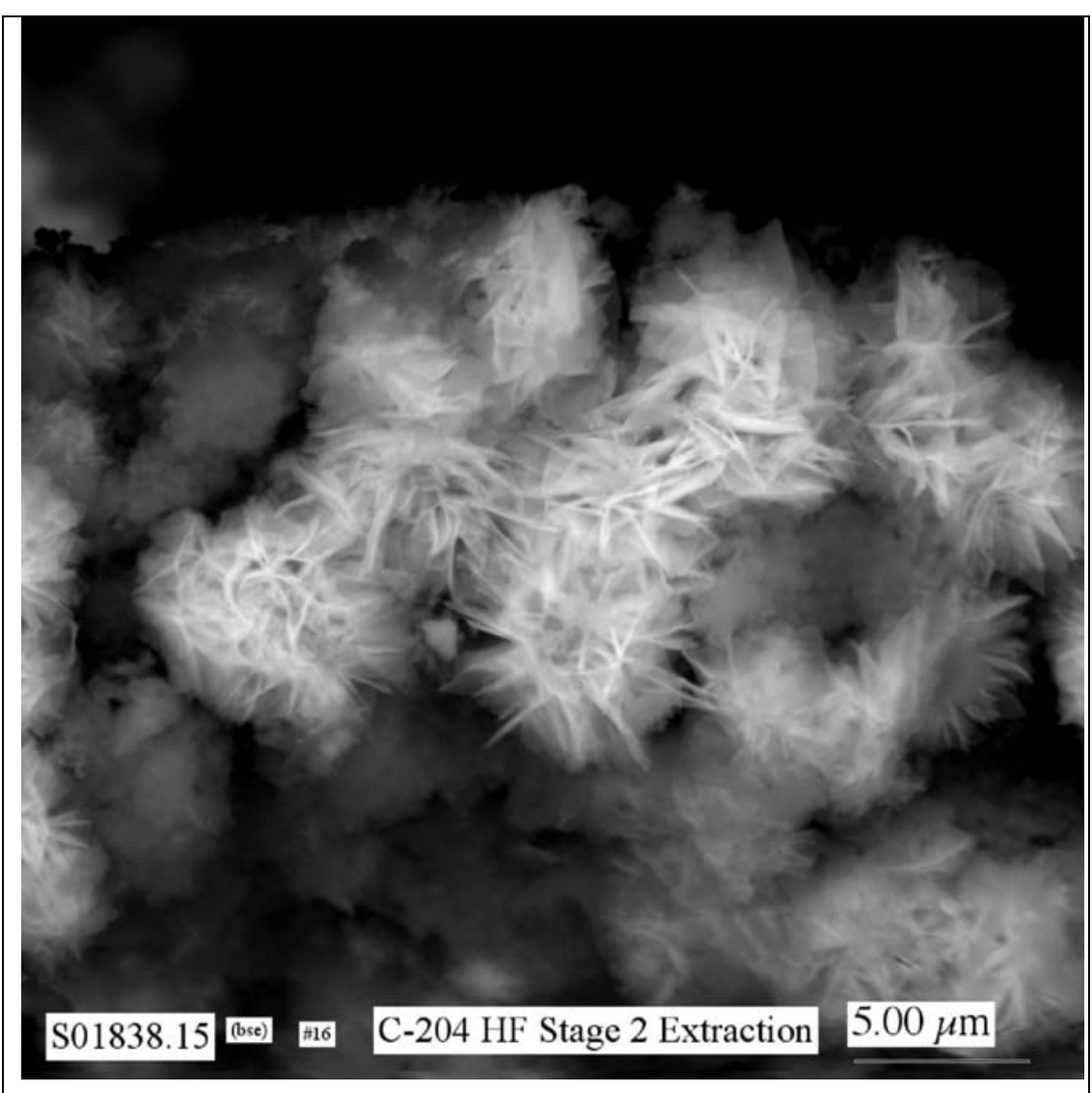

Figure C.124. Micrograph for mount 19650-16 showing some atypical feather-like crystallites in material remaining from 3-day HF/NaF sequential extraction of C-204 sludge [The orientation of these crystallites on the mount within the SEM chamber prevented their analysis by EDS.] 


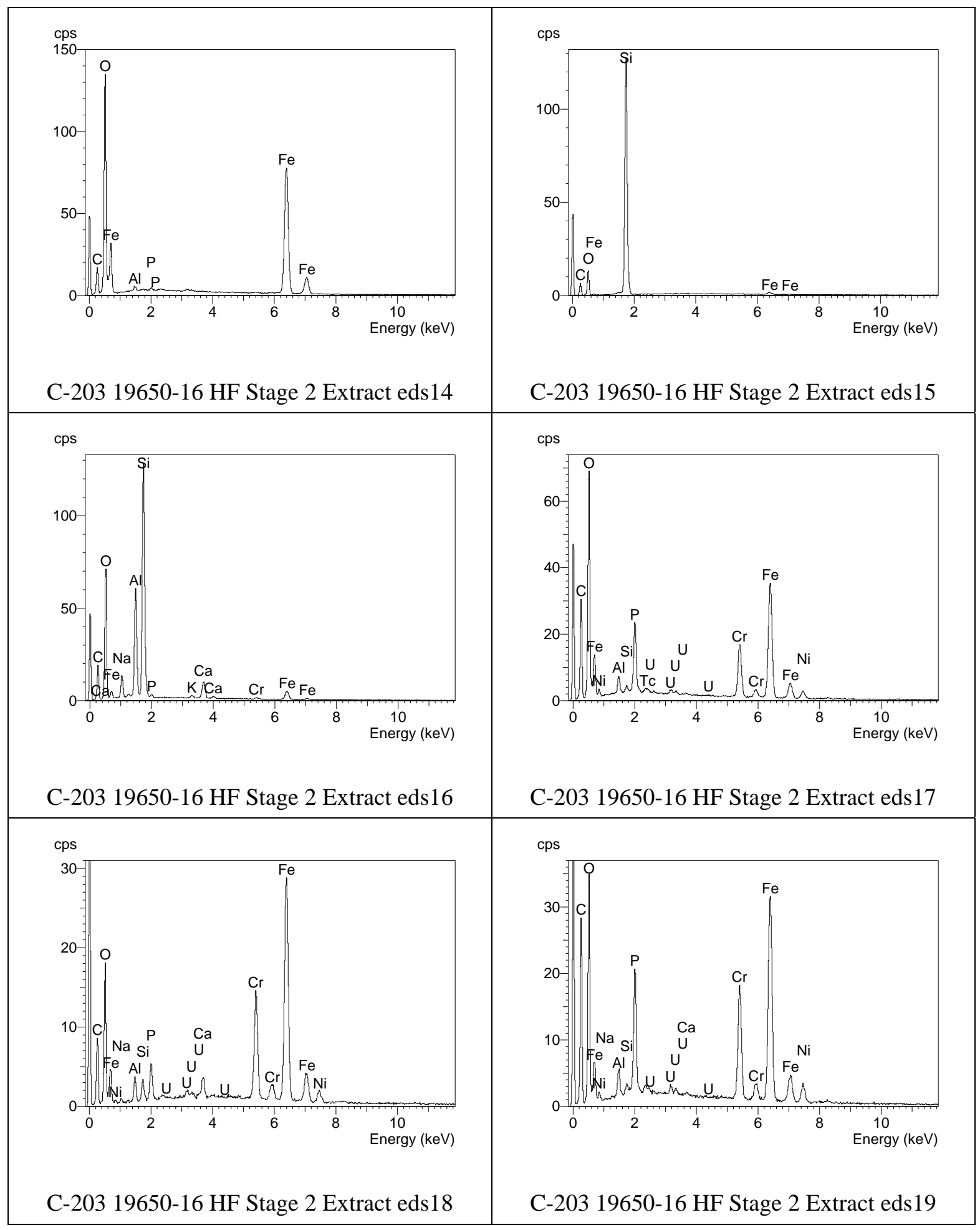

Figure C.125. EDS spectra for analyses eds14 through eds19 for particles in SEM mount 19650-16 of residual solids remaining after the 3-day HF/NaF extraction of C-204 sludge 


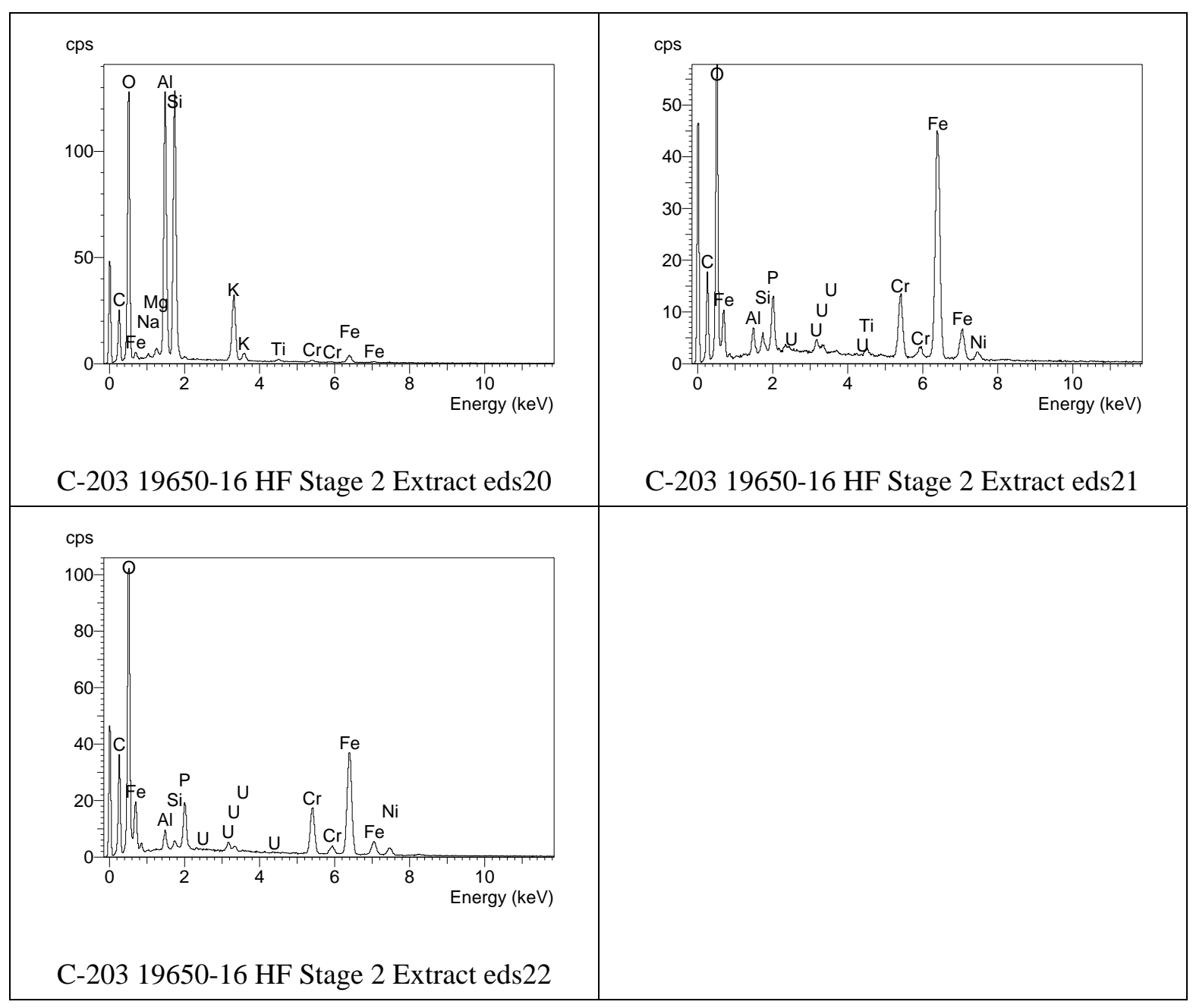

Figure C.126. EDS spectra for analyses eds20 through eds22 for particles in SEM mount 19650-16 of residual solids remaining after the 3-day HF/NaF extraction of C-204 sludge 


\section{Appendix D}

SEM Micrographs and EDS Spectra for Natural Specimen of Čejkaite 


\section{Appendix D}

\section{SEM Micrographs and EDS Spectra for Natural Specimen of Čejkaite}

This appendix includes the scanning electron microscope (SEM) micrographs and energy-dispersive X-ray spectrometry (EDS) spectra recorded for the natural specimen ${ }^{(a)}$ of čejkaite $\left[\mathrm{Na}_{2}\left(\mathrm{UO}_{2}\right)\left(\mathrm{CO}_{3}\right)_{3}\right]$ from the Svornost Mine at Jáchymov in the Czech Republic. The operating conditions for the SEM and procedures used for mounting the SEM samples are described in Section 2.4 of the main report.

The name of each SEM digital image file, sample identification number, and a size scale bar are given, respectively, at the bottom left, center, and right of each SEM micrograph in this appendix. Micrographs labeled by "bse" to the immediate right of the digital image file name indicate that the micrograph was collected with backscattered electrons. Areas identified by a letter and/or outlined by a dashed-line square in a micrograph designate sample material that was imaged at higher magnification, which is typically shown in figure(s) that immediately follow in the series for that sample.

Areas labeled by "eds" in the following SEM micrographs in this appendix identify locations of particles for which EDS spectra were recorded. The "eds" label given with each EDS spectrum correspond to the same "EDS" label used in the SEM micrographs for this sample.

The SEM micrographs recorded for the natural specimen of čejkaite are shown in Figures D.1 through D.2. The EDS spectra measured for particles in the čejkaite are given in Figure D 7-1.

(a) The mineral specimen was purchased from Excalibur Mineral Corp., Peekskill, New York.

D. 1 


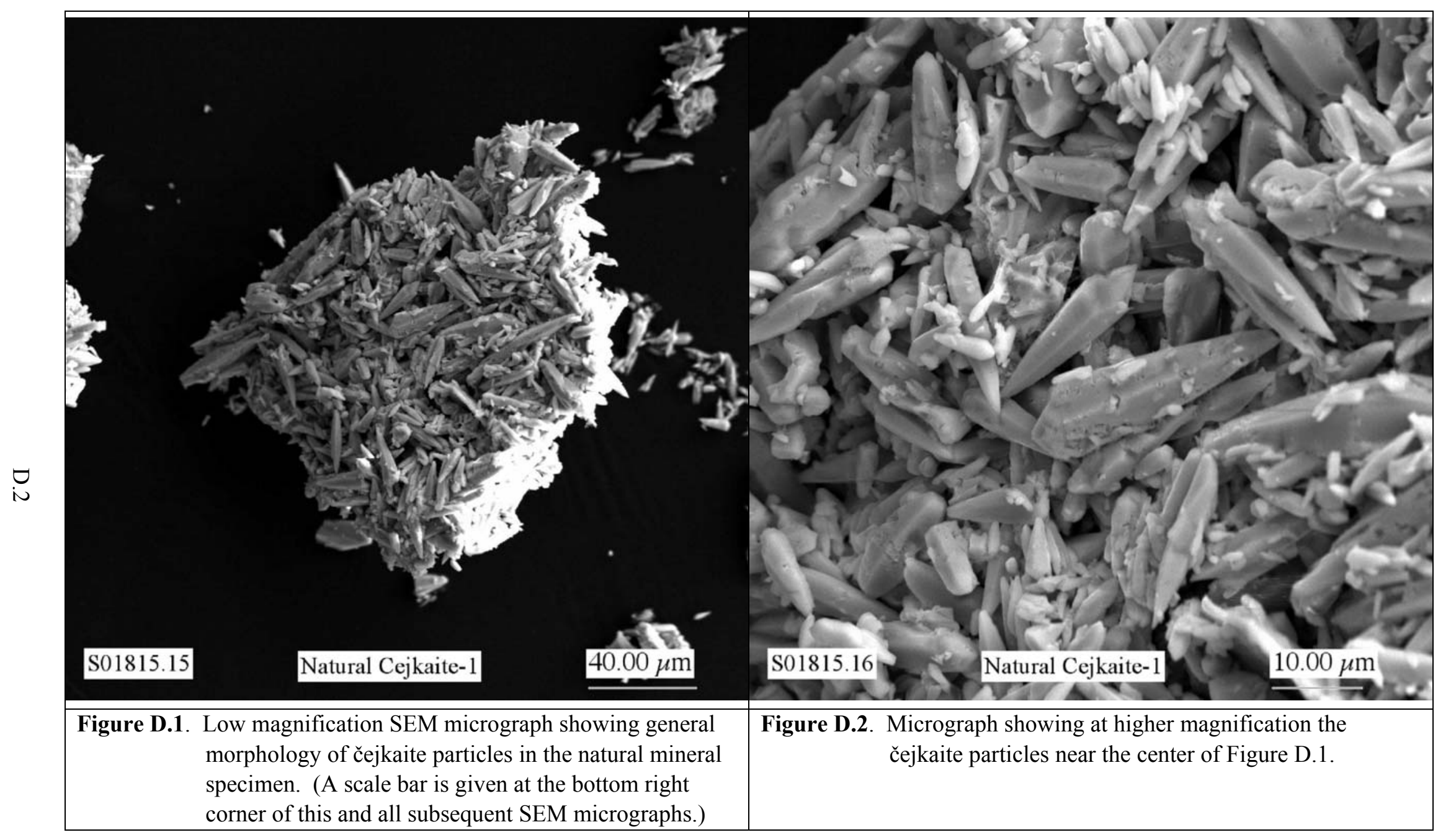




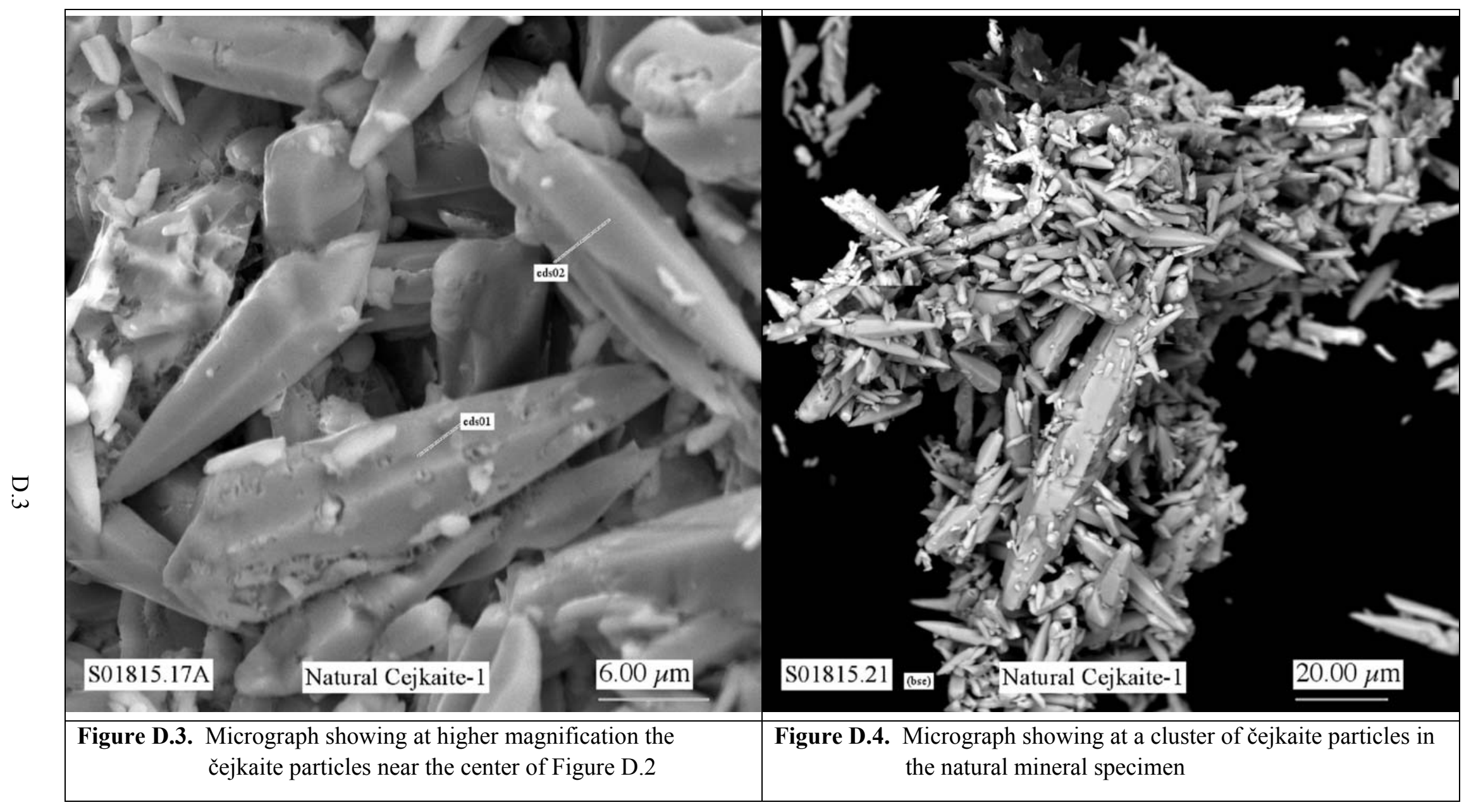




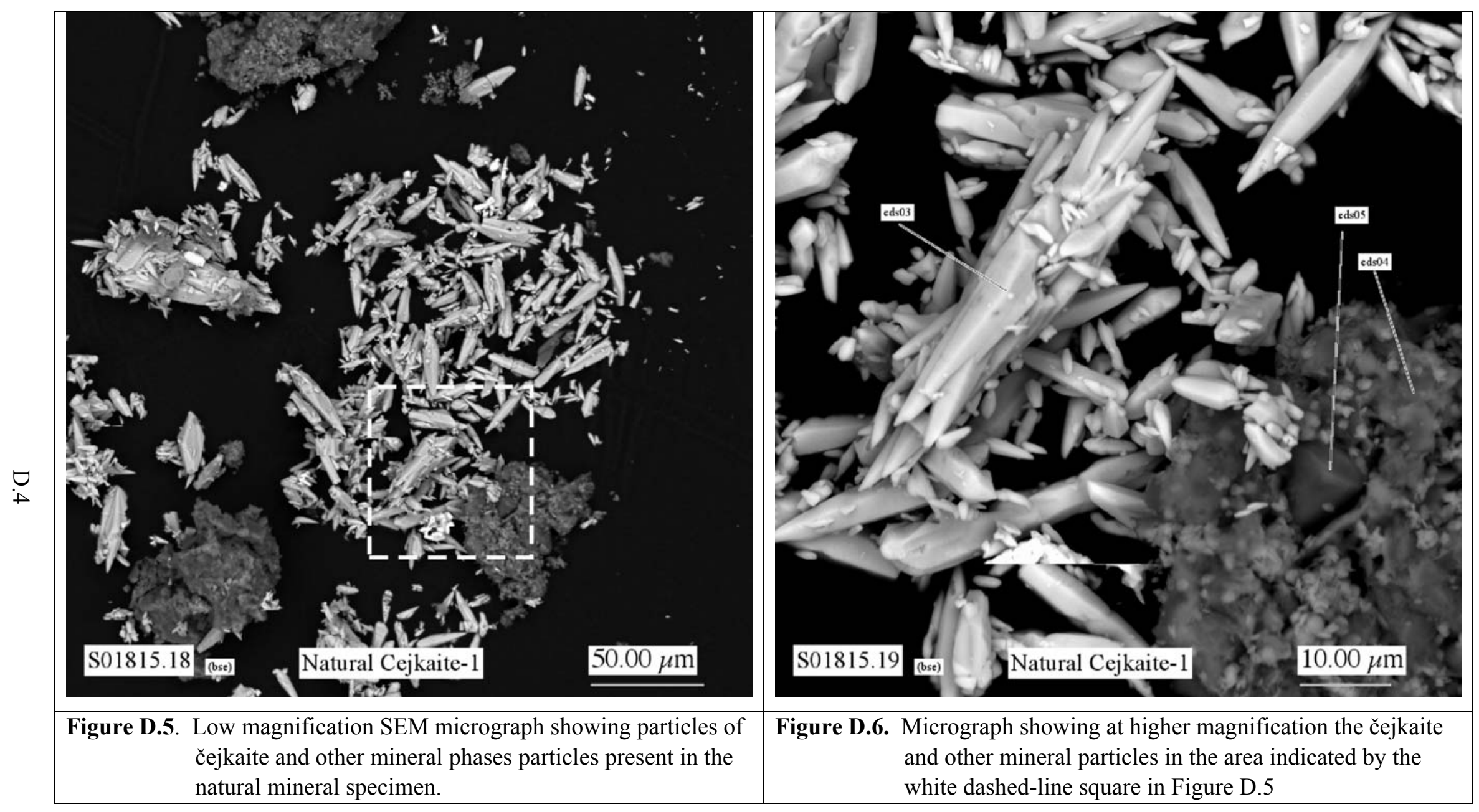




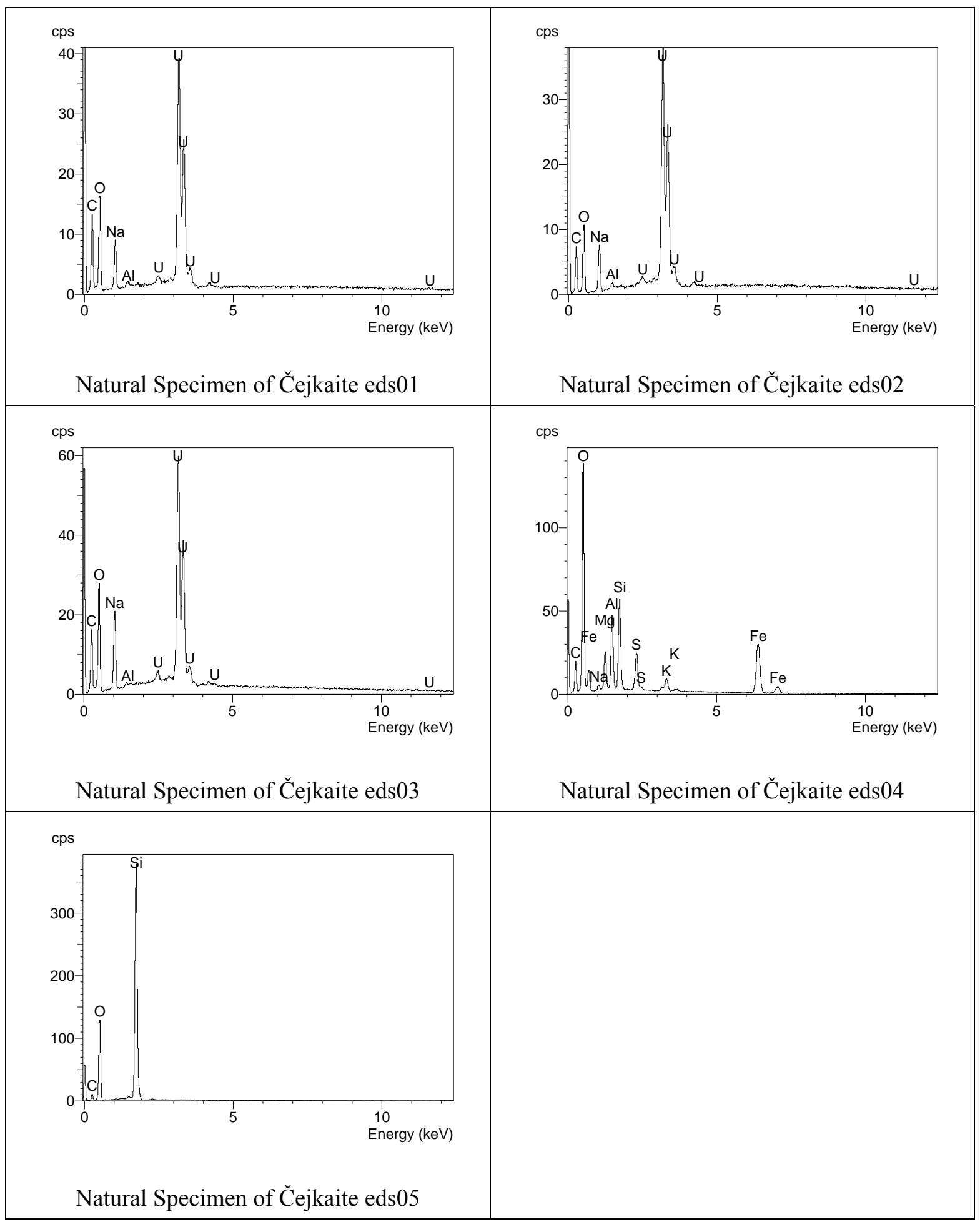

Figure D.7. EDS spectra for analyses eds01 through eds 05 for unleached natural specimen of čejkaite 


\section{Distribution*}

No. of

$\underline{\text { Copies }}$

\section{OFFSITE}

Steve Airhart

Freestone Environmental Services

1933 Jadwin Ave.

Richland, WA 99354

Dr. Harry Babad

2540 Cordoba Court

Richland, WA 99352-1609

Pat Brady

Geochemistry Department, 6118

Sandia National Laboratories

P.O. Box 5800

Albuquerque, NM 87185-0750

Charles R. Bryan

Sandia National Laboratories

4100 National Parks Highway

Carlsbad, NM 88220

Susan Carroll

Lawrence Livermore National Laboratory

MS L-219

Livermore, CA 94550

Jon Chorover

Associate Professor - Environmental

Chemistry

Department of Soil, Water, and

Environmental Science

Shantz 429, Building \#38

University of Arizona

Tucson, AZ 85721-0038
No. of

Copies

Dave G. Coles

Coles Environmental Consulting

750 South Rosemont Road

West Linn, OR 97068

Mark Conrad

Department of Earth and Planetary Sciences

University of California, Berkeley

Berkeley, CA 94720

Dr. James A. Davis

U.S. Geological Survey

MS 465

345 Middlefield Road

Menlo Park, CA 94025

Donald J. DePaolo

Geology \& Geophysics Dept. MC4767

University of California

Berkeley, CA 94720-4767

Dirk A. Dunning

Oregon Office of Energy

625 Marion Street, N.E.

Salem, OR 97301-3742

Mark Ewanic

MSE Technology Applications, Inc.

200 Technology Way

Butte, MT 59701

Markus Flury

Department of Crop and Soil Sciences

Washington State University

Pullman, WA 99164

*Distribution of this report is made by electronic media via http://www.osti.gov/bridge/. 
No. of

Copies

Amy P. Gamerdinger

2122 E. Hawthorne

Tucson, AZ 85719

Jim Harsh

Department of Crop \& Soil Sciences

Washington State University

Johnson Hall, Room 249

Pullman, WA 99164-6420

Dr. Cliff Johnston

Soil Chemistry and Mineralogy

1150 Lily Hall

Purdue University

West Lafayette, IN 47907-1150

Dr. Daniel I. Kaplan

Westinghouse Savannah River Company

Building 774-43A, Room 215

Aiken, SC 29808

Dr. Jim Krumhansl

Sandia National Laboratory

P.O. Box 5800

Albuquerque, NM 87185-0750

Dr. Christine Langston

Westinghouse Savannah River Co.

Building 774-43A

Aiken, SC 29808

Dr. Peter C. Lichtner

Los Alamos National Laboratory

P.O. Box 1663

Los Alamos, NM 87545

Sandra Lilligren

Nez Perce

P.O. Box 365

Lapwai, ID 83540
No. of

Copies

Kate Maher

The Center for Isotope Geochemistry

301 McCone Hall

University of California, Berkeley

Berkeley, CA 94702-4746

Melaine A. Mayes

Environmental Sciences Division

Oak Ridge National Laboratory

P.O. Box 2008

[Bethel Valley Road for FedEX/UPS

delivery]

Oak Ridge, TN 37831-6038

Dr. Kathryn L. Nagy

Department of Earth and Environmental Sciences

University of Illinois at Chicago (MC-186)

845 West Taylor Street

Chicago, IL 60607-7059

Heino Nitsche

Director, Center for Advanced

Environmental and Nuclear Studies

Lawrence Berkeley National Laboratory

1 Cyclotron Road

MS 70A-1150

Berkeley, CA 94720

Phil Reed

U.S. Nuclear Regulatory Commission

Office of Nuclear Regulatory Research

Division of Systems Analysis and

Regulatory Effectiveness

Radiation Protection, Env. Risk and Waste

Management Branch

MS T9-F31

Washington, D.C. 20555-0001

*Distribution of this report is made by electronic media via http://www.osti.gov/bridge/. 
PNNL-14903

Rev. 1

No. of

Copies

Richard J. Reeder

Department of Geosciences

State University of New York at Stony

Brook

Stony Brook, NY 11794-2100

Al Robinson

68705, E 715 PRNE

Richland, WA 99352

Phil Rogers

13 Mountain Oak

Littleton, CO 80127

Dr. Sherry Samson

Dept. EES

University of Illinois at Chicago (MC-186)

845 West Taylor St.

Chicago, IL 60607-7059

David Shafer

Desert Research Institute

University of Nevada

P.O. Box 19040

Las Vegas, NV 89132-0040

Dawn A. Shaughnessy

Glen T. Seaborg Center

Lawrence Berkeley National Laboratory

1 Cyclotron Road

MS 70A-1150

Berkeley, CA 94720

Doug Sherwood

Rivers Edge Environmental

1616 Riverside Drive

West Richland, WA 99353
No. of

Copies

David K. Shuh

Lawrence Berkeley National Laboratory

1 Cyclotron Road

MS 70A-1150

Berkeley, CA 94720

James "Buck" Sisson

Idaho National Engineering and

Environmental Laboratory

P.O. Box 1625, MS 2107

Idaho Falls, ID 83415-2107

Carl I. Steefel

Lawrence Livermore National Laboratory

Earth \& Environmental Sciences Directorate

MS L-204

P.O. Box 808

Livermore, CA 94551-9900

Dr. Samuel J. Traina, Director

Sierra Nevada Research Institute

University of California, Merced

P.O. Box 2039

Merced, CA 95344

Dan Tyler

Freestone Environmental Services

1933 Jadwin Ave.

Richland, WA 99354

Dr. T. T. Chuck Vandergraaf

Atomic Energy of Canada, Limited

Whiteshell Nuclear Research Establishment

Pinawa, Manitoba ROE 1LO

Canada

Dr. Jiamin Wan

Lawrence Berkeley National Laboratory

1 Cyclotron Road, MS 70-0127A

Berkeley, CA 94720

*Distribution of this report is made by electronic media via http://www.osti.gov/bridge/. 
No. of

Copies

Mr. Ronald G. Wilhelm

Office of Radiation and Indoor Air

401 M Street, S.W.

Mail Code 6603J

Washington, D.C. 20460

W. Alexander Williams

U.S. Department of Energy

Office of Environmental Restoration

EM-33

19901 Germantown Road

Germantown, MD 20874-1290

ONSITE

3 DOE Office of River Protection

P. E. LaMont

H6-60

R. W. Lober

H6-60

R. B. Yasek

8 DOE Richland Operations Office

B. L. Foley

J. P. Hanson

R. D. Hildebrand

K. A. Kapsi

J. G. Morse

K. M. Thompson

DOE Public Reading Room (2)

16 CH2M HILL Hanford Group, Inc.

K. C. Burgard

M. P. Connelly (5)

T. E. Jones (2)

F. J. Anderson

A. J. Knepp

S. Lambert

F. M. Mann

W. J. McMahon

H6-60

A6-38

A5-13

A6-38

A5-13

A6-38

A6-38

H2-53

E6-35

E6-35

E6-35

H6-60

E6-35

E6-35

E6-35
No. of

Copies

C. W. Miller

H9-03

D. A. Myers

E6-35

T. L. Sams

H6-05

3 Duratek Federal Services, Inc., Northwest Operations
M. G. Gardner
H1-11
K. D. Reynolds
H1-11
D. E. Skoglie
H1-11

3 Environmental Protection Agency
N. Ceto
B5-01
D. A. Faulk
B5-01
M. L. Goldstein
B5-01

\section{Fluor Federal Services}

R. Khaleel

E6-17

R. J. Puigh

E6-17

8 Fluor Hanford, Inc.

T. W. Fogwell

E6-35

B. H. Ford

E6-35

J. G. Hogan

H1-11

D. G. Horton

E6-35

V. G. Johnson

E6-35

S. M. Narbutovskih E6-44

B. A. Williams $\quad$ E6-44

M. I. Wood

H8-44

Stoller
R. G. McCain

B2-62

5 Washington State Department of Ecology

S. Dahl

$\mathrm{H} 0-57$

J. A. Caggiano

H0-57

*Distribution of this report is made by electronic media via http://www.osti.gov/bridge/. 
No. of

Copies
A. D. Huckaby
H0-57
J. Yokel
$\mathrm{H} 0-57$
F. Hodges
H0-57

55 Pacific Northwest National Laboratory

D.H. Bacon

K9-33

S. R. Baum

P7-22

B. N. Bjornstad

K6-81

C. F. Brown

P7-22

R. W. Bryce

K. J. Cantrell

R. E. Clayton

W. J. Deutsch (10)

P. E. Dresel

K. N. Geiszler

M. J. Fayer

A. R. Felmy

J. K. Fredrickson

M. D. Freshley

J. S. Fruchter

N. J. Hess

J. P. Icenhower

C. T. Kincaid

E6-35
No. of

Copies

K. M. Krupka (5)

K6-81

I. V. Kutnyakov

P7-22

G. V. Last

K6-81

V. L. LeGore

P7-22

M. J. Lindberg

P7-22

C. W. Lindenmeier

K6-96

W. J. Martin

K6-81

S. V. Mattigod

K6-81

B. P. McGrail

P. D. Meyer

C. J. Murray

R. D. Orr

E. M. Pierce

N. Qafoku

R. G. Riley

R. J. Serne

H. T. Schaef

W. Um

M. Valenta

T. S. Vickerman

S. B. Yabusaki

J. M. Zachara

K6-81 Hanford Technical Library (2)
K6-81

BPO

K6-81

K6-81

K6-81

K3-61

K6-81

P7-22

K6-81

$\mathrm{P} 7-22$

$\mathrm{P} 7-22$

$\mathrm{P} 7-22$

K9-36

K8-96

P8-55

*Distribution of this report is made by electronic media via http://www.osti.gov/bridge/. 